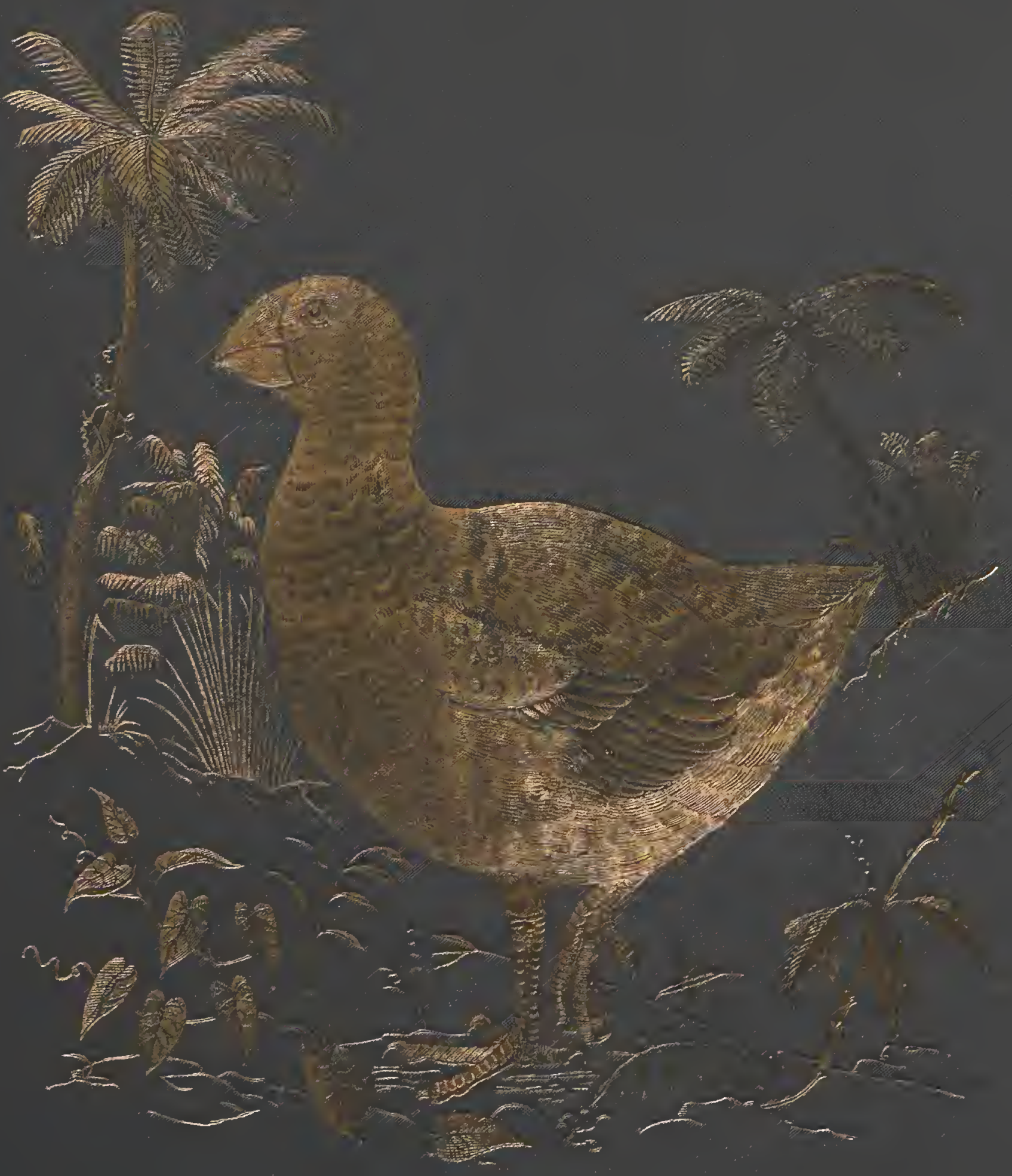





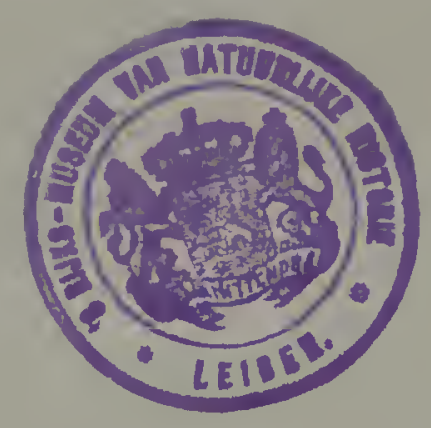





\title{
A H Is TORY
}

OF THF

\section{BIRDS OF NEW ZEALAND.}

BY

\author{
SIR WALTER LAWRY BULLER, K.C.M.G., \\ D.Sc., F.R.S., \\ F.L.S., F.G.S., F.R.G.S., F.R.C.I., Hon. F.S.Sc. ; \\ ' OfFICIER DE L'INSTRUCTION PUBLTQUE' DE IA FRANCE; \\ GALTLEIAN MEDALLIST OF THE FACULTY OF NATURAL SCTENCES, ROYAL UNIVERSITY, FLOREATCE ; \\ CORRESPONDING MLEMBER OF THE ZOOLOGICAL SOCTETY OF LONDON, OF THE AMERICAN ORNITHOLOGISTS' UNION, \\ AND OF THE ORNITHOLOGICAL SOCIETY OF VIENMA; \\ MEMBER OF THE BRITISH ORNITHOLOGISTS' UNION, OF 'THE PERMANENT INTERNATIONAL \\ CONITTTEE ON ORNITHOLOGY, OF THE ANTHROPOLOGICAL INSTITUTE OF GREAT BRTTATN, \\ AND OF THE NEW-ZEALAND INSTITUTE.
}

SECOND EDITION.

V 0 L U M E I.

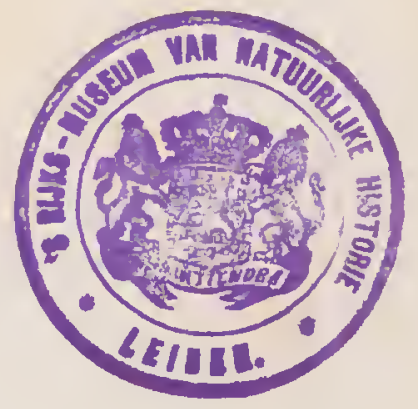

L $0 \mathrm{~N} D 0 \mathrm{~N}$ :

PUBLISHED (FOR THE SUBSCRIBERS) BY

THE A UTHOR,

8 VICTORIA CHAMBERS, VICTORIA STREET, WESTMINSTER, S.W.

1888. 


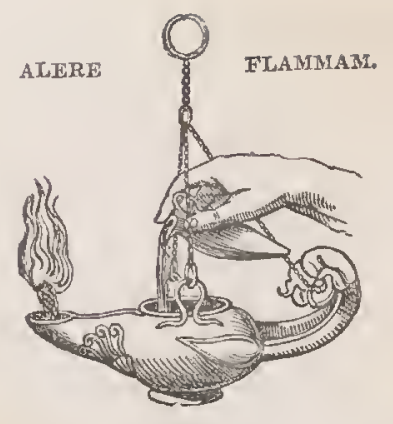

R IXTED BY TAYLOR A D FRANOIS, RED LION COURT, FLEET STREET. 


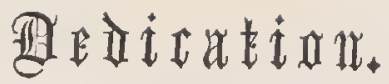

TO MY SONS,

\section{WALTER LEOPOLD AKD}

\author{
ARTHUR PERCIVAL, \\ NOW AT THE UNIVERSITY OF OAMBRIDGE, \\ BOTH OF WHOM WERE BORN IN NEW ZEALAND, \\ AND SPENT THEIR EARJIER YEARS
}

AMID THE SCENES AND SURROUNDED BY THE NATURAL OBJECTS

DESORIBED IN THE FOLLOWING PAGES,

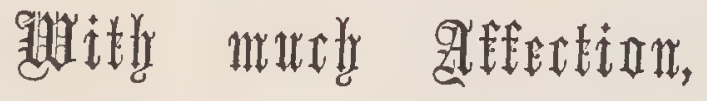

I DEDICATE THIS BOOK. 



\section{ORIGINAL PROSPECTUS.}

Iт has been remarked by a celebrated naturalist that "New Zealand is the most interesting ornithological province in the world;" and in a qualified sense this is no doubt true. The last remnant of a former continent, and, geologically considered, probably the oldest country on the face of our globe, it contains at the present day the only living representatives of an extinct race of wonderful Struthious birds.

Within recent historic times this circumscribed area, scarcely equal in extent to that of Great Britain, was tenanted, to the entire exclusion of Mammalia, by countless numbers of gigantic brevipennate or wingless birds, of various genera and species, the largest attaining to a stature nearly twice that of a full-grown Ostrich. These colossal ornithic types have disappeared; but their diminutive representatives (the different species of Apteryx) still exist, in diminished numbers, in various parts of the country; and these are objects of the highest interest to the natural-historian. But apart from this view of the subject the avifauna of New Zealand presents many special features of considerable interest. A large proportion of the genera are peculiar to the country; while some of the forms are perfectly anomalous, being entirely without a parallel in any other part of
the world.

Under the changed physical conditions of the country, brought about by the operations of colonization, some of these remarkable forms have already become almost, if not quite, extinct, and others are fast expiring. It has been the author's desire to collect and place on record a complete life-history of these birds before their final extirpation shall have rendered such a task impossible; and it will be his aim to produce a book at once acceptable to scientific men in general and useful to his fellow-colonists.

It may be mentioned that the author's official position in New Zealand, during a period of more than twelve years, has enabled him to visit nearly every part of the country, while his frequent intercourse with the various native tribes has been highly favourable to such an object as
the present undertaking. 
The work will comprise an introductory treatise on the ornithology of New Zealand, a concise diagnosis of each bird in Latin and English, synoptical lists of the nomenclature, and a popular history and description of all the known species-and will contain coloured illustrations, by Keulemans, of all the more interesting or characteristic forms. It will be published in five Parts, each containing not less than seven coloured lithographs, comprising altogether about seventy figures of New-Zealand birds.

London, January 1872. 


\section{PREFACE TO FIRST EDITION.}

THE study of Ornithology has always been a source of intense enjoyment to me; and to write a history of the Birds of my native country was one of the day-dreams of my early boyhood. In maturer years my intervals of leisure, during an active official life in the colony, have been chiefly devoted to the collection of materials for such an undertaking; and the result is now presented to the public in a form which will, I trust, be acceptable to both the scientific and the general reader.

With what amount of success I have executed my self-imposed task it is not for me to decide. I am conscious, however, of having bestowed much honest labour upon it; and the lighly favourable manner in which it has been reviewed, as well as the numerous letters of commendation and approval which I have received from persons in every way competent to form a judgment, give me reason to believe that my efforts have not been misdirected.

As a proof that I have spared myself no trouble to make the work complete I may mention that, without a single exception, the descriptions of the species have been taken from specimens actually before me, and that every measurement given throughout the book has been made or verified by myself. The life-histories are, for the most part, records of my own observations during a number of years; and I have endeavoured to make them as truthful as possible. It will be seen, however, that I have not failed to avail myself of the notes of other local naturalists, whose contributions are, in every instance, duly acknowledged.

I take this opportunity of expressing my gratitude to the Colonial Government for having granted me a prolonged leave of absence, on the most liberal terms, for the purpose of visiting England to superintend the publication of my work. To the authorities of the British Museum my thanks are due for the facilities which have been afforded me of studying the contents of perhaps the finest collection of Birds in the world, and to the gentlemen having charge of that department for their unvarying courtesy and attention-even my application to be allowed to remove the rare Notornis from its hermetically closed case, for the purpose of examination, having been readily complied with.

In working out the historical synonymy of the species I have found the Library of the 
Zoological Society of great service; and in consulting authorities I have received valuable assistance from Mr. R. B. Sharpe, the late librarian, whose long connexion with the Society has made him familiar with the bibliography of the subject. The excellent lists already published by Mr. G. R. Gray and Dr. Otto Finsch had rendered this part of my task a comparatively light one; but all the references have been carefully verified, and the chronology given for the first time; while numerous synonyms have been added, and the whole of the nomenclature critically examined and revised.

To my brethren of the British Ornithologists' Union I hereby tender my acknowledgments for the readiness with which they have at all times given me the benefit of their opinions and judgment on doubtful points, or lent me specimens for comparison.

In conclusion I have only to state that, in consideration of the generous assistance accorded to me by the New-Zealand Government, I have presented the whole of my collection of Birds, on which the descriptive letterpress is chiefly founded, to the Colonial Museum at Wellington, where it will in future be accessible for purposes of reference.

W. L. B.

London, March 1873. 


\section{NOTICE OF THE NEW EDITION.}

THE success which attended the Author's first edition of 'The Birds of New Zealand' (published in 1873, and containing comparatively few illustrations) has induced him to enter upon a more ambitious undertaking. Limited as that was to an impression of 500 copies, the whole edition was privately subscribed for ; and the drawings on the stones, from which Mr. Keulemans had produced the inimitable Plates, were then erased. Published at Five Guineas, the price rapidly rose till, in a few years, a copy fetched $£ 20$ at public auction in New Zealand; then $£ 21$ in London (at the sale of Sir William Jardine's library); and, finally, in Melbourne, the extraordinary price of $£ 3710 s$. Even within the last few months, with the new edition well in progress, a second-hand copy reached $£ 26$ at Mr. Sotheby's sale-rooms.

The interval of thirteen years since elapsed has been spent by the Author in New Zealand, where he has enjoyed exceptional opportunities for obtaining fresh specimens and extending his knowledge of this remarkable avifauna.

This work will be issued in Thirteen Parts (to Subscribers only) at the price of One Guinea each, or Twelve Guineas for the whole if paid in advance.

Each part (except the last) will contain facsimiles of four beautiful coloured drawings by $\mathrm{Mr}$. Keulemans, the birds being represented as they appear in life, with accessories drawn from the native flora of the country. These will be highly finished pictures in the best style of modern art, all the colour-stones being drawn either by or under the immediate direction of Mr. Keulemans himself. Specimens of these Plates, exhibited at the last Soirée of the Royal Society, were pronounced by 'The Times' reviewer " absolutely perfect."

A figure will be given of every form peculiar to New Zealand; and the enlarged size (Imperial 
Quarto) will enable the artist to group the sexes or allied species together wherever it may be found desirable.

The final Part will contain a General Introduction, profusely illustrated with woodcuts, the List of Subscribers, and a complete Index to the whole work.

London, September 30, 1887.

Extracts from Professor Newton's Address to the Biological Section of the British Association (Manchester, 1887).

"When on a former occasion (at Glasgow in 1876) I had the honour of addressing a Department of this Section, I pointed out the enormous changes that were swiftly and incvitably coming upon the fauna of many of our colonies. The fears I then expressed have been fully realized. I am told by Sir Walter Buller that in New Zealand one may now live for wecks and months without sccing a singlc cxample of its indigenous birds, all of which, in the more scttled districts, have been supplanted by the aliens that have been importcd; whilc further inland these last are daily extending thcir range at the cost of the cndemic forms. A letter I have latcly reeeived from Sir Jamcs Hector wholly confirms this statement, and I would ask you to bear in mind that thcse indigenous species are, with scarccly an execpition, peculiar to that country, and, from every scientific point of view, of the most instructive character. They supply a link with the past that once lost can never be recovered. It is thereforc incumbent upon us to know all we can about them before thcy vanish. . . . The forms that we are allowing to be killed off, being almost without exception ancient forms, arc just those that will teach us more of the way in which life has spread over the globe than any other recent forms; and for the sake of postcrity, as well as to eseape its reproach, we ought to lcarn all we can about them beforc they go hence and arc no more seen. . . . . . Onc thing to guard against is the presumption that the fauna originated within its present area, and has been always contained therein. Thus, I take it, that the famna which characterizes the New-Zealand Region-for I follow Professor Huxley in holding that a Region it is fully entitled to be called-is the comparatirely-little changed relic and representative of an early fauna of much wider rangc." 


\section{PREF A CE.}

As stated in the Prospeetus, this new and enlarged edition of "The History of the Birds of New Zealand 'is the outcome of a very general and rapidly increasing demand for a seeond issue. Its publication was commenced in June 1887, and the Author hopes to have the seeond volume completed by the end of February 1889.

Owing to the favourable reception aecorded to this new ' History' in the Australasian Colonies, and the consequently increased number of Subscribers, the Author found himself in the gratifying position of being able to reduee the priee of each Part from One Guinea and a half (as announeed in the original prospeetus) to One Guinea; but, as already notified, the edition will be strictly limited to 1000 copies, of which only about 250 will be available for Europe and Ameriea.

Although the Author has adhered to the general method and style of the former edition, he ventures to hope that the alterations and additions in the body of the work fairly represent, so far as New Zealand is concerned, the great advanee which has been made in Ornithological Science during the present decade. The book itself is on a larger scale, being Imperial instead of Royal Quarto, and the Plates, instead of being hand-eoloured lithographs, have been produced by the more costly but more exact and satisfaetory proeess of printing in eolours. It is generally admitted that nothing so perfeet in colour-printing has hitherto becn attempted; and the Author feels that special thanks are due to the talented artist, Mr. J. G. Keulemans, and to his able assistant, Mr. F. van Itcrson, for the fidelity with which the drawings on stone have been exeeuted; also to Mr. Otto Mayer (of the firm of Judd \& Co.) for the faithful care and attention bestowed on the printing of the Plates, from first to last, so as to ensure the best possible finish.

To the Subseribers in England and the Colonies, and particularly in New Zealand, who have responded so liberally to the announcement of a New Edition, the Author tenders his grateful aeknowledgments; for without sueh support he would never have undertaken so costly an enterprise. He would fain hope that the honest and patient labour whieh he has devoted to the work will be deemed a fitting return for their generous eonfidence.

Inner Tcmple, London,

IIarch 1888.

W. L. B. 



\section{N T R 0 D U C T I $0 \mathrm{~N}$.}

THE first published list of the birds of New Zealand was drawn up by the late Mr. G. R. Gray of the British Museum, and appeared in 1843 in the Appendix to 'Dieffcnbach's Travels.' This enumeration contained the names of eighty-four recorded species; but many of these were of doubtful authority, and have since been omitted. In the following year the same industrious ornithologist, in the 'Voyage of H.M.SS. Erebus and Tcrror,' produced a more complete list, embracing the birds of New Zealand and the neighbouring islands, accompanied by short specific characters, and illustrated by twenty-nine coloured figures, many of them of life-size. In July 1862 he published in 'The Ibis' a revision of this synopsis, with the newly-recorded species added, including, moreover, the birds inhabiting the Norfolk, Phillip, Middleton's, Lord Howe's, Macaulay's, and Nepean Islands. This enumeration contained altogether 173 species, of which 122 were said to occur in New Zealand and the Chatham Islands. In the 'Essay on the Ornithology of New Zealand,' written by myself at the request of the Exhibition Commissioners, in 1865, and afterwards published by the New-Zealand Institute*, eleven additional species were recorded; and in a paper which I communicated to the Wellington Philosophical Society in August 1868 + I gave the names of fourteen more. A few other species havc since been added to the list; while, on the other hand, it has been found necessary to strike out several which had been admitted on insufficient evidence.

My first cdition of the present work, published in 1873, contained descriptions of 147 species; and in my ' Manual of the Birds of New Zealand,' prepared at the request of the Colonial Government in 1882 , twenty-nine more species were added to the list. The prescnt edition does not profess to add many more to the number; but the classification and nomenclature have been revised, and a far more complete history has been given of each species than was possible before, seeing that I have, for a further period of fourteen years, enjoyed favourable opportunities for becoming better acquainted with the subject.

In the Introduction to the former edition it was stated that I had considered it necessary to omit the following species, there being no satisfactory evidence of their having occurred in New Zealand, viz. :Halcyon cinnamomina, Anthochcera carunculata, Gerygone igata, Rhipidura motacilloides, Aplonis zealandicus, A. caledonicus, Ortygometra Auminea, O. crex, Nesonetta aucklandica, Anous stolidus, Procellaria incerta, P. mollis, Dysporus piscator, Phalacrocorax sulcirostris, and Aptenodytes pennantii. Further research has shown that Gerygone igata is only a synonym of G. Alaviventris;

* Trans. N.-Z. Instit. 1868, vol. i. $\quad$ Ibicl.pp. 105-112. 
that Nesonetta aucklandica belongs legitimately to our list; and that Anthochoera (rectius Acanthochcora) carunculata and Aptenodytes pennantii (=A. longirostris), being of occasional occurrence, have now an undoubted claim to a place in our recognized Avifauna.

I ought perhaps here to refer to a species mentioned in the former Introduction as a newlydiscovered addition to the New-Zealand Avifauna, but now omitted from our list. It was introduced by me in the following terms:- "In a country possessing such forms as Notornis and Porphyrio we might naturally look for the occurrence also of Tribonyx. Both of the latter are known to have a wide geographic range, while Notornis, which is a strictly local form, appears to combine in some measure the characters of each, being allied to Porphyrio in the form of its bill and in its general colouring, and to Tribony $x$ in the structure of its feet; while in the feebleness of its wings and the structure of its tail it differs from both. The recent discovery, therefore, in the South Island, of an example of Tribonyx mortieri which has been brought to England, and is now living in the Zoological Society's Gardens, is a very interesting fact in geographic natural history.

"The former acquisition by the Society of a similar bird, in July 1867, led to the discovery by Dr. Sclater that the species figured and described by Mr. Gould in his 'Birds of Australia' under that name was not the true Tribonyx mortieri of Du Bus (Bull. Acad. Sc. Brux. vii. p. 214), but a distinct bird, characterized by its smaller size and by the absence of white stripes on the wing-coverts. Dr. Sclater accordingly proposed the name of Tribonyx gouldi for the latter species (Ann. N. H. 1867, xx. p. 122), and gave the following distinguishing characters for T. mortieri:- 'Major; alis albo striatis ; plaga magna hypochondriali alba.'

"The bird now in the 'Gardens' was brought home (with other birds from New Zealand) by Mr. Richard Bills, and purchased by the Society on the 21st October, 1872. I am informed by the late owner that it was captured on the shores of Lake Waihora, in the Province of Otago, by a party of men who hunted it down with dogs. When first brought to him at Dunedin it was very wild and shy; but it soon became reconciled to confinement, and when he exhibited the bird to me in London it was perfectly tame and would feed from the hand" *.

Professor Hutton, having made the necessary inquiries on the spot, satisfied himself that the story was a pure invention, and that the dealer had purchased the bird in Dunedin, where it had donbtless been brought from Australia.

After the appearance of my first edition Dr. Otto Finsch, who had previously written several papers on the subject, contributed to the 'Journal für Ornithologie' (1874, p. 107) an admirable article entitled "Zusätze und Berichtigungen zur Revision der Vögel Neuseelands," which every student ought to consult.

* "Descr. 9 . Crown and sides of the head, nape, hind neek, baek, aud rump brownish olive, washed more or less with ehestnut; wing-eoverts greyish olive, shading into brown, eaeh feather with a white streak down the centre; throat, fore neck, breast, and sides of the body dark ashy grey, passing into slaty blaek ou tho abdomen and under tail-covcrts, where the plumage is slightly tipped or freekled with grey; the overlapping feathers on the flanks pure white in their apieal portion, forming a eonspieuous mark on eaeh side of the body; under wing-eoverts dull blackish brown, and all largely tipped with white; quills blackish brown, the secondaries brownish olive on their outer webs; tail-feathers blaek, the middle ones tinged with brown on their outer margins. Irides bright crimson, with a paler rim surrounding the pupil; bill greenish yellow, lighter towards the tip; legs and feet pale plumboous tinged with yellow, the elaws blaek. Total length 16.5 inches; extent of wing 25 ; wing, from flexure, 8 ; tril 4.5 ; bill, along the ridge 1.5 , along the edge of lower mandible 1.4 ; tarsus 2.75 ; middle toe and elaw 3.25 ; hind toe and claw 1.1." 
In 1875 there appeared a new edition of the 'Voyage of the Erebus and Terror,' with an Appendix from the pen of Mr. R. Bowdler Sharpe, containing valuable notes on many of the species, and giving illustrations of some birds not figured in the earlier issue.

The most reeent work containing notices of New-Zealand birds is Mr. Seebohm's on 'The Geographieal Distribution of the Charadriidæe, "where there is an excellent plate by Keulemans representing Charadrius obscurus in full summer plumage.

With regard to the ehanges I found it necessary, in my first edition, to make in the generally accepted nomenclature, my explanation was a simple one. While fully admitting the advantages of the rule "quieta non movere" in the case of names which had obtained universal currency, I considered it better, in undertaking a general revision of the whole subject, to apply the strict principle of modern nomenelature, and, in all cases where the subject was free from doubt, to adopt the oldest admissible title. I knew that we could not look for any finality in the generic appellations so long as the science was a progressive one; but I was desirous of giving something like fixity and permanence to the specific names; and with this view I endeavoured, so far as I could, to rectify all existing errors-altering the names entirely in cases where it appeared to me that wrong ones had hitherto been employed, and eorrecting obvious classical defeets in otliers-substituting, for example, Hymenolcemus for IIymenolaimus, and antipodum for antipodes. In no instance did I introduce any ehange without very careful consideration and research; and the fact that the authorities in the British Museum adopted, with scarcely a single exception, my correetions and identifieations in the classifieation of the New-Zealand birds in the national collection, may, I think, be aceepted as a proof that I exereised proper judgment in this respect.

In the present edition some other corrections of a trivial kind have been made in the nomenclature, and in every instance I have given what I venture to think are sufficient reasons for the proposed changes. For example, no ornithological student will object to the rectification of albicilla into albicapilla, or the substitution of Limosa nova zealandice for the museum name of Limosa baueri, originally published without any description.

In my elassifieation I have departed considerably from the system followed in my first edition. This was inevitable in order to keep paee with the progress of Ornithological seience. I may state that I have in general, and as far as practicable, adhered to the scheme of arrangement adopted in 1883 by a Committee of the British Ornithologists' Union for the elassifieation of the birds of Great Britain. But wherever I have thonght it necessary to make any alteration in the arrangement of the Ordinal groups, I have not hesitated to do so. For example, I have made the Orders Gallivi and Coluniz follow Accipitres instead of being placed after StEGAropoDES, as I eonsider this an equally natural arrangement and better suited to the proposed division of my work into two volumes, the first closing with the last-mentioned Order, and the seeond opening with the Limicols. I shall treat the Order

* Doubtless it is easy cnough to discover "blunders and omissions" in any book that professes to treat exhanstively of the birds of a particular country, or the members of any special group or division; but Mr. Seebohm seems to have been cxecptionally unfortunate in his references to Ncw-Zealand spccies. He says of Charddrius olscurus that "it brceds in the mountains, novce zealanclice coast in winter;" he describes Anarhynchus frontalis as an "inland species;" and he confounds Himantopus not casy, horre in winter plumage with the Australian Stilt under the novel title of "Himantopus lencocephalus picatus." It is thologists too an unsparing hand." 
GAVIE as naturally coming next, instead of being divorced by the interposition of PYGopodes, as proposed by the B.O.U. Committee *. Gralla, Herodiones, Steganopodes, and Tubirares will then follow in the order named; and I shall place PYGopoDes after ANseres, closing the great Carinate division with the specialized group of ImPENnes or Penguins. After that, and concluding the work, will come a history of the Ratite forms in New Zealand (the various species of Apteryx), interesting not only on account of their low development but, as already explained, in respect of their relation to the extinct Struthiones $\phi$.

In my arrangement of the genera composing the great Order of PASSERES I have for the most part followed the now well-beaten track of modern systematists; but in some instances I have ventured to depart from it, giving my reasons in every case. For example, I have followed Professors Parker and Newton in placing the Corvidæ at the head of the Order instead of the Turdidæ, and I have accordingly commenced my history of our Avifauna with an account of the New-Zealand Crow. It must be acknowledged, however, that Glaucopis, instead of being a typical Crow, betrays certain strongly aberrant characters, and it is possible that we may hereafter have to alter its exact location. In the present unsettled state of Ornithological nomenclature I am anxious to avoid, as far as possible, the multiplication of names; but Glaucopis may prove to be one of those abnormal Antipodean forms of a very ancient fauna-generalized types though existing in a specialized form-which have no analogues or representatives in the Northern Hemisphere. In this event it must ultimately become the type of a new Family, to which the name of Glaucopidide might be appropriately applied. At page $30 \mathrm{I}$ have given my reasons for removing our two species of Thrush from the typical Turdidæ and placing them in a new Family under the name of Turnagridæ. So far, however, as the NewZealand Ornis is concerned, alterations of this kind will not affect the generic arrangement of the groups in their mutual relation to one another.

But, as remarked in my former Introduction, any system of classification, however excellent in itself, or ably conceived and elaborated, must of necessity be a provisional or tentative one, so long as our knowledge of the structural character and natural affinities of the vast majority of species continues so imperfect as it confessedly is at present. When the anatomy of every known bird on the face of the globe has been as fully investigated as that of the Rock-Dove (Columba livia) was by the late Professor Macgilliviay, and its life-history becomes as thoroughly known, then, but not till then, will it be possible to devise a system of arrangement absolutely true to nature. The aim and purpose of all classification being to aid the memory in its effort to comprehend and master the complex and ever varied productions of nature, or, in other words, to assist the mind by a ready association of ideas

\footnotetext{
* "Prof. Parker long ago obscrved (Trans. Z. S. v. p. 150) that eharaetcrs exlibited by Gulls when young, but lost by them when adult, are found in certain Plorers at all ages, and hence it would appear that the Gavie aro but morc advanced Limicolce. Tho Limicoline genera Dromas and Chionis have many points of rescmblanco to the Laricle; and on the whole the proper inforenec would secm to be that the Limicole, or something very liko them, form the parent-stock whence have doscended the Gavice, from which, or from their ancestral forms, the Alcide have procecded as a degencrate branch."-Enc. Brit. vol. xviii. p. 45.

+ Professor New ton, in his able article "Ornithology" in the 'Encyelopxdia Britannica,' in treating of the recent aud existing forms of toothless Ratitx, says:- "Some systematists think there can he littlo question of the Struthiones being the most spccialized and therefore probably the lighest type of these Orders, and the present writer is rather inclined to agree with them. Nevertheless the formation of the bill in the Apteryges is quite unique in the whole Class, and indicates therefore an extraordinary amount of specialization. Their funetionless wings, however, point to their being a degraded form, though in this matter they are not much worse than the Megistanes, and are far above the Immanes-some of which at least appear to have becn absolutely wingless, and were thus the only members of the Class possessing but a single pair of limbs."
} 
in the grand study of Creation, it follows that the method of arrangement which best subserves this practical end is the right one to adopt. But we must be content to see our carefully elaborated systems swept away one after another, till, perhaps, in the distant future some gifted mind shall arise, who, with the constructive energy of a second Cuvier, may be able to fashion, from the more complete materials at his command, a system perfect in all its parts and destined to endure till time shall be no more.

In portraying the manners and habits of the various species I have been careful to omit nothing that seemed calculated to elucidate their natural history. It has been said that a zoologist cannot be too exact in recording dates and other apparently trivial circumstances in the course of his observations, and that it is better to err on the side of minuteness than of vagueness, because an observer is scarcely competent to determine how far an attendant circumstance, trivial in itself, may afterwards be found to enhance the value of a recorded fact in science when viewed in relation to other facts or observations. It must be borne in mind, however, that we are as yet only imperfectly acquainted with many of the native species, and that probably, in the listory of all that are here treated of, new facts or new features of character will hereafter come to light. It is extremely difficult to cultivate an intimate acquaintance with birds that are naturally shy and recluse, and especially so in a thinly peopled country, where they rarely cross the path of man and must be assiduously sought for in bush, swamp, and jungle. While relying generally on my own opportunities for observation, I have not failed to avail myself of the kind assistance of others; and in the body of the work numerous acknowledgments will be found of information furnished by correspondents in various parts of the country, who, amid the multifarious duties and engagements of a colonial life, have found time to take notice of the natural objects around them.

Before passing on to a consideration of the existing Avifauna it may be useful to take a rapid survey of the Families and Genera known to us by their fossil remains as having formerly inhabited New Zealand, or roamed over the continent of which these islands are the only remnants at the present day. These ornithic relies of a bygone time have been interpreted, restored, and classified with marvellous felicity by Professor Sir Richard Owen in his 'Memoirs of the Extinct Wingless Birds of New Zealand "*. 'These memoirs had appeared, from time to time, since the year 1838, in successive Parts of the 'Transactions of the Zoological Society of London,' and following the example of Baron Cuvier, who thus reprinted his numerous detached papers inder the title of 'Recherches sur les Ossemens Fossiles de Quadrupèdes,' the venerable Professor has collected his many exhaustive Memoirs and combined them with additional matter and general remarks in two splendid volumes, replete with illustrations. In the prospectus announcing this work he did me the great honour to say that "his purpose, long entertained, was strengthened by the appearance and favourable reception of an excellent and comprehensive work on the existing Birds of New Zealand, to which the present Volumes may be deemed complementary." The volumes, thus modestly announced, commence with an Introductory Notice of the circumstances which led to the discovery and restoration of the extinct Avifauna of Nerv Zealand; the descriptions which follow are accompanied by illustrations of the natural size of the fossils, together with reduced views of the restored skeletons on which the several genera and species have been founded; the whole is preceded by an illustrated Anatomy of the existing wingless bird (Apteryx australis), which, as the Professor states, is the nearest ally of the 
extinct Dinornis, and is followed by notices of the food, footprints, nests, and eggs of the Moas, the Maori traditions relating to these gigantic birds, the causes and probable period of their extirpation, and a speeulation on the conditions influencing the atrophy of the wings in flightless birds-to all of whieh the learned author has appended Supplementary Memoirs on the Dodo, Solitaire, and Great Auk, with evidences of other extinct birds in Australia and Great Britain.

\section{THE ANCIENT AVIFAUNA.}

The first Moa-bone of which we have any record was a mere fragment of a femur six inches in length, with both extremities broken off, which was brought to England in 1839, and offered for sale at the Royal College of Surgeons by an individual who stated that he had obtained it in New Zealand from a native who told him that it was the bone of a great Eagle. Professor Owen, on its being first submitted to him, assured the owner that "it was a marrow-bone like those brought to table wrapped in a napkin"; but on subsequent and more critical examination he arrived at the eonviction that it had in reality eome from a bird, that it was the shaft of a thigh-bone, and that it must have formed part of the skeleton of a bird as large as, if not larger than, the full-sized male Ostrich, with this very striking difference, that whercas the femur of the Ostrich, like that of the Rhea and the Eagle, is "pneumatic," or contains air, the huge bone, of which a fragment was now submitted to him, had becn filled with marrow like that of a beast. The price askcd for this unique specimen was only ten guineas, and although Professor Owen strongly rccommended its aequisition, the Museum Committec dcelined to purehase the "unpromising fragment." Much against the advice of his scientific contemporaries Owen insisted on publishing his conclusions, announcing boldly - "So far as my skill in interpreting an osseous fragment may be credited, I am willing to risk the reputation for it on the statement that there has existed, if there does not now exist, in New Zealand a Struthious bird, nearly, if not quite, equal in size to the Ostrich."

After the publication of Professor Owen's paper the bone was purchased by Mr. Bright, M.P. for Bristol, and many years subsequently came into the possession of the British Museum, where this historic relic is now carefully preserved.

More than three years elapsed before any confirmatory evidence was received from New Zealand; and then came a lettcr from the Rev. W. Cotton to Dr. Buckland, followed by another from the Rev. W. Williams, giving an account of the discovery of large numbers of these fossil remains and accompanied by a box of specimens, which triumphantly established the accuracy of Owen's prevision. The specimens transmitted by Mr. Williams were, as a matter of course, confided by Dr. Buckland to the learned Professor for determination; and these materials, scanty as they were, enabled him to define the generic characters of Dinornis, as afforded by the bones of the hind extremity. An examination of a second and richer collection sent home by Mr. Williams, together with three additional specimens lent by Dr. (afterwards Sir John) Richardson of Haslar Hospital, enabled him to discriminate six distinct species of the genus, aseending respectively from the size of the Great Bustard to that of the Dodo, of the Emu, of the Ostrich, and finally attaining a stature far surpassing that of the last-named biped.

The first of these was a Cursorial bird which, on account of the agreement of its tibia in its general characters with the same bone in the larger species, he referred at that time to the genus Dinornis, but which subsequent investigations proved to belong to another genus, characterized by 
the presence of a strong hind toe, for which the name of Palapteryx was proposed. As this bird had something of the appearance of the Great Bustard, he called it Dinornis otidiformis.

It may be here mentioned that in the Ostrich, Rhea, and Cassowary there is no vestige of a hind toe or hallux.

The next was a three-toed Struthious bird differing from the other species of Dinornis in its relatively shorter and broader metatarsus, in which characters it appeared closely to resemble the extinct Dodo (Didus ineptus) of the Isles of France and Rodriguez; and as it could not have been greatly superior in size to that bird, he named it Dinornis didiformis. Judging by its skeleton, this bird stood a little under four feet in height, or of intermediate size between the Cassowary and the Dodo. In the metatarsal of this bird, as with the larger species of Dinornis to be presently mentioned, there was not the slightest trace of the articulation of a fourth posterior toe, the generic distinction from Didus and Apteryx being thus distinctly indicated.

The next species described, which appears to have attained the average height of the Ostrich (about seven feet), with a more robust and stronger build, he named Dinomis struthioides, and pointed out characters which placed the fact of its being a good and true species beyond all cavil or doubt.

Another species, which attained the height of nine feet, he provisionally named Dinornis in. gens; but, as will appear further on, this bird was also subsequently referred to the genus Palapteryx. Then came the discovery of a still larger form, standing ten feet in height if not more, which he distinguished as Dinornis giganteus. A fair idea of the size of this gigantic bird, in comparison with the stature of an ordinary-sized man, may be obtained from the accompanying woodcut, which is a reduction from the lithograph forming the frontispiece to $\mathrm{my}$ first edition*. The representation of the skeleton is from a photograph of the magnificent specimen in the Canterbury Museum, and the figure of the Maori, clothed in a dogskin mat and "wrapt in contemplation," is taken from the portrait of the old Ngapuhi chief,

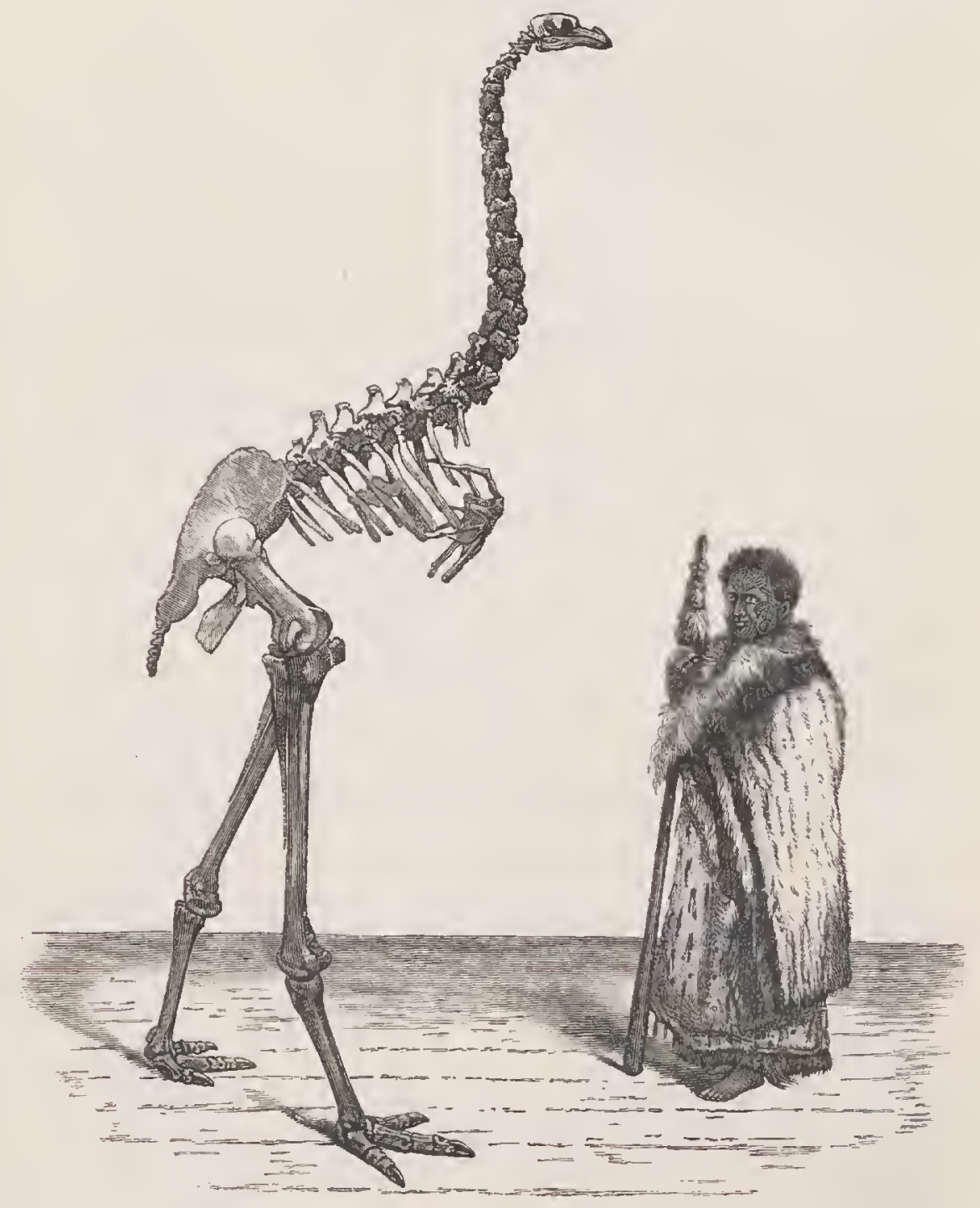
Tamati Waka Nene, as given in Angas's 'New Zealanders illustrated.'

* Copies of this interesting pew 'Zealanders ilustrated.'

and the Rev. James Buller's ' Forty plate have appeared in Kennedy's 'New Zealand,' Sir Julius Vogel's 'Handbook of New Zealand, Rer. James Buller's 'Forty Years in New Zealand.' 
Yet another form, with a stature of about five feet, had to be discriminated, and this Owen named Dinornis dromioides, on account of its sinilarity in size to the Emu.

Not content with this large addition to the hitherto known Struthious birds of the world from one small area of land, the learned Professor made a happy forecast of further discoveries yet in store, for he then wrote:-

"Already the heretofore recorded number of the Struthionidx is doubled by the six species of Dinornis determined or indicated in the foregoing pages; and both the Maori tradition of the destruction of the Moa by their ancestors and the history of the extirpation of the Dodo by the Dutch navigators in the Isles of Maurice and Rodriguez, teach the inevitable lot of bulky birds unable to fly or swim, when exposed, by the dispersion of the human race, to the attacks of man. We may therefore reasonably anticipate that other evidences await the researches of the naturalist, which will demonstrate a further extent of the Struthious order of Birds anterior to the commencement of the present active cause of their extinction."

Among the most important contributors to the history of Dinornis at this early period were the Rev. William Colenso, F.R.S., who not only collected specimens of the bones, but published a very interesting memoir on the subject in the 'Tasmanian Journal' (vol. vii., 1843), and the Rev. Richard Taylor, who, in 1844, wrote as follows:-

"Early in 1843 I removed from the Bay of Islands to Wanganui, and my first journey was along the coast of Waimate. As we were resting on the shore near the Waingongoro stream, I noticed the fragment of a bone which reminded me of the one I found at Waiapu. I took it up and asked my natives what it was. They replied 'a Moa's bone; what else? Look around and you will see plenty of them.' I jumped up, and to my amazement I found the sandy plain covered with a number of little mounds entirely composed of Moa-bones; it appeared to me to be a regular necropolis of the race. I was struck with wonder at the sight, but lost no time in selecting some of the most perfect of the bones. I had a box in which my supplies for the journey were carried; this I emptied, and filled with the bones instead, to the amazement of my followers, who exclaimed 'What is he doing? What can he possibly want with these old Moa-bones?' One suggested 'hei rongoa pea ' (to make medicine perhaps); to this the others consented, saying ' koia pea' (most likely)."

Other stray collections continued to arrive from time to time, till at length Mr. Percy Earl, in 1846, unearthed from the turbary deposits of Waikouaiti and sent to England a more extensive series of bones than any other collector had succeeded in bringing together. These collections all found their way, more or less directly, into Professor Owen's hands, and he was thus enabled to rectify or confirm many of his former deductions. He was also enabled to add several new species. One of these was Dinornis casuarinus, nearly agreeing in size with $D$. dromioides, aud combining the stature of the Cassowary with more robust proportions and especially more gallinaceous characters in the feet. A mutilated femur of this bird he had previously regarded as belonging to a young individual of the last-named species, and when he afterwards corrected the error he pointed out that it was a mistake on the safe side, "the caution which refrains from multiplying specific names on incomplete evidence being less likely to impede the true progress of zoological science than the opposite extreme." The most abundant of the remains collected by Mr. Earl belonged to this species (D. casuarinus); but there were also in the collection bones of another very remarkable species, which was named Dinornis crassus, in allusion to the strength of its osseous frame. It was intermediate in size between Dinornis ingens and D. struthioides, and, with a stature equal to that of the Ostrich, the 
femur and the tarso-metatarsus of this bird present double the thickness in proportion to their length. Of this species Prof. Owen writes:- “It must have been the strongest and most robust of Birds, and may be said to have represented the pachydermal type and proportions in the feathered class." A third new species, following next, in order of size, to Dinornis didiformis, and strictly confined in its range to the North Island, was named Dinornis curtus.

These more complete materials contained indubitable proof that Dinornis dromioides possessed, in common with $D$. ingens, the character of a distinct hind toe. Among the true forms of Dinornis this member was reduced (as in the Apteryx) to a high-placed hallux of diminutive size and functionless character, the attachment of this rudimentary toe being merely ligamentous. In most of the skeletons of Dinornis hitherto found there was no trace whatever of a hallux; but Professor Owen has, with every show of probability, ascribed this absence to the extremely small size of these bones and the ease with which they could be overlooked or lost rather than to their non-development, although at an earlier date he was inclined to make it a character of generic importance.

In 1850, Sir George Grey, who had been actively collecting Moabones in the district lying under Tongariro mountain, forwarded his collections to the British Museum; and two years later, Professor von Hochstetter, the naturalist attached to the Expedition of the Imperial Austrian frigate 'Novara,' who had undertaken a topographical examination of the North Island, obtained a rich collection from the same locality.

Most of these remains were found to belong to Palapteryx ingens, of which the annexed imaginary sketch is given in Prof. Hochstetter's 'Neu-Seeland ' (1863, p. 438).

Up to this period of our narrative the remains discovered appear to have belonged exclusively to birds of the Struthious Order; and, as Professor Owen had on

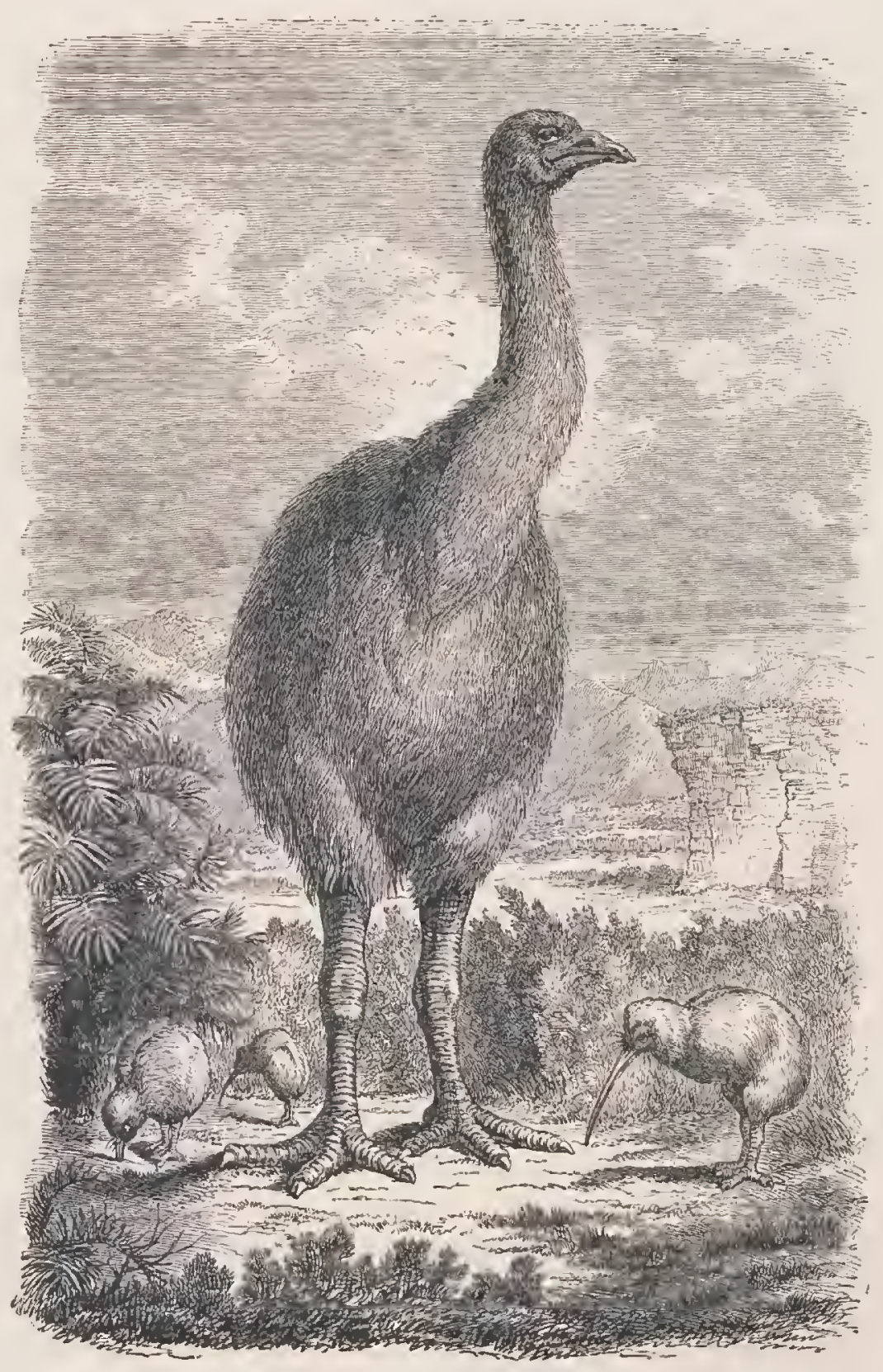
more than one occasion explained, the existing Apteryx, notwithstanding the inferiority of size, modified structure of the palate, and 
different proportions of the beak, was the nearest living representative of these extinct and comparatively ancient forms*.

But new discoveries of a most interesting kind were yet in store for the great comparative anatomist, by which he was afterwards able to demonstrate further links of connection between the extinct types and still existing forms.

In 1852-55 it fell to the lot of Mr. Walter Mantell (at that time a Government Land-Purchase Commissioner) to explore the Moa-bone deposits at Waingongoro, in the North, and at Waikouaiti, in the South Island, and the extensive collections which he then made and transmitted to England not only "exeited the delight of the natural philosopher, and the astonishment of the multitude," but, having been deposited in the British Museum, these new materials, in hitherto unknown abundance, enabled the Professor not only to verify some of his former eonclusions, but to establish the characters of several new genera $\uparrow$. No doubt the most important result was the discovery of Dinornis elephantopus, "a species which, for massive strength of the limbs, and the general proportion of breadth or bulk to height of body, must have been the most extraordinary of all the previously restored wingless birds of New Zealand, and unmatched, probably, by any known recent or extinct member of the class of Birds"\$.

The excellent woodcut on the next page, showing this skeleton as articulated in the British Museum, is copied by permission from Dr. Thomson's 'Story of New Zealand,' p. 32.

But, in addition to this splendid Moa, the collection eontained other very interesting novelties. Among these were Aptornis, the giant prototype of the existing Woodhen (Ocydromus), and notably the fossil remains of Notornis mantelli, a huge Coot, of which three recent or living examples were

* As to the affinities of the Apteryx, deducible from its anatomy, Prof. Owen says :- "Commeneing with tho skeleton, all the leading modifications of that basis of its structure comnect it closely with the Struthious group. In the diminutive and keelless sternum it agrees with all the known Struthious species, aur with these alone. The two posterior emarginations which we observe in the sternum of the Ostrich are present in a still greater degree in the Apteryx; but tho feeble development of the anterior extremities, to the miseles of which the sternum is mainly subservient, as a basis of attachment, is the eondition of a peculiarly ineomplete state of the ossification of that bone of the Apteryx; and the two sub-cireular perforatious which iutervene between the origins of the pectoral muscle on the one side, and those of a large inferior dermocervical muscle on the other, form one of several unique struetures in the anatomy of this bird."

$\uparrow$ "The Kainga (at the stream now knowll as Awamoa) whieh we found in 1852 afforded further unmistakable proof of the coexistence of man with the Moa-the bones and egg-shells of Dinornis and its kindred, mixed with remains of crery arailable variety of bird, beast, and fish used as food by the aborigiues, being all in and aroutud the umus (or native orens) in whieh tbey had becu cooked. Although my collection from this place reached Eugland in 1853, it remaiued unopened nutil after my arrival there in 1850, when I eausen it to be conveyed to the crypts of the British Museum, and there mupaeked it in the presence of the great authority on our gigantic birds, Professor Owen. With the exceptiou of two small collectious which were seleeted for me by Professor Owen, and which I gare, one to the SLuseum of Yale College, U.S., and the other to that of the Jardin des Plantes, the whole of this eollection is now in the British Musenm. The fragments of egg-shells from these umus raried in size from less than a quarter of an iuch of greatest diameter to three or four inches. These, after eareful washing, $I$ had sorted; and haring, with some patienee, fonnd tho fragments which had originally been broken from ench other, and fitted them together, I succeded in restoring at least a dozen eggs to an extent sufficient to show their sizo and outliue. Six or seren of the best of these I gave to the British Museum after their purchase of the eollection; one is in the Inserum of the College of Surgeons; the rest, including one rery beantiful egg with a polished ivory-like surface, are still in iny ownership somewhere in England. Some idea of the labonr entailed by this attempt to rehabilitate eggs may be gathered from the fact that sevoral of those restored consisted of between 200 and 300 fragments. I may add that in the markings, size, and so forth (making allowance for the alteration of the former towards the ends of the egrgs) I made ont about twenty-four varieties, of which I bare specimens."-1Iantell.

¥ "By tho side of the metatarsus of Dinomis elephantopus, that of $D$. crassus shrinks to moderato if not slender dimensions. But the peculiaritics of the elephant-footed Dinomis stand out still more conspicuously when the bonos of its lower limbs are contrasted with those of $D$. gigunteus."-Owen. 
afterwards obtained, and which, there is every reason to hope, still exists in the high tablelands and remote fastnesses of the South Island *.

The abundant remains of Aptornis enabled the Professor to discriminate two species, namely Aptornis otidiformis (originally, from the examination of a single bone, referred to Dinornis) and the still larger Aptornis defossor, of such size and strength that, to quote his own words, " the civil engineer might study perhaps with advantage the disposition of the several buttresses, beams, and arched plates which support the iliac roof of the pelvis, and strengthen the acetabular walls, receiving the pressure of the thigh-bones in this huge and powerful Woodhen."

I may here mention that an Aptornis skull, dug up by Mr. W. W. Smith at Albury, near Oamaru, affords slightly larger measurements than any hitherto recorded of $A$. otidiformis, and that Sir Richard Owen, to whom I presented the specimen, wrote to me saying:"The facial part exceeds in size that of figs. 2 and 3 (pl. xliii. of the 4 to vols.), but so little as not to support a distinct species, unless the rest of the skeleton affords corroborative characters $\uparrow$. The specimen you have kindly presented and which, for your sake, I shall value while the brief remainder of life lasts, is evidently, from its specific gravity, from a bird that has long passed away. I should, however, rejoice if confirmatory characters justified me in introducing to our Zoological Society an Aptornis bulleri." Then followed the discovery, in succession, of Dinornis geranoides, D. gravis, D. rheides, and
D. robustus. Of the last-mamed

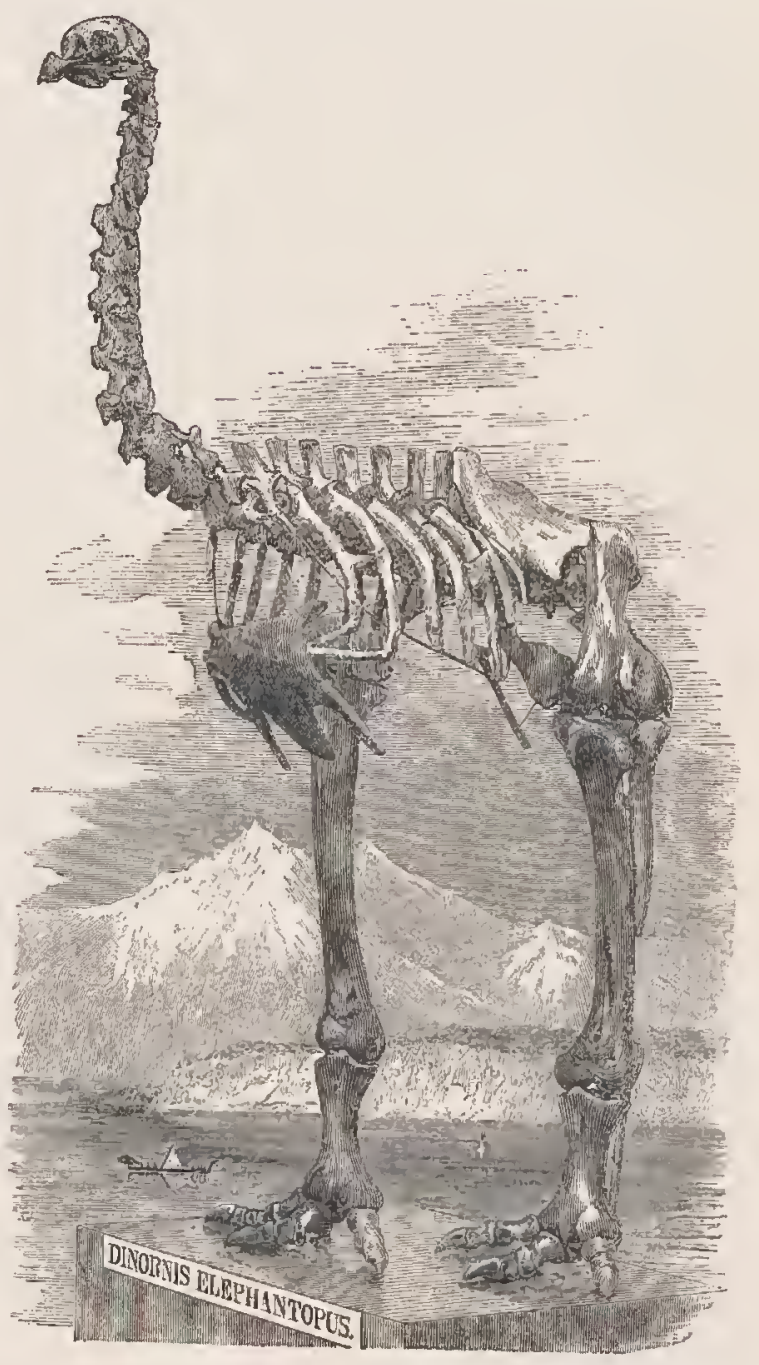
York, in a remarkable state of preservation, with portion almost perfect skeleton in the museum at feathers still attaching to the preservation, with portions of the integuments and quill-part of the articular cartilages. With sacrum, and the legs still preserving some of the ligaments and interthe 'Proc. Linn. Society' (his valuable series, which will be found fully described by Mr. Allis in been an object of diligent. viii. p. 50), were found the rudimentary wing-bones which had so long immediately beneath it, buried in the heap of sand with which the remains a male bird, because lying bones of four young ones, presumably the of sand with which the remains were covered, were the fair one from analogy, inasmuch Struthious birds, alone, inasmuch as the male Apteryx, and indeed that sex in the majority of Derforms the duty of incubation.

* Dr. Meyer, from a careful comparison of the bones, concludes that the South-Island bird is a distinct species, for which (in his 'Abbildungen von Vögel-Skcletten') he has proposed the name of Notornis hochstetteri
† In relation to tririal differences; jct, taken in connction unquestionably support the conclusions of 
Subsequently another species, coming from the extreme North, was determined by Prof. Owen, and named Dinornis gracilis, on account of the remarkable length and slenderness of its legs.

But there seemed to be practically no limit to the ornithic wonders revealed by the Post-pliocene deposits of New Zealand. Professor Owen had already well nigh exhausted the vocabulary of terms expressive of largeness by naming his successive discoveries ingens, giganteus, crassus, robustus, and elephantopus, when he had to employ the superlative in Dinornis maximus to distinguish a species far exceeding in stature even the stately Dinornis giganteus. In this colossal bird, as the Professor has well remarked, some of the cervical vertebræ almost equal in size the neck-bones of a horse! The skeleton in the British Museum, even in an easy standing posture, measures eleven feet in height, and there is evidence that some of these feathered giants attained to a still greater stature.

A fair idea may be gained of its proportionate size from the accompanying woodcut, which appeared some years ago in 'The Illustrated London News,' representing the entire left leg of a Moa (now in the Madras Government Museum) obtained by Major Michael, of the Madras Staff Corps, from the Glenmark swamp, about 40 miles from Christchurch, where it was found in situ, at a depth of four feet, by a party of workmen who were cutting a drain. The measurements are :Femur $1 \mathrm{ft} .6$ in.; tibia 3 ft. 3 in.; tarsus $1 \mathrm{ft} .8$ in.; outer toe $9 \frac{3}{4}$ in.

The corresponding right leg was exhumed a considerable time afterwards, when Mr. Fuller was conducting a search on behalf of the Canterbury Museum, and this specimen, with the phalanges complete, is now in my private collection.

In November 1878, Mr. H. L. Squires of Queenstown, South Island, obtained and forwarded to the British Museum the head of a Moa with a continuous part of the neck, with the trachea enclosed and covered

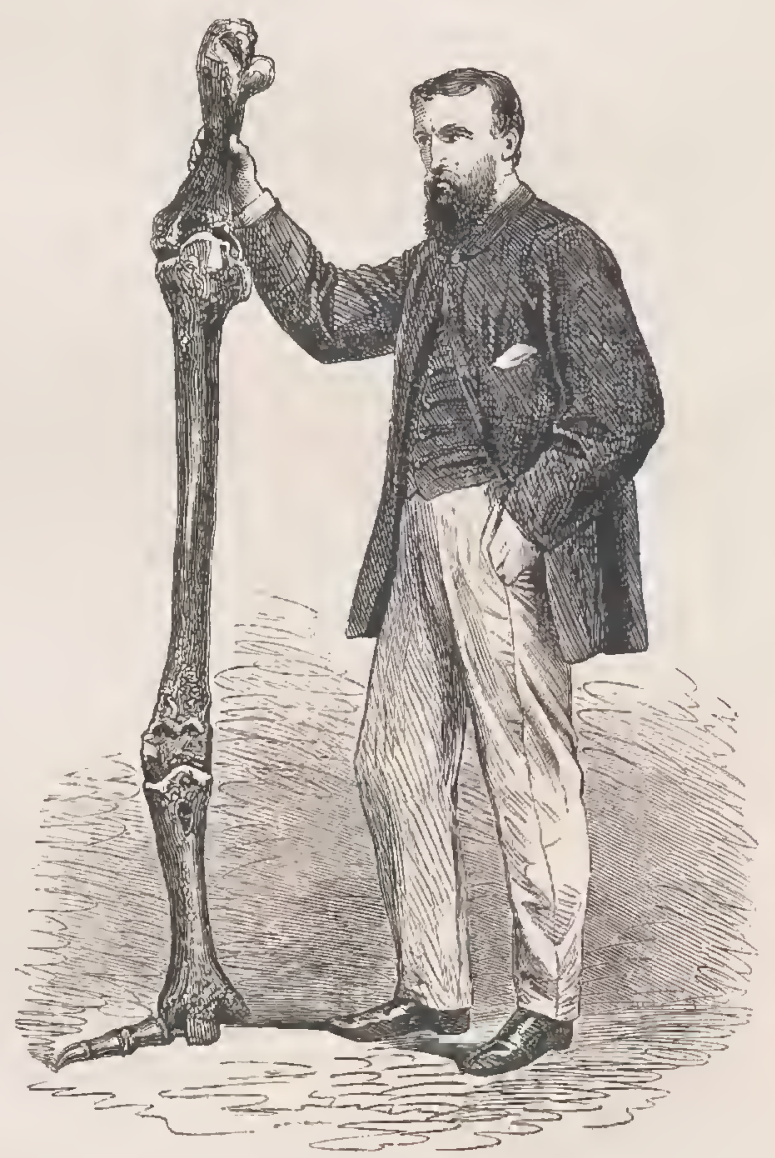
by the dried integument, and exhibiting even the sclerotic bone-ring of the dried eyeballs; also the bones of both legs with the feet covered by the dried skin, with some feathers adhering to it, and with the claws intact.

It was this specimen that enabled Sir Richard Owen to characterize his Dinornis didinus, and we may imagine the delight with which the veteran scientist embraced this opportunity of examining, for the first time, a specimen in which the characters could be studied as in a living or recent bird, and the value of his deductions from the study of single bones thereby tested, as well as the satisfaction with which he found his general conclusions so amply verified. This bird was scarcely larger than Dinornis didiformis, but presented characters of sufficient importance to separate it specifically from that form. The result of a close comparison of this dried head with that of existing Struthious birds was that "the Moa is found to repeat most closely, in the form and proportions of the beak, and in the shape, relative positions, and dimensions of the narial, orbital, and auditory apertures, the Emus 
of the Australian continent." Two points of considerable interest were established by this specimen, namely, the existence, at any rate in this species of Moa, of a strong hind toe with almost grasping power, and secondly the remarkable fact that the tarsus was feathered right down to the toes.

The other newly-discovered species (D. parvus) was founded on a nearly complete skelcton procurcd during the construction of a new road, about forty miles to the north-west of Nelson. The opportunity thus afforded of examining the entire osteology of a single bird was of extreme inportance in the final determination of the generic characters. In size Dinornis parvus was scarcely superior to the Bustard (Otis $\operatorname{tarda}$ ); and, although the smallest known member of this race of Struthious birds, it had proportionately the largest skull of all the Dinomithidce. On this curious fact Owen thoughtfully remarks that if the peculiarly nutritious roots of the common fern contributed, together with buds or foliage of trees, to the food of the various species of Moa, the concomitant gain of power in the locomotive and fossorial limbs does not appear to have called for a proportionate growth or development of brain or of bill.

But the turbary deposits of New Zealand had not yet yielded up the whole of their wonderful story of the past. In the year 1868, it was discovered that the Glenmark swamp was a veritable necropolis of extinct birds. It is said that portions of no less than eightcen skeletons were dug up from the spot whence Major Michael obtained his leg of Dinornis maximus and within an area of about ten squarc fect. Under the able direction of the late Sir Julius von Haast, and with indefatigable zeal, these fossil remains were exhumed literally by thousands, scnt to the Canterbury Museum in waggon-loads, sorted and classified there, and then distributed among the museums of the world, producing in return, by a judicious system of interchange, some $£ 20,000$ worth of specimens of various kinds, and helping materially to place the Canterbury Museum in the proud position which it now occupies in the Colony.

Sir Julius von Haast worked out the collections which he had formed in a very painstaking manner, and published the results in an Address to the Philosophical Institute of Canterbury. His
minute observations minute observations and measurements over a wide field of specimens had the effcct of confirming in
a very remarkable and specific distinctionner the conclusions arrived at previously by Sir Richard Owen as to generic part of a skeleton.

But perhaps the most important discovery was that of the existence, contemporaneously with the Moa, of a gigantic bird of prey, far excecding the Golden Eagle in size, to which Haast gave discussed by the discoverer in a paper published in the Transactions of the New-Zealand Institute *; and it has become a favourite theme of speculation whether the true function in life of this great Raptor was not to prey upon the smaller species of Dinornis, or the chicks or young broods of the
more gigantic forms. A second and smaller species was afterwards described, under the name of Harpagornis assimilis;
but it is not unlikely that this was the male of $H$. moorei, the disparity in size, which is the only difference, being thus easily explained.

In addition to this wondrous store of bones, so intermixed and packed together that in some instances therc were twenty-five or thirty specimens from different birds imbedded in one solid mass, Sir Julius Haast had afterwards the opportunity of examining another interesting collection of Moa- 
bones made by Mr. T. F. Cheeseman, from a cave at Pataua, near Whangarei, in the far North, and practically the same district from which the Rev. W. Cotton obtained the first bones of Dinornis curtus in 1844-45. In this collection there was an almost perfect skeleton of a species appreciably smaller than the last-named one; and, under the name of Dinornis oweni, Haast dedicated this to "the illustrious biologist to whom science in New Zealand is so much indebted" *.

In a paper published in 1874 , Sir Julius Haast proposed a new classification of the extinct Struthiones, which, so far, does not appear to have met with general acceptance. He divided them into two Families, which he named respectively the Dinornithidae and the Palapterygida, each with two genera, the former comprising Dinornis and Meionornis, and the latter Palapteryx and Euryapteryx. He made the total absence of hind toe or hallux the distinguishing character of the first-named Family, thus following the broad line by which Owen had already differentiated his genera Dinornis and Palapteryx. He ventured, moreover, to characterize his Family Palapterygidoe as one in which the anterior limbs are entirely absent; but his conclusions on this head are far from being decisive. It would appear more likely, from the analogy of the case, that in those species in which the wings are supposed to have been wholly absent they existed only in a very rudimentary form, and that the small bones have perished, leaving no trace behind for the modern student of palæontology. It seems to be placed beyond doubt that in all the so-called Wingless Birds, by long-continued disuse of the anterior limbs through many successive generations, these organs had become enfeebled and ultimately atrophied and dwarfed to the condition of mere rudiments, as is now conspicuously apparent in the existing species of Apteryx. Professor Owen has suggested that in the case of Dinornis " the degree of atrophy, which seems to have been carried to a total loss of the limb-appendages of the scapulo-coracoid arch, implies the operation of the influence of disuse through a period of pre-Maori æons greatly exceeding the time during which the Lamarckian law has operated on the Cassowary, the Rhea, and the Ostrich."

Following this came the discovery by Sir James Hector of the remains of an extinct Goose, of very large if not gigantic proportions, and undoubtedly flightless. This proved to be the bird a few detached bones of which Professor Owen had previously referred to a genus " hitherto unknown to science," and supposed to be of the Struthious Order, for which he proposed the name of Cnemiornis calcitrans. The first tolerably complete skeleton of this Anserine form, which was certainly contemporaneous with the colossal Moas, was obtained by the IIon. Captain Fraser in the Earnsclough caves, and was afterwards presented by him to the British Museum. Another coeval species determined by Professor Huxley, was the giant Penguin (Palceeudyptes antarcticus), of which the bones were discovered by Mantell in the Oamaru limestone in 1849. To the same species are doubtless referable the fossil remains more recently found by Mr. James Duigan at Hokitika. These were discovered imbedded in a reef exposed only at low water and forming part of the Seal Rock, a bold headland which protects the anchorage of Woodpecker Bay. The bones were thoronghly mineralized, resembling the condition in which fossil reptilian bones are usually found $\uparrow$.

Even now, although the Post-pliocene bone-deposits of New Zealand, both North and South, have been pretty thoroughly explored, new species of Wingless Birds are being from time to time added to the list. During the last seven years Professor Owen has characterized two new species from the

\footnotetext{
* Trans. Zool. Soc. vol. xii. p. 171 .

$\uparrow$ Trans. N.-Z. Instit. vol. iv. pp. 341-346.
} 
South Island as Dinornis didinus and D. parvus; and he has suggested that another, which may ultimately turn out to be new, might be appropriately named Dinornis huttoni, in compliment to the discoverer.

As already mentioned Sir Julius Haast addcd Dinornis oweni to the list of species; and he likewise discovered an extinct form of Apteryx, far exceeding in size those existing at the present day, to which he gave the name of Megalapteryx hectori.

Doubtless other forms, perhaps as interesting and remarkable as any yet brought to light, remain entombed to reward the zeal and enterprise of the future explorer.

Bearing on the question of the geographical relations of the New-Zealand Avifauna, one very important fact presents itself to us. In the same way that, as at the prescnt day, certain well-marked species in the North Island are represented in the South Island by closely allied but yet specifically distinct forms, so it was also with the extinct Avifauna. The strong-limbed Moas with bulky frames were Dinornis gravis, D. crassus, D. elephantopus, D. robustus, and D. maximus, and these appcar to have been strictly confined to the South Island. Six species having proportionately thin leg-bones and a slighter frame, namely, Dinornis didiformis, D. dromioides, D. gracilis, D. struthioides, D. ingens, and D. giganteus, appear to have bcen restricted in their range to the North Island. Dinornis rheides, which appears to have inhabited both Islands, is intermediate in the strengtl 1 and thickness of its limbs; and two species remarkable for their small size-Dinornis geranoides and D. curtus-have hitherto been found only in isolated localities.

As remarked by Sir Richard Owen, in one of his latest Memoirs, Dinornis maximus is spccially remarkable for its great size and strength even in a race of giants. One specimen exhibits such extreme measurements that Owen has suggested the existence of a yet taller species, for which he selects the provisional name of Dinomis altus.

Having had opportunities of examining very large series of boncs, exhibiting an almost continuous gradation of size from the largest to the smallest, my own belief is that some at least of the birds differentiated above are mere varieties or conditional states of one and the same species; but their discrimination is not the less interesting and important from a scientific point of view. Even Professor Hutton, whose paper "On the Dimensions of Dinornis Bones" (Trans. N.-Z. Inst. vol. vii. pp. 274-278) goes far to establish this view, especially as to the impossibility of defining " any strict line of demarcation between Dinornis elephantopus and D. crassus, is constrained to add :"Still, notwithstanding all that I have said, I am convinced that it will be necessary to retain the names both of crassus and elephantopus to mark both ends of the series as characterized by the proportions of the metatarsus, the length of which in D. crassus is more than four times the breadth of the middle of the shaft, while the length is less than four times the breadth in D. elephantopus and
D. gravis."

It is clear that Owen has not founded his species of different stature on a mixture of old and young birds, as has been alleged by some naturalists, because in the Canterbury Museum are exhibited not only young bones of each species, from the click to the full-grown bird where (to take only one bone as a guidc) the tarsal epiphysis of the metatarsus is not yet quite anchylosed *, but also of such species a series of specimens, generally showing two distinct sizes, from which it may be reasonably

bones "We have possess, amongst others, tho leg-bone of a specimen of Dinornis maximus which is in size only sccond to the largest bones we have, but in which this immature character in the metatarsus is not yet quite effaced."-Von Haast. 
inferred, by the analogy of other Struthious birds, that these represent the male and female of each specics.

Not the least interesting fact connectcd with these giant Wingless Birds is that they have passed away within the historic period. The remains of all the species mentioned above have been discovered intermingled with human boncs; they have been found, calcined and chopped, amid the rejectamenta of old Maori feasts in the ancient kitchen-middens of both Islands-facts whicl, quite apart from Maori tradition, prove incontcstably that they were coeval with the early native inhabitants, and that their final extirpation was accelerated, if indeed it was not occasioned, by human agency.

The only question remains-At what period of history did they cease to exist? The late Sir Julius von Haast, who had devoted years of study to the subject, came to the conclusion that the extinction of the various species of Dinornis dates back perhaps a thousand years, and that the association with man, as proved by the numerous kitchen-middens and cave-habitations which he himself explored, had relation to a prehistoric or autochthonous race which, in the remote past, inhabited New Zealand ". He wrote an elaborate paper, on "Moas and Moa-hunters," in support of this contention; but I do not think this view of the subject has obtained much support. 'To my mind the evidences of the comparatively recent existence of, at any rate, several species of Dinornis are overwhelming. The circumstance already mentioned of the discovery of a skeleton with a portion of the skin and feathers attached, in such a climate as that of New Zealand, is entirely opposed to the theory of remote antiquity.

Then, again, the comparatively recent date of the bones of even the larger species is attested by their chemical condition and the large amount of animal matter they contain. As compared with a recent tibia of the Ostrich, containing 26.51 of animal matter, the fossil femur of Dinornis didiformis has been found to contain 25.99. According to another comparative analysis, a recent femur of the Ostrich contained 34.86 of animal matter, and a fossil femur of Dinornis struthioides $37 \cdot 86$. As Professor Owen has already remarked, this superabundance of animal matter in the bone of the extinct bird is due chiefly to the fact of its being a marrow bone, whilst that of the Ostrich contains air.

With many of these buried skeletons are found little hcaps of crop-stones, of a kind that are now met with only at a distance of forty or fifty miles from the place of interment. I have in my possession a very interesting collection of these "gizzard-stones," consisting of quartz-pebbles, carnelians, and

* Even this champion for the great antiquity of the Moa would appear to have latterly somewhat changed his views on this subject. I have a letter in my possession from him stating that having read the report of my speech in the Native Land Court, as Counsel for the Ngatiapa in the Rangatira case, with the Appendix containing an account of Apa-hapai-taketake and the pet Moa of the Ngatituwharetoa tribe-a story accepted by both the contending parties as true-he felt almost constrained to abandon the ground he had so persistently taken up.

The following is an extract from the evidence given on that occasion by tho leading witncss, Hue Te Huri :- "I have heard the name of Apa-hapai-taketake an ancestor of the Ngatiapa tribe. He was the original source of the quarrel. Apa-hapai-taketake stole a Moa, which was a pet bird of the Ngatituwharctoa. While doing so he fell over a cliff and broke his thigh and was thenceforward nicknamed 'Hapakoki' ('Hop and go one '). He got off with tho Moa in spite of this. Then Ngatituwharetoa heard of it, and they went down upon his place and carried off his wifo Hincmoatu in payment (utu) for the Moa which he had stolen. Then Hapakoki in great wrath went and seized the kumaras of Kawerau; and Ngatituwharetoa, in equal wrath, mado an attack on the Nratiapa. Then the Ngatiapa left and came to Maunganui, on the Tpper Rangitikei ; for all this happened at Putauaki, near the Awa-o-te-Atua, in the Bay of Plcnty. The Ngatitnwharetoa pursued them and attacked them at Maunganui. Ngatiapa moved on south and settled on the north-east side of tho Taupo Lake; but they wero followed up and again attacked, and they again moved on to Tawhare-Papauma and Moturoa, south of Taupo, and close to Rotoaira, on the edge of the lake of that name." 

pieces of ehert, all worn and polished by attrition, showing that they had been in use for a considerable
time *.

The Hon.Walter Mantell, whose opinions on this point are entitled to every consideration, assigns a higher antiquity to the Moa-bones that are found under the stalagmite which forms the flooring to certain limestone cares, similar in character to those bone-cavcs in which traces of the early animals that inhabited Great Britain have been preserved to us; and he has declared his conviction that the more aneient species of Moa wcre extirpated by a race whieh inhabited New Zealand before the arrival of the aboriginal Maoris $\dagger$.

Many of these bones have been found undcr a considerable depth of fluviatile deposits which may be of Quaternary or even of Plioeene age.

There ean be doubt, however, from the evidences already mentioned, that some of the species, even of the largest stature, existed contemporaneously with the ancestors of the present race; and Mr. Mantell himself, during his early explorations in the South Island, discovered, drawn upon the walls of a eave in the Waitaki valley, a rude likeness of the Moa by some aboriginal artist of a bygone generation, painted with red oehre on the face of the rock, probably soon after the arrival of the first Maori immigrants.

Mr. Dallas, who, in 1865, deseribed (Proc. Zool. Soc.) the feathers of Dinornis rolustus, was the first to establish the fact that the feathers in some of the species of Moa possessed a large accessory plume or double shaft, as in the Emus and Cassowaries of Australia and the Indian Archipelago. In these feathers "the barbs consist of slender flattened fibres, bearing long silky and very delieate barbules, without any trace of barbieels."

In 1870 some feathers were found by Mr. S. Thomson, at the junction of Manuherekia with the Molyneux river, in assoeiation with Moa-bones under fifty feet of sand. Captain Hutton, in a letter to Professor Owen, described the feathers as being "quite fresh in appearance," and as having "lost none of their colouring." The largest of these is 7 inehes in length, and gradually widens from 25 of an inch at the base to rather more than 75 at the tip, where it is broadly rounded off. "The lower half is downy, the barbs having uneonnected barbules, and is of a brownish-grey colour. In the upper half the barbs are rather distant, unconnected, and without barbules. The brownish grey of the lower part passes gradually into black, which colour it keeps as far as the rounded tip, which is pure white, forming a narrow segment of a circle." It would seem from this description that these

\footnotetext{
* Mr. Frederick Chapman (to whom I am indebted for thcse 'Mroa-stones') writes :- "When we came upon the ground disturbed by the wind (the soil being shifting sand) we soou found a number of distinct groups of gizzard-stones. It was impossible to mistalke them. In several cases they lay with a few fragments of the heavier bones. In all cases they were in lay thickly str even where they had become scattered, each group only covered a few square yards of ground, and in that space one place itrewn. ..... The peculiar feature of the stones was that thcy were almost all opaque white quartz pebbles. In one place I found a small group of small pebbles of different colour, more like the few brown water-worn pebbles which may be of pebbles. I I d a d wese lay with a set of bones mueh smaller than the very large bones I found with most of the elusters is possible that the not gather these brown pebbles, as I thought it uncertain whether they were gizzard-stones or not, though it pebbles lying the speeies to which the smaller bones belonged was not so careful in selecting white stones. A glance at the and I collected about in the surrounding country showed that the quartz-pebbles were not collected here. . . . . Mr. Murdoch belongs to a three sets of pebbles, and these I can pronounce complete or nearly so. It is beyond question, too, that each set giant set a distinet bird. No. 1 weighs 3 lb. 9 oz.; No. 2 weighs 4 lb.; while No. 3 weighs no less than 5 lb. 7 oz. This (Trans. N.-Z.

† Trans. N.-Z. Inst. vol. i. pp. 18, 19.
} 
feathers belonged to a different species of Moa to that in the York Museum; but as none of the bones were obtained it was impossible to say to which of those enumerated above. Hutton's drawing of the feather (as given at p. 442 of the 'Memoirs') does not accord very well with his description. The figure given on plate cxiv. (l.c. vol. ii.) from the same correspondent seems to be more accurate.

At a somewhat later date other Moa-feathers, in an equally fresh condition, were found in a locality between Alexandra and Roxburgh; and these, according to Hutton, are distinguished by the presence of barbules to the tips, from which it may be inferred that they belonged to a less typical Struthious form.

In 1871 Dr. (now Sir James) Hector described a remarkable specimen from the same district, being the neck of a Moa, apparently of the largest size, upon the posterior aspect of which the skin, partly covered with denuded feathers, was still attached by the shrivelled muscles and ligaments*. This unique specimen was found by a gold-miner in a cave, or under an overhanging mass of micaschist, and is now in the Colonial Museum at Wellington.

In 1874 Professor Hutton described the right foot of Dinornis ingens "with the whole of the skin and muscles of the posterior side well preserved." It was found by Mr. Allen in a deep crevice among mica-schist rocks in the Knobby Ranges, in the provincial district of Otago. Of this specimen a figure, one-fourth the natural size, appeared in 'Nature' (Feb. 11, 1875). 'Through some inexplicable mistake the specimen is stated therein to be in the Natural History Museum at Paris; whereas,

* Sir James Hector, writing on this subjeet, says:- "The abore interesting discoreries render it probable that the inland district of Otago, at a time when its grassy plains and rolling hills were covered with a dense serubby vegetation or a light forest growth, was where the giant wingless birds of New Zealand lingered to latest times. It is impossible to convey an idea of the profusion of bones which, only a fow years ago, were found in this district, scattercd on the surface of the ground, or buried in the alluvial soil in the neighbourhood of streams and rivers. At the present time this area of country is particularly arid as compared with the prevalent character of Yow Zealand. It is perfectly trecless-nothing but the smallest sized shrubs being found within a distance of sixty or seventy miles. The surface-features comprise romnd-backed ranges of hills of schistose rock with swamps on the top, deeply cut by ravines that open out on basin-shaped plains formed of alluvial deposits that have been everywhere moulded into beautifully regular terraces, to an altitude of 1700 feet above the sea-level. That the mountain-slopes were at one time covered with forest, the stumps and prostrate trunks of large trees, and the mounds and pits on the surface of the ground which mark old forest land, abundantly testify, although it is probable that the interrening plains have never supported more than a dense thicket of shrubs, or were partly oceupied by swamps. The greatest number of Yoa-bones were found where rivers debonch on the plains, and that at a comparatively late period these plains were the hunting-grounds of the aborigines, can be proved almost ineontestably..... Still clearer evidenco that in very recent times the natives travelled through the interior, probably following the Xroa as a means of subsistence, liko natives in the countries where large game abounds, was obtaiued in 1865-6 by Messrs. J. and W. Murison. At the Maniatoto plains bones of several spoeies of Dinomis, Aptomis, Apteryx, large Rails, Stringops, and other birds are exceedingly abundant in the alluvium of a partieular stream, so much so that they are turned up by the plongh with facility. . . . A desire to account for the great profusion of Moa-bones on a lower terraco shelf nearer the margin of the stream, led the Messrs. Murison to explore the ground earefully, and by exeavating in likely spots they found a series of cireular pits partly lined with stones, aud containing, intermixed with charcoal, abundance of Moa-bones and egg-shells, together with bones of the dog, the egg-shells being in such quantities that they consider that hundreds of eggs must have been cooked in each hole. Along with these were stone implements of various kinds, and of several other varieties of roek, besides the ehert which lies on the surface. The form and contents of theso cooking-ovens correspond exactly with those described by Mantell in 1847, as occurring on the sea-const; and among the stone implements which Mantell found in them, ho remembers some to have been of the same chert which occurs in situ at this loeality, fifty miles in the interior. The greater number of thesc chert specimens found on the coast are with the rest of the collection in the British Museum.... The above facts and arguments in support of the view that the Moa survived to very recent times are similar to those advanced, at a very early period after the settlement of the colony, by Walter Mantell, who had the advantage of direct information on the subject from a generation of natives that has passed away. As the first explorer of the artificial Hoa-beds, his opinion is entitled to great weight. Similar conclusions were also drawn by Buller, who is personally familiar with the facts described in the North Island, in an articlc that appeared in the 'Zoologist' for 1864."' 
as a matter of fact, it has never left New Zealand and is now in the Otago Museum. This woodcut had appeared originally in 'La Nature'; and by the courtesy of the editor of that journal I am enabled to reproduce it here. Some excellent anatomical notes on this foot, by Dr. Conghtrey, were published in the 'Transactions of the New-Zealand Institute' (vol. vii. p. 269).

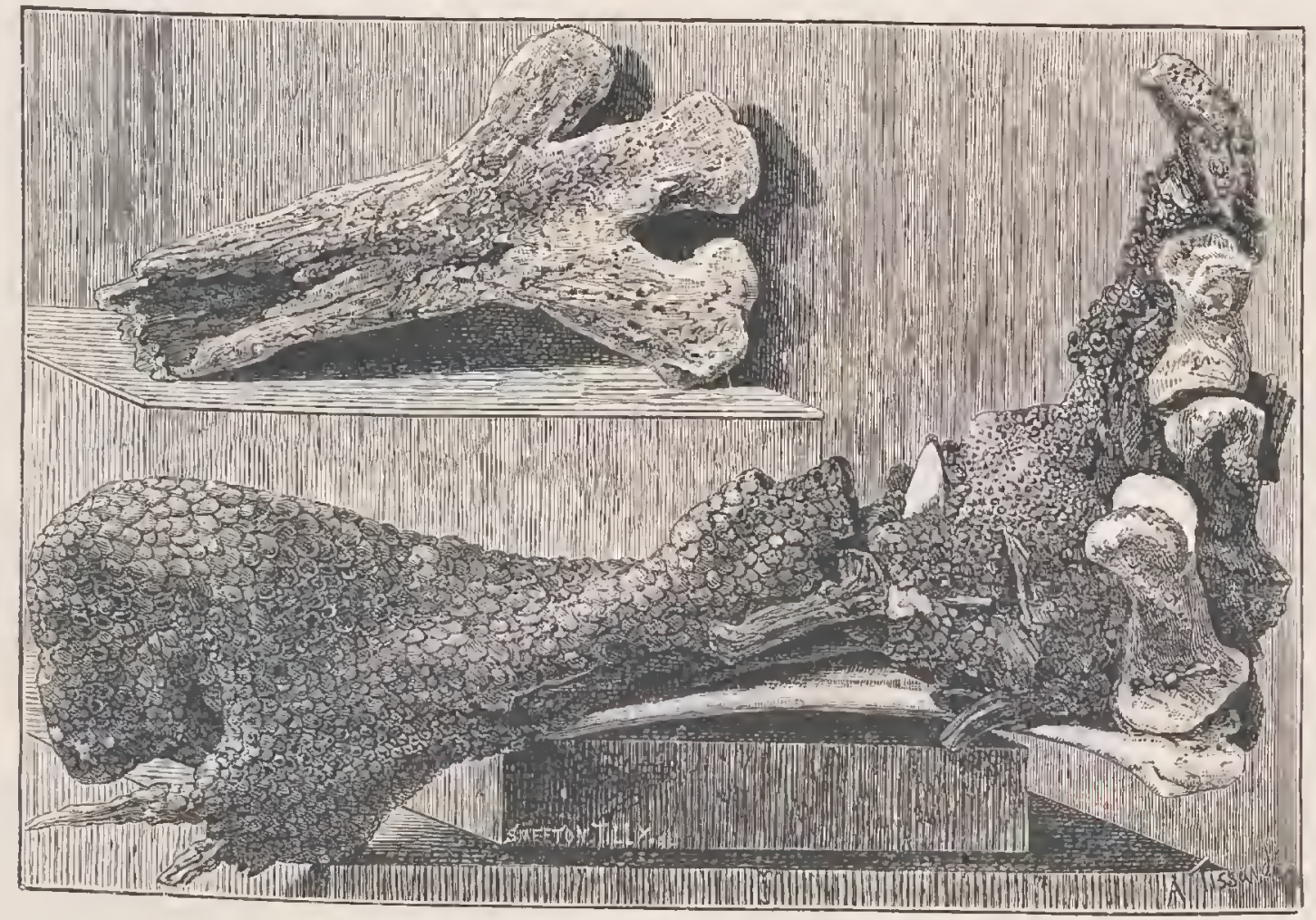

Two years later Mr. Taylor White discovered in some cares in the Wakatipu district (South Island) Moa-feathers of two very distinct types. Some of these feathers are now in my possession; they are in a high state of preservation, the colours being perfectly fresh, and many of them have both shafts quite entire. The largest of them measures nearly $6 \frac{1}{2}$ inches in length, and is of a uniform pale yellowish white, being the only feather of this kind out of more than a hundred collected. It is single-shafted, there being no sign whatever of the former attachment of an accessory plume; the barbs are rather distant, unconnected, and filamentary or hair-like, and are placed at such an angle with the shaft as to give a maximum breadth of about an inch and a half in the middle portion of the feather, the width diminishing towards the tip and tapering downwards almost to the base of the tube, there being no downy part *. This unique feather is evidently a dorsal one, and probably helped to form the loose uropygial fringe or lower mantle in one of the smaller species of Moa. Another feather belonging to the same bird, and measuring nearly five inches in length, is of a similar filamentary character, but is furnished with an accessory plume only 25 of an inch shorter than the main one; the former being dark brown with black margins, and the latter of a uniform brownish-yellow colour. There are smaller feathers, all of them single-shafted, with more distant, rigid, and shortened barbs, in which the shaft is of a transparent yellow colour, like polished amber. These, I should infer from their character, are from the neck of the bird. The rest of the feathers in this group, some of which are double-shafted, are deeply webbed with silvery-brown down for about two thirds of their basal

* A representation of this feather appeared in the Trane. N.-Z. Institnte (rol. xviii. pl. ii.); but the figure is a misleading one, as it represents the barbs thickly furnished with barbules, whereas in the feather itself they do not exist at all. 
extent, reddish brown in their apical portion, with whitish tips. It is probable that all these feathers belonged to Dinornis casuarinus, bones of which species were found in association with them in the Wakatipu cave, together with fragments of egg-shell of a pale green colour. The feathers from the Queenstown cave are of an entirely different type, and these may perhaps have belonged to Dinornis didinus. They measure from four to five inches in length; from the base for more than two thirds of their extent they have thick downy webs, of a uniform width of half an inch and of a greyish-brown colour, darker towards the shaft, the barbs having minute, thick-set barbules; then follow long, unconnected filaments, of a still darker brown, which run into a compact apical web of dark purple-brown, tipped with yellowish brown. Many of these feathers have an accessory plume, but this is always downy in its whole extent, which scarcely exceeds half the length of the main shaft. On placing a number of these feathers together they present a soft, glossy appearance and look as fresh as if plucked yesterday from the body of a living bird.

But a still more recent instance is afforded by the very interesting specimen of the Moa's foot in the University Museum at Cambridge, obtained in the Hector Ranges, Otago, in 1884. It was brought to England by Mr. W. J. Branford, who stated that he had himself found it in a cave where, as he believed, there was the entire skeleton of this bird and some more beside.

Professor Newton having kindly lent me this unique specimen for the purpose of having it photographed, I submitted it to Sir Richard Owen, who unhesitatingly pronounced it the metatarsal of Dinornis elephantopus*.

The bone is in a perfectly fresh condition, with about four square inches of dark brown integument, having a tuberous surface and with underlying dried tendons of a maximum thickness of 1.5 inch, adhering to the proximal extremity and representing the true heel; the astragalus (or a bone that performs the same function in the Apteryx, though not hitherto recorded in Dinornis) is in position, two of the phalanges are still articulated to the metatarsal by means of dried ligament, and a portion of the tough covering of the sole, nearly half an inch in thickness and of a yellowish-brown colour, is still attached to the lower surface.

Another piece of concurrent testimony was afforded by the discovery, about the year 1860, of a perfect Moa's egg, from whicl the contents had been extracted through an artificially bored hole on one side. It was found in an ancient Maori sepulchre at Kaikoura, and in such a position, in relation to the skeleton, as to suggest the idea that it had been placed in the hands of a corpse buried in a

* In the foregoing pages I lave made free use of Sir Richard Owen's name in connection with the successive discoveries of the Dinornithidx; I have stated his riews as they were developed from time to time, and I have given publicity to one of his letters to myself. Under these circumstances, I thought it right to submit the proof-sheets to him before going to press. The learned Professor returned them to me without a single alteration, but accompanied by a letter which I am glad (with his permission) to place on permanent record, the more so as he assures me that the active work of his life is ended and his last contribution made to the Royal Society, of which body he has becn so distinguished an ornament for upwards of half a century.

"MT DEAR BULLER, -

"Sheen Lodge, Richmond Park, 22nd March, 1888.

"Seldom have I enjoyed a morning more, in the quiet period of my existence, than during the perusal of the sheets of your 'Introduction,' so kindly submitted to mc.

"Conclusions and inferences which had escaped my memory havo been brought back, and I seem to be repeating or living again an active period of my zoological life.

"The Moa-bone from Hector Ranges, Otago, is a metatarsal of Dinomis elephantopus. . . . . . .

"I do not recall anything that I could add which would heighten the pleasurc your fricndly visit has given me.

"Ever yours,

"Sir Walter Buller, K.C.M.G., F.R.S."

"RICHARD OWEN." 
sitting posture. This unique egg was brought to England, and sold by auction at Stevens' salerooms, where it fetched only $£ 105$, and came into the possession of the late Mr. Dawson Rowley of Brighton, who figured and fully described it (under $D$. ingens) in his 'Ornithological Miscellany' *.

In 1866 two more eggs were discovered in the alluvial sandy loam of the Upper Clutha plains, Otago. One of these was two feet from the surface, the othcr only about a foot apart from it and three inches deeper. Of the first and more perfect one pieces wcre fitted togethcr, making nearly one complete side of the egg, which was estimated to measure 8.9 inches in length by 6.1 in breadth. It contained the bones of an embryo chick, which are now preserved in the Colonial Museum. The shell had been eroded by the solvents of the soil, but on the granular surface so produced the characteristic linear air-pores vere distinctly visiblc. The shell yielded 0.9 per ccnt. of organic matter, showing that it had not been long enough in the soil to part with all its soluble constituents $\dagger$.

No one who takes the trouble to examine the skeleton of Dinornis parvus which now stands in the Palæontological gallery of the British Muscum, exhibiting bleached but not fossilized bones, some of them still retaining their inherent "grease," will be able to resist the conclusion that the bird to which they belonged was living at a comparatively recent date.

The wcll-marked footprints of the Moa in the sandstones of Poverty Bay-modcls of which are now to be seen in most of our public muscums-are interesting historically, but their presence in such a formation is quite consistent with the alleged antiquity of the bird. The case is diffcrent, however, with the round cakes of excrement collected by Mr. Taylor White, with other Moa remains, in the Wakatipu cave, the condition of which was such that undigested fragments of fern-stalk and other vegetable matter could still be detected $\$$.

Further evidence of the comparatively recent existence of Dinornis. is afforded by the fact that mixcd with its remains are the bones of many species of birds still inhabiting New Zcaland. Among these I may mention the following genera:-Nestor, Stringops, Platycercus, Himantopus, Howatopus, Limosa, Larus, Diomedea, Rallus, Porplbyrio, Anas, Phalacrocorax, and Eudyptula.

With respect to the much reiterated assertion that the present race of Maoris have no traditions relating to the Moa, I would state that their ancient folk-lore, their historical waiatas (or songs), and probably the best modern authority on the traditions of the Maoris, has left on record $\oint$ a very full history of the Moa, as derived from these sources. According to that account the Moas still existed in considerable numbcrs when the first Maori immigrants arrived, from 500 to 600 years ago. There was little or no excitement in hunting these birds, because of their sluggish habits. They were numbers wholesale by setting the grass and scrub on fire, the Maoris killing in this manner vast numbers more than they could use, or even find, when these fires spread to any great distance. Thus * This egg was submitted to me for examination soon after its exhumation, and I made the following notes :-It is perfectly
oval and measures 0.3 inehes in brown as if it had 9.3 inehes in length by 7 inches in breadth; of a pale cream-colour, stained on one side with yellowish matter. The egg has a smeared with the yoke, an appearance which may have bcen due to contact with decomposed animal is about that of a new shillin appearance, the surface looking more like half-polishod Moa-bone than ego-shell, and its thiekness point of a pen-knife, and din. The ontire surface is covered with short linear air-pores, or minute puncta, as if made with the of pencilled markings, and disposed longitudinally; bcing filled with darker matter than the shell thej present the oharaeter dark markings on onc varying in extent from mere points to lines one tenth of au inch in length; there are some irregular in the shell.

\& Heetor in Proc. Zool. Soc. 1867, p. 996.

§ Tam. cit. pp. 102-103; cf. John White, tom. cit. p. 79.

† Trans, N.-Z. Instit. rol. viii p. 99. 
persecuted, the Moas rapidly diminished in numbers, and finally became extinct. . These traditions all agree in representing the Moa as living on fern-root, and as being inactive in its habits but fighting fiercely in self-defence. "As inert as a Moa" is a saying in use to the present day; and the name "moa," still applied to a small patch of cultivation, has allusiou to the manner in which these birds scratched up and harrowed the fern-root grounds.

From what we know of the range and habits of the Struthiones in other parts of the world, it cannot be supposed that the extinct race of Moas, comprising twenty, if not more, species or varieties, some of them attaining to colossal dimensions, were always confined within the geographic limits of modern New Zealand. The Ostrich inhabits the arid deserts of Africa, the Rhea (of which there are two, if not three, species, each occupying a separate district) is spread over a great portion of Anerica, extending from Patagonia to Peru, two species of Emu and a Cassowary occupy the Australian continent, the range of each being well defined, and eight other species of Cassowary are limited to New Britain, New Guinea, and the islands of the Indian Archipelago, each inhabiting a separate area. It may be safely assumed that the Moas of the remote past roamed over a wide continent now submerged, and that when, by the gradual subsidence of their domain beneath the waters of the Great Pacific, they were driven as it were into a corner and overcrowded, the struggle for existence became a severe one and the extinction of the race commenced; that the more unwieldy giants, thus "cabined and confined," were the first to succumb; and that the smaller species, perhaps in course of time differentiated from their ancestors by the altered physical conditions of their environment, continued to live on till their final extirpation by man within recent historic times.

Professor Owen compares New Zealand to one end of a mighty wave of the unstable and ever-shifting crust of the earth, of which the opposite end, after having been long submerged, has again risen with its accumulated deposits in North America, showing us in the Connecticut sandstones of the Permian period the footprints of the gigantic birds which trod its surface before it sank; and he surmises that the intermediate body of the land-wave, along which the Dinornis may have travelled to New Zealand, has progressively subsided, and now lies beneath the Pacific Ocean. But Professor Hutton, in his treatise 'On the Geographical Relations of the New Zealand Fauna,' considers it necessary to account for the phenomenal number of Struthious species inhabiting New Zealand, as compared with the other much larger areas of the earth's surface. He supposes the existence of an ancient continent, with one or two species of Dinomis; then, by some convulsion of nature, this continent sinks beneath the ocean, leaving its mountain-ranges exposed, in the form of islands, and the only refuge for the surviving Noas; after a sufficiently long period to allow of specific changes, there is an elevation of the land and the differentiated birds are mingled together; then follows the final subsidence, when New Zealand as the central mountain-chain becomes a "harbour of refuge" for them all. In support of this bold hypothesis he refers to the remarkable fact of five or six distinct species of Cassowary inhabiting isolated localities extending from New Britain and New Guinea to the Molucca Islands. His general conclusion is thus expressed :- "The distribution, therefore, of the Struthious birds in the Southern Hemisphere poiuts to a large Antarctic continent stretching from Australia through New Zealand to South Americi, and perhaps on to South Africa. This continent must have sunk, and Australia, New Zealand, South America, and South Africa must have remained isolated from one another long enough to allow of the great differences observable between the birds of each country being brought abont. Subsequently New 'Zealand must have formed part of a smaller continent, not connected either with Australia or South America, over which the Moa roamed. 'T'his must have been 
followed by a long insular period, ending in another continent still disconnected from Australia and South America, which eontinent again sank, and New Zealand assumed somewhat of its present
form."

Mr. A. R. Wallaee, commenting on this, in his 'Island Life,' says:- "If New Zealand has really gone through such a series of ehanges as here suggested, some proofs of it might perhaps be obtained in the outlying islands whieh were onee, presumably, joined with it. And this gives great importanee to the statement of the aborigines of thc Chatham Islands, that the Apteryx formerly lived there, but was exterminated about 1835 . It is to be hoped that some search will be made here and also in Norfolk Island, in both of which it is not improbable remains either of Apteryx or Dinornis might be discovered. So far we find nothing to objeet to in the speeulations of Captain Hutton, with which, on the eontrary, we almost wholly agree; but we cannot follow him when he goes on to suggest an Antarctic continent uniting New Zcaland and Australia with South America, and probably also with South Africa, in order to explain the existing distribution of Struthious birds. . . The suggestion that all the Struthious birds of the world sprang from a common ancestor at no very remote period, and that their existing distribution is duc to direet land communieation between the countries they now inhabit, is one utterly opposed to all sound principles of reasoning in questions of geographical distribution. ..... We havc direct proof that the Struthious birds had a wider range in past times than now. Remains of extinct Rheas have been found in Ccntral Brazil, and those of Ostriehes in North India; while remains, believed to be of Struthious birds, are found in the Eoccne deposits of possible that such an amount sea appears to be not more than about 1500 fathoms deep it is quite possible that such an amount of subsidence may have occurred. It is possible, too, that there may have been an extension northward to the Kermadec Islands, and even further to the Tonga and Fiji Islands, though this is hardly probable, or we should find more community between their productions and those of Ncw Zealand. A southern extension towards the Antaretie continent at a somewhat later pcriod seems more probable, as affording an easy passagc for the numerous species of SouthAmeriean and Antarctie plants, and also for the identical and elosely allied freshwater fishes of these
eountries." Professor von Haast, in his 'Anniversary Address to the Philosophical Institute of Canterbury'
(1874), objeeted to the above theory on the ground that the geological record of these islands, so far'
as we are aequainted with it, the land. He thus states the case:- " An unt our assuming sueh rcpeated changes in the level of good number of the species of its :- "An unfortunate eountry, such as New Zealand, of which a distant eountries, species of its fauna and flora show great resemblancc to other species from establish connexions in be dipped down and brought up again a grent many times in order to eross from the one to various directions, so that a bird or fish, a shell, inseet, or centipede might to pass." But Professor IIutton, morcover, without allowing any other species from the same country in an able artiele ' 1884, vol. ii. parts 1 . an extensive Antaretie eontinent, which, after qualifying his former theory by abandoning the idea of with South America, eontinent, and substituting a South-Pacific eontinent eonnecting New Zealand (

Which the various speeies of Moa were probably developed, Professor Hutton thus sums up his eonclusions:- Our general results
then are that in early Mesozoic timos Now Zealand, Eastern Australia, and India formed one biological region, land probably 


\section{THE EXISTING AVIFAUNA.}

Having given the reader a rapid glance at the extinct genera and species, it may be useful now to take a general view of the existing Avifauna, for the purpose of indicating the points in which it differs from that of every other zoological region on the earth's surface, and of showing the close relation of some of our present forms to the types that have passed away.

The leading feature in the Ornithology of New Zealand is thus expressed by a very accomplished zoological writer :- "Recent birds being divided into two great and trenchantly marked groups, of very unequal extent, the smaller of these groups (the Ratitce) is found to contain six most natural sections, comprising, to take the most exaggerated estimate, less than two score of species, while the larger group (the Carinatce), though perhaps not containing more natural sections, comprehends some ten thousand species. Now, two out of the six sections of this small group are absolutely restricted to New Zealand; and these two sections contain considerably more than half of the species known to belong to it. Thus, setting aside the Carinate birds of our distant dependency (and some of them are sufficiently wonderful), its recent Ratite forms alone (some twenty species, let us say) may be regarded as the proportional equivalent of one tenth of the birds of the globe-or numerically, we may say, of an avifauna of about one thousand species" *.

A perusal of the following 'History' will show that the Avifauna of New Zealand possesses other' distinguishing features of a very striking character, a full review and discussion of which would occupy many pages; but some of the more prominent of these may be here mentioned, more, however, in the way of general indication than with the intention of exhaustive treatment.

The feature that first strikes the general ornithologist is the comparatively large number of apterous birds, or species in whicl the anterior limbs are so feebly developed as to be absolutely useless for purposes of flight. Conspicuous among these are the four species of Apteryx, in which the wings are reduced to mere rudiments; next in order of development come the various species of Ocydromus, of which I shall have something to say further on, and the remarkable Ocydromine form,

extending eontinuously from New Zealand to New South Wales and Tasmania. At the close of the Jurassic period the NewZealand Alps wero upheared and the geosynelinal trough between New Zcaland and Australia was formed. During the Lower Cretaceous period a largo Paeifie eontinent extended from New Guinea to Chili, sending south from the neighbourhood of Fiji a peninsula that included New Zealand. Nearly all the southern part of Ameriea was submerged. Western Australia and Eastern Australia formed two large islands lying at some distanee from tho eontinent. This eontinent supported dieotyledonous and other plants, inseets, Iand-shells, frogs, a few lizards, and perhaps snakes and a few birds, but no mammals. In the Upper Cretaceous period New Zealand becamo separated and reduced to two small islands ; the South Pueifie continent divided in the middle between Samoa and the Society Islands and-the eastern portion being elevated while the eentre sank-it ultimately beeame what we know now as Chili, La Plata, and Patagonia. In the Eoceno period elevation commenced in our district; Eastern Australia was joined to New Guinea, whieh stretehed through New Britain to the Solomon Islands. Nẹw Zealand was also upheared and extended towards Ncw Caledonia, but the two lands were divided by an arm of the sea. The mainland of New Guinea had by this time been invaded from the north by a large number of plants, birds, lizards, suakes, \&c., whieh migrated south into Eastern Australia and a few passed over the New-Caledonia channel and reached New Zealand. But still no mammals. In the Oligoeene period New Zealand again grudually sank, earrying with it the sparse flora and fauna it had reeeived, and in Mioeene times was redueed to a eluster of islands; Eastern Australia all this time reeeiving eonstant additions to its fauna and flora through New Guinea. In the Plioeene period elevation onee more took place; New Zealand extended towards the Kermadee Islands, and the eontinent of Australia was formed; after which subsidence again occurred in New Zealand."

* 'Nature,' July 18, 1872 . 
distinguished by Hutton under the generic name of Cabalus, from the Chatham Islands; then Notornis, the huge brevipennate Rail already mentioned; a small flightless Duck (Nesonetta aucklandica), strictly confincd to the Auekland Islands; and, finally, the well-known Ground-Parrot (Stringops habroptilus), in which the sternum is almost devcid of a keel. The explanation in all these cases is sufficiently obvious. In a country like New Zealand where there have bcen no indigcnous Mammalia, and consequently few birds of prey, spccies that habitually seek their food on the ground have no inducement to take wing, and from long disusc, continued perhaps through countless generations, lose the Carinate charaeter of the sternum, and with it the faculty of flight, for without the keel on the breast-bone to give attachment to the great pectoral muscles the wings, however ample they may be in their outrvard development, are practieally useless for purposes of flight.

Taking the Carinate division of our Avifauna, another very prominent eharaeteristic is the number of endemic genera and speeics. The families, with a few exceptions to be hereafter mentioned, are the same that occur in other parts of the world; but when we come to examine the subordinate groups, the specialization is at once apparent. Out of a total of 88 genera, 47 belong to the Limicolce, Herodiones, and the five web-footed Orders, and these, being in a sense cosmopolitan, may for the present be put out of sight. Of the remaining 41 genera, 21 are strictly peculiar to New Zealand. But even in the other more widely-spread genera there are many species that are not known elsewhere. Thus, out of a total of 181 species, composing the present list of our Carinate, no less than 93 are strictly endemic. Even among the most diffuse Orders there are genera restrieted in their range to the New-Zealand rivers or coasts, or to the outlying islands. Thus among the Limicolæ we have two strictly peculiar genera, Thinornis and Anarhynchus, and among the Anseres two more, namely, Hymenolcemus and Nesonetta.

Of the former, Thinornis belongs really to the Chatham Islands, for although T. novoe zealandice is comparatively common there, only straggling flocks are met with, at uneertain intcrvals, on the New-Zealand eoast; and of the latter, Nesonetta is confined exelusively to the Auekland Islands, the only known species, $N$. ancklandica, never having been met with elsewhere. The other two genera I have instanced, Anarhynchus and Hymenolomus, are restricted to New Zealand, never having been met with on the outlying islands.

Undoubtedly the most remarkable bird we have among the Waders is the Wry-billed Plover (Anarhynchus frontalis), in which, as the name implies, the bill is asymmetrical, being always turned to the right, a modification of structure admirably fitted to the bird's peculiar habits of feeding. 'The curvature in the bill is eongenital, being equally present in the embryo ehick, although not so fully developed; and this faet furnishes a beautiful illustration of the law of adaptation and design that prevails throughout the whole animal kingdom. A bird endowed with a straight bill, or with an upeurved or deeurved onc, would be less fitted for the peculiar mode of hunting by which the Anarhynchus obtains its living, as must be at once apparent to any one who has watched this bird running rapidly round the boulders that lie on the surface of the ground and inserting its scoop sidewise at every step, in order to collect the insccts and their larvæ that find concealment there. But there is another feature in the natural history of this speeies that is deserving of special notice, whieh is this: the fully adult bird is adorned with a black pectoral band, which, in the male, measures .75 of an inch in its widest part. Now it is a very curious circumstance that this band is, as a rule, far more conspicuous on the right-hand side, where, owing to the bird's peculiar habit of feeding, 
there is less necessity for concealment by means of protective colouring* * This character is constant in all the specimens of the male bird that I have examined, although in a variable degree, the black band being generally about one third narrower and of a less decided colour on the left side of the breast,-from which we may, I think, reasonably infer that the law of natural selection has operated to lessen the colouring on the side of the bird more exposed to Hawks and other enemies whilst the Anarkynchus is hunting for its daily food. There can be no doubt that a protective adrantage of this sort, however slight in itself, would have an appreciable effect on the survival of the fittest, and that, allowing sufficient time for this moditication of character to develop itself, the species would at lengtl, under certain conditions of existence, lose the black band altogether on the lefthand side.

Commenting upon the above remarks, in my first edition, the accomplished Editor of 'The Ibis" (Mr. Salvin) indulged in the following reflections:-

"It would appear that the peculiarly shaped bill would only be an efficient weapon for obtaining food in this way so long as the bird walked one way round the stone, i.e. bearing to the off side or from west to east! The wider portion of the pectoral band would thus be always next the stone, and more hidden than the narrower or left portion. Has running round stones always the same way been the cause which enabled those birds which practised it to survive and transmit this habit to their offspring? and has their success been further promoted by the tendency to reduce the exposed side of their pectoral band, a secondary sexual character? Or has the process been reversed and the protection given to those birds which ran one way round stones, keeping the prominent portions of their pectoral bands from sight, tended to produce the curvature of the bill? The development of both characters seems to hang upon the birds acquiring the habit of running only one way round stones " + .

It seems to me that the more correct way of putting it is that the bird must, under any circumstances, keep the stone around which it is feeding to the right; for, in whatever way the habit may have been acquired, it is obvious that inasmuch as the curvature of the bill is always to the right it can only serve as an efficient scoop when the bird is in the left position in relation to the stone.

I do not propose to enter here into a discussion of the theory which a consideration of these facts seems necessarily to involve; but such cases as this can be rationally accounted for only on Darwinian principles, and I see myself no difficulty whatever in reconciling this view of the evolution of species by means of natural selection with a belief in the unity of design in Creation, and with the acceptance of the great truths of revelation. It is not a question of the Creation itself, as divinely rerealed to man, but as to the plan and method of the Creation ; and when, instead of the old literal interpretation of Sacred Scripture, we understand by the "six days" of the Mosaic record so many vastly extended geologic epochs, every difficulty in the way of orthodox belief disappears \$.

* Mr. Secbohm states that in the two specimens which his collection contains this unsymmetrical character of the pectoral band is not observable, but he does not give the sex; and it is a curious fact, for which I do not pretend to offer any explanation, that in the fcmale bird, in which the pectoral zone is quite inconspicuous, the peculiarity I hare mentioned is hardly noticeable, if it is not entirely absent. As to the feature itself in relation to the male bird, I can only say that I have never met with a single example in which it was not more or less mavifest; indeed the first to call my attention to it was Sir James Heetor, with whom, years ago, I examined the fino series of specimens in the Colonial Aluscum, and with the result I have stated.

+ Ibis, 1873 , p. 93 .

‡ "Allowing that Almighty Power has worked by constant laws, we have to consider the lapse of time during which our globe may have revolved in its orbit, iu a condition approximating to the present, $i$. e. capable of sustaining vegetable and 
'To quote the language of one of the ablest and most liberal-minded of our theologians:"Science discloses the method of the World, Religion its cause, and there is no conflict between them, except when either forgets its ignorance of what the other alone can know."

The next point to be noticed is the comparative abundance, in comparison with the rest of our Avifauna, of Rails, Ducks, and Cormorants. The first-named group contains in addition to Notornis and its allied form, Porphyrio, four, if not five, species of Ocydromus, three of Rallus, two of Ortygometra, and the diminutive Ocydromine representative in the Chatham Islands. Of Ducks, New Zealand possesses 11 species, belonging to ten genera, this number being far in excess of the proportion of Anseres to the general number of birds in other countries of similar extent. Of these Ducks, seven species are endemic, two of them (Nesonetta and Mergus) being confined to the small area of the Auckland Islands. Of Shags or Cormorants, including two at present doubtful forms, there are no less than fourteen species, of which eight, if not nine, are endemic, so that New Zealand in this respect takes the palm against all competitors. Some of the species, too, are of singular beauty, whereas in all other parts of the world the members of this family are noted for their plain faces and sombre plumage.

Seeing that New Zealand is so rich in Cormorants, it is indeed remarkable that there is no indigenous species of Plotus, a form so characteristic of Australia on the one hand and South America on the other. I have already recorded the occurrence of Plotus novce hollandice as a straggler, which serves only to accentuate the inexplicable fact of its not being a native.

The entire absence of Woodpeckers might have been expected, as these birds do not extend beyond Celebes, never having been met with in the Moluccas or in Polynesia, New Guinea, or Australia. But it is difficult to account for the non-appearance of Swifts and Swallows, except as occasional visitants from Australia.

On the other hand, the Parrots are well represented. Besides the very typical Stringops hatro-

animal life npon it. We have to allow time for those forgotten migrations of our race, for the previous rise of their religions and other cnltured ideas in the East, and for the possible transmutation of animals from the sanrians \&c., revealed by gcological investigations, to the present species. The several thousand jears which hare elapsed since some of the existing species were
preserved as preserved as mnnmies in Egypt appear to have offected no change. Int when we contemplate even 10,000 yeurs as relatively a fall if able to refect omewhat in the natural state of crror in which the mind of an eplemeral snmmer-day's insect might the chrysalis, it minht form estimates of time from the duration of its own existence? Living for one day after its rise from a century, have allowed about sixty days a long period for the life of the man who can crush it, just as we, able to live torards statement wickcdly prout sixty centuries only for the duration of hnmanity npon the earth. Tho insect might fancy the a simile, it docs not seem an informed that onr existences might extend to some 20,000 times the duration of its day. $\Lambda \mathrm{s}$ 25,550 days of mas, so man irrational proportionate comparison by ' rule of three ' to say that, as tho insect's one day is to tho completion of its prin, so may the human 70 years be to $1,788,500$ years for the life of the world, past and future, after the and about the thirtiety formations. If we allow abont a fourth of these for the past changes of species (viz. 400,000 years), scientific culture, the part (viz. 50,000 years) for man's growth from infancy, from crude civilization to our present state of than our old do, compntation seems reasonable in the light of scientific facts. It is at all events more consonant with them

"From a consideration of the posidele-lend of Arts and Creeds.

the earth can have been cooling to possible sonrees of the heat of the sun, as well as from calculations of the period during which William Thomson conclndes cooling to bring abont the present rate of increase of temperature as we descend beneath the snrface, Sir maximum possiben the crust of the earth cannot have been solidified mnch longer than 100 million years (the putable. . . . . . So far as the tions), and this conclusion is held by Dr. Croll and other men of eminence to be almost indisby physicists is not far as the time required for the formation of the known stratificd rocks, the hundred million years allowed demanded by $\mathrm{Jr}$. only ample, but will permit of even more than an equal period anterior to the lowest Cambrian rocks, as Huxlcy and Professor Ram demand supported and enforecd by the arguments, taken from independent standpoints, of Professor and Professor Ramsay."-Island Life. 
ptilus, already mentioned, we have seven species belonging to the genera Platycercus and Nestor, all of which are peculiar to New Zealand and her satellites.

As compared with the Avifauna of Anstralia, the paucity of species is particularly noticcablc in the following well-distributed families, namely, Sylviidce, Campephagidce, Muscicapidce, Alcedinidce, Columbidae, and Tetraonidce.

The families belonging exclusively to New Zealand are five in number-the Tumagrida, Xenicidce, Nestorida, Stringopida, and Apterygidce - and, as already indicated, possibly a sixth represented by the remarkable genus Glaucopis. The great development of the Procellariidce, or Family of Petrels, is a featurc which New Zealand shares in common with Australia and Southern Polynesia. The Sonth Pacific is the great nursery, so to speak, of this extensive Family, and no less than 33 species have, from time to time, been recorded on thc New-Zealand coasts or from the surrounding seas. These include nearly all the known species of Albatros, and a number of oceanic birds of considerable interest, although as a rule not conspicuous for their beauty. Somc of thesc have a rangc extending over both hemisphcres; others are confined to apparently small tracts of ocean; while others again are migratory within certain degrees of latitude and longitude. Altogether they comprise a well-defined group of Birds (raised now to the dignity of an Order, under the name of Tubinares), whosc cconomic and domcstic history, owing to their pelagic and semi-nocturnal habits, has not yet been fully investigated or rccorded.

The occasional capture in New Zealand of such tropical forms as Phaethon rubricauda and Tachypetes aquila, although interesting occurrences per se, cannot be regarded, in any strict sense, as a feature in the Avifauna.

Of Meliphagine birds New Zealand posscsscs a fair number in the gcnera Prosthemadera, Anthornis, Pogonornis, and, in a lesscr degrec, in Zosterops and the brush-tongued Nestor, all of which are endemic; but the honey-eating genera of Australia, such as Ptilotis, Meliphaga, and Tropidorhynchus, are entirely absent. Acanthochara carunculata has occurred in a wild state, but only as an extremely rare straggler from the Eucalyptus-brushcs of its native conntry.

Among the Limicole therc are several species which touch at New Zealand in their seasonal migrations to and from the higher latitudes of the Eastern Hemisphere, or make this country their winter residence. Dr. Otto Finsch, as far back as 1867, in the Notes appended to his German translation of my 'Essay on the Ornithology of New Zealand,' expressed his surprise that such species as Strepsilas interpres, Totanus incanus, and Tringa canutus had not been rccorded among thesc seasonal migrants. Since that time all of thesc, as well as Phalaropus fulicarius, Numenius cyanopus, and Tringa acuminata, have been added to the list. The two most remarkable instanccs, however, of this class are, on the onc hand, the occasional occurrence of the Eastern Golden Plover (Charadrius fulvus), whose range extcnds over Australia, Ncw Guinea, the islauds of the Indian Archipclago, and Polyncsia, and northwards to its breeding-grounds in Siberia and Kamtschatka, and, on the other, the regular autumnal migration of the Bar-tailed Godwit (Limosa novce zealandice), which gocs northwards to breed in the high latitudes of Eastern Asia. To my mind, in the wholc romance of natural history there is nothing to be compared with this scasonal migration of the Godwit. This bird is the Eastern representative of the European Limosa lapponica, to which it bcars a close resemblance; and, like that species, it has a very extensive geographical range. Both of thcm are migratory in their respective hemispheres; and while the other species breeds in the high Northern 
latitudes of Europe, and returns in winter to North-west and East Africa, our bird spends a portion of the year in Siberia, and visits, in the course of its migration, the islands of the Indian Archipelago, Polynesia, Australia, and New Zealand! Towards the end of March, or beginning of April, large flocks may be seen at the far North taking their departure from our conntry. Rising from the beach in a long line and with much clamour, they form into a broad semicircle, and mounting high in the air, take a course due north: sometimes they rise in a confused mauner, and, after circling about at a considerable height in the air, return to the beach to reform, as it were, their ranks, and then make a fresh start on their distant pilgrimage. After foreign travels and adventures which the pen of Audubon alone could do justice to, the flocks begin to reappear at the north during the first week of November, and then rapidly disperse along the coast.

This subject of the seasonal migration of certain birds is a very wide one and full of interest. There is probably nothing in the whole field of ornithological research more remarkable than this traditional habit, acquired no doubt by experience accumulated through countless generations. The same unerring instinct which guides the Ground-Lark to her nest under some particular tussock in the midst of a wilderness, miles in extent, of exactly similar tussock, or which enables the sea-bird to single out her own eggs from among the thousands clustered together on the bare rock or sandy beach, likewise guides the movements of the migrant when the time comes round for its annual pilgrimage.

We have in New Zealand two species of Cuckoo belonging to different genera-both migratory and both parasitic. One of these (the Long-tailed Cuckoo), which is a native of the Society Islands, visits this country in the summer and breeds with us, entrusting the task of rearing its young to a little Warbler not larger than an English Wren. It arrives, year after year, during the second week of October, and leaves us again before the end of February-this migratory habit, persevered in through long generations, having become a necessary part of its natural existence. In the whole range of ornithological biography, there is perhaps nothing more marvellous than this punctual aunual migration across some fifteen hundred miles of ocean. The other species, known as the Shining Cuckoo, visits us from Australia, performing its journey of a thousand miles with the same wonderful precision as to dates of arrival and departure, my register showing only a maximum variation of five days during a continuous period of ten years. Curiously enough, this mild little caterpillar-hunter entrusts the rearing of its young to the same bird that performs that friendly office for its predatory congener four times its size. But apart from these regular summer visitants, with which most colonists are familiar, we have numerous instances of eccentric and casual migration which are indeed very curious. The history of the little Zosterops, or Blight-bird, is a case in point. This migrant crossed Cook's Strait, for the first time within the memory of man, in the winter of 1856 , coming over in numerous flocks, as if to explore the country; then retired for two years, and reappeared in greater numbers than before in the winter of $\mathbf{1 8 5 8}$, since which time it las been a permanent resident in the North Island, breeding in every district, and becoming more plentiful every year. This migration was no doubt induced, in the first instance, by a scarcity of some particular food-supply in the South case is, that after the second migration the natural impulse to return home had lost its influence.

In Australia we have several records of non-migratory birds performing a kind of exodus from their orwn part of the country, swarming into some distant region, where they have remained for five or even ten years, and then disappearing as suddenly as they had come. 'Take, for example, the 
beautiful little Warbling Parrakeet (Melopsittacus undulatus), which, prior to 1838, was so rare in the southern parts of Australia that only a single example had been sent to Europe, but arrived in that year in countless multitudes. Or take the case of the Australian Moorhen (Tribonyx ventralis). This bird, althongh not endowed with any extraordinary powers of flight, acting under some mysterious influence, left its home in the remote interior and visited South Australia in 1840, coming in such countless myriads that whole fields of corn were trodden down and destroyed in a single night, and the streets and gardens of Adelaide were alive with them. But the casual occurrence with us of migratory species from Australia is even more singular, because it seems impossible to assign any definite cause. In March, 1851, a flight of the Australian Tree-Swallow appeared at Taupata, near Cape Farewell ; ten years later they were observed again at Wakapuaka, near Nelson, and a specimen obtained; and after a further lapse of fully twenty years another flight-from which a specimen is now in my possession-appeared for several days in succession in the outskirts of Blenheim. More recently, the Press Association announced the appearance of "Swifts" at the White Cliffs, near Taranaki, and on receiving the only specimen that was shot, I found it to be the true Australian Swift (Cypselus pacificus), a bird common enough on the Hunter but migratory northward, and believed by most naturalists to be identical with the species inhabiting China and Amoorland. The two instances of the occurrence in New Zealand, after an interval of twenty years, of the Australian Wattlc-bird (Acanthocera carunculata), and more recently, in both North and South Islands, of the well-known Australian Roller (Eurystomus pacificus), are cases in point; and other instances might be given of the mysterious, overpowering impulse, under the influence of which certain birds, without any apparent motive, perform almost incredible aerial journeys without a break of any kind.

Another remarkable feature in the New-Zealand Avifauna is the inherent tendency to albinism *. The condition itself is no doubt due to the absence of the colouring-piginent in the feathers; but the difficulty is to find any sufficient cause for this in a temperate climate like that of New Zealand. In India, as is well known, the tendency is in the opposite direction, melanism being of very frequent occurrence.

Strange to say, there is the same tendency to albinism in the imported birds. Albino Sparrows

* In the body of the present work will be found carefully reeorded instances of albinism, more or less pronouneed, in the following species, viz. :-Gliucopis wilsoni, G. cinerea, Heteralocha acutirostris, Creadion carunculatus, Myiomoirc macrocephala, Anthus nove zealandice, Anthornis nelanura, I'rosthemadera novce zealandice, Platycercus novce zealendice, P. auriceps, Nestor mevidionalis, Spiloglaux novce zectlandice, Sceloglaur albifacies, Circus gouldi, Carpophaga novee zeulandia, Hcematopus longirostris, H. unicolor, Himantopus nowe zealandiu, Limosa novce zealandice, Larus dominicanus, Ocydronus earli, O. austratis, Porphyrio melanonotus, Ardea sacra, Phalacrocorax nove hollandice, Ossifraga gigantea, Anas superciliosa, A. chlorotis, A. gibberifrons, Pocliceps rufipectus, Apterye australis, A. mantelli, and A. oweni.

To the above list Mr. Kirk has reccntly added Myiomoira toitoi, having deseribed ("Ibis," 1858, p. 42) a speeimen in the possession of Mr. J. H. Drew of Wanganui, in whieh the only indieation of the normal colouring is a small patrh of faint grey on one of the primaries, the whole of the remaining plumage being pure white.

In my aeeount of Anthus novce zealandice I have stated (at p. 64) that albinos, more or less pure, are of eommon oeeurrenee. In the above-eited eommunieation Mr. Kirk says of this speeies :- "While travelling through the bush on tho east coast of the Wellington province, I eame on a Maori plantation, and was shown by one of the natives a Ground-Lark exhibiting a tendeney both to albinism and melauism. 'Tho following is a deseription, jotted down in my locket-book:-Top of head, and down as far as a line through the eye, dull black; tho whole of the body and wings, with the exeeption of the two outer primaries, were a delieate ereamy white; the outer primaries retained the normal greyish-brown eolour. The outside tail-feathers, which in an ordinary specimen wonld be white, were in this case jet-black. This bird, which was one of the most curious freaks of nature I ever saw, had been tamed, would come when ealled and allow itself to be picked up and examined, as though conseious of deserring attention on account of its extraordinary and fantastic dress. I endearoured to effect a purchase, but without suecess, the Maoris appraring to set great store by their pet." 
are far more common than they are in their native eountry, and even the Sky-Lark (Alauda arvensis) not unfrequently exehanges its sober dress for a yellowish-white one. In illustration of this I brought to England two speeimens of the latter, one of which I presented to the British Museum, the other to the Natural-History Museum at Cambridge.

Among the Parrots I have recorded some beautiful erimson and yellow varieties, and in the ease of Platycercus novce zealandice a single instanee of eyanism. But the only New-Zealand birds in whieh I have ever deteeted any tendeney whatever towards melanism, and then only in a slight degree, were Anthornis melanura and Miro albifrons.

Many traveller's in New Zealand liave remarked on the notable absenee of bird-life, especially in the woods; and at certain seasons of the year this is indeed rery noticeable. But, as fully explained in my history of the Wood-Pigeon at page 232, the relative abundanee or scarcity of birds is entirely regulated by the food-supply, whieh, in turn, is governed by the seasons. At all times, however, in winter and summer alike, the New-Zealand woods, whether alive with birds or not, possess an inclescribable charm owing to their evergreen charaeter. In my several aeeounts of their feathered inhabitants I have, as the reader will pereeive, never lost an opportunity of paying my tribute to the luxuriant beauty of these woods; but I hare always felt that it was quite impossible to do full justiee to the subjeet *.

In the strietest sense of the term, New Zealand is without "song-birds"; but such speeies as the Tui, the Korimako, and the Piopio possess voeal porvers of a very respeetable kind, the compass and variety of their notes adding greatly to the eharm of the New-Zealand woods. For example, the North-Island Thrush (Tumagra hectori) has many notes exaetly resembling those of its English namesake. As fully explained at pp. 28, 29 this handsome speeies is rapidly dying out and will soon be but a memory of the past. But with the disappearanee of this native Thrush, the English songster is fast beeoming established in the eountry, frequenting the outskirts of the bush in the neighbourhood of European settlements and supplying to the loyal eolonist yet another link of attachment to "dear old England."

Setting aside, however, their elaim to the highest order of song, the birds of New Zealand do not fail, especially in the early morning, to make their native woods eeho with delightful music, "eaeh one giving out his own notes without any regard for the others, the seore having evidently been written for the whole, since the innumerable strains make one divine harmony." In the midst of this melody of song, the harsh cry of the Kaka calling to its fellows will sometimes for a moment break the spell, but the performers, heedless of the discordant note and with bursting throats, continue their morning coneert, till, as if by eommon eonsent, they cease altogether and disperse in quest of their daily food.

Another fenture not to be lost sight of in considering the present condition of the New-Zealand Avifauna is the rapid way in whieh it is being affected, and in some instances effaeed, by the intro-

* Mr. W. R. Ringland, of Belfast, who accompanied me through one of the northern forcsts, in the summer of 188t, thus graphically describes it in his ' Notes of 'Travel' :-

"This bush scenery is indeed very wonderful. The enormous cabbage-trees, the gorgcous creepers clinging in a green network to the tall pines, the denso undergrowth of shrubs, the trec-ferns, the great kauris, and the oxquisite tints of the whole mass of riotous regetatiou are beantiful beyond description. Then the strange silence, unbroken even by the whir of a birds wing, the unchanging samcuess of the bush, that confuses you until you cannot tell how far you have travelled, the charred treetrunks on either side of the road that have been burnt down to clear a passage, and the oppressive loneliness of it all, tell that you are far away from the beaten track of travel, and far into the heart of M.aoriland." 
duction of the so-called useful and ornamental birds from other parts of the world. The conditions of existence are very favourable to the establishment and increase of many of the imported forms, and, as a consequence, the indigenous species are being displaced and supplanted by them to a very alarming degree. The colony of New Zealand, like every other new country, has been, from time to time, possessed as it were by a rage for acclimatization; and the zeal for the introduction of novelties has not always been tempered by the judgment which comes of experience. The Author must himself plead guilty to having been accessory to the importation of the House-Sparrow in 1865, having in that year, on behalf of the Wanganui Acclimatization Society, advertised in the London newspapers offering a reward of $£ 100$ for 100 pairs of House-Sparrows delivered alive in the colony. The advertisement and the importation alike succeeded; and at the present day myriads of these birds in all parts of the country attest the fact, and in the grain-season especially they elicit even from their strongest partisans the admission that they are not an "unmixed blessing." While, however, admitting myself that the "Sparrow nuisance" does exist in rather an aggravated form, I do claim on behalf of this bird full credit for its strictly insectivorous habits at a certain season of the year, and I have never lost an opportunity, in spite of the odium, of putting in a plea for the poor persecuted Passer domesticus*.

* As with all questions of this kind, thero is mueh to be said for and against tho Sparrow, and numerous experiments have been made by friends and foes for the purpose of demonstrating the actual truth of the case. The following nowspaper reeord eontains the result of one of these experiments, and, so far as my observation goes, the wcight of evidenee is invariably in favour of the bird :--"A hnndred and eighteen Sparrors have been offered npon the altars of seienee. As was tho ease with the Pagan sacrifiees, their entrails have been carefully inspected, in order to furnish guidanee to the inquirers. But it has not been in seareh of the eabalistic information to be derived from quaint eontortion, or the eredited, though impossible, absenee of the heart, or some other vital organ, that the saerificial knife has been bared. The eontents of the stomaehs of tho victims have been examined, tabulated, reeorded. Three culprits alone, out of this heeatomb of the favourites of Cytherea, were proved, by tho unsparing seareh, guilty of having lived for the past four-aud-twonty hours upon grain. In fact, there were three thieves out of the 118; all the other pietims had worked, more or less, for their living. Beetles, and grubs, and flies, and larvae of all obnoxions kinds had been their diet. In 75 of the birds, infants of all ages, from the eallow fledgling to the littlo Pecksy and Flapsy that eould just twitter along the gronnd, hardly any but inseet remains were deteeted. What would the starred and indnstrious pionecrs who have reared their wonderful temple and eity by the Great Salt Lake have given for the aid of an army of English Sparrows against that greater and more formidable host of grasshoppers which thriee all but annihilated the settlement?"

To give the other side of the argument, and to show that the prejudiee against the Sparrow and its eonsequent punishment is not eonfined to New Zealand, I may quote the following newspaper account of its status in Australia :- " Rome onee owed its salvation to a Goose, but it has been reserved for the Sparrow in those degenerate modern days to threaten a flourishing young State with serious loss, if not, as the farmers assert, absolute ruin. Rabbits have for some jears played an important part in direeting legislation in some of the Australasian Colonies, and now iu South Australia the Sparrow is beeoming a power in the land, and ealls for all the machinery of special Acts of Parliament to keep it within bounds. The bird, which only a ferr years ago sueh efforts were made to aeelimatize in Australia, and whosc first arrival was hailed with greater enthusiasm than would now be displayed on the landing of a Bend Or, a Duehess, or a prize merino, is now doomed to extermination-if that ean possibly be aehieved. So rapidly havo tho few pairs whieh were introduced a few years ago multiplied uuder the congenial skies and amid the luxuriant vegetation of the Australian Colonies, whero there are few or none of the cheeks on their increase which exist in the Old Country, that the agriculturists eomplain of the serious injury done by them to their wheat and fruit erops, and have ealled upon the Government to dovise some meaus of ensuring their destruction. . . . . Its work is done on a seale dishenrtening to the eultivator, and under eonditions he eanuot control, for the seed is taken out of the ground, the fruit-bud off the tree, the sprouting regetable as fast as it grows, and the fruit ere it is ripe, and therefore before it ean be housed and saved. Neither aprieots, eherries, figs, apples, grapes, peaehes, plums, pears, neetarines, loquats, olives, wheat, barley, peas, eabbages, cauliflowers, or seeds or fruits of auy kind, are spared by its omnivorous bill; and all means of defunee tried against its deprodations, whether searcerorrs, traps, netting, shooting, or poisoning, are deelared to bo insufficient to eope with the enemy. It remains to be scen whether the reward offered by the Government for the heads and eggs of these destructive little birds will result in any diminution in their numbers." 
To my mind the popular outcry against the Sparrow is scarcely warranted by the actual state of the case. It is only at one particular period of the year, when the farmer's grain is "dead ripe " that this bird nakes any inroad upon it. In large fields the loss is barely noticeable; but in the case of a small patch of grain, say an acre or two at the edge of the forest or in a bush-clearing, it naturally becomes a serious matter, because the Sparrows appear to concentrate their forces on such inviting spots, and to leave practically nothing but straw for the reaper. Hence, of course, the outcry and clamour on the part of the small farmer. But if people really knew how much the country is indebted to this much-abused bird, I venture to think that there would be a still louder outcry against the sinful practice, now so general, of poisoning Sparrows. It is a fact that on some farms they are poisoned in such numbers that the ground is literally strewed with their dead bodies, and labourers may be seen filling large baskets with them, and carrying them off in the confident belief that a great service is thus rendered to the farming industry of the country. But what are the facts? Is the Sparrow insectivorous, or not, in the strict sense of the term? Let us study it in the breedingseason, which extends in New Zealand from September to December or January. Each pair produces a brood of five young ones. These young birds are fed entirely and exclusively on animal food. Every five minutes or so during the long summer day one or other of the parent birds visits the nest carrying in its bill a caterpillar or a grub, a beetle, fly or worm, but never a graill of corn or fruit of any kind. Now let us consider what this means. Hundreds of thousands of Sparrows, all intent on the same business, having young ones at home that must have insect food of some sort! Every bush, every furrow, every inch of ground is hunted over and ransacked to supply that imperative demand. Millions of insects in all stages of development are daily passed into the insatiable throats of these young Sparrows. I would ask, what does this imply? How much direct benefit does not this bring to the husbandman? The answer is obvious. But look for a moment at the result. In former years the North Island, and especially the Auckland province, was periodically visited by a veritable plague of caterpillars. About once in three or four years the caterpillars came in legions and swept all before them. They would pass over a smiling field of young corn at night and leave scarcely a blade for the dews of morning. Whole districts were devastated in this manner, and the hopes of the farmer for the coming season hopelessly ruined. There was no means of openly meeting an insidious enemy of this kind. It was a moving army of atoms, and to attempt to meet and destroy it would have been a mere mockery*. Since the introduction of the Sparrow and other insectivorous birds the dreaded plague of caterpillars has disappeared. It has become, indeed, a mere matter of history. In their irritation at losing a handful of grain, the small farmers appear to be now bent on ruthlessly

* Under the sensational heading of "Trains stopped by Caterpillars," the following telegram onee appeared in the colonial
papers :"(UNITED PRiss assoctation.) Wanganui, February 13.

"The trains this morning and evening between Waverley and Nukumaru, on the way to Wanganui, were brought to a standstill throngh countless thousands of eaterpillars on the rails. The officials had to sweep and sand the metals before the trains could proceed."

Another similar ease is this recorded in the 'Rangitikei Adrocate':- "In the neighbourhood of Turakina an army of caterpillars, hundreds of thousands strong, was marching across the line, bound for a new field of oats, when the train came along. Thousands of the creeping vermin were erushed by the wheels of the engine, and suddenly the train came to a dead stop. On examination it was found that the wheels of the engine had become so greasy that they kept on revolving without advancing, as they could not grip the rails. The guard and the engine-driver procured sand and strewed it on the rails and the train made a fresh start, but it was found that during the stoppage eaterpillars in thousands had erawled all over the engine and orer all the carriages inside and out." 
destroying the feathered friends to whose untiring efforts the very existence of their crops is in a large measure due *.

Then, again, to pursue the argument in another direction, if the Sparrow is fond of ripe grain it is still fonder of the ripe seeds of the variegated Scotch thistle. This formidable weed threatened at one time to overrun the whole colony. Where it had once fairly established itself it seemed well-nigh impossible to eradicate it, and it was spreading with alarming rapidity, forming a dense growth which nothing could face. In this state of affairs the Sparrows took to eating the ripe seed. In tens of thousands they lived on the thistle, always giving it the preference to wheat or barley. They have succeeded in conquering the weed. In all directions it is dying out, and simply because it has no chance of propagating itself in the only way possible, that is to say, by a dissemination of its seed. I would ask, is not this a benefit to the agriculturist of a kind to entitle the bird to the care and protection of the whole community?

It should be remembered, also, that the services of the Sparrow as a scavenger in our colonial streets are not to be despised. The droppings of the horses are turned over by these industrious little birds and scattcred to the winds, and in a variety of other ways they contribute to the cleanliness and purity of our thoroughfares.

The resultant fact is that for all these inestimable benefits we must be prepared to pay something; and it seems to me that the small tithe of grain which the Sparrows lery at a time of the year when everything else fails them is a very moderate consideration indeed. But it is the old story over again of ignorant prejudice and popular clamour. In Hungary, as we are informed, the same indiscriminate crusade was carried on some years ago, and was persevered in till not a Sparrow remained; then, after sufficient time had elapsed to sbow what an error had been committed, the Government had to offer a bonus of so much per head for the birds in order to reestablish them in that countryt.

* Even Mr. J. H. Gurncy, Jun., whose pamphlet 'On the Misdeeds of tho Sparrow' is the most recent eoutribution to the subject, and who urges the necessity of kceping down this bird, feels bound to say:- "It may bo that in some exceptional seasons (whon a great plague of insect-lifo shall again oceur), as in 1574 , when it is said cockehafers gathered in such numbers on the banks of the Severn as to prevent the rorking of the water-mills, and in 1858 when they formed a black eloud in Galway, which darkened the sky for a league, destroying vegetation so completely as to change summer into winter ("Wild Birds' Protection Report,' p. 170), Sparrows will do good. Bearing this in mind no one should adrocate their extirpation." He candidly says " that they mix the corn with considerable quantities of wild seeds, including, be it frcely armitted, the clestructive knotgrass and corn-bindwecd; but even then they take corn by preference." And he concludes: "Although it is desirable to keep them down at all times, it should be remarked that the mischief done by them at harrest-time is 20 -fold greater than at seed-time."

† Thus writes tho accomplished historian Hicholct:- "The "miserly agrioulturist' is the accurate and forcible expression of Virgil. Mriserly, and blind, in truth, for he proscribes the birds which destroy insects and protect his crops. Not a grain will he spare to the bird which, during the winter rains, hunted up the future insect, sought out the nests of the larve, examined them, turned over overy leaf, and daily destroyed myriads of future caterpillars; but sacks of corn to the adult insects, and whole fields to the grasshopper's which the bird would have combated! With his eye fixed on the furrow, on the present moment, without sight or foresight; deaf to the grand harmony which no one ever interrupts with impunity, he has everywhere solicited or approved the laws which suppressed the much-needed assistant of his labour, the insect-destroying bird. And the insects have avenged the bird. It has becomo necessary to recall in all haste the banishod. In the island of Bourbon, for example, a price was sot on each Martin's head; they disappeared, and then the grasshoppers took possession of the island, devouring, extinguishing, burning up with harsh acridity all that they did not devour. The same thing has occurred iu North America with the Starling, the protector of the maizc. The Sparrow even, which attacks the grain, but also defends it-the thiering, pilfering Sparrow, loaded with so many insults, and stricken with so many maledictions-it has been secn that without him Hungary would perish; that he alone could wage the mighty war against the cockchafers and the myriad winged focs which 
But the same popular prejudice was for a long time directed against the Common Pheasant. Gradually the country settlers were won over to a due appreciation of this valuable bird*.

In addition to those already mentioned, the following English birds may now be considered permanently established in the country:-the Common Thrush, Blackbird, Sky-Lark, Greenfinch, Linnet, Chaffinch, Redpoll, Goldfinch, and Starling. Some years ago a number of Rooks were imported by the Auckland Acclimatization Society, but they do not appear to have spread far beyond the district in which they were first liberated.

In addition to two species of Quail, we have imported very successfully from Australia the Indian Minah and the Native Magpie, both of which are useful and ornamental birds.

Many other species have been introduced, and have appeared to thrive in their new home, although they cannot yet be looked upon as fairly established.

I am not aware that any serious effort has been made to introduce Owls of any kind, but this is a matter well worth the attention of the local Acclimatization Societies. In 1873 I sent out from England a pair of Wood-Owls (Syrnium aluco). They arrived safely at Napier, and after recruiting their strength were turned loose in a distant part of the Province. The Hon. Mr. Ormond, as superintendent of the Province, gave orders for their protection under the Act; but notwithstanding all these precautions, the unfortunate immigrants fell victims to popular prejudice.

In some of the principal lakes in both islands the Australian Black Swan (Chenopis atrata), the first of which were introduced into the North Island by myself, about the year 1864, is now to be seen in considerable flocks, often numbering many hundreds. They appear to associate freely with the Grey Duck (Anas superciliosa), but it is an undeniable fact that on waters where this Swan

reign in the low-lying lands; his bunishment has been revoked, and the eourageous militia hastily recalled, whieh, if not strietly diseiplinod, are not the less the salvation of the eountry."

The Sparrow in New Zealand has an able and ever-ready ehampion in Xr. W. T. L. Travers, the well-known barrister, who thus attaeked a proposal in the Colonial Legislature to exterminate it:- " War is to be waged against the Sparrows, under the anthority of Parliament. The following short extracts show the wisdom brought to bear in diseussing the question. The Hon. Mr. Chamberlain says that the Hawk is tho natural enomy of the Sparrow, a deduetion, no doubt, from the namo "Sparrowhawk' applied to one speeies of Hawk, but no New-Zealand Hawk that I know of ever touehes a Sparrow. Mr. Oliver tells us that it was a mistake to introduce the Sparrow, and so does Mr. Gray. Mr. Miller sajs that nono but the agrieulturist was fit to diseuss the question, and drew a comparison between the Sparrow and the Starling, whieh was about as appropriate as if he had attompted to eompare tho Sparrow with the elephant. Mr. Aeland said that the Sparrow did not destroy iusects. Ir. Holmes read some oxtraets in support of his opinions against the Sparrow, and I can supply him with auy quantity more of the same kind, emanating from equal ignoranee of the subject. It would be well if hon. gentlemen, in dealing with this question, wonld take the trouble to read the evidenee given bofore a eommittee of tho House of Lords on the subject of Sparrowelubs in England, and if they should still entertain any respect for tho intelligenee of that august body, they would probably be disposed to ehange the opinions abovo expressed. Not many years ago the agrieulturists of Ilungary sueeeeded in getting tho Sparrow proseribed by law, and he disappeared from the land. Within five years from that timo the Government wero eompelled to spend 230,000 rix dollars in reintrodueing him from other eountries. In the North Island, and in the northern parts of the South Island, the euttivatiou of valuable deeiduous trees was praetieally impossible until the large eieada had been greatly redueed in numbers, and if Mr. Aeland had seen, as I and many others have, the Sparrow actively engaged in destroying theso oreatures and devonring them, he might probably ehange his opinion. The nestling Sparrow eannot eat hard food, and eareful obserration has shown that a pair of parent Sparrows will bring upwards of 3000 inseets to the nest in the eourse of a single day to feed its brood."

* A praetieal farmer thus writes to one of tho newspapers:-_."As much has been written and said for and against this beautiful bird, I will add my experienee on the subjeet. On the one hand the Pheasants completely eleared a patch of maize for me; but on the other hand, when, some time after, I shot one of the dopredators, its erop was found to contain about half-apint of fragments of blaek eriekets. I have therefore resolved for the future to endeavour to seare them away from my crops, but on no aecount to exterminate them." 
establishes itself the Ducks rapidly disappear. It is said also to be very inimical to the presence of the White Swan *.

Another bird that bids fair to be well acclimatized is the Cape or Egyptian Goose (Chenalopex agyptiaca). Just before I left the colony one of these Geese was shot on Te Aute Lake, and submitted to me as a supposed addition to the New-Zealand Avifauna. Recognizing the species, and being satisfied that the individual bird was a wild one, I wrote to Sir George Grey for the purpose of ascertaining whether he had brought any of these Geese from the Cape. The information in reply was exactly what I had expected. Sir George Grey bronght eight or ten of these birds with him to the Colony in 1860. They bred freely at the Kawau, and many of them crossed over to the mainland. Judge Rogan informed Sir George that he had seen as many as four shot at the Kaipara during his residence there. The fact that it has already found its way to the Hawke's Bay district shows how this species is establishing itself in a country where certainly all the conditions are favourable to its existence.

\section{ORIGIN OF THE NEW-ZEALAND AVIFAUNA.}

I have already said enough about the ancient and existing forms of bird-life in New Zealand to convince the most casual reader that we have within this comparatively small area a very remarkable ornithological province. In some respects it is quite unique, and, taken altogether, it is perhaps, to the student of biological history, the most interesting insular district on the face of our globe. In his admirable work on 'The Geographical Distribution of Animals,' Mr. Wallace has given, in a large woodcut, an ideal scene in New Zealand, representing some of its more singular forms. Referring to this, he says, "no country on the globe can offer such an extraordinary set of birds as are here depicted"; and in his elaboration of the subject, he has thrown more light than any previous writer on the origin and development of these peculiar ornithic types.

Looking to the fragmentary character of the New-Zealand fauna generally-the almost total absence of Mammalia and Amphibia, the phenomenal development of wingless birds that existed till quite recent times and are now represented by the various species of Apteryx , the highly specialized forms of non-volant Rails, besides the many other endemic genera of land-birds, and the great pancity of reptiles and insects-we must conclude that it is but the remnant of an ancient fauna, perhaps the most ancient in the world, which formerly occupied a very much wider area of the earth's surface.

Professor Newton, in his Address to the British Association last year, called the attention of naturalists generally to the extreme interest which attaches to every portion of this unique fauna. Remarking on its origin and development he says:- "One thing to guard against is the presumption

* It is popularly supposed that the Blaek Swan and the White Swan will not live together on the same waters; but the faet is that no systematie attempts, so far as I am aware, have yet been mado to aeclimatize the White Swan, either in Australia or New Zealand. Years ago, Baron von Mueller showed mo a small floek of White Swans eommingling with their dark cousins on a fine sheet of water in the Melbourne Acelimatization Gardens. A few tame pairs have been placed on ponds and ormamental waters in the South Island, and these havo bred freely enough notwithstanding the constant presence of the Black Swan. In the North Island the oxperiment has not yet been tried. Sir George Grey was unfortunate enough to lose one of the beautiful pair presented to him by Her Najesty, or the North Island might have been ultimately stoeked from Kawau. I am now arranging to send out some of these noble birds as a present to the Ngatiraukawa tribe, in order that they may be plaeed on the Horowhenua Lake, where the other species is already established, and it will be intoresting to note their future history. 
that the fauna originated within its present area, and has been always contained therein. Thus I take it that the fauna which characterizes the New-Zealand Region-for I follow Professor Huxley in holding that a Region it is fully entitled to be called-is the comparatively little changed relic and representative of an early fauna of much wider range; that the characteristic fauna of the Australian Region exhibits in the same way that of a later period; and that of the Neotropical Region of one later still." He points out that the indigenous species are with scarcely an exception peculiar to the country, and from every scientific point of view of the most instructive character; and he urges the importance of their closest study, because the Avifauna is now being fast obliterated by colonization and other agencies, and with it will pass into oblivion, unless faithfully recorded by the present generation, a page of the world's early history full of scientific interest.

The biological problems which the peculiar fauna and quasi-tropical flora of New Zealand suggest can only be met and reasonably explained on the hypothesis of a former land-connection between these islands and the northern or tropical portion of Australia; the severance, by submersion of the intervening land, having taken place at a period anterior to the spread of Mammalia over this portion of the earth's surface. Mr. Wallace has, I think, made it perfectly clear that this ancient land-connection was with North Australia, New Guinea, and the Western Pacific Islands, rather than with the temperate regions of Australia. At p. 443 of his 'Island Life' he gives a reduced map showing the depth of the sea around Australia and New Zealand, as established by the most recent soundings. From this it is manifest, as he points out, that there is a comparatively shallow sea, or, in other words, a submarine bank, at a depth of less than 1000 fathoms, indicating the additional land-area that would be produced if the sea-bottom were elevated 6000 feet. This submerged plateau, if we may so term it, presents a remarkable conformation, extending in a broad mass westward and then sending out two great arms, one reaching to beyond Lord Horve's Island, while the other stretches over Norfolk Island to the great barrier reef, thus forming the required connection with tropical Australia and New Guinea. It is argued that the ancient land-connection thus indicated, with perhaps, at a still more remote epoch, a connection with the great Southern continent by means of intervening lands and islands, will explain many of the difficult zoological problems that New Zealand presents.

This theory, while it accounts for the introduction into New Zealand by a north-western route, in very ancient times, of the Struthious type of birds, from which all the linown species of Dinornis and Apteryx may have descended, explains too the tropical character of much of the New-Zealand flora, which is somewhat anomalous considering the temperate climate of New Zealand as we know it. Mr. Wallace states, as the result of careful research, that there are in New Zealand thirty-eight thoroughly tropical genera of plants, thirty-three of which are found in Australia, and, with a very ferv exceptions, in the northern or tropical portions only. To these may be added thirty-two more genera of plants which, though chiefly developed in temperate Australia, extend also into the tropical or subtropical portion of it, and which, it may reasonably be inferred, reached New Zealand by the same route. But to make this line of reasoning perfectly intelligible, it ought to be mentioned that the geological history of Australia shows it to have been for an immense period of time divided into an Eastern and a Western island, in the latter of which only the largely peculiar flora of temperate Australia-distinguished by its Eucalypti, Proteas, and Acacias-was developed, and where alone the marsupial Mammalia had their home. At this period, according to the above theory, New Zealand was in connection with the tropical portion of the Eastern island alone. This important geological fact will therefore account for the non-introduction into New Zealand, along with the 
ancestors of the Moas and Kiwis and the tropical plants referred to, of the marsupial fauna and the peculiar temperate flora so characteristic of Australia as we now know it *.

Sir Joseph Hooker, undoubtedly the ablest and most accomplished of living botanists, referring to an apparently insoluble enigma in the relations of the flora of New Zealand with that of Australia, thus expresses himself in the Introduction to his well-known 'Flora of Australia ':-

"Under whatever aspect I regard the flora of Australia and New Zealand, I find all attempts to theorize on the possible causes of their community of feature frustrated by anomalies in distribution, such as I believe no two other similarly situated countries on the globe present. Everywhere else I recognize a parallelism or harmony in the main common features of contiguous floras, which conveys the impression of their generic affinity, at least, being affected by migration from centres of dispersion in one of them, or in some adjacent country. In this case it is widely different. Regarding the question from the Australian point of view, it is impossible in the present state of science to reconcile the fact of Acacia, Eucalyptus, Casuarina, Callitris, \&c. being absent in New Zealand, with any theory of trans-oceanic migration that may be adopted to explain the presence of other Australian plants in New Zealand; and it is very difficult to conceive of a time or of conditions that could explain these anomalies, except by going back to epochs when the prevalent botanical as well as geographical features of each were widely different from what they are now. On the other hand, if I regard the question from the New-Zealand point of view, I find such broad features of resemblance and so many connecting links that afford irrefragable evidence of a close botanical connection, that I cannot abandon the conviction that these great differences will present the least difficulties to whatever theory may explain the whole case."

It will be seen that the theory of which an outline has been given, while accounting in a rational manner for the marked peculiarities of the New-Zealand fauna, offers at the same time a probable solution of some of the strange anomalies of its flora in relation to that of Australia.

Mr. Wallace has explained that, in zoology, discontinuity in the areas of distribution must be accepted as an indication of antiquity, and that the more widely the fragments are scattered the more ancient we may, as a rule, take the parent group to be. "Thus the marsupials of South America and Australia are connected by forms which lived in North America and Europe; the camels of Asia and the llamas of the Andes had many extinct common ancestors in North America; the lemurs of Africa and Asia had their ancestors in Europe, as did the Trogons of South America, Africa, and

* "If we examine the geological map of Australia, we shall sec good reason to conclude that the eastern and the western divisions of the country first existed as separate islunds, and only became united at a comparatively recent epoch. This is indieated by an enormous stretch of Cretaceous and Tertiary formations extending from tho Gulf of Carpentaria complctely across the continent to the mouth of the Mrurray River. During the Cretaccous period, therefore, and probably throughout a considerable portion of the Tertiary epoch, there must have been a wide arm of the sea occupying this area, dividing the great mass of land on the west-the true seat and origin of tho typical Australian flora-from a long but narrow belt of land on the east, indicated by tho continuous mass of Secondary and Palicozoic formations already referred to, which extend uninterruptedly from Tasmania to Cape York. Whether this formed one continuous land, or was broken up into islands, cannot be positively determined; but the fact that no marine Tertiary beds oceur in the whole of this area renders it probable that it was almost, if not quite, continuous, and that it not improbably extended across to what is now New Guinea. At this epoch, then, Australia would consist of a very large and fertile western island, almost or quite extra-tropical, aud extending from the Silurian rocks of the Flinders range in South Australia to about 150 miles west of the present wost coast, and southward to abont 350 miles suuth of the Great Australian Bight. To the east of this, at a distance of about 250 or 400 miles, extended, in a north and suuth direction, a long but comparatively narrow island, stretehing from far south of Tasmania to New Guinea; while the crystalline and Secondary formations of Central North Australia probably indicate the existence of one or moro large islands in that direction."-Island Life. 
tropical Asia. But besides this general evidence, we have direct proof that the Struthious birds had a wider range in past times than now. Remains of extinct Rheas have been found in Central Brazil *, and those of Ostriches in North India, while remains believed to be of Struthious birds are found in the Eocene deposits of England; and the Cretaeenus rocks of North Ameriea have yielded the extraordinary toothed bird, Hesperomis, which Professor O. Marsh declares to hare been a 'carnivorous swimming Ostrich.' As to the second point, we have the remarkable faet that all known birds of this group have not only the rudiments of wing-bones, but also the rudiments of wings, that is, an external limb bearing rigid quills or largely developed plumes. In the Cassowary these wing-feathers are reduced to long spines like poreupine-quills, while even in the Apteryx the minute external wing bears a series of nearly twenty stiff quill-like feathers $\dagger$. These faets render it probable that the Struthious birds do not owe their imperfect wings to a direct evolution from a reptilian type, but to a retrograde development from some low form of winged birds, analogous to that which has produeed the Dodo and the Solitaire from the more highly developed Pigeon type. Professor Marsh has proved that, so far back as the Cretaeeous period, the two great forms of birds-those with a keeled sternum and fairly developed wings and those with a eonvex keel-less sternum and rudimentary wings-already existed side by side; while in the still earlier Archooopteryx of the Jurassie period we have a bird with well-developed wings, and therefore probably with a keeled sternum. We are evidently, therefore, very far from a knowledge of the earlier stages of bird-life, and our acquaintance with the various forms that have existed is scanty in the extreme; but we may be sure that birds aequired wings, and feathers, and some power of flight before they dereloped a keeled sternum, sinee we see that bats (with no such keel) fly very weli. Sinee, therefore, the Struthious birds all have perfeet feathers, and all have rudimentary wings, which are anatomically those of true birds, not the rudimentary fore legs of reptiles, and since we know that in many higher groups of birds-as the Pigeons and the Rails-the wings have become more or less aborted, and the keel and the sternum greatly reduced in size by disuse, it seems probable that the very remote ancestors of the Rhea, the Cassowary, and the Apteryx were true flying birds, although not perluaps provided with a keeled sternum or possessing very great powers of flight $\$$. But in addition to the possible aneestral power of flight, we have the undoubted fact that the Rhea and the Emu both swim freely, the former having been seen swimming from island to island off the coast of Patagonia. 'This, taken in eonneetion with the wonderful aquatic Ostrieh of the Cretaeeous period diseovered by Professor Marsh, opens up fresh possibilities of migration; while

* Reinhardt is of opinion that "the ancient and the medern Ihea are of ene and the same species."-Ibis, 1882, p. 332.

† "See Buller's illustration in Trans. N.-Z. Tnstit. vol. iii. plate 12 b. fig. 2."

¥ "Professor" Marsh has shewn that there is geod reason for believing that the power of flight was gradnally acquired by Birds, and with that pewer would be asseciated the development ef a kcel to the sternum, on which the volant facnlty se much depends, and with which it is se intimately cerrelated that, in certain forms which have to a grenter or less extent given up the use ef their fore-limbs, the keel, though present, has become prepertionally aborted. Thus the Carinate type would, from all we can see at present, appear to have been evolved from the Ratite. This view receives further support frem a censideration of the results of such embryelogical research as has already becn madc-the unquestionable ossification of the Ratite sternum frem a smaller number of paired centres than the Carinate sternum, in which (with the doubtful exception of tho Anatidæ) an additional, uppaired centre makes its appearance. Again, the geographieal distribution of existing, er comparatirely recent, Ratite forms points te the same conclusien. That these ferms-Moa, Kiwi, Emeu and Cassowary, Rhea, and finally Ostrich -must have had a common ancestor nearer to them than is the ancestor of any Carinate ferm secms te need no preof. If we add to these the Alpyornis of Madagasear, tho fessil Ratitæ of the Siwalik rocks, and the as yet but partially recegnized Struthiolithus of Southern Russia, to say nething of G'astornis, the evidence is stronger still. Scattered as these Birds have been or are throughout the world, it seems justifiablo to consider them tho survivals of a very ancient type, which has hardly undergone any essential modification since the appearance of Bird-life upon the earth-even thongh one at least of them has become rery highly spccialized."-Prof. Newton in Enc. Brit. vol. xviii. pp. 43, 44. 
the immense antiquity thus given to the group and their universal distribution in past time, renders all suggestions of special modes of communication between the parts of the globe in which their scattered remnants now happen to exist altogether superfluous and misleading "*.

In his last-named work, Mr. Wallace divides all known islands in to two classes, "Continental" and "Oceanic." The former are always more varied in their geological formation-containing both ancient and recent stratified rucks-are rarely remote from a continent, and always contain some land Mammalia, also Amphibia and representatives of the other classes of animals in considerable variety. The "Oceanic" islands are usually far removed from continents and are always separated from them by very dcep seas, are entirely without land Mammalia or Amphibia, but are generally well stocked with birds and insects and with some reptiles. Now New Zealand, which is undoubtedly "Continental" in its geological formation, also in the existence of the suburerged bank already described connecting it in ancient times with North Australia and New Guinea, is as decidedly "Oceanic" in its zoological character, except as regards its wingless birds and the remarkable tuatara lizard (Sphenodon punctatum), which is said to constitute per se a distinct order of Reptilia of extreme antiquity. Mr. Wallace therefore terms New Zealand and the Celebes, where the conditions are somewhat similar, "Anomalous islands;" but Ancient continental may be perhaps a more convenient term.

As already explained, at the time of the supposed land-connection to the North-west, the Marsupial fauna could not have reached the eastern land now forming part of Australia; but it seems very probable that, at this early period, tropical Australia was tenanted by some Struthious kind of bird, perhaps volant in its character, which had reached this land, by way of New Guinea, through some ancient continental extension. If this theory, so well propounded by Mr. Wallace, is the true one, then the Cassowaries of New Guinea, the Emus of Australia, the extinct Dromornis of Queensland, and the Moas and Kiwis of New Zealand are doubtless the modified descendants of this ancestral type. "The total absence (or extreme scarcity) of manmals in New Zealand obliges us to place its union with North Australia and New Guinea at a very remote epoch. We must either go back to a time when Australia itself had not yet received the ancestral forms of its present marsupials and monotremes, or we must suppose that the portion of Australia with which New Zealand was connected was then itself isolated from the mainland, and was thus without a mammalian population. . . But we must on any supposition place the union very far back, to account for the total want of identity between the winged birds of New Zealand and those peculiar to Australia, and a similar want of accordance in the lizards, the freshwater fishes, and the more important insect groups of the two countries. From what we know of the long geological duration of the generic types of these groups we must certainly go back to the earlier portion of the Tertiary period at least in order that there should be such a complete disseverance as exists between the cliaracteristic animals of the two countries, and we must further suppose that, since their separation, there has been no subsequent union or sufficiently near approach to allow of any important inter-migration, even of winged birds, between them. It seems probable, therefore, that the Bampton shoal west of New Caledonia, and Lord Howe's Island further south, formed the western limits of that extensive land in which the great wingless birds and other isolated members of the $\mathrm{New}$-Zealand fauna were developed. Whether this early land extended eastward to the Chathain Islands and southward to the Macquaries we have no means of ascertaining; but as the intervening sea appears to be not more than 1500 fathoms deep,

* 'Island Life,' by Alfred Russel Wallace, pp. 451, 452. 
it is quite possible that such an amount of subsidence may have occurred. It is possible, too, that there may have been an extension northward to thc Kcrmadec Islands, and even further to the Tonga and Fiji Islands, though this is hardly probable, or we should find morc community between their productions and those of New Zealand. A southern extension towards the Antarctic continent at a somewhat later period seems more probable, as affording an easy passage for the numerous species of South American and Antarctic plants and also for the identical and closcly allied freshwater fishes of these countries. The subsequent breaking up of this extensive land into a number of separate islands-in which the distinct species of Moa and Kiwi were developed-their union at a later period, and the final submergencc of all but the existing islands, is a pure hypothesis, which seems necessary to explain the occurrence of so many species of these birds in a small area, but of which we have no independent proof" *.

In a preceding section I have already mentioned that, as a rule, the species of Dinornis which, in former timcs, inhabited the North Island were differcnt in character from their contemporaries in the South Island, although the two areas of land are only separated by a strait scarcely eighteen miles across in its narrowest part. The samc fcaturc is maintained to the present day in the existing Avifauna, clearly showing that each island has a biological history of its own. 'Thus the Saddlc-back (Creadion carunculatus) of the North is represented in the Sonth by C. cinerens, a closely-allied species, but differing in the colour of its plumage; Turnagra hectori (now almost extinct) is represented by T.crassirostris, a species that will soon follow suit, although still plentiful in certain localities; the Weka (Ocydromius earli) is represented by several other closely-rclated species (O. australis, O. fuscus, and O. brachypterus) so closely resembling the northern bird both in appcarance and habits that they are called "Woodhens" by the settlers of both islands and by them, as well as by the natives, arc generally regarded as identical; the Popokatea (Clitonyx albicapilla) is represcnted by another species (C. ochrocephala) differing in colour, but so closely allied to it that the Maoris apply the same name to both; the 'Toutouwai (Miro australis), to which precisely the same remark applies, is represented by M. albifrons, and Glaucopis wilsoni by G. cinerea, distinguishable only by the colour of its ornamental wattles. Another case in point is furnished by the two representative species of Apteryx, the North Island bird being characterized by a differcnt structure of plumage to that of the well-known Aptery.x australis inhabiting the South Island. Till of late years it was believed that Apteryx oweni, which differs entircly from botll of these species in the grey colour and mottled appearance of its plumage, was confined to the colder districts of the South Island; but in $1876 \mathrm{I}$ communicated to the Wellington Philosophical Society the discovery of this bird ncar the summit of the Tararua monntains on the north side of Cook's Strait, where it was found frequenting the stunted vegetation immediately below the snow-linet. The existence of this species was entirely unknown to the Maoris of the North Island, and its occurrence undcr the conditions I have mentioned is a very interesting fact in geographical distribution.

Analogous cases of representative species in more or less widely separated areas are of frequent occurrence in other parts of the world. "The cause of this" (writes Mr. Wallace) "is very easy to understand. We have already shown that there is a large amount of local variation in a considerable number of species, and we may be sure that were it not for the constant intermingling and intercrossing of the individuals inhabiting adjacent localities this tendency to local variation would soon form distinct races. But as soon as the area is divided into two portions, the intcrcrossing is stopped,

$$
\text { * 'Island Life,' p. 454. † Trans. N.-Z. Instit. vol. viii. pp. 193-194. }
$$


and the usual result is that two closely allied races, classed as representative species, become formed. Such pairs of allied species on the two sides of a continent, or in two detached areas, are very numerous; and their existence is only explicable on the supposition that thcy are descendants of a parent form which once occupied an arca comprising that of both of them,- - that this area then became discontinuous, - and, lastly, that, as a consequence of the discontinuity, the two sections of the parent species became segregated into distinct races or even species."

In his 'Geographical Distribution of Animals' Mr. Wallace treats New Zealand and her satellites as forming a subregion of Australia. The Australian, or "great insular region of the earth," is divided by him into four subregions, distinguished as the Austro-Malayan, Australian, Polynesian, and New Zealand. The last-named subregion is made to include Norfolk Island, Phillip and the Nepean Isles, Lord Iowe's Island and the Kermadec Isles on the north, the Chatham Islands on the east, the Auckland, Macquarie, Emerald, Campbell, Antipodes, and Bounty Islands on the south and south-east.

Other prominent writers on the subject have claimed for New Zealand full recognition as a separate biological province, quite distinct from Australia and every other rcgion of the earth. My own study of the subject having brought me to the same conclusion, I propose to examine here, very briefly, the grounds upon which Mr. Wallace links New Zealand to Australia as contiguous sections of one biological region. He admits, of course, that there is a "wonderful amount of speciality," but he contends that "the affinities of the fauna, whenever they can be traced, are with Australia or Polynesia."

If we take Mr. Wallace's own table of the geographical distribution we find, on a careful analysis, that out of twenty-eight families stated to be common to Australia and New Zealand, three are includer in error, namely Sittidæ, Dicæidæ, and Pandionidæ, thus reducing the number to twenty-five. Of these, fifteen are admitted by him to be cosmopolitan, and may therefore be discharged from the present inquiry. Of the remaining ten, four belong to the Old World, four to the Oriental, Ethiopian, Austro-Malayan, and Polynesian regions respectively, and one highly specialized family, the Spheniscidæ, to the south temperate regions, leaving thus only one family, the Paridæ, as restricted in its range to the two countries. This family is represented in New Zealand by a single genus, Certhiparus, about the true position of which there is considerablc doubt, and this genus again is represented by a single species, so that, as regards the mere distribution of families, the argument altogether fails. Let us now examine the far more important question of identical or representative genera and species in the two countries, for this after all is the true test of a common origin. Of the twelve. genera of Australian birds which he treats as belonging equally to New Kealand, it may be remarked that two (namely Graucalus and Acanthochcera), each of them represented by a single species, have only occurred in New Zealand as accidental straggiers, at very long intervals; that Tribonyx, as already explained at p. xiv, has never actually occurred in a wild state; and that Orthonyx and Hieracidea have, on further investigation of their characters, been replaced by two endemic genera, Clitonyx and Harpa. Of the remaining seven, two alone (Gerygone and Sphenoca$c u s)$ are characteristic of Australia, the others ranging over a great part of the southern hemisphere; thus, Platycercus is spread over New Guinea and Polynesia, as well as Australia, Rhipidura cxtends to India, and Zosterops through Polynesia and the Malay Archipelago to India and Africa. Of the five species mentioned by Mr. Wallace as being identical in Australia and New Zealand, it may be mentioned that three (Acanthochcera carunculata, Graucalus melanops, and IIirundo nigricans) are among our rarest stragglers from abroad, and that the Shining Cuckoo (Chrysococcyx lucidus) is in 
annual migrant to and from Australia: thus leaving only Zosterops ccerulescens to be accounted for, and this species has been sufficiently treated of already.

Mr. Wallace's strongest point is the Family Meliphagidæ, which is a very typical and welldistributed Australian group. But accepting, as I think we must do, his theory of the introduction of the ancestral types into New Zealand by way of tropical Australia and New Guinea, it is easy to account for the presence of this peculiar form in both countries, inasmuch as the Meliphagidæ have representatives as far north as the Sandwich Islands, whilst other members of the group are spread through the Austro-Malayan subregion, finding their extreme western limit in the Celebes. Supposing that the ancient type reached New Zealand by the north-ivestern route, it then resolves itself into a mere question of time and "descent with modification."

Dr. Otto Finsch, who has written several interesting papers on New-Zealand Ornithology, appears to me to exaggerate very much the importance of this feature, for he accepts it as a proof of "far more intimate connection with Australia than one would suppose from the geographical position of the two countries." He is unable, however, to account for the absence of true Trichoglossi in New Zealand, seeing that this group is so strongly developed in the temperate parts of Australia.

It is a point of some significance that the Meliphagine genera in New Zealand are not very closely related to those of Australia, except in the case of Pogonornis, which approximates somewhat to Ptilotis, a decidedly subtropical genus. Apart from the true Honey-eaters, the only genera that Mr. Wallace specially refers to as related to peculiar Australian ones are Niro and Myiomoira (allied to Petroeca), Ocydromus (allied to Eulabeornis), and Hymenoloemus (allied to Malacorhynchus). It seems to me, therefore, that he has not succeeded in establishing a co-ordinate relation between the avifaunæ of these so-called subregions of Australia.

It is worthy of remark also that, with the exception of the highly developed Meliphagidæ, comprising four very distinct genera (and numbering altogether only five species), none of the NewZealand families contain more than two genera, presenting a marked difference in this respect to the numerous subordinate groups among the birds of Australia.

Seeing that the Shining Cuckoo (Chrysococcyx lucidus) is met with in New Guinea, and probably further west, that it is likewise found in tropical Australia, and that it comes to us from the nortll, or north-west-for it always makes its appearance first at the extreme north-it is easy to understand that the migratory impulse has been inherited from time immemorial, and the more so as the closelyallied species (C. plagosus) is also a summer visitant to the temperate and southern portions of Australia. But it is very difficult to imagine why the Long-tailed Cuckoo (Eudynamis taitensis), which hibernates in the warm islands of the Pacific-the Friendly, Society, Marquesas, Fiji, and Samoa groups-ranging over more than $40^{\circ}$ of longitude, should make its annual pilgrimage across 1500 miles of ocean to New Zealand *.

The Waders are, for the most part, cosmopolitan, and are therefore of little account when estimating the geographical relations of the avifauna.

* Mr. Wallace says, in his account of the Chatham Islands ("Island Life,' p. 454):-“" It is stated that the Zosterops differs from that of New Zealand, and is also a migrant; and it is therefore believed to come every year from Australin, passing over New Zcaland, a distance of nearly 1700 miles!" But this is evidently a lepsus calami, the bird intended being the Chrysococcyn. Prof. Hutton stated (Trans. N.-Z. Instit. vol. จ. p. 225) that this happened in tho case of C. plagosus; but, I have showu elsewhere that he was wrong in his identification of the specics, the Shining Cuckoo (C. lucidus) which annually risits the Chatham Islands being identical with the New-Zealand bird. Chrysococcys playosus, distinguished by its narrower bill, has never been met with in New Zealand, and it would be strange indeed if this Australian species had occurred in the Chatham Islands to the eastward. 
One of the most widely distributed species is the Eastern Golden Plover (Charadrius fulvus), which, at all times rare in New Zealand, is plentiful in Australia, and spreads itself over the Polynesian Islands and the Indian Archipelago, westward to Ceylon, and northward to Siberia and Kamtschatka, where it rears its young.

Several of our Ducks are common to Australia, but it is well known that this Order is a very diffuse one in all parts of the world. Our common Grey Duck (Anas superciliosa), for example, extends its range into Tasmania and Australia, over a large portion of Polynesia, and as far north as the Sandwich Islands; whilst the White-winged Duck (Anas gibberifrons) is met with, not only in Australia, but in New Caledonia and the Indian Archipelago. The genus IIymenolcemus, represented by our peculiar Mountain Duck, is closely related to an Australian one, and our Shoveller (Rhynchaspis variegata) is a representative species to that inhabiting Australia and Tasmania, the two forms being very closely allied. Two other Ducks, however (Dendrocygna eytoni and Nyroca australis) are so rare with us that they may fairly be regarded as Australian stragglers. Even where the species is peculiar to New Zealand, the genus to which it belongs may be a widely spread one: for example, Fuligula nove zealandice belongs to a genus which has representatives in the northern parts of America, in Europe and in Asia, and our splendid Casarca variegata represents a genus which is almost cosmopolitan.

One of the most puzzling of these occurrences is the Little Bittern (Ardetta pusilla), which, although decidedly rare, has been met with on the west coast and in the southernmost part of the South Island. Botlı this and our common species (Botaurus pociloptilus) are birds of feeble wing; yet they are identical with the species inhabiting temperate Anstralia, showing that they must have preserved their individuality as species for a very long period of time. The same remark applies to our Porphyrio melanonotus, and, in a lesser degree, to Rallus philippensis and Ortygometra affinis, which are very closely related to $R$. pectoralis and O.palustris respectively.

When we come to compare our avifauna with that of the Polynesian "subregion" there is still less resemblance, for the only genera common to both are the two referred to above, whilst the ouly species mentioned by Mr. Wallace as identical is our other migratory Cuckoo (Eudynamis taitensis). It is true that he questions the fact of these Cuckoos being migratory at all, and endeavours to account for their disappearance in winter by suggesting that " in a country which has still such wide tracts of unsettled land, they may only move from one part of the islands to another." But quite apart from the lengthened form of the wing in both of these Cuckoos, which at once proclaims them "birds of passage," the fact of their seasonal arrival in and departure from our country, as fully recorded in my account of each species, is well attested, and forms an essential part of their natural history.

Besides the genera of occasional or accidental occurrence (Acanthochcera and Hirundo) and the migratory Cuckoo already mentioned, the only groups of land-birds common to New Zealand and Polynesia are Platycercus, Carpophaga, and Zosterops, and the widely spread genera Rhipidura, Halcyon, and Circus*.

* It may be worth noting that I have remarked the following similarity between the names employed in the Fijian and Maori languages for the same or corresponding birds:-

\begin{tabular}{lll}
\multicolumn{1}{c}{ Fijian. } & & \\
Kawakawasa. & $=$ & Kawekawea (Eudynamis taitensis). \\
Lulu. & $=$ & Ruru (an Owl). \\
Kaka (a kind of Parrot). & $=$ & Kaka (Nestor mericlionalis). \\
Toa (any fowl-like bird). & $=$ & Moa (Dinornis). \\
Toro. & $=$ & Toroa (an Albatros). \\
Kula (a red Parrot). & $=$ & Kaka-kura.
\end{tabular}


The Cormorants are evidently adapted by nature to a cold or temperate climate, for as we advance towards the Tropics they disappear, and it is said that not a single species is to be found in the whole of Polynesia.

In New Caledonia and the New Hebrides, which form a sort of transition ground into Australia proper and the Papuan group, we have the same genera, and in addition thereto, inhabiting New Caledonia, a flightless Rail, allied to the New-Zealand Woodhen.

The Chatham Islands to the east of New Zealand, the Auckland Islands, and the other scattered islets to the south and south-east are so obviously related to New Zealand geographically, besides coming within the political limits of the Colony, that I have included their birds in the present work. It is interesting to notice, however, that these islands nearly all contain one or more peculiar species, shorwing that the isolation has been of sufficiently long duration to allow of this development. Thus in the Chatham Islands and the adjacent islets there are seven peculiar species, namely, Anthornis melanocephala, Gerygone albofrontata, Miro traversi, Sphenceacus rufescens, Rallus dieffenbachii, Cabalus modestus, and Phatacrocorax featherstoni.

In the Auckland Islands, lying about 300 miles to the south of New Zealand, the three species mentioned by Mr. Wallace as peculiar (Anthus aucklandicus, Platycercus aucklandicus, and P. malherbii) have been proved to have no existence as valid species; but, as already mentioned, this small area contains two species of Duck (Nesonetta aucklandica and Mergus australis) hitherto not met with elsewhere; also a Snipe (Gallinago aucklandica) and a species of Rail (Rallus brachypus), both of which are supposed to be peculiar to these small islands.

From Macquarie Island, still further south, we have the handsome Phalcerocorax nycthememes and possibly a new species of Rail; from Campbell Island, so far as our present knowledge extends, another fine Cormorant ( $P$. magellanicus) and a peculiar Penguin; from the Snares the unique Eudyptes atrata, described by Prof. Hutton; and from Antipodes Island the interesting GroundParrakeet (Platycercus unicolor) lately discovered by Captain Fairchild. A small Hawk received by me from Macquarie Island is undoubtedly the same as our Harpa ferox, and the Rail which Prof. Hutton has distinguished as Rallus macquariensis seems to me to be merely a local race of $P$. phitippensis, if at all separable from that species. There can be no doubt, therefore, of the propriety of including even this remote island in the New-Zealand region.

The case is different, however, with the islands to the north of New Zealand. The instauces mentioned by me at p. 24 of the present volume make it abundantly clear that at some period there was a land-comnection with Lord Howe's Island, Norfolk Island, and the Nepean group, and possibly with the Kermadec Islands * to the eastward ; but, owing to the introduction from time to time of a colonist population, so to speak, from the nearer continent, the avifauna of these islands is decidedly more Australian than New Zealand. With the exception of Nestor productus and Notomis alba, all the species of land-birds inhabiting Norfolk Island and the Nepean group belong to Australian genera; and of the sixteen recorded species, all but three occur also in various parts of Australia.

The same remarks apply to Lord Howe's Island lying midway between Norfolk Island and Australia. With the exception of Ocydromus sylvestris, all the birds belong to well-known Australian

* Mr. J. F. Cheeseman, who accompanied the Annexation expedition to the Kermadee Islands last year, has lately communicated to the Linnean Society (through Sir Joseph Hooker) a report on the flora of these islands. He mentions incidentally that the land-birds found there, which were fow in number, appeared to belong to New-Zcaland species, but he does not state what these birds were. 
types, and the speeies themselves are identical, with the exception of Zosterops strenuus and Z. tephropleurus, both of which, strange to say, are peeuliar to this small island.

'To summarize the results, it may be mentioned that out of sixty-nine speeies of "land-birds" (exclnding the Herons and Bitterns) only eleven have a wider range than New Zealand. Of these exeeptions five are only aceidental stragglers from Australia; two are annual migrants; and the remaining four are Zosterops ccerulescens, Rallus phitippensis, Ortygometra tabuensis, and Porphyrio melanonotus. But, what is even more remarkable still, out of thirty-four genera, after making a similar elimination to the above, not less than twenty-two are strietly endemic, showing at a glance how restricted is the eharacter of the New-Zealand Avifauna.

That the Ornis of New Zealand may have been, from time to time, affeeted by easual immigration from Australia is probable enough, for, as we have seen, even during recent years, many individual eases of the kind have been reeorded at irregular intervals; and it is rather matter for surprise, on this ground, that there is not a stronger family likeness, so to speak, between the indigenous birds of the two countries at the present day.

\section{CONTENTS OF VOL. I.}

Before concluding this Introduction it may be well to offer one or two general observations on the Families and Genera treated of in the present volume, whieh eloses with the New-Zealand WoodPigeon (Carpophaga nove zealandice).

The number of speeies described is fifty-five, and these have been referred to twenty-three Families and thirty-five Genera. Of the former four, and of the latter seventeen, are strietly endemic or peeuliar to the New-Zealand Avifauna.

Of the fifty-five species all but eight are endemie, being found only in New Zealand and the adjacent islands. Of the exceptions one is Zosterops cerulescens, whose erratie history has already been notieed, two are migratory birds (Eudynamis taitensis and Chrysococcyx lucidus), which only spend the summer with us, and five are occasional stragglers from the continent of Australia, not one of whieh has ever been known to breed with us. Indeed, in estimating the eharacter of the Avifauna it is hardly fair to take count of these accidental visitants-such birds, for example, as the Australian Swift, whieh has been reeorded only once in the history of the Colony and may never reappear, or the Australian Honey-eater, which has been recorded twiee; so that, adopting this view, the number is reduced to one. It will thus be seen at a glance that the so-called "land-birds" are, almost without exception, eharaeteristic of the eountry. Even in the ease of Zosterops, which I have treated as identical with the Australian bird, there is some ground for regarding the New-Zealand form as a distinet loeal race. The late Mr. Gould and myself had no difficulty in picking out two of our birds from a whole ease of Australian speeimens, so manifest was the differenee in the tone of eoloration. While aeeepting therefore the identity of the species, I would point out that the difference I have mentioned ean only be aecounted for on the supposition that the birds hare been separated for a eonsiderable length of time. This tends to support my location of the species in the south-west region of the South Island, before it eame northwards, and is therefore opposed to Professor Hutton's theory * that it arrived quite recently from Australia.

$$
\text { * 'Ner-Zealand Magazine,' January 1876, p. } 96 .
$$


Coloured Illustrations are given of the following species :-

The Blue-wattled Crow (Glaucopis wilsoni).

The Orange-wattled Crow (Glaucopis cinerea).

The Huia (Heteralocha acutirostris), male and female.

The Saddle-back (Creadion carunculatus).

The Jack-bird (Creadion cinereus).

The North-Island Thrush (Turnagra hectori).

The South-Island Thrush (Turnagra crassirostris).

The North-Island Tomtit (Myiomoira toitoi).

The South-Island Tomtit (Myiomoira macrocephala).

The North-Island Robin (Miro australis).

The South-Island Robin (Miro allifrons).

The Grey Warbler (Gerygone flaviventris). Figured on same Plate as the Long-tailed Cuckoo.

The White-head (Clitonyx albicapilla).

The Yellow-head (Clitomyx ockrocephala).

The New-Zealand Creeper (Certhiparus novce zealandice).

The Fern-bird (Sphenoeacus punctatus).

The New-Zealand Pipit (Anthus novce iealandice).

The Pied Fantail (Rhipiclura flabellifera).

The Blaek Fantail (Rhipidure fuliginosa).

The Silver-eye (Zosterops ccerulescens).

The Bell-bird (Anthornis melamura), male and female.

The Tui or Parson bird (Prosthemadera nove zealandice), adult and young.

The Stitch-bird (Poyonornis cincta), male and female.
The Bush-Wren (Xenicus longipes).

The Rock-Wren (Xenicus gilviventris).

The Rifleman (Acanthidositta chloris), male and female.

The New-Zealand Kingfisher (Halcyon vagans), adult and young.

The Long-tailed Cuekoo (Eudynamis taitensis), adult and young.

The Shining Cuekoo (Chrysococcyx lucidus), with young in Warbler's nest.

The Yellow-fronted Parrakeet (Platycercus auriceps).

The Red-fronted Parrakeet (Platycercus nove zealandice).

The Orange-fronted Parrakeet (Platycercus alpinus).

The Kaka Parrot (Nestor meridionalis), with rariety "Kaka-Kura."

The Kea Parrot (Nestor notabilis).

The Kakapo or Owl Parrot (Stringops habroptilus), with Alpine variety.

The Morepork (Spiloglaux nova zealandice).

The Laughing-Owl (Sceloglaux albifacies).

The New-Zealaud Harrier (Circus gouldi), adult and young.

The Quail-Hawk (Harpa nove zealandice), adult and young.

The Ner-Zealand Quail (Coturnix nove zealandix).

The New-Zealand Pigeon (Carpophaga nove zealandice).

I have endeavoured to make the technical part of the work as exhaustive and exact as possible. After the diagnostic characters of each species (rendered, according to the usual custom, in Latin), I have given full descriptions of both sexes, with their seasonal changes of plumage (if any), followed by an account of the young, commencing with the nestling, or fledgling, and noting the various adolescent states of plumage in the progress of the bird towards maturity. Under the head of 'Varieties,' I have been careful to record erery appreciable departure from the normal character that has come under my notice during an acquaintance with this peculiar Ornis extending over the best part of my life.

The measurements of each bird described are given in inches and decimals. In taking the extreme length my rule has always been to measure from the tip of the bill, following its curvature (if any) to the end of the tail. The advantage of this plan is that by deducting the measurements of the culmen and the tail, which are given separately, the exact length of the body may be ascertained. The same rule has been followed in regard to the claws wherever measurements are given.

In order to make the descriptions intelligible to the ordinary reader, some knowledge is essential of the names usually applied to the various parts of a bird and to the feathers which cover them. To supply an index to the descriptive terms commonly employed throughout the present work, it may be useful to reproduce here, on a slightly reduced scale, the diagram given in my 'Manual of the Birds of New Zealand,' the outline selected for the purpose being that of one of our commonest species. 
References.-1, forehead; 2, crown or vertex; 3, hind head; 4, napo; 5, lore or loral space; 6 , eje (shaded margin iris); 7 , ear-coverts; 8 , hind neck; 9 , side of neck; 10 , back or dorsal region; 11 , rump or uropygium; 12 , upper tail-coverts ; 13 , tail-feathers or reetrices; 14 , primaries or quills; 15 , sccondarics; 16 , larger wing-corerts; 17 , lesser wing-coverts (including "median"); 18, earpal flexure, or bend of wing; 19, scapulars; 20, chin; 21, throat; 2y, fore ncck; 23, breast ; 24 , abdomen; 25 , vent; 26 , under tail-coverts; 27 , tibial plumes; 28 , cero; 29 , ridgc of upper mandible or culmen; 30 , lower mandible; 31 , tarsus ; 32 , middle toc and claw ; 33 , hind toe and claw, or hallux.

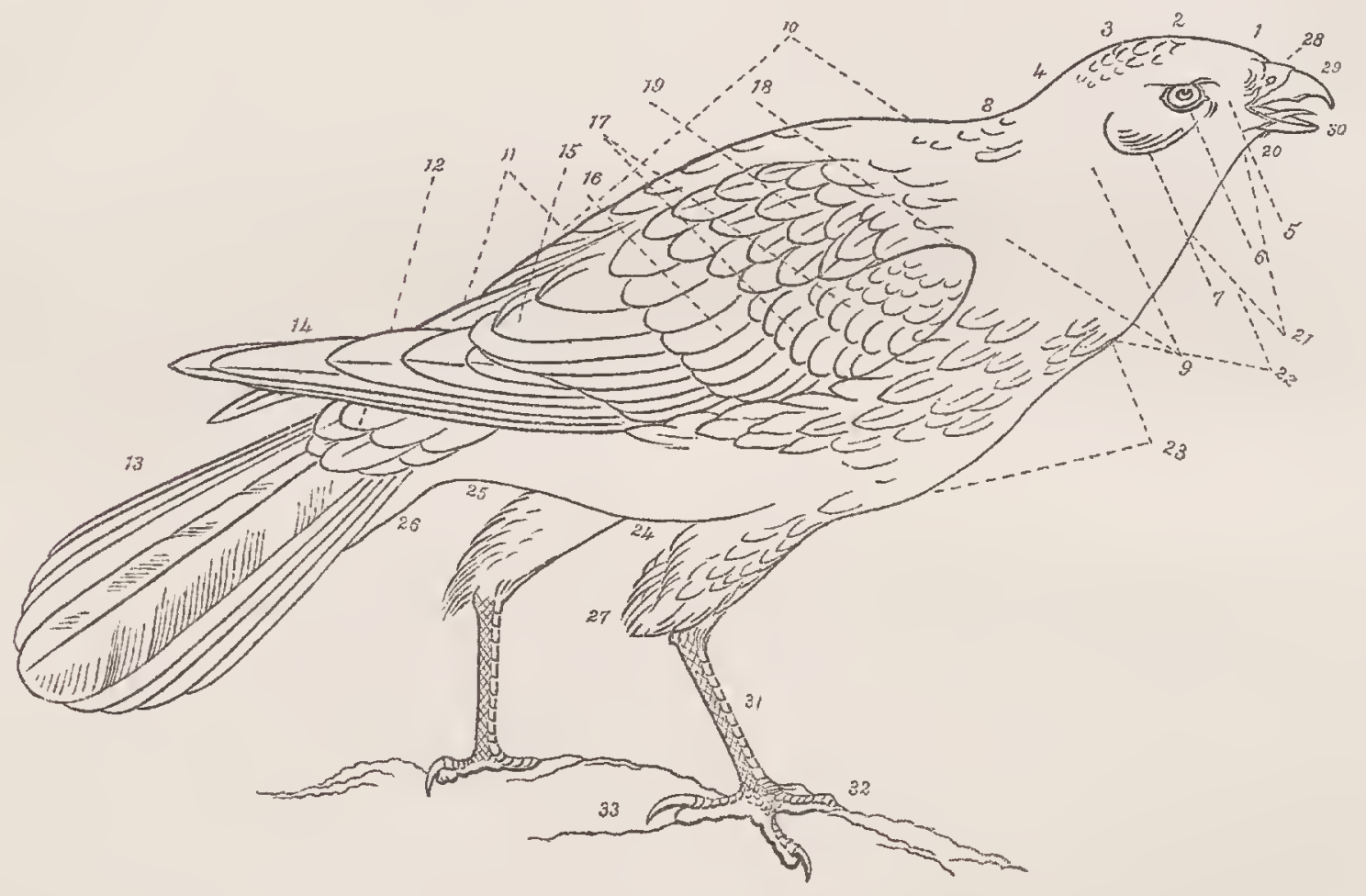

Outline of New-Zealand Harrier (Circus goulcli).

\section{CLASSIFICATION.}

In order to show at a glance the scheme I have adopted for the systematic arrangement of the existing Avifauna of New Zealand, I shall give here a Synopsis of the classification, with the superficial characters of each genus as at present defined.

As the characters of the genera are given in their entirety, I have thought it unnecessary to overload this section by adding the characters of the Orders and Families, which may be obtained from any text-book*.

I do not underrate the importance of the internal organs for determining generic distinctions. "But" (as Dr. Günther says, in his Preface to vol. vii. of the British Museum Catalogue of Birds) "it seems to me that investigations in the latter direction must lead to more numerous subdivisions than Ornithologists are inclined to admit at present."

Of every endemic group, except the Orvls (which do not differ widely from the genus Carine), I have given a woodcut in illustration of one or more of the characters.

* For the gencric characters I have, for the most part, rclied on Mr. G. R. Gray's 'Genera of Birds,' iu which work, although somewhat out of date, the definitions, taken as a whole, are marvellously correct. Hany of the genera have since becn split up by other ornithologists, but the broad lines remain; and while following these I have not hesitated to introduee such alterations and modifications as I decmed ncecssary. 


\section{Subclass CARINATA.}

Order PASSERES.

Family CORVID出. CRows.

\section{Genus GLAUCOPIS, Gmelin. Endemic.}

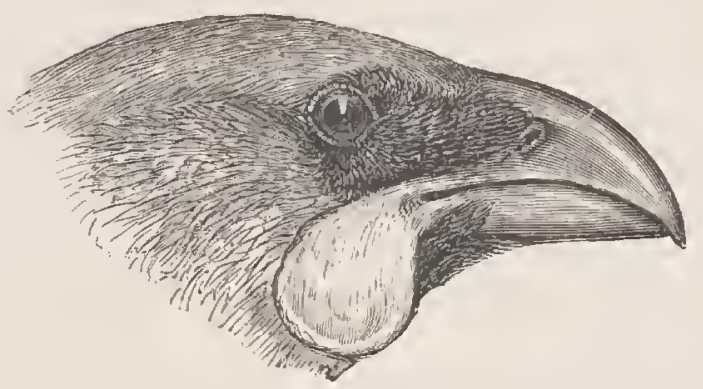

Generic einaraeters.-Bill short, strong, with the eulmen elevated at the base, and suddenly eurved from the base to the tip, which is entire; the sides eompressed, and the gonys lengthened and slightly arelied; the nostrils basal, lateral, piereed in a membranous ehannel, and the opening partly eoneealed by the frontal plumes. Wings short and rounded, with the sixth and seventh quills equal and longest. Tail moderately long and rounded, with the shaft of eaeh feather ending in a bristly point. Tarsi long, longer than the middle toe, and strongly seutellated in front, with one lengthened seale. Toes moderate, the lateral ones unequal and free at their base, the outer toe the longest; the hind toe very long and strong, and all armed with strong eurved elaws.

Family STURNID无. Starlixgs.

Genus HETERALOCHA, Cabanis. Endemic.

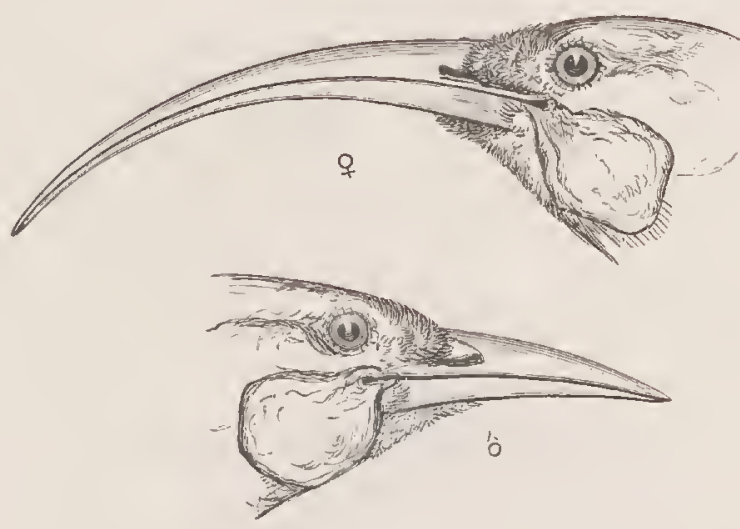

Ges. енAR.-Bill long, arehed, and aeutely pointed, with the eulmen, lateral margins, and gonys eurved to the tips; mueh produeed in the female, forming a sexual eharaeter; the sides eompressed; the nostrils basal, lateral, and plaeed in a short, broad, membranous groove, whieh is mostly eovered by the projeeting plumes, leaving the opening small and exposed. Wings long and rounded, with the fifth, sixth, and serenth quills nearly equal and longest. Tail rather long, broad, and somewhat rounded. Tarsi mueh longer than the middle toe robust, and eurved in front, with slightly divided broad seales. Toes long and robust, with the inner toe shorter than the outer and free at the base; the outer united at its base; the hind toe two thirds the length of the tarsus, and armed with a very long, strong, eurved, aeute elaw; those of the fore toes long, eurved, and aeute. 
Genus CREADION, Vieillot. Endemic.

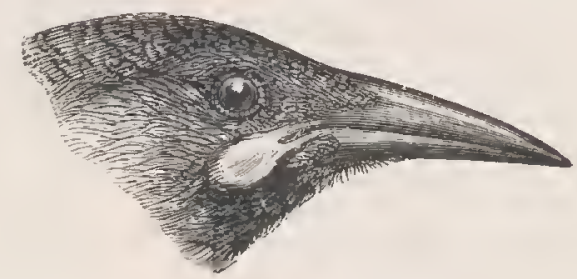

GEN. char. - Bill longer than the head and rather straight, with the culmen flattened and sloping and the sides compressed to the tip, which is depressed and obtuse; the lateral margins straight, and angulated near the base; the gonys long and asecnding; the nostrils lateral, and placed in a membranous groove, which is mostly clothed with short feathers, with the opening suboval. Wings short and rounded, with the first quill short, and the fourth, fifth, and sixth equal and longest. Tail long and rounded. Tarsi nearly as long as the middle toe, and covered in front with almost entire scales. Toes long; the lateral toe unequal, with the outer united at the base ; the hind toe long and strong; the claws long, curved, and very acute.

\section{Family TURNAGRIDÆ. TiICK-Billed Thrushes.}

Genus TURNAGRA, Lesson. Endemic.

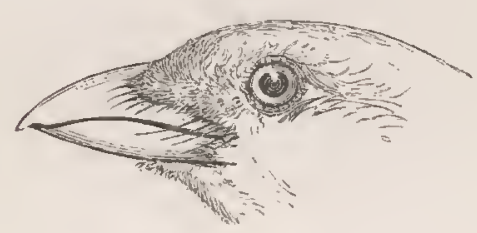

Gen. char.-Bill short, broad, and clevated at the base, with the eulmen eurved and the sides compressed to the tip, which is emarginated; the lateral margins much eurved, and the gonys long and ascending; the nostrils basal, with the opening anterior, rather rounded, and slightly covered with a few bristles and plumes. Wings moderate and rounded, with the fifth and sixth quills equal and longest. Tail long, broad and rounded. Tarsi longer than the middle toe, strong, and covered in front with broad scalcs. Toes long and strong, with the outer toe longer than the inner, and united at its base; the hind toe long, strong, and armed with a strong curved claw.

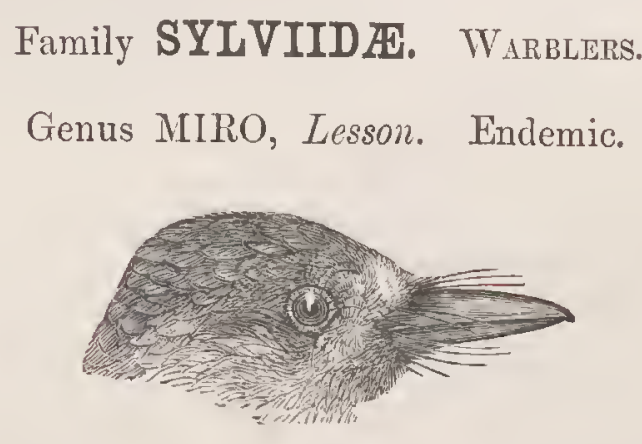

GeN. char.-Bill two thirds the length of the head, slender, straight, higher than broad, sides compressed, the culmen slightly curved, the gonys long and ascending; nostrils basal, the opening rather large and suboval. Wings moderate, extending to half the length of the tail, rounded and concave, with the first quill very short, the third nearly as long as the fourth, which is the longest, the fifth and sixth scarcely shorter. Tail moderate, rather broad and even, the feathers cut sharply off at their tips. Tarsi very long and slender. 
Genus MYIOMOIRA, Reichenbach. Endemic.
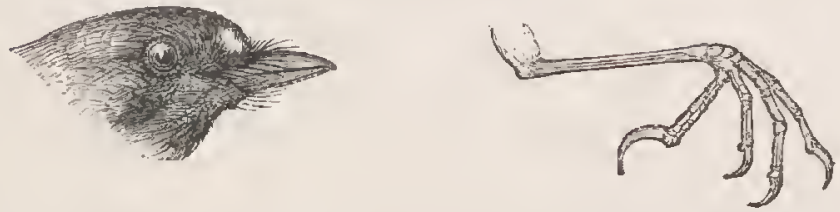

GEN. eHAR.-The same as in Miro, exeept that the bill is shorter, being only one third the length of the head, narrow and sharp-pointed; the wings longer, extending for two thirds the length of the tail; and the elaw of hind toe weaker.

Genus GERYGONE, Gould. New Zealand, Australia, New Guinea, and Indo-Malayan Islands.

Gen. eHAr.-Bill moderate, slender and straight, with the eulmen slightly eurved, and the sides eompressed to the tip, which projeets beyond the lower mandible; the gonys long and aseending; the nostrils basal and in a membranous groove, with the opening linear. Wings rather short and rounded, with the first quill very short, and the third nearly as long as the fourth, whieh is the longest; fifth and sixth seareely shorter. Tail long and rather rounded. Tarsi twiee the length of the middle toe, slender, and eovered in front with an entire seale. Toes moderate, with the inner toe shorter than the outer, which is united at its base; the hind toe long, and armed with a moderately strong, eurved claw.

Family PARID正. Tits.

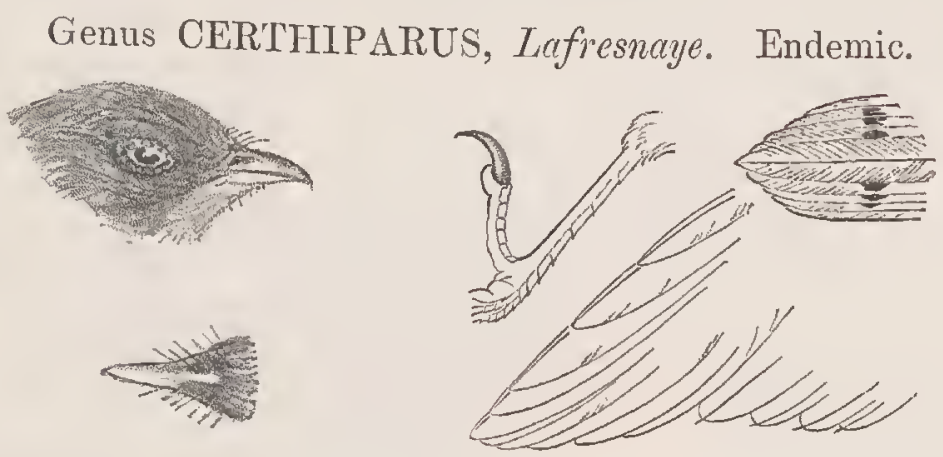

Gex. char.-Bill moderate, with the eulmen eurred and the sides eompressed to the tip, whieh is entire, and the gonys long and slightly aseending; the nostrils lateral, plaeed in a groove, with the opening lunate, and partly eoneealed by the projeeting frontal plumes. Wings moderate and rounded, with the fifth quill the longest. Tail long and rounded. Tarsi mueh longer than the middle toe, and broadly seutellated in front. Toes long, with the lateral ones equal; the hind toe long and strong, the elaws moderate, slightly eurved and aeute.

\section{Family TIMELIID尼. Grass Warblers.}

Genus CLITONYX, Reichenbach. Endemic.

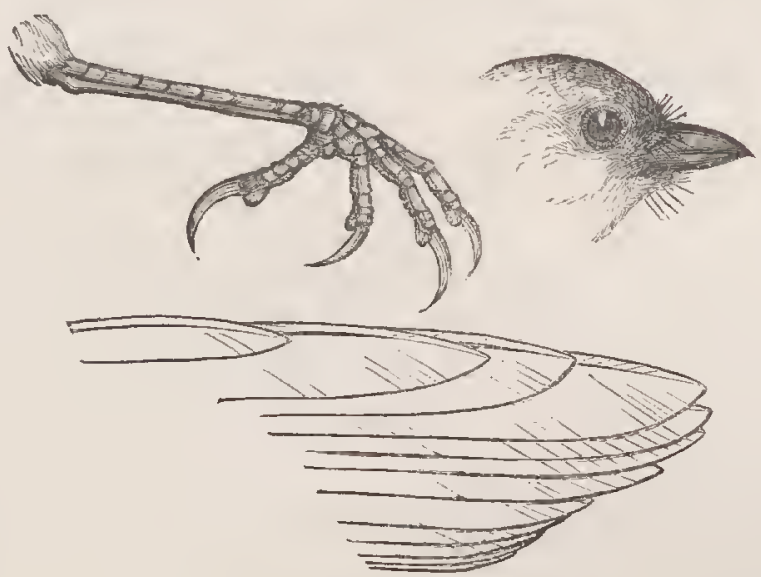

GeN. CHAR. - Bill half as long as the head, robust, with the eulmen eurved and the gonys aseending; the tip 
of the upper mandible projeeting over the lower; the nostrils basal, with a large suboval opening. Wings rather long, reaching to the middle of the tail, much rounded, with the fifth and sixth quills equal and longest. Tail rather long, broad, and rounded, the feathers slightly ineurved, and the shafts more or less denuded at their tips. Tarsi mueh longer than the middle toe, and proteeted anteriorly by broad seales. Toes strong, and armed with well-eurved, aeute elaws, that of the hind toe speeially so.

\section{Genus SPHENGEACUS, Strickland. New Zealand and Australia.}

Gen. ehar.-Bill short, and more or less strong, with the eulmen more or less eurved, and the sides compressed to the tip, whieh is entire or slightly emarginated; the gonys long and aseending; the gape furnished with very short weak bristles; the nostrils basal, placed in a membranous groove, with the opening lunate, exposed ancl partly elosed by a scale. Wings short and rounded, with the fourth and fifth quills equal and longest. Tail long, graduated on the sides, with more or less filamentous webs. Tarsi rather longer than the middle toe, strong, and eovered in front with broad scutellations. Toes lengthenerl and slender, with the lateral toes nearly equal, the outer united at its base; the hind toe long, and armed with a long elaw.

\section{Family MOTACILLID正, PIPITS.}

Genus ANTHUS, Bechstein. Cosmopolite.

GEv. eHAR. - Bill more or less straight and slender, with the eulmen almost straight or slightly eurved, and the sides eompressed to the tip, whieh is emarginated; the lateral margins straight and infleeted; the gonys long and aseending; the nostrils lateral, plaeed in a short broad groove, with the opening rounded and partly closed by a membrane. Wings noderate, with the first tliree quills equal and longest. Tail modcrate and cmarginated. Tarsi longer than the middle toe, rather slender, and eovered in front with broad trensverse seales. Toes long and rather slender; with the lateral toes equal, and the onter one slightly united at its base; the hind toe long; the clars of the anterior toes rather short and eurved, and that of the hind toe very long and aeute.

\section{Family CAIMPEPHAGID正. Caterpiliar-eaters.}

Genus GRAUCALUS, Cuvier. Africa, Oriental Region, and Australia.

GEx. ellar.-Bill sloort, and broad at the base, with the culmen rather depressed, slightly eurved, and the sides gradually eompressed to the tip, which is emarginated; the gonys long and slightly ascending; the gapc furnished with a few short bristles; the nostrils basal, lateral, rounded, and concealed by the frontal plumes. Wings moderate, with the first quill short, the sceond shorter than tlie third, and the third more or less shorter than the fourth, whieh is the longest. Tail long, broad, and rounded on the sides. Tarsi short, the length of the middle toe, and eorered in front with broad seales. Toes moderate, the inner toe shorter than the outer, which is united at its base; the lind toe moderate and broad, padded beneatl ; the elaws moderate, eompressed, and curved.

\section{Family IIUSCICAPID后, FLYCATChers.}

\section{Genus RHIPIDURA, Vig. \& Ilorsf. New Zealand, Australia, New Guinea, India, and Indo-Malayan Islands.}

Gev. ellar. - Bill moderate, broad at the base, and narrowing towards the end, with the eulmen rather depressed and eurved to the tip, which is cmarginated; the lateral margin straight; the gonys long and slightly ascending, and the gape furnished with numerous Iengthened bristles; the nostrils basal, lateral, and partly covered by the plumes and bristles. Wings long and rather pointed, with the first quill short and the fourth and fifth the longest. Tail lengthened, broad, and graduated. Tarsi longer than the middle toe, and eovered in front with broad seales. Toes short, with the outer one longer than the inner, the hind toe long, and the elaws moderate, curved, compressed, and acute. 
Family HIRUNDINID尼. Swallows.

Genus PETROCHELIDON, Cabanis. Peculiar to Old World.

Gen. енAr.-Bill short, strong, broad at the gape, gradually eompressed on the sides; the eulmen elevated at the base, and slightly eurved to the tip; the nostrils basal, rounded, and exposed, without a superior membrane, the aperture longitudinal or oval. Wings long, with the first quill the longest. Tail square or only slightly emarginate. Tarsi longer than the middle toe and elothed with plumes. Toes long, not feathered, the lateral ones unequal; the claws moderate and eurved.

\section{Family MELIPHAGIDE. HoNEY-Eaters.}

Genus ZOSTEROPS, Vig. \& Horsf. New Zealand, Australia, South Africa, India, and the Malay Archipelago.

GEN. CHAR.-Bill moderate, and slightly eurved, with the eulmen eurved, and the sides eompressed to the tip, whieh is aeute and emarginated; the gonys long and slightly aseending; the gape furnished with very short weak bristles; the nostrils basal, and plaeed in a broad groove, with the opening elosed by a lunate seale. Wings moderate, with the first quill very small, and the fourth and fifth equal and longest. Tail moderate, broad and slightly emarginated in the middle. Tarsi rather longer than the middle toe, and eovered in front with broad seales. Toes rather long; with the outer toe rather longer than the inner and united at its base; the lind toe long, strong, and armed with a long eurved elaw.

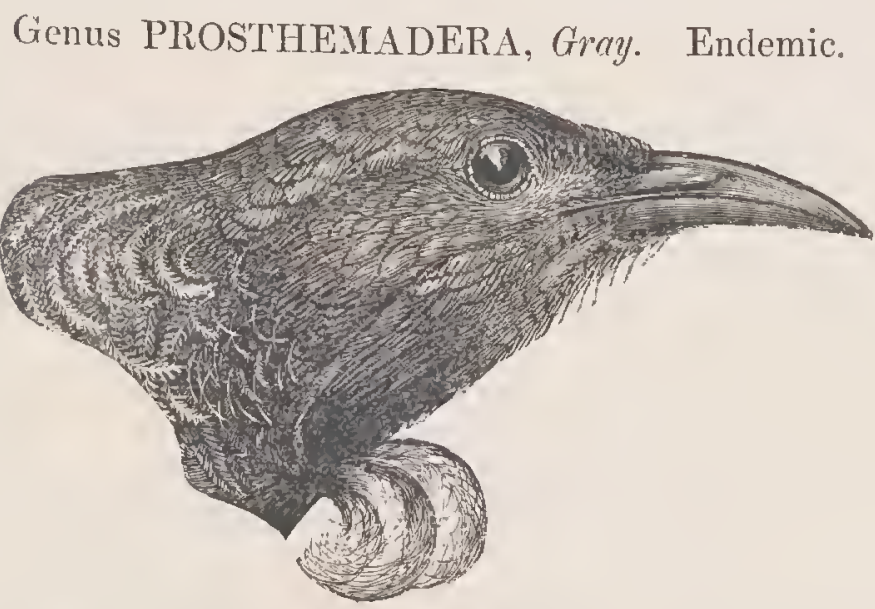

Gex. CH.ıR.-Bill long, rather slender, broarl and elevated at the base, with the eulmen and lateral margius eurved and the sides eompressed to the tip, which is slightly emarginated and aeute; the gonys long and eurved; the nostrils basal, large, in a broad membranous groove, and the opening eovered by a prominent membranous seale. Wings morlerate, with the fifth and sixth quills equal and longest, and the third, fourth, fifth, and sixth more or less emarginated in the middle of the inner webs. Tail long, broad, aud rounded on the sides. Tarsi as long as or longer than the middle toe, and eovered in front with transverse seales. Toes moderate, with the inner toe shorter than the outer, whieh is united at its base; the elaws long, slender, eurved, and very aente.

\section{Genus ANTHORNIS, Gray. Endemic.}

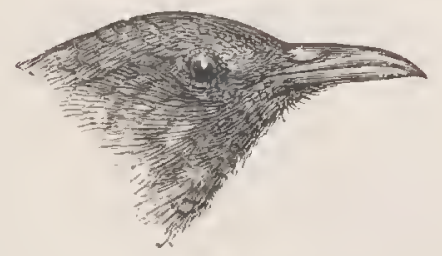

Ges. char.-This genus differs from the preeding one in the form of the wings, whieh are moderate, with the 
first quill short and pointed; the seeond shorter than the third, aeutely pointed in the male, and emarginated and narrowing into a long point in the female; the third rather shorter than the fourth, fifth, and sixth, which are equal, longest, and rounded at the ends.

Genus POGONORNIS, Gray. Endemic.

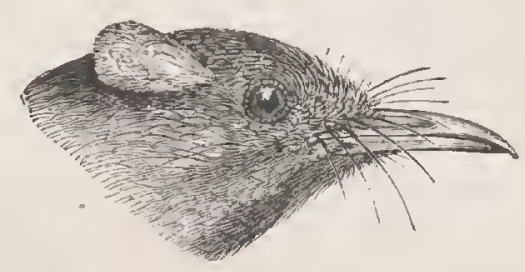

GEN. errar.-Bill moderate, very slender, and much eompressed on the sides, with the eulmen and lateral margins gradually curved to the tip, which is strongly emarginated; the gonys long and eurved; and the gape furnished with lengthened slender bristles; the nostrils basal, large, and placed in a large groove, with the opening linear, oblique, and eovered by a membranous seale. Wings moderate, witl the fourth quill the longest. Tail moderate and emarginated. Tarsi long and robust, and eovered in front with transverse seales. Toes long, with the outer longer than the inner, and united at its base; the hind toe long and strong; the elaws long, compressed, and aeute.

Genus ACANTHOCHÆRA, Tig. \& Horsf. Peculiar to Australia.

Gex. enar. - Bill long, rather slender, broad, and elevated at the base, with the eulmen and lateral margins eurved, and the sides eompressed to the tip, whieh is slightly cmarginated and aente; the gonys long and eurved; the nostrils basal, large, in a broad membranous groove, and the opening eovered by a prominent membranous seale. Wings moderate and rounded, with the first four quills graduated, and the fifth and sixth equal and longest. Tait long, broad, and graduated on the sides. Tarsi as long as, or longer than, the middle toc, and eovered in front with transverse seales. Toes moderate, with the inner toe shorter than the outer, whieh is united at its base; elaws long, slender, eurvel, and very acute.

\section{Family XENICID正. Dwarf PitTas.}

Genus XENICUS, Gray. Endemic.

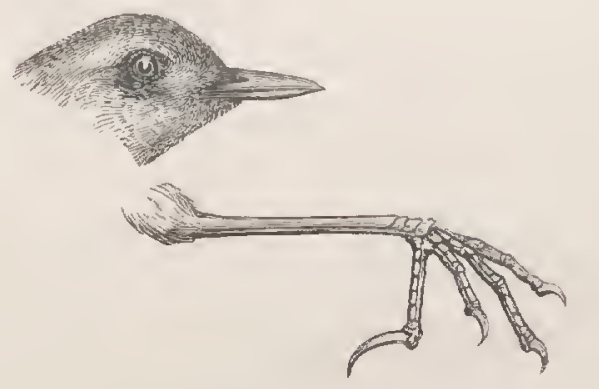

GEN. CHAR.-Bill moderate, more or less straight, moderately narrow at the base, and eompressed to tip; eulmen slightly curved at the apex; margin straight; gonys angulated one third of its length, and advancing towards the tip, and straight to the base; nostrils sunk in a short broad groove, with the opening large, oval, and partly closed by a membrane. Wings short, romded, with the third, fourth, and fifth quills nearly equal and longest. Tarsi lengthened, slender, longer than the middle toe, eovered by an entire scale. Toes rather long, slender; inner toc free at the base, the outer one eonnected nearly to the first joint of the middle toe; claws long, curred, and very aeute. 
Genus ACANTHIDOSITTA, Lafresnaye. Endemic.

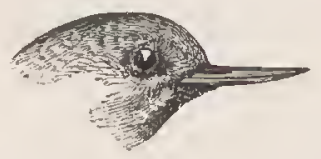

GeN. CHar.-Bill long, straight, and very slender, with the culmen straight and slightly curved at the tip, the sides compressed, and the gonys long and gradually advancing upwards; the nostrils basal, lateral, and placed in a deep, broad groove, with the opening linear and near the culmen. Wings moderate, with the third and fourth quills the longest, the first shorter than the second, which is shorter than the third and fourth. Tail short and rounded. Tarsi shorter than the middle toe, and covered in front with an almost entire scale. Toes long and very slender, the lateral toes unequal, the outer longest and united at its base, the hind toe nearly as long as the middle one; the claws long, compressed, and curved.

\section{Order PICARI A. \\ Family CYPSELIDÆ⿸尸. SwIFTS.}

\section{Genus CYPSELUS, Illiger. Warmer parts of the World.}

Gen. CHAll.-Bill short and depressed, with the gape very wide, and the sides gradually eompressed to the tip, which is curved ; the nostrils basal, lateral, and large, with the opening longitudinal, on each side of the culmen, and the margins beset with small feathers. Wings lengthened, with the second quill longest. Tail moderate, forked or uneven. Tursi very short, and feathered to the base of the toes. Toes all directed forwards, short, thick, and armed with short, curved, and compressed claws.

\section{Family CORACIID玨, RoLLers.}

Genus EURYSTOMUS, Vieillot. The warmer parts of the Old World, Australia, New Guinea, and the Malay Archipelago.

GEN. eHAR.-Bill strong, depressed and broad at the base, sides much compressed towards the tip, which is hooked; nostrils basal, oblique, partly covered by a plumed membrane. Wings long and pointed, reaching to end of tail; second quill the longest. Tail moderate and even. Tarsi shorter than middle toe, and covered with transverse scales. Toes long, united at the base; hind toe long; claws moderate, curved, and acute.

\section{Family ALCEDINID床, KIVGFishers.}

Genus HALCYON, Swainson. Africa, India and its Archipelago, Australia, New Zealand, and the islands of the South Pacific.

Gen. ehar. - Bill long, broad at the base, sometimes depressed, with the sides gradually compressed, and the culmon more or less straight to the tip, which is acute; the lateral margins usually straight, and the gonys more or less straight and ascending; the nostrils basal and lateral, placed in a small membranous space, with the opening small, longitudinal, and partly concealed by the projecting plumes. Wings moderate, with the first quill long, and the third the longest. Tail moderate, and rounded on the sides. Tarsi very short, rather slender, and covered in front witl transverse scales. Toes moderate and uncqual, with the outer toe long and united to the third joint, and the inner to the second joint, of the middle toe; the elaws moderate, compressed and acute. 


\section{Family CUCULID西. Cuckoos.}

Genus EUDYNAMIS, Vig. \& Horsf. Oriental Region, Australia, New Zealand, and Polynesia.

GeN. char. - Bill long, broad, with the culmen curved, and the sides compressed to the tip, which is slightly cinarginated; the gonys short and angulated; the nostrils basal, lateral, and placed in a short membranous groove, with the opening large and exposed. Wings moderate, with the fourth and fifth quills equal and longest. Tail lengthened and rounded. Tarsi rather short, robust, and covered in front with broad scales. Toes unequal, the outer anterior toc the longest.

\section{Genus CHRYSOCOCCYX, Boie. Warmer portions of the Old World.}

GEN. енAR.-Bill broad, and rather depressed at the basc, with the culmen curved, and the sides gradually compressed towards the tip, which is entirc and acute; the gonys long and arched; the nostrils basal, lateral, and placed in a short, broad, membranous groove, with the opening round and cxposed. Wings lengthened and pointed, with the third quill the longest. Tail long and graduated, or even, and the outer feathers on each side shorter than the others. Tarsi very short, feathercd bclow the knee, and the cxposed part covered with broad scales. Toes inequal ; the outer anterior toc the longest, and united to the inner one at the base.

\section{Order PSITTACI.}

\section{Family PLATYCERCID无, ParrakeEts.}

\section{Genus PLATYCERCUS, Tigors. New Zealand, Polynesia, Australia, and New Guinea.}

GEN. cHAR.-Bill moderate, with the sides swollen, and the culmen rounded, and arehed to the tip, which is sonuctimes obtuse; the lateral margins curved and slightly dentated, or cntirc; the gronys broad, rather biangular on the sides, and curved upwards; the nostrils basal, lateral, cxposed, and rounded, and placed in a small rounded cere near the culmen. Wings moderate and concave, with the first quill shorter than the second and third, which are nearly equal and longest, and the webs of the first four quills suddenly dilated ncar the basc. Tail lengthence, broad, and nearly even, or much graduated, with the featliers towards the tip morc or lcss narrowed and rounded or pointed. Tarsi shorter tlan the middle toe, and covcred with minute seales. Toes moderate, much padded beneath, the outer anterior one the longest; and the claws long, compressed, curved, and acute.

\section{Family NESTORID正, NESTORS.}

Genus NESTOR, Wagler. Endemic.

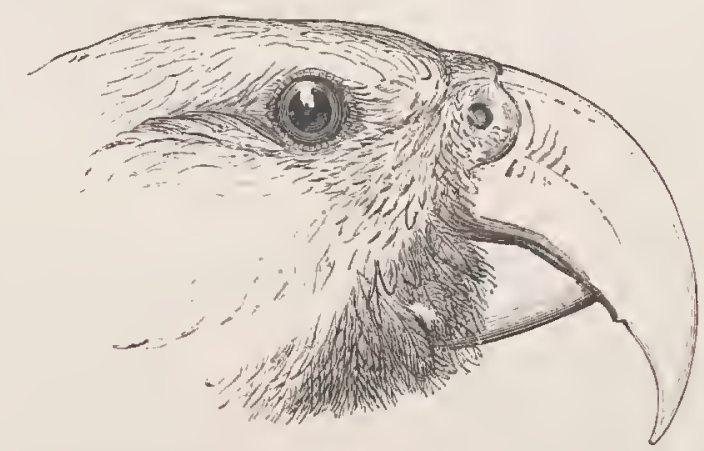

GEN. CHAR. - Bill much lengthened, the sides compressed, especially near the culmen, which is rounded and much arched to the tip, which is long and acute; the base of the lowcr mandible partly hidden by the projecting feathers and the sides rather compressed, with the gonys nearly flat and ascending towards the tip; the nostrils moderate, rounded, and placed in the cerc. Wings long and pointed, with the third and fourth quills the longest. Tail modcrate, and ncarly cren at the end, with the feathers firm and broad, and the shafts prolonged beyond the web. Tarsi as long as the inner anterior toe and corered with small scales. Toes moderate, the two outcr oncs the longest, and all corered with small irregular scalcs. 


\section{Family STRINGOPID王. OWL ParRots.}

Genus STRINGOPS, Gray. Endemic.

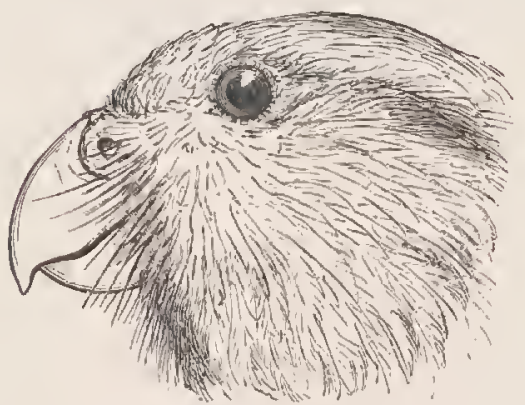

GEN. EHAR.-Bill higher than broad, slightly compressed, and grooved on the sides; the culmen mueh eurved to the tip, which is aente; the lateral margins dentated in the middle; the lower mandible with the gonys broad, rounded, and much grooved longitudinally, and the base of both mandibles eovered by the basal feathers, with the shaft of each prolonged into hairs; the nostrils basal, lateral, large, and rounded. Wings rather short and rounded, with the fifth and sixth quills equal and longest. Tail moderate, weak, and mueh rounded, with the end of each feather rather pointed, and the shafts projeeting beyond the web. Tarsi short, robust, and covered with rounded seales. Toes unequal, and eovered with quadrate seales, exeept at the end of each toe, where the seales are transverse; the elaws long, strong, and slightly eurved.

\section{Order STRI G ES.}

\section{Family STRIGID正, OWLS.}

Genus SPILOGLAUX, Kaup. The Indian Peninsula, Ceylon, China, Japan, the Malay Archipelago, Australia, New Zealand, and Madagascar.

Gen. CHar. - Bill short, partly coneealed by the projeeting plumes, the sides eompressed, the eulmen muels arehed to the tip, which is hooked and aeute; the nostrils basal, lateral, and hidden by the frontal plumes. Wings rather long and pointed, with the first quill mueh shortened, the third and fourth quills equal and longest. Tail rather long and nearly even. Tarsi longer than the middle toe, and eovered with plumes. Tocs short, and eovered with seattered hairs; the elaws long, arehed, and aeute.

\section{Genus SCELOGLAUX, Kaup. Endemic.}

Gro. ehar.-Similar to Spiloglaux, but distinguished by its more developed tarsi, whieh are twiee the length of the middle toe, and thiekly feathered in their whole extent.

\section{Order A CCIPITRES.}

\section{Family FALCONID无, Hawks.}

\section{Genus CIRCUS, Lacépède. Most parts of the World.}

GEN. CIIAR.-Bill moderate, elevated at the base of the eulmen and arehed to the tip, whieh is looked, the sides compressed, and the lateral margins festooned; the nostrils large, oval, and partly eoncealed by the eurved hairs of the lores. Wings long, with the third and fourth quills nearly equal and longest. Tail long and rounded on the sides. Tarsi long, slender, and eompressed, the outer side eovered with transverse scalcs, and the inncr with small seales. Toes modcrate, with the outer one longer than the inner; the claws long, slcnder, and aeute. 
Genus HARPA, Bonaparte. Endemic.

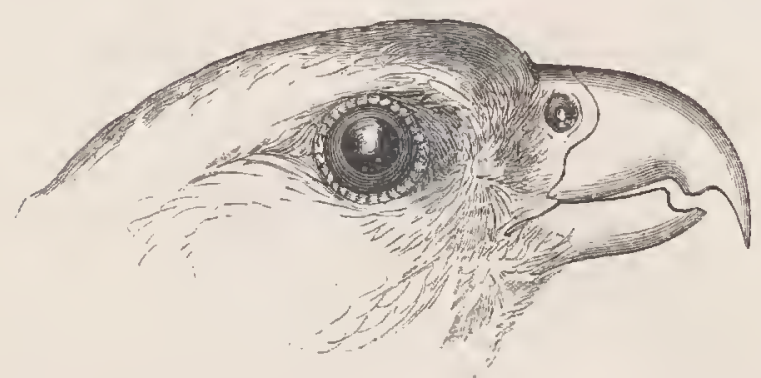

Gen. CHaR. - Bill short, strong, with the eulmen muel arehed from the base to the tip, which is aeute; the sides eompressed, the lateral margins strongly toothed near the tip; the nostrils plaeed in a short eere, naked, and rounded, with a eentral tuberele. Wings moderate, with the seeond and third quills nearly equal and longest. Tarsi lengthened, rather slender, and eovered in front with rounded seales. Toes long, especially tlie middle toe, which is more than twice the length of the eulmen, the lateral ones equal, the hind toe rather long; the elaws moderately robust.

\section{Order G A L L I N $\underset{E}{ }$.}

\section{Family TETRAONIDAE. QUAILS.}

Genus COTURNIX, Moehring. Warmer and temperate parts of Old World, Australia, and New Zealand.

Gen. char. - Bill short, more or less elevated at the base and arehed to the tip, whiel is obtuse; the sides compressed ; the nostrils basal, lateral, and covered by a hard seale. Wings moderate, with the seeond, third, and fourth quills the longest. Tuil very short, mostly hidden by the eoverts, and pendent. Tarsi short, eovered in front with divided seales, and unarmed. Toes moderate, united at their base, with the inner toe shorter than the outer; the hind toe short; the elaws short, and slightly eurved.

\section{Order COLUMBA. \\ Family COLUIMBIDE,. PigEONS.}

Genus CARPOPHAGA, Selby. India, the Malay Archipelago, Australia, New Zealand, and Polynesia.

GEN. eHAR. - Bill moderate, slender, with the base depressed, the tip compressed and moderately arelied, and the margin slightly sinuated; the nostrils placed in the soft basal portion of the bill, and forming a longitudinal slit. Wings moderate and pointed; with the seeond, third, and fourth quills nearly equal and longest. Tail lengthened, and generally rounded. Tarsi very short, and elothed with down below the knec. Toes strong, and broadly padded below; with the outer toe longer than the inner, and the hind toe mueh developed.

\section{Order L I M I C O L A.}

Family CHARADRIID死, Plovers.

Genus CHARADRIUS, Limn. Cosmopolite.

GEN. CHAR.-Bill more or less short, robust, and straight; the eulmen, for two thirds its length, usually depressed, and the tip vaulted and curved; the sides eompressed, and furnished on both mandibles witl a groove, 
which extends on the uppcr mandible for two thirds of its length; the nostrils basal, linear, and placed in a groove. Wings long and pointed, with the first quill the longest. Tail moderate, broad, and rounded. Tarsi longer than the middle toe, more or less slender, and eovered in front with small retieulated seales. Toes three, moderate; the onter toe longer than the inner, and more or less united at the base by a membrane, the inner toe usually free; the hind toc wanting; the elaws small, eompressed, and slightly eurved.

Genus THINORNIS, Gray. Endemic.

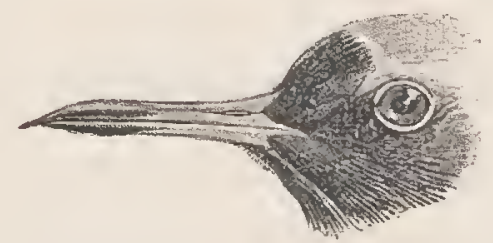

GEN. енAR.-Bill long, straight, and slender, with the apex seareely vaulted and aeute, the sides eompressed, and both mandibles grooved; the nostrils lateral, plaeed in a groove tlat extends for two thirds the length of the bill, and the opening linear. Wings long and pointed, with the first and seeond quills nearly equal and longest. Tail long and rounded. Tarsi as long as, or shorter than, the middle toe, strong and eovered with small seales. Toes three, more or less long and robust; with the outer toe rather longer than the iuner, and united at the base by a membrane, and all margined on the sides; the lind toe wanting.

Genus ANARHYNCHUS, Quoy \& Gaim. Endemic.

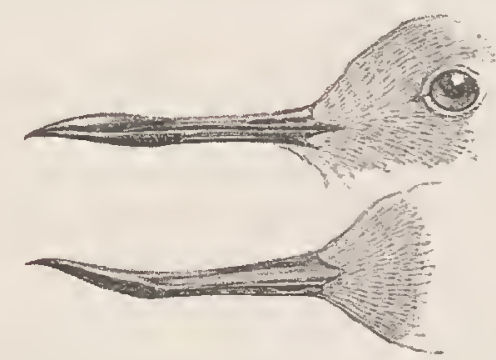

GEx. elar.-Same as Thinornis, but with the bill asymmetrieal, being always turned to the right.

\section{Genus LOBIVANELLUS, Strickland. Australia.}

Gen. eHAR.-Bill moderate, and more or less strong, with the eulmen depressed at the base and vaulted at the tip, the sides eompressed and grooved; the nostrils lateral, basal, and placed in the groove of the upper mandible, whieh extends for two thirds its length, with the opening linear; the front and sides of the head lobed. Wings long and pointed; with the first, seeond, and third quills nearly equal and longest; armed at the flexure witl a sharp spur. Tail moderate, broad, and even. Tarsi mueh longer than the middle toe, slender, and eovered in front witlı divided broad seales. Toes four; the three anterior toes long and ratlier slender; the outer toe longer than the inner, and united at the base; the hind toe sliort and elevated.

\section{Genus STREPSILAS, Illiger. Cosmopolite.}

GEN, eHAR.-Bill rather shorter than the head, straight and slightly depressed at the base, with the eulmen straight, and the sides mueh eompressed to the tip, whieh is truneated; the lateral margins of botll mandibles eurved upwards at the tip; the gonys moderate and ascending; the nostrils lateral, and plaeed in a membranous groove that extends half the length of the upper mandible, with the opening linear and longitudinal. Wings very long and pointed, with the first quill the longest. Tail moderate, and slightly rouuded. Tarsi as long as the middle toe, robust, and eoverer in front with broad seales. Toes long, the outer toe rather longer than the inner, and both free at the base, and the sides of all margined by a narrow membrane; the lind toe elevated, with the tip resting on the ground. 


\section{Genus HEMATOPUS, Linnceus. Most parts of the world.}

Gen. char.-Bill longer than the head, strong, straight, with the culmen slightly depressed at the base, and the apieal portion mueh eompressed to the tip, which is obtuse; the nostrils plaeed in a lateral membranous groove, whieh reaches nearly to the middle of the bill, with the opening linear. Wings long, with the first quill the longest. Tail moderate and even, or slightly rounded. Tarsi strong, longer than the middle toe, and eovered with small retieulated seales. Toes moderate, strong; the lateral toes united to the middle toe by a basal membrane, espeeially the outer one; the elaws strong, broad, and slightly eurved.

\section{Family SCOLOPACID丑. SNIPES.}

\section{Genus RECURVIROSIRA, Linn. Most parts of the world.}

GEN. енAR. - Bill very long and slender, with the eulmen slightly depressed at the base, the sides grooved to the middle and eompressed to the tip, whiel is gradually pointed; the nostrils lateral, and plaeed in the groove, with the opening linear and membranous. Wings long and pointed, with the first quill the longest. Tail short and rounded. Tarsi mueh longer than the middle toc, rather eompressed, and eovered in front with retieulated seales. Toes united together by an indented web; the outer toe rather longer than the inner; the lind toe extremely short; the elaws short, eompressed, and aeute.

\section{Genus HIMANTOPUS, Brisson. Most parts of the world.}

GEN. cliar.-Bill mueh longer than the head, very slender and straight, with the sides grooved to the middle and eompressed towards the tip, whieh is aeute; the nostrils basal, and plaeed in the groove, with the opening long, linear, and elosed by a membrane. Wings long and pointed, with the first quill the longest. Tail short and nearly even. Tarsi very long, slender, and eovered in front witl retieulated seales. Toes moderate, and united at the base by a small nembrane, espeeially the outer toe; the hind toe wanting; the elaws small, eompressed, and aeute.

Genus PHALAROPUS, Brisson. Inhabits the northern regions of the globe, migrating to the more temperate climes during severe winters.

Gin. char.-Bill as long as, or longer than, the head, more or less slender, but sometimes enlarged and depressed towards the tip, whieh is eurved and aeute; the sides grooved for nearly its whole length, in whieh groove the nostrils are plaeed, with the opening basal, linear, aud partly elosed by a membrane. Wings long and pointed, with tlee first and second quills equal and longest. Tail more or less short or rounded. Tarsi as long as, or longer than, the middle toe, rather robust and eompressed. Toes long; the lateral toes united to the middle by a menbrane that runs along the margin of each toe, whieh is more or less lobed; the hind toe moderate, elevated, and slightly margined by a membrane; the elaws short and aeute.

\section{Genus GALliNAGO, Leach. Cosmopolite.}

Gin. ehar.-Bill long, straight, groored, and eompressed on the sides, and the eulmen rather depressed near the tip, whieh is obtuse, and eurved orer that of the lower mandible; the nostrils basal, placed in the groove, with the opcning oblong and exposed. Wings moderate and pointed, with the first and seeond quills equal and longest. Tail short and rounded. Tarsi moderate, shorter than the middle toe, strong, and eovered in front with narrow transverse seales; the tibia bare for a short spaee above the tarsal joint. Toes long, the inner toe shorter than the outer, and free at their base; the hind toe moderate and elevated, with the elaw long and eurved.

Genus TRINGA, Linn. All the more genial parts of the world.

Gix. char.-Bill as long as, or longer than, the head, straight, slencler, with the sides eompressed at the base, and rather dilated and depresser at the tip; the nostrils plaeed in a nasal groove, whieh extends to near the tip, basal, lateral, and longitudinal. Wings moderate and pointed, with the first quill the longest. Tail rather short and nearly even. Tursi stroug, rather long, and eovered in front with transverse scales. Toes moderate, slightly united at the base of the outer toe, and all margined on the sides by a membrane; the hind toe very small and elevated. 


\section{Genus TOTANUS, Bechstein. Both Hemispheres, and especially in the temperate and northern portions.}

Gen. Char._-Bill more or less long and strong, with the eulmen straight or slightly curved, and the sides eompressed to the tip, whieh is slightly eurved and aeute; the gonys long and slightly curved upwards; the nostrils linear, and plaeed in a membranous groove, whieh does not extend beyond half the length of the bill. Wings reaehing beyond the end of the tail and pointed, with the first quill the longest. Tail moderate and nearly even. Tarsi as long as, or longer than, the middle toe, more or loss slender, and covered in front with numerous very narrow seales. Toes long, slender, the anterior toes united by a membrane, espeeially the outer; the hind toc slender, elevated, and hardly touehing the ground.

\section{Genus I.IMOSA, Brisson. Cosmopolite.}

GEx. CHAR.-Bill long, rather slender, and more or less inelined upwards towards the tip, with the sides eompressed and grooved on both mandibles for nearly their entire length; the nostrils lateral, basal, and placed in the groove, witl the opening longitudinal and elosed by a membrane. Wings long and pointed, witl the first quill the longest. Tail short and even. Tarsi longer than the middle toc, rather slender, and covered in front with narrow transverse seales. Toes long; the outcr toe united to the middle toe by a membrane as far as the first joint; the inner toe slightly united; the hind toe long, slender, and partly resting on the ground; the elaws short and obtuse.

\section{Genus NUMENIUS, Latham. Cosmopolite.}

Gen. enAr.-Bill more or less long, slender, and curved from the base, with the sides eompressed and grooved for ncarly its whole length; the tip of the upper maudible projecting over that of the lower, and rather obtuse; the nostrils basal, lateral, and placed in the lateral groove, with the opening longitudinal, and eovered by a membrine. Wings long and pointed, with the first quill the longest. Tail short and even. Tarsi longer than the middle toe, slender, and eovered in front with narrow transverse scales. Toes moderate, the lateral ones unequal and united at their base; the hind toe long, slender, and partly resting on the ground; the claws short and obtuse.

\section{Order G A V I A.}

\section{Family LARID无. GuLLS.}

Genus LARUS, Limn. All parts of the world except Polynesia.

Gex. cHar. - Bill more or less strong, as long as or shorter than the head, straight, and lateraliy eumpressed, with the eulmen straight at the base and arehed to the tip, the gonys slightly angulated and advaneing upwards; the nostrils lateral, with the opening near the middle of the bill, and lougitudinal. Wings lengthened and pointed, with the first quill the longest. Tail moderate and even. Tarsi nearly as long as the middle toc, strong, and eovered in front with transverse scales. Toes moderate, the anterior ones united by a full wcb; the hind toc short and elevated.

\section{Genus STERCORARIUS, Brisson. The colder regions of both Hemispheres.}

GEN. CHan.-Bill moderate, straight, and strong, with the eulmen straight, rounded, and eovered with a membranous or bony eere; the apex curved, vaulted, and strong; the gonys mueh angulated and aseending; the nostrils plaeed in the fore part of the eere, narrow, and cularging anteriorly. Wings lengthened and pointed, with the first quill the longest. Tail moderate and rounded, with the two entre feathers sometimes lengthened. Tarsi longer than the middle toe, strong, and eovered in front witl strong seales. Toes moderate aud strong, the anterior one united by a full web; the hind toe very small and hardly clevated. 


\section{Family STERNID无。 TERNS.}

\section{Genus STERNA, Linn. Cosmopolite.}

GEN. CHAR. - Bill more or less long, strong, with the culmen slightly curved to the tip, which is acute; the gonys straight, and half the length of the bill ; the nostrils lateral, placed towards the middle of the bill, and longitudinal, with the frontal plumes advancing close to, or near, the opening. Wings very long and pointed, with the first quill the longest. Tail more or less long and generally forked. Tarsi more or less long and slender. Toes moderate, the two outer ones nearly equal, and the three anterior ones united by an indented web; the hind toe very short; the claws moderate, slightly eurved, and aeute.

\section{Genus HYDROCHELIDON, Boie. Southern Hemisphere.}

GEN. eHAR.-Bill strong, short, with the culmen rather arched to the tip, which is acute; the sides eompressed, and the gonys long, straight, and advancing upwards to the tip; the nostrils basal, lateral, and longitudinal, with the frontal plumes projecting to the opening. Wings long, with the first quill the longest. Tail moderate and slightly emarginated. Tarsi rather shorter than the middle toe and slender. Toes long, slender, the two outer toes equal and longest, the three anterior toes united only at the base, the web eontinuing along the inner margin of each toe; the hind toe moderate and slender; the claws also long and slender.

\section{Order G R A L L AE.}

\section{Family RALLID再. RAILS.}

\section{Genus RALLUS, Linn. Cosmopolite.}

GEN. eHAR. - Bill longer than the head, slender, and straight, with the eulmen slightly curved from the front of the nostrils, and the sides eompressed to the tip, which is obtuse and slightly emarginated; the gonys long and slightly curved upwards; the nostrils placed in a membranous groove, which extends for two thirds the length of the bill, with the opening exposed and linear. Wings short, with the second and third quills equal and longest. Tail short and rounded. Tarsi moderate, shorter than the middle toe, and covered with transverse seales. Toes long and rather slender, the inner toc shortcr than the outer, both free at their base; the hind toe short and slender; the claws short, compresser, and very acute.

\section{Genus ORTYGOMETRA, Limnceus. Australia, New Zealand, and Polynesia.}

GEN. errar. - Bill shorter than the head, and more or less strong, with the eulmen keeled, slightly eurved, and the sides compressed to the tip, which is slightly emarginated; the gonys short and aseending; the nostrils lateral and placed in a membranous groove, with the opening exposed, linear, and near the middle. Wings moderate, with the seeond and third quills equal and longest. Tail short and graduated. Tarsi rather robust. Toes more or less long and slender, with the inner toe rather shorter than the outer, the hind toe very slender, and rather short; the claws moderate, eompressed, and acute.

\section{Genus OCYDROMUS, Wagler. Endemic.}

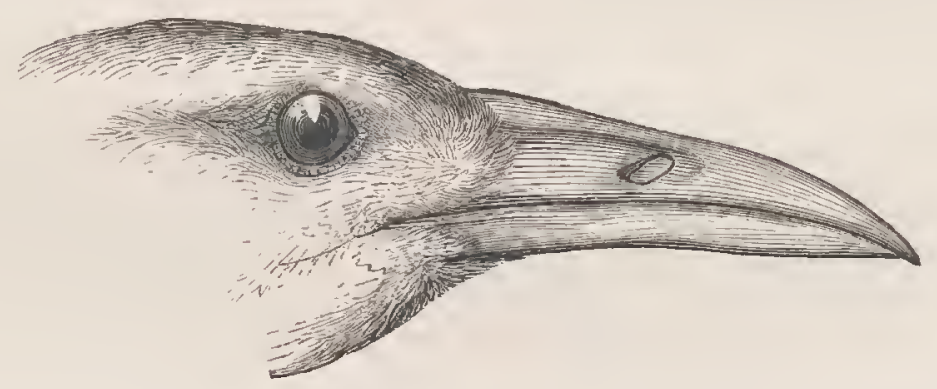

GEN. CHAR.-Bill rather long, and very strong, with the culmen slightly eurved and the sides mueh eompressed to the tip, which is slightly emarginated; the gonys short and aseending; the nostrils lateral, and plaeed in the 
fore part of a membranous groove, with the opening oval and exposed. Wings very short and rounded, with the fifth and sixth quills equal and longest; the seeondaries and the eoverts lengthened and very soft. Tail more or less lengthened, round and soft. Tarsi robust, shorter than the middle toe and eovered with transverse seales. Toes long and strong, with the inner toe rather shorter than the outer, the hind toe short and rather slender; the elaws moderate and rather aeute.

\section{Genus PORPHYRIO, Brisson. Most parts of the World.}

GrN. eHAR.-Bill short, very muel elevated at the base, whieh is flat and broadly dilated on the forehead; the culmen mueh arehed to the tip; the sides mueh eompressed; the nostrils plaeed in a small nasal groove and rounded. Wings moderate, with the seeond, third, and fourth quills nearly equal and longest. Tail short and rounded. Tarsi long, shorter than the middle toe, and seutellated with broad transverse seales. Toes very long, slender, and free at their base, with the lateral ones unequal, the outer longest; the elaws long, slender, and somewhat eurved.

\section{Genus NOTORNIS, Owen. Endemic.}
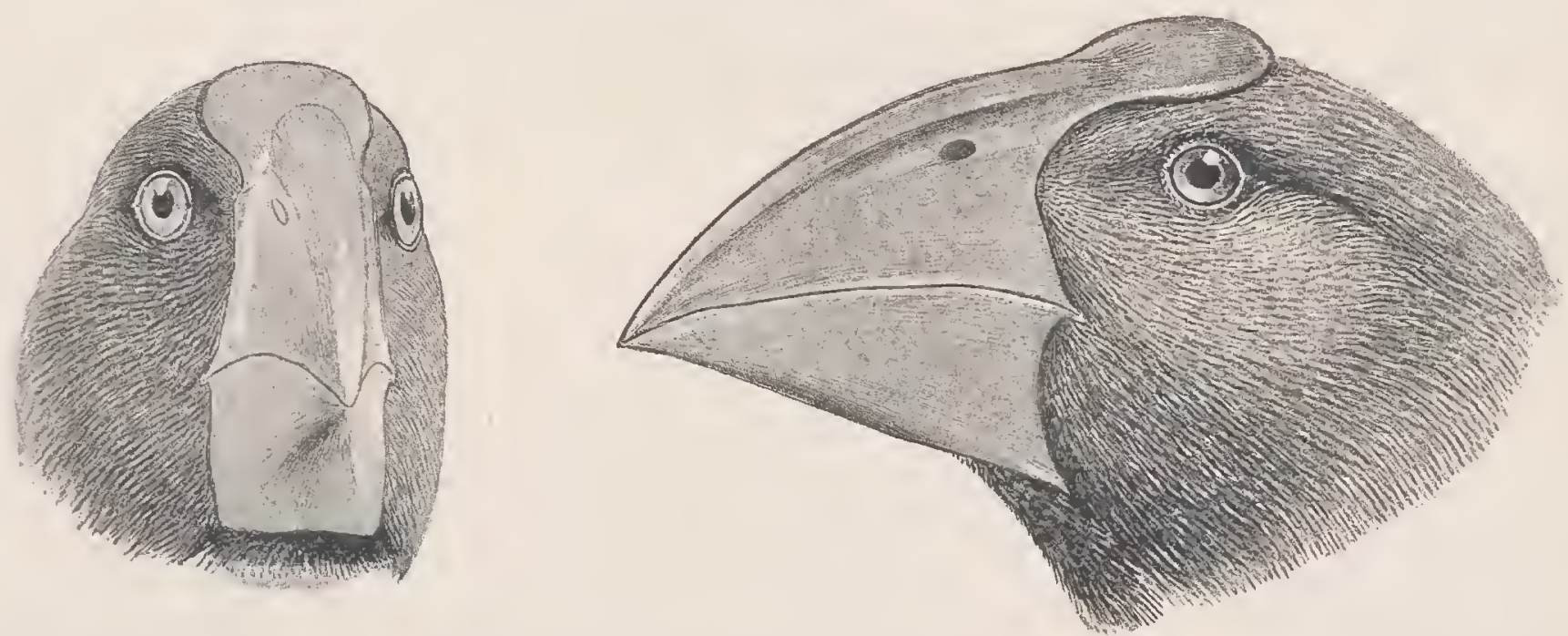

GEN. ClAR.-Bill somewhat shorter than the head; greatly eompressed on the sides, botl mandibles being mueh deeper than broad; tomia sharp, eurving downwards, inelining inwards and slightly serrated; eulmen elevated, mueh arehed and rising on the forehead to a line with the posterior angle of the eye; llostrils round and placed in a depression near the base of the bill. Wings very short, rounded, and slightly coneave; primaries soft and yielding, the first sliort, the third, fourth, fifth, sixtl, and seventh equal and the longest. Tail-feathers soft, yielding, and loose in texture. Tarsi powerful, longer than the toes, almost eylindrieal; very broad anteriorly, defended in front and on either side posteriorly by broad and distinet seutellæ; the spaees between the seutellæ retieulated. Anterior toes large and strong, armed with powerful hooked nails, and strongly seutellated on their upper surfaee; hind toe short, strong, plaeed somewhat high on the tarsus, and armed with a blunt hooked nail.

Genus CABALUS, Iutton. Confined to the Chatham Islands.

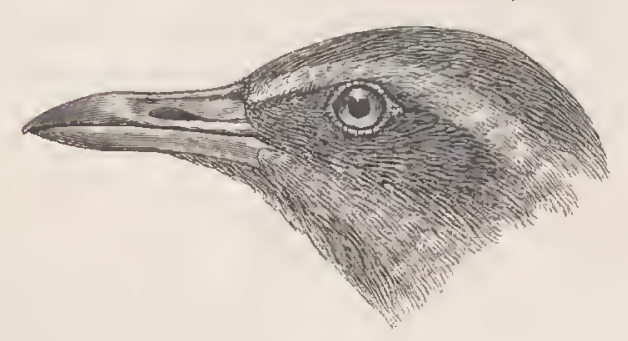

Rallus philippensis.

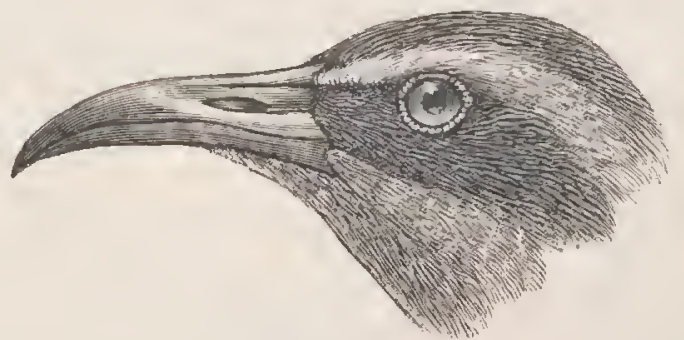

Cabalus dieffenbachii.

Gen. eHar.-Bill longer than the head, moderately slender and slightly eurved, eompressed in the middle and slightly expanding towards the tip; nostrils plaeed in a membranous groove, which extends beyond the middle of the bill; openings exposed, oval, near the middle of the groove. Wings very short, rounded; quills soft, the outer 
webs as soft as the inner, fourth and fifth the longest, first ncarly as long as the sccond; a short compressed claw at the end of the thumb. Tail very short and soft, hidden by the coverts. Tarsi moderate, shorter than the middle toc, flattencd in front, and eovered with transverse scales. Toes long and slender, inner nearly as long as the outer; hind toe short, very slender, and placed on the inner side of the tarsus; claws short, compressed, blunt.

Nore.-This genus was established by Professor Hutton for the reception of a small form of flightless Rail, which he had previously described under the name of Rallus modestus. In my former edition I treated the bird as the young of Rallus dieffenbachii, an extremely rarc form of Rail from the Chatham Islands, which Mr. G. R. Gray had originally placed in the genus Ocydromus. It has becn clearly shown that Cabalus modestus has Ocydrominc eharaeters in its skeleton, and, whether an adult bird or not, it is undoubtedly right to scparate it generieally from Rallus.

Mr. Sharpe, in treating of Cabalus dieffenbachii (App. Voy. Ereb. \& Terr. p. 29), says :- "In his latest articlc on the 'Birds of Ncw Zcaland,' Dr. Finseh believes in Rallus modeslus of Hutton bcing a distinct species from R. dieffenbachii. I examincd the type of Captain Hutton's species, and thoroughly believe it to be the young of the lattcr Rail. Perlaps Captain Hutton is right in referring this Rail to a genus or subgenus intermediate between Rallus and Ocydromus, and I have thercforc, for the present, adopted his genus Cabalus."

\section{Order H E R O D I O E S. \\ Family ARDEID无. Herons.}

Genus ARDEA, Lim. Most parts of the World.

GEN. char. - Bill lengthened and more or less slcnder, with the eulmen nearly straight to the tip, which is acute and cmarginated, the sides eompressed, and tle lateral margins straight and sometimes serrated; the gonys moderate and ascending; the nostrils lateral, basal, and placed in a groove, whieh extends for more than lialf the length of the bill, witl the opening linear, and closed by a membranous seale. Wings long, with the first quill nearly as long as the seeond and third, which are equal and longest. Tail rather short and even. Tarsi longer than, or as long as, the middle toe, rather slender, and covered in front with transverse scales, those near the toes large and of a hexagonal form. Toes long and rather slender; the outcr toe longer than the inner, and united at the basc; the hind toc long; the claws moderate, slight, curved, and acute.

\section{Genus NYCTICORAX, Stephens. Most parts of the World.}

GEN. CHAR.-Bill rather longer thau the head, strong, with the culmen gradually curved, and the sides compressed to the tip, whiel is emarginated; the gouys long and ascending; the nostrils lateral and placed in a groove, with the opening linear and elosed by a membranous scale. Wings long, with the first quill shorter than the second and third, which are equal and longest. Tail short and even. Tarsi as long as the middle toe, rather strong, and covered with large irrcgnlar seales. Toes long, rather slcuder; the outer toe longer than the inner, both united at their base, especially the former; the hind toe long, rather slcnder, and on the same plane with the others; the claws moderate, eurved, and acutc.

\section{Genus BOTAURUS, Stephens. All parts of the World.}

GEN. char.-Bill long and straiglit, with the culmen straight, flattened at the basc, and rounded and curved to the tip, whiel is strongly emarginated, and the sides compressed; the gonys short and ascending; the nostrils basal, and placed in a deep groove that cxteuds for two thirds of the length of the bill, with the opening lincar. Wings long, with the threc first quills equal and longest. Tail short and creu. Tarsi as long as the middle toe, rather strong, and covcred in front with broad transverse scales. Toes very long and rather slender; the claws very long, slightly curved, and very acute. 


\section{Family PLATALEID床. SPoonbilLs.}

Genus PLATALEA, Linn. Most parts of the World.

Gen. енAR.-Bill lengthened, straight, thin, much depressed, and broadly dilated at the tip, whieh is spatulaformed, with a lateral groove eommencing on the forehead, extending, in a parallel line with the edgc, to the tip, which is slightly bent clownwards; the nostrils basal and placed in a groove, with the openiug oval and partly closed by a membrane. Wings long, and the second quill the longest. Tail short. Tarsi longer than the niddle toe, rather slender, and covered with reticulated scales. Toes long, with the anterior toes much united at their base by a membrane, which extends along the sides of the toes to the tip; the lind toe long, rather elevated, and only partly resting on the ground; the claws short, searcely eurved, and obtuse.

\section{Order S'TEGA NOPO D ES.}

\section{Family PELECANID正, Pouched Birds.}

\section{Genus PHATACROCORAX, Brisson. Cosmopolite.}

Ges. ehar.-Bill moderate, straight, somewhat slender, with the culmen eoneave and suddenly hooked at the tip; the sides eompressed and grooved; the nostrils basal, linear, plaeed in the lateral groove, and seareely visible. Wings moderate and pointed, with the second and third quills the longest. Tail moderate, and rounded at its end. Tarsi short, one third shorter than the middle toe, mueh compressed, and eovered with reticulated scales. Toes long, with the outer toe rather longer than the middle one, and all four united by a fill web. The base of the lower mandible is furnished with a coriaceous poueh, which is eapable of extension.

Genus PLOTUS, Lim. Various parts of America, Asia, and Africa, Australia and New Guinea.

Gen. енar.-Bill longer than the head, straight, and very slender, with the sides much eompressed to the tip, which is very acute, the lateral margins finely serrated, and the gonys long and slightly ascending; the nostrils basal, linear, and searcely visible. Wings long, with the second and third quills equal and longest. Tail long and broad towards the end, which is rounded. Tarsi half the length of the middle toe, strong, and covercd with small seales. Toes rather long, all united by a broad web; the outer toe as long as the middle one; the elaws short, eurved, and aeute.

\section{Genus DYSPORUS, Illiger. Cosmopolite.}

Gex. ehar.-Bill longer than the head, robust, straight, broad at the base; with the sides compressed, and grooved towards the tip, which is slightly curved, and the lateral margins obliquely and unequally serrated; the nostrils basal, lateral, linear, placed in a lateral groove and almost invisible. Wings long, pointed, and tuberculated, with the first two quills the longest. Tail moderate and graduated. Tarsi short, one third shorter than the outer toe, rounded anteriorly and keeled posteriorly. Toes lengtlened, the outer and middle ones nearly equal, and all four connected by a full membrane; the claws moderate and rather flat, that of the middle toe serrated, and the hind elaw rudimental. Beneath the base of the lower mandible is a naked space, reaching towards the breast, whieh is capable of expansion.

\section{Genus TACHYPETES, Vieillot. Confined to the Tropics.}

GEN. eHAR.-Bill longer than the head, broad at the base, with the eulmen depressed, coneave, and suddenly hooked and acute; the sides compressed and grooved; the lateral margins dilated on the sides near the base; the nostrils basal, lateral, lincar, placed in the lateral groove, and seareely visible. Wings extremely long and narrow, with the first two quills the longest. Tail very long and strongly forked. Tarsi very short, one third shorter than the outer toe, much compressed, and half eovered with feathers. Toes long, all united by a strongly indented web, the latcral ones unequal, the onter one the longest, and the hind boe lialf the length of the middle one; the claws moderate and curved. The throat naked, and capable of being dilated into an extcnding pouch from near the tip of the lower mandible downwards to the breast. 


\title{
Family PHAËTHONID灰, Tropic-BiRDs.
}

\author{
Genus PHÄ̈THON, Linn. Tropical seas.
}

Gen. char. - Bill as long as the head, broad, and dilated at the base; with the culmen elevated, eurved, and the sides much eompressed to the tip, which is entire and aeute; the lateral margins more or less serrated; the nostrils basal and lateral, with the opening linear, partly elosed by a membrane, and exposed. Wings long and pointed, with the first quill the longest. Tail moderate and graduated, witl the two middle feathers lengthened and linear. Tarsi shorter than the middle toe, strong, and eovered with small seales. Toes long; the outer toe longer than the inner; the three anterior ones and the hiud toe all united together by a broad membrane; the elaws small, eompressed, and acute.

\section{Order 'T U B I N A R E S.}

\section{Family PROCELLARIID届* PETRELS.}

\section{Genus DIOMEDEA, Linnceus. Colder parts of both Hemispheres, but more especially in the Southern Ocean.}

GEN. еHAR.-Bill longer than the head, very robust, straight; the sides compressed and longitudinally grooved, with the tip greatly eurved and acute; the lateral margins dilated and eurved; the eulmen broad, eonvex, and rounded; the lower mandible weak, compressed, with the tip truncated; the nostrils placed near the base, in the lateral groove, covered by a tube which is short, widening and spreading anteriorly from the side of the bill, witl the aperture somewhat rounded and open in front. Wings very long, very narow, with the second quill the longest. Tail short and rounded. Legs short, strong, with the tarsi one fourth shorter than the middle toc, and the inner toe the shortest. The two lateral toes margined exteriorly by a narrow membrane; the web between the toes full and entire; the hind toe and elaw entircly wanting; the elaws short and obtuse.

\section{Genus PELECANOIDES, Lacép. Southern Hemisphere.}

Gen. ehar.-Bill shorter than the head, broad at the base, and much depressed; the sides swollen, grooved, and gradually compressed towards the tip, which is lengthened, compressed, arehed, and aeute; the lower mandible broad at the base and suddenly compressed at the tip, which is, with the gonys, arehed and acute; the sides longitudinally grooved and deep; beneath is placed a membranous pouch, eapable of extension ; the nostrils basal, one fourth the length of the bill, flattened above, and forming two lengthened, sublinear, exposed apertures, placed side by side on the surface. Wings very short, with the first two quills nearly equal and longest. Tail short and rounded. Tarsi rather shorter than the middle toe, laterally eompressed, and eovered with small seales. Toes long; the outer nearly as long as the middle toe; the hind toe and elaw wanting.

\section{Genus PRION, Lacépède. Southern Hemisphere: generally observed between $30^{\circ}$ and $70^{\circ}$} south latitude.

Gen. errar.-Bill the length of the head, broad or very broad at the base, depressed above; eulmen nearly straight, laterally swollen, but gradually compressed towards the tip, which is arehed, elevated, eompressed and acute; the lateral margins dilated near the base, with a series of very fine laminx running along the whole length internally rather above the margin; the lower mandible broad at the base, gradually compressed torvards the tip, which is

* Upon a closer study of the subject, I have docided on recognizing a larger number of groups in this Family than were admitted into my first edition, or into my ' Nanual,' published in 1882. This will add to the total number of genera indicated at p. xxxvii ; but as none of these are endemic it will not affect my genoral argument.

The late Mr. Forbes, in lis excellent account of the Petrels, in the ' Voyage of the Challenger' (Zool. vol. iv. pp. 1-61), recognized a separate family under the name Oceanitidæ, embracing the four closely allicd gencra Garrodic, Oceanites, Pelugodroma, and Fregetta, which form together a very compact section. I prefer, however, to retain the whole of these natural groups under the general denomination of Procellariidæ, leaving the proposed divisions to take rank as subfamilies. 
much compressed, with the margin and gonys arched; the nostrils basal, tubular, elevated above the culmen, short, opcning with two apertures in front. Wings modcrate, pointed, with the first quill nearly cqualling the second, which is the longest. Tail moderate, broad, and rounded at the end. Tarsi shorter than the middle toe, laterally compressed, aud covered with small scales. Toes long, the outer nearly as long as the middle, and the hind toe nearly in the form of a broad, short, pointcd claw.

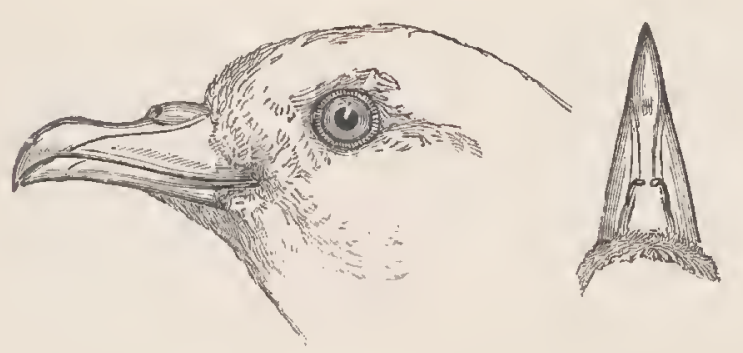

Prion turtur.

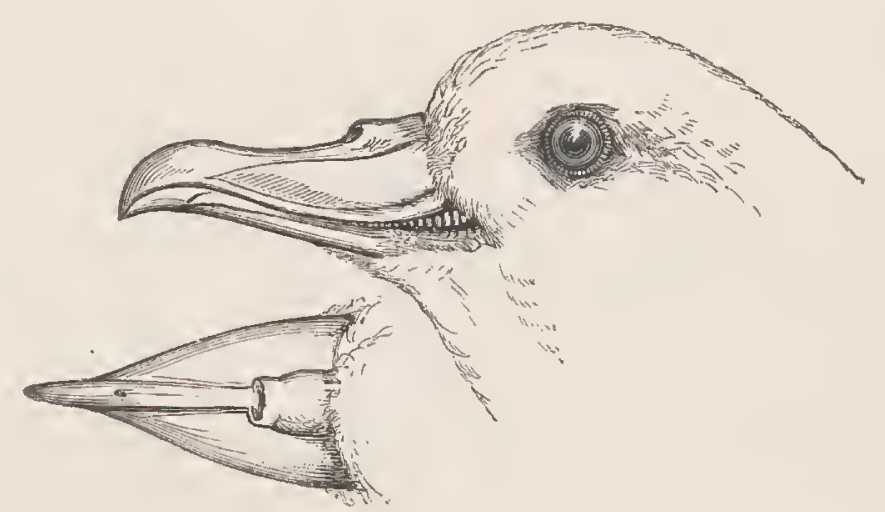

Prion vittatus.

Genus HALOBENA, Is. Geoff. Southern Hemisphere.

Gen. CHAR.-Bill nearly as long as the head, more or less broad at the base; the sides gradually compressed towards the tip, which is much elevated and arched, lengthencd and acute; the uppcr mandible furnished near its edge with laminatcd serrations, lout few and inconspicuous as compared with Prion; the lower mandible shorter than the upper, with the tip and gonys arched and acutc; the nostrils basal, tubular, lorny, elevated above the culmen, with the aperture double, frontal, and crescent-shaped. Wings long, pointed, witl the first quill the longest, and the second scarcely shortcr. Tail moderatcly long and truncated. Legs with the apical part of the thigh hardly naked. Tarsi shorter than the middle toc, latcrally compressed, and covered with small scales. Toes long, with the outer as long as the middle toe, the inncr shortest, aud all unitcd by a full web; the lateral toes margined cxteriorly, the hind toe in the form of a large subtriangular claw.

\section{Genus DAPTION, Stephens. Southern Hemisphere.}

Gen. char.—Bill much dilated, unguis small and weak; inter-ramal space wide and partially nakcd; oblique sulci on inner face of cutting-edge of mandible ; nasal tubes long. Wings long and pointed, with the second primary nearly as long as the first. Tail rather short, moderately rounded. Tarsi and toes as in Estrelata.

\section{Genus CESTRELATA, Bonaparte. Chiefly confined to Sonthern Hemisphere.}

Gen. CHar.-Bill about as long as the tarsus, stout, compressed, higher than broad throughout, lateral outlines nearly straight, and converging to the unguis, which is much compressed; unguis very large and strong; outline of upper mandible very convex, rising almost immediately from the end of the nasal tubes, leaving but a very short and quite concave culmen proper; outline of lower mandible nearly straight, the gonys a little concave; sulci on both mandibles distinct. Wings rather long, extending beyond the tail when folded, and pointed; the second primary nearly as long as the first. Tail, which is composed of twelve feathers, long and much produced, sometimes almost cuneate, usually much rounded. Tarsi moderatcly compressed, and about as long as, or a littlc less than, middlc toe; hallux short, sessile, conical, acute, and clcvated.

\section{Genus OSSIFRAGA, Hombr. et Jacq.}

GEN. CHAR. - Bill as long as, or rather exceeding, the tarsus, very robust; the nasal case very long, depressed, carinated, the aperture small. Wings of moderate length, rcaching to end of tail. Tail modcrately long and rounded. Tarsi short, bcing much less than the middle toe without its claw, compressed, stout, reticulated. 


\section{Genus THALASSCECA, Reich. Southern Hemisphere.}

Gen. emar.-Bill slightly shorter than the tarsus, higher than broad at the base, the commissure a little eurved. Wings of moderate length, reaehing to the end of tail. Tail short, more or less rounded, eomposed of fourtecn feathers. Tarsi slender, eompressed, retieulated, shorter than the middle toe; outer toe as long as the middle one; inner toe eonsiderably shorter; hallux very short, being only observable as a stout, obtuse, subeonieal elaw.

\section{Genus PUFHINUS, Brisson. Both Hemispheres.}

Gen. crak.-Bill as long as, or shorter than, the head, much eompressed, and grooved obliquely on the sides; the tip lengthened, arched, suddenly looked and aeute; the lower mandible somewhat shorter than the upper, witl the apical margin and gonys equally eurved with the upper, the latter angulated beneath, and the sides longitudinally grooved; the nostrils basal, elevated above the euhnen, opening obliquely in two tubes, plaeed side by side. Wings long, slender, somewhat acate, with the first quill the longest. Tail moderate and rounded, composed of twelve feathers. Legs moderate, with the apieal part of the tibia naked. I'arsi compressed and equal in length to the middle toe. Toes long, the outer equal to the middle one, the imner shortest, and the lateral toes margined exteriorly by a narrow membrane.

\section{Genus ADAMASTOR, Bonaparte. Southern Hemisphere.}

Gen. енAr.-Bill about three fourths the length of the tarsus, broad and stout at the base, narrowing regularly to the strong, very convex, eompressed unguis; nasal tubes rather long, very broad, depressed, but vertically truneated at their extremity, and with an unusually thin septum. Wings rather short, the primaries broad and stout, the second as long as the first. Tail rather short and shightly euneate. Tarsi shorter than the middle toc without its elaw, outer toc larger than the middle.

\section{Genus MAJAQUEUS, Reich. Southern Hemisphere.}

Gex. char.-Bill a little shorter than the head, about equal to the tarsus, stout, eompressed, ligher than broad at the base, the eulmen rising immediately from the nostrils; unguis large, very eonvex, much hooked, eommissure unusually eurved; outline of lower mandible straight as far as the unguis; nasal tubes long, elevated lateraily, obliquely flattened, earinated along the median line, apically truncated, with a considerable emargination; the nostrils eireular. Wings eomparatively long. Tail very short and subtruneated, the graduation of the lateral feathers being slight. Tarsi greatly abbreviated, being much shorter than the middle toe without its elaw; outer toe, without elaw, longer than the middle; tip of inner elaw reaehing to base of middle one.

Genus OCEANITES, Keys. et Blas. Almost cosmopolite on the high seas.

GEn. eHAR.-Bill shorter than the head, slender, weak, the sides mueh eompressed, and slightly grooved, with the tip suddenly hooked and acute; the lower mandible shorter than the upper, the tip arehed, with the gonys hardly angular beneath; the nostrils elevated above the culmen at its base, tubular, with a single aperture in front. Wings long and pointed, with the first quill much longer than the third, and the seeond the longest. Tail of moderate length and even. Leys long, slender, with the naked space of the tibia extensive. Tarsi longer than the middle toe, and oereate in firont. Toes rather short, the outer toe nearly equal to middle one, and the inner' the shortest, with the elaws rather narrow and pointed.

\section{Genus PELAGODROMA, Reich. Southem Hemisphere.}

Grs. ehar.-Differs from Oceanites in having the seeond quill shorter than the third, the tail fureate, and the tarsi seutellated in front, with the nails broad and flattened, and the hallux in the form of a triangular elaw.

Genus GARRODIA, Forbes. Southern Hemisphere.

Gen. char.-Similar to Pelagodroma, but with somewhat shorter legs, and having the sternum posteriorly entire, instead of being excarated on its margin. 
Genus FREGETTA, Bonaparte. Southern Hemisphere.

GEN. cIn R.-Differs from Pelagodroma in having the tarsi ocreate, the feet very slort, with the nails peculiarly broad and blunt.

\section{Order A NSERES.}

\section{Family ANATID正. Ducks.}

Genus ANAS, Linn. Cosmopolite.

GEN. errar.-Bill longer than the head, higher than broad at the base, nearly of equal breadth throughout; the eulmen nearly straight, and depressed to the tip, whieh is armed with a strong broad nail ; the lamellæ of the upper mandible hardly visible beyond the lateral margin, strong, and widely set, espeeially near the middle; the nostrils plaeed near the base of the culmen, lateral and oval. Wings moderate and pointed, witl the tertials lengthened and acute, and with the first quill the longest. Tail short and wedge-shaped. Tarsi slorter than the middle toc and compressed. Toes united by a full web; and the hind toe small and somewhat lobed.

\section{Genus NESONETTA, Gray. Endemic.}

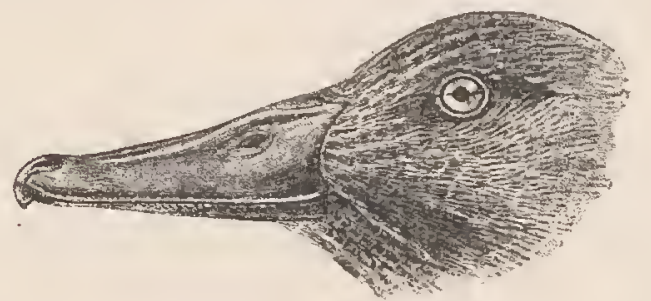

GEN. cHak.-Bill shorter than the head, the width and clevation at the base equal; the eulmen gradually sloping to the tip, which is armed with a modcrate-sized nail, the sides eompressed and of equal breadth throughout; the lamella of the interior margins of the upper mandible sniall and widely set, strongest near the base; the nostrils near the base lateral and oval. Wings very short and pointed, with the seeond quill the longest. Tail short and wedge-shaped, with the end of the stem of each feather bare and rigid. Tarsi robust, about two thirds the length of the middle toc. Toes strong, with the outer toe shorter than the middle, and all the fore toes united by a full web; the hind toe short, clevated, and somewhat lobed.

\section{Genus MERGUS, Linn. North Temperate regions; also Auckland Islands.}

GEN. char. - Bill as long as, or longer than, the head, straight, slender; the eulmen elevated, and convex towards the tip, which is suddenly hooked and armed witl a large broad nail; the lateral margins of both mandibles serrated with short and widely-set teetl, all pointing backwards; the nostrils lateral, placed near the base of the bill, oblong, piereed longitudinally in a membrane and pervious. Wings moderate and pointed, with the first and seeond quills of nearly equal length and longest. Tuil moderate and graduated. Tarsi shorter than the middle toe. Toes moderate; the outer and middle oncs of nearly equal length, and the three anterior ones united by a full web; the hind toe moderate and mueh lobed.

\section{Genus CASARCA, Bonaparte. Europe, as well as Australia and New Zealarid.}

GEN. CHAR.-Bill as long as the head, nearly straiglit, the width equalling the height at the base, the anterior half depressed, and scareely curved upwards at the tip, which is armed with a strong, broad nail; the basal part of the lateral margin straight, and the apieal part slightly eurved upwards; the lamellæ of the upper mandible prominent below the lateral margins, slender, and set rather widely apart; the nostrils suboval, near the base of eulmen. Wings moderate, with the seeond quill the longest. Tail short and roundei. Tarsi robust, shorter than the middle toe. Toes long, and united by a full web; and the hind toe long, elevated, and lobed. 
Genus DENDROCYGNA, Swainson. Most parts of the World, but migratory in their habits.

GEN. енar.-Bill long, higher at the base than broad, witl the eulmen sloping to the tip, whieh is armed witlı a strong, broad nail, and the lateral margins straight; the lamellæe of the upper mandible advaneing below the lateral margins, slender, and set widely apart; the nostrils large, oval, and plaeed near the base of eulmen. Winys short and rounded, with the seeond, third, and fourth quills the longest; the first quill with a deep notel in the middle, and the seeondaries nearly as long as the quills. Tail moderate, and rounded at the end. Tarsi slightly shorter than the middle toe, robust. Toes long, the lateral ones united to the middle one by an indentated membrane; and the hind toe very long, elevated, and simple.

\section{Genus RHYNCHASPIS, Stephens. Most parts of the World.}

Gen. eifar. - Bill longer than the head, narrowed at the base; the eulmen straight, depressed, and the side mueh dilated for nearly half its length from the tip, which is furnished with a small hooked nail; the lamellx of the upper mandible very prominent near the middle, slender and widely set; the nostrils plaeed near the base and eulmen, lateral, and oval. Wings lengthened and pointed, with the first quill nearly as long as the seeond, whieh is the longest. Tail rather short and werge-shaped. Tarsi mueh shorter than the middle toe. Toes united by a full web, and the hind toe very small and slightly lobed.

Genus FUligula, Stephens. Besides New Zealand, members of this genus inhabit the northern regions of Furope, Asia, and America, migrating to the temperate parts in winter.

GEN. eHAR.-Bill nearly as long as the head, broader at the base than high, the eulmen gradually sloping to the tip, whieh is armed with a broad and strong nail; the sides dilated, espeeially anteriorly, where it is rounded, the lateral margins straight and eurved upwards to the nail ; the lamelle of the upper mandible not prominent, and widely set; and the nostrils small, oblong, and near the middle of the bill. Wings moderate and pointed, with the first quill the longest. Tail short and rounded. Tarsi half the length of the middle toe and eompressed. Toes lengthened and united by a full web.

\section{Genus NYROCA, Fleming. Most parts of the World.}

GEn. eHar.-Bill as long as the head, ligher at the base than broad; the eulmen gradually sloping towards the tip, whieh is depressed, slightly dilated, and armed with a strong nail; the lamella of the upper mandible not prominent; and the nostrils oval and plaeed near the base. IVings lengthened and pointed, with the first two quills the longest. Tiil short and rounded. Tarsi half the length of the middle toe and eompresser. Toes lengtlsened and united by a full web.

\section{Genus HYMENOLAMUS, Gray. Endemic.}

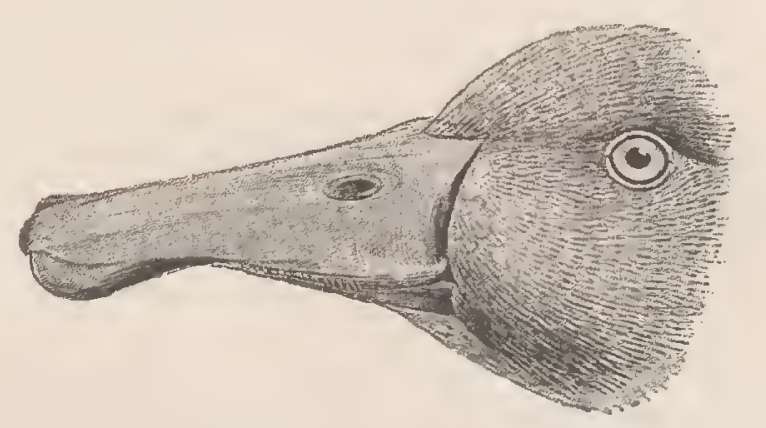

Gen. eran.-Bill as long as the head, eqnally eompressed, elevated at the base, with the enimen for thrce fourths of its length straight and then slightly sloping to the tip; the sides shelving from the eulmen to the lateral margins, of whieh the basal lialf is firm, and furnished with lengthened slender laminis; the apieal half of the margin eomposed of a soft flexible skin that hangs over the lower mandible, widening towards the tip, where it is truneate, and the nail not very prominent; the nostrils situated near the middle, and oval. Wings short, slender, 
with the first, second, and third quills ncarly equal, but the second the longest; the shoulder armed with a short, blunt spur. Tail lengthened and composed of broad feathers, with the end rather rounded. Tarsi nearly as long as the middle toc, cxclusive of the claw; the fore toes strong and fully wcbbed, and the hind toc moderate and strongly lobed.

\section{Order PYGOPODES. \\ Family PODICIPEDID सE. GRebes.

\author{
Genus PODICEPS, Latham. Cosmopolite.
}

GEN. char.-Bill more or less long, strong, straight, the eulmen slightly curved at the tip, which is acute and entire; the sides much eompresscd, and the gonys short and advancing upwards to an acute point; the nostrils placed in a short groove, with the opening longitudinal and exposed. Wings short and pointed, with the first or sometimes the second quill the longest, and slightly emarginated ncar the tips. Tail short, not apparent. Tarsi shorter than the middle toe, much compressed, the anterior and posterior edges eovered with small scales, which are serrated posteriorly, and the sides with transverse scales. Toes long, the outer the longest, depressed, margined on the sides, especially on the inner side, and united at the base to the middle toe; the hind toe short and strongly lobed; the claws short, very broad, flat, and obtuse.

\section{Order I M PE NNES.}

\section{Family SPHENISCID西, Penguins.}

\section{Genus EUDYPTES, Vieillot. Southern Hemisphere.}

GEN. CHAR.—Bill more or less long, straight, much compressed, and grooved on the sides, and the culmen rounded and curved at the tip, which is acute; the end of the lower maudible truncated, and the gonys moderate and advancing upwards; the nostrils lincar, placed in the lateral groove, which extends for three fourths of the lengtlı of the lill ; and the frontal plumes advancing to the opening. Wings imperfect. Tail long, and composed of narrow rigid feathers. Tarsi very short, much flattened, and covered with small scales. Toes long and strong, with the anterior ones united to the middle one by a web, the lateral tocs unequal, the outcr the longest; the hind toc very small, and united to the tarsus at the base of the inner toc; the claws strong, compressed, and slightly curved.

\section{Genus EUDYPTULA, Bonaparte. Australia and New Zealand.}

GEN. char.-Bill moderate, much compressed, and strong, with the culmen rounded and curved at the tip; whieh is acute; the tip of the lower mandible suddenly truncated, and the gonys moderate and curved upwards ; the nostrils rather rounded, and placed in the latcral groove near the middle of the bill. Wings imperfect, and. covered with scale-like plumcs. Tail very short. Tursi very short, thick, flattened, and covered with small scales. Toes long, the lateral ones uncqual and mited to the middle toe by a web; the hind toe very small, and united to the tarsus at the base of the inner toe ; the elaws long, compressed, and slightly curved.

\section{Genus APTENODYTES, Forster. High southern latitudes only.}

GEN. CHAR. - Bill longer than the head, rather slender, compressed on the sides, slightly bent at the end, with the base of the upper mandible covered with short close-set plumes, and the side grooved to near the tip, which is acutc; the lower mandible covcred with a smooth naked skin; the nostrils linear, and placed in the lateral groove. Wings imperfect, and covered with scalc-like plumes. Tail very short, and composed of narrow rigid feathcrs. Tarsi very short, flattened, and covered with short plumes. Toes rather short and depressed, the anterior ones united by a web; the lind toe very small, and almost entircly connected to the inner side of the tarsus; the claws large, depressed, and very slightly eurved. 


\section{Subclass RATITE.}

Order APTERYGES.

Family APTERYGID尼. KIWIS.

Genus APTERYX, Shaw. Endemic.

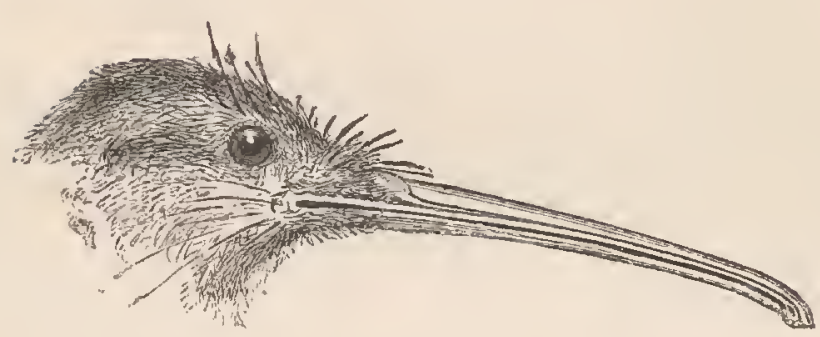

Gex. Char.-Bill more or less lengthened, very slender, with the base eovered by a bony eere, broad, and rather depressed; the eulmen rounded, straight to near the tip, which projeets over that of the lower mandible, and rather obtuse; the sides gradually eompressed, and grooved towards the end; the gonys very long and slightly eurved; the nostrils plaeed on eaeh side at the tip, very small, and sublinear; the base of the bill furnished with lengthened hairs. Wings abbreviated and eovered with feathers. Tail not apparent. Tarsi the length of the middle toe, very robust, and eovered with variously sized seales, those of the inner and outer sides the smallest. Toes three before, with the lateral ones equal, and all eovered above with broad scales; the hind toe very short, united to the tarsus, and armed with a long, strong, and rather aeute elaw. 


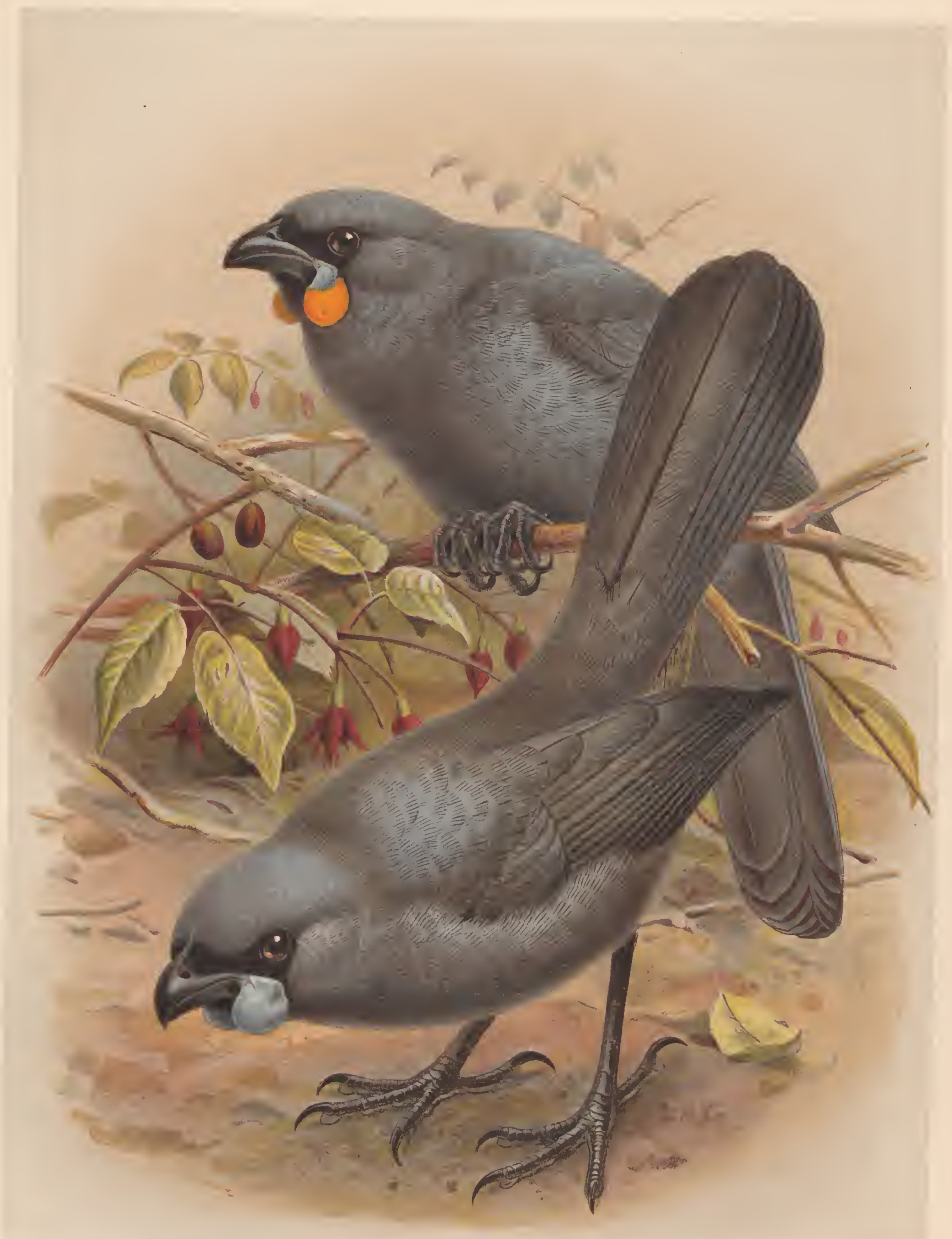

BLUE-WATTLED CROW.

GLAUCOPIS WILSONI.
ORANGE-WATTLED CROW.

GLAUCOPIS CINEREA. 


\section{GLAUCOPIS WILSONI.}

\section{(BLUE-WATTLED CROW.)}

Glaucopis wilsoni, Bonap. Consp. Gen. Av. i. p. 368 (1850).

Callceas wilsoni, Gray, Ibis, 1862, p. 227.

Callceas olivascens, Pelz. Verh. zool.-bot. Gesellsch. Wien, 1867, p. 317, note.

Glaucopis olivascens, Finsch, J. f. O. 1870, p. 324.

\section{Native name.-Kokako.}

$A d$. suprà sehistaeeo-einereus, subtùs paullò eyaneseens : loris cum vittâ frontali angustâ, regione oeulari mentoque nigerrimis: faeic laterali et gutture paullò eanescentibus : fronte posticâ et supereilio indistineto albidis : earuneulâ rietali ovali utrinque eyaneâ : remigibus et reetrieibus nigrieantibus dorsi eolore lavatis : rostro et pedibus nigris : iride saturatè brunneâ.

Juv. dorso toto olivaeeo-fuseo : abdomine toto eum hypoehondriis et subeaudalibus pallidè einereo-brunneis : earuneulis minoribus, pallidè cyancis.

Adult male. General plumage dark einereous or bluish grey, tinged more or less on the upper surfaee of the wings and tail and on the rump and abdomen with dull brown; a band of velvety blaek, half an ineh broad, surrounds the base of the bill, fills the lores, and eneireles the anterior portion of the eyes; immediately above this band and eontinued over the eyes light ashy grey, shading into the darker plumage; quills and tail-feathers slaty black. Irides blaekish brown; bill and legs blaek. The wattles, which form a distinguishing feature in this bird, are, during life, of a bright ultramarine-blue; but they fade soon after death, and in the dried state beeome almost blaek. Total length 17.25 inehes; extent of wings 20.5 ; wing, from flexurc, $7 \cdot 25$; tail $7 \cdot 75$; bill, along the ridge $1 \cdot 25$, along the edge of lower mandible 1 ; tarsus $2 \cdot 5$; middle toe and elaw $2 \cdot 15$; hind toe and elaw $1 \cdot 5$.

Female. Similar to the male, but somewhat smaller and more deeply tinged with brown on the lower part of
the baek, rump and a tail $7 \cdot 25$.

Young. The young of both sexes have the whole of the back and the upper surfaee of the wings and tail, as well as the sides of the body, dull olivaecons brown; the abdomen and under tail-eoverts yellowish brown; the wattles smaller than in the adult and of a pale blue colour.

Nestling (only partially fledged). Frontal band very ineonspieuous exeept in front of the eyes; wattles extremely small and of a pinky eolour. The plumage as in the adult but duller, and the wing-feathers washed on their outer vanes with brown.

Note. Professor Hutton is of opinion that the female is " rather larger than the male ;" but my observations lcad me to an opposite eonelusion. I must admit, however, that I have found the size somewhat variable in both sexes. The wattle is always appreeiably smaller in the female. In a pair from Wainuiomata, that of the male measured $\cdot 75$ of an ineh in diameter, and that of the female only 5 , besides being less rounded in form.

Varieties. There is a fine albino speeimen in the Colonial Museum, obtained in the Rimutaka ranges and presented by a settler, who had it alive for several months. The whole of the plumage is white, with a ereamy tinge on the fore neck and undcrparts; the shafts of the quills and tail-feathers conspicuously 
whiter; the caruneles very small and eolourless; bill horn-eoloured; feet ycllowish brown; the tail-feathers somewhat abraded at the tips.

Another abnormal specimen in the same eollection (received from the Wairarapa district) has the entire plumage of a washed-out ash-grey colour, paler and tinged with brown on the quills and tail-feathers. There is an approaeh to the normal bluish-grey colour on the throat and towards the edges of the frontal patch, which is dull brown instead of velvety black; bill and feet brown; earuncles faded to the same colour.

Obs. As will be seen from the above synopsis, I am unable to admit the so-ealled Glaucopis olivascens to the rank of a distinct species. It was founded on a specimen obtained at Auckland by M. Zelebor, and the diagnostie characters by which it is distinguished from G. cinerea are the brownish-olive colour of the back, wings, and tail, the greyish olive of the underparts, its greater sizc, and the "dusky colour of the mouth-caruncles." As I have already shown, this description applies to the young of $G$. wilsoni. The dusky eolour of the wattles is of no value as a speeifie charaetcr, because, as already mentioned, these appendages entirely change colour in dried spccimens, leaving no trace of the original blue. Even in the living bird the colour of the wattles varies considerably in its tone, according to age and other physical conditions; and Dr. Hector has observed that when in eonfinement its wattles undergo rcmarkable variations, the cxterior margin sometimes assuming a decided yellowish tinge, and again changing back into blue. Dr. Hector writes to me that of three spccimens caught together, of which the sex was ascertained, two with olive-brown backs and very small wattles proved to be males, while the third, which had large wattles, of a deep blue eolour, and only a slight tinge of brown on the upper parts, was unmistakably a female; and he expresses his bclief that Glaucopis olivascens is the male of G. wilsoni. Accepting the result of Dr. Hector's dissection as eonclusive evidence of the sex in cach case, I should be inclined to pronounce his two brown-backed males birds of the first year, and the female an adult in full breeding-plumage. I may add that the bird from which my deseription of the adult male is taken was shot in eompany with two othcrs (an adult fcmalc and a young male), all of which were carefully sexed by myself.

THrs singular represcntative of the Crow family is sparingly dispersed over the North Island, being very local in its distribution. It is met with morc frequently in the wooded hills than in the low timbered bottoms, but its range is too eccentric to be defined with any precision. During many years' residence at Kaipara, north of Auckland, I ncver obtained more than five specimens, all of which werc shot in the low wooded spurs of the Tangihua ranges. In particular localities, however, even further north, it is comparatively plentiful: for example, between the headwaters of the Wairoa and Whangarci rivers there are several strips of forest in which I never failed to meet with the Kokako; and in the Kaitara ranges in the Whangarei district it was, till within the last few years, rather abundant. I have heard of its occurrence in various parts of the Waikato district*, and in certain localities in the Hawke's Bay and Wellington provincial districts it is far from being an uncommon species. During the autumn months it is comparativcly plcntiful in the Mangorewa forest between Tauranga and Rotorua. The traveller, at this season, frequently meets with it hopping about along the road or among the bushy branches of Solanum on either side.

The Kokako is adorned with fleshy wattles of a brilliant blue colour, which spring from the angles of the mouth, and when the bird is in motion they are compressed under the chin. The first specimen obtaincd from the Tangihua ranges was a fine bird in full plumage; but the Maori who brought it had torn off the beautiful wattles and pasted them, by way of ornament, on his dusky cheeks.

The notes of the male are loud and varied ; but the most noticeable onc is a long-drawn organnote of surpassing depth and richness. I have not been able to discover whether the fcmale is

* The Maoris state that it is common at Taupo and at Maungatautari, one of those whom I questioned on the subjeet observing, "Whero the range of the Huia eeases, that of the Kokako begins." Reischek met with several on the Great Barrier, but never saw it on the Little Barrier, nor on the Hen and Chickens. Lying off Cape Brett, the southernmost head of the Bay of Islands, there is a wooded islet called by the Maoris "Motukokako," in allusion to its having been at one timo inhabited by this bird. 
similarly endowed, but I have often heard two or more Kokakos, each in a different key, sounding forth these rich organ-notes with rapturous effect; and it is well worth a night's discomfort in the bush to be awakened at dawn by this rare forest music. I never hear it without being reminded of Waterton's saying of the pretty snow-white Campanero, that " Actæon would stop in mid-chase, and Orphens himself would drop his lute" to listen to its toll. Another of its notes may be described as a loud cackle, while others, again, are scarcely distinguishable from those of the Tui, resembling the soft tolling of a distant bell ; but it is only in the early morning that they can be heard to perfection. It has another note, which is very much like the mewing of a cat; but this is only occasionally heard, and then immediately before rain, indicating, it would seem, a highly sensitive nature.

In the pairing-season the male bird loves to display himself before the other sex, arching his neck, spreading his wings, and dancing round the mate of his choice in a very ludicrous manner. They manifest much mutual attachment, and often continue to associate in pairs long after the cares of reproduction have been got rid of and the brood of young ones lave grown up and dispersed.

This species subsists chiefly on small fruits and berries, but, like all the members of the family to which it belongs, it will readily partake of insect food of every kind. I have sometimes found its crop distended with the ripe pulpy seed of the tataramoa (Rubus australis), or with the berries of the kaiwiria (Parsonia albifora) and kareao (Rhipogonum scandens); and it is said to feed also on the leaves of the thistle and wild cabbage. The branch depicted in the Plate is that of the native fuchsia, or kohutuhutu, the fruit of which forms a part of its favourite diet. When feeding, it often uses its feet, after the manner of a parrot.

Its wings are small and rounded, and its flight is consequently feeble and generally limited to very short distances. Its progression through the forest is usually performed by a succession of hops, the wings and tail being partially spread-a movement precisely similar to that of the Huia (Heteralocha acutirostris).

'The stomach of this species consists of a very inuscular sac, with a tough epithelial lining or integument, which pcels off readily on being pulled, as with the fruit-eating Pigeons and some other birds. The plumage is beautifully soft and silky, owing to the peculiar tcxture of the feathers. The wattles are smooth and somewhat glossy, but their rich cerulean colour gradually fades out after death.

In disposition the Kokako inherits the true characteristics of the Crow family, being inquisitive, shy, and crafty. I purchased a live one from the Otaki natives in the winter of 1862, and as it shared my apartments for nearly a week (much to the discomfiture of my excellent landlady), I had a good opportunity of studying its habits and character. I was often much amuscd with the tricky manœurres of this sprightly bird, and I rcgretted the accident which deprived me of so intelligent a companion. It generally remained concealed under a side table in a dark corner of the room; but in cold weather was accustomed to steal quietly to the inside of the fender, in order to get warmth from the fire. My presence had become familiar to it, but on the entrance of a stranger it would immediately spring out and hop away to its dark retreat under the corner table.

The bird represented in the Plate is one of a pair shot on the Poroporo ranges during the Huiahunting expedition of which an account is given further on. They were found perched in the midst of a superb bunch of puawhananga (Clematis indivisa), and fecding with avidity on the white petals, stopping at intervals to coy with each other and converse in a low musical twitter. The mated pair, with their unique floral surrounding, formed a lovely picture of real nature.

On dissecting the male, I found the whole of the viscera and even the membrane and skin covering it stained to a vivid blue; and on opening the stomach, I found it crammed with comminuted vegetable matter of a perfectly black colour. On examining some of this matter after washing it in cold water, I found that it was in reality composed of Clematis-flowers, the change in colour being apparently due to the action of some acid in the bird's stomach.

Mr. Reischek found a nest of this species in a bunch of Astelia, the birds having simply made a 
round depression in the centre of the clump and placed a few dry twigs there. There were three young birds. Two of these sprang out of the nest on his approach, but were afterwards shot; the youngest he managed to catch before it could escape, and from this I have taken my description of the nestling. On another occasion he met with the nest near the wooded summit of the Waitakere ranges. It was a large irregular-shaped structure, composed of twigs and moss coarsely put together, and placed high up on a miro tree. The young birds (three in number) had just left the nest, but had not yet quitted the tree. They were shy and wary, and, on an alarm being sounded by one of the parent birds, they immediately secreted themselves in the thick foliage, from which it was found impossible to dislodge them. This was on January 3rd, which fixes approximately the breedingseason; although my son discovered a nest at Whangarei, containing three well-fledged nestlings, at a somewhat earlier date.

I agree in the opinion expressed by Mr. Kirk * that the egg brought to the Colonial Museum by Mikaera on October 20, 1885, and disposed of as the egg of the Huia t, is in reality that of the present species. Subsequent events have shown that Mikaera's testimony cannot be depended on; and no credence can be given now to his statement that it was "taken from a cavity in a dead tree." The egg contained a young bird, apparently just ready for extrusion, and both embryo and shell are now in the Museum collection. The egg is ovoido-conical in form, measuring 1.45 by 1.05 inches, and is of a pale stone-grey, irregularly stained, freckled, and speckled with purplish grey, the markings in some places running into dark wavy lines. The chick has the bill very stout, with the caruncles at the angles of the mouth well developed and of a flesh-white colour. The whole of the body is bare, with the exception of what appears (in spirit) to be strips of coarse, black, hair-like filaments, from one half to three quarters of an inch in length, but which are in reality tufts of extremely fine downy feathers. A strip of these filaments encircles the crown, a line passes down the course of the spine, and there is another along the outer edge of each wing and behind each thigh.

Accepting, as I do, the view so well formulated by Professor Parker, that "in all respects, physiological, morphological, and ornithological, the Crow may be placed at the head, not only of its own great series (birds of the Crow-form), but also as the unchallenged chief of the whole of the Carinate " $\downarrow$, I have, in my systematic arrangement of the New-Zealand ornis, accorded the foremost rank to the family Corvidæ, instead of placing the Turdidæ at the head of the list as is now the fashion with writers on Systematic Ornithology. Some doubts, however, having hitherto existed as to the true position of the genus Glancopis, I was glad of the opportunity to place a skeleton of this species in the hands of Dr. Gadow, of Cambridge, in order that he might investigate its natural affinities. That gentleman made a critical examination of the bones, and compared them with those of Strepera, Gymnorhina, Paradisea, Struthidea, Graucalus, Ptilonorhynchus, Heteralocha, and Sturnus, with the following general result. He finds that Glaucopis is a Corvine form, being closely allied to the Austrocoraces, a group of birds which form a connecting-link between the true Corvidæ and the Laniidæ. It agrees with Strepera, and shows considerable similarity in structure with Ptilonorkynchus, although Glaucopis presents in its skull, sternum, and sacrum several characters which are peculiar to the genus. Struthidea agrees with Glaucopis by far less than might have been supposed, whilst Graucalus is still further removed, being apparently on the line through which Glaucopis reaches the Muscicapine forms. Dr. Gadow sums up the results of his investigation by saying that "if a Satin-bird could be induced to marry a Piping-Crow, their offspring might, in New Zealand, become a Glaucopis."

* Journal of Science, 1882-83, vol. i. p. 262.

† Trans. New-Zealand Instit. 1875, vol. viii. p. 192.

‡ "There are, of course, innumerable points in regard to the Classification of Birds which are, and for a long time will continue to be, hypothetical as matters of opinion, but this one seems to stand a fact on the firm ground of proof" (art. "Ornithology," Encyel. Brit., by Prof. Newton, F.R.S.). 


\title{
GLAUCOPIS CINEREA.
}

\author{
(ORANGE-WATTLED CROW.)
}

Cinereous Wattle-bird, Lath. Gcn. Syn. i. p. 364, pl. xiv. (1781).

Glaucopis cinerea, Gm. Syst. Nat. i. p. 363 (1788).

Cryptorhina calloeas, Wagl. Syst. Av. Cryptorhina, sp. 5 (1827, ex Forster, MSS.).

Callocas cinerea, Forster, Descr. Anim. p. 74 (1844).

\section{Native name.-Kokako.}

Ad. similis G. wilsoni, vix saturatior, paullò minor : earuneulis aurantiaeis ad basin tantùm eyaneis distinguendus.

Adult. Similar in plumage to G. wilsoni, but with less of the brown tinge on the lower parts, and the tail-feathers blaekish towards the tips. It is readily distinguished, however, by the eolour of the wattles, which are of a rieh orange, elanging sometimes to vermilion, and blue at the base. Irides blaekish brown; bill and feet blaek. Total length 16 inehes; wing, from flexure, $6 \cdot 25$; tail 7 ; bill, along the ridge $1 \cdot 25$, along the edge of lower mandible 1 ; tarsus $2 \cdot 5$; middle toe and elaw $2 \cdot 15$; hind toe and elaw $1 \cdot 5$.

Partial albino. There is an interesting speeimen in the Colonial Museum, whieh was obtained by Mr. Henry Travers at the foot of Mount Franklin, in the Spencer ranges, in January 1869 . The general plumage as in ordinary speeimens; hind head, sides and fore part of neek, and the whole of the baek largely marked with pure white : one or two of the quills in eaeh wing are either wholly or partially white, and there are a few seattered white feathers on the sides, abdomen, and thighs.

THIS species is the South-Island representative of Glaucopis wilsoni, to which it bears a general resemblance, except in the colour of its wattles and its rather smaller size. Like the Nortli-Island species also, its distribution is very irregular: thus, in Otago, Dr. Hector found it very plentiful on Mount Cargill and in a strip of bush near Catlin river, but never in the intervening woods; while in the Nelson provincial district, as I am informed by Mr. Travers, its range is exclusively restricted to certain well-defined localities, althougl the berries on which it is accustomed to feed abound everywhere. It is said to be very abundant on some of the wooded ranges of Westland, and Sir J. von Haast has obtained numerous specimens from the Oxford ranges in the provincial district of Canterbury.

I ought to add that, in the summer of 1867, one of these birds was seen by Major Mair at Tc Mu, near Lake Tarawera, in the North Island. He followed it for somc distance, in the low scrub, and got near enough to obtain a good view and to observe its bright orange wattlcs.

The habits of this bird differ in no essential respect from those of the prcceding species. Mr. Buchanan, of the Geological Survey, has mentioned to me a rery curious circumstance frequently obscrved by himself at Otago: he lias seen these birds travelling through the bush on foot, Indian fashion, sometimes as many as twenty of them in single file, passing rapidly over the ground by a succession of loops, and following their leader like a flock of sheep; for, if the first bird should have occasion to leap over a stone or fallen tree in the line of march, every bird in the procession follows suit accordingly!

I saw a pair of caged ones at Hokitika, in the possession of Mr. $\mathbf{M}^{\circ} \mathrm{Nee}$, who told me that he had snared them in the woods with perfect ease. They were apparcntly quite reconciled to confinement, hopping from perch to perch in a very lively manner, and occasionally meeting to utter a low chuckling 
note, as if in confidential intercourse. I observed that they usually carried the wattles firmly compressed under the rami of the lower jaw.

One of the many interesting discoveries, since the publication of my first edition, has been the 'finding of the nest and eggs of the Orange-wattled Crow. The Canterbury Museum contains two nests of this bird, both of which were obtained at Milford Sound.

One is a massive nest, with a depth of eight inches, composed of rough materials, but with a carefully finished cup. The foundation consists of broken twigs, some of them a quarter of an inch in diameter, and placed together at all angles, so as to form a compact support; over this a layer of coarse moss and fern-hair, to the thickness of two inches or more; then a capacious well-rounded cup, lined with dry bents, intermixed with fern-hair. The general form of the nest is rounded, but at one end of it the twig foundation is raised and produced backwards, for what purpose can only be conjectured*. The other is of similar construction, composed of numerous broken twigs, intermixed with dry moss, and the projection is as conspicuous as in the former, extending some eight inches beyond the nest proper, which is about a foot in diameter. The cup-shaped depression is shallower than in the other, but has the same thick lining of dry grass. This nest was, I am informed, found among the branches of a totara overhanging a strean of water, in the month of January, and contained at that time young birds. The other nest also was discovered in the vicinity of water $\uparrow$.

Two eggs of this species, collected by Docherty on the west coast, were presented by Mr. Potts to the Canterbury Museum, where I had an opportunity of examining them. They are of a regular ovoido-conical form, one of them being slightly narrower than the other, measuring, respectively, 1.60 by 1.15 , and 1.65 by 1.10 inches. They are of a dark purplish grey, irregularly spotted and blotched with dull sepia-brown. These spots and markings are thicker and more prominent at the larger end, and of various shades, the lighter ones fading almost to purple and presenting a washed-out appearance.

Mr. W. D. Campbell has published \$ an account of two nests which he found, in the month of February, in the low bush which covers the river-flats of Westland. One of these nests contained an egg, and the other two nearly-fledged birds. The nests, which were built in the branches of the Coprosma scrub, about 9 feet above the ground, measured 15 inches externally, were somewhat loosely constructed of twigs and roots, and had a well-formed cup-shaped interior, lined with pineroots and twigs. He kept the two young birds for some weeks in a cage for the purpose of studying their habits. During life their wattles were of a light rose tint, changing into a violet colour towards the base; but after death, when their skins were dried, the wattles assumed a dull orange tiut.

* In eonneetion with the above I may mention that in the Canterbury MIuseum there is a mueh larger nest, from Australia, exhibiting the same form of construetion in a moro pronouneed degree. It was presented by the Baron A. von Hïgel, who obtained it at Dandenong, Mount Vietoria, and who assigns the strueture to the Lyre-bird (Menura superba). It is composed ehiefly of twigs and small stieks, some of them half an ineh in diameter, laid together in a eompaet mass. The eavity is doep, rounded, and lined witli soft fern-fronds, some of whieh are also interlaeed with the framework of tho uest. Its width on the outside is only 15 inehes; but, owing to its extension backwards, its length is 2 feet 6 inches. The eup is situated at the proximal end, where the nest is more eompaet and somewhat raised, but without any appearanee of a dome.

t The author of 'Out in the Open' deseribes, at p. 105, tho funding of five nests, at heights varying from ten to seventeen feet from the ground, in the bush that friuges Milford Souud. This was in the month of January, and one of the nests eontained two young birds, apparently just hatehed. "They" were partially elothed with slate-eoloured down, whieh on the eranium stood up like a broad erest, or rather erown; tho neek and uuderparts were quite bare; beaks flesh-eolour, with a greenish tinge about the point of tho upper mandible; rietal membrane pale greenish, ehanging to blue; wattles rosy pink, like an infant's hand; legs and feet slatish anteriorly, dull flesh-eolour behind; elaws dull white. The old bird suffered a close inspeetion of its homo and its iumates without uttering any alarm-ery or showing any signs of defending its young."

‡ Trans. New-Zealand Instit. 1879, vol. xii. pp. 249, 250. 


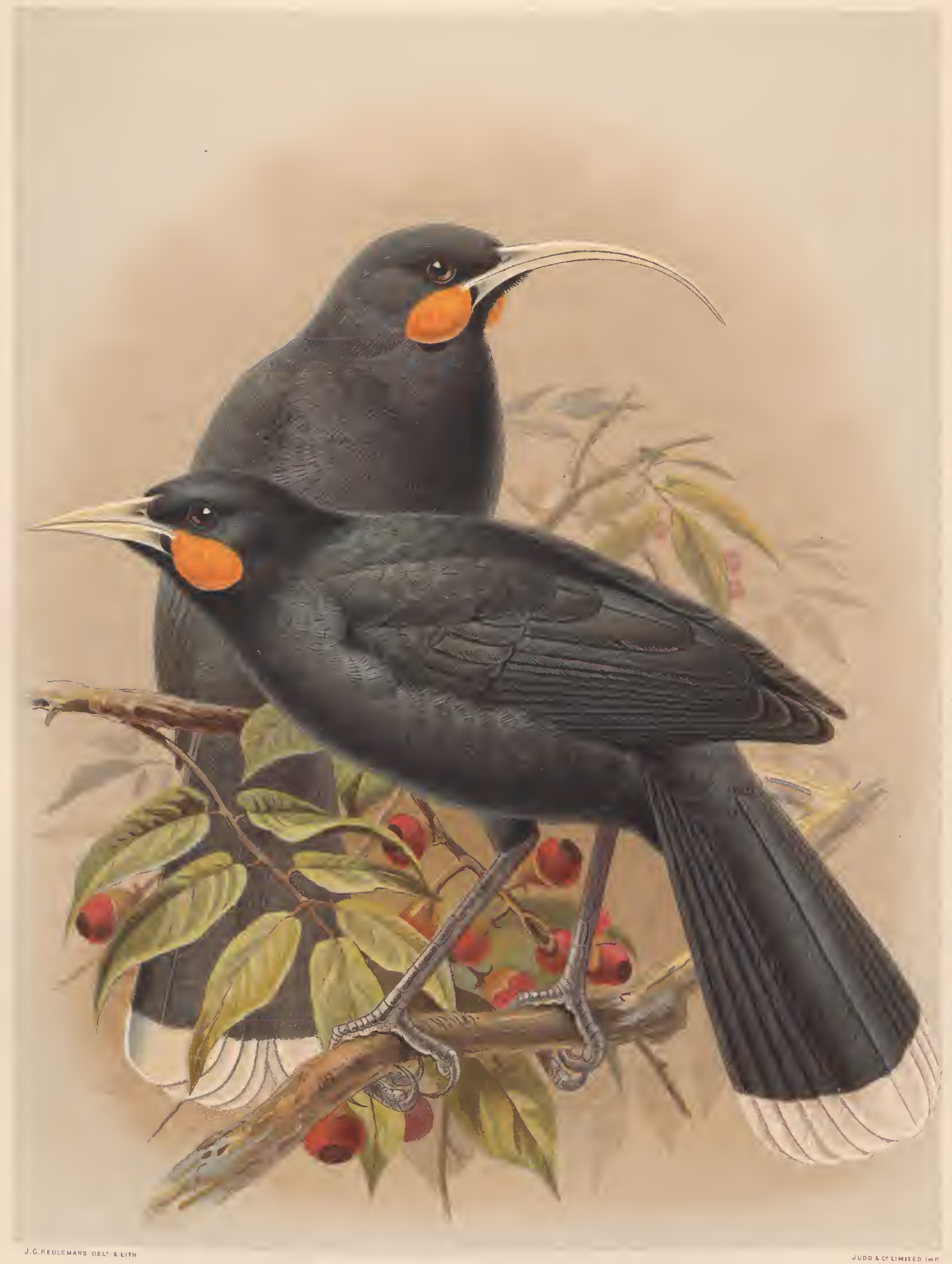

HUIA. (MALE AND FEMALE)

HETERALOCHA ACUTIROSTRIS.

(THREE-FIFTHS NATURAL SIZE.) 



\section{HETERALOCHA ACUTIROSTRIS.}

(HUIA.)

Neomorpha acutirostris, Gould, P.Z. S. 1836, p. 144 (q).

Neomorpha crassirostris, Gould, P.Z.S. 1836, p. 145 (o ).

Neomorpha gouldi, Gray, List of Gen. of B. p. 15 (1841).

Heteralocha gouldi, Cab. Mus. Hein. Th. i. p. 218 (1850).

\section{Native name.-Huia.}

đ̛ undique sericeo-niger, sub ecrtâ luce obscurè viridi nitens : caudâ conspicuè albo terminatâ : pileo earuneulis magnis rotundatis lætè aurantiacis utrinque ad basin mandibulæ positis ornato : rostro valido, eburneo, versus basin cinereo: pedibus einereis, unguibus eorneis.

\& mari similis, scd rostro longo valdè decurvato semper distinguenda.

Adult. The whole of the plumage is black, with a green metallie gloss; the tail with a broad terminal band of white. Bill ivory-white, darkening to blackish grey at the base. Wattles large, rounded, and of a rich orange-eolour in the living bird. Tarsi and toes bluish grey; elaws light hom-colour.

Male. Length 18.75 inches; cxtent of wings 22.5 ; wing, from flexure, 8 ; tail 7.5 ; bill, along the ridge $2 \cdot 75$, along the edge of lower mandible 2.75 ; tarsus 3 ; middle toc and elaw 2.5 ; hind toe and claw 2.

Female. Length 19.5 inches; extent of wings 21 ; wing, from flexure, $7 \cdot 5$; tail $7 \cdot 25$; bill, along the ridge 4 , along the edge of lower mandible 4.12 ; tarsus 3 ; middle toe and claw $2 \cdot 25$; hind toc and elaw $1 \cdot 75$.

Young female. Differs from adult bird in having the entire plumage of a duller black, or slightly suffused with a brownish tinge, and with very little gloss on the surface. Under tail-eoverts tipped with white, and the terminal white bar on the tail washed with rufous-yellow, especially in the basal portion. Wattles small and palc-coloured. Bill only slightly eurved.

In another specimen in my possession, apparently a year older, the tail-coverts are without the margin, the white on the tail-feathers is purer, and the bill is pcreeptibly longer, with a darkened tip. In another, the tips of both mandibles arc perfectly black for about half an inch in cxtent; the tail-feathers are only slightly stained with rufous, but instead of having an even white border the shafts are black to their tips, and the terminal bar has an emarginate edge.

Young mate. On comparing a spceimen in my collection with the above, the same gencral remarks apply, exeept that the under tail-coverts are not tipped with white at all, while the soft feathers on the lower part of the abdomen are largely tipped with pale rufous and white. The pale rufous wash on the tail-bar is likewise more eonspienous.

Varieties. The Maoris speak of a "red-tailed Huia," but I have no doubt that this is merely the condition of tail notiecd above. A single tail-fentlicr in my possession has the tcrminal band stained with rust-colour, and this would be described by a Maori as "red." They also say that the birds from the Ruahine range have a somewhat broader band on the tail than those from Tararua, the skins from the former locality being in mueh greater demand on that account. $\Lambda$ specimen which eamc into my hands had a single whitc feather in the tail-not a feather of the full quality but aborted in its character, being short, narrow, and shaped like one of the outer primaries, although filling the place of an ordinary tail-feather. In another 
specimen there was a narrow white streak down the shaft-line of the middle feather. The most remarkable variety, however, is that known to the Maoris as a Huia-ariki. I have ncver seen but one of these birds, of which I have already published the following notice *:-

"I have received from Captain Mair some feathers which, in colour, have much the appearance of the soft grey plumage of Apteryx oweni, but which arc in reality from the body of a Huia, being of extremely soft texture. I hope to receive the skin for examination, but in the meantime I will give a quotation from the letter forwarding the fcathers :--Old Hapuku, on his death-bed, sent for Mr. F. E. Hamlin, and presented him with a great taonga. This has just been shown to me. It is the skin of a very peculiar Huia, an albino I suppose, called by the Hawke's Bay natives 'Te Ariki.' I send you a few feathers. The whole skin is of the same soft dappled colour, but the feathers are longer and softer. The bill is nearly straight, strong, and of full length. The wattles arc of a pale canary-colour. The centre tail-feather is the usual black and white, while the others on each side are of a beautiful grey colour. These birds are well known to the Huia-hunting natives of Hawke's Bay; and to possess an 'Ariki' skin one must be a great chief. The spccimen I have described was obtained in the Ruahinc mountains."

The skin was aftcrwards sent to me, for examination, and was exhibited at a Meeting of the Wellington Philosophical Socicty. It is that of a male bird of the first ycar. The whole of the body-plumage is brownish black, obscurely banded or transversely rayed with grey; on the head and neck the plumagc is darker, shading into the normal glossy black on the forchead, face, and throat. The tail-feathers arc very prettily marked: with the exception of the middlc onc, which is of the normal character in its apical portion, they are blackish brown, irregularly barred and fasciated with different shades of grey, and with a tcrminal band of white; the under tail-coverts, also, arc largely tipped with white, indicating adolescence.

Obs. In some adult examples of both sexes the white at the end of the tail is tinged more or less with rufous. It should be noted also that the brightness of the fleshy wattles depcnds, in some measure, on the health or condition of the bird; for during sickness they change to lemon-yellow. A recently killed specimen weighed 14. $\frac{1}{2}$ oz. The palate and soft parts of the throat are bright yellow. The tongue is horny and slightly bifid at the tip. In fully matured examples the wattle measures nearly an inch across.

THIS is one of those anomalous forms that give to the New-Zealand avifauna so much special interest. Considerable difference of opinion has existed among naturalists as to its proper position in our artificial system. For many years it was placed, by common consent, among the Upupidæ, and that it possesses strong affinities to the Hoopoes is, I think, undeniable. Dr. Finsch proposed to group it in a separate family with Glaucopis and Creadion, under the name of Glaucopidæ; and Mr. Sharpe, in the British Museum Catalogue, has placed it with both of those forms in the family Corvidæ. According to my view, however, the investigation of its anatomy by the late Prof. Garrod leaves no doubt whatever that its natural place is among the Starlings.

The late Mr. Gould, who was the first to characterize the form, was deceived by the great difference in the shape of the bill, and treated the sexes as distinct species, naming them respectively Neomorpha acutirostris and $N$. crassirostris—a very natural mistake, "many genera even," as Mr. Gould observes, "having been founded upon more trivial differences of character." Mr. G. R. Gray, having determined their identity, proposed to substitute the specific name of gouldi, in compliment to the original describer; and his example has been followed by others; but I have deemed it more in accordance with the accepted rules of zoological nomenclature to adopt the first of the two names applied to the species by $\mathrm{Mr}$. Gould; and the name Neomorpha having been previously used in ornithology, it becomes necessary to adopt that of Heteralocha, proposed by Dr. Cabanis for this form.

In November 1870, 1 communicated to the Wellington Philosophical Society a paper $\uparrow$ containing

* Trans. New-Zealand Instit. 1878, vol. xi. p. 370.

† Op. cit. 1870, vol. iii. pp. 24-29. 
all the information I could collect respecting the Huia, which was then a somewhat rare species. As will presently appear, the bird is now far more plentiful than formerly. But, in order to preserve its full history, I will reproduce here a portion of that paper:-

A well-known writer in 'Nature' (Dr. Sclater), in describing the peculiarity in the form of the bill that distinguishes it from the female, observes: "Such a divergence in the structure of the beak of the two sexes is very uncommon, and scarcely to be paralleled in the class of birds. It is difficult to guess at the reason of it, or to explain it on Darwinian or any other principles." In the absence of any published account of its habits, beyond mere fragmentary notices, I have thought the subject of sufficient interest to justify my placing before the Society the following complete account of all that I have been able to ascertain respecting it. The peculiar habits of feeding, which I have described from actual observation, furnish to my own mind a sufficient "reason" for the different development of the mandibles in the two sexes, and may, I think, be accepted as a satisfactory solution of the problem.

Before proceeding to speak of the bird itself, I would remark on the very restricted character of its habitat. It is confined within narrow geographical boundaries, being met witl only in the Ruahine, Tararua, and Rimutaka mountain-ranges, with their divergent spurs, and in the intervening wooded valleys. It is occasionally found in the Fagus forests of the Wairarapa valley, and in the rugged country stretching to the westward of the Ruahine range, but it seldom wanders far from its mountain haunts. I have been assured of its occurrence in the wooded country near Massacre Bay *, but I have not been able to obtain any satisfactory evidence on this point. It is worthy of remark that the natives, who prize the bird very highly for its tail-feathers (which are used as a badge of mourning), state that, unlike other species which have of late years diminished and become more confined in their range, the Huia was from time immemorial limited in its distribution to the district I hare indicated.

My first specimen of this singular bird (an adult female) was obtained in 1855, from the Wainuiomata hills, a continuation of the Rinutaka range, bounding the Wellington harbour on the northern side-the same locality from which Dr. Dieffenbach, nearly twenty years before, received the examples figured by Mr. Gould in his magnificent work 'The Birds of Australia.' I have since obtained many fine specimens, and in the summer of 1864 I succeeded in getting a pair of live ones. They were caught by a native in the ranges, and brought down to Manawatu, a distance of more than fifty miles, on horseback. The owner refused to take money for them; but I negotiated an exchange for a valuable greenstone. I kept these birds for more than a year, waiting a favourable opportunity of forwarding them to the Zoological Society of London. Through the carelessness, however, of a servant, the male bird was accidentally killed; and the other, manifesting the utmost distress, pined for her mate, and died ten days afterwards.

The readiness with which these birds adapted themselves to a condition of captivity was very remarkable. Within a few days after their capture they had become perfectly tame, and did not appear to feel in any degree the restraint of confinement; for, although the window of the apartment in which they were kept was thrown open and replaced by thin wire netting, I never saw them make any attempt to regain their liberty. It is well known, however, that birds of different species differ widely in natural disposition and temper. The captive Eagle frets in his sulky pride; the Bittern

* Mrr. Kase informs me that when travelling, two years agro, in the South Island he saw several Huias in a forest lying betwcen Nelson and Picton. He states that he was quite elose to them, and could not possibly be mistaken in the bird, with which he is familiar. Mr. W. T. Owen, who is a very eareful observer, assures me that he met with it on the other side of Nelson. If the range of the Huia docs in reality extend aeross the Straits, it is a very remarkable fact in the geographieal distribution of this mueh-restrieted species. That it does oecasionally wander far beyond the limits assigned to it in the North Island is certain, because in 1881 Mr. Ambrose Potts met with one near Te Rinopoanga, in the Patea eountry. This was not an escaped bird, beeause the natives of the distriet knew nothing about it, and would searcely eredit the statement. 
refuses food and dies untamable; the fluttering little Humming-bird beats itself to death against the tiny bars of its prison in its futile efforts to eseape; and many speeies that appear to submit readily to their changed endition of life, ultimately pine, sicken, and die. There are other speeies, again, which cheerfully adapt themselves to their new life, although eaged at maturity, and seem to thrive fully as well under eonfinement as in a state of nature. Parrots, for example, are easily tamed; and I have met with numerous instanees of their voluntary return after having regained their liberty. This eharaeter of tamability was exemplified to perfection in the Huias.

They were fully adult birds, and were eaught in the following simple manner. Attraeting the birds by an imitation of their ery to the plaee where he lay eoneealed, the native, with the aid of a long rod, slipped a running knot over the head of the female and secured her. The male, emboldened by the loss of his mate, suffered himself to be easily caught in the same manner. On receiving these birds I set then free in a well-lined and properly ventilated room, measuring about six feet by eight feet. They appeared to be stiff after their severe jolt on horsebaek, and after feeding freely on the huhu grub, a pot of which the native had brought with them, they retired to one of the perehes I had set up for them, and euddled together for the night.

In the morning I found them somewhat recruited, feeding with avidity, sipping water from a dish, and flitting about in a very aetive manner. It was amusing to note their treatment of the huhu. This grub, the larva of a large noeturnal beetle (Prionoplus reticularis), whieh eonstitutes their prineipal food, infests all decayed timber, attaining at maturity the size of a man's little finger. Like all grubs of its kind, it is furnished with a hard head and hoiny mandibles. On offering one of these to the Huia, he would seize it in the middle, and, at once transferring it to his perch and placing one foot firmly upon it, he would tear off the hard parts, and then, throwing the grub upwards to secure it lengthwise in his bill, would swallow it whole. For the first few days these birds were comparatively quiet, remaining stationary on their perch as soon as their hunger was appeased. But they afterwards beeame more lively and active, indulging in play with each other and seldom remaining more than a few moments in one position. I sent to the woods for a small branched tree, and placed it in the centre of the room, the floor of which was spread with sand and gravel. It was most interesting to watch these graeeful birds hopping from branch to braneh, oceasionally spreading the tail into a broad fan, displaying themselves in a variety of natural attitudes and then meeting to earess each other with their ivory bills, uttering at the same time a low affectionate twitter. They generally moved along the branehes by a suecession of light hops, after the manner of the Kokako (Glaucopis wilsoni); and they often deseended to the floor, where their mode of progression was the same. They seemed never to tire of probing and ehiselling with their beaks. Having diseovered that the eanvas lining of the room was pervious, they were ineessantly piereing it, and tearing off large strips of paper, till, in the eourse of a few days, the walls were eompletely defaced.

But what interested me most of all was the manner in whieh the birds assisted eacls other in their search for food, beeause it appeared to explain the use, in the eeonomy of nature, of the differently formed bills in the two sexes. To divert the birds, I introduced a log of decayed wood infested with the hulu grub. They at onee attacked it, carefully probing the softer parts with their bills, and then. vigorously assailing them, seooping out the decayed wood till the larva or pupa was visible, when it was earefully drawn from its cell, treated in the way deseribed above, and then swallowed. The very different development of the mandibles in the two sexes enabled them to perform separate offices. The male always attaeked the more decayed portions of the wood, eliselling out his prey after the manner of some Woodpeekers, while the female probed with her long pliant bill the other eells, where the hardness of the surrounding parts resisted the ehisel of her mate. Sometimes I observed the male remove the decayed portion without being able to reach the grub, when the female would at onee eome to his aid, and accomplish with her long slender bill what he had failed to do. I noticed, however, that the female always appropriated to her own use the morsels thus obtained. 
For some days they refused to eat anything but huhu; but by degrees they yielded to a change of food, and at length would eat eooked potato, boiled rice, and raw meat minced up in small pieees. They were kept supplied with a dish of fresh water, but seldom washed themselves, although often repairing to the vessel to drink. Their ordinary eall was a soft and clear whistle, at first prolonged, then short and quickly repeated, both birds joining in it. When exeited or hungry, they raised their whistling note to a high piteh; at other times it was softly modulated, with variations, or ehanged into a low chuckling note. Sometimes their ery resembled the whining of young puppies so exaetly as almost to defy deteetion.

I had afterwards another eaptive Huia, whieh eame from the Fagus-covered hills at Wainuiomata. 'This bird became very tame, knew me well, and always welcomed my approaeh by making a melodious ehirping note. He was fond of fresh meat, ehopping it up into very small pieees with his bill, making a sound like the tapping of a Woodpecker as lie eut up his dinner on the floor of his eage. He ultimately made his escape, and although he remained about the gardens and shrubberies of Wellington for more than two months, consorting freely with the Indian-Minahs, and oeeasionally indulging in a flight over his old habitation, he seemed to prefer freedom to captivity, and remained at large; but disappeared at last, having probably fallen a vietim to the eatapult of some city larrikin.

Dr. Dieffenbach, in forwarding his speeimens of the Huia to Mr. Gould, in 1836, wrote:- "These fine birds enn only be obtained with the help of a native, who ealls them with a shrill and longcontinued whistle resembling the sound of the native name of the speeies. After an extensive journey in the hilly forest in search of them, I had at last the pleasure of seeing four alight on the lower branches of the trees near which the native accompanying me stood. They eame quick as lightning, descending from branch to branch, spreading out the tail and throwing up the wings."

On the first oecasion of my meeting with this speeies in its native haunts, I was struek by the same peeuliarities in its manners and general demeanour. In the summer of 1867 , aeeompanied by a friend and two natives, I made an expedition into the Ruahine ranges in seareh of novelties. After a tramp on foot of nearly twenty miles through a densely wooded eountry, we were rewarded by finding the Huia. We were climbing the side of a steep acelivity, and had halted to dig speeimens of the eurious vegetating eaterpillar (Sphceria robertsii), which was abundant there. While thus engaged, we heard the soft flute-note of the Huia in the wooded gully far beneath us. One of our native eompanions at once imitated the call, and in a few seconds a pair of beautiful Huias, male and female, appeared in the branehes near us. They remained gazing at us only a few instants, and then started off up the side of the hill, moving by a suceession of hops, often along the ground, the male generally leading. Waiting till he could get both birds in a line, my friend at length pulled trigger; but the cap snapped, and the Huias instantly disappeared down the wooded gully. Then followed a chevy of some three miles, down the mountain-side and up its rugged ravines. Once more, owing to the dampness of the weather, the eap snapped, and the birds were finally lost sight of. I observed that while in motion they kept near each other, and uttered constantly a soft twitter. The tail was partially spread, while the bright orange lappets were usually eompressed under the rami of the lower jaw.

We camped that night near the bed of a mountain rivulet, in a deep wooded ravine, and soon after dawn we again heard the rieh notes of a Huia. Failing to allure him by an imitation of the eall, although he frequently answered it, we crossed to the other side of the gully, and elimbed the hill to a elump of tall rimu trees (Dacrydium cupressinum), where we found him. He was perehed on the high limb of a rimu, ehiselling it with his powerful beak, and tearing off large pieces of bark, doubtless in seareh of insects; and it was the falling of these fragments that guided us to the spot and enabled us to find him. This solitary bird, which proved, when shot, to be an old male, had frequented this neighbourhood (as we were informed by the natives) for several years, his notes 
being familiar to the people who passed to and fro along the Otairi track leading to Taupo. On asking a native how the Huia contrived to extract the huhu from the decayed timber, he replied "by digging with his pickaxe"-an expression which I found to be truthfully descriptive of the operation; and on dissecting this specimen I found an extraordinary development of the requisite muscles. The skin was very tough, indicating, probably, extrcme age. The stomach contained numerous remains of coleopterous insects, of the kind usually found under the bark of trees, also one or two caterpillars.

On skinning the two sexes, it is at once apparent that the head of the male is formed on a different model to that of the female. In the latter the skin peels off very readily, but in the male the head seems too large for the neck. This difference is occasioned by the greatly developed muscles, forming a rounded mass or cushion on each side of the occiput, which enables this sex to wield his chisel in the effective manner described.

In October 1883, I made a special expedition into the mountain-forest in quest of the Huia; and as it will serve to completc my history of the species, I have transcribed the following narrative from my note-book:-

Taking the early train from Wellington to Masterton on the 9th, I met Captain Mair by appointment, and we forthwith made our arrangements for a start on horscback at daybreak. Instead of a fine day, as we had hoped, the morning opened with a heavy shower, which somewhat delayed our departure, and the day turned out drizzly. Our road lay through a bush and along a highway which had been formed but not metalled. The mire was knee-deep for the horses, and, for most part of the way, it was very toilsome work. 'The distance to be traverscd was only twenty miles, the first four of which were over a hard road; but the shades of evening were closing in around us by the time we reachcd our camping-ground at the foot of the Patitapu range, and our Maori attendant (Rahui) had barely time to fix up our tent and collect "whariki" for bedding before thick darkness had set in. Our approach to this camping-place lay along the edge of a wooded ravine. On the opposite side from us there was a grove of tall manuka trees, several hundred acres in extent. Rahui informed us that this was a favourite resort of the Huia when fceding on the weta or tree-cricket (Deinacrida thoracica). The dull russet-green of the manuka bush was rclieved on the sides of the ravine by thosc ever changing, evcr beautiful, light-green tints so characteristic of our New-Zealand woods. Here and there a shapely rewarewa reared its tapering top, spangled all over with bunches of crimson flower, while along our path were fringcs of the scented pukapuka with its dark green leaves, showing thcir silver lining as they yielded to the brecze, and covered with a profusion of creamcoloured inflorescence. At intervals might be scen a lcafless kowhai laden with a wealth of beautiful golden blossom, and in the more open parts of the widening valley clumps of Cordyline with their waving crowns of green; whilst, adding immeasurably to the charm of the whole scene, the star-like clematis, in huge white clustcrs, hung everywhere in graceful festoons from the tangled vegetation. Down in the bcd of the ravine, and hiding the babbling brook, the stunted overhanging trees were for the most part clothed in a luxuriant mantle of kohia, kareao, and other epiphytic plants.

Such was the spot in which we first heard the soft, whistling call of the Huia! Rahui imitated the cry, and in a few moments a fine male bird camc across the ravine, flying low, taking up his station for a few seconds on a dead tree, and then disappearing, as if by magic, in the undergrowth below. Our guide continucd to call, but the Huia was shy and would only respond with a low chirping notc. But this was enough, and led us to where he was engaged, apparently grubbing among the moss on the ground. We shot the bird, which proved to be in beautiful plumage, and Rahui accepted this as an earnest of our success on the morrow.

Our camp was selected as only a nativc can select in the bush. The spot fixcd upon was a gentle slope under the shadow of a three-stcmmed tawhero (Weinmannia racemosa), sheltered all round by close-growing porokaiwiria, torotoro, and other shrubby trees, and the whole fenced in, as 
it were, by a thick undergrowth of bright green pukapuka, mixed with the still brighter mahoe, and protected in front by a perfect nctwork of kareao vines, attached to and suspended from the higher trees. We soon had a roaring camp fire and some ribs of mutton roasting for supper. As the night closed in upon us we heard all round the solemn notes of the New-Zealand Owl : first, a distinct koukou, kou-kou; then in a weaker key (perhaps the responsive call of the female) keo-keo-keo; and then, in altemation, the alarm-note and the ever familiar cry of "more-pork."

Even aftcr a pall of darkness had settled on the woods, some Tuis in the tall trce-tops kept up a delicious liquid song, like the measured tolling of a silver bell, and far into the night could be hcard, at intervals, the low whistling note of the Kaka communing with his mate. Then all was quiet, the night being very dark, and nothing broke the stillness of the forest till the Huia-call of our native guide brought us to our senses in the early dawn. But the day turned out unpropitious. The drizzling rain continued and a strong breeze sct in; so we detcrmined to shift our camp to the other side of the range. Our road lay along the side of another ravinc. We had not proceeded more than a mile when Rahui's call was answered from the other side. The bird's loud cry was presently succeeded by a whistling whimper, and then he came towards us, bouncing through the brushwood as if in a desperate hurry. Descending to the ground a few yards in front of us, he hopped along the surface, and then up the trunk of a prostrate tree, with surprising agility. My companion took a shot at him; but owing to the dampness his gun missed fire, and the bird, taking alarm, disappeared in an instant, all our efforts to recall him proving of no avail. On reaching the head of the valley, we tcthered our horses and commenced the ascent of the range, which we found vcry steep. About halfway up, we rested on the ground. Rahui continucd his call-a loud clear whistle-not much like the ordinary call of the bird, being louder and morc shrill. In a few seconds, without sound or warning of any kind, a Huia came bounding along, almost tumbling, through the close foliage of the pukapuka, and presented himself to view at such close range that it was impossible to fire. This gave me an opportunity of watching this beautiful bird and marking his noble bearing, if I may so express it, bcfore I shot him. While waiting to get the bird within propcr range, I heard far below me the rich note of the Kokako, repeated several times. It is scarcely distinguishable from the call of the 'Tni, but is preceded by a prolonged organ-notc of rare sweetness. My next shot was at an adult male Huia who came dashing up, with reckless impetnosity, from the wooded gully. Being anxious to obtain a perfect specimen, I risked a long shot and only wounded my bird. Down he went to the ground like an arrow, with a sharp flute-note of surprise or pain, and then dartcd off, kangaroo-fashion, covering the ground with wonderful rapidity, and disappeared in the tangle.

We found the desccnt of the range much easier than our toilsome climb. Remounting our horses we continued up the valley. At a turn in the road, at a spot hemmed in by a wooded amphitheatre of beautiful shapcly trees (chiefly rata), we halted for a moment to gaze on the sccne. On a tree, immediately in front of us, a pair of Wood-Pigeons were sitting side by side, showing off their ample white breasts under the rays of sunlight glancing through the rain-drops. Whilst we were looking at and admiring this little picture of bird-life, a pair of Iruias, without uttering a sound, appeared in a tree overhcad, and as they were caressing each other with their beautiful bills, a charge of No. 6 brought both to the ground together. The incident was rather touching, and I felt almost glad that the shot was not mine, although by no means loth to appropriate the two fine specimens. Before we reached our next camping-ground, at the foot of Poroporo, we had bagged anothcr bird (a female of last year) who was unattended, and came up quite fearlessly to her doom.

After we had secured our horses and "refreshed the inner man," Rahui and I started again for Huias, whilst our companion remained to fish for eels in the creek near our camp. After we had walked about a mile, a bird answered our call, and immediately afterwards a pair of Huias alighted in a pukatea tree above us. I brought them down, with right and left, and then another 
bird (a young male) appeared on the scene. He exhibited great excitement and was evidently at a loss to know what it all meant. Uttering a low, sibilant cry, with a tender pathos, he hopped down lower and lower, till within a yard or two of my head. I could easily have knocked the pretty creature over with a stick, but had not the heart to do so. I was less scrupulous, however, about having him caught, and in far less time than I take to write it, Rahui had selected a long stick, fixed a noose at the end of it, and slipped it over the bird's head. The Huia nimbly jumper through the loop but was caught by the feet. On finding himself a captive, he uttered no sound, but, in the most practical way, at once attacked my hands with his bill, striking fiercely and repeatedly at a whitefaced signet-ring. On the following day Rahui managed to snare another; which was fortunately a female, thus making a pair of young birds. They became at once reconciled to confinement, eating freely of the huhu grub, and resting very contentedly on a percls to which they had been attached by a thong of flax. The young of the first year has a low and rather plaintive cry, easily distinguished from all other sounds in the forest, and plcasant enough to the ear. Our third and last day turned out wet and stormy; but we nevertheless got some more Huias, our bag consisting altogether of sixteen birds, exclusive of the live ones.

The Huia never leaves the shade of the forest. It moves along the ground, or from tree to tree, with surprising celerity by a series of bounds or jumps. In its flight it never rises, like other birds, above the tree-tops, except in the depth of the woods, when it happens to fly from one high tree to another. The old birds, as a rule, respond to the call-note in a low tremulous whistle or whimper, and almost immediately afterwards answer the summons in person, coming down noiselessly and almost with the rapidity of an arrow. Occasionally a shy old bird refuses every allurement, and takes himself quietly off. These knowing ones are distinguished by the bird-hunters as Huia-paoke. Young birds answer the call, although somewhat feebly, but do not, as a rule, present themselves. With these, it is necessary to mark down the direction, and follow them up with gun or suare.

They are generally met with in pairs, but sometimes a party of four or more are found consorting together.

Its food consists largely, as already stated, of the huhu grub; but it also subsists on the weta and other insects of various kinds, and the berries of such trees and shrubs as hinau, porokaiwiria, poukaka, and karamu. In the stomachs of those which I opened I found hinau berries (Elceocarpus dentatus), orthopterous insects, caterpillars, and the remains of a large spider; and Mr. Drew informs me that birds skinned by him had been feeding on the green and brown Mantis.

Within its restricted habitat the Huia appears to maintain its position notwithstanding the wholesale slaughter of late years. To say nothing of the zeal of collectors, who obtain large numbers for the European markets, the natives annually kill a great many for the sake of their feathers. For example: a party of eleven natives went out for a month and scoured the wooded country lying between the Manawatu gorge and Akitio, and brought in 646 skins; and a party of three men obtained a considerable number near Turakirai on the south-western side of the Wairarapa Lake. Other instances of the kind might be given, all tending to show that the struggle for existence with the Huia is becoming a severe one. Already the fate of several species which, a few years ago, were plentiful enough in these wonds has been decided. In the course of our expedition, which extended altogether 27 miles beyond Masterton, we travelled over a broad extent of broken, wooded country, and, to say nothing of Korimako and Pitoitoi (which have long since disappeared), we never saw or heard the notes of either the Piopio, the Tieke, or the Hihi, all of which birds were at one time more numerous even than the Huia. The Zosterops was everywhere abundant, also the Grey Warbler and Rifleman, and along the edges of the bush we found the Tomtit comparatively plentiful; the Parrakeet chased its mate through the tree-tops with sharp cries of "twenty-eight"; the Tui, in its playful flight, mounted high in the sunlight overhead; and among the tangle of the underwood the ever-present Flycatcher displayed its pretty fan-like tail. But, of course, the charm of these 
dark Fagus-woods was the beautiful bird for which we had expressly come, and of which we had secured so many fine specimens.

One of the birds shot on our last day was a sitting female. The whole of the abdomen was denuded of feathers, and the skin had a smooth or polished appearance, as if the bird had been incubating for some time. This was on Octobcr 12, and was pcrhaps a case of carly nesting, as none of thc other birds presented any such appearance. In the ovary was a cluster of eggs, the largest of which was scarccly equal to a No. 6 shot. The ovarial duct was much enlarged, from which it may be inferred that the egg had only lately been laid. Another point deserving of notice is that the bird was very fat, even the intestines being overlaid with thin layers; whereas most of the birds we shot were in rather poor condition. May we not fairly infer from this that the male bird attends upon and feeds the female during incubation?

In the generality of dried spccimens, and in the published drawings that have hitherto appeared, the bill is of a yellowish horn-colour; but this, instead of being natural, is caused by the decomposition of the animal matter inside. I have succecded in rctaining the ivory whitcness of the bill, in prescrved specimens, by treating them after the manner recommended by Waterton for preserving the bill of the American Toucan (see 'Wanderings,' p. 103) -that is to say, by removing with a sharp scalpel the whole of the inncr substance, lcaving nothing but the outer shcll, which then retains its original appcarancc. The process is a tedious one; but the result amply repays the trouble. The wattles of the Huia arc of a bright orangc colour, and during life are usually carried half-curled inwards.

I have given elsewhcre * a figure of the dried head of a Huia handed to me, many years ago, by a native who had been wearing it as an ear-ornament. This specimen, which is now in the University Museum at Cambridge, represents a more highly curved form of bill than is usually met with.

I have also described and figured a curious deformity in the bill of this bird. The lower mandible, in this instance, having becn at some time accidentally broken off, the upper mandible had considerably overgrown it, becoming somewhat thickencd bcyond the point of friction \$.

In my former edition I mentioncd that a live fcmale Huia had been added to the collection of the Zoological Society. The cage containing it was kcpt in the "Parrot House," bcing placed between

* Trans. New-Zealand Institute, 1870, vol. iii. pl. iv. fig. 3.

$\uparrow$ O r. cit. 1877, vol, x. p. 211.

¥ More curious still is tho case of deformity recently described by the Rev. W, Colcnso, F.R.S., in a paper read before the Hawke's Bay Institute on tho 9th August, 1886 (not yet published), of which the author has kindly sent me a copy, from which I extract the following:- " The head exhibited is that of a female Huin, the upper mandible of its bill being greatly and strangely deformed. From about one inch or one-fourth of the normal length of the npper mandiblo from its base it suddenly riscs and remains at an angle of $45^{\circ}$, forming a regular, ascending, sub-erect spiral of two large and equal curves of $\cdot 75$ of an inch, open, interior diameter, not unlike a gigautic cork-screw, and reminding ono of the spiral horn of the Strepsiceros. The total length of this deformed mandible, following tho curres, is just six inches. It is flat above and devoid of nostrils, and the end or tip is sharply pointed. . . . The lower mandible is $2 \cdot 75$ inches long, being vory much shorter and not so much eurved as this portion of the bird's bill is in the normal state. . . . There is not the slightest indieation of the upper mandible ever having been broken or bruised. . . . . From its strange configuration it appears to have been far more than mercly uscless, for it must have been always an obstaclo in the way and tho means of keeping the bird's mouth constantly open. How it could have managed to cxist seems truly monderful!" Tide woodcut on page 17.

In counection with this tendency to abnormal growth, I may mention a suggestive circumstance that has lately come under my notice. A male bird which I presented to the Zoologieal Society was fully adult when I brought it to England. For about a year, in its new home, it has becn fed on soft food, the bill boing thus deprived of the ordinary wear and tear incident to the natural habits of the species. $\Lambda_{\mathrm{s}}$ a consequence, the bill has far outgrown in length its normal proportious, and has assumed a somewhat eurved form, resembling that of an immature femalc. Tho wattlcs have retained their rich orange colour, and the bird seems to be in perfect health.

Mr. T. W. Kirk mentions (Trans. N.-Z. I. vol. xii. p. 249) another eurious instaneo of deformity in the bill of a female Huia, in the Musenm Collection at Wellington, and gives a woodcut to illustrate it. In this ease, it appoars to have resulted from an accident, a shot having probably passed through and split the upper maudible immediately below the nostril. 
those of a Toucan on one side and a Hornbill on the other; and I was assured by Mr. Bartlett, the Superintendent of the Gardens, that this bird (although without a mate of its own species) seemed perfectly happy and contented in the midst of these new surroundings. It was supplicd with a mixed food, in which boiled eggs, frcsh meat, and earthworms formed the principal ingredicnts; but its diet requircd careful regulation, to prevent scouring, to which the bird was very liable. It did not, however, long survive this condition of things, and ultimately succumbed, as I vcnture to think, to the tropical heat of its environment-the prosector's official report being that it had died " in a much emaciatcd condition, but without organic disease" *.

.Thcre is now living in the "Wcstern Aviary" in the same Gardens a fine male bird which I brought to England in April 1886, and which had been in possession of the Wairarapa Maoris for nearly a year previous to my leaving the colony.

A study of this living bird has enabled my artist to depict the species in the highly characteristic attitudes shown in the Plate. The berries represented are those of the titoki (Alectryon excelsum), on which the Huia doubtless feeds, for although habitually insectivorous, I have often found in the stomach the lsernels of the hinau and other berries; and Mr. Tone informs me that he once saw

* As stated in the Introduetion to my former edition (page xvii) the loss to the eolleetion was a gain to seienee, for the late Prof. Garrod had thus an opportunity of studying the osteology aud anatomy of this singular form ; and I quoted the following passages from his valuable paper on the subjeet read before the Zoologieal Soeiety on the 21st of May, 1872:-

"The arrangement of the feathers is eompletely Passerine. Tho rhombie saddle of the spinal traet does not enelose any ephippial spaee, therein differing from the Crow's and resembling the typieal Starling's. There are nineteen remiges, of whieh ten are on the hand; they increase in size up to the fifth. The reetrices are twelve in number. The oil-gland is nude. . . . The gizzard is well developed. The intestines are 16 inehes long, with the bile-duets $2 \frac{1}{2}$ inehes from the gizzard. The exea are 1 ineh from the eloaea and $\frac{1}{4}$ ineh long, being eylindrieal. There is one earotid artery, the left. . . . The palate is strietly ægithognathous; that is, the romer is truneate in front abruptly, and eleft behind; tho postero-osternal angles of the palatines are produeed; the maxillo-palatines are slender, and approaeh towards, but do not unite with, ono another, nor with the vomer, whieh they partly embraee. There is no ossifieation in tho nasal soptum anterior to the vomer. The whole eranial eonfiguration elosely resembles that of Stumus; but the mandible, instead of being bent upwards, is straight. Like it, tho palatines are narrow and approximate; the antero-internal angles of the posterior portions of those bones are redueod and rounded off, as is sometimes the ease with Sturnus. The vomer is eompletely truneated in front, and is not prolonged forwards at its external angles, as in Corves and its allies. Tho zygoma is not so slender as in Sturnus; but the eurves are similar. The artieular surfaees on tho quadrate bone for the mandible are proportionally very largo. The anterior extremities of the pterygoid bones artieulate with the sphenoidal rostrum mueh as in Corvus, meeting in tho middlo line behind tho posterior extremities of the palatines for a short distanee. Tho maxillo-palatines, in their approximate portions, are shorter from before baekwards than in Sturnus, and mueh resemble those of Corvus. The antero-inferior proeesses of the orbit are large and spongy; they almost toueh the zygoma. But the most eharacteristie jortion of the skull of Ueteralocha is the oceipital region; and in this it presents a great oxaggeration of the peeuliarities of Sturnus and its allies. In Corvus and most Passerines the digastrie museles oeeupy a narrow spaee intervening between the auditory meatus and the mass of oecipital muscles, not exteuding so high up the skull as the latter. The oeeipital ridge eneloses a spaee elongated from side to side, and of bit little depth. In Sturnus the digastries are mueh broader, and they narrow the oeeipital spaee; they also extend up the skull to so great an oxtent that they nearly meet in the middle line abore the origin of the biventres eervieis museles; but in Heteralocha they are of still greater size, and, meeting abovo the middle liue, they form a strong ridge, whieh extends for some distanee into the parietal region vertieally. This peeuliar development of these muscles produces a corresponding ehange in the shape of tho space enelosed by the oecipital ridge. In Ifeterabocha it is almost cireular, and it extends somo way above the foramen magmum. In Sturnus there is an approximation to this eondition. A rertieal parieto-occipital ridge in many othor birds elosely resembles that of Heteralocha; but it is the median limit of the temporal fossa in most. Correlated with this extensive digastrie origin is a large surfaee for its insortion. The angle of the mandible is prolonged direetly baekwards for this purpose, in a manner unique among Passerine birds, but well seen in the Anatidce. In Sturnus the angle of the mandible is slightly prolonged baekwards for a similar purpose. . . . In the sternum Heterclocha differs in no important point from Sturnus, except that the posterior notehes tend to be eonverted into foramina, as observed by Mr. Eyton in his 'Osteologia Arium.' . . . . In eonelnsion, it may be stated that the anatomy of Ileteralocha shows elearly that it is truly P'asserine, and not related to $U_{p}$ upa, as was previonsly supposed by most authors. When examined more in detail its relation to the Sturnidae is found to be very intimate, and its strueture is elearly not elosely allied to that of the Corvidce. In its relation to Sturnus it seems to present an exaggeration of the peeuliarities of that bird, whieh would place it at the head of the family."-Proc. Zool. Soc. 1872, pp. 643-647. 
three of them, at Akitio, feeding with avidity on the ripe fruit of the kahikatea (Podocarpus dacrydioides).

The Maoris prepare the skin in a very primitive way: cutting off the wings and legs, they strip the body and then flatten the skin to dry between two sheets of totara bark, tied tightly round with native flax, taking special care to keep the tail-feathers unsoiled. The latter are much prized as head-plumes on festive occasions, and for the ornamentation of the dead. In former days very artistic boxes (papa-huia) were carved in relief as easkets for these precious feathers.

This species builds its nest in hollow trees, forming it of dry grass, leaves, and the withered stems of herbaceous plants, earefully twined together in a circular form, and lined with softer materials of a similar kind*. An egg was brought to me on the 1lth October, 1877, by Mikaera of Wainuiomata, who stated that it was found by him in utero when engaged in skinning a Huia. As already mentioned on page 4, the testimony of this man is not very reliable; but there can be little doubt that this is in reality the egg of the Huia, for it agrees in general character with one subsequently received at the Colonial Museum and described by Mr. Kirk †. My specimen was perfectly fresh when brought to me, and the shell was of such extreme delieacy that it was fractured under the gentlest handling in blowing. It is ovoido-elliptical in form, measuring 1.8 inch in length by $1 \cdot 1$ inch in breadth, of a very delicate stone-grey, inclining to greyish white, without any markings except at the larger end, where there are, chiefly on one side, some seattered rounded spots of dark purple-grey and brown; towards the smaller end there are some obsolete specks, but over the greater portion of its surface the shell is quite plain.

The specimen described by Mr. Kirk is somewhat smaller, being 1.45 inch in length by 1.1 in its widest diameter, the shell "having a beautifully fine and delicate structure, and pure white without any trace of markings whatever." This egg was obtained by Mr. G. M. Hewson from the Maoris of Murimotu, who assured him that it was that of the Huia.

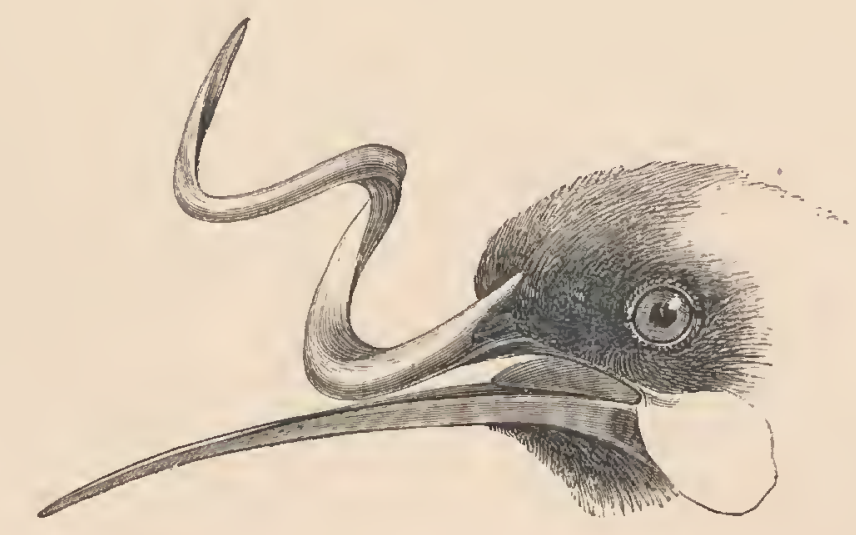

Abnormal growth of a Huia's bill (from a photograph). Sec footnote, p. 15.

\footnotetext{
* See an interesting account by Mr. Potts ('Zoologist,' 1884, p. 387) of a nest found in the cavity of an ancient hinau tree at Manawatu. On November 18th it contained one young bird. Another nest in the same ncighbourhood contained three.

$\uparrow$ Journal of Science, 1882-83, rol. i. p. 263.
} 


\title{
CREADION CARUNCULATUS.
}

\author{
(TIIE SADDLE-BACK.)
}

Wattled Stare, Lath. Gen. Syn. iii. p. 9, pl. 36 (1783).

Sturnus carunculatus, Gm. Syst. Nat. i. p. 805 (1788, ex Lath.).

Creadion pharoides, Bonn. et Vieill. Enc. Méth. p. 874 (1823).

Icterus mufusater, Less. Voy. Coq. i. p. 649, pl. xxiii. fig. 1 (1826).

Xanthornus carunculatus, Quoy et Gaim. Voy. de l'Astr. i. p. 212, pl. 12. fig. 4 (1830).

Oxystomus carunculatus, Swains. Classif. of B. ii. p. 270 (1837).

Creadio carunculatus, Cab. Mus. Hein. Th. i. p. 218 (1850).

\section{Native names.}

Tieke, Tiraweke, Tirauweke, and Purourou.

ô ad. nitidè niger: dorso cum tcctricibus alarum, supracaudalibus et subcaudalibus lætè ferrugineis : carunculis rictalibus miniatis : rostro et pedibus nigris : iride nigricanti-brunncâ.

우 mari similis, sed minor ct carunculis minoribus distinguenda.

Adult male. General plumage glossy black; back, wing-coverts, upper and lower tail-coverts bright ferruginous. Irides blackish brown; bill and legs black; wattles varying in tint from a clear ycllow to a bright vermilion, being apparently affected by physical conditions, such as the health of the bird or the temperature of the weather. Total length 10 inches; extent of wings 12.5 ; wing, from flexure, 4 ; tail 3.5 ; bill, along the ridge 1.25 , along the edge of lower mandible 1.4 ; tarsus 1.5 ; middle toe and claw 1.25 ; hind toe and claw $1 \cdot 1$.

Female. Of inferior size to the male, and having the wattles of a somewhat lighter colour.

Young. Has the colours of the adult, but with the tints duller and no sheen or gloss on the plumage; the wattles extremely small and of a pale yellow colour.

Obs. In the Natural-History Museum of the Jardin des Plantes, in Paris, I observed an adult specimen in partial albino plumage; and in the Canterbury Museum there is an example with a single white feather on the brcast.

THIS bird derives its popular name from a peculiarity in the distribution of its two strongly contrasted colours, black and ferruginous, the latter of which covers the back, forms a sharply defined margin across the shoulders, and sweeps over the wings in a manner suggestive of saddle-flaps. The colours, in the male bird especially, are of so decided a kind as to attract special attention, to say nothing of the loud notes and eccentric habits of this remarkable bird. The bill is strong, sharply cut, and wedge-shaped, being well adapted for digging into decaying vegetable matter in search of larvæ, grubs, and insects, on which this species largely subsists. Berries, tender buds, and other vegetable substances likewise contribute to its support. From the angle of the mouth on each side there hangs a fleshy wattle, or caruncle, shaped like a cucumber-seed, and of a changeable bright yellow colour. The wings are short and feeble, and the flight of the bird, though rapid, is very laboured, and always confined to a short distance. 


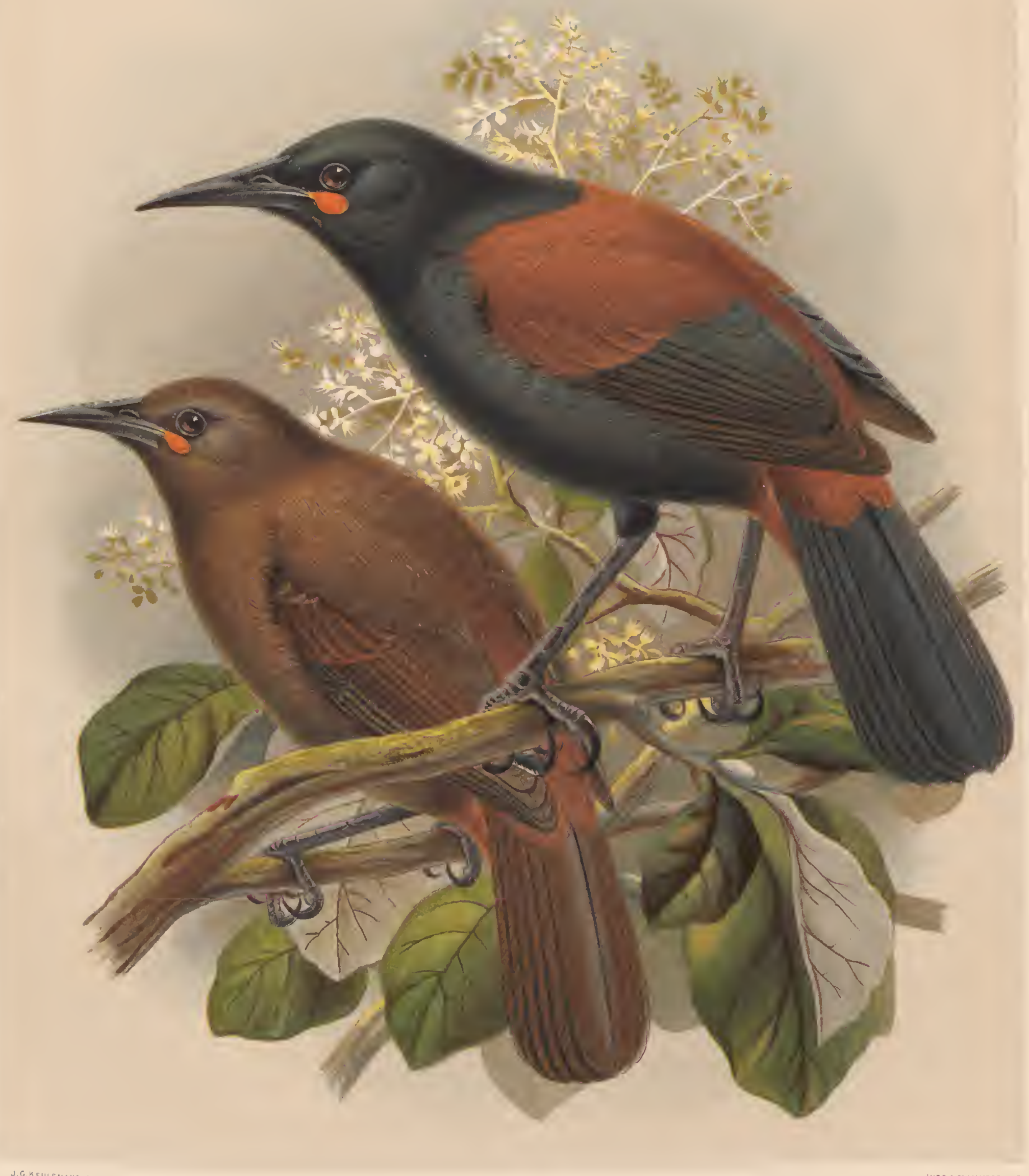

JACK - B IR D

CREADION CINEREUS
SADDLE - BACK

CREADION CARUNCULATUS 

[The range of this species extends as far north as the Lower Waikato, beyond which district it is only rarely met with. It is numerous in the wooded ranges between Waikato Heads and Raglan, and is occasionally found in the neighbourhood of the Hunua coal-fields; but I have never heard of its occurrence in the Tauranga district, on the cast coast, although I have an excellent ornithological correspondent there. In the summer of $1852 \mathrm{I}$ obtained a pair at the Kaipara; but the bird was decidedly a rara avis, fow of the natives in that part of the country being familiar with it. Captain G. Mair met with it once at Kaitaia, near the North Cape, and he afterwards saw a pair in the Maungatapcre bush, near Whangarci. These are the only instances I can give of its occurrence on the mainland north of Auckland; but, strange to say, it is very plentiful on the Barrier Islands, in the Gulf of Hauraki. Mr. Layard was the first to notice its existence there, having shot a specimen on the Little Barrier, which he visited, in company with Sir George Grey, in 1863. He speaks of it (Ibis, 1863, p. 244) as "an apparently very rare bird ;" but Captain Hutton, who visited these islands in Deccmber 1867, found it on both the Great and Little Barrier, and "very common" on the latter*. It is comparatively abundant in the wooded hills in the vicinity of Wellington and in those skirting the Tararua and Ruahine ranges; and it occurs also, and more plentifully, in many parts of the South Island.]

This species, formerly comparatively plentiful but now extremely scarce in the North Island, is very irregular in its distribution. In my first edition I endeavoured as above (within the brackets) to describe its range; but I omitted to mention that in one locality north of Auckland-a small wood at Kaitaia called Mauteringi, some three or four miles in extcnt-this bird was plentiful, although rarely evcr met with in other parts of that district. Although never seen in the Bay of Plcnty woods, it was, till within the last fcw ycars, numerous enough in the Ngatiporou country, where the natives were accustomed to regard it also as a bird of omen. A war-party hearing the cry of the Tieke to the right of their path would count it an omen of victory, but to the left a signal of evil. It is also the mythical bird that is supposed to guard the ancient treasures of the Maoris. The relics of the Whanauapanui tribe-mere pounamus and other heir-looms of great antiquity and value-are hidden away in the hollow of a trce at Cape Runaway, and it is popularly believed that the Tieke keeps guard over these lost treasures. According to Maori tradition, among these hidden things is a stone atua, which possessed at one time the power of moving from place to place of its own accord, but has since become inactive.

At the present time it is morc plentiful on the Hen (a little wooded islet in the Hauraki Gulf) than anywhere else, a fact which may be attributable to the absence of wild cats; for on the Barrier Islands, where the cat lias obtained a footing, this bird is nearly exterminated. On the Hcn, according to Mr. Reischek, it is actually increasing in numbers. During his earlier visits they wcre only to be met witl on the west and north-wcst sides of the island; on his last visit, after a lapse of only four years, they were to be heard and seen everywhere, being indeed the commonest bird on the island. They appeared to be of all ages; but neither here nor on the mainland did he ever meet with Creadion cinereus, which appears to be strictly confined to the South Island, where both species commingle.

The natives state that this species usually places its nest in the hollow of a tree, and they point to holes in well-known trees where the Tiekc has reared its young for many years in succession. A pair is said to be still breeding in the hollow of the famous tree at Omaruteangi, known all over the country as "Putatieke" $\dagger$. The bird is accordingly regarded with some degree of superstitious

* Trans. New-Zealand Inst. 1868, vol. i. p. 160.

+ Putatieke : a renowned hinau tree in the Urewera country. It is supposed to possess miraculons attributes. Sterile women visit it for the purpose of inducing conception. They elasp the treo with their arms, and repeat certain ineantations by way of invoking the atua. 
reverence by the Arawa, who will not allow it to be wilfully destroyed. Those who have read Maori history will be familiar with the story of Ngatoroirangi and his sacred Tiekes of Cuvier Island. Hence the proverb, "Manu mohio kei Reponga," commonly applied to a man wise in council, and used in the sense of our own proverbial saying "Old birds are not to be caught with chaff."

Dr. Hector has informed me of a peculiarity in the habits of this species as observed by him in Otago. It is accustomed to follow the flocks of Clitonyx ochrocephala through the bush; but for what purpose it is difficult to imagine. Wherever he saw a flock of Yellow-heads there was invariably one of thcse Saddlc-backs in attendance, mingling freely with them and, as it were, exercising a general supervision over the flock. He assures me that, during many months' residence in the woods, he had almost daily opportunities of verifying his observations regarding this very curious fact.

Active in all its movements, it seldom remains more than a few seconds in one position, but darts through the branches or climbs the boles of the trees, performing the ascent by a succession of nimble hops, and often spirally. It is naturally a noisy bird, and when excited or alarmed becomes very clamorous, hurrying through the woods with crics of "tiaki-rere," or a note like cheep-te-te, quickly repeatcd several times. At other times it has a scale of short flute-notes, clear and musical; but the most remarkable exhibition of its vocal powers takcs place during the breeding-season, when the male performs to his mate in a soft strain of exquisite swcetness. This lovc-song is heard only on a near approach, and it is at first difficult to believe that so clamorous a bird could be capable of such tender strains.

When fecding its young the fcmale has a diffcrent cry-a low, musical whistle, repeated once or twice. When the nest is invaded, or the safety of the young threatencd, the male bird becomes very excited and utters his shrill cry with renerved energy and with quicker repetition.

The Plate represents the bird on a flowering branch of the pukapuka (Brachyglottis repanda); and I may here mention that in this and some other instances Mr. Keulemans has availed himself of my son's drawings of the New-Zealand flora.

Professor Hutton discovered the nest of this species on the Little Barrier Island. It was situated about two feet down the hollow stem of a dead trce-fern that had been broken off at the top, and from which he saw a Saddle-back emerge. The nest was roughly composed of stems of IIymenophyllum and dead fibres of nikau (Areca sapida), and lined with the fine papery bark of the Leptospermum; and it contained threc cggs, which, at the time they were found (December 27 th), had been slightly sat upon. One of these specimens was kindly forwardcd to me and is now in the Colonial Museum; it measures 1.4 inch in length by 1 in breadth, and is white, marked and spotted, especially at the thicker end, with purplish brown of different shades.

An cgg more recently received by the Canterbury Museum, from the West Coast, is of a rather elliptical form, mcasuring 1.2 inch in length by 85 of an inch in its greatcst width. It is of a delicate purplish grey, becoming lighter at the smaller end, and marked all over the surface, but more thickly at the larger end, with points, spots, and blotches of dark purple and brown.

I was informed by an intclligent Maori at Wcllington that this bird is accustomed to repair, for many successive seasons, to the cavity in which it has once reared its brood, and that, although the numbcr of eggs is gcnerally three, he has occasionally found a nest containing four. 


\section{CREADION CINEREUS.}

(JACK-BIRD.)

Creadion carunculatus (var.), Dieff. Repor't to N.-Z. Comp. (1844).

Creadion camenculatus (juv.), Hombr. \& Jacq. Voy. Pôle Sud, Zool. iii. p. 12, fig. 4 (1853).

Creadion cinereus, Buller, Essay N.-Z. Orn. p. 10 (1865).

Creadion carunculatus (juv.), Finsch, Journ. f. Orn. 1867, p. 343 ; Hutton, Cat. of B. of N. Z. 1871, p. 17 ; Buller, Birds of N. Z. p. 149 (1873).

\section{Native name.-Tieke.}

Ad. cinerasccnti-brunneus, subtùs pallidior: scapularibus alisque umbrino lavatis: supracaudalibus et subcaudalibus læctè rufescentibus : tectricibus alarum minimis rufo maculatis.

Adult. The cntire plumage dark cinereous brown, paler on the underparts, and tinged with umber-brown on the wings and scapulars; the tips of the small wing-coverts and the entire upper and lower tail-coverts bright rufous.

Young. May be distinguished by the extreme smallness of the caruncles.

Obs. Individuals vary in the general tonc of the plumage, some being greyish and others more strongly suffused with brown; the extent of the rufous markings on the wing-coverts is likewise variable, and in some examples they are entirely absent.

Mr. Potts has published * some interesting notes on six spccimens in the Canterbury Museum, all in the plumage of Creadion cinerens, for the purpose of showing "how much variation may be met with in the young state of C. carunculatus." He admits, however, that these supposed young birds wcre "procured at different seasons of the year," which he accounts for on the supposition of an "cxtcnded brceding-scason," or "that the adult state is not arrived at till the second year:" It will be seen from what follows that this view is untenablc.

Ir my 'Essay on the Ornithology of New Zealand,' published by command in 1865, I characterized and named what appeared to me then a new species of Creadion in the following terms:- "This species is of the size and general form of $C$. carnunculatus, to which it bears a close affinity; but the colouring of the plumage is altogether different. The common species (the 'Saddle-back') is of a deep uniform black, relieved by a band of rufous brown, which occupies the whole of the back, and, forming a sharp outline across the shoulders, sweeps over the wing-coverts in a broad curve. In the present bird, horvever, the plumage is of a dark cinereous brown, paler on the underparts, and tinted with umber on the wings and scapularies; the upper and lower tail-coverts, and a few spots on the smaller wing-coverts, bright rufous. The wattles are of the same colour and shape as in Creadion carunculatus, but somewhat smaller."

My new species was at once attacked by Dr. Otto Finsch, who declared his belief that it was the young of Creadion carunculatus. Subsequently, in a paper which appeared in the 'Transactions of the New-Zealand Institute' (vol. v. p. 208), Dr. Finsch expressed his satisfaction that "Captain

* ' Out in the Open,' pp. 202, 203. 
Hutton's examination of the types" had "shown C. cinereus to be undoubtedly the young of the above-namcd species." In my reply (l.c. vol. vi. p. 116) I explained that an examination by myself of a fine series of specimens in the Canterbury Museum*, showing what appeared to be transitional changes of plumage, had forccd me to this conclusion, and that I had communicatcd the result to Captain Hutton long before the appearance of his 'Catalogue.' I was careful, neverthelcss, to add the following qualifying passage:- "I confess, however, that the subject is still beset with some difficulty in my own mind. Supposing the plumage of $C$. cinereus to be the first year's dress of C. carunculatus, it seems to mc quite inexplicablc that the bird has ncver been met with in that state in the North Island. Captain Hutton suggests that this is due to the comparative scarcity of the species at the North. But during sevcral years' residence in the province of Wellington I obtained probably upwards of fifty specimens, at various times, without ever detecting any sign of this immature condition of plumage. Admitting the comparative scarcity of the species, one would naturally suppose that the younger birds would be more likely to fall into the collector's hands than the fully adult ones. It may be suggested whether the condition of the Canterbury-Museum specimens has not possibly resulted from intercrossing; for we have not heard of any further examples of the kind being obtained. At any rate, till a specimen in the supposed immature dress has actually been taken in the North Island, the point cannot, I think, be considered finally set at rest."

The descriptive notes which I had made will be found at page 149 of my former edition, with a statemcnt of the conclusion arrived at. But I then added :- " $\mathrm{Mr}$. Buchanan has observed the so-called C. cinereus in Otago in the summer, and Captain Hutton saw four birds in this plumage near Collingwood in the montl of August; while, in the North Island, I have obtained fully-colourcd specimens of $C$. carunculatus all the year round. It is sufficicntly obvious, therefore, that the formcr cannot be a seasonal state of plumage."

Strange to say, after a lapse of nearly fifteen years, the rcquired evidence is forthcoming, and my Creadion cinereus recovers the specific rank so long denicd to it.

In $1881 \mathrm{Mr}$. A. Rcischek, a very careful observer, wrote to me as follows:- "About Creadion cinereus I have this to state: In December 1877, when I was on the west coast of the South Island, I shot about twenty of both kinds and of both sexes. What were supposed to be the young of C. carunculatus (your Creadion cinereus) I found on dissection to be fully adult birds, both malc and female. My obscrvations on this point were perfectly reliable. In December $1880 \mathrm{I}$ stayed on the Hen (an island in the Hauraki Gulf) three weeks, and shot about thirty spccimens of Creadion carunculatus, all of them being in the common saddle-back plumage. I could only determine the sex in each case by dissection, and what appcared to bc the young birds differed only firom the adult in having the wattles smaller and lighter in colour. I roamed over the whole island during my stay there, and never saw a bird in the plumage of your Creadion cinereus."

In 1882, and again in the early part of 1884, this naturalist re-visited the Hen, and on both occasions remained there a considerable time exploring every part of the island and collecting its productions. During his last visit he saw probably forty or more birds, all in the plumage of C. carunculatus, and collected many specimens of both sexes and all ages. On the Little Barrier he found the species scarce, and obtained only two specimens; while on the Chickens and Island of Kawau he did not mect with the bird at all. In some which he dissected the testes were almost microscopic, the only external differences between these and the old birds being that the plumage

* This scries consists of four birds, all obtained in onc locality :-No. 1 is in the plumage of Creadion cinereus, as deseribed abovo: No. 2 presents a fow blaek tonehes on the head and nock: No. 3 has some new blaek feathers betwcen the crura of the lower mandible, also on the sides of the head and along the cdges of the wings; the upper wing-coverts bright ferruginous; the half-grown new secondaries and tail-fcathers perfectly black, the back and rump presenting indications of change: No. 4 is in the plumage of C.curunculatus, as described at page 18 . 
was not so glossy, and the wattles not so large or bright. In the adult male these ornamental appendages are of a beautiful orange colour, and in the adult female a little lighter. In the young birds they are still lighter and extremely minute.

To place the matter, however, beyond all doubt, he found, on the occasion of his last visit (on the 14th February), two adult birds feeding a young one, and was successful enough to secure all three birds, whieh he carefully preserved and marked. He was loth to part with these speeimens; but, to enable me to demonstrate the specifie value of Creadion cinereus, he handed all three birds over to me (marked respectively male, female, and young), and they are now in my collection.

In $1859 \mathrm{I}$ found this species very abundant in the woods on Banks' Peninsula; but it has long since disappeared before the advancing tide of European settlement. It is still, however, comparatively plentiful on the western and south-western portions of the South Island.

Its habits are precisely similar to those of Creadion carunculatus, already described; and its mode of reproduction is the same*.

It has become the habit to speak of this bird as the Brown Saddle-back; but this is a misnomer, inasmueh as the absence of the "saddle" is its distinguishing feature. I have accordingly adopted the name of Jack-bird, by whieh it is known among the settlers in the South Island. Why it should be so called I cannot say, unless this is an adaptation of the native name "Tieke," the same word being the equivalent, in the Maori vernaeular, of our "Jack."

That the two speeies occasionally interbreed is, I think, suffieiently evident from the specimens in so-called transitional plumage, in the Canterbury Museum, already specially mentioned. This is known to oceur pretty often with the two allied speeies of Fan-tailed Flycatcher (Rhipidura flabcllifera and $R$. fuliginosa) in the South Island, and, as there is every reason to believe, likewise in the ease of our two species of Oyster-eateher, in both islands.

Under the head of Sturnidx, Mr. G. R. Gray, in his 'List of the Birds of New Zealand,' published in 1862, included the genus Aplonis, with two species, A. zealandicus and A. obscurus. In my former edition, I omitted these birds altogether, as I had been unable to obtain any satisfactory evidenee of their oceurrenee in New Zealand. In my 'Manual of the Birds of New Zealand' (published in 1882) I admitted Aplonis zealandicus on the authority of Dr. Finsch, who wrote:"This is aul excellent and typieal speeies, which $I$ had the pleasure of seeing in the Leiden Museum, being one of the typical specimens brought home by the 'Astrolabe' Expedition. Dr. Hartlaub informs me that there are three specimens in the Museum in Paris, all marked 'Tasman's Bay, New Zealand,' and eolleeted by the French travellers." Further investigation, however, has satisfied me that it has no elaim whatever to a place in the New-Zealand avifauna.

Last year I visited the Museum of the Jardin des Plantes in Paris for the express purpose of examining the type specimens referred to by Dr. Finsch; and, through the courtesy of Dr. Oustalet, the officer in eharge of the Ornithological department, I had an opportunity of thoroughly investigating the subject.

* "For its nesting-place a hollow or decayed tree is usually selected; sometimes the top of a tree-fern is preferred. We found a nest in a dead trec-fern not far from Lake Mapourika, Westland. This was of slight construction, built principally of fern-roots, deeply woren into rather a deep-shaped nest with thin walls; for as the structure just filled the hollow top of the tree-fern, thick walls were unnecessary. Another ncst, in a small-sized decajed tree in tho Okarita bush, was in a holc not more than three feet from the ground. It was roughly constructed, principally of fibres and midribs of decayed leaves of the kickie, with a few tufts of moss, lcaves of rimu, lined with moss and down of trec-ferns; and it mcasured across, from outside to ontside of wall, 12 inches 6 lines, carity 3 inches diameter, depth of carity 2 inches. The egg, measuring nearly 1 inch 4 lines through the axis with a breadth of $11_{2}^{1}$ lines, sprinkled over with faint purplish marks, towards the broad end brownish purple, almost forming one large blotch."-Out in the Open, p. 202. 
There are two specimens in the mounted collection, from the voyage of the 'Astrolabe,' labelled Aplonis zealandicus, Quoy \& Gaim., but without any habitat being assigned to them, the words "New Zealand" on the label liaring been crossed out. On referring to the original entry in MM. Quoy and Gaimard's catalogue of the 'Astrolabe' collection, I found the following note under the No. relating to this species_ "Vani koro (New Hebrides) et New Zealand." There seems to be no other authority than this for considering it a New-Zealand bird; and I have no doubt, in my own mind, that the true home of the species is in the New Hebrides, the addition of "New Zealand" being merely a mistake in the entry, especially as there is no locality named. It is not the kind of bird that would rapidly become extinct; and if the French travellers had met with it during their casual visit to New Zealand, it is fair to assume that the species would have been known to the inhabitants of the country. The specimen in the Leiden Museum being simply a duplicate from this collection, the same remarks apply to that also. For these reasons I again reject Aplonis zealandicus as a New-Zealand form; but as one species occurs on Norfolk Island and possibly another on Lord Howe's Island-within what is in reality the New-Zealand zoo-geographical region, although not within the scope of the present work-and as the claims of Aplonis zealandicus may again come up for discussion, I think it may be useful to place on record a full description of the species; and as there is much confusion in the nomenclature of this and the closely allied forms from Polynesia and Australia, I will add the result of my recent examination and identification of specimens both at Paris and in the British Museum.

As to the species itself being a good and valid one, I agree with Dr. Finsch, for although closely related to the other members of this confused group, the bright rufous colouring on its upper parts makes it readily distinguishable.

According to the views propounded by Mr. A. R. Wallace in his 'Geographical Distribution of Animals,' and now generally accepted, Norfolk Island, Phillip Island (or the Nepean group), Lord Howe's Island, and the Kermadec Isles represent the minimum extension to the northward of a continental area perhaps exceeding that of Australia in extent, of which New Zealand in ancient times formed a part. The existence at the present day, or till within a very recent date, of a species of Kaka Parrot (Nestor productus) on Phillip Island, of a form of Weka Rail (Ocydromus sylvestris) on Lord Howe's Island, and of the great brevipennate Rail (Notornis alba) on Norfolk Island, if not on Lord Howe's Island as well, indicates bcyond doubt a former land connection, because it would be manifestly impossible for birds of this kind to traverse a wide extent of ocean. That the separation from each other of these distant habitats, hy the submersion of the intervening land, took place at a very remote period, is sufficiently evident from the extreme specialization of the forms I have mentioned, although undoubtedly referable to the generalized New-Zealand types. From this point of view, it might be deemed advisable to include the birds inhabiting these various islands in the New-Zealand avifauna, which Mr. Wallace has already practically done by defining the boundaries of the New-Zealand "sub-region." It will be found, however, on a closer examination, that, owing probably to accidental transportation and occasional immigration of individuals, over a long period of time, the avifaunæ of these islands hare acquired features more in common with Australia than New Zealand. This very instance, indeed, of the existence in Norfolk Island of Aplonis fuscus (although not mentioned by Wallace) betrays this fortuitous relation, if I may so term it, of its ornis to that of Australia and of Central Polynesia. I have therefore decided to confine myself, in the present work, to the islands which come within the political limits or jurisdiction of New Zealand, namely, the Chatham Islands on the east, the Auckland Islands, Campbell Island, Macquarie Island, and Antipodes Island on the south and south-east; and I shall only refer incidentally to the occurrence of allied forms in the remote islands to the north in my treatment of our local species. As the number of Plates is necessarily limited, I shall figure only birds that are actually found in New Zealand, but 
I shall be careful to give an illustration of every endemic species. Birds that are common to other countries may or may not be figured, according to the circumstances of each particular case.

Aplonis zealandieus.-Two examples (in Paris) : no sex stated; but one is slightly larger than the other, with the eolours of the plumage a little brighter, and is presumably the male.

ot ad. General plumage rufous-grey, darker on the upper parts and deepening to rufous-brown on the lower part of baek, rump, and upper tail-eoverts ; from the anterior edge of the eye a dull blaek streak extending to the nostrils; the primaries bright rufous on their outer webs only, being blaekish brown on their immer webs; large wing-eoverts and bastard quills bright rufous; tail-feathers dark rufous-brown, with a rieh vinous tinge on their outer edges; underparts lighter, the feathers of the breast and abdomen having obseure, narrow, greyish margins; flanks, vent, and under tail-eoverts rufous-brown, mixed with tawny yellow, the feathers beeoming lighter at the tips. Bill blaekish brown, with a reddish tinge on the under mandible; legs and feet pale brown; elaws yellowish brown. Total length 7.5 ineles; wing, from flexure, 4 ; tail $2 \cdot 5$; litll, along the ridge $\cdot 75$, along the edge of lower mandible $\cdot 75$; tarsus $\cdot 8$; middle toe and elaw 9 .

\& ad. Similar to the male, but with duller plumage, and of somewhat smaller size.

Obs. I am satisfied that A. rufipennis, Layard, from Vaté Island, New Hebrides, deseribed in 'The Ibis,' 1881, p. 542, is this bird, and not Calornis cantoroides as suggested by Canon Tristram.

Alumen Spreirs. Aplonis tabuensis, Gmel. (=A. vitiensis, Layard, = marginatus, Gould,=marginalis, ITartl.,= marginata, Cass., $=$ cassinii, Peale). - More strongly built, and being a lighter-eoloured speeies; only a rufous tinge on the plumage of the upper parts, with a purplish sheen on the liead and neek; an obseure faeial streak; the peetoral feathers with pale shaft-lines, giving a slightly streaky eharaeter to the breast. In young birds the sheen is absent and the peetoral streaks are more eonspieuous. Irides red.-Hab. Tonga group, Savage Island, Friendly Islands, and Fiji. There is a slight differenee observable in speeimens from Tonga and Fiji, but nothing of any speeifie value.

Aplonis fuscus, Gould.-I do not think this form is separable from A. tabuensis. It is slightly browner on the upper parts than speeimens from Tonga, but eannot be distinguished from some Fiji examples of the latter speeies. - Hab. Norfolk Island and Australia.

Aplonis brevirostris, Peale.-This speeies also seems to me seareely separable from A. tabuensis, the only differenees being in its somewhat smaller size, the darker erown, and the less streaky appearanee on the underparts. In all essential respeets the birds are alike. In the 'Hand-list of Birds' (vol. ii. p. 26) Mr. G. R. Gray makes Aplonis custralis, Gould, a synonym of this speeies, bnt I have not seen this type.-Hab. Samoa.

Aplonis nigroviridis, Less.(=A. pacificus, Forst.?,=striatus, Gmel., =obscurus, Dubus, =viridigriseus, G. R.Gr.). -Slaty grey, with a darker head and neek, and a very pereeptible gloss on the plumage, espeeially on the upper surfaee; the faeial streak broader than in A. zealandicus. The young of this speeies has the entire plumage slaty grey, paler and mixed with light brown on the underparts, some speeks of white on the eheeks, and the small wing-eoverts narrowly margined with whitish grey; but even in the young state the faeial streak is quite eonspieuous, having the appearanee of a dull inky stain.-Hab. New Caledonia and Lord Howe's Island.

Aplonis caledonicus, Bp.-Entire plumage blaek and glossy, with green refleetions in eertain lights and purplish on the head and throat. The sexes are alike, exeept that the female has less gloss on the plumage. Prinee Bonaparte's type, marked by lis own hand, is in the Museum at Paris. The British Museum eontains a good number of speeimens, showing very little variation, and all from New Caledonia. .A speeimen marked Aplonis mavornata, but without any referenee, differs from $A$. caledonicus in having the entire plumage diugy brown, without any gloss, the feathers of the underparts narrowly margined with grey. This may prove to be the young of $A$. caledonicus, but no loeality is given.

Aplonis atronitens, G. R. Gray.-This seems to be a good speeies, with a mueh more robust bill than any of the preeeding, and having the entire plumage brownish blaek, with little or no gloss on the surface. The single speeimen in the British Muscum was obtained by Sir George Grey from the Loyalty Islands. 


\title{
TURNAGRA HECTORI.
}

\author{
(NORTH-ISLAND THRUSH.)
}

Otagon tanagra, Schl. Ned. Tijdschr. Dierk. iii. p. 190 (1865).

Turnagra hectori, Buller, Ibis, 1869, p. 39.

Turnagra tanagra, Gray, Hand-l. of B. i. p. 284 (1869).

Keropia tanagra, Finsch, J. f. O. 1870, p. 323.

\section{Native names.}

Piopio, Koropio, Korohea, and Tiutiukata.

Ad. statura T. crassirostris sed rostro crassiore, suprà olivaseenti-brunneus : pileo nusquam striolato: uropygio caudâque elare rufis : gutture albo: peetore superiore einerascente : abdomine medio albo, parte imâ et subeaudalibus conspieuè flavieantibus : hypoehondriis olivascentibus : rostro et pedibus saturatè brunneis : iridè flavâ.

Adult. Crown of the head, hind neek, and upper parts generally elear olive-brown; throat pure white ; breast and abdomen ashy grey, darker on the former, the abdomen and the under tail-eoverts tinged with yellow; sides olive-brown, washed with yellow; wing-feathers dark olive-brown, dusky on their inner webs; tailfeathers and their upper eoverts bright rufous, paler on their under surfaee, the two middle ones tinged above witlı olive-brown. Irides yellow; bill and feet dark brown. Total length 11 inches; wing, from flexure, 5.25 ; tail 5 ; bill, along the ridge $\cdot 8$, along the edge of lower mandible 1 ; tarsus 1.25 ; middle toe and elaw $1 \cdot 25$; hind toe and elaw 1.

Young. Birds of the first year differ in having the feathers at the base of the upper mandible, the tips of those eovering the erown and sides of the head, the small feathers fringing the eyelids, and a broad zone on the upper part of the breast bright rufous; the primary and secondary wing-eoverts, and sometimes the secondary quills, are also largely tipped with the same eolour, and the grey of the underparts is darker, but with a tinge of orange-yellow under the wings.

IN January 1869 I communicated to 'The Ibis' the description of a new species of Thrush inhabiting the North Island, and differing from the South-Island bird (Turnagra crassirostris) not only in plumage, but in its superior size and more strongly developed bill ; and I named it in compliment to my friend Dr. (now Sir) James Hector, F.R.S., Director of the Colonial Museum and Geological Survey of New Zealand.

In an editorial footnote to my paper, Professor Newton suggested that this species might be identical with one described, in a Dutch work, by Professor Schlegel, four years before, without, however, any habitat being assigned to it. This opinion has since been verified by a careful comparison of the specimen I have figured with the type of Schlegel's Otagon tanagra in the Museum at Vienna; and under ordinary circumstances the name I have proposed would of course be reduced to a synonym. It will be observed, however, that Professor Schlegel has used a common generic name to distinguish the bird specifically, while he refers the form to the genus Otagon, established by Bonaparte in 1850. As I can see no valid reason for setting aside the generic title of Turnagra 


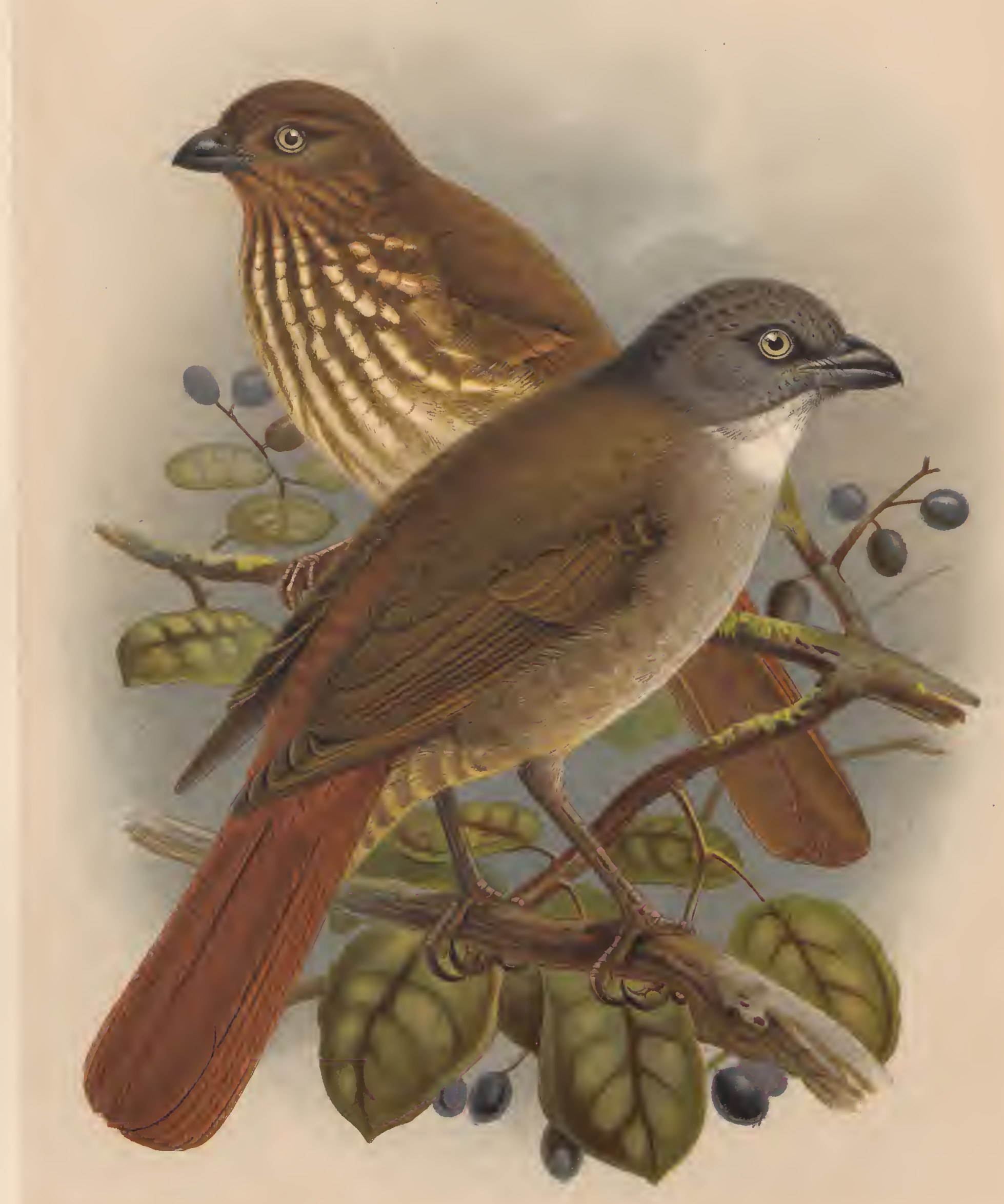



proposed by Lesson as early as $\mathbf{1 8 3 7}$, and as the adoption of the older specific name would, according to this view, give the confused result of Turnagra tanagra, I have deemed myself justified in retaining the distinctive appellation of $T$. hectori. At the same time I am anxious to give due prominence to the fact that Professor Schlegel was the first to discovcr the existence of this new spccies.

There is a peculiar charm about the New-Zealand forest in the early morning; for shortly after daylight a number of birds of various kinds join their voices in a wild jubilee of soug, which, generally speaking, is of very short duration. This was the morning concert to which Captain Cook referred in such terms of enthusiasm; and the woods of Qucen Charlotte's Sound, where his ship lay at anchor, are no exception to the gcneral rule. In illustration of this, I take the following from an entry in one of my note-books:- "Tuesday, 5 A.M.-At this moment the wooded valley of the Mangaone, in which we have been camped for the night, is ringing witl delightful music. It is somewhat difficult to distinguish the performers amidst the gcneral chorus of voices. The silvery notes of the Bell-bird, the bolder song of the Tui, the loud continuous strain of the native Robin, the joyous chirping of a flock of White-heads, and the whistling cry of the Piopio-all these voices of the forest arc blended together in wild harmony. And the music is occasionally varied by the harsh scream of a Kaka passing overhead, or the noisy chattering of a pair of Parrakects on a neighbouring trce, and at regular intervals the far-off cry of the Long-tailed Cuckoo and the whistling call of its bronze-winged congener; while on every hand may be heard the soft trilling notes of Myiomoirc toitoi." For more than an hour after this concert had ceased, and the sylvan choristers had dispersed in search of their daily food, onc species continued to enliven the valley with his musical notes. This bird was the Piopio, or' New-Zealand Thrush, the subject of the present article, and unquestionably the best of our native songsters. His song consists of five distinct bars, cach of which is repeated six or seven times in succession; but he oftcn stops abruptly in his overture to introduce a variety of other notes, one of which is a peculiar rattling sound, accompanied by a spreading of the tail, and apparently expressive of ecstacy. Some of the notes are scarcely distinguishable from those of the Yellow-head; and I am inclined to think that the bird is endowed with mocking-powers. The ordinary note, however, of the Piopio, whence it derives its name, is a short, sharp, whistling cry, quickly repeated.

It was when I obtained a caged Piopio that I first became acquainted with its superior vocal powers. In $1866 \mathrm{I}$ purchased one for a guinea from a settler in Wellington, in whose possession it had been for a whole year. Although an adult bird when taken, it appeared to have become perfectly reconciled to confinement; but on being placed in a new cage it made strenuous assaults on the wire bars, and persevered till the feathers surrounding its beak were rubbed off and a raw wound exposed. It then desisted for several days; but when the abraded part had fairly healed, it renewed the attempt, and with such determined effort that the fore part of the head was completcly disfigured, and the lifc of the bird endangered. On beiug removed, however, to a spacious compartment of the aviary, it immediately became reconciled to its condition, madc no further efforts to escape, and for a period of fifteen months (when it came to an untimely end) it continued to exhibit the contentment and sprightliness of a bird in a state of nature.

I observed that this bird was always most lively during or immediately preceding a shower of rain. He often astonished me with the power and variety of lis notes. Commencing sometimes with the loud strains of the Thrush, he would suddenly change his song to a low flute-note of exquisite sweetness; and then abruptly stopping, would give vent to a loud rasping cry, as if mimicking a pair of Australian Magpies confined in the same aviary. During the early morning he emitted at intervals a short flute-note, and when alarmed or startled uttered a sharp repeated whistle.

This caged bird was generally fed on dry pulse or grain; but he also evinced a great liking for cooked potato and raw meat of all kinds; in fact he appeared to be omnivorous, readily devouring 
earthworms, inseets of all kinds, fruits, berries, green herbs, \&c. He was supplied daily with a dish of fresh water, and was aceustomed to bathe in it with evident delight. At one time he occupied the same division of the aviary with a pair of Australian Ring-Doves which had eommenced to breed. The Doves were allowed to bring up their first brood in peace; but when the hen bird began to build a seeond time, she was closely watehed by the Piopio, and immediately the first egg was deposited he darted upon the nest and devoured it. The innocent little Ring-Dove continued to lay on in spite of repeated robbery, and had at length to be plaeed beyond the reaeh of her persecutor. During the day the Piopio was uneeasingly aetive and lively; at night he slept on a pereh, resting on one leg, and with the plumage puffed out into the form of a perfectly round balk, the eircular outline broken only by the projeeting extremities of the wings and tail. Every sound seemed to attraet his notice, and he betrayed an inquisitiveness of disposition which in the end proved fatal ; for having inserted his prying head through an open chink in the partition, it was seized and torn off by a vicious Sparrow-Hawk in the adjoining compartment of the aviary.

In the wild state this speeies subsists chiefly on insects, worms, and berries. I have shot it on the ground in the act of grubbing with its bill among the dry leaves and other forest débris. Its flight is short and rapid. It haunts the undergrowth of the forest, darting from tree to tree, and oceasionally descending to the ground, but rarely performing any long passage on the wing. It is very nimble in its movements; and when attempting on one occasion to cateh one of these birds with an almost invisible horsehair noose, it repeatedly darted right through the snare, and defeated every effort to entrap it.

In my former edition of this work I stated that the Piopio was at that time eomparatively common in all suitable loealities throughout the southern portion of the North Island, but was extremely rare in the country north of Waikato. I mentioned also that a speeimen whieh I shot in the Kaipara distriet in the summer of 1852 (doubtless a straggler from the south) was quite a novelty to the natives in that part of the country; that it was reeognized, however, by an old Maori, who ealled it a "Korohea," a name quite unknown in the south, and who stated that in former years it was very abundant in all the woods. I ventured then to express a belief that the bird whose biography I had undertaken to write would soon be equally scarce elsewhere. And so it has proved, for the North-Island Piopio is now one of our rarest speeies, and is eertainly doomed to extinction within a very few years.

In the Bay of Plenty district it has never been heard of since the time of Hongi's famous invasion (about the year 1820). A little wooded spur near Te Puke settlement, behind Maketu, frequented by a pair of these birds at that troublous period has ever sinee borne the name of Piopiorua ; and to the present day the old men talk of the ominous appearance in their district of this " manu aitua" at the time that the bloodthirsty warrior landed in his war-canoes and spread terror and destruetion with his newly aequired firearms*.

The last aceessible plaee in whieh I met with it was Horokiwi, about 25 miles from Wellington.

* Captain Mair, who took a prominent part throughout the late Maori War, and finally won the New-Zealand Cross by his gallant conduct at Ohinemutu, informs me that on one occasion, when in closo pursuit of Te Kooti and his followers in the Urewera country, he unexpectedly eame npon a pair of these birds in the bush, and, at the risk of scaring his nobler game, could not resist the temptation of shooting both specimens of so rare a species. This was at a place betweon tho Whalatane and Rangitaiki rivers. During very many years spent in the Bay of Plenty he has never seen or heard of the Piopio in that distriet or in the Rotorua country; but he once heard its unmistakable note in some low bush at the northern end of Lake Taupo. In February 1880 he shot a pair at Taumarunui, near the jumetion of the Wanganui river with the Ongarue in the Tuhna country, at a point about 250 miles by the river from the town of Wanganui. This pair had been known to the natives as inhabiting that partieular locality for several years. In the hope of securing them he travelled more than fifteen miles through the bush. He found them perfeetly tame, answering his call and hopping round him, apparently quite heedless of his presence; but his efforts to ensuare them were all in rain, the bird always darting through the loop and escaping. 
This was some twenty years ago-when riding through this lovely wooded valley-at a time when the road passed through the primitive forest, all untouched by the hand of man, disclosing to the eye ncw beauties at every turn as it followed the course of a tortuous mountain-stream. From the timc of my first visit up to the present (and I have passed through the valley hundreds of times) I havc never tired of this beautiful sylvan scenery; but at the period I speak of the bush was an almost impcrious tangle, the lowcr tree-tops bound together with kareao and other creeping plants, and the trees themselves laden with a ricli epiphytic growth. Even now it is a delightfully refreshing rcsort. The tawa rears its fcathery branches of soft palc green, and beside it rises, like a sentinel, the cone-shaped top of the darker Knightia excelsa; the bright green of the rimu with its graceful, drooping boughs, is everywhere present; and, as the eye scans the scene more closely, almost every tree common to the Ncw-Zealand bush may be readily distinguished, all growing in rank profusion, plentifully sprinkled with the star-like crowns of giant trec-ferns, varied here and there witl the bending palm-like top of the nikan (Areca sapida), its huge stem springing up from the shady depths of the uneven forest-the whole presenting a bcautiful picture, in ever varying tints, and almost subtropical in the luxuriance of its growth. In this valley there are yet somc matchless groups of Cyathea medullaris and other tree-ferns; but the hand of civilization is upon the wilderness, the virgin forest is receding more and more, the axe of the woodman is incessant, and the bushman's fire is doing cvery season its further work of devastation. A few ycars hence, and the sylvan beauty of Horokiwi with all its swect memories will have passed away for cver!

One peculiarity about this species is its derotion to some particular locality, beyond which it nercr wanders very far. Mr. C. Field, a Government surveyor, who has spent the best part of his life in the woods, writes to me:- "I have seen the bird in the same spot year after year, and generally in pairs, exccpt when the hen is nesting. To my certain knowledge a pair of them have kept to the same locality, on a valley flat by the side of a stream, for a pcriod of scven or eight years." My last fresh spccimens (two males and one female prcserved in spirit) werc received in January 1884, from this gentleman, who obtained them far up the wooded valley of the Pourewa on the west coast, wherc he was conducting a trigonometrical survcy. A year latcr a skin was sent in by Mr. Tone, another Govcrnment surveyor, who was employed on the east coast, and who informed me that the bird was still to be met with in the woods at Akitio.

A pair has been known to frcquent for several seasons a spot on the westcrn side of the Rangataua lake, near the source of the Mangawhero river, at the foot of the Ruapehu mountain. A correspondent who visited the place in the summcr of $18 S 0$ was informed by the resident natives that the birds had always nested there. He could hcar their musical song from his camp across the lake, and on going over he found the old birds in a maire tree, but could see nothing of the young brood. They were very tamc and fearless, and on his simulating their notcs they readily camc to the ground and hopped about, scratching the surface and turning over the lcaves as if in search of insects.

It shows how rare the bird has become when its habitat is thus localized. Indeed, it has already cntirely disappeared from a tract of country where in former years it was specially abundant. In proof of this, I may inention the expcrience of Mr. Morgan Carkeek, who in 1884, at the instance of the Public Works Departmcnt, made a careful exploration of the Mokau-Wanganui district. Starting from the foot of Mount Egmont he followed down the Patca river, then up the north-cast branches of this and the Wanganui rivers, crosscd the watershed, and followed up the north-wcst branches of the latter into the Tuhua country; and then returned, by a route lying betwecn the Whitc Cliffs and Mokau, to the sea-coast. All the country thus traversed is heavy bush-land and, for the most part, excessivcly rough and broken. During the whole journey, which occupicd about two months, he never oncc saw or heard a Piopio! 
As to its nidification, I may mention that in the Ruahine ranges I met with a breeding-pair of these birds late in December. The sudden disappearance of the female and the eautious demeanour of the male satisfied me that I was in the immediate vicinity of the nest; but I nevertheless failed in my endeavours to find it. The bird resented my intrusion on its sanctum by a peculiar purr, not unlike the alarm-note of the American Cardinal (Cardinalis virginianus), aceompanied by a sudden spreading of the tail.

A native onee described the nest to me as being of large size and eomposed of moss, twigs, and dry leaves. He assured me that he had twiee met with it in the high scrub near the Manawatu river, and that in both eases the nest eontained two eggs. This was many years ago; but that the aceount was reliable may be inferred from the faet, since ascertained, that this description applies very well to that of a closely allied species in the South Island.

Although Tumagra has hitherto been placed among the Turdidæ, the form is admittedly an aberrant one. Dr. Finsch has suggested the propriety of uniting it to Glaucopis, but I do not think this view has met with any acceptance or support. Fortunately I was able to bring with me to England a speeimen in aleohol, which I forwarded to Dr. Gadow, of Cambridge, for anatomical study. After making an autopsy, with his accustomed eare, he writes to me as follows :- "I am sorry to say that the outcome of my investigation regarding Turnagra is not very striking. After all, you are quite right in your suggestions as to its position and affinities. The fact is, we know so little of the anatomy of the many birds belonging to the Timeliidæ that comparison with these forms is almost out of the question. At any rate, it is satisfaetory to know that there are not present any known characters to indicate other affinities, or to negative your suggestions."

Mr. Sharpe has plaeed Turnagra among his Timeliidæ; but I have decided to make it the type of a new family, Turnagridæ, beeause the form seems to differ quite as much from typieal Timelia as it does from Turdus.

As it is important to place on permanent record the results of Dr. Gadow's patient study of the subjeet, I shall here append his report in full, together with his detailed remarks on Glaucopis (referred to on page 4), in order to show that there is no relationship between these two forms, notwithstanding the similarity of some of the external characters:-

"TrRnagrs.-Stomach quadrangular, flattened, very museular. Crop absent. Tongue fleshy, with a few short bristles on the sides near the tip. Intestinal convolutions Thrush-like, certainly not Corvine, with decided graminivorous adaptation. Syrinx museles acromyodean. Pterylosis agrees with Nitzseh's Subulirostres s. Canoræ. Ten primaries; terminal (or first) long ; tip of wing formed by third to seventh; sixth longest. Nine secondaries. Twelve tail-feathors. Metatarsus like that of Thrushes or Sylvixe. Sternum and shoulder-girdle agree with many birds: Struthideu, Graucalus, Strepera, Ptilonor7uynchus, Turdus (i.e. all alike). Conctusion: After examination of the digestive apparatus, the pelvie nerve-plexus, the skeloton, and the pterylosis, I feel inelined to put Tumagra with the wido and ill-defined gronp of Timeliidre. Tumarga is certainly neither Corvine nor Fringilline, and it is in faet a member, of the Southern (Indian-Australian) mass of Thrush-like birds. Its bill and certain modifieations of its digestive apparatus seem to show that this bird is a 77 rush with graminivorous propensities. I would put it into Sharpe's subfamily Ptilonorhynchinx, to which Ailuroclus belongs, but unfortunately Ptilonorhynchus itself is rery different from Timeliida in its pterylosis."

"Gradcopis.-After examination of the skeleton I am satisfied that Glaucopis eomes nearest to the Corvidæ. Tho skull, although in general configuration and beak very similar to that of Struthidec, differs from tho latter. Barring tho peeuliar laerymals, it agrees with Ptilonorlunnclus, also with Strepert, and, more remotely, with Paraclisea. No agreement with Gruucalus. Comparison with Heteralocha and Sturnus is not possible. Skull, consequently, agrees with Ptitonorhynchus and Strepera. Sternum: agrees most with that of Strepera, far Iess with Grancalus, Struthidea, Paralisect. Ptilonorthynchus disagrees in elavieles, like Ireteralocha and Stumus. Pelvis and sacrum: agrees with Graucalus, Heteralocha, and Ptilonorhynchus, also with Strepera, Paratisea, and Struthiclea. Metatarsal scutes: agreo most with IIeteralocha; through the fusing eondition in which the scutes are, very much with Ptilonorhynchus and Gymnorhina. Hyoid bones: Corvidio. Pterylosis: Strepera and Ptilonorhynchus, but the latter has considerably more remiges. Conclusion: Glaucopis is nearly allied to the Austrocoraces. It agrees best with Strepera (Gymnorhininx in general), and shows some considerable similarity in structure with Ptitonorhynchus. Stmethidece agrees with Glaucopis by far less than you might perhaps suppose, and Graucalus is still further removed. Heteralocha is an unmistakablo Starling form, and has littlo of importance in common with Glaucopis." 


\title{
TURNAGRA CRASSIROSTRIS.
}

\author{
(SOUTH-ISLAND THRUSH.)
}

Thick-billed Thrush, Lath. Gen. Syn. ii. pt. 1, p. 34, pl. xxxvii. (1783).

Tanagra capensis, Sparrm. Mus. Carls. pl. 45 (1787).

Turdus crassirostris, Gm. Syst. Nat. i. p. 815 (1788, ex Lath.).

Isanius crassirostris, Cuv. Règn. Anim. p. 338 (1817).

Campephaga ferruginea, Vieill. Nouv. Dict. d'Hist. Nat. x. p. 48 (1817).

Tanagra mucularia, Quoy et Gaim. Voy. de l'Astr. i. p. 186, pl. vii. fig. 1 (1830).

Teropic crassirostris, Gray, List of Gen. of B. p. 28 (1840).

Turnagra crassirostris, id. op. cit. p. 38 (1841).

Loxia turdus, Forst. Descr. Anim. p. 85 (1844).

Otagon turdus, Bonap. Consp. Gen. Av. i. p. 374 (1850).

Ceropia crassirostris, Sundev. Krit. Framst. Mus. Carls. p. 9 (1857).

Turnagra turdus, Gray, Hand-l. of B. i. p. 284 (1869).

Ad. suprà olivaeeo-brunneus, pileo vix cinerascente irregularitcr fulvo striato : tectricibus alarum dorso concoloribus, rufo terminatis, faseiam dupliccm alarem exhibentibus : remigibus brunucis, cxtùs dorsi colore marginatis, primariis ad basin rufo lavatis : supracaudalibus rufo tinctis, imis omuinò rufis : cauclâ latè rufâ, rectricibus duabus mediis ct reliquarum apicibus olivaceo-brunneis : loris cum rcgione oculari genisque brunncis pallidè rufo maculatis: regionc paroticâ pileo concolore, angustè fulvo striatâ: subtùs olivasccils, gutturc toto rufescente lavato, plumis mcdialiter fulveseentibus: pectoris plumis medialiter albidis, utrinque olivaeeo marginatis, quasi striatis: pectore superiore vix rufescente lavato: hypochondriis magis olivascentibus; abdomine imo ct subcaudalibus flavo lavatis : subalaribus rufis : rostro pedibusquc saturatè brunncis : iride flavâ.

-Adult. General plumagc olive-brown, darker on the upper parts; forchead, lores, throat, and sides of neck largely marked with rufous; breast, abdomen, and undcr tail-coverts covered with broad longitudinal spots of yellowish white, narrower towards the sides of the body; on the abdomen and under tail-covcrts less of the olive-brown, with a strong tingc of yellow; wing-feathers dark olive-brown, dusky on their inner webs; the superior and lesscr wing-coverts largely tipped with rufous, forming two broad transverse bars; lining of wings pale rufous; tail, for the most part, with the upper coverts bright rufous, the two middle featlers and the apical margins of the rest olive-brown, only slightly tinged with rufous. Irides yellow; bill and feet dark brown. Total length 11 inches; wing, from flexure, 5 ; tail 5 ; bill, along the ridgc $\cdot 7$, along the edge of lower mandible $\cdot 8$; tarsus $1 \cdot 25$; middle toc and claw $1 \cdot 15$; hind toe and claw 1 .

Young. May be distinguished from the adult by tlic larger amount of rufous colouring on the forehcad, sides of the head, throat, and upper wing-coverts.

Obs. In some specimens the bend of the wing and the cxterior cdges of the outer primaries are also marked with rufous. The colour of the bill likewise varies, in different examples, from a light brown to dusky black.

'THIS fine species is confined to the South Island. Formerly it was excessively abundant in all the elevated wooded country; but of late years it has become comparatively scarce, while in some districts 
it has disappeared altogether. This result is attributable, in a great measure, to the ravages of eats and dogs, to whieh this species, from its ground-feeding habits, falls an easy prey.

Sir James ITeetor informs me that, during his exploration of the West Coast in the years 1862-63, he found it very abundant, and on one oeeasion eounted no less than forty in the immediate vieinity of his eamp. They were very tame, sometimes hopping up to the very door of his tent to piek up crumbs; and he noticed that the camp-dogs were making sad havoc among them. He is of opinion that in a few years this species also will be numbered among the extinct ones.

Mr. Buehanan, of the Geological Survey, assures me that in the woods in the neighbourhood of Dunedin, where it was formerly very common, it has been quite exterminated by the wild cats. It may be here observed that there is no indigenous cat in our country; but ill-fed or ill-used members of the raee, in the struggle for existenee, frequently quit the settlers' houses and betake themselves to the woods, where they, in course of time, produee a purely wild breed. 'To this cause is partly owing the almost entire extermination of the Quail and other ground speeies.

It is worthy of remark that Mr. Burton obtained a speeimen on Stephens Island on the south side of Cook's Strait.

The habits of this bird differ in no respeet, so far as I am aware, from those of its congener in the North Island. The following incident is illustrative of its predaceous nature:-My brother, Mr. Fleteher Buller, while residing in Canterbury, obtained a live one from the woods, and plaeed it in a cage with a pair of tame Parrakeets (Platycercus novce-zealandice). On the following morning he found, to his dismay, that the newly introduced bird had slain both of his fellow prisoners, and was actually engaged in eating off the head of one of them!

There is a nest of this bird in the Canterbury Museum, obtained from the River Waio, County of Westland. It is a round nest, somewhat loosely eonstructed, composed of small, dry twigs, shreds of bark, fragments of moss, \&e., with a rather large cup-shaped cavity, lined with dry grasses and other fibres. To all appearanee it is carelessly, but nevertheless firmly, fixed in the forked twigs of a small upright branch. In the same eollection there is another nest from Lake Mapourika, whieh is formed of soft green moss on a tapering foundation of small twigs, eompletely filling the eruteh of a manuka fork and being fully a foot in depth. Another, formed externally of dry twigs, is of more irregular shape, but is likewise built in a forked braneh as a means of support. The eireular eup is neatly lined with dry bents. Mr. Potts, who studied this bird pretty elosely in Westland, states that the nest is generally found among the thiek foliage of the tutu (Coriaria ruscifolia), but sometimes in karamu or manuka, that it is sometimes finished off with soft tree-fern down as a Jining, and that it usually contains two eggs ; and he is of opinion that the bird breeds twiee in the season. The Museum colleetion eontains four speeimens of the egg, which exhibit eonsiderable differenee in form. Two of them-probably from one nest-are very ovoido-eonical ; one of these measures 1.3 inch by I.05 inch, and is pure white, marked at irregular distances over the entire surface with speeks and roundish spots of blackish brown. The other is slightly narrower in form, the white is not so pure, and the markings are less diffuse, being eolleeted into reddish-brown blotches towards the larger end. The other two eggs (apparently also from one nest) are of a long ovoido-elliptieal form, and of equal size; the one I tested mensuring 1.6 inch in length by .95 of an inch in its widest part. The shell is pure white, with widely-scattered irregular spots of blaekish brown, less numerous and of smaller size in one than in the other. Both eggs have a rather glossy surfaee. 


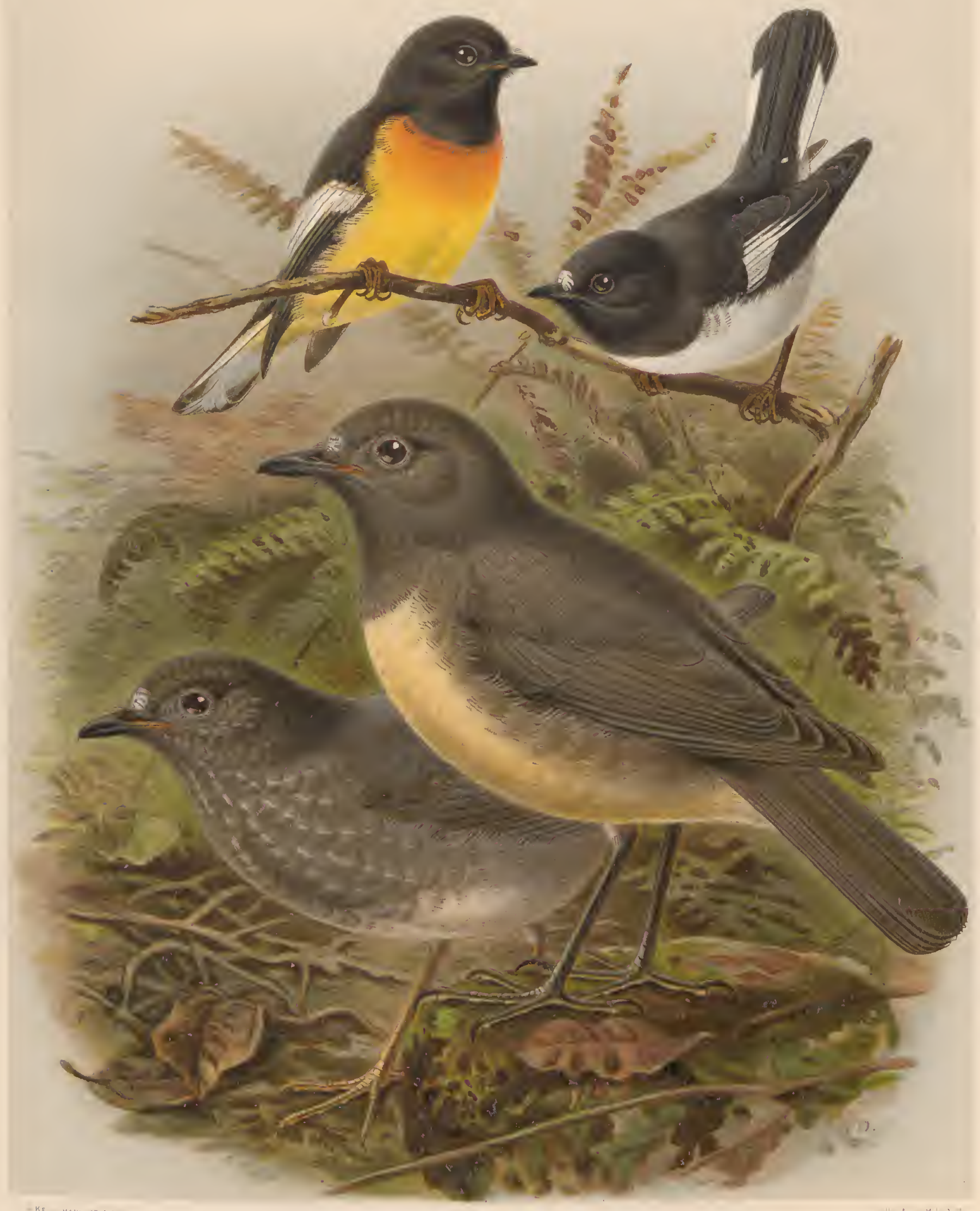

SOUTH-ISLAND TOMTIT

MYIOMOIRA MACROCEPHALA.

NORTH-ISLAND ROBIN
NORTH-ISLAND TOMTIT

MYIOMOIRA TOITOI

SOUTH-ISLAND ROBIN

MIRO ALBIERONS 



\section{I R 0 A US'T R A L IS.}

(NORTH-ISLAND ROBIN.)

Turdus australis, Sparrm. Mus. Carls. iii. pl. 69 (1788).

Muscicapa longipes, Garnot, Voy. Coq. i. p. 594, pl. xix. fig. 1 (1826).

Myiothera nover-zealandice, Less. Man. d'Orn. i. p. 248 (1828).

Miro longipes, Less. Tr. d'Orn. p. 389 (1831).

Petroica australis, Gray, Voy. Ereb. and Terror, p. 7 (1844).

Myioscopus longipes, Reich. Syst. Av. Taf. lxvii. (1850).

Petroica longipes, Gray, Ibis, 1862, p. 223.

Miro longipes, Buller, Birds of New Zealand, 1st ed. p. 119 (1873).

\section{Native names.}

Pitoitoi, Toutou, Toutouwai, and Totoara.

ô saturatè cinercus, scapis plumarum albidis: maculâ frontali albâ: tectricibus alarum dorso concoloribus: rcmigibus brunneis, cxtùs cincreo lavatis : cauda nigricante: facie laterali cincreâ, albido magis distinctè striolatâ : abdomine medio albicante: corporis latcribus cincreis : snbcaudalibus albidis: cruribus cincreis albido terminatis : subalaribus pallidè cincreis : primariis intùs ad basin albidis : rostro nigricanti-brunneo, mandibulâ brunnescentiore: pedibus pallidè brunneis : iride nigrû.

q pallidior: remigibus brunnescentibus : facic laterali cinerascentc, albo striolatâ: pectore superiore pallidè cinerascente, plumis mcdialiter albido striatis : abdomine albido.

Adult male. Head, neck, and all the upper surface dark slaty grey, plumbeous bencath; the shafts of the feathers greyish white, forming rathcr conspicuous lines on the crown and nape; a frontal spot at the base of the upper mandible pure white; rictal bristles black; throat, fore neck, and sides of the body palcr slaty grey ; the lower part of the breast, the middle of the abdomen, the vent, and the under tail-coverts white, blending on the cdges with the darker plumage of the surrounding parts ; wing-feathers dull smoky brown, with lighter shafts; lining of wings and a broad oblique bar on the under surface of all the quills execpt the first three primarics pure whitc; tail-feathers dull smoky brown, the shafts light brown on their upper and white on their under aspect. Irides black; bill blackish brown; tarsi and toes palc yellowish brown; soles dull yellow. Total length 6 inches ; extent of wings $9 \cdot 25$; wing, from flexure, 3.5 ; tail $2 \cdot 65$; bill, along the ridge $\cdot 6$, along the edge of lowcr mandible $\cdot 8$; tarsus $1 \cdot 35$; middle toe and claw $\cdot 95$; hind toc and claw $\cdot 8$.

Female. Slightly smaller than the male and with duller plumage; the upper parts tinged with smoky brown; the throat, fore neck, and sides of the body lighter, the contre of each feather inclining to grcyish white.

Young. The young of both sexes rescmble the female in the comparative brownness of the plumage of the upper parts; the rictal membrane is largely developed and of a rich orange-colour.

Obs. In this and the other closely allied species the feathers of the body have loose or disunited filamentous barbs, and arc very soft in texturc, especially on the upper parts.

Note. I entirely agree with Dr. Finsch that this form should be separated from Petroeca (erroneously called Petroica); but I am mable to follow him in adopting the genus Myioscopus of Rcichenbach, the namc of 
Miro proposed by Lesson having a prior claim in regard to date. The long legs, shorter wings, and stouter bill distinguish this genus from Petroca and bring it nearer to Erythacus.

Tris species is confined to the North Island, where, till within the last ten years, it was very common in all the wooded parts of the country; but it is represented in the South Island by a closely allied and still common species, the Miro albifrons. There is a specimen of the North-Island Robin in the Auckland Museum said to have been obtained at Nelson; but I have never found this bird south of Cook's Strait, and vice versâ as regards the South-Island Robin. 'The two species may therefore be regarded as true representatives of each other in the North and South Islands respectively.

Generally speaking, in New Zealand it is only on the outskirts of the woods that we meet with insessorial birds in any number. As we penetrate into the heart of the forest, the birds become fewer, till at length they almost entirely disappear. But there is one species whose range seems to be quite without restraint: common enough in the open coppice, it is to be found also in the gloomiest and most secluded parts of the forest. This bird is the subject of our article-the Pitoitoi or Toutouwai * of the natives and the "Robin" of the colonists.

I have been assured by officers who accompanied the celebrated Taranaki Expedition under Major-General Sir Trevor Chute, in 1866, that during that long and irksome march the Robin was the only bird that gave any sign of life to those interminable and gloomy forests through which the army passcd. The lively twitter and song of the smaller birds had ended with the first day's march, the harsh cry of the Kaka (Nestor meridionalis), which had attended them far into the bush, had gradually ceased to be heard, and the Wood-Pigeon (Carpophaga novo-zealandice), whose range extends to the summits of the low wooded ridges of the interior, was no longer to be met with. An oppressive silence reigned around them, broken only by the shrill chirp of the startled Robin as the advanced guard cut a path for the troops through the hitherto untrodden woods. Indeed the presence of this little bird was the only exception to the utter absence of animal life, and almost the only relief to the monotony of the march. Perched on a low branch, it might frequently be seen looking gravely down, as if in silent wonderment, on the weary ranks, as they toiled their way through this virgin forest in the very heart of the enemy's country!

As the popular name implies, it is naturally a tame bird; and in little-frequented parts of the country it is so fearless and unsuspicious of man that it will approach to within a yard of the traveller, and sometimes will even perch on his head or shoulder. It is the favourite companion of the lonesome wood-cutter, enlivening him with its cheerful notes; and when, sitting on a log, he partakes of his humble meal, it hops about at his feet, like the traditional Robin, to pick up the crumbs.

Like its namesake in the old country, moreover, it is noisy, active, and cheerful. Its note is generally the first to herald the dawn, while it is the last to be hushed when the evening shades bring gloom into the forest. But there is this noticeable difference between the morning and the evening performance: the former consists of a scale of notes coinmencing very high and running down to a low key, uttered in quick succession, and with all the energy of a challenge to the rest of the feathered tribe; and I have sometimes heard a native, when listening to this strain, exclaim "Ka kanga te manu ra!" (How that bird swears!). The evening performance is merely a short chirping note, quickly repeated, and with a rather melancholy sound. Three or four of them will sometimes join in a chirping chorus, and continue it till the shades of advancing twilight have deepened into night.

* There are some curious coincidences with Maori names, of which this is an instance. The Robin is called "Toutouwai" by the Ngapuhi tribe at the far north. The small European Owl, Athene noctua, has "Koukouwai " as its Greck name. Drop the final syllable, and we have the Maori name for the New-Zealand Owl, "Koukou." 
It lives almost entirely on small insects and the worms and grubs which are to be found among decaying leaves and other vegetable matter on the surface of the ground in crery part of the woods. Its nature is pugnacious and, in the pairing-season, the male birds often engage in sharp encounters with each other.

It generally breeds in the months of October and November. It constructs a large and compact nest, composed externally of coarse moss firmly interwoven and thickly lined inside with the soft hair-like substance which covers the young stems of the tree-fern. It is usually built against the bole of a tree, at a moderate elevation from the ground, being often found attached to and supported by the wiry stems of the kiekie (Freycinetia banksii), a climbing parasitical plant which is everywhere abundant. I have found scores of the nests of this species, and almost invariably in the situation described.' I found one, however, placed in the fork of a tree at some elevation, and another in the truncated stem of a tree-fern (Cyathea dealbata). The eggs are nsually three in number, broadly ovoido-conical, and measuring 95 of an inch in length by .70 in breadth; they are of a crcamy white colour, thickly freckled and speckled with purple and brown, these markings being denscr at the thick end, where they form an indistinct purplish zone.

Should the nest happen to be molcsted after the young are hatched, the parent birds manifest the utmost solicitude, hopping about near the intrnder with outspread and quivering wings, uttering a low piping note, and showing every symptom of real distress.

The last example of the nest I examined was obtained recently on the Little Barrier Island, where it was found supported against the bole of a tree about five feet from the ground. It is not so massive as many I have seen, and is composed chiefly (and probably for protective purposes) of the green moss which clings to the trunks of old trees, mixed with dry leaves and little twigs of wood; the cup, which is rather shallow, measures three and a half inches in diameter and is deeply lined with fern-hair and vegetablc fibres. It was found about the middle of December, just after the young birds had quitted it.

But for the fact that much of the foregoing article applies equally to the South-Island species, it would have been almost necessary to expunge it from the present edition; for, alas! its subject, instead of being, as formerly, the commonest of our native birds, is now one of the rarest. It is still comparatively plentiful on the Island of Kapiti, and on some of the wooded islets in the Hauraki Gulf; but it is seldom met with on the mainland, and, in common with many other native forms, its doom is sealed.

Ornithologists everywhere must regret this, because the genus to which it belongs has no representative in any other part of the world; and those who are at all familiar with the bird itself will assuredly grieve over its threatened extirpation. Personally I regard this gentle Robin with a strong sentiment of affection. In the days of my boyhood it was one of the dominant species, and some of my earliest memories are associated with it. The first nest $\mathrm{I}$ ever found in my juvenile excursions through the bush near the parental home-the dear old Church Mission station of forty years ago-was naturally that of the Robin. It was the first bird of which I ever prepared a specimen; and having, while yet at school, conceived the idea of writing a history of our native birds, I well remember that the first species whose biography I essayed to sketch was this everyday companion of my holiday rambles. Its presence therefore never fails to awaken reminiscences of the past; but unfortunately ere long the bird itself will be but a memory of by-gone years. Either on account of its being an easy prey to wild cats and rats, or else in obedience to some inexplicable law of nature, the species is rapidly dying out; and it requires no prophetic vision to foresee its utter extinction within a very short period. Well may the Maori say, as he laments orer the decadence of his own race- "Eren as the Pitoitoi has vanished from the woods, so will the Maori pass away from the land and be forgotten!" 


\title{
MIRO ALBIFRONS.
}

\author{
(SOUTH-ISLAND ROBIN.)
}

White-fronted Thrush, Lath. Gen. Syn. ii. pt. 1, p. 71 (1783).

Turdus albifrons, Gm. Syst. Nat. i. p. 822 (1788).

Miro albifrons, Gray, in Dieff. Trav. ii., App. p. 190 (1843).

Petroica albifrons, Gray, Voy. Ereb. and Terror, p. 7, pl. 6. fig. 2 (1844).

Turdus ochrotarsus, Forster, Descr. Anim. p. 82 (1844).

Muscicapa albifrons, Ellman, Zool. 1861, p. 7465.

$\delta$ similis $M$. australi, sed multo major et magis fuliginosus, scapis plumarum minùs distinctè albis : sed præeipuè pectore ct abdomine medio ochrascenti-albis distinguendus.

Adult male. Head, neck, sides of the body, and all the uppcr surface dark sooty grey, the basc of the feathcrs plumbcous; at the root of the upper mandible a small spot of yellowish white; breast, abdomen, and vent ycllowish white, tinged with lemon-ycllow on the breast, and forming a tolcrably well-defincd linc agaiust the dark plumage of the forc ncck; inner lining of wings, flanks, and under tail-coverts greyisle white; quills and tail-feathers smoky black; an oblique bar of white on the inner facc of the wings, as in M. austratis. Irides black; bill brownish black; palate and soft parts of the mouth yellow; tarsi, toes, and claws brownish black; soles of the fect dull yellow. Total length $7 \cdot 25$ inches; extent of wings $10 \cdot 5$; wing, from flexure, 4 ; tail 3 ; bill, along the ridgc $\cdot 65$, along the edge of lowcr mandible $\cdot 85$; tarsus $1 \cdot 5$; middle toc and claw $1 \cdot 05$; hind toe and claw $\cdot 9$.

Female. Somewhat smaller than the male, and having the plumage of the upper parts tinged with brown; therc is less ycllow on the breast, and the grey of the underparts is lighter.

Obs. This spccics may readily be distinguished from $M$. australis by its appreciably larger size, its black legs and darker coloration, and the morc defined pateh of yellowish white on the under surfacc. The white shaft-lincs arc not so distinct on the crown and nape, but are far more so on the throat and fore neck, owing to the ground-colour of these parts being darker than in $M$. australis. The frontal spot is smaller and less conspicuous.

Dr. Finsch has expressed an opinion in favour of uniting $M$. australis and $M$. albifrons; but a glance at the Plate will show how decidedly the two specics differ from cach other in their cxternal characters *.

Var. My collcction contains a specimen received from Christchurch in which the whole plumagc is suffused with brown, and the underparts are smoky grey instead of being white + .

Note. The figure of this species in the 'Voyagc of the Erebus and Terror' is ineorrect, on account of the exaggerated extent of white on the underparts; but the attitude is a very characteristic one.

THe habits of this bird differ in no respect from those of its near congener Miro austratis; and the account given in the foregoing pages may be considered equally applicable to both species.

* "These birds scem to be scarccly distinct" (Finsch, Trans. N.-Z. Inst. rol. v. p. 207).

$\dagger$ In the 'Journal of Science,'vol. ii. p. 170, a full description is given of a pied example, or partial albino, the whitc preponderating over the normal colour, and the breast being creamy yellow. 
It has large lustrous eyes, and the feathercd fringe to the eyelid imparts to them an unusually prominent appearancc. When its attention is excited, it assumes a very erect position, and flips its wings and tail, often uttering a short chirp betwecn each operation. It is popularly said to have the power of expanding and contracting the small white spot on its forehead, but the explanation is a simple one: when the bird is at rest, it habitually raises the frontal fcathers, making the head look large and rounded and rendering the whitc spot almost invisible; when excitcd or alarmed the feathers are immediately dcpressed and the frontal spot is at once conspicuous.

Under the head of Eudynamis taitensis, mention will be made of its services as fostcr-parent to the young of that Cuckoo, of which we have at least one undoubted instance.

On comparing the eggs of this specics with thosc of $M$. australis, thcre is a manifest diffcrence. They are slightly larger and more ovoido-conical in form, measuring 1.05 inch in length by $\cdot 7$ in brcadth. They present also more individual variation than do thosc of the North-Island bird, which are all marked on the same pattern. In two eggs of M. albifrons in my son's collection one has the entire surface minutely and indistinctly freckled with grey, whilst the other has the larger end splashed all over with confluent spots of purplish brown, with a few widely scattered sperks over the rest of the surface. Another (taken from the nest in February) is somewhat pyriform in shapc, measuring 9 of an inch in length by $\cdot 7$ in breadth; the obtuse end thickly smudged with dull brickred, washed ovcr with brown, and a few sprinkles of the same colour on other portions of the shell.

Some doubts having existed as to the true position of the genera Miro and Myiomoira, I furnished Dr. Gadow with specimens in spirit of Miro albifrons and Myiomoira toitoi to enable him to study their internal characters, and he reports, as the result of his investigations, that both forms are true Singing-birds, and that the place I had already assigned them, in my former edition, among the Sylviidæ is undoubtedly the right one*. 'lhis fact is of some importance from a systematic point of view, bccause of the relation of this group to others about whosc location in the systcm there is much differcnce of opinion.

In the Britislı Museum Catalogue (Birds, vol. iv.) Mr. Sharpe places both these forms among the Muscicapidæ, associating $M$. toitoi and $M$. macrocephala with twelve other species in the genus Petrceca, with a range cxtending over Australia, New Zealand, and the Pacific Islands.

Profcssor Newton, in his ablc article on "Omithology" (Encycl. Brit.), has the following remarks:- "There is no doubt whatever as to the intimatc relationship of the 'Thrushes (Turdidæ) to the Chats (Saxicolinæ), for that is admitted by nearly every systematizer. Now most authoritics on classification are agreed in associating with the lattcr group the Birds of the Australian genus Petroeca and its allies-the so-called 'Robins' of the English-speaking part of the great southerr communities. But it so happens that, from the inferior type of the osteological characters of this very group of birds, Prof. Parker has called them (Trans. Zool. Society, v. p. 152), 'Struthious Warblers' $t$. Now, if the Petroca group bc, as most allow, allied to the Saxicolinæ, they must also be allied, only rather morc remotely, to the Turdidæ-for 'Lhrushes and Chats are inseparable, and therefore this connexion must drag down the Thrushes in the scalc. Let it be granted that the more highly developed Thrushes have got rid of the low Struthious features which characterize their Australian relativcs, the unbroken series of connecting forms chains them to the inferior position, and of itself disqualifics them from the rank so fallaciously assigned to them."

* “Mirno atbifrons (Passeres, Acromyodi, Turdiformes).-Stands very well with the Sylriidæ, where you have already put it. Tail-feathers twelve. Primary remiges ten, the terminal one being loug, more than half the length of the next. Seeondary remiges nine. Pterylosis typically Sylviine and Turdine. Metatarsus eompletely eneased by three long seutes or shields, one anterior and two lateral, the latter forming a sharp posterior prominent keel; truly Sylviine. Intestines agree with Sylviine birds likewise. Stomach eontained inscets. Nothing peculiar about Miro at all. The same applies to Myiomoira."-H. GADow.

† "Petraca has been statod by Professor Parker to be a 'Iraeheophone' (i.e. Mesomyodian), having 'the muscles of lowor larynx quite indistinet.' In three speeimens, however, of that genus examined by me I find a perfeetly Oscinine syrinx with its muscles as well developed as in other birds of the same size " (Forbes, P. Z. S. 1882, p. 545). 


\section{MIRO TRA VERSI.}

(CHATHAM-ISLAND ROBIN.)

Miro traversi, Buller, Birds of New Zealand, 1st ed. p. 123 (part ii.), June 1872.

Petroica traversi, Hutton, Ibis, July 1872, p. 245.

Ad. omninò niger, remigibus et reetrieibus paullò brunneseentioribus : rostro nigro : pedibus nigris, plantis flavis : iride saturatè brunneâ.

Adult male. The whole of the plumage blaek, the base of the feathers dark plumbeous; wing-feathers and their eoverts tinged with brown, the former greyish on their inner surfaee; tail-feathers blaek, very slightly tinged with brown. Irides dark brown; bill black; tarsi and toes blaekish brown, the soles of the feet dull yellow. Total length 6 inehes; wing, from flexure, $3 \cdot 4$; tail $2 \cdot 6$; bill, along the ridge $\cdot 5$, along the edge of lower mandible $\cdot 7$; tarsus $1 \cdot 1$; middle toe and elaw 1 ; hind toe and elaw $\cdot 8$.

Female. Slightly smaller than the male, and without the brown tinge on the wings and tail.

THis species was discovered by Mr. Henry Travers during an exploratory visit to the Chatham Islands in 1871. Through the courtesy of His Exeellency Sir George Bowen (who forwarded them in his despatch-box to the Colonial Office), I received specimens of the male and female in time to include this bird, in its systematic order, in my former edition. In dedicating the species to the enterprising naturalist who had discovered it, I thus unavoidably anticipated Professor Hutton, who had proposed the same name for it, but did not publish his description till after mine had appeared.

Mr. Travers supplies the following note respecting it:- "I only found this bird at Mangare, where it is not uncommon. It is very fearless, possessing in other respects the habits of Petroica albifrons and $P$. longipes. Its ordinary note is also the same, but I did not hear it sing. It appears to be specially obnoxious to Anthornis melanocephala, which always attacks it most savagely when they meet."

This form appears to be the small degenerate representative of the New-Zealand Robin, which, strangely enough, does not occur in the Chatham Islands; but it is even more remarkable still that, so far as our information goes, the present bird is not found either on the main island or on its satellite, Pitt Island, being confined exclusively to Mangare, which is described as a mere rocky slet covered with low rigid scrub.

The antipathy, mentioned by Mr. 'Travers, on the part of Anthornis melanocephala towards this species is quite unaccountable, because the ordinary habits of the two birds do not conflict in any way, whilst between Anthornis melanura and the Robin in New Zealand the most perfect amity exists. Possibly the pugnacious habit has been developed by the insular nature of its environment, and the more severe conditions of life in the struggle for existence.

It may be here stated that the Chatham Islands, to which frequent reference will be made in the course of this work, are situated about 450 miles eastward of New Zealand, in lat. $42^{\circ} \mathrm{S}$. 'The group consists of Wharekauri, about seventy miles in extent, shaped like an isosceles triangle, and presenting a low diversified surface of bush, lake, and open land, with much fertile soil ; Pitt Island, about ten miles in circumferenee, separated from the main island by a deep channel, and now occupied by a sheep-farmer; Mangare, the home of Mirotraversi, as mentioned above; South-east Island and other small rocky satellites, which are uninhabited. 


\title{
MYIOMOIRA TOITOI.
}

\author{
(NORTH-ISLAND TOMTIT.)
}

Muscicapa toitoi, Garnot, Voy. Coq. i. p. 590, t. xv. fig. 3 (1826).

Miro toitoi, Gray, in Dieff. Trav. ii., App. p. 191 (1843).

Petroica toitoi, Gray, Voy. Ereb. and Terror, Birds, p. 6 (1844).

Myiomoira toitoi, Reich. Syst. Av. Taf. lxvii. (1850).

Muscicapa albopectus, Ellman, Zool. 1861, p. 7465.

\section{Native names.}

Miromiro, Komiromiro, Pimiromiro, Ngirungiru, Pingirungiru, and Pipitori.

đ̃ suprà sericeo-niger : maeulâ frontali conspicuâ albâ : tectrieibus alarum plcrumque nigris, medianis brunnescentibus : remigibus brunneis, primariis interioribus arl basin albo maeulatis, secundariis magis conspicuè notatis, plagam albam exhibentibus: caudâ nigrâ, rectricibus tribus exterioribus ferè omninò albis, hasi pogonii interni et apiee pogonii extcrni execptis nigris : facie laterali, gutture toto et pectore superiore nigris, gulâ vix brunnescente : corpore reliquo subtùs albo, basi plumarum nigricante: rostro et pedibus nigrieantibrunneis : plantis pedum flavicantibus : iride nigrâ.

o mari dissimilis: brunnea, subtùs albida, lypochondriis brunnescente lavatis : loris et facie laterali brunneis, fulvescente variis.

Adult male. Head, neck all round, and all the upper parts black; frontal spot, at the base of the upper mandible, white; brcast and nnderparts pure white, the black of the forc neek having a sharply defined lower edge; wing-feathers crossed near their base by an angular pateh of whitc, which is narrow and interrupted on the primaries, broad and continuous on the secondaries, the blaek shafts, however, forming fine intersecting lines; tail black, the three outer feathers on each side crossed obliquely upwards by a broad bar of white, which covers more than a third of their surface. Irides and rictal bristles black; bill and tarsi blackish brown; toes paler, yellow on their inner surface. Total length 5 inches ; wing, from flexure, 3 ; tail $2 \cdot 25$; bill, along the ridge $\cdot 4$, along the edge of the lower mandible $\cdot 5$; tarsus $\cdot 75$; middle toe and claw $\cdot 8$; hind toe and claw $\cdot 65$.

Adult female. Upper surface smoky brown, with a minutc frontal spot of white; throat, fore neck, and all the underparts greyish white, more or less clouded with dull smoky brown; wing-featliers blackish brown, a bar across the base of the secondaries and some indistinct marks on the webs of the outer primaries fulvous whitc; tail black, the three outer feathers on caeh side barred obliquely with white, as in the male.

Young. In the young male the colours are mueh duller and browner, and the sharply defincd pectoral line is wanting; but the plumage is suffieiently different from that of the femalc to distinguish the sexes.

Obs. The scxes do not present any perceptible differenec in size. Individuals, however, vary perceptibly. The measurcments of an ordiuary bird are given above; but a smaller example of the adult malc which I sliot in the Forty-Milc Bush gave the following results:-Length 4.75 iuches; cxtent of wings 8 ; wing, from flexure, $2 \cdot 75$; tail 2 ; bill, aloug the ridge $\cdot 25$, along the elge of lowcr mandible $\cdot 5$; tarsus $\cdot 75$; middle toc and elaw $\cdot 75$.

In both sexes the tongue, palate, and intcrior of the mouth, as well as the anglc, arc orange-yellow; differing in this respeet from Clitony $x$, in whieh the male bird has a black mouth and the female a fieshcoloured one. 
T'rrIs elegant little bird belongs to the North Island, where it has a pretty general distribution, being met with in all localities suited to its habits*. It is a familiar species, seeking the habitations of man, and taking up its abode in his gardens and orchards. It is always to be seen in the clearings and cultivated grounds near the bush, moving about in a peculiar fitful manner, and in the early morn may be heard uttering a prolonged trilling note, very sweet and plaintive. Its usual attitude is with the wings slightly lowered and the tail perfectly erect, almost at a right angle with the body. It has a sparkling black eye, and all its actions are lively and sprightly. The strongly contrasted plumage of the male bird renders it a conspicuous object; but the female, owing to her sombre colours and less obtrusive habits, is rarely seen. Its note in the early morning is like the Maori syllables ngi-i-ru, ngiru-ngiru, from which it derives its native name, the first syllable being somewhat prolonged. Throughout the day, and often till late in the evening, it utters, at frequent intervals, a soft note like the words "Willoughby-willoughby," repeated several times. This is often heard in association with the musical trill of Gerygone, the two birds warbling, as it were responsively, from the same bush.

It is very tenacious of life, and I have found it difficult to kill, even with dust-shot, the bird often flying some distance after being mortally wounded. On examining it after death, one is struck with the disproportionately large size of the head, which is kept drawn in upon the body during life, as shown in the figure. The plumage, which is peculiarly soft and yielding, is distributed in welldefined tracts or areas, as in all other Carinate birds; but the intervening spaces are unusually wide, being perfectly smooth and bare, and the skin on the hind neck rises in a peculiar, naked fold, with a narrow line of feathers on the top like a mane.

It is interesting to watch this active little creature as it flits about the fences and fallen timber in the bush-clearings, where it is to be found at all hours of the day. It rests for a moment on its perch, flirting its wings and tail in a rapid manner, then darts to the ground to pick up a grub or earthworm, and, flying upwards again almost immediately, clings by its tiny feet to the upright bole of a tree or somc other perpendicular surface, a peculiar attitude which it appears to delight in. Its food consists of small insects and their larvæ; and it proves itself useful by devouring a destructive little aphide which infests our fruit-trees. I have opened many and in every instance found its stomach full of minute insect remains, proving how serviceable it must be to the husbandman.

Like its allies, Erythacus for instance, this bird has a pugnacious spirit, and during the pairingseason the males meet and fight on the slightest provocation, whether real or imaginary.

I have noticed that it often manifests an attachment for a particular locality, resorting to the same perch day after day. The Maoris, too, have observed this; and at Otaki they passed their title to a plot of ground through the Native Land Court under the name of "Te-tau-a-te-Miromiro" (the perching-place of the Miromiro).

It is far less plentiful than it formerly was in our fields and gardens. There seems no reason to fear, however, that the species is dying out, for in the Fagus forests of the interior I have found it extremely plentiful. In the woods at the foot of Ruapehu and neighbouring high lands, where, save the occasional twitter of small birds in the branches, all is silent as the grave, this pretty little creature is always to be met with. It flits noiselessly from one tree to another, then descends to the ground, and in a few instants reappears on its perch, flirting its tail upwards, and emitting at intervals a soft call-note of peculiar sweetness. Destitute of animal life as these sub-alpine woods undoubtedly are, they are not without their attractions. Owing to their high elevation vapourclouds are continually hanging over them, causing a perpetual moisture. In consequence of this the

* Mr. Sharpe says (Cat. Birds Brit. Mus.) that M. toitoi is found in tho Chatham Islands. But this is obviously a mistake, the only specics at present known from these islands being $M$. dieffenbachii, which, as explained above, is identical with $M$. macrocephala of the South Island. 
trees on their outer faeies are more or less eovered with kohukohu, a feathery fungus of a pale green eolour, hanging like drapery from the branehes, while their trunks and limbs are elad to their very tops with the richest profusion of lichens and mosses. No idea can be formed of the quasi-tropieal richness of these woods in this respeet by any one who has not aetually visited them.

Its ally, Myiomoira macrocephala, in the South Island, has the same habit of frequenting high altitudes; for not only is this bird met with among the high tussoek-grass on the plains, but likewise on the summits of the ranges, flitting about among the snow-grass and other stunted vegetation, at an elevation of 5000 feet or more, and subsisting on the small alpine lepidoptera and their larre, or sueh diptera and other minute inseets as inhabit these mountain heights.

Common as this speeies is, I have found it diffieult to study its breeding-habits, and have never sueeeeded in finding more than one nest. I met with this in the Upper IIutt valley, in the neighbourhood of Wellington, as late as the 3rd of Deeember. It was plaeed in the cavity of a tree a few feet from the ground, and eontained four young birds apparently about a week old. The nest was composed entirely of dry moss, shallow in its eonstruetion, but with a neatly finished rim or outer edge. The parent birds manifested some solieitude for the safety of their offspring while 1 was handling them. After I had replaeed the young birds and retired a few steps from the spot, the female squatted upon the nest, which was sufficiently near the entranee of the eavity to be distinetly visible; and on being disturbed she fluttered away with wings outstretehed and quivering, as if unable to fly, and apparently to divert attention from the nest.

Mr. Weston Brown, a bird-colleetor at Wellington, showed me a pair of newly fledged young birds of this species whieh he had taken himself. He informed me that he had found them in a rudely eonstrueted nest in the hollow of a whitewood tree, and about 9 inches from the entranee. There were only two young birds in the nest, and these were male and female. The plumage of the former was strongly suffused with brown; but the eolours were suffieiently distinet to indieate the sex.

During the early part of the breeding-season the female is never risible, and $I$ think it is probable that while engaged in the task of ineubation she is attended and fed by the male, for $I$ have seen the latter carrying food in his bill. As late as September 30, I have seen as many as ten males in an afternoon's ramble, without eatehing a glimpse of the other sex. The young birds do not seem to pair till the seeond year; for in the breeding-season I have, on disseetion, found well-plumaged birds with mieroscopie testes, whilst in others these organs were developed to the size of buck-shot, being conspieuously large for so small a ereature.

There is every reason to believe that this speeies breeds twiee in the season, because it is a eommon thing to find nests containing fresh eggs in Oetober and again in December. The usual eomplement of eggs is four, but sometimes there are only three. Mr. Reisehek told me that, on the Little Barrier, he eame upon a nest, eontaining three eggs, which through some misadventure had got filled with rain-water. The birds seemed fully aware of the gravity of the situation, and were flitting around it in a very exeited and distressed manner; but when he proeeeded to take possession of both nest and eggs they sat perfectly quiet and did not utter a sound.

The nest is a compact round strueture, with a thiek foundation, and eomposed of dry moss, grass, and vegetable fibres, felted together; the eup, whieh is comparatively large, measuring 2.25 inches in diameter, is often lined with the inner bark of the ribbon-wood (Hoheria populnea), and the outer rim is well pressed together just as if bound by some invisible thread. The eggs are of large size in proportion to the bird, measuring 85 ineh in length by 80 in breadth; they are in form broadly ovoido-eonical and are ereamy white, freekled all over with yellowish brown, the markings running together and forming a elouded zone near the larger end. Sometinies the zone is absent and the freckled appearanee less pronouneed. A speeimen taken from a nest in the hole of a dry stump differs in being of a pale reddish tint, thiekly speekled and freekled with light brown. 


\title{
MY I O MO IRA MACROCEPHALA.
}

\author{
(SOUTH-ISLAND TOMTIT.)
}

\author{
Great-headed Titmonse, Lath. Gen. Syn. ii. pt. 2, p. 557, pl. lv. (1783). \\ Parus macrocephaitus, Gm. Syst. Nat. i. p. 1013 (1788, ex Lath.). \\ Paehyeephalus? macroeephalns, Steph. Gen. Zool. xiii. p. 267 (1826). \\ Rhipidura macrocephala, Gray, in Dieff. Trav. ii., App. p. 190 (1843). \\ IIiro forsterorum, Gray, op. cit. ii. p. 191 (1843). \\ Miro dieffenbachii, Gray, op. cit. ii. p. 191 (1843). \\ Petroica macrocephala, Gray, Voy. Ereb. and Terror, Birds, p. 6 (1844). \\ Petroiea dieffenbachii, id. op. cit. p. 6, pl. 6. fig. 1 (1844). \\ Turdus minutus, Forst. Descr. Anim. p. 83 (1844). \\ Miro macrocephala, Bonap. Consp. Gen. Av. i. p. 299 (1850). \\ Muscicapa macroeephala, Ellman, Zool. 1861, p. 7465. \\ IIuscicapa minuta, Ellman, tom. cit. p. 7465 . \\ Myiomoira dieffenbachii, Gray, Hand-l. of B. i. p. 229 (1869). \\ Myiomoira maerocephala, id. op. cit. p. 229 (1869).
}

\section{Native names.}

The same as those applied to the preceding species.

ơ similis $M$. toitoi, sed maculâ frontali albâ minore et pectore flavido distinguendus.

o similis feminæ $M$. toitoi, sed pectore flavido lavato.

Adult male. Similar to $M$. toitoi, except in the colour of the under surface, which is pale lemon-yellow instead of being wlite, deepening to orauge where it meets the black of the fore neck, and fading away into yellowish white on the vent and under tail-coverts; the white frontal spot, moreover, is somewhat less distinet than in the former bird. Irides lustrons black. Legs and feet blaekish brown, the under surface and sides of the tocs orange-yellow. Total lengtl $5 \cdot 4$ inches; extent of wings $8 \cdot 5$; wing, from flexure, $3 \cdot 2$; tail $2 \cdot 2$; bill, along the ridge $\cdot 35$, along the edge of lowex mandible $\cdot 55$; tarsus $\cdot 7$; middle toe and claw $\cdot 8$; hind toe and claw $\cdot \%$.

Female. Similar to the female of $M$. toitoi, but having the breast and abdomen washed with very pale lemonyellow, and the wing-bar tinged with fulvous.

Young. In the young of both scxes the yellow is reduced to a scarcely perceptible tinge, and in some examples is altogether wanting. In the young mate the breast is obscurely mottled with dusky black, and in the young female these markings are brown and extend to the flanks.

Varieties. A rery pretty albino specimen, received from Otago, has nearly the whole of the body white, with a wash of bright yellow on the head, breast, and abdomen; on the fore part of the breast there is a broad mark of velvety black, and on the upper surface there are a few scattered feathers of the same; some of the wing-feathers are pure white, the rest are black; the two middle tail-feathers are white, the outer ones blaek, obliquely crossed with a bar of white; bill and legs as in ordinary speeimens.

Another albino, in the Otago Museum, has the general plumage white, with a faint tinge of brown on the 
head and of yellow on the body, therc bcing a bright wash of canary-ycllow on the breast. Wings and tail parti-eoloured, several of the tail-feathers being entirely blaek; bill and feet white.

Obs. Individuals vary much both in size and in the tone of their eolouring, some males having the underparts of a uniform pale lemon-yellow, others rieh eanary-yellow, deepening into orange on the breast. The one figmred is a higlly eoloured speeimen in my own eolleetion. A spccimen in the Canterbury Museum measures only $4: 75$ inches in length, eorresponding, both in size and plumage, with the type of Mr. G. R. Gray's M. dieffenbachii ; and I have reeeived equally small examples from the Chatham Islands; but, after a very carcful eomparison, I am unable to admit the validity of the supposed new speeies*.

T'ris 'Tomtit is the South-Island representative of the preceding species, which is only found north of Cook's Strait. It appears, however, to enjoy a wider geographical range; for I obtained specimens at the Chatham Islands, and the Antarctic Expedition brought some from the Auckland Islands.

The stomachs of all those I opened were crammed with small diptera, coleoptera, and caterpillars, showing the strictly insectivorous character of this species.

The habits of this bird are similar to those of its nortlern ally (M. toitoi), except that it appears to be less recluse in its nidification; for it is a common thing to find its sonewhat elaborate nest, and often in exposed situations, a favourite location being under the head of the ti (Cordyline australis).

There is much variation in nests from different localities, but a very typical example in my collection is of a rounded basket-shape, with a thick foundation, measuring four inches across the top, with a maximum depth of a little over three inches. It is composed of moss, dry leaves, roots of umbelliferous plants, minute fragments of bark and other vegetable substances, compactly bound together; and the cup, which is fully an inch and a half in depth, is thickly lined witl soft tree-moss. Mixed with the building-materials I have enumerated are some small tufts of sheep's wool; and passing right through the wall of the nest, apparently to serve as a support, there is a bent fern-stalk nearly six inches long $t$.

The eggs, which are generally three in number, but occasionally four, are ovoido-conical, measuring $\cdot 75$ inch in length by 6 in breadth; they are white, with a broad freckled zone of purplish brown at the larger end, and with the whole surface dusted or minutely freckled with paler brown; sometimes without the zone, and beautifully speckled all over with various shades of brown.

* Professor Hutton, I believe, still recognizes two species, both of them found in tho South Island. In the critieal notes appended to his "Catalogue' (1871) he remarked:- "Mr. G. R. Gray describes Petroice dieffentuchii as being smaller than P. macrocephala, and with the yellow on the eliest darker; but of the two species that are found in the South Island it is the larger one that has the darker colour on tho ehest. It is therefore doubtful which of the two is the true macrocephala." The answer to the ahove is that $I$ have in my possession a scries of specimens showing every gradation of colour between the two extremes. and that the darkest is likewise the smallest of them ail.

$\uparrow M r$. W. W. Smith sends me the following note:- "I have found the nest many times under the head of the cabbage-tree, and occasionally in a suspended elump of roots on a clay bank. I have also met with it in thick masses of 'bush lawyer.' In 1880 I diseovered one in a matipo tree fully nine feet from the ground. I havo observed considerable difference in the size and shape of the nests, some being large and very roughly construeted, others small and highly finished." Mrr. Potts writes :- "Two nests which we presented to the Casterbury Museum wero of remarkable shape : one, a firm eompact structure, placed in tho forked head of a ti tree, resembled a very neat moss basket with a handle aeross the top; the second, also from a ti tree, owing, perhaps, to the foundation slipping between the leaves, was built up till it reached the great height of sixtcen inches. We have found others placed on a rock : and one, now in the Colonial Husoum, was built betwocn the brace and shingles in the roof of an empty cottage" (Trans. New-Zealaud Inst. 1869, vol. ii. p. 59). In a letter to myself, ho adds the following interesting partienlars of two other nests found by him :-_"No. 1 was built ehiefly of sprays of clinoing plants, strengthoned with grass-bents and a few picees of split ti-palm leaf, lined with moss, as usual. The whole fabric appeared much rougher and more loosely put together than is usually the case with the nest of this bird. It was placed in a ti-palm, and contained two woll-fledged young birds and three bad cggs. No. 2: this nest was composed almost entiroly of moss, with a fow slender strips of bark fixed to the ontside, and ormamented insido with a few Parrakect-feathers; it was plaecd on a ledge in a mossy recess among the rocks iu dense bush, and contained four cggs." 


\title{
GERYGONE FLAVIVENTRIS.
}

\author{
(GREY WARBLER.)
}

Curruca igata, Quoy et Gaim. Voy. de l'Astrol., Zool. i. p. 201, pl. xi. fig. 2 (1830).

Acanthiza igata, Gray, in Dieff. Trav. ii., App. p. 189 (1843).

Gerygone flaviventris, Gray, Voy. Ereb. and Terror, p. 5, pl. 4. fig. 1 (1844).

Gerygone igata, id. op. cit. p. 5 (1844).

Gerygone assimitis, Buller, Essay on Orn. N. Z. p. 9 (1865).

Acanthiza flaviventris, Gray, Hand-1. of B. i. p. 219 (1869).

$$
\text { Native names.-Riroriro and Koriroriro. }
$$

Ad. suprà griseseenti-brunneus, dorso et uropygio eum supraeaudalibus olivaeeo lavatis, his læatiùs tinetis: tectricibus alarum remigibusque brunneis, extùs angustè olivaceo limbatis: rectricibus cinerascenti-brunneis versùs apicem conspicuc̀ nigricantibus, duabus externis maeulâ anteapicali albâ notatis, reliquis ad apicem pogonii interni albo maculatis: facie laterali gnttureque toto sordidè eincreis: corpore reliquo subtìs albieante, abdomine imo et hypochondriis flavido tinetis, his etiam paullò olivascentibus : rostro et pedibus saturatè brunneis : iride rubrâ.

Juv. similis adultis, sed coloribus dilutioribus.

Adult male. Upper parts brownish grey, tinged on the baek with olivaceous brown; throat, forc part of neck, breast, and sides cinercous grey; abdomen and under tail-coverts white, the former slightly tinged with yellow; primaries dark brown, paler on the inner webs; tail-feathers dark brown in their basal, almost black in their apical portion, and, with the exeeption of the two median ones, having an angular white spot near the tip on their inner webs. The plumage is sooty blaek at the basc, but this is only observable on moving the feathers. Irides red; bill, tarsi, and tocs dark brown. Total length 4.5 iuches; extent of wings 6 ; wing, from flexure, $2 \cdot 12$; tail 2 ; eulmen 3 ; tarsus $\cdot 75$; middle toe and elaw $\cdot 5$; hind toe and claw 75 .

Female. Similar in plumage, but of smaller size.

Young. In the young bird the tints of the plumage generally are paler and there is an entire absenee of the ycliow tinge. Irides brown.

Obs. In some adult examples the measurements are slightly larger than those given above, thcre is an absence of the yellow tinge on the abdomen, and the white spot on the lateral tail-feathers is terminal.

Note. A figure of this bird in the act of feeding a young Cuckoo will be found on the Plate representing Eudynamis taitensis. The illustration given in the 'Voy. de l'Astrolabe' is scarcely recognizable.

In the warm sunlight of advancing summer, when the manuka-scrub is covered with its snow-white bloom and the air is laden with the fragrance of forest flowers, amidst the hum of happy insect-life, a soft trill of peculiar swectness-like the chirping of a merry cricket-falls upon the ear, and presently a tiny bird appears for an instant on the topmost twigs of some low bush, hovers for a few moments, like a moth before a flower, or turns a somersault in the air, and then drops out of sight again. This is the Grey Warbler, the well-known Riroriro of Maori history and song. 
This little bird, of sombre plumage and unobtrusive habits, is an interesting species, whether we regard it merely as the familiar frequenter of our gardens and hedgerows, or, more especially, as the builder of a beautiful pensile nest and the foster-parent of our two parasitieal Cuckoos (Eudynamis taitensis and Chrysococcyx lucidus). It belongs to a group of which there are numerous representatives in Australia, and its habits are in no way different from those of its relations.

It is plentiful in every part of New Zealand, and appears to be as mueh at home in the woods as in the open scrub. I have scen it hunting for its minute prey in the leafy tops of forest trecs, the tawa being its favourite resort, probably on aecount of some speeial kind of insect food. On one oceasion, after very cold wcather, I picked up a dcad onc at the foot of an aged kauri tree, with a smooth trunk fully seventy feet in height. In the Hot Lakes distriet I have found it flitting round the stcaming gcysers, apparently unaffected by the sulphur fumes, and eatching the minute flies that are attraeted thither by the humid warmth. Down by the sea-shore its note may be heard in the low vegetation that fringes the ocean beach; whilst far up the mountain-side, where the scrub is scarce and stunted, it shares the dominion with the evcr-present Zosterops. Its sweet trilling warble is always pleasant to the ear, bcing naturally associated in the mind with the hum of bees among the flowcrs, and the drumming of loeusts in the sunshine. It bceomes londer and more persistent in the spring-time; and "Kua tangi te riroriro" has become a sort of watchword among the Maoris, signifying "Planting-time has commenced: let us be up and doing." I remember the late Sir Donald McLean commencing one of his most successful Maori speeches with those figurative words, using them of course in a political sense *.

Its food consists of minute flies and insects and their larræ, in the eager pursuit of which it appears to spend its whole time, moving about with great agility and uttering at short intervals a note of much sweetness, though of little variety. The bird is easily attracted by an imitation of this note, however rudely attempted, and may be induced to fly into the open hand by quickly revolving a lcaf or small fern-firond, so as to represent the fluttering of a captive bird. Layard eompares the note to the creaking sound of a whecl-barrow; and I have sometimes heard it so subducd and regular, as to be scarcely distinguishable from the musieal chirping of the pihareinga or native cricket.

When resting on a twig, it has a habit of flipping its wings after the manner of a Goldfinch. Its ordinary flight is in short undulations with the tail outspread, showing the markings on the lateral feathers.

Where the rank growth of braeken eovers the open land, mixed here and there with the flowering Leptospermum and blcnding its sombre tints with the dark-green clumps of tupakihiforming together a close thieket over which the wild convolvulus twines itself and exhibits its pendent flowers of pink and white-here the Grey Warbler has its home in absolute seeurity, and here in some shady recess it hangs its pear-shaped nest and rears its little brood. It builds a large and remarkably ingenious nest, in whieh it lays from three to six eggs, and, as I am inelined to think, breeds twice in the season. The construction of the nest, which is of grcat size as eompared with the bird, oecupies of necessity a considerable time. In one instance noted, I observed the birds collecting materials for thicir work towards the end of August, and the young did not quit the elump of elimbing-rose in which the nest was placed till the first week in Oetober.

Seleeted on account of its unwearied industry, or because of the peculiar fitness of its warm domed nest for the nurture of a semitropical specics, this little bird is the willing vietim of our two migratory Cuekoos, the Warauroa and Kohcperoa-the former of whieh, at any rate, deposits its egg in the nest of this species, while both of them delegate to this tiny ereature thc task of rearing their young.

* "I hea koe $i$ te tangihanga o te xiroriro"? (Where were you when the Riroriro began to sing ?) : a proverb applied to a lazy man who negleets his planting. 
I have found the intrusive egg of the former in the nest with those of the Grey Warbler, and I have frequently observed the voracious young Cuckoo being attended and fed by the foster-parent, but I have never seen the young of these birds together. Either the parasitie egg being the first hatched, the others are neglected and allowed to perish, or the intruder, finding the accommodation insufficient, by virtue of his superior size and strength casts out the rightful occupants and usurps entire possession of the nest.

Although, as already mentioned, the Grey Warbler appears to lay twice in the season *, it would seem that one nest serves the purpose of rearing two broods; for, allowing that the family would require the attention of the old birds up to the middle of October (though probably it would be later), there would not be time to build another nest before the arrival of the Cuckoos to spend the summer with us and to deposit their eggs for incubation. The production of double broods in this ease would seem to be a provision of nature to enable this species to maintain its ground, seeing that the demands of the parasitical Cuckoos involve in many cases the loss or destruction of the legitimate offspring. Instead of being scarce, the Grey Warbler continues to be one of our commonest speciesa circumstance owing, no doubt, in some measure, to its being a pensile-nest builder, and thus escaping the ravages of the Norway rat, the great enemy to the increase or perpetuation of our indigenous birds.

The young on leaving the nest are extremely nimble and somewhat shy. For several days after quitting their domed eradle they remain in its vicinity, following the old birds about in a restless manner and emitting incessantly a scarcely audible piping note. On these occasions I have noticed that the birds hunt all day long in a wide circle, with the nest-home as a eentre; and they probably take their young family back to it at night for shelter and warmth. The nests of most birds, when the young have flown, are polluted and unserviceable, being easily distinguishable as "old nests;" but this is not the case with the nest of the species under consideration. The cavity or chamber is deeply lined with soft feathers; and to keep the interior clean and pure, the roung birds may be seen elevating their bodies to the edge of the orifice on the sicke of the nest and ejecting the alvine discharge to some distance. Thus the nest is kept in perfect condition for eontinmed use, in the manner suggested, for the rearing of a second brood. At the close of the breeding-season it may be observed that this bird has the shafts of the tail-feathers denuded, often to the extent of a quarter of an inch, the result, no doubt, of its laborious building-operations.

I have examined a large number of their nests in various parts of the country and in almost every variety of situation; and while invariably exhibiting the pensile character, they are, as a rule, referable to one or the other of two distinct types - the bottle-shaped nest with the porch or vestibule, and the pear-shaped form without the porch. 'This peculiarity, coupled with the significant fact that in some instances the eggs were pure white, in others speckled or spotted with red, led me at one time to suspect the existence of two distinct but elosely allied species; and a manifest clifference in the size of some examples tended to strengthen that view. In my 'Essay on the Ornitlology of New-Zealand" (1865) I described the two forms of nest, and proposed to distinguish the builder of the large pear-

* In further support of my riew as to a double brood, I am glad to find room for the following valuable note received from Mr. J. Brough, of Nelson :- " It may interest you to know exactly the time it takes the Grey Warbler to construet its nest. On Norcmber 29 I took a nest with five eggs which $I$ had found close to my camp. On December 1 the birds commenced a fresh nest near the site of the old one. I watehed them carefully, and will give you the result as entered every night in my diary.Dec. 2. Showery day; warblers hard at work. Dec. 3. Snow showers; but no interruption in the work. Dec. 4 \& 5 . Snowing all day, but warblers hard at work from morning till night. Dec. 5. Fine day; birds working diligently. Dec. 6. Another fine day; warblers completed their nest. Dec. 8. First egg laid. Dec. 11. Another egg. Dec. 12. Third egg. Dec. 13. Fourth egg laid, and hen commenced to sit. Whilst the building of the nest was procoeding, I noticed that the male bird undertook the chief part of the labour in collecting and carrying materials, and that the wearing of these materials together and building of the nest was performed almost entirely by the female." 
shaped strueture as Gerygone assimilis. It may yet be necessary to recognize the existenee of a larger and a smaller race, although the subject requires further investigation. $\mathrm{Hy}$ present belief is that the difference in size is only sexual. It may be eonsidered settled, however, that the ascertained difference is not such as to justify a specific separation.

Sinee the foregoing was written, Mr. R. B. Sharpe has expressed his belief that the bird brought from New Zealand by the 'Astrolabe' Expedition in 1829 (Gerygone igata, Quoy et Gaim.) is a distinct speeies. Being anxious to determine the point for myself, I lately paid a visit to Paris and examined the type. I was unable to find any eharaeter by which it eould be distinguished from the common speeies. It is appareutly a young bird with soft plumage; there is no tinge of yellow on the underparts, and the dark grey of the upper surface is somewhat suffused with brown *

Strictly speaking, aeeording to this view, Gerygone igata ought to take the place of Gerygone flavicentris, owing to its priority over the latter; but, in the first plaee, the name is a barbarous one and objectionable on that account, and, secondly, I am unwilling to disturb a name that has been in general curreney for close upon fifty jears.

The two forms of nest above alluded to were thus described in my "Essay' (p. 9):--"That of the smaller species is a compact little nest, mensuring about 6 inches by 3.5 . It is 'bottle-shaped,' full and rounded at the base, and tapering upwards to a point, by whieh it is suspended. It is composed of a variety of soft materials--spiders' nests, dry moss, grass, vegetable fibres, \&c. The spiders' nests eonsist of a soft silky substance, by the aid of whielı the materials eomposing the nest are woven into a compaet wall, with a smooth and finished exterior. The entrance, which is situated on the side of the nest, is so small as barely to admit the finger, and it is protected from the weather by a rery ingenious eontrivance. It is surrounded by a protecting rim or ledge, eomposed of extremely fine roots interlaced or loosely woven together and firmly secured to the groundwork of the 11est. 'This facing is arched at the top so as to form a vestibule or porch, while at the base it stands out boldly from the wall, and is nearly an ineh in depth, thus furnishing a firm and seeure threshold for the bird in its passage to and from the eell. The interior apartment or cavity is abont two inches deep, and is thiekly lined with soft feathers; and the nest forms altogether a well-proportioned and symmetrieal structure, testifying alike to the skill and industry of the modest little builder. The nest of the other species is of a somewhat similar size; but it is fuller in the middle than the one described, and is pear-shaped towards the apex instead of tapering. The materials composing it are of coarser texture, there is less execution or finish about it, and the ingenious poreh, the peenliar feature of the one, is altogether wanting in the other."

A speeimen of the nest, with a poreh entranee, in Dr. Sisson's possession, measures nine inches, and is produced downwards to a point, instead of being rounded as in the typieal examples.

* Having given the result of my own cxamination of the type of Gerggone igata, I think it is only right to quote, in full, the conelusion in an opposite direction arrived at by Mr. Sharpe, in his notes to the 'Voyngo of the Lrebus and Terror,' pp. 25, 26:- "During a recent visit to Paris I examined, in company with Dr. Oustalet, tho type of this species, which still exists in the Jardin des Plantes. ...... We eompared the type with Dr. Buller's figure and with tho specimens of Gerygone faviventris and we could not believe that the two species were identical. I take the following observations from my note-book:- ' It is very elose to G. flaviventris, bnt instead of being grey on the throat, the latter is whitislı washed with yellow, a shade of which is also apparent on the eheeks; sides of the breast washed with brown; abdomen whito, the flanks washed with rellow. Wing 1.95 inch, tarsus '75.' The tail is imperfect, but on the feathers which romain tho whito spot is decidedly more correctly doseribed as terminal instead of subterminal. I mention this latter observation à propos of the following remarks made by Dr. Buller in his great work: 'In some examples tho measurements are slightly larger, there is an absenco of the yellow tingo on the abdomen, and the white spot on the lateral tail-feathers is terminal.' The Inst-niamed author does not secm to allow these differences to be specific; but I think that further investigation by the field-observers in New Zealand may prove G. igata to be a good species, and I leave the matter in thcir hands." On the other hand, Dr. Finsch, in a letter to myself, stated, as the result of an independent examination:- " It will interest you to hear that the epecimen of the so-called Gerygone igata in the IIuseum at Paris is positively Gerygone flaviventris." 
As I have previously pointed out, in a communication to the Wellington Philosophical Society (November 12,1870), among the substances used as building-materials by this bird, spiders' nests are always eonspicuous; indeed, in some specimens, the whole exterior surface is covered with them. The particular web chosen for this purpose is an adhesive eocoon of loose texture and of dull green colour. These spiders' nests contain a cluster of flesh-coloured eggs or young; and in tearing them off the bird necessarily exposes the eontents, which it eagerly devours. Thus, while engaged in collecting the requisite building-material, it finds also a plentiful supply of food-an economy of time and labour very necessary to a bird that requires to build a nest fully ten times its own size, and to rear the Cuekoo's offspring in addition to its own. Curiously enough, the bird uses only the greencoloured nests of Epeira verrucosa, and rejects the orange-coloured nests of E. antipodiana. I think this may be explained on the prineiple of assimilative or protective eolouring. Dry freshwater algxe are sometimes used for binding the exterior and giving additional firmness to the structure.

In the Canterbury Muscum there is a beautiful nest of this species, composed almost wholly of sheeps' wool intermixed with soft dry leaves. It is almost globular in shape, with the entrance near the top, and is lightly suspended from a branch of Leptospermum. There is also another of much larger size, composed of wool and spiders' nests, with fragments of eotton and twine carefully interwoven, and furnished with a hoodless vestibule or porch, eomposed of fibrons rootlets; the threshold is unusually deep and firm, probably because of the very yielding materials of which the nest is built.

Anothcr series presents some eurious departures from the normal type, showing that the exact form of the nest is often the result of accident, the strueture being adapted to the materials of which it happens to be composed and to the circumstances of its location. The subjoined woodcuts may help to illustrate the subject. Fig. 1 represents a nest of larger size than usual, and of a long elliptical shape, which exhibits the uncommon feature of several soft Emu-feathers, workerl into the felting among the other building-materials. Fig. 2 shows a nest of the ordinary form, ornamented with the long dry leaves of the red gum (Eucalyptus rostrata), around and among which the neat strueture is most cleverly built. In fig. 3 there is a manifest departure from the typical charaeter exhibited in fig. 4. Lastly, fig. 5 shows the eondition of the nest after the young Cuekoo usurper has pulled it out of shape and symmetry. Four is the normal number of eggs, although there are sometimes six. They differ somewhat in size; and in shape are ovoido-eonical or slightly pyriform. They are sometimes pure white, but more generally freckled and marked with purplish brown, and are so fragile in texture as to bear only the most delieate handling. Ordinary specimens measure $\cdot 7$ of an ineh in length by $\cdot 5$ in breadth. I have remarked that among the highly variable eggs of this species several distinct types may be recognized, and that all the eggs in one nest are invariably alike. Thus there is the spotted variety, in which the whole surfaee is studded with seattered dots of purplish brown; seeondly, the freekled variety, in whieh the coloration is more diffuse; and, thirdly, the zoned variety, presenting a broad zone of colour near the thick end. Two examples, taken from a nest which eontained also an egg of the Shining Cuckoo, had the thick end broadly capped with reddish brown.

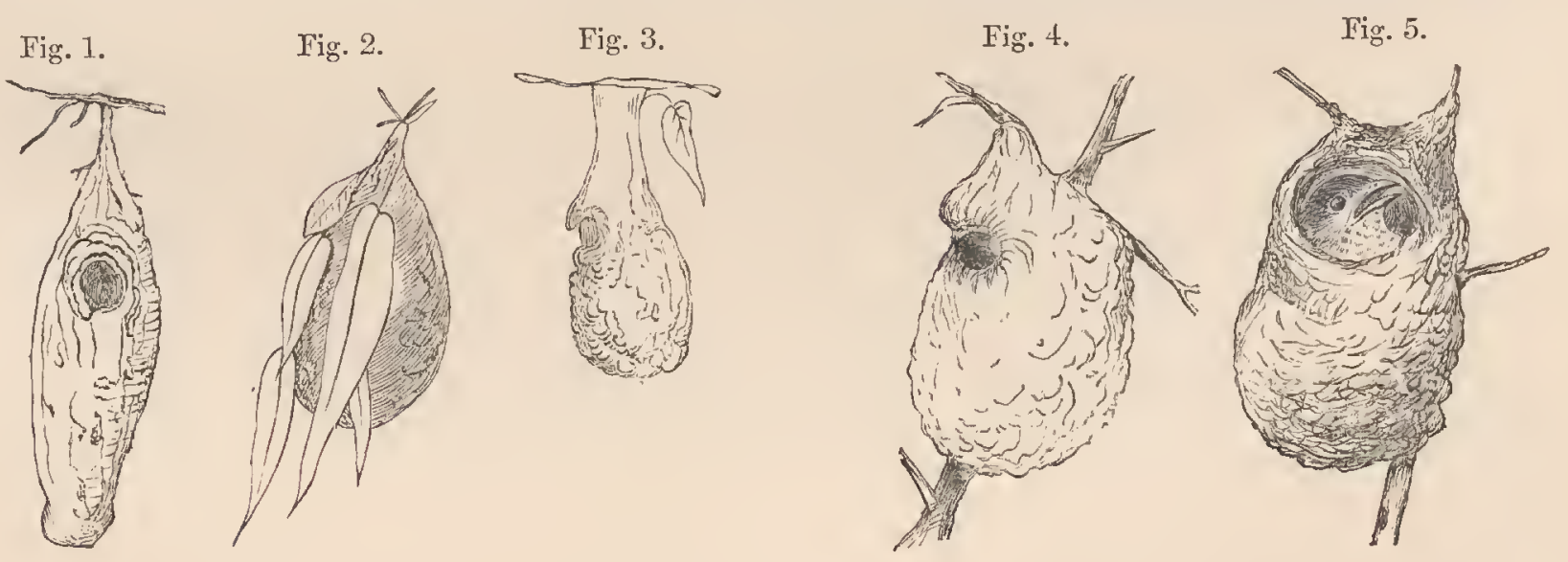




\title{
GERYGONE ALBOFRONTATA.
}

\author{
(CHATHAM-ISLAND WARBLER.)
}

Gerygone? albofrontata, Gray, Voy. Ereb. and Terror, p. 5, pl. 4. fig. 2 (1844).

Acanthiza albofrontata, Gray, Hand-1. of B. i. p. 219 (1869).

Ad. suprà olivaseenti-brunneus, pileo obseuriore, uropyģio et supraeaudalibus` læetè et conspieuè rufeseenti-fulvis : teetrieibus alarum et remigibus eineraseenti-brunncis, dorsi eolore limbatis: reetrieibus cineraseentibrunneis, versus apicem purpuraseenti-nigris et fasciâ fulveseente transversim notatâ, pennis duabus centralibus reliquorumque apieibus omninò cinerascenti-brunncis : fronte, supcreilio et faeie laterałi albidis, loris et regione parotiê̂ brunneo notatis : subtùs albicans, abdomine imo et lypochondriis flavicantibus : subeaudalibus et tibiis fulvis : subalaribus albieantibus flavido lavatis : iride eruentatâ : rostro brunneo, gonyde pallidiore: pedibus saturatè brunneis.

Adult male. Upper surfaee rusty brown, lighter on the wings and rump; the whole of the plumage plumbeous beneath ; forehead, sides of the head, fore neek, breast, and the underparts generally greyish white, tinged with yellow on the flanks and abdomen; an obseure streak of dusky brown passes through the eyes; wingfeathers dusky brown, with lighter shafts, margined on their outer webs with yellowish brown; inner lining of wings yellowish white; tail-feathers rusty brown, tinged with rufous towards the base, darker brown in their apieal portion, with the tips paler; the two ontermost feathers on each side with a broad subterminal bar of fulvous white, and the two sueeeding ones with an obscure triangular spot of fulvons white on the inner webs; upper tail-eoverts rufous-brown. Irides blood-red; bill and feet blaekish brown. Total length $5 \cdot 75$ inehes ; wing, from flcxure, $2 \cdot 6$; tail 2.5 ; bill, along the ridge $\cdot 4$, along the edgc of lower mandible $\cdot 5$; tarsus $\cdot 9$; middle toe and elaw $\cdot 65$; hind toe and elaw $\cdot 65$.

Female. Similar to the male, but slightly smaller, and without the yellow tinge on the underparts.

Obs. In my former edition, under the head of Gerygone albofrontata, I observed :- "I have never met with this bird in New Zealand; but it is highly probable that the supposed new species of Gerygone lately observed by Mr. Potts and his son in Westland, of which an aceount will shortly appear in 'The Ibis,' will prove to be the same." As Professor Hutton, however, has sinee pointed out (Traus. N.-Z. Inst. vol. v. p. 2222), "Mr. Potts's speeimen, as he deseribes it, differs from G. albofiontata, not only in the abscnce of the white forehead, but also in the dark eolour of the wings, in having the two eentre tail-feathers black, and in the chin, cheeks, and breast being grey ; in all which respects it agrees witl Gerygone flaviventris."

THIS fine species was originally described and figured by Mr. G. R. Gray, in the "Voyage of the Erebus and Terror,' from a specimen alleged to have been "brought by Dr. Dieffenbach from New Zealand." The specimen itself, however, which is now in the British Museum, is labelled as from the Chatham Islands, whence other examples have since been obtained. Mr. Henry Travers reports that he met with it on all the islands of the group, although it is by no means common. He observed that it had much the same habits as the New-Zealand species. T'he nest of this bird is similar to that of Gerygone flaviventris; but with a larger aperture, and without any threshold projection, although the upper edge is overhanging. The green-coloured nests of the meadow-spider (Elpeira) are nsed among the building-materials, and likewise the white cocoons of some ground species, which I have not been able to identify. The eggs (of which I have three specimens) are slightly oroido-conicul, measuring .75 inch in length by 55 in breadth; pinkish white, marked over the entire surfare with minute specks and linear freckles of reddish brown, which coalesce and form a cap at the larger end. 


\title{
GERYGONE SYLVESTRIS.
}

\author{
(BUSH-WARBI,ER.)
}

Gerygone sylvestris, Potts, Trans. N.-Z. Inst. 1872, vol. v. p. 177.

Ad. ô similis G. flaviventri, sed suprà saturatior : teetricibus alarum nigris, extùs flavido lavatis: remigibus brunncis, cxtùs flavido lavatis : subalaribus albidis : caudâ brunncê, nigro conspicuè transfasciatî, rectrieibus duabus mediis nigris brunnco terminatis, duabus cxternis albidis conspicuè transfasciatis ct brunneo terminatis : supracaudalibus schistaeeo-nigris, flavido terminatis : rostro nigro, versus apicem flavicantc: pedibus nigris, plantis flavicantibus : iride cruentatâ.

Adult male. "Upper surface dark olivaceous; wings smoky black, exeept first two feathers, outer wcbs fringed with ycllow; ehcek dark grey, darkest in a line from the gape through the eye; chin grey; neck and breast pale grey; abdomon white; under wing-eoverts white; upper wing-coverts brown, margined with yellow; upper tail-coverts slaty blaek, tipperl with yellow; tail brown, with a broad band of black, two centre feathers black, tipped with brown, four feathers on each side tipped with white on inner webs, pale brown on outer web, two outer feathers broadly barred with white, tipped with brown. Bill blaek; both mandibles horn-colour at the point; legs and fcet blaek; inside of feet ycllowish flesh; irides bright bloodred. Bill, from gape, 6 lines; wing from flexure 2 inches; tail 2 inehes 2 lines; tarsus 9 lincs ; middlc toe and claw 5 lines; total length 4 inches 5 lines. Male bird killed in full song, Dec. 20." (Potts.)

TIIE above Warbler, of which unfortunately no specimen exists in any collection, by which to test its value as a species, was first made known by Mr. T. H. Potts, who described it as above in a communication he made to 'The Ibis' in 1872 (p. 325), but without then proposing any name for it. Hc afterwards characterized it, under the name of Gerygone Alaviventris, in the 'Transactions of the New-Zealand Institute '; and, never having seen the bird, I have quoted his description of it.

The following is the account he gives:- "Whilst journeying in the dense bush which clothes the western slopes of the Middle Island, making acquaintance with the Kiwi and Kakapo, the note of a bird was heard that was new to us; it was evidently that of a Gerygone, but differed much from that of our familiar gully-haunting Warbler. The habitat was unusual, in the thick bush, between the bluff of Okarito and Lake Mapourika; whereas our little Riroriro delights in trilling from the shrubs on the creek-side or more open country, or in flitting about the bushy vegetation of the gullies that fringe or form the outskirts of a forest. Neither my son, who accompanied me, nor myself had ever heard a similar note. For the next fer days, whilst rambling in that locality, we heard the same note repeatedly, and saw the birds, but we never observed one of them on the outside of the bush."

Possibly to this species belongs the alpine bird mentioned by Mr. Reischek in a letter to myself, as having been met with by him during his trip to the west-coast sounds in search of Notornis :"At Dusky Sound (on the 2nd July, 1884) I ascended one of the heavily wooded ridges, and on arriving at the top $I$ heard a new bird. It was out of sight in the folinge of a tree, and got away before I could get a glimpse of it. Its call consists of three notes, like di-di-di, repeated several times. I went in search of it again but without success. I have been exploring in the NewZealand forests for the last eight years and am familiar with all the birds' notes; but this one was quite new to me, and was evidently produced by some small bird which I have not yet seen." 


\section{CERTHIPARUS NOVE ZEALANDIE.}

(NEW-ZEALAND CREEPER.)

New-Zealand Titmouse, Lath. Gen. Syn. ii. pt. 2, p. 558 (1783).

Parus nove seelandia, Gm. Syst. Nat. i. p. 1013 (1788, ex Lath.).

Parus novee zealandice, Lath. Ind. On. ii. p. 571 (1790).

Parus zelandicus, Quoy \& Gaim. Voy. de l'Astrol. i. p. 210, pl. xi. fig. $3 *$ (1830).

Certhiparus nova zelandice, Lafr. Rev. Zool. 1842, p. 69.

Certhiparus novae seelandia, Gray, in Dieff. Trav. ii., App. p. 189 (1843).

Certhipains maculicaudus, Gray, op. cit. ii. p. 189 (1843).

Parus urostigma, Forst. Descr. Anim. p. 90 (1844).

Certhiparus nova zealandice, Finsch, J. f. O. 1870, p. 254.

\section{Native names.-Pipipi and Toitoi.}

o suprà choeolatino-brunneus, pileo pantlulum obseuriore: facie laterali nuehâque cincraseentibus: teetrieibus alarım dorso eoneoloribus: remigibus brunneis, primariis extìs angustè fulveseente limbatis, secundariis latiùs dorsi eolore lavatis : caudâ rufescenti-choeolatinâ, reetrieibus (duabus mediis exeeptis) faseiâ nigrâ transnotatis: subtùs rufescenti-albns, corporis lateribus et teetrieibus subeaudalibus ehoeolatino lavatis: rostro et pedibus pallidè brunneis, unguibus fulveseenti-brunneis : iride saturatè brunneâ.

q mari omninò similis.

Juv. vix ab adultis distinguendus, sed magis vinaceo tinetus.

Adult. Fore part of hearl, erown, back, rump, and upper surfaee of wings bright cinereous brown, inclining to rufous; quills light brown, the outer webs tinged towards their base with rufous; tail-feathers pale rufous, and, with the exeeption of the two middle ones, erossed on their inner web, about lialf an inch from the tip, with a broad band of black; sides of head and nape einereous grey ; throat, breast, and abdomen rufouswhite. Irides grey; bill, tarsi, and toes pale brown; claws lighter brown. Total leugth 5.25 inches ; extent of wings 6.75 ; wing, from flexure, 25 ; tail 26 ; tarsus 75 ; bill, along the ridge $\cdot 5$, along the edge of lower mandible $\cdot 6$; middle toe and elaw $\cdot 6$; hind toe and claw $\cdot 6$.

Young. Plumage as in the adult, but suffused with vinous brown.

Obs. The sexes are alike, both as to size and colouring.

Remarks. I earefully examined, with the late $\mathrm{Mr}$. G. R. Gray, tlie examples in the British Museum on which he had founded lis distinetion between Certhiparus nove zealandice and C. maculicaudus. The individual differenees wcre trivial, and I felt perfeetly satisfied that the new speeies eould not be maintaiued-a eonelusion in whieh Mr. Gray coneurred.

* In the "Voyage de l'Astrolabe ' there is a figure intended to represent this bird, under the title of "Mésange de la Nouvelle Zélande;" but without the descriptive text it would be quite impossible to idcntify the species, the drawing being very defeotive and the eolouring incorreet. 
This lively little species is confined to the wooded parts of the South Island*. I met with it in Nelson and in Otago, but more abundantly in the Canterbury provincial district. On Banks Peninsula I found it particularly numerous, but I was never able to discover its nest.

Like the other members of the group to which it belongs, it is a gregarious species, associating together in small flocks, and hunting diligently for its insect food among the branches and dense foliage of the forest undergrowth. On being disturbed or alarmed they quickly assemble and chirp round the intruder for a few minutes; and on being reassured they disperse again in search of food.

One of their ordinary notes is not unlike the cry of Creadion carunculatus, although, of course, much feebler.

I have seen them consorting with the Yellow-head in the low underwood, owing doubtless to a community of interest, their habits of feeding being very much the same. They seem to prefer the outskirts of the bush, where insect-life is more abundant; but they are also to be met with in the thick forest.

During severe seasons it has been known to leave the shelter of the bush and to frequent the sheep-stations, flitting about the meat gallows and picking off morsels of fat from the bones and skins of the butchered aninals, exactly after the manner of Zosterops under similar circumstances.

In the stomachs of those I examined I found the scale-insect, with minute coleoptera, diptera, and their larvæ, all testifying to the strictly insectivorous character of the bird. The ovary of one which I opened on November 3 contained a small cluster of eggs, the largest being of the size of buck-shot, indicating a late nesting-season.

A nest of this species in the Canterbury Museum is of a rounded form, with a slightly tapering apex, and not unlike a. large pear in shape. The structure is composed of dry vegetable fibres, fragments of wool, moss, spiclers' nests, and other soft materials closely felted together. The entrance is placed on the side, about one third distant from the top, and is perfectly round, with smoothened edges. The interior cavity is decply lined with soft, white, pigeon feathers $\uparrow$. It will be seen, therefore, that the nest of this species shows its affinity to Gerygone rather than to Clitonyx, with which it is associated in the British Museum Catalogue (vol. viii.). I have grouped the birds together on one Plate merely for the sake of artistic convenience.

This bird breeds late in the year, for the nest just mentioned was found far above the Rangitata gorge, in the month of December, and contained three nestlings. Mr. Potts reports that it was "placed in a black-birch between the trunk and a spur, from whence sprouted out a thick tuft of dwarfed sprays, about seven feet from the ground." He says that it usually lays three eggs and that he has a note of finding the young in the nest as late as December 25 th.

There are two eggs of this bird in the Otago Museum. They are broadly ovoido-conical, measuring $\cdot 7$ of an inch in length by $\cdot 6$ in breadth, and white with small purplish and brown spots, which run together and form a zone round the larger end.

* Captain Hutton, writing from Auckland, in the North Island, stated, in a letter to 'The Ibis' (1867, p. 379), that Certhiparus novce zealundice is "one of the commonest birds in tho bush about here;" but he was evidontly confounding this bird with some other speeies, probably Clitony.x albicapilla, at that time common enough. He repeated, in his "Catalogue of the Birds of Now Zealand ' (published in 1871) that Certhiparus nove zealandie inhabits " both islands; " but this is undoubtedly an error. I have uever heard of the oceurrence of this bird, even as a straggler, in any part of the North Island.

† Cf. Trans. N.-Z. Instit. 1872, vol. v. pl. 37. 


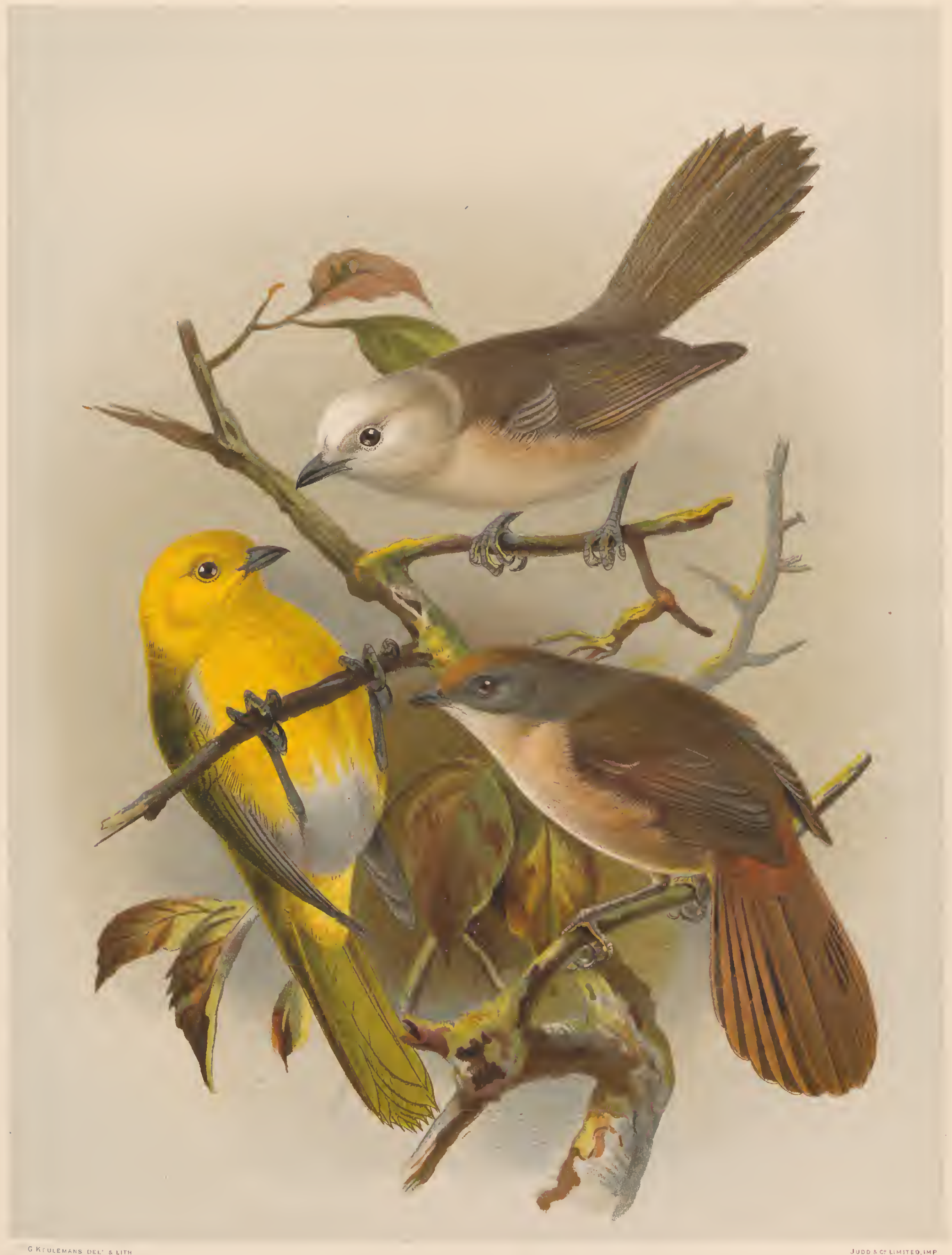





\section{CLITONYX ALBICA PILLA*.}

(THE WHITE-HEAD.)

Fringilla albicilla, Less. Voy. Coq. i. p. 662 (1826).

Parus senilis, Dubus, Bull. Acad. Roy. Brux. vi. pt. 1, p. 297 (1839).

Certhiparus senilis, Lafr. Rev. Zool. v. p. 69 (1842).

Certhiparus albicillus, Gray, Voy. Ereb. and Terror, p. 6 (1844).

Certhiparus cinerea, Ellman, Zool. 1861, p. 7465.

Mohoua? albicilla, Gray, Ibis, 1862, p. 220.

Orthonyx albicilla, Finsch, J. f. O. 1870 , p. 253.

Orthonyx albicilla, Buller, Birds of New Zealand, 1st ed. p. 101 (1873).

Certhiparus albicillus, Gadow, Cat. Birds Brit. Mus. vol。 viii. p. 75 (1883).

\section{Native names.}

Popotea, Poupoutea, Popokotea, and Upokotea.

$A d$. pileo undique et pectore supcriorc albis : dorso toto brunneo, supracaudalibus pallidioribus : tectricibus alarum dorso coneoloribus: remigibus saturatè brunneis, extùs dorsi colore lavatis, primariis paullò pallidiùs limbatis : pogonio interno flavieanti-albo marginato : caudâ flavicanti-brunneâ : pectore medio fulveseenti-albo : eorporis lateribus brunneis, dorso coneoloribus : subalaribus albis, brunneo lavatis : rostro nigro: tarso et pedibus plumbeseenti-nigris, plantis pallidioribus, unguibus brunneis : iride nigrâ.

Juv. vix ab adultis distinguendus, sed coloribus dilutioribus et pileo brunneo lavato.

Adult male. Head and neek all round, breast, inner face of the wings, and middlc of the abdomen white, sliglitly tinged with brown; sides of the body and flanks pale vinous brown; the whole of the baek, rump, and upper surface of wings vinous brown, paler on the upper wing-coverts; quills blackish brown, the primaries narrowly margined on their outer webs with grey, and more broadly on their inner webs with yellowish white; tail-feathers and their coverts pale yellowish brown on their upper aspect, sometimes tinged with rufous, the shafts darker; paler on the under surface, with white shafts. Irides blaek; bill and rictal bristles blaek; tarsi and toes bluish blaek, with paler soles and brown elaws. Total lengtl 6.5 inehcs; extent of wings, 8.4 ; wing, from flexure, 2.9 ; tail $2 \cdot 75$; bill, along the ridge 4 , along the cdgc of lower mandible $\cdot 5$; tarsus 1 ; middle toe and claw $\cdot 8$; hind toe and elaw $\cdot 6$.

Female. Similar to the malc but somewhat smaller. Total lengtl 6 inclies; extent of wings $7 \cdot 75$; wing, from flexure, 2.6 ; tarsus 9 ; middle toe and claw $\cdot 6$.

Obs. In the malc bird the palate and soft parts of the mouth are black, and in the femalc flesh-coloured.

Young. Upper parts palc vinous brown, whitish on the head; tliroat and underparts greyish white, shading into brown on the sides; wings tinged with yellow on their inner edges.

* Acting on Professor Newton's suggestion, I haro substituted allicapilla for albicilla; for the bird is white-headcd and not white-tailed, and I cannot belicve that Lesson ever intended to apply tho latter name to it. Although it has hitherto been the practice to use it, I think $I$ am justified in rectifying what was obriously a lapsus calami. 
MY account of this species in the former edition of this work commenced thus :- "This interesting little bird is distributed all over the North Island, but is replaced in the South by a representative species, the Orthonyx ochrocephala or Yellow-head. It frequents all wooded localities, but seems to prefer the outskirts of the forest and the low bush fringing the banks of rivers and streams. It is gregarious in its nature; and the report of a gun, the cry of a Hawk, or any other exeiting eause will instantly bring a floek of them together, produeing a perfeet din with their loud ehirping notes. It is a curious or inquisitive bird, following the intruder as he passes through the bush, and watehing all his movements in a very intelligent manner. If he remains stationary for a few moments, it will peer at him through the leaves with evident euriosity, and will hop gradually downwards from twig. to twig, stretching out its neek and ealling to its fellows in a loud chirp, and approaching the object of this scrutiny till almost within reaeh of his hand."

But alas! what of the Popokotea in this year of grace 1887? In the interesting aceount which Mr. Reischek has furnished me of a collecting tour he made through almost every part of the island lying to the north of Hawke's Bay, he says:- "I found one pair of Orthonyx albicilla on Castle Hill, Coromandel, one pair in the Pirongia ranges, Waikato, and one pair in the Tuhua ranges, near Mokau; that was all." So this is the rapid fate of the pretty, noisy, little White-head, once the commonest bird in all our northern forests!

Even five years ago it was quite plentiful on Te Iwituaroa, at the north-east extremity of the Kuranui-whaiti range in the Waikato district; but now it has disappeared entirely. It is still numerous on the island of Kapiti in Cook's Strait, and on the Little Barrier; but, strange to say, it no longer exists on the Great Barrier, Kawau, the Hen and Chickens, or indeed, so far as I am aware, on any of the other islands in the Hauraki Gulf. The only localities on the mainland in whieh I have met with it of late are the wooded hill-tops in the Upper. Wairarapa district, and a elump of busl near the Owhaoko station in the Patea eountry, at a considerable elevation above the sea. It has a simple but very melodious song, some bars of it reminding one of the musical notes of English birds. Its loud clirp is not unlike that of the House-Sparrow, but sharper.

Its food eonsists of insects and minute seeds. It is very active in all its movements, flitting about among the leafy branches and often ascending to the lofty tree-tops; clinging by the feet head downwards, and assuming every variety of attitude as it prosecutes its diligent search for the small inseets on whieh it principally subsists. I have frequently observed it inserting its beak into the flower of the Metrosideros, either for the purpose of extracting honey, or, as is more likely, to prey on the insects that are attracted by it. I have also known them occasionally eaught on the tuke baited with these flowers to allure the Tui and Korimako, which are genuine lioney-eaters.

I have found scores of nests of this species, and have made frequent but ineffectual attempts to rear the young in a eage. The nest is usually fixed in the fork of a low shrubby tree, frequently that of the Ramarama (Myrtus bullata), and is always so placed as to be well coneealed from observation. It is a round, compaet, and well-construeted nest, being composed of soft materials, such as moss, diy leaves, spiders' nests, shreds of native flax, and sometimes wool, all firmly knit together. The cavity is deep and well rounded, the walls being formed of dry bents and vegetabie fibres, and thickly lined with soft feathers. The lip or outer edge of the nest is earefully bound in with these fibres, sometimes mixed with spiders' webs, and often presenting a high degree of finish. 'The eggs are usually three in number, but sometimes four; they are of proportionate size, measuring $\cdot 8$ of an ineh in length by 6 in breadth, rather rounded in form, and with a shell of very delicate texture. They are creamy white, minutely speekled or marbled over the entire surface with reddish brown, the markings being denser towards the thick end, where they somctimes form an irregular zone. During incubation the hen bird sits closely, and leaves the nest with reluctance, almost permitting herself to be touched by the hand before quitting it. 
I have before me now a beautiful nest of this species, which was taken on the Little Barrier in Deeember, and contained three young birds. It is almost spherical, exeept at the top, whieh is flattened, measuring in its largest part 4 inches by 3 ; and its structure is very close and compact, all the materials eomposing it being well felted together; the eup or cavity is rather deep and rounded with an overhanging lip, the erges being very closely bound and interlaced; and the opening measures just two inehes in diameter. The nest is eomposed of many eoloured mosses and lichens, dry leaves, grasses, vegetable fibres, and here and there a feather closely interwoven with the web; and the interior is lined with fine grass-bents and a few feathers.

For the rapid disappearance of our indigenous birds it is hard to assign any special cause. The introduced rat is undoubtedly an important factor in the business by preying on the eggs and young of suel speeies as habitually nest in places accessible to them; but we ean hardly account in this way for the almost total disappearanee of the pert little White-head, once the commonest denizen of our woods. The introdneed bee gets a share of the blame in the ease of honey-eating and treehole nesting birds, like the Korimako and Stitch-bird on the one hand, and the Kaka and Parrakeet on the other; but with eren less probability than the Norwegian rat ean this agent be eredited with the destruetion of the White-hcad. The disappearanee of the Quail we are accustomed to attribute to the introduetion of sleep and the prevalence of tussoek fires; the diminution of the Wild Duek to the extensive draining-operations of the farmer ; and the thinning of the Wood-Pigeon to the wholesale slanghter of these birds by both Eurrpeans and natives, and in some distriets without cessation all the year through. But we find it extremely difficult to discover any suffieient reason for the wonderfully rapid extinction of the White-liead, or Popokatea, in most parts of the island. No doubt it is due to a variety of causes, operating with more or less foree, all round, and thus furnishing another illustration of what appears to be an almost universal natural law- that indigenous forms of animal and vegetable life sooner or later succumb to, and are displaced by, more vigorous types from without. As the Maori is being rapidly supplanted by his Anglo-Saxon neighbour, as the rat has exterminated and replaeed the kiore maori, as the native fern and other herbaceous vegetation disappears in all directions before the spreading grass and elover of the eolonist, so in like manner the native birds, or at any rate many of the well-known speeies, are giving place to the ever-increasing numbers of Sparrows, Linnets, Greenfinehes, Yellowhammers, Starlings, and other introdueed birds that are now to be met with in every part of the eountry.

On the other hand, how are we to aceount for the almost total disappearanee of the introdueed Pheasant from the Waikato and other districts, where a few short years ago they were exeessively abundant, proving almost a plague to the farmers and Maori eultivators? Some aseribe it to the Hawks, but these were always as numerous as they are uow ; some to poisoned wheat laid for rabbits, but the Pheasant has disappeared from districts where there are no rabbits, and eonsequently no poisoned wheat. Others belicve that the native Woodhen is responsible for the ehange; but the habit of feasting on Pheasants' eggs, whenever it gcts the ehanee, is by no means a newly acquired one with this bird. Doubtless there are agencies at work of which at present we have no knowledge. The faet nevertheless remains, and is quite as inexplicable as in the case of some of our indigenous birds.

For my own part, I deplore very mueh this displacement of the natural Avifauna, whieh appears to be almost ineritable, because many interesting types will disappear for ever. Efforts are being made to save some of them by means of island reserves, but I fear the task is a hopeless one. All therefore that remains to us now is to reeord their history as fully and minutely as possible for the benefit of seience. This I shall endeavour to aeeomplish in the present work, deseribing faithfully their habits of life, and omitting nothing that may seem likely to prove of interest or value to the student of the future. 


\title{
CLITONYX OCHROCEPHALA.
}

\author{
(THE YELLOW-HEAD.)
}

Yellow-headed Flycatcher, Lath. Gen. Syn. ii. p. 342 (1783).

Muscicapa ochrocephala, Gm. Syst. Nat. i. p. 944 (1788, ex Lath.).

Certhia heteroclites, Quoy \& Gaim. Voy. Astrol. i. pl. 17. fig. 1 (1830).

IF́houa hua, Less. Compl. Buff. ix. p. 139 (1837).

Orthonyx icterocephalus, Lafr. Rev. Zool. 1839, p. 257.

Orthonyx heteroclitus, Lafr. Mag. de Zool. 1839, pl. 8.

Mohoua ochrocephala, Gray, List of Gen. of B. p. 25 (1841).

Muscicapa chloris, Forst. Descr. Anim. p. 87 (1844).

Orthonyx ochrocephala, Gray \& Mitch. Gen. of B. i. p. 151, pl. 46 (1847).

Orthonyx ochrocephala, Buller, Birds of New 'Zealand, 1st ed. p. 103 (1873).

Certhiparus ochrocephalus, Gadow, Cat. Birds Brit. Mus. vol. viii. p. 76 (1883).

\section{Native names.}

The same as those applied to the preceding species: "Canary" of the colonists.

$A d$. pileo undique et corpore subtùs læè̀ eitrinis, nuehâ vix olivascente, abdomine imo eum eruribus erissoque cineraeeis : dorso toto olivaseenti-brunneo, flavido lavato, uropygio eonspieuè læetiore flavo: teetricibus alarum et supraeaudalibus olivaceo-flavis, illarum majoribus saturatioribus, potiùs olivaceo-viridibus : remigibus brunneis, extùs dorsi eolore lavatis, primariis cano limbatis, pogonii interni margine lætè flavieante : eaudâ olivaeeo-flavâ, subeaudalibus et subalaribus olivaeeo-flavis, his albido lavatis : rostro nigro: pedibus nigris, unguibus saturatè brunneis : iride nigrâ.

o mari similis, sed coloribus obscurioribus.

Juv. similis adulto, sed pilco et nuehâ olivascente lavatis.

Adult male. Head and breast, sides of the body, and upper part of the abdomen bright eanary-yellow ; shoulders, baek, and upper surfaee of wings yellowish brown, with an olivaceous tinge; upper surface of tail and the outer margins of the secondary quills dark olivaceous yellow; the eolours are blended where they meet, the nape being more or less mottled with yellowish brown; lower part of abdomen greyish white; thighs and flanks pale brown; upper and lower tail-eoverts yellow; the whole of the plumage dark plumbeous at the base. Irides blaek; bill and feet black; elaws dark brown. Total length 6.75 inehes; extent of wings 9.5 ; wing, from flexure, $3 \cdot 25$; tail 2.75 ; bill, along the ridge $\cdot 5$, along the edge of lower mandible $\cdot 7$; tarsus 1 ; middle toe and elaw 87 ; hind toe and elaw $\cdot 75$.

Female. Similar to the male, but with the tints of the plumage generally duller.

Young. The young bird differs from the adult in having the yellow plumage tinged with olivaceous, espeeially on the erown and nape, where the latter eolour predominates; rietal membrane yellow.

Obs. The shafts of the tail-feathers are often found denuded at the tips. During the breeding-season the testes are enormously developed, attaining to the size of small marbles. 
THIS bright-coloured bird is the southern representative of Clitonyx albicapilla. Its range is confined to the South Island, wherc it is quite as common as the preccding species formerly was in the North. A narrow neck of sea completely divides their natural habitat-a very curious and suggestive fact, inasmuch as this rule applics equally to several other representative species treated of in the present work.

The habits of this bird are precisely similar to those of its northern ally; but it is superior to the latter in size and in the richcr colour of its plumage, while its notcs are louder and its song more varied and musical. A flock of these Canary-likc birds alarmed or excited, flitting about among the branches with much chirping clamour, and exhibiting the bright tints of their plumage, has a very pretty effect in the woods. Even under ordinary conditions it is very pleasing to watch their movements. Hopping from twig to twig, and calling to each other almost continuously in a short clcar notc, they pass quickly through the branchcs, moving the body deftly, first to one side then to the other, as they pry into every crevicc for the insect food on which they live; then, aftcr remaining stationary a few scconds, they utter a louder and morc plaintive note and fly a few yards further to repeat these movcments; and so on, all through the day, with nevcr tiring persistence. Sometimes they may be seen hunting among thc mosses and lichens that grow on the bark of old forest trees, on which occasions they will ascend the trunks in company, clinging to the hanging vines or any other projecting point, as thcy make their rapid scarch, and finally consorting togethcr in the topmost branches. Their black eyes, in a sctting of yellow plumagc, have a pretty effect, and nothing sccms to escape thcir closc scrutiny. They love to move about in the thick foliage, indicating their presence when not chirping by an audible rustling of the green leaves.

The discharge of a collector's gun, the snapping of a stick under foot, or the cry of a wounded bird, will sometimes bring a flock of forty or fifty of these bright-coloured creatures into the branches ovcrhead, wherc they move restlessly about, pecring down and chirping with noisy din, as if in eager consultation.

In all the specimens opened by me the stomach contained comminuted insect rcmains, chiefly those of minute coleoptera, and larvæ of various kinds.

A life-size drawing of this species, by Mitchell, appeared long ago in the 'Genera of Birds ;' but the attitude is unnatural, the bird being placed on the ground instead of a tree. The attitude in which Mr. Keulcmans has clepicted the bird is a highly characteristic one.

On comparing the ncst of this specics with that of Clitonyx albicapilla, it appears to exhibit more care and finish in its general construction, although composed of the same materials. It is a round and compactly built structure, composed chicfly of mosses, fclted together with spiders' webs, and having the cup lined with fine grasscs. In the specimen under examination there are a few feather's of the Tui and Parrakeet intermixed with the other materials. Mr. Potts has "sometimes found it placed in the hollow trunk of a broad-lcaf." His son found a nest containing two young birds. It was built of moss, grass, and sheep's wool, with a few feathers intermixed, and was placed in a cluster of young shoots on the sidc of a black birch, near a shephcrd's homestead.

The eggs differ in colour from those of C.albicapilla, but the type is the same. They are ovoidoclliptical in form, mcasuring $\cdot 9$ inch by $\cdot 7$ inch, although some specimens which $\mathrm{I}$ havc examined were slightly smaller. Thcy arc of a uniform reddish cream-colour, minutcly and faintly frcckled over the entirc surface with a darker tint, approaching to palc brown. In one of my specimens the entire surface is of a warm salmon-colour, without any freckled markings; and another is minutcly freckled and dotted with reddish brown, of which colour there are also some irregular smeared markings towards the smaller cnd. The last-mentioned spccimen differs also from the typical form in being almost pcar-shaped, with the thick end rather flattened, and measuring only 75 of an inch in length by $\cdot 65$ in breadth. 
As to the systcmatic position of this form, much doubt and uncertainty existed till the appearance of a paper "On the Structure of the genus Orthonyx," by the late Mr. Forbes, the Proscctor to the Zoological Society, in which he gave the results of a careful dissection and comparison of the typical Orthonyx spinicauda of Anstralia with the so-called Orthonyx ochrocephala from New Zealand *. 'This examination convinced him that the two forms arc not really congencric, the New-Zealand bird, apart from its entirely dissimilar coloration, diffcring from the Australian in its morc slender bill, less development of the nasal operculum, less spiny tail, and more slender claws. Hc states further that internally the skull and the syrinx exhibit differences, slight in amount, but greater than those usually found in birds of the same genus; and he concludes thus:- "Under these circumstances it scems that Clitonyx of Reichenbach $\dagger$ will be the correct generic term for the New-Zealand birds, as Lesson's name Mohoua, though of prior application, is not only barbarous but, what is more important, liable to be confounded with Mohoo, also a gcnus of Passeres from the Pacific Subregion. In the present unsatisfactory condition of the systcmatic grouping of the Oscinine Passeres, it is impossible for mc to point out clearly any dcfinite position either for Orthonyx or Clitonyx, though both forms might, I apprehend, bc safely placed in Mr. Sharpe's somewhat vaguely defined "Timeliidse." "

The above conclusions were based upon an examination of $C$. ochrocephala only from New Zealand. It will be seen that I have placed the North-Island form (C. albicapilla) in the same genus. I am aware that Dr. Finsch has proposed to scparatc these birds generically, and that his views have been adopted by one or two of our local naturalists. It appcars to me, however, quitc impossible to find any sufficient distinguishing characters. It will be seen, on comparison, that the wing-feathers present the same proportional arrangcment in both species, and that the bill and feet of C. albicapilla, although somewhat more slender, are formed on exactly the same model as in C. ochrocephala. Apart from these external characters, the two forms agree in other essential respects. The peculiar feature of a black mouth (in the male) is common to both; their style of song is the same; the sexes are alike in both, and their habits of nidification are very similar. It is true that the colour of the plumage is differcnt, and that there is some dissimilarity in the coloration of the eggs, but these differences have no generic value. On these grounds I adhere to my old contention $\ddagger$ that the two species belong to the same genus.

Dr. Gadow, in the 'Catalogue of the British Museum' $(l . c$.$) , while accepting this relationship$ of the two forms to each other, has groupcd them togcther with the New-Zealand Creeper in the genus Certhiparus. So far, however, from adopting this arrangement, I have dcemed it neccssary not only to separate these birds generically but to place them in different Families.

* "Both forms are typical Singing-birds ("Oscines Normales'), with a well-dereloped Oscinine syrinx with its normal complement of four pairs of muscles. Of these the short anterior musclc ruus to the anterior end of the third bronchial semiring alone in 0 . spinicauda; whilst in 0 . ochrocephala this ring reccives its muscular supply from a fasciculus of tho lony anterior muscle. They thus differ essentially from Menura, with which they have been associated, that bird having but theree pairs of muscles peculiarly arranged. In this, as in all other points examined-with one cxception in the casc of Orthonyx spinicuudathese birds quite resomble the normal Passeres, as they do in having the bilaminate tarsus and reduced 'first' (tconth) primary nearly always associated with the normal Acromyodian syrinx. Orthonyx spinicunda, howerer, has a peculiarity quite unknown to $\mathrm{me}$ in any other bird, inasmuch as its carotid artory, the left alone of these vessels (as in all Passeres) bcing dereloped, is not contained anywhere in the subrertebral canal, but runs up superficially in company wilh the left vagus nerve to near the head, where it bifurcates in the usual manner. . . . . In Orthony ochrocephula the left carotid retains its normal situation, though the point of cntrance into the canal is somewhat higher up than is usual in other Passcres." (P. Z. S. 1882, pp. 544, 545.)

+ Handb. Spec. Ornith. p. 167 (1851).

t Trans. N.-Z. Inst. vol. vii. p. 204. 


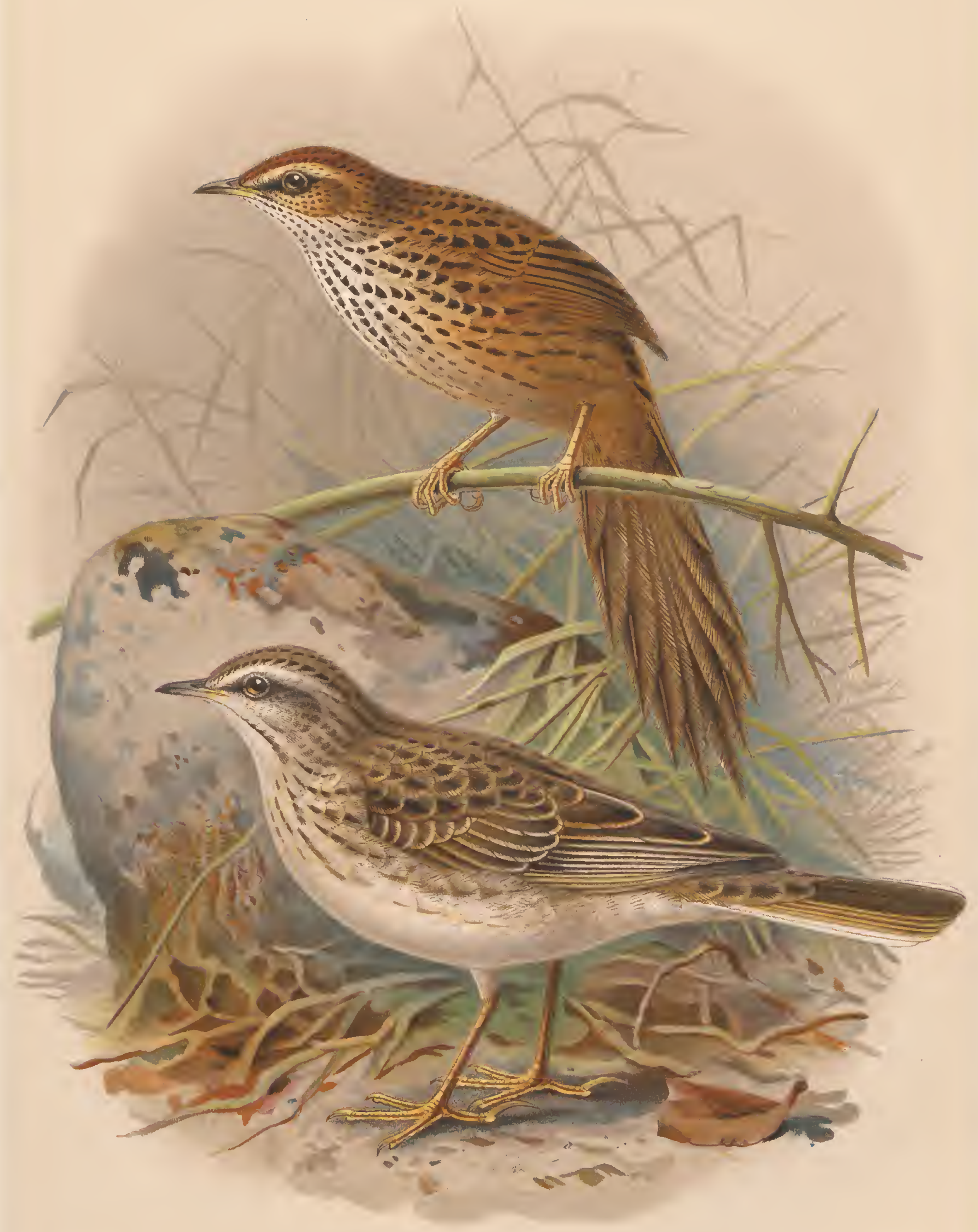

FERN-BIRD, SPHENUACUS UNCIATUS

NEW-ZEAIAND PIPIT ANTHUS NOVE \%HALAN, A 



\section{SPHEN E A C US PUNCTA T US.}

(FERN-BIRD.)

Synallaxis punctata, Quoy \& Gaim. Voy. de l'Astrol. i. p. 255, t. 18. fig. 2 (1830).

Sphenocacus punctatus, Gray, Voy. Ereb. and Terror, p. 5 (1844).

Megalurus punctatus, Gray, Gen. of B. i. p. 169 (1848).

\section{Native names.}

Mata, Matata, Kotata, Nako, and Koroatito.

Ad. suprà ochrascenti-fulvus, dorsi plumis medialiter nigris, lineas latas longitudinales formantibus : pileo rufescente, fronte immaculatâ, vcrticc angustiùs nigro striolato: loris et regione oculari albidis : facie laterali albidâ, brunneo maculatâ, regionc paroticâ brunnescente : tectricibus alarum dorso concoloribus ct codem modo mcdialiter nigris : remigibus r"cetricibusque nigricanti-brunneis, ochrasccnti-fulvo limbatis, his acuminatis, scapis versùs apicem nudis : subtùs albescens, hypochondriis et subcaudalibus ochrascenti-fulvis, latè nigro striolatis : gutture indistinctè, pectore superiore magis distinctè, brunneo punctatis et pectore laterali nig ro lineato : rostro brunnescente, mandibulâ flavicante : pedibus flavidis : iride nigrâ.

Adult. Uppcr parts dark brown, each feather margined with fulvous, shading into rufous-brown on the forehead and crown; streak over the cyes white; throat, fore neck, breast, and abdomen fulvous-white, each feather with a central streak of black, giving to the underparts a spotted appearance; wing-feathers and their coverts blackish brown, edged with bright fulvous; tail-feathers dark brown, with black shafts. Irides black; bill and feet pale brown. Total length 6.5 inches; wing, from flexurc, $2 \cdot 25$; tail 3.25 ; bill, along the ridge $\cdot 4$, along the edge of lower mandible 6 ; tarsus 75 ; middle toe and claw $\cdot 7$; hind toe and claw $\cdot 6$.

Young. The young assume the adult plumage on quitting the nest.

Obs. The tail-feathers have the barbs disunited in their whole extent.

THIS recluse little species is one of our commonest birds, but is oftener heard than seen. It frequents the dense fern (Pteris aquilina) of the open country, and the beds of raupo (Typha angustifolia) and other tall vegetation that cover our swamps and low-lying flats. In these localities it may constantly be heard uttering, at regular intervals, its sharp melancholy call of two notes, $u$-tick, u-tick, and responsively when there are two or more. When the shades of evening are closing in, this call is emitted with greater frequency and energy, and in some dreary solitudes it is almost the only sound that breaks the oppressive stillness. In the Manawatu district, where there are continuous rauposwamps, covering an area of 50,000 acres or more, I have particularly remarked this; for, save the peevish cry of the Pukeko, occasionally heard, and the boom of the lonely Bittern, the only animate sound I could detect was the monotonous cry of this little bird calling to its fellows as it threaded its way among the tangled growth of reeds.

Large portions of the North Island consist of rolling land covered with stunted brown fern, this being the characteristic feature for twenty miles at a stretch, broken only by little patches of bush in the gullies. Intersecting these fern-ridges are narrow belts of wiwi-swamp, of a dark 
grecn colour from the character of the vegetation. These beds of rushes, which form blind watercourses during the winter season, are dry in summer and are then a favourite resort for the "Swamp-Sparrow," as this bird is sometimes called. In thesc localities it may always be found, somctimes in pairs but usually singly, the habits of the species being solitary, except of course in the breeding-season. But other places also are frequented by it. As alrearly mentioned, it inhabits the raupo-swamps; and in the tangled vegetation which fringes our low-lying rivers, under a thick screen of native bramble and convolvulus, its melancholy note may frequently be heard, particularly towards nightfall. But it is never met with in the forest, or at any great clevation from the sea.

During my last visit to the Hot Lakes district, I found it still plentiful in all suitable localities. There are marshy tracts occurring at intcrvals along the road from 'laupo to Ohinemutu, and the familiar note of this little bird was the only relief to those quiet solitudes. The pairing-season had commenced, and it was most pleasant to hear the couples singing thcir simple duct, the notes being always in harmony and responsive. When excited or alarmed its cry becomes sharper, being not unlike the call "Philip, Philip!" with a short pause between.

Like the other members of the group to which it belongs, it is a lively creature, active in all its movements, and easily attracted by an imitation of its note; but, when alarmed, shy and wary. Its tail, which is long and composed of ten graduated feathers, with disunited filaments, appears to subserve some useful purposc in the daily cconomy of the bird; for it is often found very much denuded or worn. When the bird is flying, the tail hangs downwards. Its wings are very feebly developed, and its powers of flight so weak that, in open land where the fern is stunted, it may easily be run down and caught with the hand; but in the swamps it threads its way through the dense rced-beds with wonderful celerity, and eludes the most careful pursuit. When surprised or hard pressed in its more exposed haunts, it takes wing, but ncver rises high, and, after a laboured flight of from fifteen to twenty yards in a direct line, drops under cover again. Its food consists of small insects and their larvæ and the minutc seeds of various grasses and other plants.

Major Jackson, of Kihikihi, who is a keen sportsman, assurcs me that this bird has a very strong scent, so much so that when he has been out phcasant-shooting his pointer has "stood" to it quite as staunchly as if it had been a game bird.

This pretty little creature is not excmpt from the common ills that "flesh is heir to." A specimen brought to me on the 8th March presented a remarkable diseased swelling, larger than a pea, at the root of the beak. Aftcr carefully examining it, I turned the little sufferer frce, leaving Dame Nature, in this case as in others, to work out her own cure.

It is a matter of extreme difficulty to study the breeding-habits of species that resort to the dense vegetation of the swamps. Even a systcmatic search for the nests, in such localities, is of very little use, and the collector must trust to the chaptcr of accidents for opportunities of examining them. Although so common a bird, I have only once succeeded in finding the nest. This discovery was made many years ago, on the edge of a raupo-swamp, near the old Mission Station on the Wairoa river. The nest was a small cup-shaped structure, composed of bents and dry grass-leaves, not very compact, but with a smooth and carefully lined interior. It was attached to reed-stems standing together, and contained four young birds, which showed remarkable nimbleness, darting out of the ncst and disappearing in the long grass on the first moment of my approach. I have, however, heard of others, containing sometimes four eggs, sometimes three. The eggs are ovoido-conical in form, measuring $\cdot S$ of an inch in length by 6 in breadth, and are creamy white, thickly speckled ovcr the entire surface with purplish brown.

Mr. Potts describes the nest as being composed of grass-leaves, with generally a few fcathers of the Swamp-hen, and sometimes a small tuft of wool. The breeding-season appears to embrace the montlis of October and November; for on Novcmber 4 he found a nest containing three young birds, and three days later, but in another locality, a nest with four eggs in it. 


\section{SPHENCEACUS FULVUS.}

(EULVOUS FERN-BIRD.)

Sphenceacus fulvus, Gray, Ibis, 1862, p. 221.

Megalums fulvus, Gray, Hand-l. of B. i. p. 206 (1869).

$A d$. similis S. punctato, sed paullò major: ubique lætiùs fulveseens, plumis vix ita distinetè medialiter lineatis: peetore etiam minùs distinetè maeulato: eaudâ minùs acuminatâ, seapis plumarum haud nudis, sed ad apicem ipsum plumiferis.

Adult. Upper parts dark fulrous, each feather eentred with black; forehead and erown slightly stained with rufous; line over the eyes, throat, fore neek, breast, and upper part of abdomen fulvous-white, obseurely spotted on the breast with brown; sides of the body, flanks, thighs, and lower part of abdomen bright fulvous; primaries and seeondaries blaekish brown, margined on their outer webs, and the three innermost secondaries broadly margined all round, with briglit fulvous; tail-featleers fulvous, with a dark sliaft-line, and lighter on the edges. Total length $7 \cdot 5$ inehes; wing, from flexure, 2.5 ; tail 4 ; bill, along the ridge ${ }^{\circ} 4$, along the edge of lower mandible $\cdot 6$; tarsus $\cdot 75$; middle toc and elaw $\cdot 7$; hind toe and elaw $\cdot 6$.

Young. An example in the Canterbury Mnseum, so immature that the tail-feathers are only two inehes long, has more fulvous in the plumage and no indieation whatever of a supereiliary streak.

Obs. Mr. Sharpe says of the type in the British Museum:-- Similar to S. punctatus, but ratler larger, and very mueh lighter and more oelıraeeous in eolour. Both on the upper and under surface the black eentres to the feathers are not so broad, and thus the plumage appears more distinetly streaked" (Cat. Birds B. M. vii. p. 98).

THIS species, as distinguished by Mr. G. R. Gray, bears a general resemblance to Sphenoeacus punctatus; but, on comparing them, the following differences are manifest:-The present bird is larger and has the whole of the plumage lighter; the upper parts have the central marks much narrower, and on the lind neck and rump they are entirely absent; the white superciliary streak is less distinctly defined, the spots on the under surface are less conspicuous, and the tail-feathers, which are much paler than in $S$. punctatus, differ likewise in their structure, the webs being closely set, instead of having loose disunited barbs.

Several specimens have passed through my hands, all of which have been obtained in the South Island.

Mr. Potts distinguishes the eggs of this bird from those of S. punctatus as being "slightly larger and white, marked with reddish-purple freckles."

Whilst, however, keeping the form distinct for the present, I am far from being satisfied that it can be separated from S. punctatus. I am more inclined to regard it as a somewhat larger local race, with a corresponding modification of plumage. But for the fact that the latter species is as common in the South Island as in the North, this might be treated as the representative form. 


\title{
SPHENCACUS RUFESCENS.
}

\author{
(CHATHAM-ISLAND FERN-BIRD.)
}

Sphenœeacus rufescens, Buller, Ibis, 1869, p. 38.

Megalurus rufescens, Gray, Hand-1. of B. i. p. 206 (1869).

$A d$. suprà saturatè castancus, pileo concolore : dorso paullò fulvescente, plumis latè medialiter nigris : tectricibus alarum medialiter nigris, dorso concoloribus : remigibus nigris, rufcscentc limbatis : caudâ rufescente, subtùs fulvescentiore, scapis pennarum nigris : loris et supercilio distincto fulvesccnti-albis : rcgione paroticâ saturatè castancâ, nigro notatâ : gcnis fulvescentibus, nigro maculatis : subtìs fulvescenti-albus, corporis lateribus castaneis nigro striolatis, dorso concoloribus: subalaribus stramineis, rufescente lavatis: rostro corneo, mandibulâ flavicante : pedibus flavicanti-brunneis : iride nigrâ.

Adult male. Upper parts dark rufous-brown, brightcst on the crown and hind neck; streak over the cyes, throat, breast, and abdomen dull rufous-white, slightly tinged with ycllow on the throat; sidcs of the head, earcoverts, and a series of spots from the base of the lower mandible brownish black; sides of the borly and the flanks bright rufous-brown, each feather with a central strcak of black; wing-feathers dusky black, margined on both webs with rufous-brown; the wing-coverts and the scapularics broadly centred with brownish black; tail-feathers clear rufous-brown, with glossy black shafts, palcr on their under surface. Irides black; bill and feet ycllowish brown. Total length $7 \cdot 25$ inches; extent of wings 7 ; wing, from flcxurc, $2 \cdot 25$; tail $4: 25$; bill, along the ridge $\cdot 5$, along the edge of lower mandible $\cdot 7$; tarsus 1 ; middle toe and claw $\cdot 85$; hind toe and claw $\cdot 75$.

Female. Similar to the male, but somewhat smallcr in size and with rather duller plumage.

Obs. Prof. Hutton states that two of the specimens collected by Mr. Travers are "variegated with white feathers, principally on the wings."

THIs well-marked species is confined to the Chatham Islands, where it was first discovered, in 1868, by Mr. Charles Traill, a gentleman greatly devoted to conchology, who visited that group for the purpose of collecting its marine shells. He obtained it on a small rocky isle, lying off the coast of the main island, during one of his dredging-expeditions; but he was unable to give me much information respecting its habits or economy, merely stating that he observed it flitting about among the grass and stunted regetation, and succeeded in knocking it over with a stone.

Mr. Henry Travers says :- "I only found this bird on Mangare, where it is not uncommon. Its peculiar habit of hopping from one point of concealment to another renders it difficult to secure. It has a peculiar whistle, very like that which a man would use in order to attract the attention of another at some distance; and although I knew that I was alone on the island, I frequently stopped mechanically on hearing the note of this bird, under the momentary impression that some other person was whistling to me. It also has the same cry as Sphenocacus punctatus. It is solitary in its habits and appears to live exclusively on insects."

I am indebted to Mr. Walter Shrimpton for an egg obtained on Pitt Island, and assigned, I believe correctly, to this species. It is broadly ovoido-conical, measuring 80 of an inch in length by .65 in breadth, and has the entire surface covered with a speckled or marbled graining of reddish brown on a creamy-white ground. 


\title{
ANTHUS NOVER ZEALANDIE.
}

\author{
(NEW-ZEALAND PIPIT.)
}

New-Zealand Lark, Lath. Gen. Syn. ii. pt. 2, p. 384, pl. 21 (1783).

Alauda novae seelandioe, Gm. Syst. Nat. i. p. 799 (1788).

Alauda littorea, Forst. Descr. Anim. p. 90 (1844).

Anthus novce zealandiae, Gray, Voy. Ereb. and Terror, Birds, p. 4 (1844).

Anthus grayi, Bonap. Consp. Gen. Av. i. p. 249 (1850).

Anthus aucklandica, Gray, Ibis, 1862, p. 254.

Corydalla aucklandica, id. Hand-l. of B. i. p. 253 (1869).

Corydalla novce zealandioe, id. op. cit. i. p. 253 (1869).

\section{Native names.}

Pihoihoi and Whioi ; "Ground-Lark" of the colonists.

Ad. brunneus, fulveseente lavatus, plumis medialiter paullò saturatioribus, uropygio unicolore fulvescenti-brunnco : loris et supercilio lato fulvescenti-albis : lineâ brunneâ per oculum ab ortu rostri duetâ : genis et regione paroticâ albidis, hâc paullò brumneo maculatâ : fasciâ mystaeali irregulari brunneâ: colli latcribus dorso coneoloribus et codem modo notatis : teetricibus alarum brunneis, minimis latè et conspieuè aurantiacofulvo lavatis, majoribus angustè fulvido marginatis : remigibus brunneis, primariis angustissimè, secundariis latiùs fulvo marginatis : eaudâ brunncâ, fulvo marginatâ, rectriee extimâ ferè omninò albâ, pogonio intcrno versùs basin brumneo, proximâ versùs apicem obliquè albâ, tertî̂ extùs angustè albo limbatâ: subtùs fulveseenti-albus, hypoehondriis brunneis: pectore superiore brunneo longitudinaliter maeulato: rostro eorneo, mandibulâ flavieante : pedibus flavieanti-brunneis : iride saturatè brunneâ.

Juv. similis adultis, scd pallidior, plumis indistinetè fulvo marginatis : eollo postieo conspieuè fulvescentc : tectrieibus alarum, remigibus et rectricibus latiùs fulvo marginatis : subtùs sordidè albus, pcetore superiore vix distinctè brunneo striolato.

Adult. Upper parts brownish grey, darker on the rump and upper tail-coverts; on the back, eaeh feather centred with brown; from the base of the bill a broad line of white passes above, and an irregular band of blaek cxtends aeross the eyes; chccks grcyish white, minutely spotted with blaek; ehin, or intererural space, white; throat, fore neck, and upper part of breast fulvous, with numcrous broad dashes of brown; underparts white, tinged on the flanks aud under tail-coverts with fulvous; sides of the body greyish white, with longitudinal strealis of brown; all the plumage of the underparts plumbeous at the base; wing-fcathers and their eoverts dark brown, margiued on their outer webs with fulvous-grey, broadest on the tertiaries, and redueed to a mere line on the primaries; the marginal colour ehanges to fulvous-white on the secondaryeoverts, presenting, when the wings are closed, a series of small erescentie bands; tail-feathers dark brown, with palcr edges, exeept the two outermost ones ou cach side, whieh are white, the inner one erossed by an oblique band of dusky brown, and the onter one with a merc strcak of the same colour near the root. Irides very dark brown, almost black; bill and feet yellowish brown. Total length 8 inches; extent of wings 12 ; wing, from flexure, 3.75 ; tail 3 ; bill, along the ridge $\cdot 5$, along the edge of lower mandible $\cdot 75$; tarsus 1 ; middle toe and elaw 85 ; hind toe and claw $\cdot 75$.

Young. The young has the breast more spotted, and the feathers of the upper parts narrowly margined with pale rust-eolour. 
Obs. The sexes are alike. In some cxamples the under tail-coverts are pure white, while in others the upper wing-coverts arc broadly margined with light rufous-brown. Allowing for this variation, I cannot sec the propriety of admitting the supposed new species from Queen Charlotte's Sound (Anthus grayi, Bonap.), which I have accordingly expunged from our list.

Varieties. Albinos, more or less pure, are of common occurrence. The following is the description of an example in the Canterbury Museum:-Gencral plumage pure white, varied on the back and wings with brownish grey; some of the quills and tail-feathers pure white, the others dark brown, as in ordinary specimens; bill and fect white horn-colour; the hind claw conspicuously long, measuring 55 of an inch. Another specimen, in Mr. J. C. Firth's finc collection at Mount Eden, has the whole plumage dull ercamy white, stained and washed on the upper parts of the body with yellowish brown. Captain Mair writes to me :- "I saw a pure white Lark, two days in succession, at Sulphur Point, bnt could not find it when I went with a gun"; and several other correspondents refer to similar oceurrences in various parts of the country.

OF this bird I may remark that it is a true Pipit both in structure and in its habits of life. It bears a general resemblance to an Australian speeies (Anthus australis); but the specifie differences are sufficiently manifest on an actual comparison of the two birds.

It is eommon throughout the eountry, frequenting the open land, and sometimes resorting to the dry sands along the sea-shore. During the autumn months it is gregarious, and may then be observed in flocks varying in number from twenty to fifty or more, alternately collecting and mounting in the air with a loud cheerful note, and seattering themselves again on the open ground to search for their food, which eonsists of inseets and their larvæ, small earthworms, and oecasionally minute seeds as well. At sundown the floeks break up, eael bird sceking a eonvenient resting-plaee for the night; and with the first streak of daylight they begin to reassemble. On the approaeh of winter the floeks disperse *, and the birds appear to pair off at onee, and remain so till the breeding-season arrives. They are always plentiful on the settlers' farms, and may be seen during the summer months perehed in large parties on the roofs of the country houses or on the surrounding fences and outbuildings. They may sometimes be observed in similar situations within the towns, and notably on the roofs of churches and other lofty edifices. They love to resort to the roads and beaten paths, where they amuse the traveller by their playfulness, running before him as he advances, then rising in the air with a sharp but pleasant chirp, settling down again and running forward as before, and continually flirting the tail upwards. During the heat of the day they may often be seen sitting on the logs or fences with their beaks wide open as if gasping for air. They repose at night on the ground, finding shelter among the grass or fern on the open ridges or on the wayside, where the benighted traveller, as he plods along, may often disturb them and hear the sharp rustling of their wings as they rise startled at his very feet.

When searching for food, a floek of these birds will spread themselves out in all directions; but the instant a Hawk appears in sight, or some other common danger threatens, they will rise into the

* Tho aecurasy of the above statement, in my former edition, having been called in question (Ibis, 1874, p. 38), I mado careful observations over a continuous period of ten ycars, during which time I was eonstautly moving from one part of the colony to the other. From the notes in my diary I have abstracted tho following particulars:- Autumn months (March, April, aud May), numerous floeks, and often of considerable size, all over the country; winter months (Junc, July, and August), always in pairs ; spring and summer (September to February, inclusive), still in pairs, but sometimes eongregating. I have secn a flock numbering upwards of fifty as early as September 4. In the months of November and December it is a common thing to seo parties of fivo or six, cousisting probably of early broods of the year ; aud I find a note of oue party of five on the 23 rd October. The autumnal gathering commences about tho sccond week in March, at the close of a prolonged brceding-scason, with probably two broods; and I have no record of any flock after the beginning of Juno. Professor Hutton's statement that "6 they congregate in the autumn after the breeding-season is over and disperse to breed in spring" would scem to imply that the flocks keep together during the winter; but this is certainly not the case. 
air together with much clamour, and sometimes mount to a considerable height. I have frequently seen a number of them pursue and harass the Bush-Hawk, whieh is doubtless their worst natural enemy. Their ordinary flight is rapid and undulating, being performed, as it were, by a suceession of jerks. During the breeding-season the male bird frequently soars, mounting to a height in the air, and then deseends with tremulous wings and outspread tail, uttering a prolonged trilling note, very pleasant to the ear.

This is one of the few speeies that appear to thrive and increase in the cultivated districts; and in loealities where formerly it was only tolerably plentiful it has kept paee with the progress of eolonization, beeoming every year more abundant. It frequents the mountain-tops, being often met with above the snow-line. Mr. Ernest Bell observed one on the very summit of Mount Egmont.

It is never met with in the woods; and I have observed that in the open eountry it is rarely seen to alight on a green tree or shrub, although often poising itself on the slender stalks of the Phormium tenax or on a bunch of fern. I have oceasionally seen it dusting itself after the manner of some gallinaeeous birds, rolling in the dust with evident delight, and then shaking its feathers, probably in order to free the body of parasitie inseets.

It is amusing to watch a pair of them chasing and making love to each other at the eommeneement of the breeding-season, each one alternately springing up in the air, with expanded wings and tail, and eurvetting over the other in the most playful manner. The eall of the young resembles the sharp note of the Silver-eye (Zosterops carrulescens); and when engaged in feeding them, the parent bird displays an unusual degree of eaution in the presenee of an intruder, alighting ten or fifteen yards from the nest, and loitering about for a eonsiderable time with the food in its bill before attempting to deliver it. I lave seen a pair skimming playfully together over the ground but close to the surfaee, when one would suddenly drop out of sight in the vieinity of the nest, leaving the other to pursue its wayward flight, as if to divert attention.

The natives catch this bird by mcans of a running-noose at the end of a long stick; and there are various modes of trapping it, very generally known and appreciated among colonial sehool-boys.

I have noticed that it is very subject to a disease of the foot, whieh takes the form of a large irregular swelling. This may probably result from aecidental burns; for I have often observed these birds alight on ground over which a fire had reeently passed, leaving a light surfaee of smouldering ashes, and rise again immediately in evident pain.

On the Hastings-Napier railway line and elsewhere I have observed a peeuliar habit which this species has developed of following the train. I have seen, in autumn, a flight of a hundred birds keeping abreast or a little ahead of the train in rapid motion for two or three miles at a stretch, picking up stragglers en route, and to all appearance thoroughly enjoying the exeitement.

The breeding-season of the New-Zealand Pipit extends from October to February or Mareh, and, like the other members of the same group, it appears to rear two broods; for I have seen wellfledged young ones in November, while nests eontaining eggs are often met with as late in the season as January or the early part of February. 'The nest is eomposed of dry grass and other fibrous substances loosely put together, and is always plaeed on the ground, generally in a horse's footprint or in some natural depression, and under shelter of a tussock or clump of rushes. The eggs are usually four in number, rather ovoido-conieal in shape, mcasuring, as a rule, $\cdot 9$ of an inch by $\cdot 65$, and marked over the entire surfaee with numerous spots or freckles of dark grey on a paler or ashy ground. A fine series of eight in my son's eolleetion exhibit a considerable amount of individual variation both in form and eolouring. The smallest of these measures .85 inch in length by 65 in breadth, and is almost a perfcct oval; and the largest 1 inch in length by $\cdot 70$ in breadth. The ground-eolour varies from pale stone-grey to a warm creamy-grey, and the markings pass through every gradation, from a covering of uniform speckles and freckles of greyish brown to a mueh darker charaeter, blotehed and mottled with purplish brown of different shades. 


\title{
GRAUCALUS MELANOPS.
}

\author{
(AUSTRALIAN SHRIKE.)
}

\author{
Black-faced Crow, Lath. Gen. Syn. Suppl. ii. p. 116 (1801). \\ Corvus melanops, Lath. Suppl. Ind. Orn. p. xxiv (1801). \\ Rollier à masque noir, Levaill. Ois. de Paradis, pl. 30 (1806). \\ Ceblepyris melanops, Temm. Man. d'Orn. i. pl. lxii. (1820). \\ Graucalus melanops, Vig. \& IIorsf. Tr. Linn. Soc. xv. p. 216 (1826). \\ Graucalus melanotis, Gould, P.Z.S. 1837, p. 143. \\ Campephaga melanops, Gray, Cat. B. N. Guin. p. 32 (1859). \\ Colluricincla concinna, Hutton, Cat. B. New Zealand, p. 15 (1871). \\ Grancalus concinnus, Hutton, Trans. N.-Z. Inst. vol, v. p. 225 (1872). \\ Grancalus melanops, Buller, Birds of New Zealand, 1st ed. p. 148 (1873).
}

Descr, exempl. ex N.Z. Suprà cincreus: teetricibus alarum dorso eoncoloribus : remigibus nigrieanti-brunneis, primariis angustè, seeundariis latiùs albido marginatis : rectricibus nigrieanti-brunneis, parte basali einereâ, pennis externis ad apiecm albis, duabus exterioribus graduatim obliquè albis, reetriee extimâ etiam albo marginatâ : facie laterali totî nigrâ : gutture et pectore superiore einereis dorso eoncoloribus : eorpore reliquo subtùs albo: rostro nigro versùs basiı mandibulæ brunneseente: pedibus saturatè brunneis.

New-Zealand excmple (young). General plumage light einereous or ashy grey; a patelı of black fills the lores, erosses the eyes, and eovers the eheeks and ear-eoverts; on the upper part of the breast the grey fades into white, with a purplish tinge; lower part of breast, lining of wings, flanks, abdomen, and under tailcoverts pure white; wing-feathers dark brown, the primaries narrowly and the secondaries broadly margined with greyish white; tail-feathers dark brown, the two middle ones tinged with ashy grey, especially in their basal portion; the lateral ones tipped progressively outwards with white, the outermost one on eaeh side having an ineh at the extremity and a narrow line along the apieal portion of its outer web pure white. Bill black, ehanging to brown at the base of the lower mandible; legs blackish brown. Total lengtlı 13 inehes; wing, from flexure, 8 ; tail $5 \cdot 5$; bill, along the ridge 9 , along the edge of lower mandible $1 \cdot 25$; tarsis $1 \cdot 12$; middle toe and claw $1 \cdot 2$; hind toe and elaw $\mathbf{l}$.

Adult male (from Australia). Gencral colour above light French grey, the wing-eoverts like the baek, with edgings of still lighter grey; primary-eoverts and primaries black, externally edged vitlı grey, inelining to white towards the tips of the quills; sceondaries black, the outer aspeet of the feathers light grey on the innermost, with the outer web grey and the inner one black; two eentre tail-feathers ashy grcy, blacker towards the tip, whieh is white, all the other feathers black, washed witlı grey towards the base and tipped with white, which increases in extent towards the outermost feather, which is also edged with white along the outer web; entire forehend, feathers above the eye, ear-eoverts, sides of face, sides of neck, entire throat, and fore neek black, with a greenish gloss, fading off paler towards the chest, whieh is iron-grey, becoming gradually lighter and more delieate grey on the sides of the body, so as to leave only the lower abdomen and under tiil-coverts pure white; thighs grey; under wing-coverts and axillaries pure white, as also the inner lining of the quills, whieh are otherwise aslyy grey below; bill black; feet dull ashy ; iris black. Total length $12 \cdot 5$ inehes, eulmen $1 \cdot 05$, wing $7 \cdot 65$, tail $5 \cdot 75$, tarsus $1 \cdot 05$. (Cat. Birds Brit. Mus. vol. iv. p. 31.)

Obs. " $\delta$, Louisiade Islands speeimen, wing 8.1 inehes; $q$, N.W. Australia, wing $7 \cdot 1$ inelies. These two seem to be the extremes, and every intermediate link between them can be found." (Id.l.c.) 
THE example from which the above description is taken was shot by Mr. Giblin at Motueka, in the Provincial district of Nelson, and now forms part of the public collection in the Nelson Museum. Mr. Huddleston informs me that he saw the bird in the flesh, and knows the precise locality in which it was shot. There can be no doubt, therefore, as to the authenticity of the specimen as a NewZealand bird; but as it appears to be quite unknown to the natives of the country, it may, I think, be safely assumed that this was an accidental visitant from Australia, where the species is very plentiful. Another example was shot at Invercargill in April 1870, and forrvarded to the Colonial Museum. Of this Professor Hutton writes $(l . c$.$) :- " Like the bird shot in Nelson province, this one also has the$ general plumage of the young of $G$. melanops; but the feathers of the chin and forehead are similar to those on the throat and top of the head, and not lighter as in G. melanops; there is also no indication of any black feathers coming on the chin or upper part of the head. It differs from the Australian bird in having a more slender bill, a rather longer tail, the feathers of which are acutely pointed at the tip instead of being rounded, and in having much more white on the wings. These differences are, I think, quite sufficient to warrant its being kept as a distinct species" *. He adds:"Mr. Mantell has informed me that he saw this bird many years ago at Port Chalmers in Otago; Mr. W. Travers says that he has seen it at Nelson, and Captain Fraser says that he saw it near Hawea Lake in Otago."

This species is liable to so much variation, both in plumage and size, that I am unable at present to consider the form which las thus occurred at such rare intervals in New Zealind as distinct from the Australian one. Of the latter Mr. Gould says that the "infinite changes of plumage which these. birds undergo from youth to maturity render their investigation very perplexing."

Dr. Finsch expresses liis belief that the bird which has occurred in New Zealand is G. parvirostris, Gould; but Mr. Sharpe, in his account of G. melanops (Cat. of Birds Brit. Mus. iv. p. 31) says :"This species varies much in size, but it is impossible to believe in the existence of more than one species; and G.parvirostris is little more than a race of the present bird."

I have gone carefully over the whole series of skins in the British Museum, and am confirmed in uny original conclusion that our bird is the young or immature state of G. melanops. I attach no value to the two characters on which Professor Hutton appears mainly to rely, namely, the white margins to the greater wing-coverts and the more acutely pointed tail-feathers. In a large series, of all ages, I find the extent of white on the wings very variable, and in the younger birds the tailfeathers are undoubtedly narrower at the points than in fully adult specimens. In the Nelson bird, of whicl a full description is given above, it will be seen that the former of Professor Hutton's distinguishing characters is absent. I should be inclined to give more weight to the colour of the primaries, as described by him, because in every specimen of $G$. melanops examined by me the first five primaries are uniform brownislı black, or with only a very narrow greyish-white margin on the outer web, there being no sign of any white tips. 'This difference, however, appears to me too trivial to separate the species, the more so as it is wanting in the Nolson example. The "white circular

\footnotetext{
* Grateatds concinnus, Hutton (l.c.):- "The whole of the upper surface uniform pale grey, the feathers of the forehead with the shafts darker; feathers of the throat and breast pale grey, slightly tipped with white; those of the upper abdomen and thighs palo grey, with white eircular bands; lower abdomen, vont, and under tail-eoverts pure white; a broad band of bluek passes from the nostrils and gape through and below the eye to the region of the ears; primaries brownish blaek, the first slightly tipped with white, the seeond, third, fourth, and fifth margined outwardly and slightly tipped with white, the remainder margined all round with a white band, which is broader on the tip and inner web; seeondaries greyish blaek, with more or less grey on the ontor webs near the base, and with a rather broad white margin on the outer web and tip; greater wing-coverts margined outwardly with white; tuil-feathers acutely pointed at the tip, the two middle ones brownish grey, laterals brownish blaek tipped with white, the white deereasing inwards; shats of the tail-feathers greyish blaek above and pure white below ; bill (dry) brownish black, paler at the base; legs and feet (dry) blaek. Wing 8 inehes; tail 7 ; tarsus $1 \cdot 1$; hind toe $\cdot 8$; middlo toe $1 \cdot 1$; bill, eulmen, $\cdot 85$, breadth at nostrils 4 , height at nostrils $\cdot 35 . "$
} 
bands" afford to my mind further evidence of immaturity. If, however, it were the young of G. parvirostris (as suggested by Dr. Finsch), it ought to present other markings, for the young of this form exhibits numerous arrow-heads of brownish black on its chin and throat.

Assuming, therefore, the species to be the same, this bird is very common in New South Wales, especially in the summer months, frequenting " plains thinly covered with large trees," rather than the thick brushes. It is said to be also abundantly dispersed over the plains of the interior, such as the Liverpool, and those which stretch away to the northward and eastward of New South Wales.

"It breeds in October and the three following months. The nest is often of a triangular form, in consequence of its being made to fit the angle of the fork of the horizontal branch in which it is placed; it is entirely composed of small dead twigs, firmly matted together with a very fine, white, downy substance like cobwebs and a species of lichen, giving the nest the same appearance as the branch upon which it is placed, and rendering it most difficult of detection. The ground-colour of the eggs, which are usually two in number, varies from wood-brown to asparagus-green, the blotches and spots, which are very generally dispersed over their surface, varying from dull chestnut-brown to light yellowish brown; in some instances they are also sparingly dottcd with deep umber-brown; their medium length is thirteen lines, and breadth ten lines. Its note, which is seldom uttered, is a peculiar single purring or jarring sound, repeated several times in succession." (Gould, Handb. Birds Austr. i. pp. 193, 194.)

The ornithology of New Zealand has now been so thoroughly explored that we cannot hope to make any further additions to our list of species, except by recording accidental visitants like the above at long intcrvals of time- such birds, for example, as Acanthochcerce carunculata and Eurystomus pacificus; or the occurrence of foreign Waders, such stragglers from the flock as may occasionally pass out of their course to New Zealand during their seasonal migration-as, for instance, Charcadrius fulvus and Phalaropus ruficapillus; or of oceanic species whose home is on the rolling sea and whose habitual range, within uncertain degrecs of latitude and longitude, is often extended almost indefinitely by the terrific and long-continued storms that sweep over the face of the great Pacific Ocean-such as the beautiful red-tailed Tropic-bird (Phaëton mubricauda), or that noble "Vulture of the sea," Tachypetes aquila, and the rarer kinds of Petrel. The opportunities, however, of recording such occurrences are becoming every year more difficult for the practical ornithologist, owing to the number and variety of foreign birds that are being introduced into the country through the cfforts of Acclimatization Societies and other local agencies. In the early days of the colony nothing that was new escaped the vigilant eye of the Maori, and the appearance of a strange bird, whether on the sea-shore, in the lagoons, or on the land, was immediately noticed, and the fact sooner or later reportcd to the colonists. But nowadays the country teems with imported birds of every kind -'Thrushes and Blackbirds, Greenfinches and Linnets in the woods and shrubberies; Phcasants, Partridges, and Quail in the open, with Sky-Larks and Starlings on the meadows; Black Swan and Egyptian Geese on the lagoons, and the ubiqnitous Sparrow in every street and hedgerow, besides numberless other introduced species of more or less importance. Consequently, when a Maori sees a bird hitherto unknown to him he puts it down in his mind as a "manu pakeha," and pays no further heed to it.

The occurrence in New Zealand, from time to time, of Australian and Polynesian forms, without any suspicion of human intervention or of artificial assistance such as that afforcled by ships' rigging, is a matter of extreme interest to the philosophic naturalist, because these cases serve to illustrate the manncr in which the avifaula of oceanic islands lying far apart from one another or from any continental area-as, for example, Norfolk Island and Lord Howe's Island-may undergo, in process of time and by inseusible degrees, important changes of feature through the accidcntal intrusion of foreign types. For this reason, I have been very careful to notice in the present work every instance of the kind that has come to my kuowledge. 


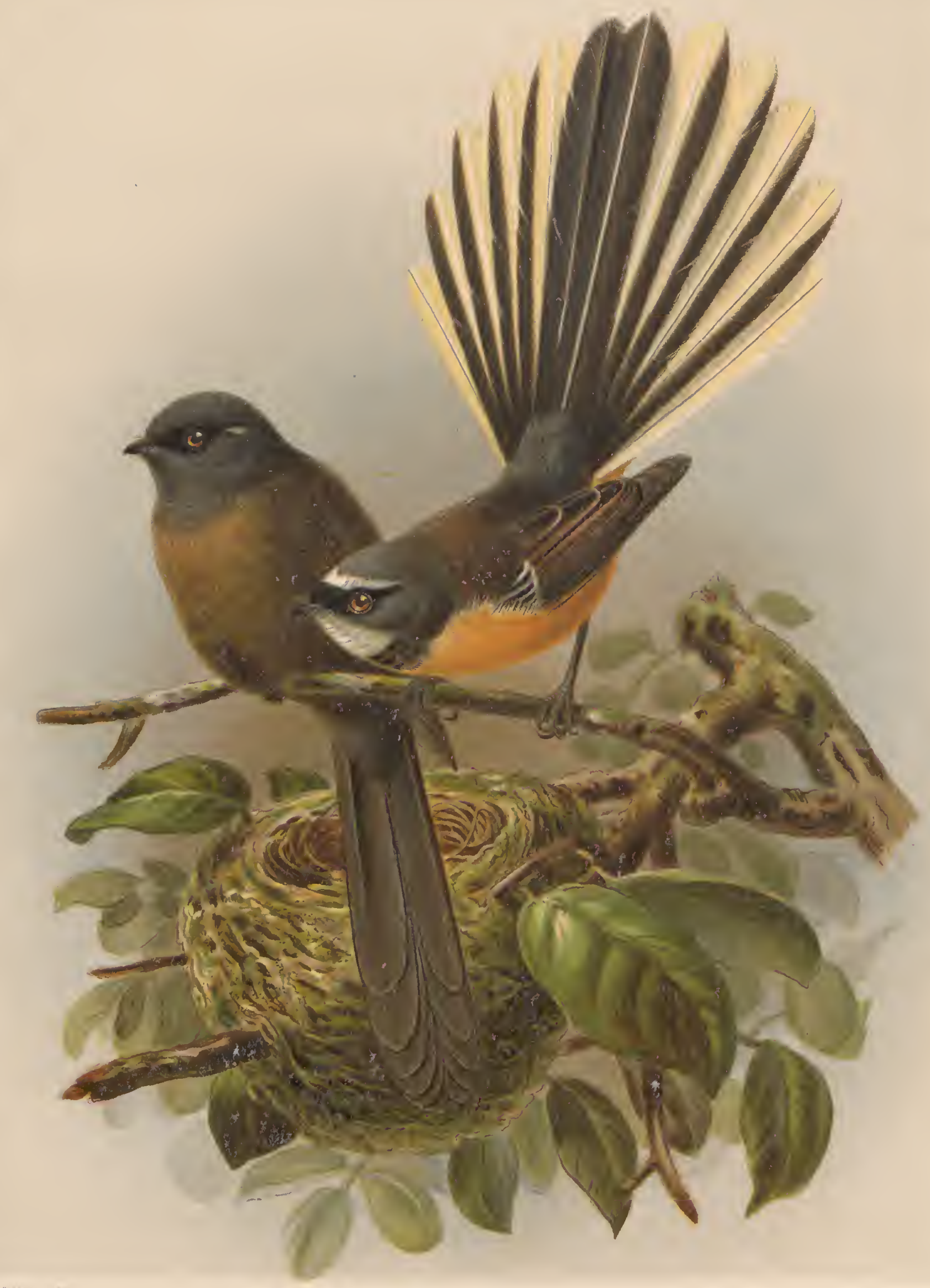

BLACI FANTAIL

RIIPIDURA FULIGINOSA

PIED FANTAIL

RHIPIDURA.FLABELIIFERA 



\title{
RIIPIDURA FLABELLIFERA. \\ (PIED FANTAIL.)
}

\author{
Fan-tailed Flycatcher, Lath. Gen. Syn. ii. pt. 1, p. 340, pl. xlix. (1783). \\ Muscicapa fabellifera, Gm. Syst. Nat. i. p. 943 (1788, ex Lath.). \\ Rhipidura flabelliferu, Gray, in Dieff. Trav. ii., App. p. 190 (1843). \\ Muscicapa ventilabrum, Forst. Descr. Anim. p. 86 (1844). \\ Rhipidura albiscapa, Cass. U. S. Expl. Exp. p. 150 (1858, nec Gould).
}

\section{Native names.}

Piwaiwaka, Tiwaiwaka, Piwakawaka, Tirairaka, Pirairaka, Tiwakawaka, and Pitakataka.

$A d$. suprà olivaseenti-brunneus, pileo nigrieante : lineâ supraoeulari albidâ : teetrieibus alarum brunneis, olivaceo

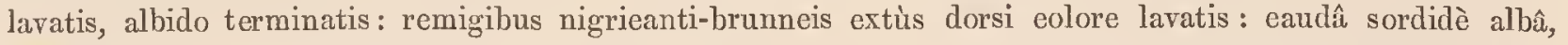
seapis purè albis, reetrieibus duabus eentralibus nigrieantibus ad apieem albidis, reliquis extùs brunneseentinigris, pennâ extimâ omninò albidâ : facie laterali pileo eoneolore : gulâ albidâ: torque peetorali nigrâ: subtùs aurantiaeo-fulvus, pectore superiore et subeaudalibus pallidioribus : eruribus nigricantibus : rostro nigro: pedibus brunneseenti-nigris : iride nigrâ.

$J u v$. similis adulto, sed suprà magis brunneseens: gutture griseseenti-albo: eorpore reliquo subtùs sordidè fulveseente: torque peetorali absente: teetrieibus alarum fulvido apieatis, et seeundariis extùs eodem colore marginatis.

Adult male. Crown, nape, and sides of the head sooty blaek; the whole of the back, rump, and upper surface of wings dark olive-brown; the small wing-eoverts tipped with fulvous white; rietal bristles blaek; throat and mark over the eyes greyish white; aeross the fore neek and upper part of breast a broad band of sooty blaek; lower part of breast and all the under surfaee fulvous, tinged with cinuamon, the lase of the feathers plumbeous; quills dark olive-brown, with paler shafts, the inner seeondaries edged with fulvous white; the two middle tail-feathers brownish blaek, with pure white shafts, and tipped with greyish white; the lateral feathers greyish white and, with the exeeption of the outermost one on eaeh side, margined on their outer welss with brownish blaek, all having pure white shafts. Irides and bill blaek; feet blaekish brown; soles greyish. Total length 6.5 inehes ; extent of wings 8 ; wing, from flexure, $2 \cdot 75$; tail 4 ; bill, along the ridge 3 , along the edge of lower mandible 4 ; tarsus $\cdot 7$; middle toe and elaw 6 ; hind toe and claw 5 .

Female. Similar in plumage to the male, but slightly smaller.

Young. The young bird has the tlroat greyish white; the breast and all the under surfaee dark fulvous brown; the small wing-eoverts are largely tipped and the seeondaries narrowly edged with fulvous brown, and the plumage of the baek is morc or less tinged witl the same eolour.

Obs. I have observed birds in the young plumage as late as the middle of Mareh; but the adult livery is eertainly assumed at the first moult.

Tü Pied Fantail, ever flitting about with broadly expanded tail, and performing all manner of 
fantastic evolutions, in its diligent pursuit of gnats and flies, is one of the most pleasing and attractive objects in the New-Zealand forest.

It is very tame and familiar, allowing a person to approach within a few feet of it without evineing any alarm, sometimes, indeed, perching for an instant on his head or shoulders. It will often enter the settler's house in the bush, and remain there for days together, elearing the windowpanes of sand-flies, fluttcring about the open rooms with an incessant lively twitter during the day, and roosting at night under the friendly roof*. It is found, generally in pairs, on the outskirts of the forest, in the open glades, and in all similar localities adapted to its habits of life. It loves to frequent the wooded banks of momtain-streams and rivulets, where it may be seen hovering over the surfaee of the water eollecting gnats; and I have counted as many as ten of them at one time so engaged. It affects low shrubby bushes and the branches of fallen trces; but it may often be seen eatering for its insect-food among the topmost branches of the high timber.

You may always make sure of finding it flitting noiselessly about the bushes at the edges of the little mountain-stream whieh

$$
\begin{aligned}
& \text { "Chatters over stony ways, } \\
& \text { In littlo sharps and trebles, } \\
& \text { And bubbles into eddying bays, } \\
& \text { And babbles on the pebbles." }
\end{aligned}
$$

These localities often swarm with minute diptera, on which the bird subsists. And I have seen five or six of them together displaying thcir fans, and hawking, as it wcre, for these invisible flies above the surfaee of the water.

In winter it generally frequents the darker parts of the forest, where inseet-life is more abundant at that season ; but it is nevertheless to be met with, wherever there is any bush, all the year round. It is a true Flycateher, subsisting entirely by the ehase : darting forth from its pereh, it performs a number of aërial evolutions in pursuit of invisible flies-the snapping of its mandibles as it catehes its prey being distiuctly audible-and generally returns to the twig from whiel it started. It hops about along the dry branehes of a prostrate tree, or upwards along the tangled vines of the kareno (Rhipogonum scandens), with its tail balf expanded and its wings drooping, seizing a little viction at almost every turn, and all the while uttering a pleasint twitter. When hurt or alarmed it immediately eloses its pretty fan, and silently flies off in a direct course, disappearing in the denser foliage.

It breeds twice in the season, producing four young ones at each sitting. It generally commences to build in September, and brings out its first brood about the last week in October. The second brood appears to leave the nest about the beginning of January.

The nest is a beautiful little structure, compact and symmetrieal. A forked twig is the site usually selected; and the nest, instead of being placed within the fork for support, is built around it, the branchlets being thus made to serve the purpose of braees and stays to strengthen the work and to hold it together. It is therefore generally impossible to remove or detach the nest from the braneh withont tearing it to pieces. In form it is cup-shaped, the upper part towards the rim being elosely interwoven and seeurely bound, while the base is left unfinished or loosely eonstrueted. 'The materials eomposing the foundation are light-fragments of deeayed wood, eoarse mosses, and the skeletons of dead leaves. The centre and upper portion of the nest consist principally of the tough and elastie seed-stems of various mosses finely interwoven. There is an exterior wall composed of

* Major Jaekson told me a romantie story about this bird. A friend of his met with an aeeident and got his leg broken. He was carried into a little country house, and could not safely be moved for some time. During his detention ho suffered very mueh from the heat and the swarms of small fios that invaded his improvised hospital. On one oceasion, however, the window being open, a Fantail eame in from the adjoining garden, took up its station on a peg in the wall, and soon eleared the room of flies, flitting airily about, and snapping its mandibles so long as a single fly remained. After this and as long as the invalid. remained, the bird was a daily visitor, ministcring in the manner described to the peace and eomfort of the fly-pestered inmate. 
cow-hair, the downy seed-vessels of plants, and other soft materials, and the whole is admirably bound together with fine spider's' webs. The interior cavity, which is rather large in proportion to the nest, is closely lined with fibrous grasses, or bents, disposed in a circular form. I have examined numbers of nests, and I have observed that the materials employed vary slightly, according to the locality, specimens collected in the vicinity of farmhouses disclosing tufts of wool, fragments of cloth, remnants of cotton-thread, \&c. among the building-materials; nevertheless, in every instance that has come under my notice, the use of spiders' webs for binding the walls has been adhered to, thus manifesting a very decided instinct. 'The eggs are usually four in number, slightly ovoidoconical, and measuring $\cdot 7$ of an inch in length by 5 in breadth; they are white, with numerous purplish-brown freckles, denser and forming an obscure zone towards the larger end.

Mr. J. H. Gurney ('Ibis,' 1860, p. 212), in his account of the Red-throated Widow-bird (Vidua mubritorques, Swains.), says:- "These birds build amongst the grass in the open country. The nest is curiously built; they select a convenient tuft of grass, and interlace the blades as they stand, without breaking them off; so that the nest is green during the whole time of incubation, and is very beautiful when thus seen." This brings to my recollection a very pretty nest of the Pied Fantail which I found in the Kaipara woods many years ago. It was smaller and more cup-shaped than the generality of these nests, and was composed chiefly of moss firmly bound together with spiders' webs; but it was an "old nest," and the winter rains had soaked it, cansing the moss to vegetate afresh; and when it came into my hands it was covered on the outer surface with a luxuriant growth of stunted moss of the brightest green, and presented a very beautiful appearance.

To any one having any experience of bird-craft, it is very easy to discover the nest of this species. The movements of the old birds, properly interpreted, are a very sure index. As you approach the nest, the Fantails, which follow your steps with an incessant twitter, become ominously silent. If you fail immediately to discover the object of your search, and chance to wander away from it, the anxious little birds give vent to their joy by an exuberant strain of notes, which, as I have often thought, might be appropriately compared to the supposed merry laugh of one of Gulliver's Liliputians*. On one occasion I succeeded in capturing the old bird on the nest, which was found to contain four unfledged young ones. I placed my captive in a cage, together with the nest and young: she refused food, and vented her rage by pecking her young ones to death. On the following morning I liberated the parent, regretting much that I had invaded her domestic happiness.

The multiplication of numbers by second broods, in the proportion of four to one, as already noticed, appears to me a wise provision of Nature to save the species from extinction. At the close of the breeding-season the Fantails, principally in the immature plumage, are excessively abundant; by the end of the year their numbers have been considerably thinned, owing to the joint ravages of the wild cat, the Bush-Hawk, and Morepork, to all of which this defenceless little creature falls an easy prey. The reproduction by each pair of eight young ones every senson seems, therefore, almost necessary to preserve the very existence of this species in the balance of life.

Long may the Pied Fantail thrive and prosper, in the fice of cats, owls, naturalists, and the whole race of depredators; for without it our woods would lack one of their prettiest attractions, and our fauna its gentlest representative!

* In one of the Maori legends we are told that the great ancestor Maui-Potaka, whose ordinary companions were a flock of Piwaiwaka, was betrayed by this "langh" when cating up the body of Hinenuitepo and was forthwith killed. Tho myth relates how these little birds could contain tliemselves no longer, and when Hincnuitepo's hoad and shoulders had disappeared dowu Mani-Potalsa's thront "they danced about and laughed," a pretty allusion to the habits of the Fantail. 


\title{
RHIPIDURA FULIGINOSA.
}

\author{
(BLACK FANTAIL.)
}

Muscicapa fuliginosa, Sparrm. Mus. Carls. pl. 47 (1787).

Muscicapa deserti, Gm. Syst. Nat. i. p. 949 (1788, ex Sparrm.).

Rhipidura melanura, Gray, in Dieff. Trav., ii. App. p. 191 (1843).

Leucocerca melanura, Bonap. Consp. Gen. Av. i. p. 324 (1850).

Rhipidura tristis, Hombr. et Jacq. Voy. Pôle Sud, Ois. iii. p. 76, pl. xi. fig. 5 (1853).

Rhipidura sombre, iid. op. cit., Atlas, pl. xi. fig. 4 (1853).

Ad. nigricans, dorso alisque brunneo tinctis : maculâ postaurieulari parvâ albâ : subtùs dilutiùs brunneus : rostro nigro, mandibulâ versùs basin albicante : pedibus nigrieanti-brunncis : iride nigrâ.

Adult. Entirc plumage black, tinged on the baek and wings with rusty brown, and on the under surfaec with paler brown; bchind eaeh ear a small spot of white. Irides black; bill blaek; white at the basc of the lower mandible; tarsi and toes blackish brown. Total length 6.5 inches; cxtent of wings 8 ; wing, from flexure, $2 \cdot 75$; tail 4 ; bill, along the ridge $\cdot 3$, along the edge of lower mandible $\cdot 4$; tarsus 7 ; middle toe and elaw $\cdot 6$; hind toe and elaw $\cdot 5$.

Female. Similar to the malc, but with the whitc spots behind the cars much reduced.

Obs. In the full-plumagcd male the whitc mark described above usually eonsists of twelve diminutive feathers. In an example which eame under my notice at Kaiapoi this feature was exaggerated, the white spreading entirely over the ear-eoverts and surrounding feathers. In some it is scareely visible, while in others (probably young birds) it is altogether wanting.

THrs dark-coloured species is, generally speaking, restricted to the South Island, where it is far more common than the preceding one.

Its life-history differs in no respect from that of its congener, as described in the foregoing pages. The stomachs of two which I dissected contained, in addition to the remains of small diptcrous insects, the minute seeds of some wild berry.

Mr. G. R. Gray gives Cook's Strait as its habitat; but although common enough on the Nelson side, at the date of my former edition I knew of only one instance of its occurrence on the northern shore of the strait, or in any part of the North Island. After very stormy weather in May 1864, I shot a specimen in a flax-field near the mouth of the Manawatu river, on the south-west coast of the Wellington Province. It was evidently a straggler from the opposite mainland, and having by some means been deprived of its ample tail, which serves to balance the body, it had probably lost command of itself, and thus been borne across the sea by the prevailing gales. That the Flycatcher does sometimes indulge voluntarily in a water excursion, I have myself had proof; for in April 1869, when entering the Whangarei Heads, a Pied Fantail (Rhipidura flabellifera) flew off from the shore, and after making a circuit of our little steamer, apparently to satisfy its curiosity, returned to the land.

Ten years later another specimen was killed near a streamlet in the Pirongia Ranges, Waikato; and a third was obtained by my son in a shrubbery near Wellington on the 2nd April, 1876. Again, a pair of these Black Fantails visited my garden on Wellington Terrace on the 15th of the same 
month, and, as I would not allow them to be molested, returned on several successive days. They disappeared together, and I did not see them afterwards, although fondly hoping that they would breed with us, and that this pretty bird might become at length fairly acclimatized in the North Island.

Several more instances of its occurrence in the North Island, in the year following, have come to my knowledge. Major Mair recorded a second example from the Pirongia ranges in the Waikato; another was seen by Mrs. Howard Jackson in the shrubbery at Major Marshall's, near Rangitikei; and another was reported from Auckland. Of the last-mentioned Mr. T. F. Cheeseman, the Curator of the Auckland Museum, writes to me:- "You will be interested to hcar that a solitary individual of the Black Fantail has been repeatedly seen near Auckland this winter. It was first noticed by Mr. James Baber in his garden at Remuera ; afterwards it visited Mr. Hay's nursery-garden, where it remained for some weeks; and it has since been noticed about several of the residences at Remucra. I was fortunate enough to see it one evening when walking home, and can consequently vouch for its being the South Island species. Its occurrence so far to the north is certainly very remarkable."

Mr. Colenso, F.R.S., informs me that he met with one, in February 1882, at Napier; and to Mr. Leonard Reid, the Assistant Law Officer at Wellington, I am indebted for the following note :"It may interest you to know that I met with a specimen on the Pukerua Range near Pauatahanui, when out shooting there in May 1883, in company with two residents of the district who had never seen a Black Fantail before. We tried hard to secure it alive, but though, like its northern congener, it was remarkably tame and fearless, our efforts were unsuccessful. We observed none others of either species in the same locality, and though a frequent visitor to the bush in various parts of this district I have never observed its occurrence on any other occasion "*.

A very interesting phase of character exhibited by this species is that, in its wild state, it associates and interbreeds with the Pied Fantail (Rhipidura fabellifera), as represented in the Plate.

There is a ncst of this sort in the Canterbury Museum, containing three eggs. It was taken, in October 1870, by $\mathrm{Mr}$. Potts, who informed me that the female was a dark bird and the male a pied one $\dagger$. In another case of intercrossing which came under his notice the relative position of the sexes was reversed, the female being R. Alabellifera: the eggs proved to be fertile, and the young assumed the plumage of the female parent.

On the nesting-habits generally he has furnished me with the following interesting note:- "To my view, the most remarkable feature in the breeding-habits of our Flycatchers is the situation usually selected for rearing their young. Security does not appear to be the first consideration; security by concealment seems the leading fcature which guides most arboreal birds in choosing the site of their home, and it is one in which the most admirable displays of instinct may be frequently observed. The Flycatchers rather appear to be led by the same consideration which actuates many sca-birds in selecting the position of their breeding-place-proximity to the food supply. Stroll carefully along the rocky bed of a creek which rambles through some bushy gully, and you may perchance see the beautiful nest perched on some slender bough, in so delicate a manner that it appears scarcely so much to be fixcd as to rest balanced there, and without any attempt at concealment."

The eggs of this species are of similar size and shape to those of the Pied Fantail, but I have remarked that they usually have a darker zone of purple and brown spots.

* Mr. Hamilton writes :- "I obtained a specimon of this bird in the Pohue Bush, about 20 miles north of Napier, July 7 , 1885. I have scen it occasionally nearer Napier. In 1876 I got two or three in the Horokiwi district, ncar Wellington." (Trans. N.-Z. Inst. vol. xviii. p. 125.)

$\dagger$ Writing of another, exhibited at a meeting of the Zoological Society in November 1884, he says :- "Before I removed it, I saw both parent birds undertake the duties of incubation in turn, relieving each other at brief intervals. The coek bird was $R$. fuliginosa, with the aural plumes very small but quito distinct; the hen, $R$. flabellifera, occupied the nest till gently pushed off with the finger." 


\title{
PETROCHELIDON NIGRICANS.
}

\author{
(AUSTRALIAN TREE-SWALLOW.)
}

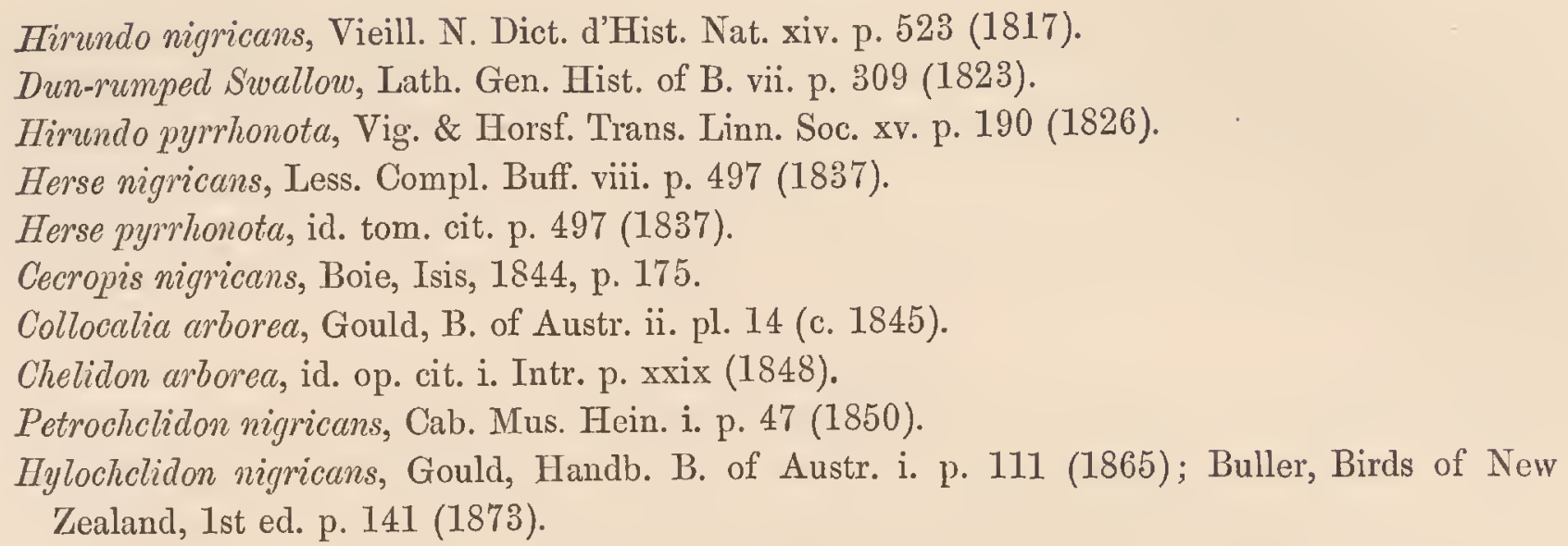

$A d$. suprà purpurascenti-niger : fronte conspicuâ ferrugineâ indistinctè nigro maculatâ : uropygio rufescenti-fulvo, seapis plumarum brunneo indicatis : supracaudalibus brunncis uropygii colore lavatis, scapis codem modo indicatis : tectricibus alarum minimis dorso concoloribus, majoribus et reniigibus brunneis, concoloribus: caudâ brunneâ, rectrice cxtimâ pogonio interno albo notatâ: remigum rectricumque scapis suprà brunneis, subtùs albidis : loris cum regione oculari et paroticâ nigricantibus : genis et colli latcribus sordidè fnlvis brunnescentc variis : subtùs fulvescens, corporis lateribus et subalaribus ferrugineis : gutture lineis longitudinalibus parvissimis, pectore et hypochondriis lineis angustioribus et longioribus striatis : rostro brunneo: pedibus brunneis : iride nigrâ.

Juv. similis adulto, sed suprà magis brunnescens : uropygio fulvescenti-albido : subtùs albieans, corporis lateralibus vix rufescente tinctis.

Adult male. Forchead chestnut-brown; crown of the head, hind neck, the whole of the back, and the small wing-coverts glossy stecl-blue; rump and inferior upper tail-coverts yellowish buff mixed with pale rufous, each feather with a narrow shaft-line of dark brown; longer upper tail-coverts dark brown with paler edges; throat, fore part and sides of neck, and all the under surface pale ycllowish buff, marked on the throat with numerous touches of brown, stained on the sides of the body, inner linings of wings, and under tail-coverts with chestnut-brown; quills and tail-fcatlicrs dark brown, with palcr shafts, greyish on their under surface and slightly glossed above. Irides black; bill, tarsi, and toes light brown. Total length $5 \cdot 25$ inches; wing, from flexure, $4: 5$; tail, to extremity of lateral feathers, 2.25 (middle feathers 44 shorter); bill, along the ridge $\cdot 25$, along the edge of lower mandible $\cdot 5$, breadth at the gape $\cdot 4$; tarsus $\cdot 4$; middle toc and claw $\cdot 55$; hind toe and elaw 45 .

Female. Slightly smaller than the male, with the colours somewhat duller and the markings on the throat less distinct; but, as a matter of fact, the sexes are searcely distinguishable from each other.

Young. Plumage of the upper parts duller, the head and back bcing dark umber-brown with only a slight steel gloss; the rump and tail-coverts yellowish brown, with darker shafts; the underparts altogether lighter, the abdomen and under tail-coverts being fulvous white, and the throat more distinctly spotted with brown.

The Tree-Swallow, which is a native of Australia, was first admitted into our list of birds on the authority of a specimen shot by Mr. Lea at Taupata, near Cape Farewell, on the 14th of March, 1856, and still preserved in the Otago Museum. 
In the summer of 1851, Mr. F. Jollie observed a flight of Swallows at Wakapuaka, in the vicinity of Nelson, and succeeded in shooting one, the description of which, as given by him, left no doubt in my mind that it was of the same species. According to a statement made by the late Sir David Monro at a meeting of the Wellington Philosophical Society in February 1875*, it would appear that about the same period there were other appearances of this Swallow in the vicinity of Nelson.

At a later period, again, the bird appeared at Blenheim, in the provincial district of Marlborough, the fact being announced to me in a letter $\uparrow$ from Mr. J. R. W. Cook, dated June 22, 1878, from which Iquote the following:-

"On Sunday, the 9th instant, about two miles from Blenheim, on the bank of the Opawa river, I saw the first Martin I have met with in New Zealand. The bird was hawking after insects close to the ground in a ploughed field. I was accompanied by two residents in the town of Blenheim, and we watched it closely for some time. It passed us at one time within a few yards. There was no mistaking either the appearance or the flight of the bird. It seemed to me more like the English House-Martin than the common Australian Martin. It seemed, however, dingier in the black than the English bird, and rather smaller-more like the Sand-Martin, in fact. Unfortunately I was absent from the district for some days after seeing it, but since returning $I$ have carefully watched for its reappearance. I have not again seen the bird, so presume it has shifted its quarters."

I had a further communication from Mr. Cook on August 23rd in which he said :- "I saw what I believe to be the same bird, about half a mile from where I saw it before, a month after its first appearance."

In April of the following year I had the pleasure of receiving from him a freshly skinned speci. men of this bird, accompanied by the following letter :-

"Since writing to you last winter, reporting the occurrence here of the Australian Swallow, I did not again notice the bird until the 16th of February last, when I saw another hawking over one of my stubble paddocks. I watched it for some time, and had good opportunities of remarking its plumage. The bird appeared to me either immature or weary, the flight being weak and uncertain. I found, too, that the white on the rump was dingy, and the chestnut on the breast faded-looking. There was a stiffish nor'-west breeze blowing at the time, and the bird tried in vain to get past a belt of willow and poplar so long as I was watching.

"On the 20th of last month (March) when duck-shooting, I mentioned the occurrence to a party of sportsmen, when one remarked 'Oh! there have been some birds answering to your description flying about Grovetown for some time back.' Grovetown, I may remark, is situated about four miles from this, and nearly in the centre of the Wairau valley. After a little talk on the subject it struck me that possibly the birds had been bred there. I said- 'The next time you see them, shoot one and send to me.' Yesterday morning one was handed in, but unfortunately I did not see the man who brought it. Fearing that the weather might not allow me to send it to yon in the flesh, I have skinned the bird and now send it to you."

Mr. Cook having very thoughtfully sent me also the body, preserved in spirit, I was able to dissect it. It proved to be an adult female, and the stomach contained four large blue-bottle flies, almost uninjured, and the remains of others in black comminuted matter.

As bearing on this point, he remarks:- "Certainly the condition of the specimen is not that of one which has lately made a long aerial trip. In skinning it, although I freely used cotton wool and kept the pepper-castor going, I could not help getting the plumage saturated with oil, owing to the excessive fatness of the body."

* Trans. New-Zealand Instit. vol. vii. p. 510.

† Op. cit. vol. xi. p. 360 . 
Writing to me again, under date of June 11th, Mr. Cook says:-

"Since I wrote I have seen no further specimens, but note a paragraph in the 'Kaikoura Star' newspaper, stating that two Swallows had been seen at Kaikoura about the same time as the birds appeared here.

"I have since seen Mr. Cheeseman, who shot the specimen I sent. He tells me there were some six or seven birds in all; that they had been hanging about Grovetown for some weeks before he shot the one; and that he fancied they were young birds, or, at least, that some of them were. He could not, however, say that the party consisted of a pair of old birds with their brood. . . . . The one interesting question possibly may be why the first notice of occurrence of the Swallow is on our east coast. If the 'drift' (from Australia or Tasmania) is to and through Cook Straits, I can understand it. Otherwise we should expect notice of arrivals on the west coasts of both islands." Commenting on the fact that this bird appears in our country only at long intervals and as a stray migrant from a warmer clime, he makes the following very pertinent remarks :- "Is our New-Zealand winter too rigorous for this family of birds? I scarcely fancy so. Even here there are few winter days when an occasional blink of sunshine does not fetch out dancing myriads of Ephemeridce on the river-banks. In olden days I fancy this was not so much the case. 'The rapid growth of willows now overhanging the water must afford protection to delicate new-born insects such as mosquito and other gnats which the old fringe of flax and toetoe never could have given. The temperature of the water in which the larvæ reach their fullest development is scarcely affected by the season. Indeed, in many snow-fed rivers the temperature, far from the source, when the water is at its lowest, must often be higher in winter than in summer, when the melting snows are in full swing and the river body too great to be affected materially by sun-heat. I hope you will agree with me that the natural acclimatization of the Australian Sivallow is not impossible."

Mr. J. D. Enys states that he observed this Swallow skimming over the Avon, near Christchurch, in the year 1861 (Journ. of Science, ii. p. 274).

On another occasion (as reported in the 'Otago Daily News') a flight of five was seen at Moeraki, still further south, by Mr. Bills, who was then engaged catching native birds for the Acclimatization Society, and got near enough to the Swallows to be sure of their identification.

There can be no doubt that these occnsional visitants are stragglers from the Australian continent, and that to reach our country they perform a pilgrimage on the wing of upwards of a thousand miles!

In its own country it is a migratory species, visiting the southern portions of Australia and Tasmania, arriving in August and retiring northwards as autumn advances.

It visits the towns, in company with the Common Swallow (Hirundo frontalis); and I remember seeing it comparatively numerous in and about Sydney, during a visit there in August 1871.

Mr. A. R. Wallace brought specimens from the Aru Islands; so also did the 'Challenger' Expedition; and it is likewise recorded from New Guinea, New Britain, and the Ké Islands.

According to Gould it breeds during the month of October, nesting in the holes of trees, and depositing its eggs (three to five in number) on the soft, pulverized wood. 'The eggs are pinky white, freckled at the larger end with five spots of light reddish brown, and measure eight lines in length by six in breadth. 


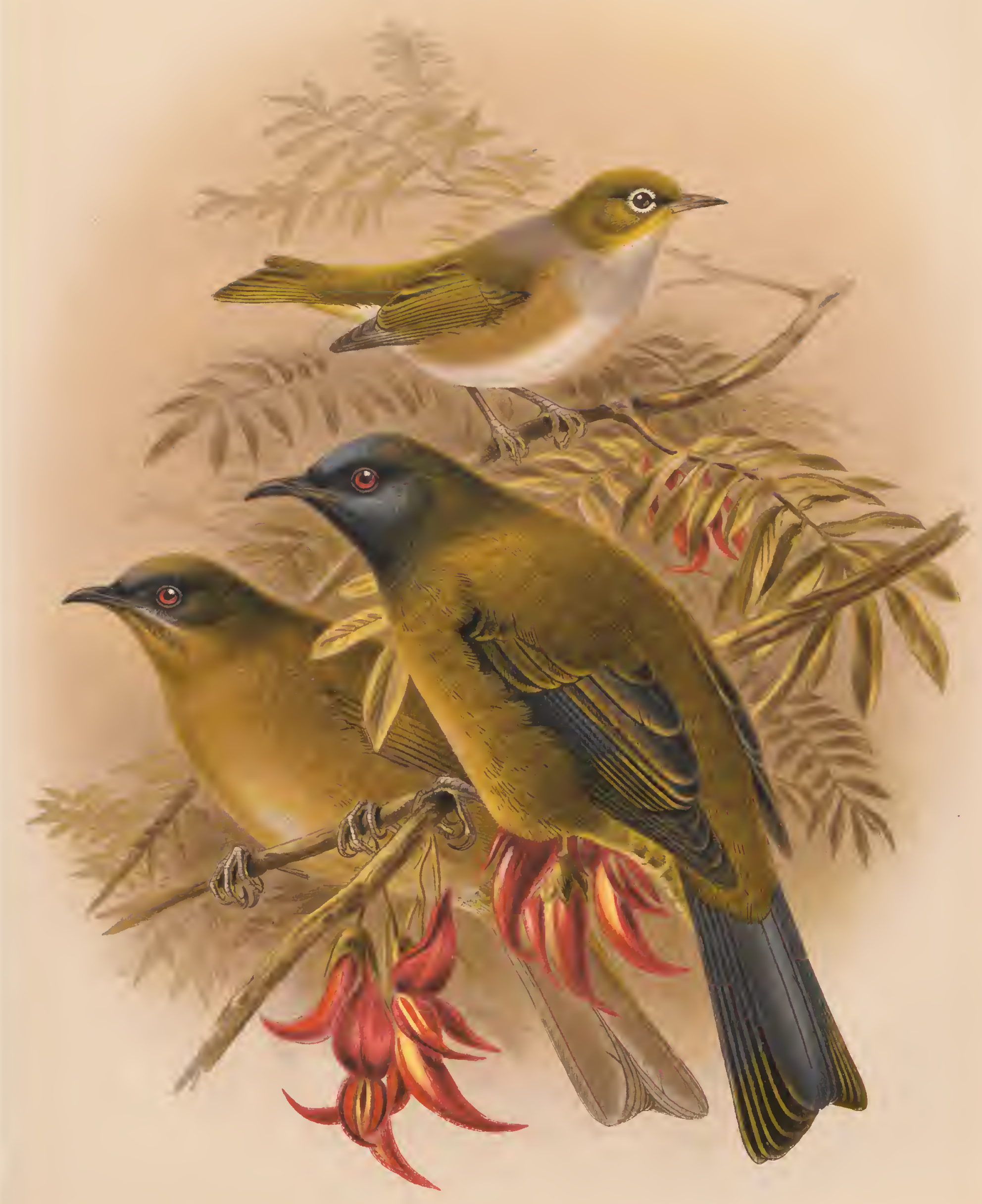





\title{
ZOSTEROPS CERULESCENS.
}

\author{
(THE SILVER-EYE.)
}

Carulean Warbler, Lath. Gen. Syn. Suppl. ii. p. 169 (1801).

Zosterops ccerulescens, Lath. Ind. Orn. Suppl. p. xxxviii (1801).

Sylvia lateralis, Lath. Ind. Orn. Suppl. p. Iv (1801, nec Sund.).

Zosterops dorsalis, Vig. \& Horsf. Trans. Linn. Soc. xv. p. 235 (1826).

Zosterops lateralis, Reich. Handb. Meropinæ, p. 94, t. cccclxiii. (1852).

Zosterops ccerulescens, Gould, Handb. B. of Austr. i. p. 587 (1865).

Zosterops lateralis, Buller, Birds of New Zealand, 1st ed. p. 80 (1873).

\section{Native names.}

Tau-hou, Whiorangi, Hiraka, Motingitingi, Kanohi-mowhiti, Karu-patene, Karu-ringi, Karuhiriwha, Poporohe, and Iringatau.

Ad. pileo et faeie laterali, dorso postieo et uropygio, eum teetrieibus alarum lætè flavieanti-olivaeeis : interseapulio seapularibusque sordidè einereis: remigibus et reetricibus brunneis, extùs dorsi eolore limbatis : regione orbitali antieâ nigrieante, annulo ophthalmico albo : gulâ albidâ vix flavieante tinetâ : gutture imo einereo : abdomine medio et subeaudalibus albidis, his flavieante lavatis : eorporis lateribus eonspieuè badiis : rostro saturatè brunneo, mandibulâ ad basin albieante : pedibus et iride pallidè brunneis.

Adult. Crown, sides of the head, nape, upper surface of wings, rump, and upper tail-eoverts bright yellowish olive; baek and seapularies einereous tinged with green; eyes surrounded by a narrow eirelet of silverywhite feathers, with a line of blaek in front and below; quills and tail-featlers dusky brown, margined with yellowish olive; throat, fore neek, and breast greyish white, tinged more or less with yellow towards the angle of the lower mandible; abdomen and under tail-eoverts fulvous white; sides pale ehoeolate-brown; lining of wings white, the edges tinged with yellow. Bill dark brown; under mandible whitish at the base; irides elear reddish brown; tarsi and toes light brown. Total length 5 inehes ; extent of wings $7 \cdot 5$; wing, from flexure, 2.5 ; tail 2 ; tarsus $\cdot 6$; middle toe and claw 6 ; hind toe and elaw 5 ; bill, along the ridge $\cdot 4$, along the edge of lower mandible $\cdot 5$.

Fledgling. Colours paler than in the adult; the throat and breast pale einereous grey; the sides of the body fulvous brown; the white eye-eirele absent, the orbits being still destitute of feathers; irides hazel-brown; tarsi and toes light flesh-eolour; bill pale brown; rietal membrane yellow.

Obs. The sexes are preeisely alike, the plumage of the female being in no way inferior to that of the male. Although I have examined a great number, I have only deteeted very slight variation in the adult birds. But Arehdeaeon Stoek, of Wellington, who is a good praetieal ornithologist, has favoured me with the following note on this subjeet:-_" I saw on Friday last, November 11, at Wilkinson's 'tea-gardens' (Wellington), what appeared to be a new variety of the Blight-bird. The white eirele around the cye was not so distinet; and the head and throat were orange-eoloured."

THE story of the irregular appearance of this little bird in New Zealand has for many years past been a fruitful topic of discussion among those who take an interest in our local natural history. Whether it came over to us originally from Australia, or whether it is only a species from the extreme south of New Zealand, which has of late years perceptibly increased, and has migrated northwards, is still 
a matter of conjecture *. The evidence which, with Sir James Hector's assistance, I have been able to collect on this subject is somewhat conflicting; but I have myself arrived at the conclusion that the Silver-eye, although identical with the Australian bird, is in reality an indigenous species. The history of the bird, however, from a North-Island point of view is very interesting and suggestive. It appeared on the north side of Cook's Strait, for the first time within the memory of the oldest native inhabitants, in the winter of 1856. In the early part of June of that year I first heard of its occurrence at Waikanae, a native settlement on the west coast, about forty miles from Wellington. The native mailman brought in word that a new bird had been seen, and that it was a visitor from some other land. A week later he brought intelligence that large flocks had appeared, and that the " tau-hou" (stranger) swarmed in the brushwood near the coast; reporting further that they seemed weary after their journey, and that the natives had caught many of them alive. Simultaneously with this intelligence, I observed a pair of them in a garden hedge, in Wellington, and a fortnight later they appeared in large numbers, frequenting the gardens and shrubberies both in and around the town. They were to be seen daily in considerable flocks, hurrying forwards from tree to tree, and from one garden to another, with a continuous, noisy twitter. In the early morning, a flock of them might be seen clustering together on the topmost twigs of a leafless willow, uttering short plaintive notes, and if disturbed, suddenly rising in the air and wheeling off with a confused and rapid twittering. When the flock had dispersed in the shrubbery, I always observed that two or more birds remained as sentinels or call-birds, stationed on the highest twigs, and that on the slightest alarm, the sharp signal-note of these watchers would instantly bring the whole fraternity together. The number of individuals in a flock, at that time, never exceeded forty or fifty; but of late years the number has sensibly increased, it being a common thing now to see a hundred or more consorting together at one time. They appeared to be uneasy during, or immediately preceding, a shower of rain, becoming more noisy and more restless in their movements. They proclaimed themselves a blessing by preying on and arresting the progress of that noxious aphis known as "American blight" (Schizoneura lanigera). They remained with us for three months, and then departed as suddenly as they had come. 'They left before the orchard-fruits, of which they are also fond, had ripened; and having proved themselves real benefactors they earned the gratitude of the settlers, while all the local newspapers sounded their well-deserved praises.

During the two years that followed, the Zosterops was never heard of again in any part of the North Island; but in the winter of 1858 it again crossed the strait, and appeared in Wellington and its environs in greater numbers than before. During the four succeeding years it regularly wintered with us, recrossing the strait on the approach of spring. Since the year 1862, when it commenced to breed with us, it has been a permanent resident in the North Island, and from that time it continued to advance northwards. Mr. Colenso, of Napier, reports that it was first seen at Ahuriri in 1862. On his journey to Te Wairoa, in that year, he saw it at Aropauanui, and found its nest containing four fledglings. The natives of that place told him that it was a new bird to them, they having first observed it there in the preceding year, 1861. The Hon. Major Atkinson, on the occasion of a visit, as Defence Minister, to the native tribes of the Upper Wanganui, in April 1864,

* The substance of the above article on Zosterops was read by tho author before a meeting of the Wellington Philosophical Society on November 12th, 1870 , and led to a discussion, in the course of which Dr. Hector madc the following rcmarks:"He said that on the south-west coast of Otago the bird was numerous, and there was rery good evidence to show that this region was its nativc habitat. While exploring there, some ycars ago, ho had remarked that the whole country was covcred with forest, which extended down to the sca, and that the whole of the vegetation, both trees and shrubs, cspecially those near tho sea-shore, seemed to have a coating of scaly inscets, the entire bush being, in fact, covered with blight. He therefore thought it probable that as these birds increased from tho superabundance of their particular food, they in course of time sent out migratory flocks, which worked their way up the coast, and at length spread over the country."-Trans. N.-Z. Inst. 1870, vol. iii. p. 79 . 
made inquiries on the subjeet, and was informed by the natives that the Zosterops had appeared in their distriet for the first time in 1863.

As far as I ean aseertain, they penetrated to Waikato in the following year, and pushed their way as far as Auekland in 1865. Major Mair, R.M., writing to me from Taupo in 1866, said :"It is now to be seen, in floeks of from 10 to 30, all over the Taupo and Rotoiti distriets; and all the natives agree that it is a reeent arrival in these parts." Professor Hutton reports that in the winter of 1867 they had spread all over the provinee, as far north as the Bay of Islands, and in 1868 he writes:- "They are now in the most northerly parts of this island." That they have eontinued to move on still further northward would appear to be the case from the following suggestive notes by Mr. G. B. Owen:- "On my passage from 'Tahiti to Auckland, per brig 'Rita,' about 300 miles north of the North Cape of New Zealand, I saw one morning several little birds flying about the ship. From their twittering and manner of flying I eoneluded that they were land-birds, and they were easily eaught. They were of a brownish-grey and yellowish eolour, with a little whitc mark round the eye. I saw several pass over the ship during the day, travelling northwards. I arrived in Auckland a few days afterwards, on the 20th of May, when the so-called Blight-birds appearcd here in sueh numbers, and I at onee reeognizcd them as the same." Mr. Seed, the Inspeetor of Customs, has furnished me with the following interesting partieulars bearing on the same point. When on an offieial visit to the lighthouse on Dog Island, situated about seven miles enstward of the Bluff, he was informed by the keeper that on one oeeasion a great number of these birds had killed themselves by striking against the lighthouse, either during the night or before the lights were put out in the morning, as he found them in scores lying dead in the gallery*. Mr. Seed eould not aseertain positively the direction whence they eame, but he understood that it was from the southward; and other inquiries at the time led him to conelude that they had eome from Stewart's Island, the extreme southern limit of New Zealand.

This tendeney of migration northwards appears to me quite ineonsistent with the idea of the speeies having eome to us from Australia.

Now let us aseertain something of its reeorded history in the South Island. Mr. Potts, says, in a letter to me:- "I first observed it (in Canterbury) after some rough weather, July 28, 1856. I saw about half a dozen speeimens on some isolated blaek bireh trees in the Roekwood valley in the Malvern Hills." In the Auekland Museum there is a speeimen of this bird, sent from Nelson by Mr. St. John (an industrions bird-eolleetor) in 1856. The skin was labelled "Stranger," and in the letter aceompanying it Mr. St. John states that these birds had made their first appearanee in Nelson that winter (the same in which they erossed to the North Island), and that " no one, not even the natives, had ever seen them before."

On a visit to Nelson in the wintcr of 1860 , I saw numerous flights of them in the gardens and shrubberies. The result of very eareful inquiries on the spot satisfied me that sinee their first appearanee there, in 1856, they had eontinued to visit Nelson every year, arriving at the eommeneement of winter, and vanishing on the approaeh of warmer days as suddenly as they had eome. On every hand the settlers bore testimony to their good serviees in destroying the eabbage-blight and other inseet pests.

About the middle of June 1861, I met with small floeks of this bird on the Canterbury Plains, evidently on thcir passage northward. I first observed them in the low serub on the broad shingle-

* The fact that they continue their flight at night is very curious. I may mention that on a dark evening in August, about 8 r.x., I observed what secmed to be a large moth fluttering against the glass of a lamp-post on Wollington Terrace. Apparently stumned, or wearicd out, it fell to the ground, aud on picking it up I found it to bo a Zosterops, which had evidently beon attracted by the gas-light. Its poor condition indicated that it was a migrant, doubtless a straggler from one of the flocks, large numbers of these birds having about that time made their appearance on the northern side of Cook's Strait. 
beds of the Rakaia, advancing in a very hurried manner, not high in the air, as migrations are usually performed, but close to the ground, and occasionally resting. But that this bird is capable of protracted flight is evidenced by the form of its wings, which are of the lengthened, acuminate character common to most birds of passage.

During a visit to Dunedin, in the sumner of 1860 , the Rev. Mr. Stack observed numerous flocks in the gardens and thickets in the environs of the town. At this season they had disappeared from the Province of Canterbury and all the country further north. In the following summer (1861) I met with numerous stragglers in the northern parts of the Canterbury Province, and I understand from $\mathrm{Mr}$. Potts that since that time it has been a permanent resident there, increasing in numbers every year. Mr. Buchanan, late artist to the Geological Survey Department, informs me that he observed the Zosterops at Otago, on his first arrival there in 1851, five years previous to its appearance in the North Island; and the following letters from correspondents go still further to prove that the species is an indigenous one there, and is only new to the country lying further north.

Mr. Newton Watt, R.M., of Campbell Town (Southland), writes as follows:- " Paitu, a chief here, and I believe the oldest man in the tribe, says it was always here. Howell says that he first noticed them on the west coast, about Milford Sound, in the year 1832, in flocks of thirty or forty, but never noticed them here (Riverton) till about 1863 , when he saw them inland and in smaller flocks. On my way back from Riverton, I was mentioning it at the Club at Invercargill, and a gentleman present told me he had first noticed them, about eighty miles inland, about the year 1861, and that his attention was first called to them from the circumstance that they were gregarious, - a habit not common with New-Zealand birds. At Campbell Town it appeared to be more scarce, being seen only in small flocks, varying in number from six to twelve. In $1866 \mathrm{my}$ sons noticed numbers of them among my cabbages, and observed that the cats caught many of them; and, further, that whilst my cabbages in the three preceding years were infested with blight, in that year there was little or no blight upon them till very late in the season. They appear to migrate from this locality in the winter, or at any rate to be scarce."

Mr. James P. Maitland, R.M., of Molyneux, writes :-_" From what I hear from old settlers of seventeen or eighteen years' standing (whom I can trust as men of observation), I am convinced we have had the birds here for that time at any rate, although all agree that they have become much more numerous everywhere during the last seven years; and this year (1867) in particular I observe them in larger flocks than ever. I confess I do not recollect noticing the bird until about six years ago; but the smallness of their number at that time, and the smallness of the bird itself, may easily account for its being unnoticed in the bush. The gardens seem to be the great attraction here, and they are the best hands I know at picking a cherry- or plum-stone clean!"

All my own personal inquiries at Otago, during my first visit there in February 1865, led me to the same conclusion.

Referring again to the migration of Zosterops from the South Island in 1856, it may, I think, be assumed that the large flights which came across Cook's Strait made the island of Kapiti in their passage, and tarried there for a time before they reached the North Island. It will be remembered that the flocks which afterwards spread over the province appeared first at Waikanae and Paekakariki, on the lee shore from that island. I found Zosterops excessively abundant at Kapiti during a visit there in April 1875. Every bush swarmed with them, and sometimes fifty or more would crowd together in the leafy top of a stunted karaka, warbling and piping in chorus, producing sylvan music of a very sweet description. They appeared to be feeding on a species of Coccus that afflicts that tree.

The large numbers of these birds that appeared in flocks at Waikanae and Otaki in the early 
part of June of the same year would seem to indicate another incursion from the South Island at that date *.

The bird whose history has been so fully recorded in these pages being once fairly established among us, it has continued to increase and multiply, and now it disputes possession of our gardens and hedgerows with the introduced Sparrows and Finches, and indeed swarms all over the country. On my last visit to the Hot Lakes I found it extremely abundant everywhere; even amid the noxious fumes at Sulphur Point I met with small flocks flitting abont in the stunted manuka scrub, and apparently quite at home in sulphuretted hydrogen! In the Bay of Plenty district it is particularly plentiful, so much so as to form an article of food to the natives. They are in season in the months of March and April, and are then collected in large numbers, singed on a bush fire to take the feathers off, and forthwith converted into huahuo and potted in calabashes. The catching is effected in a very primitive way. The birds have their favourite trees upon which they are accustomed to congregate. Selecting one of these, the bird-catcher clears an open space in the boughs and puts up several straight horizontal perches, under which he sits with a long supple wand in his hand. He emits a low twittering note in imitation of the birds', and, responding to the call, they cluster on the perches, filling them from end to end. 'The wand is switched aloug the perch, bringing dozens down together, and a boy on the ground below picks up the stunned birds as they fall. Captain Mair, when visiting Ruatahuna on one occasion, had brought to him, by two Urewera lads, a basket containing some five or six hundred of these little birds which had been killed in the manner described.

In front of the Rev. Mr. Spencer's house at Tarawera, in a hedge of Laurustinus, scarcely six yards from the door, upwards of twenty nests of Zosterops were found at one time, each containing trom three to five eggs (generally the former) of a lovely blue colour. Usually, however, these birds do not breed in communities, but scatter themselves in the nesting-season.

My son discovered a nest, containing three eggs, attached to a fern-stalk at the very edge of a boiling and steaming fumarole, near the White Terrace of Rotomahana, and suspended as it were in the midst of a perpetual vapour-bath.

In the selection of its breeding-home, this bird has manifested with us somewhat erratic tendencies: thus, for the first three or four years after its permanent location in the North Island, it wintered in the low lands and the districts bordering on the sea-coast, and retired in summer to the higher forest-lands of the interior to breed and rear its young. In the summer of 1865 a ferw stragglers were observed to remain behind all through the season, and in the following year they sojourned in flocks and freely built their nests in our shrubberies and thickets, and even among the stunted fern and tea-tree (Leptospermum) near the sea-shore. From that time to the present it has ranked as one of our commonest birds all the year round; and, what is even more remarkable, it has very perceptibly increased in numbers, whilst most of our other insectivorous birds are rapidly declining, and threaten ere long to be extinct.

To the philosophical naturalist the history of the Zosterops in New Zealand is pregnant with interest, and I feel that no apology is needed for my having thus minutely recorded it.

The natives distinguish the bird as Tau-hou (which means a stranger), or Kanohi-mowhiti (which nay be interpreted spectacle-eye or ring-eye). It is also called Poporohe and Iringatau, names suggested by its accidental or periodical occurrence.

* Six years later, about the month of July, there was another irruption of the kind, the gardens and shrubberies in and around Wellington swarming with them, many hundreds often eonsorting together in ono floek. On this oceasion, they freely visited the poultry enelosures and baek-yards in their seareh for food, and I have counted as many as thirty at one time exploring a drain-trap or elustering together on a disearded bone at the dog-kennel, and eagerly tearing off the partieles of meat adhering to it. As a rule, they seemed to be unusually tame, as if weary after their long flight; and some of them, emboldened by hunger, entered the houses and outbuildings, whilst numbers fell victims to the remorseless eat. 
By the settlers it has been variously designated as Ring-eye, Wax-eye, White-eye, or Silvercye, in allusion to the beautiful circlet of satiny-white feathers which surrounds the eyes; and quite as coinmonly the "Blight-bird," or "Winter-migrant."

I have frequently watched the habits of this little bird, and with much interest. As already stated, it is gregarious, flying and consorting in flocks, except in the breeding-seasoll, when they are to be observed singly or in pairs. As soon as a flock of them alights on a tree, or clump of brushwood, they immediately disperse in quest of food; and, on a cautious approach, may be seen prosecuting a very diligent search among the leaves and flowers, and in the crevices of the bark, for the small insects and aphides on which they principally subsist. I have opened many specimens, at all seasons, and I have invariably found their stomachs crammed with minute insects and their larvæ. In some I have found the large pulpy scale-insect (Coccus, sp.), of a dull green colour, whicli is commonly found adhering to the leaves of the ramarama (Myrtus bullata); also small caterpillars, grasshoppers, and coleoptera, and occasionally the small fruity seeds of Rubus australis and other native plants. In our orchards and gardens it regales itself frecly on plums, cherries, figs, gooseberries, and other soft fruits; but it far more than compensates for this petty pilfering by the wholesale war it carries on against the various species of insects that affect our fruit-trees and vegetables. It feeds on that disgusting little aphis known as American blight, which so rapidly covers with a fatal cloak of white the stems and branches of our best apple-trees; it clears our early cabbages of a pestilent little insect that, left unchecked, would uttcrly destroy the crop ; it visits our gardens and devours another swarming parasite that covers our roses and other flowering plants, to say nothing of its general services as an insectivorous bird. Surely, in return for these important benefits, to both orchard and garden, the flocks of Zosterops may justly be held entitled to an occasional feed of cherries, or to a small tithe of the ripe fruits which they have done so much to defend and cherish!

It is very pretty to see a pair of them feeding together on a single berry of the poroporo (Solanum nigrum) or diligently scooping out the centre of a ripe fig, their ever-changing positions being very artistic.

A favourite resort of this bird in the early part of November is the kohia creeper (Passiflora tetandra), which covers much of the low scrub on the outskirts of the forest, and is at this time a mass of white bloom. 'The little bell-shaped flowers, which diffuse so much fragrance through the woods, being full of nectar, attract the little golden butterfly (Chrysophanus enysi) and swarms of gaily-coloured diptera. Here the Zosterops, in addition to the sip of honey, finds an abundance of its favourite insect food. When thus engaged, it emits a soft plaintive cry, repeated at short intervals; but on the wing, and especially when consorting in a flock, it utters a rapid twittering note. During the breeding-season the male indulges in a low musical strain of exquisite sweetness, but very subdued, as if singing to himself or performing for the exclusive benefit of his partner. This song is something like the subdued strain of the Korimako (Anthomis melanura), but much softer.

I have already mentioned the circumstance of a flock of these birds being generally attended by two or more sentinels or call-birds, who take their station on the topmost twigs, as a post of observation, and whose sharp signal-note instantly brings the whole fraternity together. On one occasion, while out pheasant-shooting at Wangaehu, the sound of my companion's whistle, although more than 200 yards away, attracted the notice of a flock of Zosterops consorting together in the top of a lofty kahikatca tree. The call-birds gave the alarm, and the whole flock, amidst much clamour, ascended high in the air and disappeared behind a neighbouring hill. The sentinels appear to be always on the alcrt; and I have seen the same effect produced on a flock of these birds by the cry of a liawk, or any other suspicious sound, although there was no appearance of immediate danger.

If shot at and wounded it geuerally manages to escape capture by scrambling nimbly off into 
the thicket, hiding itself and remaining perfectly silent till the danger has passed. Frequent attempts have been made to keep it cagcd; but although it will readily feed, it seldom survives confinement many weeks. Only one instance of complcte success has come to my knowledge. Mrs. Fereday, residing near Christchurch, kept scveral of them caged for upwards of two years; and I am indebted to that lady for the following amusing account of these captives:-They were adult birds when taken, but soon became rcconciled to the restraints of a canary-cage, and partook readily of bread soaked in milk. They were interesting objects on account of their extreme display of mutual affection, as they were always caressing one another and prcening each other's feathers. This demonstration of affection, however, was at length carried too far, as one of them contracted a habit of pulling out his neighbour's feathers, in order to suck the oily matter from the roots of the quills. The practice was commenced during the seasonal moult, when the pen-feathers were present, but was continued afterwards, till it became necessary to turn out the offender and introduce a wild bird in its place. But the practice soon became general, each bird plucking and submitting to be plucked in the most business-like manner. The operation was usually commenced on the neck, and it was very droll, said my informant, to see the bird holding its head up, as a man would sit to be shaved, while the featliers were plucked out one by one. The birds were then separated, but they manifested the utmost distress, crying plaintively and refusing their food. On the first opportunity they resumed their old habit, and at length one of them was plucked completely bare! Finding the case hopeless, Mrs. Fereday then liberated the birds in the garden, where they scemed to suffcr from the colder temperature of the open air, and shortly disappeared altogether, probably falling victims to some predatory cat.

At the period when they were most plentiful at Wellington, an unaccountable mortality manifested itself; and in one particular locality, near 'Te Aro, sometimes as many as twenty dead ones were found in the morning under the Eucalyptus tree in which the flock had roosted for the night.

$\mathrm{Mr}$. Colenso observes that "when thcy retire to roost thcy sleep in pairs, cuddling quite close together, like love-parrots; and before they fold their heads under their wings they bill and preen eacl other's head and neck most lovingly, uttering at the same time a gentle twittering note."

Mr. Potts informs me that, in Canterbury, this species begins nesting early in October. In one instance, within his own observation, the birds commenced incubation on October 16, the young were hatched on October 25, and left the nest on November 4. In the North Island the breeding-season is somewliat later. As late as the 24th of Deccmber I met with a ncst in the Taupo-Patea country, containing two perfectly fresh eggs. The nest is a slight cup-shaped structure, with a rather large cavity for the size of the bird, and is generally found suspended by side-fastcnings to hanging vines, or to the slender twigs of Leptospermum, Olearia, and other shrubs, and sometimes to the common fern (Pteris aquitina). The eggs are generally three in number (sometimes four), ovoido-conical in form, measuring $\cdot 7$ of an inch in length by 5 in breadth, and of a beautiful, uniform pale blue colour.

Nests of this spccies exhibit some variety, both as to structure and the materials of which thcy are composed. Of three specimens now before me, one is of slight construction and shallow in its cavity, composed externally of grecn-colourcd lichen, spiders' nests, the downy seed-vessels of the pikiarero (or flowering clematis), and a few dry leaves, lined internally with long horse-hair disposed in a circular form; another is of smaller size, more compact, composed cxternally of crisp dry moss, and internally of grass-bents with a few long hairs interlaced; while the third has the exterior walls constructed entirely of spiders' nests and stiff fibrous mosses, the former predominating, and the interior lining composed wholly of long horse-hair.

At Akitio (in the North Island), where wild pigs are very plentiful, the Blight-birds habitually 
line their nests with pigs' bristles, as a substitute for horse-hair, which is generally used by them in other parts of the country. In a multitude of cases I have found the cavity of the nest lined with long horse-hair intermixed with dry bents, all carefully twined together. An example in the Canterbury Museum has the cavity lined entirely with long horse-hair, and two other specimens in the same collection have a lining composed exclusively of fine grass-stcms, carefully bent.

A specimen which I found suspended in a clump of creeping kohia was composed externally of the pale green and rust-coloured lichen so abundant on the branches of dead timber, intermixed with spider's' webs, and lined inside with dry fibrous grasses, the whole being laced together with hair, the long straggling ends of which projected from cvery part of the nest; and another, which was obtained from the low brushwood bordering on the sea-shore, was built of shcep's wool, spiders' nests, pellets of cow-hair, and fine seaweed firmly bound together with long thread-like fibres, apparently the rootlets of some aquatic plant, and lined internally with finc grass-bents and soft feathers. Sometimes the nest is constructed wholly of bcnts and dry grass.

I have lately had an opportunity of examining a bcautiful serics of thc nests of this species, and I rcmarkcd that through all the varieties of individual form and structure they presented these two essential features-the large cup-like cavity with thin walls, and the admixture of long hairs in the lining material. In one of the nests forming this series the proximity to civilization was proclaimed by a lining consisting of the flaxen hair from a child's doll!

Zosterops is not, strictly speaking, a suctorial bird; but it is closely allicd to the 'Iubilingues. The tonguc has no brush, but ends in two short filaments; and, as shown by Dr. Gadow, in his 'Account of the Suctorial Apparatus of the Tenuirostres,' is far from being thc complicated and elaborate organ generally exhibited in the tubular tongues of the Nectariniidx and Meliphagidæ.

The genus has an extensive range, for, according to thc British Museum Catalogue, its members are sprcad all over South Africa south of the Sahara, Madagascar and the Comoro Islands, the entire Indian Peninsula and Ceylon, Burmese countries, the whole of China (extending into Amoor Land), Japan, Formosa, Hainan, Malay Peninsula, all the Indo-Malayan islands, Moluccas, New Guinca and the adjacent Papuan group, and (with few exceptions) throughout the islands of the grcat Pacific Ocean.

Mr. Gould states that Zosterops corulescens "is stationary in all parts of Tasmania, New South Walcs, and South Australia, where it is not only to be met with in the forests and thickets, but also in nearly every garden."

At the Chatham Islands, whcre it is now very abundant, it is said to have made its first appearance shortly after the great fire in Australia known as Black Thursday. 


\section{ANTHORNIS MELANURA.}

(BELL-BIRD.)

Mocking-Creeper, Lath. Gen. Syn. ii. p. 735 (1782).

Certhia melanura, Sparrm. Mus. Carls. pl. v. (1786).

Certhia sannio, Gm. Syst. Nat. i. p. 471 (1788).

Philedon dumerilii, Less. Voy. Coq. Zool. i. p. 644, t. 21. fig. 2 (1826).

Anthomiza ccruleocephala, Swains. Classif. of B. ii. p. 327 (1837).

Philedon sannio, Less. Compl. Buff. xi. p. 165 (1838).

Anthornis melanura, Gray, List of Gen. of B. p. 15 (1840).

Certhia olivacea, Forst. Descr. Anim. p. 79 (1844).

Anthornis ruficeps, Von Pelz. Verh. zool.-bot. Gesellsch. Wien, 1867, p. 316.

\section{Native names.}

Mako, Makomako, Komako, Kokomako, Korimako, Kohimako, Kokorimako, Kohorimako, Titimako, and Kopara. Of the above names, Korimako is most generally used by the northern and Makomako by the southern tribes. The Ngatiawa call this bird Rearea; and the natives of the Bay of Plenty distinguish the male and female as Kokorohimako and Titapu.

$\delta$ suprà flavieanti-olivaeeus, uropygio vix læetiore : pileo undique metallieè violaeco nitente : loris et mento ipso nigrieantibus : teetrieibus alarum nigrieantibus dorsi eolore lavatis : remigibus nigrieantibus vix sub eertâ luee indigotieo nitentibus, extùs angustè olivaeeo limbatis, seapis suprà nigrieantibus, subtùs brunneseentibus : eaudâ nigrâ, subtùs pallidiore, reetrieibus extùs sordidè indigotico lavatis : subtùs flavieanti-olivaeeus, hypoehondriis imis paullò lætioribus: erisso et subeaudalibus flavieanti-albis, olivaeeo-brunneo variis : subalaribus eineraseentibus, olivaeco lavatis : faseiis axillaribus flavidis : rostro nigro: pedibus plumbeis, unguibus brunneis : iride rubrâ.

q nuari similis, sed magis olivaeeo-brunneseens, et ubique sordidior : pileo dorso eoneolore, metallieè viridi obseurè nitente : alis et eaudâ brunneseentibus, seeundariis fulvo terminatis et reetrieibus olivaeeo-viridi limbatis : faseiâ mystaeali parvâ albidâ : subtùs brunneseens, peetore pallidè ferrugineo lavato, abdomine magis olivascente : subalaribus et faseiis axillaribus sordidè flavidis.

ơ juv. similis mari adulto, sed pallidior : faseiâ mystaeali indistinetâ.

Adult male. The wlole of the plumage olive-green, ehanging to yellowish-olive on the sides of the body and abdomen; beneath plumbeous; forehead, erown, and sides of the head glossed with deep purple; primary quills and tail-feathers dusky black, darker and liaving a steel gloss on the outer webs; the seeondary quills narrowly margined outwardly with olive-green, whiel eolour spreads on the inner ones till it nearly eovers the entire web; inner lining of wings, as well as the soft ventral feathers and under tail-eoverts, pale fulvous yellow. Irides eherry-red; bill blaek; tarsi and toes dark leaden grey; the elaws brown. 'Total length $7 \cdot 75$ inehes; wing, from flexure, $3 \cdot 4$; tail, to the extremity of lateral feathers, $3 \cdot 6$; bill, along the ridge $\cdot 6$, along the edge of lower mandible $\cdot 75$; tarsus 1 ; middle toe and elaw $\cdot 6$; hind toe and elaw $\cdot 75$.

Adult female. Smaller than the male, with little or no purple gloss on the head, and readily distinguished by a 
narrow streak of white, which extends downwards from the angles of the mouth, fading off in a line with the ear-eoverts. Upper parts dull olivaeeous; throat, breast, and underparts generally ycllowish brown, strongly tinged with olive; quills and tail-fcathers dusky blaek, margined on their outer wcbs with olivaceous; linings of wings, vent, and under tail-eoverts fulvous white, washed with yellow.

Young male. Plumage lighter than in the adult bird, with a narrow indistinct line of yellowish white from the angles of the mouth.

Nestling. Plumage fluffy and colours dull. The membrane at the corners of the mouth strongly developed and of a bright yellow eolour.

Obs. The bird described by Herr von Pelzeln (l.c.) under the name of Anthornis ruficeps was, what I had always contended for *, nothing but a flower-stained example of the present speeics. In acknowledgment of this I have reeeived the following note from my fricnd Dr. Finseh, of Brcmen :- "You are quite right in respect to A.ruficeps. The red colour on thic face is eaused by external influenees; for my friend Von Pelzeln has washed the type in the Vienna Museum, and the red tinge las partially disappcared." But, even as far back as 1782 , Latham mentions $(l . c$.$) the existence of a red stain in some specimens, and ascribes it to the$ true cause, adding "this in time rubs off, and the colour of the head appears the same as the rest of the plumage."

Varieties. On the 10th Oetober, 1874, a partial albino was brought to the Canterbury Museum, and I had an opportunity of cxamining it in the flesh. Although I had seen probably some thousands of this species, this was the first instanec I could remember of any departure from the normal colour, unless it werc an occasional very slight tendency to melanism. This spccimen, which is still in the collection, is a fine male bird, with the body-plumage as iu ordinary spccimens, but having the whole of the quills and tail-feathers ashy white, the cdges of thc outer webs shightly tinged with yellow. The shafts of the quills are dark brown, those of the tail-feathers white in thcir greater portion, becoming brown towards the base; the bastardquills and tertiary eoverts arc ashy white; the large secondary coverts dark grey tipped with whitish and margined with dull olive; the axillary tufts, lower part of abdomcn, flanks, and under tail-coverts palc lemon-ycllow. Irides, bill, and feet as in ordinary examples.

Much more recently, however (in April 1885), a more perfeet albino was brought to the Museum from Akaroa. The whole plumage is white, washed with pale yellow on the baek, upper surface of wings, rump, and underparts, the basal portion of each feather being pale plumbeous; under surface of wings and tailfeathers pale slaty grey; bill and feet as in the normal condition.

THE praises of the Bell-bird were sung, a hundred years ago, by the illustrious navigator Cook, whose 'Voyages' contain the following record:- "The ship lay at the distance of somewhat less than a quarter of a mile' from the shore $t$; and in the morning we were awakened by the singing of the birds : the number was incredible, and they seemed to strain their throats in emulation of each other. This wild melody was infinitely superior to any that we had ever heard of the same kind; it seemed to be like small bells most exquisitely tuned, and perhaps the distance and the water between might be no small advantage to the sound." One has but to read this early tribute to realize how great a loss we have suffered from the almost total disappearance of this bird from the North Island. Even when writing its biography for my former edition, I had to make the following discouraging statement :-

This species, formerly very plentiful in every part of the country, appears to be rapidly dying out. From some districts, where a few years ago it was the commonest bird, it has now entirely vanished. In the Waikato it is comparatively scarce, on the East Coast it is only rarely met with,

* Trans. New-Zealand Inst. 1868, vol. i. p. 108.

† Queen Charlotte's Sound. 
and from the woods north of Auckland it has disappeared altogether. In my journeys through the Kaipara district, eighteen years ago, I found this bird excessively abundant everywhere; and on the banks of the Wairoa the bush fairly swarmed with them. Dr. Hector, who passed over the same ground in 1866, assures me that he scarcely ever met with it; and a valued correspondent, writing from Whangarei (about 80 miles north of Auckland), says:- "In 1859 this bird was very abundant here, in 1860 it was less numerous, in 1862 it was extremely rare, and from 1863 to 1866 I never saw but one individual. It now seems to be entirely extinct in this district."

The above remarks were intended to refer principally to the North Island; but even in the South, as I have elsewhere pointed out*, it is far less plentiful than it formerly was. Doubtless it is only a question of a few years, and the sweet notes of this native songster will cease to be heard in the grove; and naturalists, when compelled to admit the fact, will be left to speculate and argue as to the causes of its extinction.

My observations as to the extreme rarity of this species in the North Island, where in former years it was the commonest of the perchers, are confirmed by Captain G. Mair, who informs me that during the last ten years he has never met with it at all, except on the Island of Molsoia (a place of some historic interest in the Rotorua Lake, about 600 acres in extent), in a tract of manuka bush covering about a thousand acres of land at the foot of Mount Edgecumbe, and in the high scrub at Waitahanui about ten miles from Taupo. In the first named of these localities it is still very plentiful $\uparrow$.

In 1868, Professor Hutton found the Korimako abundant on Great Barrier Island, although even then scarce on the mainland ; and in 1871 Major Mair met with it on the Rurima Rocks and on Whale Island, in the Bay of Plenty, places about five miles apart. He records the delight with which he again listened to its sweet note, and adds, "the Maoris think there is only one, that it is the sole survivor of the race, and that it flies backwards and forwards between these islands."

Although I travelled a good deal through the forests of the interior during the ten years after my return from Europe in 1874, on one occasion only did I ever meet with this species on the mainland, and then only with a solitary bird; but during a storm-bound visit to the island of Kapiti (Cook's Strait) in April 1877, I was charmed immediately on landing to hear the musical notes of the Bell-bird again, and to meet with it in every direction among the stunted karaka groves that clothe the western slopes of that island. In the course of an afternoon I saw a score or more of them within a very limited area, and on a second and more extended visit on the following day I found them equally numerous. I met with another bird also, which has likewise become well-nigh extinct on the mainland (Miro australis), although not in such numbers as the former.

Several years later I met with the Korimako again, in sufficient abundance, on a wooded islet called Motu-taiko in the very centre of the Taupo Lake, having put in there for shelter.

The facts I have mentioned are interesting, as furnishing another illustration of the observed natural law, that expiring races of animals and plants linger longest and find their last refuge on seagirt islands of limited extent.

* Trans. New-Zealand Instit. vol. ix. p. 330.

+ Captain Mair informs me also that on the small island of Motiti, in the Bay of Plenty, the Bell-bird is very numerous, a'though it is never seen or heard on the mainland opposite. He adds :- "On Whale Island also, although there are no Tuis, Korimakos are very plentiful. It was really delightful to seo and hear them again. They abound in numbers in the shrubbery, and hearing them sing at daylight earried me back in spirit to my boyhood, at the North, thirty years ago !" My son having gone to this island, to indulge in deep-sea fishing, had to eamp there for the night. He aud his party found shelter in a little rocky carem, and being tho last day of the old year, the new year's morn was ushered in by a delightful ehorus from the Bell-birds in tho pohutukawa trees abovo them.

¥ Ten Jears later, Reisehok conld not fiud one on the Great Barrier, although the bird was still to be heard and seen on the I.ittle Barrier. 
The cause of the rapid disappearance in New Zealand of some species of birds, and absolute extinction of others, is a very interesting question, and I have already called attention to it in various published papers. In a newly colonized country, where the old fauna and flora are being invaded by a host of foreign immigrants, various natural agencies are brought into play to check the progress of the indigenous species, and to supplant them by new and more enduring forms, more especially in the case of insular areas of comparatively small extent. These agencies are often too subtle in their operation to arrest the notice of the ordinary observer; and it is only the ultimate results that command his attention and wonder. But in New Zealand some special cause, apart from this general law, must be assigned for the alarmingly rapid decrease of many of the indigenous birds: in the course of a very few years, species formerly common in every grove have become so scarce throughout the country as to threaten to become extinct at no very distant date.

Various reasons have been suggested to account for this. The natives believe that the imported bee, which has become naturalized in the woods, is displacing the Korimako, Tui, and other honey-eating birds. One of the oldest settlers in the Hokianga district (the late Judge Maning), speaking to me on this subject, said:- "I remember the time, not very long ago, when the Maori lads would come out of the woods with hundreds of Korimakos hung around them in strings; now one scarcely ever hears the bird: formerly they swarmed in the northern woods by thousands; now they are well nigh extinct." On asking him his opinion as to the cause of this, he told me that he agreed with the Maoris, that the bee, liaving taken possession of the woods, had driven the honeyeating birds away from the flowers, and practically starved them out; and he referred to the scarcity of the 'l'ui, another honey-eater, in support of this view*. But it must be remembered that both of these species subsist largely on berries and insects, and that the comparative failure of their honeyfood, even if granted, will not of itself account for the rapid decrease of these birds; while, on the other hand, the Totoara (Miro australis) and other species which do not sip flowers are becoming equally scarce. It appears to me that the honey-bee theory is quite insufficient to meet the case, and that we must look further for the real cause. As the result of long observation, I have come to the conclusion that, apart from the effects produced by a gradual change in the physical conditions of the country, the chief agent in this rapid destruction of certain species of native birds is the introduced rat. This cosmopolitan pest swarms through every part of the country, and nothing escapes its voracity $t$. It is very abundant in all our woods, and the wonder rather is that any of our insessorial birds are able to rear their broods in safety. Species that nest in hollow trees, or in other situations accessible to the ravages of this little thief, are found to be decreasing, while other species whose nests are, as a rule, more favourably placed, continue to exist in undiminished numbers. As examples of this latter class, I may instance the Kingfisher, which usually scoops out a hole for

* In this connection it is worth mentioning that on the Great Barrier and Island of Kawau, from both of which the Korimako has now disappeared, bees are plentiful; whereas on the Little Barrier and the Chickens, where the bird still lingers, there are no bees.

† In a letter which I had tho pleasure of receiving from the Rev. T. Chapman, of Rotorua, some years ago, that gentleman states:- " Wild Ducks were particularly numcrous in this district on my arrival hero: you saw them by dozens; you hardly see them now by twos. I have no doubt we owe this to the Norway rat. There is a place on the Waikato river, some twenty miles below Taupo, where the chicfs ocensionally assombled to act out two importnnt matters,- - to discuss politics and eat kouras (crayfish). A few years nfter tho Norway rat fully appeared, the kouras were no longer plentiful; and as the New Testament made Maori politics rather unnecessary, the usage of meeting no longer exists. The natives assured me that the Norway rat caught the crayfish by diving. Rowing up tho rivers you sce little deposits of shells: upon inquiry I found they were the selections of the Norway rats, who, by diving for these freshwater pipis, provide a kinaki (relish) for their vegetable suppers."

Herr F. von Fischer (Zool. Gart. 1872, p. 125) calculates that a single pair of these rats might have, after ten years, a progeny of $48,319,698,843,030,344,720$ individuals. 
its nest in the upright bole of a dead tree, quite beyond the reach of rats, and appears to be more abundant now than ever; also the Rhipidura, Zosterops, Gerygone, and othcr small birds, whosc delicate nests are secured to slender twigs or suspended among vines and creepers. And the GroundLark, again, which nests in open grass or fern land, where the Harrier keeps the rat well under control, has of late years sensibly increased, being now very common. As a matter of fact, I have known a case in which half a dozen nests of the Tui, within a radius of a hundred yards, werc robbed by rats of both eggs and young *.

But to resume our history of the "Bell-bird"-so-called from the fanciful resemblance of one of its notes to the distant tolling of a bell. Its ordinary song is not unlike that of the Tui or Parson-bird, but is more mellifluous. Its notes though simple are varied and swectly chimed; and as the bird is of social habits, the morning anthem, in which scores of thesc sylvan choristers perform together, is a concert of eccentric parts, producing a wild but pleasing melody. When singing it arches its back and puffs out the feathers of the body. I have occasionally heard a solitary Bell-bird pouring forth its liquid notes after the darkness of advancing night had silenced all the other denizens of the grove. It ought to be mentioned, moreover, that both scxes sing. When alarmed or excited they utter a strain of notes which I can only comparc to the sound produced by a policeman's rattle quickly revolved. 'This cry, or the bird-catcher's imitation of it, never fails to attract to the spot all the Bell-birds within hearing. The Maoris are accustomed to snare them by means of a tuke baited with the crimson flowers of the climbing Metrosideros. The same device is adopted for catching the Tui.

This snare, of which a figure is here given, is formed of a carefully selected piece of kareao vine, having the necessary curve upwards. The lower part of this is fastened to the thick end of a bush-rod, eight or ten feet in length, through a small hole in which a looped flax line is passed, a crook, to serve as a support, being placed on the opposite side. At the upper extremity of the artificial perch thus produced a circular flower-holder, made of split vine, is fixed, and a string connects it with the stem of the tuke, whilst the attachment of the lower end to the support is concealed by a covering of soft moss, carefully tied round with a strip of green flax, every prccaution being taken to give it a natural appearance. Having baited and set his snare, the bird-catcher hitches it by the crook to a branch in some favourable position and prepares for action. Concealing himself in a shelter of fronds, torn from a trec-fern and hastily stuck into the ground with the tops overlapping, he imitates the alarmcry of the bird by means of a nikau leaf placed between his lips. The call is soon responded to, and birds from far and near hurry to the tatal spot. The artful Maori then stops calling, and the birds, as soon as their excitement has subsided, begin to look about them and are attracted by the flowers. The instant one touches the treacherous perch, a pull on the string, bringing the loop home, secures it firmly by the leg. The tuke is then gently unhitched and lowered from the branch, cleared of its victim, and quickly reset.

* Mr. W. T. L. Travers, in an interesting artiele on the subject, says :- "The rat and the bee may each have played a part in bringing about its disappearance from the North Island, as both of these swarm all through the forest there, whilst in the South Island the rat has been nearly extirpated from the great Fagus forests by the Woodhen (Ocydromus), and the bce is limited in its range to the cultivated distriets. But tho enuse of the disappearance of this bird is mere matter of speculation, and I have only cited the ease in order to show how little we really know of the circumstances which may govern or limit the distribution of any particular species." (Trans. N.-Z. Inst. 1882, vol. xv. p. 182.) 
In former times, when this species was abundant throughout the whole country, certain forestranges were famed as Korimako preserves, and were highly prized on that account by the natives owning them. At the present day, in the investigation of native titles to land, the "snaring of Korimakos" by their ancestors is an act of ownership frequently pleaded in support of the tribal claim.

The flight of this bird is undulating, but very rapid, the wings and tail being alternately opened to their full extent and sharply closed. It sometimes mounts to a considerable height in the air, and I have occasionally observed large parties of them indulging in a playful flight far above the tree-tops.

Its food consists of minute flies and insects, as well as small berries, such as those of the karamu (Coprosma lucida) and other shrubs, and the honey of various kinds of bush-flowers. When feeding on the latter, it may be seen hanging by the feet in all positions from the slight flower-bearing twigs, while the slender bill, with the pencilled tongue protruded, is thrust into the corolla of each flower in quick succession.

In the gardens of the South Island it is still daily to be seen, moving actively about and collecting honey from various flowers. It is specially fond of the common black wattle; and it is a pretty sight to watch the bird clinging to the flower-stems in the manner described and assuming every variety of attitude as it sips the nectar from the golden tassels that cover the tree in such thick profusion*. It also attacks the full-blown flower of the common foxglove, which now grows wild in some parts of the country, piercing or tearing open the corolla with its bill in order to get at the honeyed juice.

When the korari (Phormium tenax) is in full bloom, the horn-shaped flowers are filled with delicious nectar, which the natives are accustomed to collect in calabashes, to be used as a drinkingbeverage for visitors. . 'The Bell-bird, too, loves to regale itself on this saccharine production; and while the season lasts its forehead is often stained red from the colouring-matter that adheres to the feathers. When the bird, with the change of season again, is feasting itself from the smaller cups of the pretty native fuchsia ( $F$. excorticata), the stain on the forehead changes to a very bright purple or blue.

Its ordinary chime consists of the following four notes (as set by Dr. Shortland):-

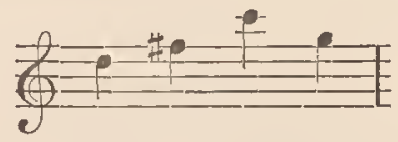

No one who has not actually listened to the melody can form any idea of the effect produced by these high notes coming from a hundred throats independently, and blending together in the richest harmony of song.

The Bell-bird commences breeding towards the end of September or early in October, and sometimes even as late as November and December. I have met with a brood of fully-fledged young birds as early as October 2S; while, on the other hand, Mr. Potts informs me that he has observed it building its nest at the end of January or beginning of February. It seems probable, therefore, that this species rears two broods in the year. Its nest may be looked for in deep wooded gullies and in the low brushwood along the outskirts of the forest. It is usually placed in the fork of a low branch, and the bird in selecting a site seems generally to prefer those bushes over which the native bramble (Rubus australis) has thrown a protecting mantle. It is a common thing to find four or five old nests of former years in the immediate vicinity of the occupied one, as if the birds formed an attachment.for a locality once chosen as a breeding-place. The nest is a rather loose structure, composed externally of small dry twigs, sometimes interlaced with the wiry stems of the bush convolvulus, over

* Forty years ago literally thousands of these birds annually frequented the groves of wattle around the old mission-station at Tangiteroria (on the northern Wairoa). Tho wattles still are there, grown to the size of forest trees, with many generations of younger ones; but, alas! the "ehime of silver bells" is no longer to be heard: the Korimakos have gone, and the groves are silent: 
which there is a layer of fine grass disposed in a concave form, and then deeply lined with feathers. The eggs are usually three in numbcr, but sometimes four, broadly elliptical or slightly ovoidoconical in shape, and measuring $\cdot 88$ inch in length by 65 in breadth. They are pure white, creamy, or pinkish whitc with a broad zone of reddish-brown spots towards the larger end, besides a few widely scattered dots of red over the general surface. In some specimens the ground-colour exhibits a delicate pinkish tinge, and the reddish markings are more numerons and distinct, often deepening to a dark chestnut-red. Among the examples in the Canterbury Museum, some are pinkish white, blotched at the larger end and densely freckled all over with pale reddish brown, whilst one of them presents delicate pencilled markings or veins towards the smaller end.

My son's collection contains a beautiful series of thirteen, presenting a considerablc amount of individual variation, not only in the surfacc tint, but in the extent and character of the markings. In some the reddish spots coalesce at the large end, forming a sort of cap, in others they present distinct blots and smudges; some have a polar zone of confluent freckles, while others are studded with roundish rust-spots; in some the markings are sharp and distinct, in others smeared or blurred; one is of a pinkish cream-colour, clouded over its major portion with reddish brown, and another is perfectly white, with a cluster of reddish dots on its larger pole and a few scattercd specks below. In form, too, they vary from the perfect ovoid to the types mentioned above.

In the selection of feathcrs for the lining of its nest this bird slows an extraordinary love of decoration, the prefcrencc being given to those of striking colours. The scarlet feathers of the Kaka, the bright grcen of the Parrakeet, and the ultramarine of the Kingfisher are sometimes found intermixed; the shining breast-feathers of the Wood-Pigeon are invariably used; and in the vicinity of habitations (as a correspondent informs me) the nest is occasionally found supplied from a neighbouring poultry-yard, the spotted plumes of the Guinca-fowl being most conspicuous*.

A nest from the Little Barrier is composed entirely of small black twigs carefully worked together and deeply lined with dark Pigeon's feathers, the cup bcing very wide, having a diameter at its rim of 3.25 inches. It was found at an elevation of thirty feet from the ground, undcr shelter of a clump of parasitic Astelia, and contained four young birds.

During the breeding-season the parent birds evince much tender solicitude for the safety of their offspring. On leaving the nest, the young have the rictal membrane (at the angles of the mouth) very large and of a bright yellow colour. The old birds liunt for them with untiring industry; and the young brood may be seen perched side by side on a branch patiently waiting for their food, and on the approach of their parents, quivering their wings with excitement, and eagerly gaping their throats, all of them together, to receive the coveted morsel.

I have made frequent attempts to rear the young, but have never succeeded. I have known instances of the adult birds being caged with success; but, like the Tui, they are liable to sudden convulsive fits, and seldom survive their confinement very long.

The Korimako from the south-west region appears to be a somewhat larger race. An egg of this bird taken at Preservation Inlet, in the month of January, is ovoido-conical, measuring 9 of an inch in length by $\cdot 7$ in brcadth. It is of a delicate pinky whitc, with irregular stained markings of reddish brown, chiefly towards the larger end, and particularly on one side of the egg, without any appearance of a zone; the other end towards the pole being quite free from markings of any kind.

* This statement in my former edition haring been questioned by Prof. Hutton ('Ibis,' 1874, p. 36), I may quote the following observations since recorded by Mr. Potts ('Journal of Science,' vol. ii. p. 278):- "Kecping several kinds of choice poultry not far from the bush afforded me special opportunitics of observing this fact. I noticed nests lined with coloured feathers as follows : red from the Kakas, green from the Parrakeets, black from the Norfolk Turkcys, buff from Cochin fowls, speckled from the Pintadoes, and white from the Geese. I have not seen a red-or green-lined nest for years, as the destruction of the woods about here (Ohinitahi) has made both Kakas and Parrakeets rare visitors." 


\title{
ANTHORNIS NELANOCEPHALA.
}

\author{
(CHATHAM-ISLAND BELL-BIRD.)
}

Anthornis melanocephala, Gray, in Dieff. 'Trav. ii., App. p. 188 (1843).

Anthornis auriocula, Buller, Essay on the Orn. of N. Z. p. 8 (1865).

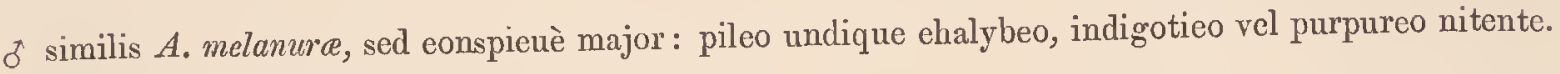

$\delta j u$. similis adulto, sed pallidior : abdomine imo eum erisso et hypoehondriis imis fulveseentibus: fronte vix ehalybeo nitente: filamentis pilei gulæque ehalybeo-nigris: faseiâ mystaeali indistinetâ, pallidè flavâ: teetrieibus alarum, remigibus et reetrieibus brunneseenti-nigris, paullò ehalybeo lavatis, extùs angustè flavieanti-olivaeeo limbatis : rostro nigro: pedibus brunneis, plantis pallidioribus, unguibus saturatè brunneis : iride aureâ.

Adult male. The whole of the plumage olive-green, lighter on the siles of the body and lower part of abdomen; beneath dark plumbeous, this being observable only on raising the featlers; forehead and erown steel-blue, elianging to a purplish-blue gloss on the sides of the head, nape, throat, and fore part of the breast, these parts appearing shot with purple and blue in eertain lights; quills dusky brown, witl yellowish-brown shafts, margined on the outer webs with yellow; the small wing-eoverts steel-blue, margined with olivegreen; tail-feathers dusky blaek, with steel-blaek margins; the soft ventral feathers and under tail-eoverts fulvous yellow, the latter with an olivaeeous tinge. Irides golden yellow (?); bill blaek; tarsi, toes, and claws dark brown. Total length 10 inehes; wing, from flexure, $4 \cdot 25$; tail 4.5 ; bill, along the ridge $\cdot \%$, along the edge of lower mandible $\cdot 9$; tarsus 1.5 ; middle toe and elaw 1.05 ; hind toe and elaw $1 \cdot 15$.

Female. Although, sinee the publication of my former edition, I have reeeived four or five examples of this bird from the Chatham Islands, I have never yet had an opportunity of eomparing the female. Prof. Hutton says that "it is similar to the female of $A$. melanura execpt as to size."

Young. An examination of the type of Anthornis melanocephala in the British Museum satisfied me that the bird named by me $(l . c$.) was only the young of this speeies. The following is a deseription of this speeimen, whieh is now in the Colouial Museum at Wellington:-The whole of the plumage yellowish olive, paler on the undcrparts, and tinged with fulvous on the abdomen, flanks, and under tail-eoverts; faint steel gloss on the forchead; produeed filaments on the erown, sides of the head, and throat stcel-blaek; from the angle of the mouth a narrow indistinet streak of pale yellow; wing-feathers and their eoverts, also tail-feathers, blaekish brown, with a faint steel gloss, their outer webs narrowly margined with yellowish olive; inner lining of wings pale yellow. Irides golden yellow; bill blaek; tarsi and toes brown, witl paler soles; elaws umber-brown. Total length 9.5 inches; wing, from flexure, $4 \cdot 4$; tail $4 \cdot 5$; tarsus $1 \cdot 5$. (On a elose inspeetion of this speeimen two minute feathers of steel-blue on the side of the head give indieation of a ehange of plumage.)

Obs. Gray's type was obtained by Dr. Dieffenbaeh, the naturalist to the New-Zealand Company, who visited the Chatham Islands in 1839. I may mention that it is not in the fully-matured plumage. Three of the tailfeather's on one side are dusky blaek, deepening to glossy steel-blaek on the outer webs; the rest are, like the wing-feathers, dusky brown, margined with olivaeeous green. In the adult male the primaries and seeondaries, as well as the tail, assume the dark colour.

THis species, which is a native of the Chatham Islands, is very similar to the well-known Anthornis melanura; but, as will be seen on referring to the measurements given above, it is considerably 
larger. It differs, moreover, in having the whole of the head and neck brightly glossed with purplish or steel-blue.

During a visit to the Chatham Islands in 1855, I observed this Anthornis in the woods near Waitangi, and procured a specimen, although, as already mentioned, I was unable at the time to identify it. In giving it a provisional name, I selected the beautiful golden irides as presenting a good distinguishable feature, those of $A$. melanura being bright cherry-red. I observed that its habits were precisely similar to those of the common Bell-bird, but that its notes appeared to be louder and somewhat less musical. Its gregarious instincts are the same; for, on imitating the alarm-cry, I was immediately surrounded by a number of these birds in a high state of excitement.

Mr. Henry Travers, from whom I have receired several specimens, states that he found it in great numbers on Mangare, less frequent on the main island, and rare on Pitt Island. It had commenced to breed in October, and its nest, which he describes as being "composed of grass and feathers, large and coarsely constructed," contained as a rule three eggs. He considers its song richer and fuller than that of its New-Zealand congener. It seemed to me very much the same, but louder.

It' is said that of late years this bird has deserted the neighbourhood of the native villages and settlers' homesteads, and retired to the southern portion of Wharekauri (as the main island is called), where the woods have not yet been destroyed *.

It is a remarkable fact that whereas the New-Zealand bird is common enough at the Chatham Islands, this larger form has never been found in any part of New Zealand. The two species subsist on the same kind of food; and it is difficult to account for this peculiarity of range on any principle of geographical distribution. Where species are representative of each other in neighbouring islands, as is the case with several birds inhabiting the North and South Islands respectively, this differentiation of character, with the necessary lapse of time, is intelligible enough; but the present case is entirely different. If the long-continued separation had affected the New-Zealand bird to any appreciable degree, the same result must presumably have happened to the same bird in the Chatham Islands, four hundred miles distant; we find, however, the same type common to both places, which in itself would occasion no surprise but for the singular fact that the larger and stronger form, associated with it, is confined strictly to the smaller area, and preserves its distinctive character.

It seems to me probable that in former times both species inhabited New Zealand, and that, as Anthornis melanura is now rapidly disappearing from the mainland, so in like manner the other species may have dicd out before we became acquainted with the country. In that case, however, it would be necessary to discover sone other factor than the Norwegian rat, which, as explained on a former page, is suspected of the principal mischief now. The survival of the extirpated race in the Chatham Islands is consistent with this supposition, because it is an observed law of nature that expiring races of animals and plants linger to the last in such insular areas.

The nest of this species is very much larger than that of the Anthornis melanura. A specimen in the Canterbury Museum measures in its largest diameter about 8 inches by 7 inches. It is composed chiefly of dry narrow flags or grasses bent in a circular form, the outer wall being strengthened with an admixture of fibrous twigs. The cavity, which is rather loosely formed, as compared with that of the latter, is roughly lined with sheep's wool, with a ferv small feathers intermixed. It contained two eggs, which differ somewhat from each other, both in form and colour. One of them is of a warm salmon-pink, thickly blotched at the larger end, and spotted at irregular intervals on the general surface with reddish brown, ovoido-elliptical in form, and measuring 1.05 inch by $\cdot 75$ inch. The other egg is more oval in form, paler in colour, and less marked with reddish brown, the spots being much smaller and more scattered over the surface.

* Zoologist, 1885, vol. xliii. p. 422. 


\title{
PROSTHEMADERA NOVE ZEALANDIE.
}

\author{
(TUI OR PARSON BIRD.)
}

New-Zealand Creeper, Brown, Illustr. Zool. pl. ix. (1776).

Poë Bee-eater, Lath. Gen. Syn. ii. p. 682 (1782).

Merops novce seelandio, Gm. Syst. Nat. i. p. 464 (1788, ex Lath.).

Merops cincinnatus, Lath. Ind. Orn. i. p. 275 (1790).

La Cravate Frisée, Levaill. Ois. d'Afr. ii. pl. 92 (1800).

Sturnus crispicollis, Daud. Traité d'Orn. ii. p. 314 (1800, ex Levaill.).

Philemon cincinnatus, Bonn. et Vieill. Enc. Méth. p. 613 (1823).

Prosthemadera concinnata, Gray, List Gen. of B. 1840, p. 3.

Certhia cincinnata, Forst. Descr. Anim. p. 78 (1844).

Prosthemadera circinata, Reich. Handb. Merop. p. 127, t. ccccxcii. fig. 3466 (1852).

Meliphaga novce zealandice, Ellman, Zool. 1861, p. 7466.

\section{Native names.}

Tui and Koko; the young bird distinguished as Pi-tui or Pikari.

ô pileo toto mctallicè viridi, collo postico, uropygio et supracaudalibus purpurascentibus : collo undiquc filamentis albis ornato: dorso rcliquo et scapularibus cuprescenti-brunneis : alâ supcrnè metallicè viridi, tectricibus alarum paullò purpurascentibus, medianis albo terminatis, fasciam alarem distinctam formantibus: remigibus nigris, extùs viridi metallico lavatis, secundariis latiùs : caudî nigrâ, suprà purpurascenti-viridi nitente: subtùs metallicè viridis, versus pectus imnm purpurascens : abdomine toto cuprescenti-brunnco: hypochondriis elongatis lætè brunneis: gutture imo fasciculis duobus albis globosis ornato: subalaribus nigris : subcaudalibus metallicè viridibus : rostro et pedibns nigricanti-brunneis : iride saturatè brunneâ.

q mari similis, sed paullò minor : coloribus sordidioribus : hypochondriis fulvescentioribus.

Juv. schistaceo-niger : tcctricibus alarum medianis ut in adultis albis : collo plus minusve albicante : rictu flavo: iride nigrâ.

Mate. General plumagc shining metallic green, with bluish-purplc reflections on the shoulders, rump, and upper tail-coverts; the hind ncck ornamented with a collar of soft filamentous plumes, curving outwards and with a white line down the centre; the middle of the back and the scapulars bronzy brown, the latter with blue reflections; the grcater wing-coverts are metallic green, those ncar the arm of the wing shining blackish purple, and the intermediate ones white in their apical portion, forming a conspicuous alar bar; the remiges are black, the primarics having an outer margin of metallic grcen in thcir basal portion, this colour spreading on the secondaries till it covers the wholc of the $\mathrm{wcb}$; tail-fcathers metallic green on their upper surface, with purplish reflcctions; lower part of breast metallic green clianging into purplish bluc; sides and abdomen blackish brown, the long flank-feathcrs shading iuto pale brown; under surface of wings and tail black; the under tail-covcrts metallic green. The throat is ornamented with two tufts of white filamentous feathers, which curl in upon each other in a globose form. Irides dark brown; bill and feet blackish brown. Total length 12.75 inches; extent of wings 18.5 ; wing from flexure 6 ; tail 5 ; culmen 1 ; tarsus 1.35 ; middle toe and claw $1 \cdot 55$; hind toe and claw $1 \cdot 25$.

Female. The female is somerilat smaller than the male; but the plumage differs in no essential respect. The 


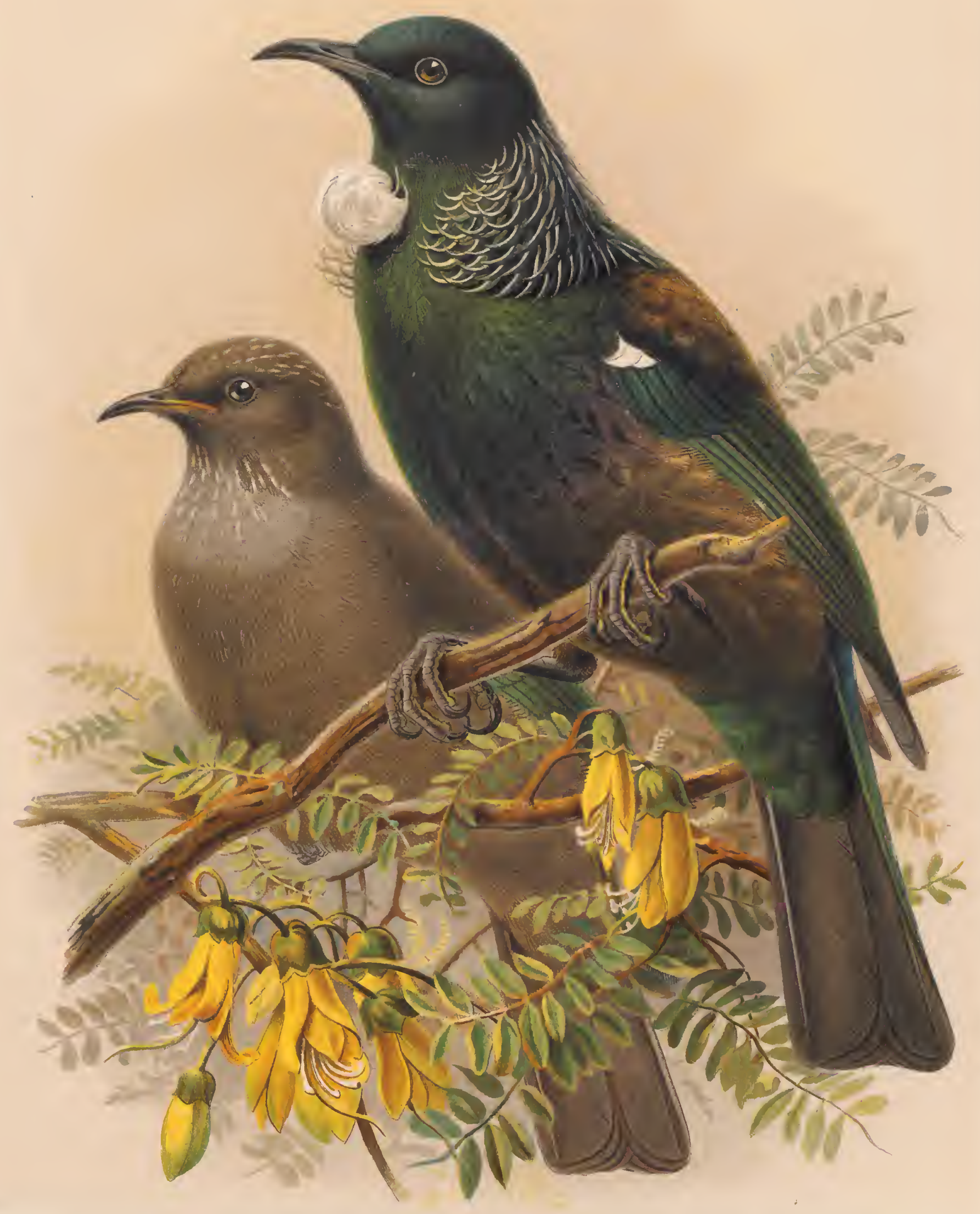

TUT OR PARSON BIRD. 

metallic tints are not so bright, and there is more brown in the phumage of the underparts. The throat is adorned with white tufts as in the other sex, but they are usually smaller.

Young. Uniform slaty black, with a broad undefined patch or circlct of greyish white on the throat, varying in extent, morc conspicuous in the femalc, and sometimes spreading all round the neck; median wing-coverts white, as in the adult; irides black; rictal membrane yellow.

Obs. In the young bird the plumage is soft and fluffy, and entirely wants the metallic lustre. In the adult state examples vary in the brilliancy of their tints, and some have a bright coppery bronze on thcir upper parts.

Progress towards maturity. About the first week of November I obtained from the nest a fledgling, in which the membrane at the angles of the mouth was very conspicuous and the plumage partly undeveloped; by the second week in December it had assumed the full juvenile dress, with a faint greyish collar, the rictal membrane had disappeared, and the throat-tufts had commenced to sprout; at the end of another month the lappets had formed but were very small; two weeks later, the new metallic plumage had begun to supplant the adolescent growth, appcaring at first in tracts, or irregular strips, on the breast and sides of the body, and then spreading outwards; and by the end of February the bird had acquired the full adult livery, although the tints of the plumage were not so brilliant as in the morc matured condition.

Varieties. Uniform brown-coloured varieties have been occasionally met with; and it is not an unusual thing to find specimens with a single white quill or tail-feather, or marked about the throat and face with scattered white feathers. In the Clristchurch Acclimatization Gardens I observed a caged one with a broad patch of white covering the outer webs of the secondaries on both wings. A beautiful albino was obtained some years ago in the Wanganui district, and now forms part of my collection in the Colonial Muscum: the general plumage is pure white; a shining black band fills the lores, crosses the forehead, and spreads down each side of the neck in an irregular patch of sooty black; lower part of back, rump, and thighs sooty black, with white featleers interspersed; wings pure white, excepting the outer secondaries and the long primary coverts, which are glossy black; bill white; tarsi and toes yellowish white.

There is another abnormally coloured bird in the Colonial Museum : head, neck all round, breast, and fore part of abdomen smoky brown; the rest of the plumage pale creamy brown, darker on the quills and tail-feathers. The throat-tufts arc as in ordinary cxamples, and there is a broad bar of whitc across the smaller wing-coverts; the frilled collar is rather inconspicuous, although the central line of white is present, and thcre is a narrow streak of the same from the angles of the mouth; the feathers of the breast have likewise fine white shaft-lines; bill and feet white horn-colour.

Sir William Fox informs me that at Porirua Harbour (near Wellington) he once observed a bird of this species with the entire plumage of a delicate fawn-colour.

THis bird is one of our most common species, and on that account generally receives less attention in its own country than its singular beauty merits. It was described and figured, as early as the year' 1776, in Brown's 'Illustrations of Zoology,' and has since been mentioncd by nearly every writer on general ornithology. In $1840 \mathrm{Mr}$. G. R. Gray made it the type of a r ew genus, in which, up to the present time, it stands quite alone.

'The early colonists named it the "Parson bird," in allusion to the peculiar tufts of white feathers that adorn its throat, and their fancied resemblance to the clcrical bands. To those who are familiar with the bird in its native woods, this namc is certainly appropriate; for when indulging in its strain of wild notes it displays these "bands," and gesticulates in a manner forcibly suggestivc of the declamatory style of preaching, or, as Dr. Thompson graphically cxpresses it, "sitting on the branch of a trce, as a pro tempore pulpit, he shakes his head, bending to one side and then to allother, as if he rcmarked to this onc and to that one; and once and again, with pent-up vehemence, contracting his muscles and drawing himself together, his voice waxes loud, in a manner to waken sleepers to their sellses!" 
Owing to its excellent powers of mimicry, and the facility of rearing it in confinement, it is a favourite cage-bird, both with the natives and the colonists. Although of very delicate constitution, it has been known to live in confinement for upwards of ten years. More frequently, however, it becomes subject, after the first year, to convulsive fits, under which it ultimately succumbs. Cleanliness, a well-regulated diet, and protection from extremes of temperature are the proper safeguards. I had as many as ten of them caged at one time; but they died off one by one, and invariably in the manner indicated. Naturally of a sprightly disposition, it is cheerful and playful in captivity, incessantly flitting about in its cage and mimicking every sound within hearing. It will learn to articulate sentences of several words with clearness, to crow like a cock, and to imitate the barking of a dog to perfection. One, which I had kept caged in the same room with a Parrakeet (Platycercus auriceps), acquired the rapid chattering note of that species; and another, in the possession of a friend, could whistle several bars of a familiar tune in excellent time. Another, which I kept for two years, although a female bird, proved to be a good mimic. I first taught it to imitate the suft whistling note of the Huia, in repetition. When perfect in that, I gave it lessons in the long plaintive whistling-cry of the Shining Cuckoo, thrice repeated; and, strange to say, after the bird had acquired that, and was accustomed to practise it a hundred times over during the day, I taught it to add, or interject, the sharp four-times-repeated note which precedes the final strain. The bird learnt all this to perfection, and never mixed the parts, exhibiting in this respect a remarkable exercise of memory*.

It has several times been brought alive to this country; and there is now to be seen in the Zoological Society's Gardens, at Regent's Park, a very healthy one which I succeeded in bringing to Fingland last year, and had the pleasure of presenting to the Society. It was one of three scarcely. fledged nestlings brought to me by a Maori shortly before I embarked on my trip home; and although all of them survived the sea-voyage, the others soon succumbed to the sererity of the English climate.

The Maoris fully appreciate the mocking-powers of this bird, and often devote much time and patience to its instruction. There are some wonderful stories current among them of the proficiency it sometimes acquires; and I may mention an amusing incident that came under my orwn notice at Rangitikei some years ago. I had been addressing a large meeting of natives in the Whare-runanga, or Council-house, on a matter of considerable political importance, and had been urging my views with all the earnestness that the subject demanded: immediately on the conclusion of my speech, and before the old chief, to whom my arguments were chiefly addressed, had time to reply, a Tui, whose netted cage hung to a rafter overhead, responded, in a clear emphatic way, "Tito!" (false). The circumstance naturally caused much merriment among my audience, and quite upset the gravity of the venerable old chief Nepia Taratoa. "Friend," said he, laughing, "your arguments are very good; but my mokai is a very wise bird, and he is not yet convinced!"

In a state of nature the Tui is even more lively and active than in captivity. It is incessantly on the move, pausing only to utter its joyous notes. The early morning is the period deroted to melody, and the Tuis then perform in concert, gladdening the woods with their wild ecstacy. Besides their chime of five notes (always preceded by a key-note of preparation), they indulge in a peculiar outburst which has been facetiously described as "a cough, a laugh, and a sneeze," and a variety of other notes, fully entitling it to be ranked as a songster.

* The Tui, as a eaged bird, is apt to beeome oxeessively fat, through overfeeding and the want of proper muscular exercise; and this may aeeount for its tendeney to fits. The intelligent bird mentioned above, without any apparent cause, began to mope and refused its food. After a day or two it beeame subjeet to epileptie fits, falling suddenly from its pereh, sereaming in its eonrulsions, and then lying perfeetly inert for several minutes. These fits eontinued to inerease in frequeney and severity, till finally it sueeumbed to one of them, and died in my hand. On disseeting it, I found the earity of the stomaeh ehoked up with an aceumulation of vellow fat, and the vital organs eompletely enveloped in fat. This exeessive fatness had no doubt interfered with the performance of life's regular funetions and had eaused the fits, whieh in the end provod fatal. 
When engaged in song, the Tui puffs out the feathers of his body, distends his throat, opens wide his beak, with the tongue raised and slightly protruded, and gesticulates with his head, as he pours forth the wild harmony of his soul. A pair may often be observed, scareely a foot apart, on the same branch, performing in eoncert, for (as with the Korimako also) both sexes sing. The notes are rich and varied-now resembling the striking together of hollow metallic rods, then a long-drawn sigh, a warble, and a sob, followed by a note of great sweetness, like a toueh on the high key of an organ. The last time I listened to the wild music of this bird, in all its depth and riehness, was from the pew of a little country ehapel, where a Maori deacon of the Church of England was delivering a sensible discourse and drawing his illustrations from surrounding objects. The chapel was overshadowed by tall Eucalyptus trees, amongst the flowers of whieh the Tuis were regaling themselves on their viseid nectar, and stopping at intervals to pour forth their full volume of song, thus giving emphasis to the preacher's appeal to nature.

One of its finest notes is a clear, silvery toll, followed by a pause and then another toll, the performance lasting sometimes an hour or more. This is generally heard at the close of the day, or just before the bird betakes itself to its roost for the night. I have, however, on one or two occasions, heard the Tui's sweet toll long after the shadow of darkness had settled down upon the forests and all other sounds were hushed.

At other times it may be heard uttering a sweet warbling note, followed by a sneeze, after that a pause, then a sharp cry of $t u-w h i t$, tu-whit, $0-0-0$, a pause again, and then its warbling note with variations, very soft and liquid, but ending abruptly in a sound like the breaking of a pane of glass. It has indeed such an endless variety of notes that it is impossible to convey in writing any adequate idea of its voeal powers*.

Its flight is rapid, graeeful, and slightly undulating, the rustling of the wings as they are alternately opened and elosed being distinctly audible. Layard mentions ('Ibis,' 1863, p. 243) the peculiar habit which this bird has of mounting high in the air during fine weather, in parties of six or more, and performing wide aërial cireles or indulging in a sportive flight, "turning, twisting, throwing somersaults, dropping from a height with expanded wings and tails, and performing other anties, till, as if guided by some preeoneerted signal, they suddenly dive into the forest and are lost to view." High in the air it may sometimes be seen elosing its wings and supporting its body for a few moments by a rapid perpendicular movement of the expanded tail; and slowly deseending in this

\begin{tabular}{|c|c|c|}
\hline Ko tu koe. & Ko wai wai. & Ka timo te tai. \\
\hline Ko rongo koe. & Korero rero. & Nga tai o te tu. \\
\hline Ko te manuwhiri. & Ka kore kore te toki. & Ko waka rara na tauna. \\
\hline Nau mai. & Te whare pa tahi. & Ma nga wai. \\
\hline Moemoe hia mai te kuri. & Te whare pa rua. & It tai taua? \\
\hline Hacre mai te manuwhiri. & Te ui te rangi ora. & E tai, homai te wai. \\
\hline No runga te manuwhiri. & E roro ki waho. & Ka hi te kai. \\
\hline No raro te manuwhiri. & Ko tu koe. & Ka kawa te kai. \\
\hline No to ti. & Ko rongo koe. & Ka whakarere te kai. \\
\hline No to ta. & Ko tenei to manuwhiri. & E kai. \\
\hline No waka i oio. & Nau mai. & Ari nui. \\
\hline Tupu kere kere. & Kaore te kai i te kainga. & Ari roa. \\
\hline Тupu a nanga. & E ronga. & Ari ma noa noa. \\
\hline Ka hea e wa. & E ronga. & E titi rau ma hewa. \\
\hline I. ki e roro. & E ronga maru awa. & E to kai moana. \\
\hline Ki tahi ka tu ke he. & Ka ha te tai. & E roro ki waho. \\
\hline
\end{tabular}


manner to a lower level, it speeds forwards with half-closed wings and tail, and then rises high in the air again by a rapid vibration of those members.

It is a pretty sight to watch a pair of them mount together in playful flight, high above the tree-tops; then, by a simultaneous movement, they descend in company and alight on the topmost twigs of some tall forest tree, where they puff out their plumage, giving a very exaggerated appearance to their bodies, and gesticulate as if in angry altercation with each other; and then, as if by mutual agreement, they rise together in the air, and disappear in opposite directions.

There is, I believe, a popular notion in the Colony that the plumage of the Tui is black, and even some old settlers, familiar enough with the bird, considered the plate in my first edition too highly coloured. But this is entirely a mistake, as may be easily proved by holding the bird against the light, at the angle of incidence. It will then be seen that the plumage presents beautiful steelblue and purple colours, with high metallic reflections, particularly on the breast, wings, rump, and upper tail-coverts. On the shoulders and mantle, also, there are.bronze reflections which no artist could ever do justice to. In the sunny glades of the forest the glancing of the light on its burnished plumage and the gleaming of its pure white epaulettes renders the Tui a very attractive object, as it glides rapidly from one tree to another, or darts into the sunshine to capture a vagrant butterfly.

The food of the Tui consists of ripe berries of various kinds, flies and other insects, and the honey of certain wild flowers. To enable it to collect the latter, the tongue is furnished at its termination with a brush of extreme fineness-a characteristic common to all the true honey-enters - the nectar ascending to the tubular portion of the tongue, apparently by capillary attraction *. When the functions of life are suspended or interfered with, this little brush protrudes from the bill. This occurs not only after death, but in the case of the sickly Tui; and the involuntary protrusion of the tongue may generally be accepted as a fatal symptom. It also feeds with avidity on the sugary bract-like spadices of the kiekie (Freycinetia banksii). In the months of October and November, when the kowhai (Sophora grandiflora), which grows so Iuxuriantly on the river-flats, has cast its leaves and is covered with a beautiful mantle of yellow flowers, its branches are alive with Tuis; and in December and January, when the Phormium tenax is in full bloom, they leave the forest and repair to the flax-fields to feast on the korari honey. At these times large numbers are caught in snares or speared by the natives, who thus supply themselves with a delicious article of food.

On these occasions the best-conditioned birds are preserved in their own fat, and potted in calabashes, "hua-hua koko" being esteemed a great delicacy. At the periodical festivals one or two of these pots, decorated with Pigeons' feathers, are placed on top of the great pile of food which is presented to the visitors at these ceremonials. Calabashes of kaka, titi, and kereru are plentiful enough, but one of "tui" gives the finishing touch to the menu at a Maori feast of the kind I have indicated.

Among introduced trees, the Tui is particularly partial to the Australian blue-gum (Eucalyptus globosa) and the common black-wattle. When these trees are in full bloom, this bird holds high carnival among the flowers, making playful sallies into the air from time to time, and uttering its melifluous notes, as if in the highest ecstasy.

At certain seasons of the year, when its favourite berries have fully ripened, the Tui becomes

* Dr. Gadow, after deseribing fully the museular apparatus in Prosthemadera, thus explains the suetorial process :- "The contraction of the mylo- and serpi-hyoid muselos presses the whole tongue and larynx upwards against the palatal roof of the mouth-eavity. The mouth is thus wholly filled up. I'hrough the eontraction of the gevio-hyoid museles the tongue will be protruded from the mouth. Now, if the serpi-hyoid nuseles relax, and the tracheo-laryngeus and tracheo-hyoideus, on tho other hand, by their contraction depress tho larynx and at the same time depress the posterior part of tho tonguo, a vacuum will be produced betweon tongue and palate. This space, again, is in connexion with the tubes of the tongue, and therefore will be fillod by the fluid into which the tips of these tubes may be inserted. In the birds in question the fluid is honey or nectar. Consequently sucking is acoomplished automatically through the mere protrusion of the tongue." (Proo. Z. S. 1883, pp. 68, 69.) 
exceedingly fat-so much so as very much to embarrass the opcrations of the taxidermist, who finds it almost impossible to keep the feathers free from the oily matter that exudes under the operator's knife. But I am unable to endorse the statement made by the revercud author of 'New Zealand and its Inhabitants' (probably on the authority of a native), that on these occasions the 'Tui relieves itself of its exuberant fat by pecking its breast!

The Tui is still very plentiful over both Islands. It has apparently been driven away from some districts where formerly it was abundant; but this is hardly to be wondered at when I state that (in spite of the wise protective legislation) I was assured by a dealer in Wellington that he had sent as many as five hundred skins to London for the ornamentation of ladies' hats !

It is easily approached and shot; but I have oftcn remarked its extrcme tenacity of life, reminding one of Mr. Gosse's charming account of Conurus flaviventer in his 'Birds of Jamaica.' Sometimes, when mortally wounded, the grasp of the feet by which the bird was clinging to the twigs or vines becomes convulsively tightened, and the falling body is seen suspended, head downward, for scveral minutes, the wings now and then giving an ineffectual flutter, till at last one foot relaxcs its hold and then the other, and the quivering body falls heavily to the ground.

There can be little doubt that the Tui brecds twice in the year. I have found birds nesting as early as August, the young being abroad in October and November; and I have received from the Maoris nestlings, not more than ten days old, as late as May 12 th, although young birds can always be obtaincd in March and April.

Under the hcad of "progress towards maturity," I have described (at page 95), from pcrsonal observation, the successive development of plumage in a young bird, taken from the ncst in Norembcr, and presenting an adult appearance at the end of February. As late as the 23rd October, I saw a young bird at Atiamuri, on the Waikato river, in which this change had scarccly been completed, much of the body-plumage being adolescent, with only vestiges of the frill and lappets. This fact tends strongly to support the riew of there being two broods in the year.

The nest of this species is usually placed in the fork of a bushy slrub, only a few feet from the ground; but I havc also found it at a considerable elevation, hidden among the leafy top of a forest trce. It is a rathcr large structure, composed chicfly of sprays or dry twigs, intermixed with coarse green moss, the cavity being lined with fibrous grasses, vcry carefully bent and adjusted. Sometimes the interior is composed of the black hair-likc substance from the young shoots of the tree-fcrn, the cavity being sparingly lined witl dry bents. One which I examined at Rangitikei was composed almost entirely of dry Leptospermum twigs, with a little green moss intermixed, the ends of the twigs projecting more or less, so that the cxterior of the nest measured nearly 12 inches across; the twigs were largest at the foundation and got smaller upwards; the cavity was large, but somewhat shallow or saucer-shaped, and the interior thickly lined with brown fern-hair, with a few long grass-leaves carefully interlaced; thus giving the nest a neatly finished appearance.

The eggs are generally thrcc or four in number and present some variety both in form and colour. There are some good cxamples in the Nelson Museum: the eggs (numbering three) in one of the nests are of a pyriform character, being blunt and rounded at thc large end and tapcing upwards to a point, measuring 1.3 inch in length by $\cdot 75$ in their widest part; they are white, with a faint rosy blush, stanned and mottled at the larger end and lightly freckled or dusted all ovcr with pale reddish brown. Those contained in another nest (also numbcring thrce) are ovoido-conical, measuring 1.05 in length by .75 ; these are of a delicate rosy tint, obscurely freckled, darker and more or less speckled with brown at the large end. A third nest contains two almost purc white eggs, intermediate in form between those described above, stained and freckled, at the larger end only, with brick-red. 'Thcre is likewise an intercsting scries of thcse egrgs in the Canterbury Museum, varying in charactcr from the true ovato-pyriform to a fusiform outline, something like a skittle-head. 
The former measure 1.5 inch in length by 9 in breadth, and are of a pinky-white colour, freckled and spotted at the larger end with reddish brown, and with marbled markings of the same colour at the smaller end : the other extreme form measures 1.7 in length by $\cdot 8$ in its widest part, and the whole surface is white with scattered specks of rust-red at the large end, each surrounded by a light stain or halo, as if the colonr had run; there are also two or three of these specks with the same stained circumference in the anterior or produced portion of the egg. Sir James Hector informs me that Tui's eggs in his possession vary from a decidedly elliptical shape to a narrow oval, and that both forms are "spotted with round dabs of red." One of my specimens from the South Island is ovoido-elliptical or slightly pyriform, measuring 1.25 inch in length by 10 in breadth, and is creamy white, much smeared and blotted with pale lake-red towards the smaller end.

The newly-hatched Tui is almost entirely bare, there being mere indications of linear tracts on the upper surface, with light woolly filaments adhering. The feathers, however, soon begin to appear, and the growth of the nestling is rapid; but the gradation in size of the three or four occupants of the same nest is very noticeable. Till about three weeks old, they have a very feeble cheep; but it is curious to see them, in their eagerness to be fed, stretch up their bodies and necks, four inches or more above the nest, with widely-gaping mouths bordered with a membrane of vivid yellow. As their development proceeds, their cry strengthens; and when they are fully fledged it becomes an almost incessant plaintive note, which changes to an impatient scream on the approach of the parent bird with food, all the nestlings craning their necks together for the first attention. After it quits the nest, and before it has attempted any song, it acquires the peculiar alarm-cry, ke-e-e-e, so familiar to the ear.

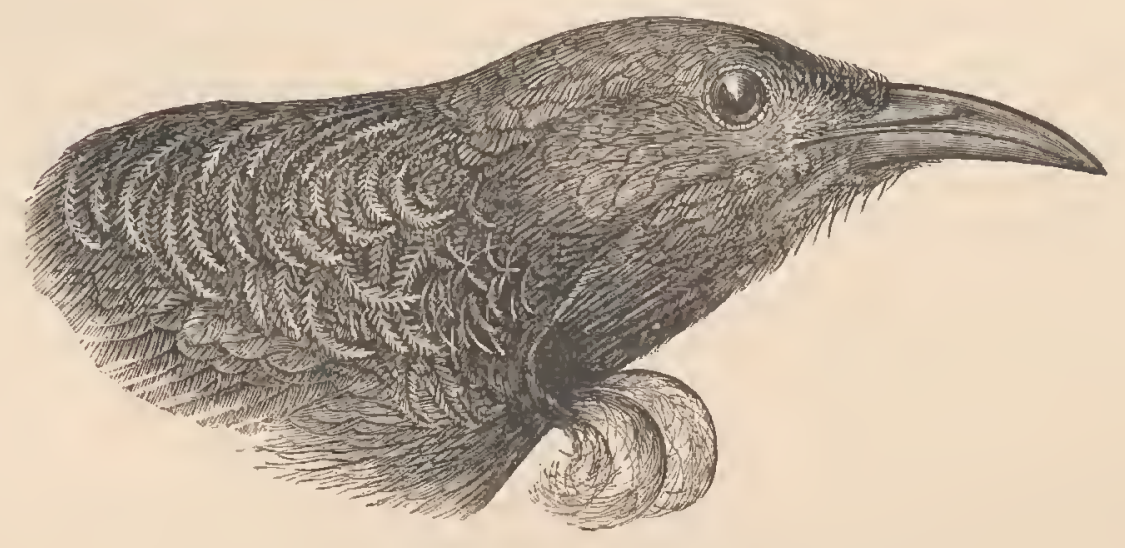

Head and neck of the Tui, showing arrangement of feathers. 


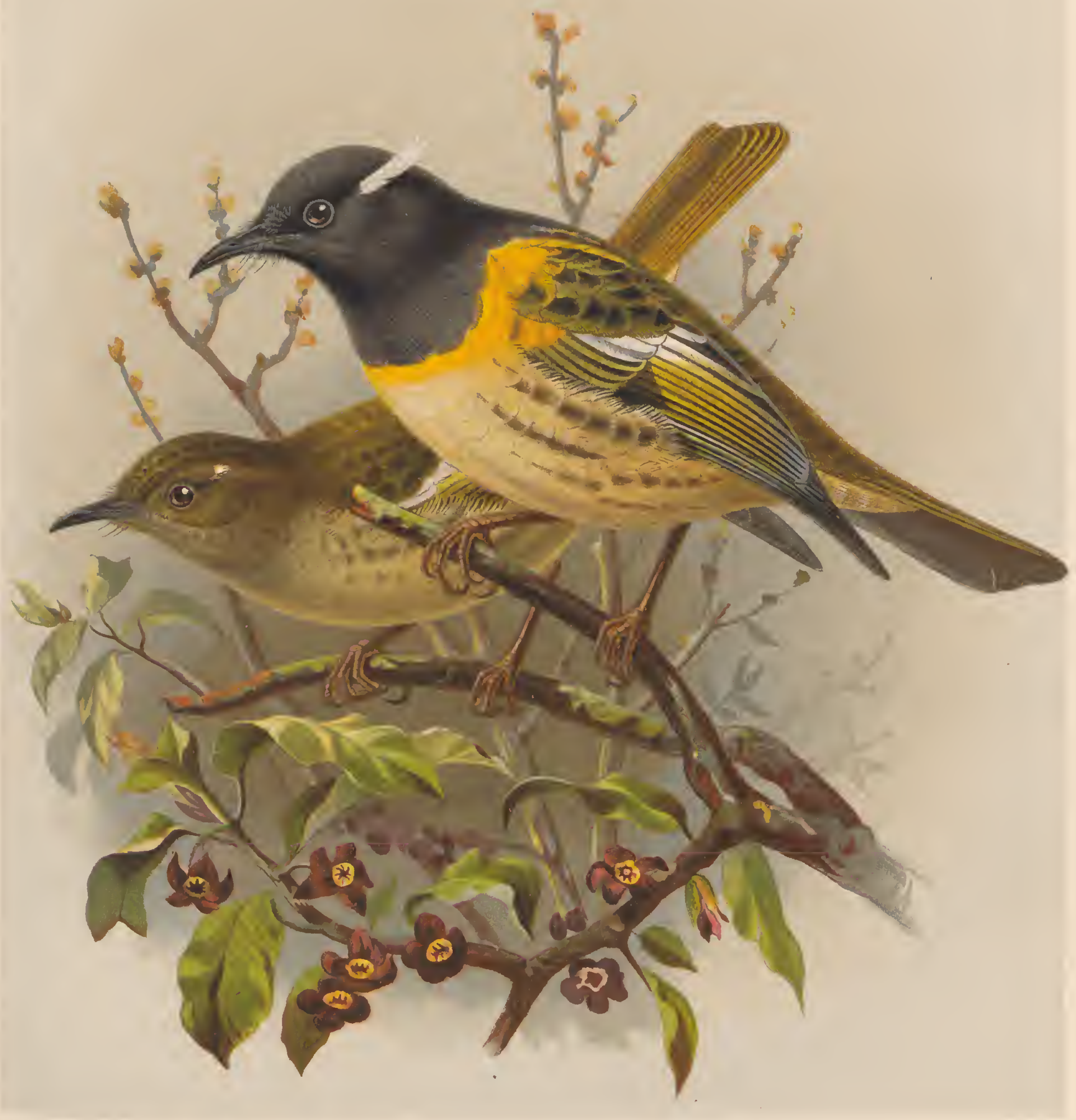

THE STITCH BIRD

POGONORNIS CINCTA

(MALE AND FEMALE) 
. 


\title{
POGONORNIS CINCTA.
}

\author{
(STITCH-BIRD.)
}

Meliphaga cincta, Dubus, Bull. Acad. Sc. Brux. vi. pt. 1, p. 295 (1839).

Ptilotis auritus, Lafr. Rev. Zool. 1839, p. 257.

Ptilotis cincta, Gray, Voy. Ereb. and Terror, Birds, p. 4 (1844).

Pogonornis cincta, Gray, Gen. of B. i. p. 123 (1846).

\section{Native names.}

Hihi, Tihe, Kotihe, Kotihewera, Tiora, and Tiheora; male and female sometimes distinguished as Hihi-paka and Hihi-matakiore or Tihe-kiore.

ô suprì nigcrrimus : faseiis duabus eonspieuis postoeularibus albis : dorso imo et uropygio cineraseenti-brunneis, vix olivaeeo tinctis: dorsi plumis quibusdam lateralibus lætè aurantiaeo terminatis : rectricibus alarum minimis lætè aurantiacis, plagam magnam formantibus, majoribus nigris, cxtùs aurantiaco marginatis : alæ spuriæ plumis ad basin albis speculum exhibentibus : remigibus nigris, primariis versus apicem albido, secundariis aurantiaeo marginatis : teetrieibus alarum majoribus intimis et secundariis dorsalibus purè albis, plagam distinctam formantibus, dorso proximis medialiter nigris : gutture toto et eollo laterali nigerrimis : torque peetorali angustâ aurantiaeâ: eorpore reliquo subtùs cinerascente, hypochondriis ct subcaudalibus saturatioribus, illis brunneo striatis: subalaribus cinerascentibus, margine alarum aurantiaeo: rostro brunneseenti-nigro : pedibus brunneis : setis rietalibus nigris : iride nigrâ.

q mari omninò dissimilis : suprà brunnea olivaceo lavata, pileo obseuriore : maculâ parvâ postoculari albâ : tectricibus alarum olivaceo-fulvo lavatis, minimis aurantiaeo nitentibus, majoribus intimis et secundariis dorsalibus albis, brunneo medialiter lineatis et marginatis, plagam magnam albam formantibus : remigibus et rectrieibus cinerascenti-brunneis, extùs latè fulvescentc lavatis, primariis ad basin pogonii interni albis : subtùs obseurè brunnea, pectore et abdomine fulvcscentibus, obseurè brunneo striatis.

Adult male. Head, neck, and upper part of the back velvety black; on each side of the head there is a tuft of snow-white feathcrs which the bird has the power of erceting. A band of rich canary-yellow encircles the breast, eontrasting finely with the dark plumage immediately above it; narrow in the centre, it widens on both sides and expands on the wings, covering the small coverts and the margins of the seapularies, and becomes very conspieuous when the wings are spread. Underparts light greyish brown, inclining to olivaeeous brown on the sides of the body. Primaries and tail-feathers black, margined outwardly with olivaceous brown; the seeondaries in their basal portion and their coverts white; the upper tail-eoverts olivaceous brown. Irides and rictal bristles black; bill brownish black; tarsi and toes pale brown. Total length 8 inehes; extent of wings 12.5 ; wing, from flexure, 4 ; tail 3 ; bill, along the ridgc $\cdot 60$, along the edge of the lower mandible $\cdot 75$; tarsus 1 ; middle toe and claw 1 ; hind toe and elaw $\cdot 75$.

Female. Obscure olivaeeous brown, darker on the upper parts, and ehanging to palc brown on the abdomen and under tail-eoverts. The primaries and outer tail-fcathers have their external webs narrowly margined with vory pale brown; the rest of the quills and tail-feathers are dusky blaek, edged externally with olivaeeous brown. There is a large spot of white on the secondaries corresponding to that in the male, with faint indications of yellow towards the root of the wing; but this is only apparent when the wings are spread. There are a few minute touches of white on each side of the head, corresponding in position to the tufts in the male bird; but these adornments are wanting in this sex. Total length $7 \cdot 25$ inehes; wing, from flexure, $3 \cdot 75$; tail $2 \cdot 75$; enlmen $\cdot 55$; tarsus 1 . 
Young male. In the Auekland Museum there is a young male, in transitional plumage, whieh is very interesting, as showing that in the young state both sexes liave the eolours of the female. At the first moult the male bird puts on the adult livery, althougl the tints of the plumage are less bright than in the fully matured bird. In the present example the plumage of the head, neek all round, and shoulders is ehanging from dull olive-brown to blaek, the new feathers being very eonspieuous and predominating. The white tufts on the head have appeared, but have not attained their full development, being only about one third of the usual size; the eanary-yellow band on the upper edge of the wings is well defined, but the peetoral zone is narrow and indistinet; on the breast the old plumage has almost entirely disappeared, being replaeed by the blaek, but there are enough remnants to show what it was originally; the rest of the body-plumage the same as in ordinary examples, being alike in both sexes.

Young female. The speeimen in the Auekland Museum las no appearanee of the white marks on the head; the spots eovering the base of the seeondaries are yellowish white or very pale fawn-eolour, beeoming pure white at the roots of the feathers; the small feathers at the earpal flexure are pale yellow; quills blaekish brown, the primaries very narrowly, and the seeondaries broadly, margined with pale olive; tail-feathers blaekish brown margined on their outer webs with dull olive.

Obs. In some examples of the male the eolours are brighter, the peetoral zone being wider and deepening to a elear orange-yellow, while the quills and larger wing-eoverts have a narrow external margin of yellowish olive.

Remarks. This speeies is furnished with hair-like bristles at the angles of the mouth measuring half an ineh in length. The tongue has a peneilled or brush-like termination; the hind elaw is almost twiee the length of those of the fore toes, whieh are about equal, measuring 25 of an ineh in their eurvature; the tail is of medium length and slightly euneiform. The plumage, espeeially that of the female, is soft to the toueh, and, in the adult, has a peeuliar silky gloss.

This New-Zealand form approaehes elosely to a numerous group of Australian birds eomprehended under the generie name of Ptilotis, among whieh it originally was plaeed. It has sinee, lowever, been reeognized as the type of a distinet genus.

Is my former edition of this work I wrote thus:- " This handsome species has only a limited range. It is comparatively common in the southern parts of the North Island, and may be met with as far north as the wooded ranges between Waikato Heads and Raglan, beyond which it is extremely rare. It is never found in the country north of Anckland, with the exception of one locality, the Barrier Islands, where Captain Hntton records it 'not uncommon' in December 1868. I have never heard of its occurrence anywhere in the South Island. It affects deep wooded gullies, and is seldom found on the summits of the ranges. In the dense timber covering old river-bottoms or lowlying flats it may be sought for'; but it rarely frequents the light open bush or the outskirts of the forest. It is, moreover, a very shy bird; and being most active in all its movernents, it is not easily shot. Its food consists of insects, the honey of various bush-flowers, and the smaller kinds of berries. It often frequents the topmost branches of the high timber, where it may be seen flitting about in search of insects. If disturbed by the report of a gun, it will fly off to a neighbouring tree with a light and graceful movement of the wings; but when descending to a lower station, it adopts a different manner of flight, elevating the tail almost to a right angle with the body, and scarcely moving the wings at all. The male bird erects the tail and spreads the ear-tufts when excited or alarmed; but the female habitually carries the tail perfectly erect and the wings drooping. The sexes vary so much in appearance that many of the natives regard them as distinct species, and call them by different names. The male bird utters at short intervals and with startling energy a melodious whistling call of three notes. At other times he produces a sharp clicking sound like the striking of two quartz stones together: the sound has a fanciful resemblance to the word 'stitch,' 
whence the popular name of the bird is derived. The female also utters this note, but not the former one; and being recluse in her habits as well as silent, she is seldom seen."

Although only fifteen years have elapsed since the above was penned, the Hihi has become the rarest of our existing native birds. To show how rapidly it has disappeared, I may mention that after my return to the colony, in 1874 , I met with it only twice-the first time in a sunny glade in the Forty-mile Bush, near Eketahuna, and two years later in a strip of forest at Tarawera, midway between Napier and Taupo. I know of one other instance of its being seen of late years on the mainland. Mr. Tone, a Government Surveyor who has been working for many years past in the bush, and is familiar with all the native birds, met with it in February 1883 on the summit of one of the wooded spurs of the Tararua range, leading down into the Wairarapa valley. He saw the bird several times during the day, heard its note and carefully observed its habits.

The Maoris allege that it still lingers in the Kauwhanga range, above the famous gorge of the Manawatu, but the report lacks confirmation. A more likely refuge is another they assign to it on the Island of Kapiti, where Korimako, Popokatea, and Toutouwai (all absent from the mainland) are still to be found.

In 1880, the indefatigable Austrian collector, Herr Reischek, determined to visit the Little Barrier in quest of this bird*. He remained on the island three weeks without any sign of it. Two years afterwards he sent down his assistant who, after. a sojourn of three months, succeeded in shooting a pair, but unfortunately. knocked them to pieces with heavy shot. In October 1882, he went down again himself, determined to remain till he had secured good specimens. After five weeks' continuous search, traversing every part of this rugged island and climbing over ranges some 2000 feet above the level of the sea, he was at length rewarded by the sight of Pogonornis. A beautiful male bird was disporting himself in the sunlight, erecting his snow-white tufts and hopping about in a very excited manner. Suddenly the bird disappeared as by magic; and the discovery immediately afterwards of an unfinished nest explained the singular performance he had witnessed. This strncture was composed of small twigs, partially lined with fine native grasses, and was placed in a bunch of mangimangi creeper hanging from a low tree, about eight feet from the ground. Frequently after this he heard the sharp call of the male bird in the vicinity of the nest and at lengtl, on November 8, succeeded in shooting both male and female. He had now discovered that the favourite haunt of the Stitch-bird was a deep ravine near the top of the range, where the rocks formed steep precipices and the low scrub was covered over with a mass of creeping mangimangi so rank and thick in its growth as to be almost impenetrable. Some idea of the inaccessible nature of the place may be gathered from the fact that it took Reischek two whole days tramping, climbing, and scaling precipices to get back to his landing-place; but he had visited the last home of the Hihi and had obtained, besides several specimens of the male bird, a female in perfect plumage.

The nature of the ground often prevented his using his gun, even with dust-shot, but he was able to make some interesting observations on the habits of the bird.

He often observed it using its brush tongue among the wild flowers, and in the stomachs of those he skinned he found some minute seeds as well as insect-remains.

On one occasion he noticed a female performing very singular antics, hopping round and round within a restricted circle, with her wings drooped and the tail sliglitly elevated. She kept up this

* Mr. Reisehel has communicated to the New-Zcaland Institute (Trans. vol. xviii.pp. 84, 87) a short account of his expedition in scarch of Pogonornis cineta ; but I prefer to give, in my own words, the more detailed information obtained from him immediately after his return. On the general habits of this spocies he says:- "I have only onco seen these birds sitting still and that was ncar the nost. They appear always on the movo, carrying their heads proudly, their wings drooped, and their tails spread and raised; and, at each suecessive movement, they utter that peculiar whistlo from which the natives have named thom Tiora. The female has a different note, sounding like toc, toc, toc, repeated several times." 
performance for fully twenty minutes and apparently for mere sport. Then some movement alarmed the bird, and in an instant she had disappcarcd amongst the mangimangi.

It is somewhat curious that whercas the male bird never descended to the ground, his mate seemed to delight in doing so, hopping about with outstretched wings, and uttering every now and then her peculiar note. On the slightest alarm, howevcr, she would hide berself and remain perfectly quiet. The male appeared to be always on the alert, keeping a strict guard, and giving the signal at the lenst sign of danger. The instinct of caution must be strongly developed in this bird, to manifest itself thus in the most secluded part of a lonely island, where probably the face of man had never appeared bcfore.

I have already remarked upon the shy and retired habits of the female. Twenty years ago, when the bird was comparatively common in the valley of the Hutt, and at Makara, near Wellington, although frequently out with the gun I never succeeded in shooting more than two of this sex; and whilst the bright-plumaged male bird was being constantly brought in to the local birdstuffers I never saw a female in their hands. One of those shot by me was too much shattered to be of any use; the other is in my old type collection in the Colonial Museum at Wellington. There is a specimen from the Little Barrier in the Auckland Museum; but this sex is a desideratum in all the other local musenms. There is one old and dingy skin in the Britisb Museum (obtained by Percy Earl in 1842), and another (from Sir William Jardine's collection) in the new University Museum at Cambridge, but no other English or foreign museum can boast a specimen of the female Hihi.

My own private collection was equally deficient till I induced Mr. Reischek, in 1884, to make another visit to the Little Barrier in quest of it. In this furthcr search he succeeded, although the rarity of the bird may be inferred from the fact that he was fifteen days on the island and did not even hear the Hihi till within the last thrce days of his stay. As already stated, the bird frequents the deep wooded ravines in the highest part of the Barrier, and to reach this ground he had to perform a toilsomc journey of two day's, on foot, being accompanied all through by his trusty dog, who had in places to be hoisted up with a rope. In the end his efforts were rewarded by lis finding a family party of five-an adult male and female with three birds of the year, curiously enough, all males. At first the male birds alone were visible. They seemed much interested in the movements of the dog, and hopped about in the branches above him, peering down in a very inquisitive manner. The female bird had secreted herself on the ground and kept perfectly silent. Once or twice she left her place of concealment, and darted off uttering on the wing her peculiar rapid snapping note. For two hours this watch was continued before there was an opportunity of shooting her.

The Maoris state that formerly this bird was very plentiful in the Rotorua district, where it was known under the name of Kotihe; and that, at a ccrtain season of the year, it was accustomed to come out of the woods to feast on the berrics of the tupakihi (Coriaria sarmentosa), on which occasions numbers were killed for the oven, sometimes as many as a lunndred being taken in a day. They were caught in the same manner as the Korimako, by means of a tuke or pewa, baited with flowers, as described at page 89. If the birds proved to be mataliana, or shy, the hunter would at once move his snare to another place, it being perfectly well recognized that these birds were often fastidious and had to be humoured.

The fine old Wanganui chief, Topine Te Mamaku, who was almost a centenarian when I last saw him, told me that in his young days this bird was very plcntiful in the Upper Wanganui districtso much so that one of the chiefs of that period always appeared on public occasions in a gorgcous feather robe which was largely ornamented with the canary-yellow feathers from the wing of the Hihi. Considering how very minute these feathers are, it may be imagined how many were sacrificed in order to make this colour conspicuous in the historic mantle, which Topine called, by way of distinction, the kahu-hihi. 
It may be here montioned that the Maoris excel in the manufacture of feather robes, many of which arc very beautiful. The robc itsclf is formed of hand-prepared Phormium-fibre, soft and silky, which is woven and plaited into a thick fabric, over which the feathers arc tastefully laid, with the webs overlapping, the shaft of each being doubled back and tied, thus imparting strength and durability to the garment. The pattern varies aecording to the kind of feather uscd, and sometimes much artistic skill is displayed in the grouping and arrangement of the colours. The kahukereru is composed of the bronzy-grecn feathers of the Wood-Pigeon, quitc resplendent in the sunshine, and relieved with stars and stripes of snow-white tufts taken from the brcast of that bird; the kahu-kaka is a mass of searlet of different shadcs, from under the wings of Nestor meridionatis; the kahu-kakariki displays the brilliant green plumage of the Parrakect, with which is usually mixcd the feathers of the Tui and othcr birds, in squares or crosses or other fanciful designs; but far more valuable than any of these is the kahu-kiwi, eovered entirely with the soft back-feathers of the Apteryx, and having a peculiarly rich effect when held against the light. One of spccial beauty, for which some forty adult birds werc placed under eontribution, was prescnted many years ago by the loyal Wanganui tribcs to Her Majesty the Qucen. There is a very fine one in the ethnological eollection at the British Museum, and another in my own collection, in both of which there is a broad margin of bright Tui and Pigcon feathers, to heighten the effect. Far and away more precious than any of these must have bcen that mantle of golden yellow of which old 'Topine had so vivid a recolleetion; and one can only compare it, in imagination, with that gorgcous coronation-robe of costly yellow plumes worn by the kings and queens of Ilawaii, of which mention is made by the early writers on Polyncsia *.

Mr. F. H. Meinertzhagen informs mc that in the spring of 1871 he obscrved a pair of Hihi nesting in a clump of blue-gums at Waimarama, near his own pretty homestead (Paparewa) about thirty miles from Napier. He at first mistook the female bird for a Green Linnet; but diseovered his error the moment he saw the male and observed its peculiar flight. Hoping to retain these rare visitants, he allowed them to hateh out and rear their brood without molestation; but he never saw anything of them afterwards. The nest, which Mrs. Meinertzhagen fortunately preserved, is now in the Canterbury Museum.

A nest was discovered many years ago in the bush above thc Kai-warawara stream, in the vicinity of Wellington, and is still preservcd in the Colonial Muscum. It is a shallow structure. with thin walls, and measures $4 \cdot 75$ inches across the top, with a cavity of $2 \cdot 35$ by $1 \cdot 35$. It is built of sprays, above which are laid fibres and dry rootlets of tree-fern; and the cavity is formed of fine grass, lined with cow-hair. This nest contained a singlc egg, of a narrow ovoid form, measuring .75 inch in length by $\cdot 6$ in breadth, of a yellowish-whitc colour, thickly spotted and clouded with pale rufous.

The assumption of the female plumagc by the young of both sexes, as described abovc, is very singular, being the only instance of the kind we havc among the Passeres in New Zealand. According to Reischek's observations on the Little Barrier, the brood generally numbers three, and the young bircls kcep together till the change of plumage has been effected. He met with four broods in all, and out of those shot, no less than five young males were in transitional plumage. He generally shot the adult male first, then attracted the female by imitating the ery of the young bircls, and after securing her, the rest of the family fell an easy prey to this insatiable collector.

* These Hawaiian robes are made with the beautiful red feathers of the Hchiwi (Vestaria coccinea) mixed with the goldenyellow plumes of a rare species of Nectarinia. "A eloak of yellow feathers could only be worn by the king" (see Lord Byron's "Voyage of H.M.S. Blonde' in 1826). "A feathered eloak which in point of beauty and magnificence is perhaps nearly equal to that of any nation in tho world" (Cook's "Third Voyage,' 1783, p. 127). Mr. Fernander states that such eloaks, "irrespective of their value as insignia of the highest nobility in tho land," represent, in feathers alone, at their present price, apart from the cost of manufacture, from five to ten thousand dollars cach ('Polynesia,' vol. ii, p. 186). 


\title{
ACANTHOCHERA CARUNCULATA.
}

\author{
(AUSTRALIAN HONEY-EATER.)
}

Merops carunculatus, Lath. Ind. Orn. i. p. 276 (1790).

Pie à pendeloques, Daud. Orn. ii. p. 246, pl. 16 (1800).

Corvus paradoxus, Lath. Ind. Orn. Suppl. p. 26 (1801).

Wattled Crow, Lath. Gen. Syn. Suppl. ii. p. 119 (1801).

Wattled Bee-eater, Lath. ibid. p. 150 (1801).

Corvus carunculatus, Shaw, Gen. Zool. vii. p. 378 (1809).

Creadion carunculatus, Bonn. et Vieill. Encycl. Méth.ii. p. 874 (1823); Vieill. Gal. Ois. i. pl. 94

(1825); Lesson, Traité d'Orn. i. p. 359 (1831).

Anthochcora lewini, Vig. \& Horsf. Trans. Linn. Soc. xv. p. 322 (1827), note.

Anthochcera carunculata, Gould, Birds of Australia, iv. pl. 55 (1848).

Anthochoera bulleri, Finsch, Journ. f. Orn. 1867, p. 342.

Anthochcera carunculata, Buller, Trans. N.-Z. Instit. vol. xvi. p. 313 (1884).

Acanthochcera carunculata, Gadow, Cat. Birds Brit. Mus. vol. ix. p. 263 (1884).

Descr. exempl. ex N.Z. Brunnea, plumis omnibus longitudinaliter albo striatis : supracaudalibus brunneis latè albo marginatis: tectrieibus alarum magis nigrieantibus, albo marginatis, minimis et medianis albo medialiter lineatis : remigibus et rectrieibus nigrieantibus eineraseenti-brunneo marginatis et albo angustiùs fimbriatis, primariis et reetricibus latè albo terminatis : pileo nigricante, vix albido lineato: eollo postico dorso coneolore et in eodem modo lineato: loris quoque nigrieantibus : fasciâ latâ suboeulari argenteseenti-albâ : regione parotica aurieulari nigrieante, albo minutè lineatâ : plagâ pone regionem paroticam fulvesecnte: genis nigrieanti-brunneis, vix albo minutè striatis : gutture et præpeetore brunneis albo lineatis : peetore albido, brunneo striato, plumis lateraliter brunneo marginatis : pectore imo et abdomine flavis : eorporis lateribus albidis, brunneo marginatis, vix flavo lavatis : tibiis brunneis albo striatis : subeaudalibus albidis, medialiter brunneis: subalaribus et axillaribus nigrieanti-brunneis, albo latè marginatis : remigibus infrà nigricantibus, intùs versus basin rufeseentibus : rostro nigricante : pedibus pallidè brunneis.

New-Zealand example. Crown and hind-head glossy brownish blaek, the feathers of the nape with narrow shaftlines of white; upper surface generally blackish brown, the feathers of the hind neck and shoulders with a broad eentral streak of greyish white; quills and tail-feathers darker brown; the primaries and all the reetriees, execpt the two middle ones, largely tipped with white; the secondaries and the two middle tailfeathers largely margined with grey, and the latter minutely tipped with white; all the wing-eoverts and the upper tail-eoverts broadly margined with fulvous white; all the primaries exeept the first largely margined on thcir inner vanes with pale rufous. From the angle of the mouth a widening pateh of short silvery-white feathers, speekled with brown, extends below the eye and is bounded by a small bare spaee, below which is a minute earuncle (now dried and eolourless) ; on the sides of the neck, behind the ear-eoverts, a broad rounded pateh of pale fulvous; sides of the head, behind the eyes, eonspicuously speckled with silvery white; fore neek and upper part of the breast dark fulvous browu with a more or less distinet streak of white down the shalts; lower part of breast greyish brown, each feather largely eentred and also margined witl fulvous white; the whole of the abdomen eanary-ycllow, with a silky sheen, the underpart of the plumage plumbeous; sides of the body faintly waslied with yellow; vent yellowish white; under taileoverts fulvous white, the eentre of eaeh feather, exeept the shaft, dull brown; thighs darker brown with light shaft-lines. Bill brownish black; legs pale reddish brown. Total length 15 inehes; wing, from 
flexure, 6.5 ; tail 6.75 ; bill, along the ridge 9 , along the edge of lower mandible 1.25 ; tarsus 1 ; middle toe and claw $1 \cdot 5$; hind toc and claw $1 \cdot 2$.

Obs. Mr. Gould, describing the freshly killed bird in Australia, states that the oblong naked spot on the sides of the head is flesh-coloured, the pendulous wattle is of a pinky blood-red colour, the irides hazcl-red, and the inside of the mouth yellow.

Is my 'Essay on the Ornithology of New Zealand,' 1865, I included the above species among our birds, on the authority of a specimen in the Auckland Museum, preserved by Mr. St. John, and said to have been obtained at Matakana, to the north of Auckland. The bird was retained in our lists for many years, but no fresh examples having been heard of, and St. John's specimen being of doubtful authenticity, its name was ultimately expunged *

After a lapse of nearly twenty years I had again the pleasure of recording it (l.c.) as a NewZealand bird.

During a visit to Marton, I was invited by Mr. Avery, the local bird-stuffer, to examine his novelties. Among these was a bird which he had himself obtained when serving with the volunteers in Mr. Bryce's expedition against Parihaka; he met with it in some high scrub at the rear of the camp at Rahotu, when on fatigue-duty, and was fortunate enough to shoot it. The bircl was new to him and he therefore skinned it, performing the operation very successfully. The skin was in a fresh condition when it came into my hands, and proved on examination to be a well-plumaged example of Acanthochcera carunculata.

This specimen, which Mr. Avery was generous enough to give me, is now in my collection; and the claim of this species to a place in the New-Zealand avifauna is undoubted. Its occurrence in our country, as a straggher from Australia, may only happen at long intervals; but the rule in such cases is to admit every species of which even a single individual has been met with in a wild state, unless there is a suspicion of its having been introduced by man.

Its habits are thus described in Gould's 'Birds of Australia ':-

"It is a showy, active bird, constantly engaged in flying from tree to tree and searching among the flowers for its food, which consists of honey, insects, and occasionally berries. In disposition it is generally shy and wary, but at times is confident and bold. It is usually seen in pairs, and the males are very pugnacious.

"It breeds in September and October. The nests observed by myself in the Upper Hunter district were placed on the horizontal branches of the Angophorce, and were of a large rounded form, composed of small sticks, and lined with fine grasses; those found by Gilbert in Western Australia were formed of dried sticks, without any kind of lining, and were placed in the open bushes. The eggs are two or three in number, one inch and three lines long by ten lines and a half broad; their ground-colour is reddish buff, very thickly dotted with distinct markings of deep chestnut, umber, and reddish brown, interspersed with a number of indistinct marks of blackish grey, which appear as if beneath the surface of the shell. Eggs taken in New South Wales are somewhat larger than those from Western Australia, and have markings of a blotched rather than of a dotted form, and principally at the larger end."

* Dr. Otto Finsch (7. c.) proposed to distinguish tho example described by me, as a new species, under the name of Anthochcera bulleri; but it is well known that this bird is subject to a considerable amount of variation, and I do not consider the differences relied upon as having any spccific value. The same remarks apply to the form described by Messrs. Vigors and Horsfield (l. e.) undor the distinctive name of $A$. levini.

Curiously enongh, when hunting up the synonymy and bibliography of this species, $I$ found that it hai been described by M. Daudin (l. c.) as far back as 1800, as a New-Zealand bird. His words are:- "Cet oiseau de la nouvelle Zćlande, est dans la galerie du Muséum de Paris." 


\section{XENICUS LONGIPES.}

\section{(BUSH-WREN.)}

Long-legged Warbler, Lath. Gen. Syn. ii. pt. 2, p. 465 (1783).

Motacilla longipes, Gm. Syst. Nat. ì. p. 979 (1788, ex Lath.).

Sylvia longipes, Lath. Ind. Orn. ii. p. 529 (1790).

Acanthisitta longipes, Gray, List of Gen. of Birds, App. p. 6 (1841).

Xenicus longipes, Gray, Ibis, 1862, p. 218.

Xenicus stokesii, id. tom. cit. p. 219.

\section{Native names.}

Matuhituhi, Piwauwau, Puano, and Huru-pounamu.

đa pileo umbrino : dorso toto viridi, uropygio læatiore: supercilio distincto albo: plumis anteoeularibus nigris : regione paroticâ brunneâ vix viridi lavatâ: tcctricibus alarum dorso concoloribus, vix flavido tinetis : alâ spuriâ nigrâ : remigibus brunneis, extùs ólivaceo-viridi lavatis : caudû suprà olivaceo-viridi, subtùs flavicante : mento albido : eorpore reliquo subtùs pulchrè cinereo, pectore vix argenteo-nitente : abdomine imo et subeaudalibus viridibus, hypochondriis olivacco-flavis : cruribus brunneis : subalaribus et marginc alari pallidè citrinis : rostro saturatè brunneo : pedibus flavicantibus.

† dissimilis: suprà ferrugineo-brunnea: uropygio vix olivaeeo tincto: supereilio lato albo: subtùs pallidè chocolatina, hypochondriis et abdomine imo sordidè flavis.

Adult male. Upper parts dark green, tinged with yellow, shading into dark brown on the forehead and erown; sides of the head black, with a broad supcrciliary streak of white extending beyond the cars, and then ehanging to yellow; sides, thighs, and rump bright grcenish yellow; fore neek, breast, and abdomen einereous grcy, with a beautiful gloss (sometimes tinged with eobalt), and softcning into greyish white on thc throat; lining of wings pale yellow; quills, on their outer webs, and the tail-feathers olivaeeous green. Irides and bill brownish black; tarsi and tocs pale brown. Extreme length 4 inehes; wing, from flexure, $2 \cdot 25$; tail 1 (more than half of it concealcd by the soft eoverts); bill, along the ridge 5 , along the edgc of lower mandible $\cdot 7$; tarsus 1 ; middle toe and elaw $\cdot 9$; hind toe and elaw $\cdot 8$.

Adult female. Upper parts umber-brown, tinged with yellowish green, espeeially on the rump; erown shaded with purplish brown; supereiliary streak white; throat, sides of the neck, breast, and upper part of abdomen delicate vinous brown; sides of the body, flanks, and thighs dull.lemon-yellow; inner lining of wings pure yellow.

Young male. Plumage generally as in the adult, but with the green tints of the upper parts paler, and the silky grey of the breast tinged with purple; crown of the head and hind part of neck choeolate-brown, blending into the olivaccous green of the upper parts; superciliary strcak broad and conspicuous.

Obs. The figure of $X$. longipes in the 'Voyage of the Erebus and 'Terror,' whieh represents a bird with a white eye-circlet and an upturned bill like that of Acanthidositta, is copied from a rough half-finished drawing of Forster's (1777) and is strikingly incorreet. Professor Hutton, whose viers are entitled to respeet, wrote

* Strictly speaking Acanthidosittidx is the right name for this family, Acanthidositta being an older genus than Xenicus, but I am unwilling to disturb a name that has already obtained currency. 


\begin{abstract}
thus, after the appearance of my former edition:- "Dr. Buller obtained specimens of $X$. stokesii which he wrongly determined as $X$. longipes; in fact all the speeimens of $X$. longipes in his colleetion were $X$. stokesii; these he eompared with $X$. stokesii in the British Museum, and naturally found them identical. But until it is explained how it is that the figure and description of $X$. longipes in the "Voyage of the Erebus and Terror' differ so mueh from specimens of $X$. stokesii, I must eontinue to regard them as two speeies" (" Ibis,' 1874, p. 37). A specimen, however, labelled by Prof. Hutton "Xenicus stokesii, female," and sent to Dr. Finsch for examination, was referred by this naturalist, without hesitation, to $X$. longipes, Gmelin. It is perfectly elear that $X$. stokesii has no existence as a speeies.
\end{abstract}

THIS species is confined to the Fagus-forests which clothe the sides of our subalpine ranges in the South Island, never being met with in the low country. In many parts of the Nelson provincial district it is quite abundant, but only in the dense bush. In the dark forest lying between Wallishead and Tophouse, also along the wooded banks of the Pelorous river, it is said to be very plentiful, and even in the Fagus-covered hills in the vicinity of Nelson it is a comparatively common bird, although less numerous now than formerly. Mr. Travers found it numerous in the Spencer ranges (Nelson) at an elevation of 3000 feet; Sir J. Hector obtained specimens in the high wooded lands of Otago, where, as he informs me, it was a very rare bird; Sir J. von Haast met with it frequently during his exploration of the interior of the Canterbury district; and I observed it in the high wooded ranges forming the inland boundary of Westland. The localities I have enumerated are all in the South Island. There are specimens, however, in the British Museum which are said to have been obtained by Captain Stokes in the Rimutaka ranges (in the provincial district of Wellington); and although I never met with the species in that district, or, indeed, in any part of the North Island, an intelligent Maori, to whom I showed a coloured drawing of the bird, appeared at once to recognize it. He said that he had often seen it in the Ruahine mountains, and that during severe winters it sometimes appeared in the low country; and he further spoke of the plumage as being "like silk," an expression so aptly descriptive of its peculiar" softness, that I believe the man was quite familiar with the bird.

The Maoris have a saying that if you kill this bird "ka panga te huka" (or, "snow will fall").

It is generally met with singly or in pairs, but sometimes several are associated, attracting notice by the sprightliness of their movements. They run along the boles and branches of the trees with restless activity, peering into every crevice and searching the bark for the small insects, chrysalids, and larve on which they feed. It is generally arboreal in its habits, seldom being seen on the ground, in which respect it differs conspicuously from the closely allied species, Xenicus gilviventris. It has a weak but lively note, the sexes always calling to each other with a subdued trill, and its powers of flight are very limited.

On comparing my specimens of this bird with the type of Mr. G. R. Gray's Xenicus stokesii in the British Museum, I feel satisfied that they are referable to one and the same species, the difference of plumage being only sexual.

In June 1882 the late Mr. W. A. Forbes made a communication to the Zoological Society, showing, from an investigation of their anatomy, that Xenicus and Acanthisitta (rectius Acanthidositta), hitherto supposed to be allied to Certhia and Sitta, were in reality mesomyodian forms, the discovery of such low types among the Passerine birds in New Zealand being a fact of considerable interest in zoo-geographic distribution. The characters pointed out by this able investigator * went

* The following is extracted from the paper referred to :-

"The subjoined drawings of the syrinx of Xenicus - with which in all points Acanthisittc appears to agree in every essential respect-will show that it has none of tho eomplex nature of that organ in the Oscines, the thin lateral tracheal muscle terminating on the upper edge of a somewhat osseous box formed by the consolidation of the last few tracheal rings, and there being uo other intrinsie syringeal muscle whatsoever. The box has a well-developed antero-posterior pessular piece. The bronehial rings are 
to show that the affinities of the Xenicidæ (as he proposed to call the family) could only make it compare with Pipridæ, Tyrannidæ, Pittidæ, and Philepittidæ. From all these groups, however, it differs widely in the number of rectrices, the character of the tarsus, and the non-oscine syrinx.

The nest (of which there is a specimen in the Canterbury Museum) is usually placed among the npturned roots of a fallen tree, or in the fork of a double trunk, at a low elevation from the ground. It is a compact structure, composed entirely of green moss, oval in form, measuring about eight inches in length by about five inches in breadth, with a small entrance on the side not far from the top, and so small as scarcely to admit the tip of the finger *.

Mr. W. W. Smith has furnished me with the following note:- "The Bush-Wren nests in small holes and forks of trees and builds a very comfortable nest. When found in a hole they are generally open at the top or cup-shaped; when built in a fork they are slightly hooded. The eggs, which are usually five or six in number, are small, roundish in shape, and white with irregular pink blotches on the thick end."

throughout of quite simple form, and are separated by but narrow intervals. None are modified in form to scrve for the insertiou of a vocal muscle, as the latter terminates"higher up, as already described, on the tracheal box, and therefore quito ont of the region of the bronchi.

"The lateral position of the singlo syringeal muscle is that characteristic of all the Mesomyodian Passeres, though in most of these it terminates on one of the bronchial rings, and not, as in the birds under consideration, on the sides of the trachea. This may ensily bo seen by comparing the accompanying figures of Xenicus with the beautiful series given by Johannes Müllor of the

A

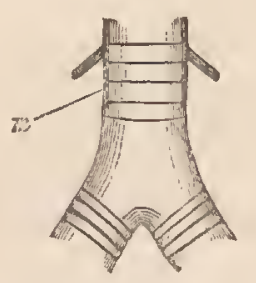

B

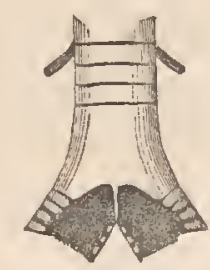

Syrinx of Xenicus longipes, much enlarged. A. From in front. B. From behind. $m$. Lateral tracheal muscle.

syrinx of many of the Neotropical Mesomyodi, with those of Garrod of Pittc, or my own of Eurylcemus, Oymbirhynchus, and Phitepitta. In fact it resembles rather that of Todus, as lately doscribed and figured by myself. Externally the non-oscine natnre of Xenicus and Acanthisitta is at once proclaimed by the structure of their wings, which have a 'first' (tenth) primary nearly as long as the preceding one, and by the non-bilaminato tarsus. The latter is covered almost completely by a singlo large seute, with only some very obsolete traces of trausrerse division below, whilst behind its edges are contiguous for the greater length of the tarsus, leaving only small areas at each end of that bone, which are covered by very small scutellæ of irregular form. The digits are slender and compressed, the foot being slightly syndactyle by tho union of the fourth toe to tho third for the greater part of its two most basal joints. The tail is short and weak; and there aro only ten rectrices in oach of my specimens. [This is the normal number.] In all other points, Xenicus and Acanthisitta conform to the general Passerine type. Thero is no trace of a plantar vinculum. The tendor patagii brevis has the peculiar arrangement characterizing the Passeres, only slightly masked by tho muscular fibres somewhat concoaling the two superimposed tendons, as is frequently the case in tho short-and-rounded-winged forms of tho group. The gluteus primus is rell-doreloped. The tongue is lanceolate and horny, with its apex somewhat frayed out and its baso spiny. The main artery of the leg is the sciatic. The sternum has a single pair of posterior notches and a bifid manubrium. In the skull tho nostrils are holorhinal, the romer broad and deeply omarginato anteriorly, the maxillo-palatines slender and recurved." (Proc. Zool. Soc. 1882, pp. 569-571.)

* One which was found in a birch-forest far up the Havelock, in the month of December, was so admirably hidden amongst the surrounding moss that its detcction was quite accidental. It was situated beneath the moss-covered roots of a ribbon-wood tree, and was pouch-shaped in form, with the opening near the top, and composed almost entirely of minute fern-roots, carefully interwoven, especially at tho entrance. It measured about 35 inches in height by 3 in breadth ; and tho cavity, whieh was profusely lined with feathers, extended to a dopth of 2.5 inches, with an opening one inch and a half across. ("Journal of Science,' vol. ii. p. 281.) 


\title{
XENICUS GILVIVENTRIS.
}

\section{(ROCK-WREN.)}

\author{
Xenicus gilviventris, Von Pelz. Verh. k.-k. zool.-bot. Ges. Wien, 1867, p. 316. \\ Xenicus haasti, Buller, Ibis, 1869, p. 37. \\ Acanthisitta gilviventris, Gray, Hand-l. of B. i. p. 183 (1869). \\ Acanthisitta haastii, id. tom. cit. p. 183 (1869).
}

đ̇ staturâ $X$. longipedis, sed hallueis ungue maximo distinguendus : suprà pallidè viridis, pileo et dorso superiore brunnesecntioribus eoneoloribus: supereilio albo, haud flavo tineto: subtùs dilutè choeolatino-brunneus, erisso eum eruribus virideseentibus, hypoehondriis latè flavis : subalaribus pallidè flavis.

I feminæ $X$. longipedis dissimilis et hujus mari magis assimilata : suprì oehraseenti-brunnea, uropygio vix virideseente : teetrieibus alarum eonspieuè nigris : remigibus brunneis, extùs dorsi eolore lavatis : subtùs pallidè isabellina, hypoehondriis virideseentibus.

Adult male. Upper parts dull olive-brown, with a greyish gloss, darker on the forehead and erown, and tinged on the baek, wing-eoverts, and rump with yellowish green; sides of the head dark brown, witl a narrow supereiliary streak of fulvous white, widening above the ears; underparts delieate purplish brown, with a silky appearanee, and fading into fulvous white at the base of the lower mandible; the sides of the body lemon-yellow; wing-feathers brown, the primaries margined on their outer webs with dull olive, the seeondaries with an apieal spot of fulvous on their outer webs; tertials and the lesser wing-eoverts blaek, forming a eonspieuous triangular spot; inner lining of wings pale yellow; tail-feathers dull olive. Irides and bill blaekish brown; tarsi and toes pale brown; claws darker. Total length 3.75 inehes; wing, from flexure, $2 \cdot 1$; tail $\cdot 75$ (nearly two thirds of it being coneealed by the eoverts); bill, along the ridge $\cdot 4$, along the edge of lower mandible $\cdot 6$; tarsus 1 ; middle toe and elaw $\cdot 9$; hind toe and elaw $\cdot 9$.

Adult female. Differs from the male in having the plumage of the upper parts dull yellowish brown, shaded with umber on the erown, and tinged with yellowish olive on the wings and rump; the supereiliary streak less distinet; and the underparts pale fulvous, stained on the sides of the body with lemon-yellow.

Obs. It will be meeessary to obtain a larger series of speeimens than is at present available, and to make a eloser investigation of the subject, before the differenees supposed to be eharaeteristie of the sexes (both of this and the preeding speeies) ean be eonsidered finally determined. It is probable that the eolours undergo some ehange in the progress of the bird towards maturity; and there is likewise reason to suspeet that a seasonal ehange takes plaee in the plumage of the malc.

MY first specimens of this bird were received from Dr. (now Sir Julius von) Haast, F.R.S., who discovered it in the Southern Alps, during a topographical survey of the Canterbury Province. In a notice which I communicated to 'The Ibis' (l.c.), I described the species as new, and named it Xenicus hasti, in compliment to the discoverer. This name, however, must, in obedience to the inflexible law of priority, give place to Xenicus gilviventris, a description of the species under that title having previously been published by Von Pelzeln, although it had not then reached the colony. Nevertheless I am glad to be able to quote Haast's account of the bird's habits as communicated to me at the time:- "It lives exclusively amongst the large taluses of débris high on the mountainsides. Instead of flying away when frightened or when stones are thrown at it, or even when shot 
at, it hides itself among the angular débris of which these large taluses are composed. We tried several times in vain to catch one alive by surrounding it and removing these blocks. It reminded me strongly of the habits and movements of the lizards which live in the same regions and in similar localities."

Another eorrespondent says that "they move about so nimbly that to procure specimens was like shooting at mice."

This species is eonfined to the South Island, being met with in the mountains, at an elevation of 3000 feet and upwards, their range appearing to commence with the snow-line, below which I have never heard of their being found.

Mr. Brough, who sent me a specimen from Nelson, says it was one of five which he met with in February on the very summit of a barren mountain. "They were dodging about among the angular rocks right on the top of the peaks, where there was no vegetation except the so-called "vegetable sheep' (Raoulia eximia), which grows freely enough among the débris or shale." 'These birds were, at that time, catching a bright-coloured alpine butterfly, which I have since identified as Phaos huttoni.

Mr. Reischek writes that he found it very plentiful on the top of Mount Alexander, near Lake Brunner, also on Mount Alcidus, near Rakaia forks, " hopping about among the débris grown over with alpine vegetation." On the heights overlooking Dusky Sound, he found it extremely rare, a circumstance which he attributes to the thousands of rats infesting that region.

Sir J. Hector found it frequenting the stunted vegetation growing on the mountain-sides in the Otago Province; and Mr. John Buchanan, the artist attached to the Geological Survey, met with it on the Black Peak, at an elevation of 8000 feet. There, where the vegetation is reduced to a height of only a few inches, it was constantly to be seen, fluttering over the loose rocks or upon the ground in its assiduous search for minute insects and their larvæ.

It is wortlyy of remark that in this species the claw of the hind toe is considerably more developed than in the tree-frequenting $X$. longipes-even exceeding the toe in length-a modification of structure specially adapted to the peculiar habits of the bird, which differ from those of the former species consistently with its habitat. They hunt much on the ground, particularly in wet weather; and will freely visit the explorer's camp, hopping about on the ground, picking at mutton-fat or anything of the kind lying outside. The young are fed on inseets; and it is amusing to see the old birds coming to the nest, sometimes with a dragon-fly almost as large as its eaptor, and dividing it among the brood.

Mr. W. W. Smith informs me that on one occasion he eollected twelve of these birds, and that the stomachs of all of them contained the minute chrysalids commonly found among fallen leaves and other decaying vegetation.

The nest, which is a more finished construction than that of the Bush-Wren, is placed in a sheltered creviee among the loose rocks or débris of the mountain. One found under these circumstances by Mr. Brough in the Nelson district, on Sept. 24, contained five eggs. This nest, which is now in my collection, is of a rounded form, laterally conpressed, and measuring five inches in its widest diameter. It is eomposed externally of wiry rootlets, intermixed with very small twigs and dry leaves. The entrance is on the side, being a perfectly round aperture about an inch in diameter. The interior of the nest is lined with soft feathers.

The egg (of which I have a single damaged specimen) is ovoido-elliptical in form, measuring .7 of an inch in length by 5 in breadth, and is perfectly white, with a slightly polished surface. 


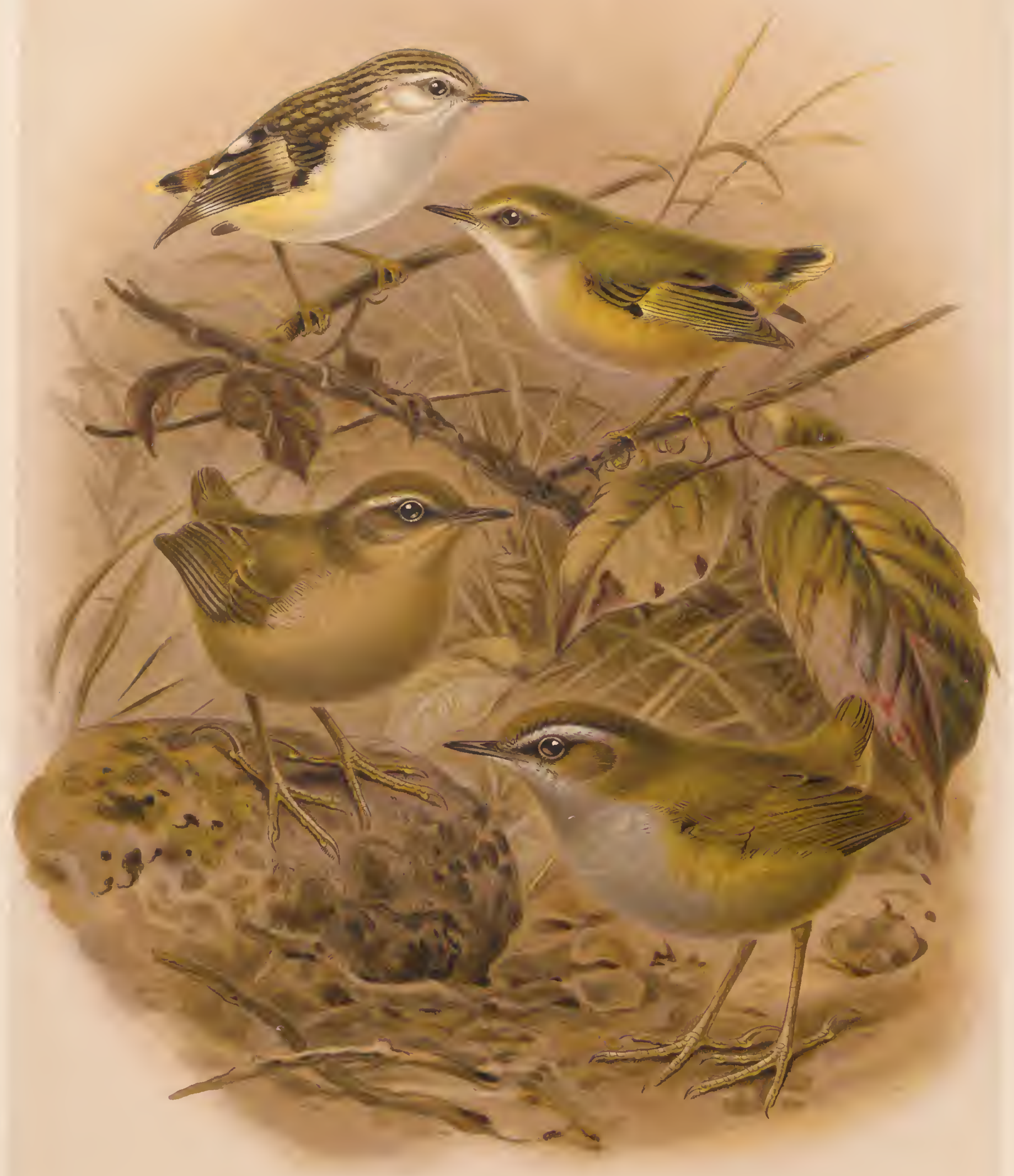

THE RIFLEMAN, ACANTHidOSITA CHLURis. (MALE AND FEMALE.)

THE ROCK-WREN. XENICUS GILVIVENTRIS. THE BUSH-WREN XENICUS LONGIPES 



\section{ACANTHID OSITTA* CHLORIS.}

\section{(RIFLEMAN.)}

Citrine Warbler, L.ath. Gen. Syn. ii. pt. 2, p. 464 (1783).

Sitta chloris, Sparrm. Mus. Carls. pl. 33 (1787).

Motacilla citrina, Gm. Syst. Nat. i. p. 979 (1788, ex Lath.).

Sylvia citrina, Lath. Ind. Orn. ii. p. 529 (1790).

Sitta punctata, Quoy et Gaim. Voy. de l'Astrol. i. p. 221, pl. 18. fig. 1 (1830).

Acanthiza tenuirostris, Lafr. Rev. Zool. 1841, p. 242.

Acanthisitta tenuirostris, Lafr. Mag. de Zool. 1842, pl. 27.

Motacilla citrinella, Forst. Descr. Anim. p. 89 (1844).

Acanthisitta tenuirostris, Ellman, Zoologist, 1861, p. 7466.

Acanthisitta punctata, Ellman, tom. cit. p. 7466.

\section{Native names.}

Tititipounamu, Kikimutu, Kikirimutu, Pihipihi, Piripiri, Tokepiripiri, and Moutuutu.

đ ad. suprì viridis, uropygio læetiorc, pileo brunneo lavato: tectricibus alarum nigris, extùs viridi lavatis : alâ spuriâ nigrâ, extùs albicante : rcmigibus nigricanti-brunneis, cxtùs viridi (ad basin pennarum lætiore) limbatis, secundariis dorsalibus pogonio externo albo conspicuè maculatis : caudâ nigrâ, ad apicem albo viridi lavato maculatâ : loris, supercilio et facic latcrali albidis, strigâ per oculum cunte fuscâ : subtùs albus, vix fulvo tinetus, corporis lateribus flavo lavatis: rostro saturatè brunneo: pedibus pallidè brunneis : iride saturatc̀ brunncâ.

q mari omninò similis, sed saturatior : pileo magis brunnescente.

Juv. suprà cincrascenti-brunneus, plumis utrinque nigro marginatis, uropygio olivascente: alâ ut in adultis coloratâ, sed extùs ad basin secundariorun conspicuè flavâ: facie laterali cinerascente, nigricantc variâ : subtùs albescens, hypochondriis flavicantibus, gutture et pectore superiorc maculis triquetris nigricantibus notatis.

Male. Upper parts dull green, tinged with yellow on the wings and rump; throat, breast, and underparts gencrally fulvous white, with a tinge of yellow on the sides of the body and abdomen; a streak over and bcyond the eyes and a lower-cyelid fringe of fulvous white; wing-feathers black, edged on their outer webs with grecn, and crossed with a band of dull ycllow immediately below the coverts, which are black; the first tertial white on its outer wcb; tail-feathers black, tipped with fuscous. Irides and bill dark brown; legs and feet paler brown, changing to yellow on the under surface of the toes. Total length 3 inches; extent of wings $5 \cdot 25$; wing, from flexure, 1.5 ; tail 25 ; bill, along the ridge 44 , along the cdge of lower mandible $\cdot 55$; tarsus $\cdot 75$; middle toe and claw $\cdot 6$; hind toe and claw $\cdot 55$.

Female. Crown, hind neck, and upper part of back olivaceous yellow, each feather margined with brown; lower part of back and rump olivaceous yellow, tinged with green; tail-coverts dull green; underparts buffy

* This has hitherto been written Acanthisitta; but Professor Newton has drawn my attention to the fact of its being erroneous. I have therofore adopted the more classic form of Acanthidositta, the etymology of which is áka $\theta \imath \delta$ - (acanthid-), crude

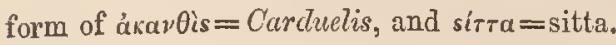


white, washed on the sides with yellow; wing-feathers dusky, margined on the outer web and marked at the base with olivaccous yellow; superior wing-coverts black; outer tertials margined with white; innermost secondary with an oblong spot of yellowish white on the outcr vane; tail-feathers blaek, tipped with fulvous.

Young. Plumage gencrally duller and suffused with yellowish brown; marked on the breast with numerous small longitudinal spots of brown.

Obs. As will be seen above, the plumage of $A$. chloris differs in the male, female, and young. Examples vary in the tone of their colouring; and a specimen in my colleetion (received from the South Island) has the rump and upper tail-coverts almost orange-coloured, without any mixture of green. I do not believe in the existenee of Acanthidositta citrina, Gmelin, although recognized as a distinet species by Dr. Finsch *.

The Rifleman is the smallest of our New-Zealand birds. It is very generally distributed over the middle and southern portions of the North Island, in all suitable localities, and throughout the whole extent of the South Island. It is to be met with generally on the sides and summits of the wooded ranges, seldom or never in the low gullies. Professor Hutton found it on the Great Barrier, and was assured by the native residents of that island that it was a migratory bird, coming and going with the Cuckoo! Mr. Reischek met with it also on the Little Barrier, but not on the other islands in the Hauraki Gulf.

In the hilly pine-forests at the head of the Wairarapa valley $I$ found this bird comparatively plentiful in the summer of 1883 . This was the more noticerble on account of the general absence of bird-life in these dark woods at all seasons of the year. On the outskirts small flocks of Zosterops consort together in the underwood, and a few Flycatchers and White-heads share the solitude with the sober Tomtit; but as we enter the woods the stillness becomes oppressive, unbroken even by the chirp of a cricket or the drumming of a locust, and, apart from the active little Rifleman, which seems perfectly at home under all conditions, the only sign of animation is an occasional night-moth lazily flapping its wings in the gloomy shade of the forest.

In its habits it is lively and active, being incessantly on the move, uttering a low feeble cheep (like the cry of a young bird), accompanied by a constant quivering of the wings. I have noticed that this cry becomes louder and more continuous towards evening. It is generally to be seen running up the boles of the larger trees, often ascending spirally, prying into every chink and crevice, and moving about with such celerity that it is rather difficult for the collector to obtain a shot. Its powers of flight are very feeble, and it simply uses its wings for short passages from one tree to another. Its tail is extremely short, and is hardly visible when the bird is in motion.

The stomachs of all that I have opened contained numerous remains of minute Coleoptera and other insects, sometimes mixed with finely comminuted vegetable matter.

It is naturally a shy bird, but of so excitable a nature that, during the breeding-season, it may be decoyed into the open hand by rapidly twirling a leaf, so as to simulate the fluttering of a bird, accompanied by an imitation of its simple note.

A bird-collector at Wellington showed me a brood of three young ones which he had taken from a nest in the cavity of a hinau, at an elevation of 20 feet or more from the ground. Finding the aperture too small to admit his hand, he cut into the tree about a foot below it, and thus disclosed the nest, which he described as being composed entirely of fern-hair, about 10 inches in length, and bottle-shaped, with a long vertical tube forming the entrance to it. In the Canterbury Museum there is a nest of this species, which appears to have been torn out of some natural cavity. It is pear-shaped, with the entrance on the side and near the bottom, and is very loosely constructed, the

* Trans. N.-Z. Inst. 1874, vol. vii. p. 227. 
materials composing it being the skeletons of decayed leaves, the wiry stems of plants, rootlets, and a few feathers.

Captain Mair discovered a nest under the thatched eaves of a Maori hut; and Mr. E. Pharazyn sent me an egg taken from another nest found concealed among the dry roots of a fallen tree. Mr. Potts has found the nest "very cleverly built, in a roll of bark that hung suspended in a thicket of climbing convolvulus," and, at another time, in a small hole in the trunk of a black birch. More than once he has known the bird to occupy the mortice-hole of a stock-yard post; also to utilize the skull of a horse, and to build between the slabs of a bush hut, adapting the form of its nest to the immediate surroundings.

The Rifleman has been found breeding as early in the year as the month of Angust; and in a specimen which I killed in the Ruahine ranges on the 23rd of December the ovary contained an undeveloped egg of the size of buck-shot, while the bareness of the underparts bore indication that the bird had already been sitting. From these facts we may, I think, reasonably infer that this species produces two broods in the season. The companion male bird on this occasion also had the abdomen bare, thus affording presumptive evidence that the sexes share the labour of incubation. The eggs vary in number from three to five; they are very fragile, broadly ovoid, or inclined to a spherical form, measuring 6 of an inch in length by 5 in breadth, and perfectly white, with a slightly glossy surface.

Before leaving the great Order of Passeres and passing on to the next, the Picariæ, it may be useful to note that most of the Passerine genera found in New Zealand are strictly endemic or peculiar to the country. Without of course taking into account the undoubted stragglers from abroad, the only exceptions to this rule are Sphenceacus, which occurs also in Australia; Gerygone and Rhipidura, of which there are representatives in Australia, Tasmania, Norfolk Island, New Guinea, and many of the Indo-Malayan Islands; Zosterops, whose range extends over the entire southern hemisphere; and Anthus, which occurs in most parts of the world.

I have already explained in my accomnt of Xenicus why it became necessary to remore that form and Acanthidositta from their old position among the Certhiidæ and to place them in a new family at the end of the Passeres. Both these forms are, in fact, dwarf Pittas of a degenerate type. They have no relations in New Zealand, and their nearest allies in Australia are the true Pittidæ, a highly specialized group extending to New Guinea and, through the entire Malay Archipelago, to India and China. One species occurs in West Africa; but in all the other zoological regions of the earth, so far as we at present know, this type is absent. 


\title{
CYPSELUS PACIFICUS.
}

\author{
(AUSTRALTAN SWIFT.)
}

IIirundo pacifica, Lath. Ind. Orn. Suppl. ii. p. lviii (1801).

New-Holland Swallow, Lath. Syn. Suppl. ii. p. 259 (1801).

Cypselus pacificus, Steph. Cont. of Shaw's Gen. Zool. vol. x. p. 132 (1817).

IIirundo apus, var. B, Pall. Zool. Ross.-Asiat. tom. i. p. 540 (1831).

Cypselus australis, Gould in Proc. Zool. Soc. part vii.1839, p. 141.

Cypselus vittata, Jard. Ill. Orn. ser. 2, pl. 39 (1840).

Micropus australis, Boie, Isis, 1844, p. 165.

Micropus vittata, id. tom. cit.

Cypselus australis, Gould, Birds of Austr. fol. vol. ii. pl. xi. (1848).

Cypselus pacificus, Gould, Handb. Birds of Austr. vol. i. p. 105 (1865).

Descr. exempl. ex N. Z. Suprà nigricanti-brunneus : dorso metallicè nitente : uropygio albo : subtùs intensc̀ fuseo : gutture cincrascenti-albo: plumis pectoris abdominisque angustè albo marginatis: rcmigibus caudâque nigricantibus : rostro nigro: pedibus nigris.

New-Zealand example. Crown of the head and general upper surface blackish brown, witl a metallic lustre on the back and upper surface of wings and tail ; rump pure white; throat and upper part of fore neck greyish white; the rest of the under surface blackish brown, but paler on the lower fore neck and under tail-coverts; the feathers of the breast aud abdomen narrowly tipped with white; quills and tail-feathers brownish black, the shafts greyish towards the basc on their under aspect; the inferior primaries, the whole of the sccondarics, and the inner lining of the wings minutely margined with greyish white. Bill and feet black. Total length $7 \cdot 75$ inches; wing, from flexure, $7 \cdot 2$; tail 3 ; bill, along the ridge $\cdot 3$, along the edge of lower mandible $\cdot 8$; tarsus $\cdot 5$; middle toe and claw $\cdot 55$.

Young (Australian specimen in British Museum). Has the plumage of the head, shoulders, and back very narrowly margined with paler brown; in front of cach eyc an angular spot of black and above that a line of greyish white; throat greyish whitc, with indistinct shaft-lines of brown; the plumage of the underparts eonspicuously marked in crescents, cach feather beeoming black in its apical portion and then broadly tipped with greyish whitc; the lining of wings uniform dark brown; the whole of the rump white with fine black shaft-lines; under tail-coverts broadly tipped with whitc.

Obs. The only sexual difference is that the female has somewhat duller plumage than the male. The amount of white on the throat is very variable, being reduced in some specimens to a merc wash of fulvous-white. The extent of white also on the uropygium varics much in individual examples, sometimes spreading dowu to the thighs.

Ore of the most recent cases, and perhaps the most interesting, of the occurrence of common Australian forms in New Zealand is that of the Swift, which made its appearance for the first time, so far as we know, in the history of the colony, in December 1884.

On sceing the newspaper accounts of the flight which had visited the White Cliffs (near the town of New Plymouth) I naturally concluded that this was another instance of the Tree-Swallow visitant from Australia, with which we had already become familiar. 
Fortunately, however, one of the birds had been shot, and the skin having been forwarded to me in a fresh condition, I saw at a glance that we had now to add another bird to our list of species.

Major W. B. Messengcr, to whom I am indebted for this unique spccimen, sent me also the following notes :-

"Respecting the Swift I shot here, I am glad to be able to furnish you with particulars. One evening, at about 6 P.Mr., four strange birds were flying about the camp, evidently in pursuit of insects. Their flight so reminded me of that of the Swift, that to make sure I shot one and took it to the office of the 'Taranaki Herald.' I believed it to be an English Swift, but from what I have since heard, I conclude that it is an Australian bird. I did not know until I received your lettcr that Swallows had ever been seen in New Zealand."

In bringing this Australian bird before the Zoological Society in October 1839, Mr. Gould wrote:-"This species is about the size of Cypselus murarius. I first met with it on the 8th March, 1839. They were in considerable abundance, but flying very high. I succeeded in killing one, which was immediately pronounced by Mr. Coxen to be new to the colony. On the 22nd I again saw a number of these birds hawking over a piece of cleared land at Yarrondi, on the Upper Hunter; upon this occasion I obtained six specimens, but have not met with it since."

In his account of the species in his "Birds of Australia' he adds:-_" Those I then observed were flying high in the air, and performing immense sweeps and circles, while engaged in the capture of insects. I succeeded in killing six or eight individuals, among which were adult examples of both sexes; but I was unable to obtain any particulars as to their habits and economy. It would be highly interesting to know whether this bird, likc the Swallow, returns annually to spend the months of summer in Australia. I think it likely that this may be the case, and that it may have been frequently confounded with Acanthylis caudacuta, as I have more than once seen the two species united in flocks, hawking together in the cloudless skics, like the Martins and Swallows of England. It is considered by some ornithologists that this bird and the Swift with crescentic markings of white on the brcast, which inhabits China and Amoorland, are the same. If this supposition be correct, this species ranges very widcly over the surface of the globe."

The British-Museum collection contains specimcns from N. S. Wales, Queensland, Tasmania, Cape York, Formosa, Penang, Tenasserim, Assam, Japan, China, and Siberia.

I have carefully examined all these examples and can find nothing whatever to justify specific scparation, although as a rule the birds from India and China have a larger and therefore more
conspicuous patch of white on the throat.

The specimen from Japan differs from typical examples in having black shaft-lines on the throat; but there is an exactly similar one from Cape York obtaincd during the voyage of H.M.S. 'Rattlesnake.'

'There is, however, a bird in immature plumage from the Hume Collection, marked "Cypselus pacificus, on, Bankasoon," which may prove to be distinct. It is of appreciably smaller size, the wing from the flexure being fully half an inch shorter; the throat-patch is covered with linear brown markings, and the whole of the uropygium is grcyish white with dark shaft-lines. 


\title{
EURISTOMUS PACIFICUS.
}

\author{
(AUSTRALIAN ROLLER.)
}

Coracias pacifica, Lath. Ind. Orn. Suppl. ii. p. xxvii (1801). Pacific Roller, Lath. Gen. Syn. Suppl. ii. p. 371 (1801). Galgulus pacificus, Vieill. Encycl. Méth. tom. ii. p. 870 (1823). Eurystomus australis, Swains. Anim. in Menag. p. 326 (1838). Eurystomus pacificus, G. R. Gray, Ann. Nat. Hist. 1843, vol. xi. p. 190. Eurystomus australis, Gould, Birds of Austr. fol. vol. ii. pl. 17 (1848).

Eurystomus pacificus, Id. Handb. Birds of Austr. vol. i. p. 119 (1865).

Eurystomus pacificus, Buller, Manual of Birds of N. Z. p. 7 (1882).

Descr. exempl. ex N. Z. Suprà pallidè viridi-griseus : tectricibus alarum minoribus dorso eoncoloribus, medianis et majoribus letiùs cyanco-viridibus: alâ spuriâ, tectricibus primariorum remigibusque nigris, extùs purpureoeæruleis, cyaneo marginatis, primariis basin vcrsus plagî magnâ pallidè argentescenti-eyanê̂ notatis:

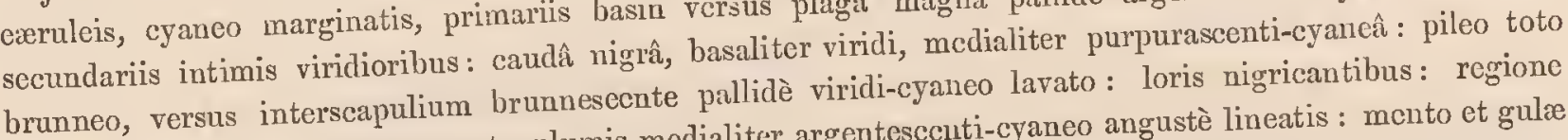
paroticâ brunneâ: gulâ cyanescente, plumis medialiter argentesccuti-cyaneo angustè lineatis : mcnto et gulæ lateribus brunneis : corpore reliquo subtùs palliliè viridi-cyaneo, pectore summo obscuriore : subcaudalibus seenti-cyancê.

New-Zealand specimen. Head and hind ncek dark brown; shoulders, baek, and seapulars dull brownish green, beeoming brighter on the rump and upper tail-eoverts and tinged with blue in certain lights; upper surface of wings grecnish blue, brighter on the large primary-eoverts; lores black ; throat dark purplish blue, eaeh feather with a central streak of lighter blue; under surface gencrally dull greenish blue, paler on the lining of the wings and under tail-coverts, and suffused with brown on the breast and sides of the body; quills black on their upper surfacc, the first primary margined externally with indigo-blue and having on its inner web towards the base a broad bar of palc silvery blue, which increases on the four suceeeding primaries and occupies both webs, forming in the open wing a conspieuous rounded patel, the shafts brown, and the outer webs beyond indigo-blue shading into black; the secoudaries and tertials bright indigo on their outer webs, ehanging in the former to bluish green towards the base; tail-feathers on their upper surface bluish green at the base, ehanging to bright indigo in their central portion aud becoming entirely black beyond; under surface of wing-and tail-feathers with a bright blue lustre, shot with green and purple in ccrtain lights. Irides dark brown; bill orange-red, shading into black at the tip of upper mandible, and becoming yellow towards the base of under mandible; legs and feet pale reddish brown. Total length 10.5 inches; wing, from flexure, $7 \cdot 75$; tail 4 ; bill, along the ridge 1 , along the edge of lower mandible $1 \cdot 25$; tarsus ${ }^{\circ} 6$; middle toe and claw $1 \cdot 25$.

Young (Australian specimen in British Museum). General plumage dull brownish grey, paler on the underparts erown of the head, hind neek, and shoulders dark brown; lores blaek; the wholc of the fore neck dull brown, faintly washed on the throat with metallie green; the whole of the wing-coverts pale bluish grecn; primaries and secondaries black, the former in their basal portion and the latter in their whole extent broadly edged on their outer webs with dark blue, fading into green; the primaries crossed in their middle portion by a band of pale silvery blue, fading into white on their inner webs; tail-feathers green towards the base, blue in the middle, and blaek in their apieal portion. Bill brownish black; legs and fect yellowish brown. 
Obs. "The sexes are alike in plumage. Irides dark brown; eyelash, bill, and feet red; inside of the mouth yellow." (Gould.)

THE first occurrence of this bird in New Zealand was recorded by Mr. F. E. Clarke in a communication to the Westland Institute, on the 18th February, 1881*, the author regarding it as the representative of a new genus which he characterized as Hirundolanius. His description of the form left no doubt on my mind that the bird was the common Australian Roller, and the subsequent receipt of the specimen itself at the Colonial Museum confirmed that view. Another example (now in my collection) was shortly afterwards obtained at Parihaka, a few miles from New Plymouth. There is a specimen in the Auckland Museum t shot by Mr. Cowan in a patch of bush near the sea, at Piha Bay, about tell miles north of Manukau harbour, towards the end of 1881; Mr. Tryon has in his possession the skin of another obtained near the Waiwakaio river, in the district of Taranaki, about a month later; and the Canterbury Museum contains a specimen received about the same period from Westland \$.

'Thus the bird has occurred almost simultaneously at no less than four places, far apart from one another, but all on the west coast; and, although of course only a visitant from Australia, the species has fully established its right to a place in the New-Zealand avifauna.

Mr. Caley, writing of this Roller in New South Wales, says $\S$ :- " It is a bird of passage. The earliest period of the year at which I have noticed it was on the 3rd of October, 1809; and I have missed it early in February. It is most plentiful about Christmas."

Mr. Gould gives us the following account of its habits :-

"In Australia the Roller would appear to be a very local species, for I have never seen it from any other part of the country than New South Wales; but the late Mr. Flsey informed me that he found it very common in the Victoria basin, and that it became very numerous about the head of the Lynd. It arrives early in spring, and, having brought forth its progeny, retires northwards on the approach of winter. It appeared to be most active about sunrise and sunset; in sultry weather it was generally perched upon some dead branch in a state of quietude. It is a very bold bird at all times, but particularly so during the breeding-season, when it attacks with the utmost fury any intruder that may venture to approach the hole in the tree in which its eggs are deposited.

"When intent upon the capture of insects it usually perches upon the dead upright branch of a tree groming beside and overhanging water, where it sits very erect, until a passing insect attracts its notice, when it suddenly darts off, secures its victim, and returns to the same branch; at other times it may constantly be seen on the wing, mostly in pairs, flying just above the tops of the trees, diving and rising again with many rapid turns. During flight the silvery-white spot on the centre of each wing shows very distinctly, and hence the name of Dollar.Bird bestowed upon it by the Colonists.

"It is a very noisy bird, particularly in dull weather, when it often emits its peculiar chattering note during flight.

"It is said to take the young Parrots from their holes and kill them, but this I never witnessed; the stomachs of the many I dissected contained the remains of Coleoptera only.

"The breeding-season lasts from September to December; and the eggrs, which are three and sometimes four in number, are deposited in the hole of a tree, without any nest; they are of a

* Trans. N.-Z. Instit. vol. xiii. p. 454.

$\uparrow C f$. Cheeseman, op. cit. vol. xiv. pp. 26t-265.

₹ "In addition to MIr. F. E. Clarke's note, it may be mentioned that an old Australian, then living at Okarito, was certain that he had seen the bird in the Qucen Charlotte's Sound district." (Journ. of Science, ii. p. 275.)

§ Trans. Linn. Soc. vol, xr. p. 202. 
beautiful pearly white, considerably pointed at the smaller end ; their medium length is one inch and five lines, and breadth one inch and two lines."

Sir T. M. Mitchell states that on dissecting a specimen obtained in N.E. Australia he found the stomach crammed with wasps and eoleopterous inseets.

Dr. Ramsay writes *- " I found this bird nesting in the hollow Eucalyptus boughs on the Richmond river in 1867 . They make no nest, but lay their eggs on the dust formed by decayed wood; not unfrequently they fight with and dispossess the Dacelo gigas, and I have seen them take the young of this bird and throw them out of the nest. The eggs are two or three in number, of a dull white, rather glossy, and sometimes variable in form, some being oval and pointed, others almost round."

This species occurs on Lord Howe's Island, where there is a perceptible blending of Australian and New-Zealand forms. It also abounds in some parts of New Guinea; and Mr. Macleay is of opinion that the birds which spend the summer in Australia pass on to the southern coast of New Guinea for the winter.

I have examined a large series of specimens collected by Mr. A. R. Wallace and others in the Malay Archipelago and now forming part of the magnificent eolleetion of cabinet skins in the British Museum. There are specimens from Penang, Malacca, Labuan, Celebes, the Sula Islands, Timor, Lombock, Flores, Gilolo, Matabello Island, Bouru, Ceram, and Dorey. As a rule these differ from Australian birds in having the patch of blue on the throat of a brighter colour. The brightest of them all is an adult example from the Sula Islands. Another speeimen from the same locality (evidently a young bird) differs in having all the eolours much duller, and instead of the throat-patch of purplish blue a mere wash of the prevailing greenish colour, with just the faintest tinge of indigo on the sides of the tluroat. In this bird the bill is reddish yellow with a brownish ridge and tip.

Another speeimen of the young (obtained by Mr. Wallaee from Matabello Island) differs in having the general plumage lighter, with a small patch of purple mixed with grey on the throat, each fenther having a central streak of cobalt-blue. In this example the feathers of the head and shoulders are narrowly, and those of the breast broadly, margined with grey; bill blackish brown, the outer edge of lower mandible dull yellow.

Eurystomus orientalis, Vig. \& Horsf, although generally regarded as merely a local race, appears to me to be a good species, readily distinguishable from $E$. pacificus by its brighter plumage and decidedly darker head and neck; but after earefully comparing Mr. Wallace's Javan specimen of E. cyanicollis, Wagl., with the former, I can find nothing to justify their separation.

Eurystomus crassirostris, Sclater, is appreciably larger and brighter than E. orientalis, although the colouring is the same, and its bill is conspicuously broader and more robust. This species, which comes from the Solomon group and New Guinea, is said to have dark red eyes.

Eurystomus azureus, G. R. Gray (brought by Wallace from Batchian), is a very distinct species, remarkable for its large size and uniform dark blue plumage. The young of this Roller has similar plumage to the adult, but the blue is of a duller hue, and the bill is blackish brown instead of being orange.

* Proc. Linn. Soc. N. S. W. vol. vii. p. 46. 


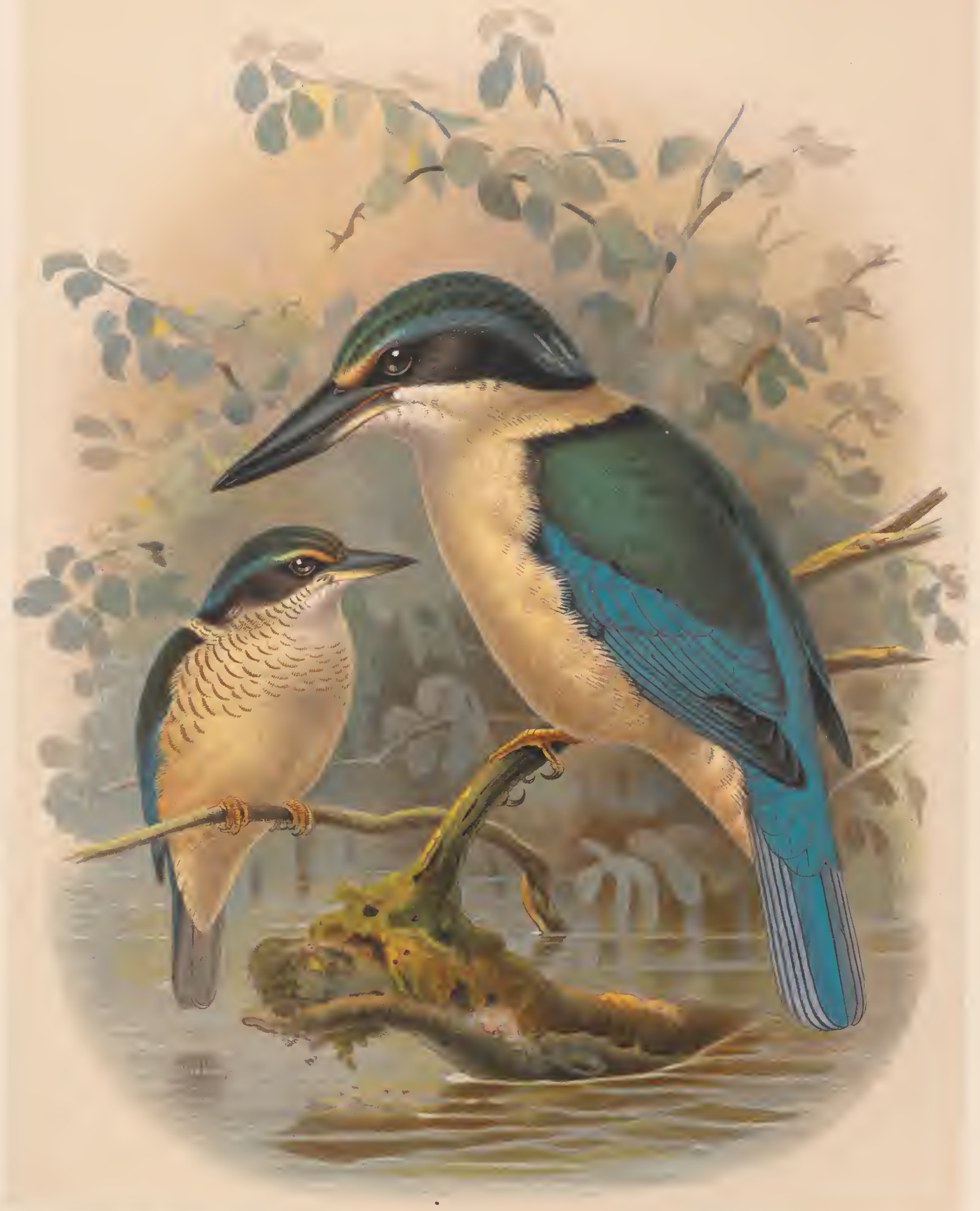

NEW-ZEALAND KINGFISHER

HALCYON VAGANS

(ADULT AND YOUNG.) 
1 


\title{
HALCYON VAGANS.
}

\author{
(NEW-ZEALAND KINGFISHER.)
}

Alcedo sacra, var. D, Lath. Gen. Syn. Suppl. p. 114 (1790).

Alcedo sacra, var. $\epsilon$, Bonn. et Vieill. Enc. Méth. i. p. 295 (1823).

Alcedo vagans, Less. Voy. Coq. i. p. 694 (1826).

Alcedo chlorocephala, var. $\gamma$, Less. Traité d'Orn. p. 546 (1831).

Halcyon vagans, Gray, Voy. Ereb. \& Terror, p. 3, pl. 1 (1844).

Alcedo cyanea, Forst. Descr. Anim. p. 76 (1844).

Todirhamphus vagans, Bonap. Consp. Gen. Av. i. p. 157 (1850).

Dacelo sancta (pt.), Schl. Cat. Mus. Pays-Bas, Alced. p. 37 (1863).

IIalcyon sanctus, Finsch, J. f. O. 1870, p. 246 ; Hutton, Cat. Birds N. Z. p. 3 (1871).

\section{Native names.}

Kotare and Kotaretare; "Kingfisher" of the colonists.

$A d$. suprà sordidè viridis, pileo laterali et dorso postico uropygioque cyanescentibus : loris et supcrcilio antieo fulvis: genis, cum regione paroticâ utrâque circà collum posticum conjunctâ, nigris vix viridi tinctis : maculâ nuchali et collo toto albidis, torquem collarcm latam formantibus : tectricibus alarum cyanescenti-viridibus : remigibus nigricantibus, primariis ad basin ct secundariis extùs lætè cyanescentibus : caudâ suprà cyanescente, subtùs griseâ : corporc subtùs toto lætè fulvescente, gutture albicante: rostro nigro, ad basin mandibulæa albo: pedibus saturatè brunneis : iride nigricanti-brunnê̂.

Juv. similis adultis, sed sordidior: tectricibus alarum fulvo marginatis : pectoris ct colli postici plumis brunneo marginatis.

Adult male. Crown, shoulders, and scapulars deep sen-grcen, with an olive tingc; back, tail-coverts, and upper surface of wings ultramarine, changing to green in certain lights; quills and tail-feathers washed with cobalt on their onter webs. A spot of briglit fulvous fills the lores, a dash of ultramarine blue, bordered above the cyes and on the occiput with white, surrounds the crown; and a broad band of black, proceeding from the angles of the mouth, completely encircles the hind head. Throat, breast, and a broad nuchal collar buffy white; the rest of the under surface delicate fawn-colour, with deepening tints. Irides black; bill black, with the basal portion of the lower mandible white; fcet dark brown, with paler soles. Extreme lengtb $9 \cdot 75$ inches; extent of wings 13.6 ; wing, from flexure, 4 ; tail $2 \cdot 6$; bill, along the ridgc $1 \cdot 75$, along the edge of lower mandible $2 \cdot 1$; tarsus 6 ; middle toe and claw $1 \cdot 05$; hind toe and claw 6 .

Female. Tints of the plumage generally duller.

Young. In the young bird the throat is pure white; the underparts fulvous-white, tinged on the sides with fawn-colour ; feathers of the breast broadly margined with dusky brown, forming an irregular pectoral zone; loral spots and nuchal collar rufous, with markings of the same colour on the fore part of the crown; nuchal collar indistinct and largely marked with brown; plumage of the upper parts darker than in the adult; the wing-coverts margined with yellow, in the form of narrow crescentic bands.

Progress towards maturity. Tints of the plumage brighter; the loral spots bright fulvous; the sides, flanks, lining of wings, and uuder tail-coverts bright fawn-colour; pcetoral zone indistinct, the dark margins being 
very narrow; nuclaal collar well defined and almost pure white. The full adult dress is not attained till after the second or third moult.

Obs. Mr. Reischek brought from the Little Barricr a brightly coloured spccimen, which comes very near to Halcyon sancta. He saw a pair of them together on the south-west side of the island. They appeared to be cractly alike in plumage, and the one he sliot proved to be a female. In this spccimcn the nuchal collar is laalf an inch wide, quite regular, ereamy white, and margined on both sides with black; throat white; underparts and flanks plain fawn-colonr; hind head, wings, and rump very bright blue; mantle largely tinged with verditer-green. Extreme length 9.5 inches; wing, from flexure, 4 ; tail 3 ; bill, along the ridge $1 \cdot 5$, along the edge of lower mandible 2 ; tarsus $\cdot 5$; middle toe and claw 1 . The bill differs from that of ordinary examples, the lower mandible having a more upward curve, and the upper, viewed vcrtically, being much compressed laterally, especially towards the point. Although I have thought it right to record these differences, I do not propose at present, at any ratc, to separate this bird from $H$. vagans, which as a specics is not very far removed from the Australian form.

Mucir difference of opinion has existed as to whether this bird is really distinct from the Halcyon sancta of Australia. Mr. R. B. Sharpe, in his 'Monograph of the Kingfishers,' pronounces it a good species, being "always of a more robust size, and having the colours much less bright than the Australian bird." Professor Schlegel and Dr. Finsch proposed uniting it to H. sancta; but in a letter which I afterwards received from the latter of these experienced ornithologists he admits that the species is quite distinct, adding that his former conclusions were bascd on two specimens only, and not on the good series of skins since obtained. I have always contended for the recognition of Halcyon vagans; and the question may now be considered fairly set at rest.

In habits the two species are very much alike. The New-Zealand bird is very generally dispcrsed, being met with in all suitablc localities. It frequents alike the sea-shore, the open country, forest-clearings, and the banks of freshwater streams. It is, moreover, one of those birds that seem instinctively to resort to the habitations of man; and instead of, like many other indigenous specics, decreasing, it thrives and multiplies under the altered physical conditions resulting from the colonization of the country. It seeks out the new home of thc settler, and becomes the familiar companion of his solitude. During the winter months especially, it resorts to cultivated grounds in quest of grubs and worms, which at this season constitute its principal food. In the early morn it may be seen perched on the fences, gateways, and out-buildings of the farmyard, sitting upright with contractcd neck, looking stiff and rigid in the cold frosty air ; and as the day advances, it cnlivens the landscape by its darting flight, while it attracts noticc by its shrill, quickly repeated call, which is not unlikc the note of the European Kestrel. In the pairing-scason this species becomes very noisy and lively, the mated birds chasing each other, in amorous play, from tree to tree or from post to post, with loud unmusical cries, something like the syllables cree-cree-cree uttercd in quick succcssion. Its ordinary call-note is more like chiu-chiu-chiu, with a clear accent. When woundcd or caught in a trap it utters a peculiar rasping cry, exactly like that of the Indian Mynah when alarmed or excited, only louder.

Thcy breed late in the year; the brood numbers five or six; and for several wceks after quitting the nest the young family keep together. 'This will probably account for the abundance of Kingfishers in the autumn months, which has been regarded by some as indicating a scasonal migration.

The flight of this species is short, rapid, and direct, being performed by a quick vibration of the wings. It flies with considerable velocity; and I have known several instances of its dashing headlong through a pane of glass. On one occasion this occurred in the church at Raglan during divine service; and the Kingfisher, after recovcring from the shock, remained to the last pcrched on the end of a pew, looking more devout, says our corrcspondent, than the Jackdaw of Rheims! Another 
instance occurred more recently at Wanganui, where, according to a local paper, the family of the Rev. C. H. S. Nicholls were startled one day at dinner by the entrance of a Kingfisher, which "flew through a pane of glass in one of the windows, scattering the fragments around," and was forthwith made prisoner by the household cat.

Its food consists of lizards, small fish, grubs, earthworms, locusts, insects of all kinds, and even mice. On examining a young Kingfisher just taken from the nest, I observed the tail of a halfgrown mouse protruding from its bill ; and on taking hold of it I drew the unmutilated carcass of the rodent from the throat of the bird. I was not previously aware that mice formed part of the Kingfisher's bill of fare *. I have often, however, witnessed its fondness for lizards, two species of which (Mocoa zealandica and $M$. omata) are very common in all the open glades. I have seen it seize the nimble little reptile by the tail, and after battering its head against a stone or the branch of a tree, to destroy life, swallow the captive, head foremost. It has been known to attack and kill chickens in the poultry-yard. On one occasion, at Otaki, I saw one of these birds dart down into the midst of a very young clutch; but the old barn-door hen proved too active, and with one rapid stroke of her bill put the assailant hors de combat. The bird was picked up stunned with the blow, but soon after, recovering itself, escaped from the hands of its captor. In Wanganui it provoked the hostility of the Acclimatization Society by preying on the young of the House-Sparrow (Passcr domesticus), which had been introduced at much expense; and the committee encouraged a crusade against the offenders by offerring a premium for Kingfishers' heads. But in the present attitude of the public towards the ubiquitous Sparrow, which has become a nuisance, it would be scarcely prudent to repeat such an offer. According to the Report of the Auckland Acclimatization Society for $1868-69$, it has proved very troublesome in destroying birds, and has even attacked and killed a Californian Quail. In Otago it has been accused of purloining the speckled trout; and in Canterbury it was found necessary to protect the newly hatched fish by stretching wire netting orer the shallow artificial streams. A valued correspondent, and very careful observer, informs me that on one occasion he killed a blackfish about twelve feet long in Whangarei harbour, and dragged it ashore; and on visiting the place a few days later he obserred an unusual number of Kingfishers present. On watching them, he found that they were preying on the sivarms of flies attracted by the dead cetacean, darting after them with the swiftness of an arrow, and capturing them on the wing.

In light rainy weather the Kingfisher is in his element in the meaclows. The moisture brings the grubs, earthworms, and other small animal life to the surface. From his post of observation on the fence he drops nimbly to the ground, swallows his captive and remounts to his perch, repeating the operation every few minutes, and for more than an hour at a time. It is evident, therefore, that this bird is of use to the agriculturist, and deserves protection rather than persecution.

When engaged in fishing, it does not plunge into the stream, like the common British Kingfisher, but dips into it lightly as it skims the surface of the water or darts clownwards from its post of observation on a rock or overhanging branch $\uparrow$.

* "It may not be gencrally known that Kingfishers aro excellent vermin destroyers, and on this account aro well worthy of protection. Yesterday a number of gentlemen in the neighbourhood of the Park Hotcl, Wellesley Strcet, observed a curious scene. A Kingfisher which was perchod on one of the newly-planted trces was observed to make a sudden dart towards the high bank at the sidc of the street, and he specdily returned to his perch on the fence which protects the tree. It was then scen that the bird had a mouse, which was alive and struggling, in his beak. The attention of those present became conecntrated on the movements of the bird, and they saw him repeatedly strike the mouse's head against the rail. As the latter became stunned, the bird remored its hold from the centre of tho animal's back to his hind quarters and tail, and while so holding it beat the mouse to death against the rail, and Hew off to devour its prey."--New Zealand Ilerald.

$\dagger$ As the fact of our Kingfisher being piscivorous has been challenged, it may be well to reprint here a note which I sent to the Wellington Philosophical Society in 1878 (Trans. N.-Z. Inst. vol. xi. p. 369) :-

"On driring round Porirua harbour on the 19th July last, I noticed an unusual number of. Kingfishers perched on the 
On the feeding-habits of this species, Mr. Henry C. Field of Wanganui has sent me the following interesting observations, which exhibit the Kingfisher in the new character of a frugivorous bird :-

"Knowing the interest you take in our New-Zealand birds, I have thought you might like to be informed of the following trait in the habits of the Kotare, which I think is not generally known. About a week before Christmas my children reported to me that in what they took to be a rat's hole in the pumice bank of the stream, just behind my garden, there was something which growled at them whenever they passed the hole or looked into it. On the matter being mentioned a second or third time the hole was examined, and proved to be a Kotare's nest, containing four young ones about half-fledged. The old birds, of course, manifested a strong objection to the nest being touched, flying round, screaming, and darting at us whenever we went close to it. I desired the children not to meddle with the young birds, but told them that if they sat a little way off and watched they would see the old ones catch fish, lizards, and insects, and bring them to the nest for the young ones to eat. The children were very pleased to do this, but quickly discovered that very few fish, and apparently very little animal food of any kind, was brought to the nest, and the young brood were being reared on the cherries out of our garden. I at first thought the children were mistaken, but as they assured me they saw the birds fly to the trees, and bring back the cherries in their bills, I examined the nest, and from the quantity of cherry stones that it contained saw that the youngsters' eyes had not deceived them. It was evident, in fact, that, up to the time they left the nest, fruit formed the chief food of the young birds. It has occurred to me that possibly the Kingfisher, from its habits, consumes a large quantity of fluid with its food, and that the juice of the fruit supplies moisture necessary to the proper growth of the young birds. At all events it is clear that young fruit forms an important article in their diet, though I never saw them eating it, or heard of their doing so at a later stage of their existence.

"I accidentally got corroborative information as to the frugivorous habits of the Kotare lately. I met Mr. Enderby, who mentioned that he had been greatly annoyed by these birds this autumn.

roeks along the beaeh, and on the telegraph wires stretched across tho numerous little bays. They were eridently attracted by the shoals of little fish that were frequenting the shallow water at the time; and at one spot I had an oeular demonstration of my argument with Captain Hutton, which I should like him to have witnessed. Ten little Kingfishors sitting in a row were in possessiou of a short span of telegraph wire overhanging tho water, and, one after the other, they wore dipping into the shallow sea-water in pursuit of fish. Sometimes two or even threo of them would dip at the same moment, raising a tiny splash all round, and then mount agaiu to the wiro or fly off to the shore with their fiuny prey. In further illustration of the piscivorous habits of the bird it may be mentioned that Mr. Brandon, of this city, has an indietment to file against the Kingfisher for robbing the fountain in his gardon of goldfish."

I have frequently observed these birds fishing from the scaffolding under Queen Street Wharf, in Auckland Harbour, at a distancc of fully two hundred yards from the shore; and my son, on one occasion, saw a Kingfisher capture a sea-minnow about four inches long and devour it.

The custodian of the trout-ponds at Hastings, near Napier, informed me, on my last visit there, that the Kingfisher had proved very destructive to the young trout, often attacking even good-sized fish in the ponds and pieking out their eyes!

The following eommunication from Capt. Mair (l.c. $\nabla 0 l . x$. p. 202) bears on the same point:-

"The Kingfisher is found in all the mountain streams of the Urewera and Bay of Plenty distriets. It subsists largelf on small freshwater fish (mohiwai of the natives), also on flies, moths, and beetles."

Mr. Potts says, in his interesting littlo volume "Out in the Open" (p. 150):- "It remains for me to state that these Kingfishers really do fish at times. We have watched with great pleasure and interost displays of their remarkable skill and activity. In the lovely island of Kawau, these birds are very numerous; and well they merit the protection extended to them for their useful labours in clearing off many of the crickets that are to be secn thero in abundance. At ebb-tide we bave noticed Kingfishers scttled on the twisted trunks of pohutukawa trees that spread out their crooked limbs over ware-washed and shelly beaehes. From such convenient perches the birds plunge boldly into tho sea, often wholly immersed, sprinkling round showers of spray. They swiftly emerge, rarely failing to bear back with them to their standing places their finny spoil." 
He said that scarcely a peach in the garden escaped having one or more large pieces pecked out of it, and that the birds did not meddle with the ripe fruit, but attacked it when it was just ripening and before it became soft. This seems to indicate that, as in my case, the fruit was wanted not for the consumption of the old birds themselves, but as food for their young, and that it was taken therefore before it was too soft to be carried in the bill, or not required after the fruit was ripe, because the young birds were then fledged. Mr. Enderby was quite positive that it was the Kotares and not Sparrows who were the depredators, as he saw them taking the fruit, and said he at first had a great mind to shoot them, till he noticed that they evidently carried it away to their nests."

I am not aware that the Kingfisher is ever nocturnal in its habits; but on one occasion, when travelling by coach along the banks of the Manawatu river, about 2.30 A.M., it being a cloudy night and quite dark, I heard the loud call-notes of this bird with startling distinctness. Probably it was a sleeper disturbed by the passing of the coach; although under these circumstances birds, as a rule, betake themselves off in silence to another roosting-place.

'Ihe New-Zealand Kingfisher commences to breed towards the end of November or early in December, usually selecting for its nesting-operations a tree denuded of its bark and decayed at heart, standing near the margin of the forest or in an old Maori clearing. By means of its powerful bill it cuts a round passage throngh the hard exterior surface, and then scoops out a deep cavity, proceeding in a horizontal direction for several inches, and then downwards to an extent of ten inches or more. The bird thus instinctively protects its chamber from the inclenencies of the weather. There is no further attempt at forming a nest, the eggs being deposited on a layer of pulverized decayed wood, the shavings and sawdust, so to speak, of the borer's operations in finishing the cavity.

The labour of boring a cavity is often greatly augmented by natural impediments. If, after drilling through the hard external surface, the bird finds the inner wood too hard for its tools, it at once abandons the spot and sounds the tree in another place. I have counted half a dozen or more of these abortive borings on a single tree, in addition to the finished one, affording evidence of indomitable perseverance on the part of the bird, and a determination not to forsake a tree which it had instinctively selected as a suitable one for its operations. In two instances, however, I have known the Kingfisher to adopt an existing hollow in a partially decayed kahikatea tree, dispensing altogether with the labour of boring and forming it.

The nestling of this species is a very curious object. On bursting from the shell it presents the following appearance: the abdomen, as in most young birds, is perfectly bare; on the other parts each feather is encased in a sharp-pointed sheath of a greyish colour, closely studded, and bristling like the quills of a porcupine. Before the young birds quit the nest, the sheathings gradually burst, exposing the true feathers in all their brilliancy; vestiges, horvever, of this spiny condition adhere to the fore part of the head for several days after the birds have quitted their cell.

On being alarmed or excited, the young Kingfisher utters a prolonged rasping cry, sounding very harsh to the ear. The parent birds are very fierce when their nest is molested, darting into the face of the intruder, and flying off again, with a loud, quickly repeated note of alarm.

Mr. Robertson, of Waireka, near Wanganui, informs me that he once saw a cat killed by a pair of these birds. The unfortunate puss had been treed by a dog and was hanging on to the bole, spread-eagle fashion, when she was fiercely attacked by a pair of Kingfishers who appeared to consider their nest in danger. After receiving repeated thrusts from the bills of her assailants the cat fell to the ground and shortly afterwards expired.

In the Canterbury district, where timber is scarce, it more frequently burrows a hole in a bank, and often near the sea-beach. On examining one of these holes, Mr. Potts observed that the bottom inclined slightly upwards from the entrance, and that the eggs were deposited on a 
layer of crustacean remains about a foot from the outside. The exuviæ within the nest eonsisted of mud, with numerous remains of erustaeea and the wings of coleopterous insects*.

The eggs are generally five in number, sometimes six, broadly oval in form, and measuring $1 \cdot 2$ inch by $\cdot 95$. They are of the purest white, with a smooth or polished surface, and very fragile in texture; sometimes the shell is marked by minute limy exerescences at the larger end.

In the British Museum eolleetion there is a specimen from Norfolk Island (marked Italcyon sancta, $\sigma^{\circ}$ ) whieh is undoubtedly referable to IT. vagans.

In 'The Ibis' (1880, p. 459) Mr. Layard deseribed a new Kingfisher from the Solomon Islands, under the name of Italcyon tristrami, stating that it was distinguishable from H. julice, Il. chloris, and $I I$. sancta by the well-marked supercilium and the rieh eolour of the underparts, in whieh respeets, he said, it exactly aceords with $H$. vagans from New Zealand. Dr. Ramsay has already pointed out (Proc. Linn. Soc. N. S. W. vol. vi. p. 833) that Layard's description does not altogether agree with the coloured figure whieh aecompanied it. Canon 'Tristram states (Ibis, 1882, p. 609) that the type of H. tristrami has "no occipital pateh whatever" and seems to be "further removed from II. vagans than from any other of the group." In reference to this $\mathrm{Mr}$. Sharpe remarks (Gould's "Birds of New Guinea'):- " We cannot understand why Canon Tristram should object to the close resemblance of $H$. tristrami and II. vagans." He expresses a doubt whether the bird exists at all in the Solomon group, all the examples in the British Museum having come from New Britain; and he adds that in all of these the nape-pateh is present, being plainly diseernible even in the nestling.

I have examined all these speeimens and I do not hesitate to say that $I$. tristrami is readily distinguishable from II. vagans by its larger size, brighter blue on the upper surfaee, more eonspieuous nuehal eollar, and greater extent and depth of einnamon hue on the underparts. But, after all, it is hardly possible to resist the conelusion that these elosely allied forms are little more, if anything, than loeal or elimatie raees of one common speeies. For example, in the British Museum there is a 'Tongan speeimen of H. sacra. (from the collection of Sir E. Home, Bart.) in which the bill is quite as large, the upper surface fully as bright, and the nape-pateh as distinet as in II. tristrami, although the underparts, as well as the nuchal collar, are perfectly white. On the other hand, a specimen of $H$. vagans (brought by IH.M.S. 'Herald' from Raoul Island), albeit a comparatively young bird, is as highly coloured in every respect as ordinary examples of If. tristrami, although it is appreciably smaller in all its dimensions.

* " Referring to your interesting account of its nesting-habits in the 'Birds of New Zealand' (1st ed.), I may mention that I have found three or four pairs building in close association in a clay bank, and that on one occasion I counted ten pairs boring in the standing trunk of a dead and decajing rimu. I have never found more than five eggrs in a rest."-Gickrre MLatr. "The Kingfisher makes its nest in our neighbourhood (Oamaru) by digging out a hole in a clay bank. $\Lambda$ tunnel is driven bank for twelve inches; at tho ond of this a round hole, five inches in diameter and two in depth, is formed, and here the beautiful white eggs are deposited. Therc are usually four or five in a nest, and the incubation takes nineteen days. After the young are hatched out, a strong stench is experienced at the mouth of the nest, owing to the nature of the food consisting of small fish, lizards, \&c. On one occasion I canght an adult bird in the vinery, where it appeared o be testing tho quality of the grapes. It bit my hand savagely when captured, and uttered a loud discordant scream." W. W. SirmTr.

"On a Kingfisher's nest and its contents:-October 10th, first egg laid in a nest on a eliff; sceond egg laid on the 12th fore $10 \mathrm{~A} . \mathrm{Ir} . ;$ third egg laid on the 14 th ; fourth egg on the 15th; fifth egg on the 16th; sixth and last egg on the 17th. Subsequently the nesting-place was measured and gave the following dimensions: entrance rather over two inchos in diameter; tunnel sixteen inches in length; egg-chamber of ovoid form, 7 inehes in length, $5 \frac{1}{2}$ in width, with a height from tho bottom of The size of the nest may create surprise when one thinks of the small space occupicd by the egras, but a roomy house is necessary, for, like those of most troglodytal breeders, the young remain in their hole till their wings are well grown." T. H. Poтrs. 


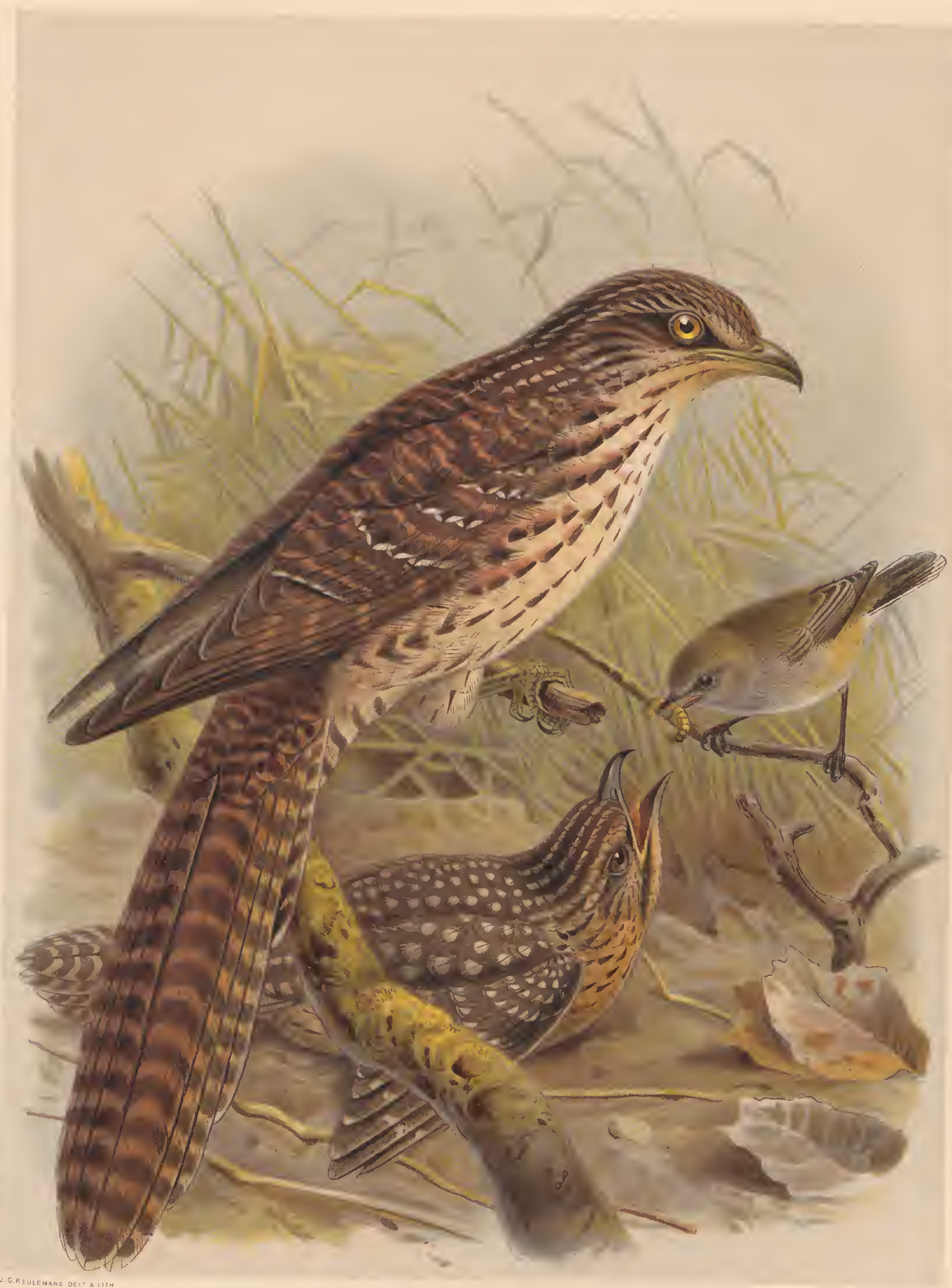





\title{
EUDYNAMIS TAITENSIS.
}

\section{(LONG-TAILED CUCKOO.)}

Le Coucou brun varié de noir, Montb. Ois. vi. p. 376 (1779). Society Cuckoo, Lath. Gen. Syn. ii. p. 514 (1782).

Cuculus taitensis, Sparrm. Mus. Carls. t. 32 (1787).

Cuculus tritius, Gm. Syst. Nat. i. p. 412 (1788).

Eudynamys taitensis, Gray, Dieff. Trav. ii., App. p. 193 (1843).

Cuculus fasciatus, Forst. Descr. Anim. p. 160 (1844).

Eudynamys cuneicauda, Peale, U. S. Expl. Exp. p. 139, pl. 38. f. 2 (1848).

Eudynamys tahitius, Gray, B. Tr. Isl. Pacif. Ocean, p. 35 (1859).

Eudynamis taitiensis, Cab. \& Heine, Mus. Hein. Th. iv. p. 56 (1862).

Eudynamis tahitiensis, Potts, Trans. N.-Z. Inst. vol. iii. p. 90 (1870).

\section{Native names.}

\author{
Koekoea, Kawekawea, Koheperoa, and Kohaperoa.
}

đad. brunneus, pileo longitudinaliter fulvo striato: eorpore reliquo superiore brunneo et pallidè ferrugineo eonspicuè at irregulariter transfasciato : teetricibus alarum fulvo maculatis : caudâ brunnco et ferruginco transfaseiatâ alboque terminatâ: remigibus brunneis, ferruginco maculatis, fascias irrcgulares formantibus : supercilio angusto fulvo: regione aurieulari brunneâ angustissimè fulvo lineatâ : genis et eollo laterali albis fcrrugineo lavatis et brunneo longitudinaliter striatis : subtìs albicans, plumis medialiter brunneo striatis et ferruginco tinctis: lyypochondriis brunnco transfasciatis: subalaribus fulvescenti-albis, angustè brunnco striatis: rostro pallidè brunneo, ad basin saturatiore, mandibulâ flavicante: pedibus viridi-flavis, unguibus brunneis : iride rubescente, interdum flavieante : regione ophthalmicầ nudâ sordidè viridi.

q vix a mari distingucnda : paullò minor : eoloribus sordidioribus.

Juv. pallidior, suprà ubique albido maculatus, nec fasciatus : caudâ pallidè fulvo transfasciatâ : subtùs ochraceus, pectore abdomineque maeulis elongatis triquetris notatis : 1'ostro flavicanti-brunneo : pedibus viridi-flavis.

Adult male. Upper surface dark brown, with a purplislı gloss, longitudinally strcakcd on the head and ncek, barred and spotted on the wings and baek with rufous; wing-coverts tipped with fulvous whitc; quills dark brown, banded with pale rufous; tail-feathers marked in their whole extent with narrow altcrnate bars of dark brown and rufous, tipped with white and finely glossed with purple; a broad line of yellowish white passing from the nostrils over the eycs, and another extending downwards from the angles of the mouth; lores and chin whitc, with numerous black hair-likc filaments; sides of the neck dark brown mixed with rufous; throat, fore part of neek, breast, and sides of the body pure white, with numerous longitudinal streaks of browu, each feather liaving a broad mark down the centre; lining of wings fulvous whitc or pale fawn-colour; femoral plumes and under tail-coverts crossed with broad arrow-head marks of brown. Bill pale brown, darker at the base, and ycllowish on the lower mandible; irides reddish brown, inclining in some to yellow; bare skin surrounding the eyes dull green; tarsi and toes grecnish yellow; claws dark brown. Total length 16.5 inches; extent of wings 21 ; wing, from flexure, $7 \cdot 5$; tail $9 \cdot 75$; bill along the ridge 1 , along the cdge of lower mandible 1.4 ; tarsus 1.5 ; longer fore toc and claw 1.4 ; longer hind toe and claw $1 \cdot 25$. 
Adult female. Slightly smaller than the male, and with the tints of the plumage duller, the purple gloss on the upper parts being seareely pereeptible.

Young. Upper surfaee blaekish brown, marked on the erown with narrow streaks, on the hind neek with fusiform and on the back with rounded spots of fulvous yellow; quills and tail-feathers blaekish brown, barred and tipped with fulvous brown. Under surface pale cinnamon-brown; on eaeh side of the throat two longitudinal streaks, and on the breast and sides of the body broad shaft-lines of dusky blaek; under taileoverts barred and tibial plumes erossed with marks of the same colour in the form of an inverted V. Bill yellowish brown; tarsi and toes greenish yellow.

Obs. In examples of the young birds mueh difference is observable both in the ground-tints and in the markings of the plumage. Some are mueh darker than others, and have the spots on the npper surfaee pale rufous instead of fulvous yellow; in others, again, they are yellowish white; some have the barred markings on the tail-feathers very obseure, while in others they are as distinet as in the adult, although not so regular in form.

phenomon in the animal world known to naturalists as "mimiery," or the law of protective resemblance. It is developed ehiefly among insects, and particularly among tho Lepidoptera. Mr. Wallace deseribes, at page 205 of his enchanting book ou the 'Malay Archipelago,' a butterfly whieh, when at rest, so closely resembles a dead leaf as almost The varied details of colouring combine to produee a disguise that so exactly represents a slightly eurved or hivelled leaf as to render the butterfly quite safe from the attacks of inseetivorous birds, except when on the wing. The flight of the insect, on the other hand, is so vigorous and rapid that it is well ablo then to protect itself. Mr. Wallace adds that in formed of small black dots, so elosely rescmbling the way in which minute fungi (he butterfies themselves! This protective imitagrow on leaves that it is impossible not to helisto from extinction must obviously favour the species in the genol assumes for similar protective purposes a elose resemblaneo to some oth instanees might be given in illnstration of this singular faet, every holonging to a totally different family or order. Numboring of variation department furnishing examples of adaptation more or less complete, and alloring in the Molneeas, was the first to diseover under natural selection or the " survival of the fittest." Mr. Whotective colouring had long been known to exist in the ease of similar instanees of mimiery among hirds, although the birds' eggs. He gives two very curious oxamples of extertal rese a Honeyrendering it impossible to placo the model and the copy near each other in an tated - "They must derive some advantage from sueker has its eolours mimicked by a species of Oriole, and the reason is thews, they may require it. Now, the Tropidorhynehi the imitation, and as they are eertainly weak birets, with small fect and lo the assemble ther in are very strong and active birds, having powerful grasping elaws, and lon to collect groups and small flocks, and they have a very loud, bawling note, which can bo loan, frequently driving away erows and even a number together in time of dauger. They are very plentiful and very pugacious, thereforo, that the smaller birds of prey hawks, which perch on a tree where a few of them are assembled. It is very reat advantage for the weaker and less eourageous have learnt to respect theso birds, and leave them alono, and it may tariation and Survival of the fittest will suffice to explain Mimetas to be mistaken for them. This being the case, the lains of voluntary action on the part of the birds themselves; and how the resemblanee has beel brought about, Nithes ' will have no difficulty in eomprehending the whole process."

those who have read Mr. Darwin's "Origin of Spoeies" will have the English Cuekoo (Cuculus canoms) is supposed to derive

Among the many minor instauces that have athacte Sparrow-Hawk (Accipiter nisus); but the resemblanee is far more jrotection from the resemblance of its markiugs to the striking betwoen our Long-tailed Cuckoo aud a North-American speces of The very pronouneed, while the peeuliar form of the bird of the former it will be observed that the markings of itself distinguishes it very readily from all other New-Zealand srom the nothing to remind us of our own Bush-Hawk; and that thero is no great protech timorous enough in the presence of a Ilawk. fact that our Cuekoo is persecuted on every possible oceasion by During a trip, however, on the Continent, in the autumn of bird. Not only has our Cnekoo the gencral contour of Cooper's to be the aceipitrine model, in a very striking likeness to our bird. Not on femoral plumes are exactly Sparrow-Hawk, but the tear-shaped markiugs on the mnderparts antifully banded tail and marginal wing-coverts, and likewise similar in both. The resemblance is earried still further in the neek. On turning to Mr. Sharpe's deseription of the "young in the distribution of eolours and markings on the sis of the terms male" of this species in his Catalogue of the Aecipitres in the Brit 
employed apply equally to our Euclynamis, even to the general words "deep brown above with a ehocolate gloss, all the feathers of the upper surface broadly edged with rufous."

The eoineident existeneo of such a remarkable resemblanee to a New-World form eannot of eourse be any protection to an inhabitant of New Zealand, and I do not pretend in this instanee to apply the rule; but in the light of natural seleetion, to whieh at present no limit ean be assigned, the faet itself is a suggestive one, and sufficiontly striking to eall for speeial mention.

THE illustration which accompanies this article, although it may have the appearance of an exaggeration, is in reality a true picture of bird-life. The Long-tailed Cuckoo, which is a native of the warm islands of the South Pacific, visits our country in the summer and breeds with us; but the task of rearing its young (as many witnesses can testify) is entrusted to the Grey Warbler (Gerygone flaviventris), figured in our Plate-a species that performs the same friendly office for the Shining Cuckoo (Chrysococcyx lucidus), anothcr summer visitant.

Drs. Finsch and Hartlaub, in their valuable work on the Birds of Central Polynesia, record the occurrence of this species in Samoa, as well as in the Friendly *, the Society, the Marquesas, and the Fiji groups of islands; but although it migrates to New Zealand, there is no mention of its occurrence in any part of Australia or Tasmania.

In the still summer's evening when the landscape is wrapped in the gloom of faded twilightwhen no sound mcets the ear but the low nuusical song of the pihareinga cricket and the occasional hum of a Prionoplus on the wing-there comes from the thicket a long-drawn cry, shrill and clear; then a pause of five minutes or more, followed by another cry; and so on at intervals till long after the pihareingas have ceased to chirp and the nocturnal beetles have folded their wings in sluggish repose. This is the first intimation we get that the Long-tailed Cuckoo has come amongst us.

It begins to arrive about the second week in October, but is not numerous till the following month, when the pairing commences. It is, however, somewhat irregularly dispersed over the country; for in the far north it is at all times a very rare bird. In the southern portion of the North Island, and throughout the wooded parts of the South Island, it is comparatively common. It appears to be most plentiful in November and Dccember, becoming scarcer in January and disappearing altogether by the end of February. I have a note, however, of its occurrence at Otaki (in the North Island) as late as the first week in April.

Young birds are not unfrequently met with in the month of March or even later; but it seems probable that these are only solitary individuals hatched too late to permit of their joining in the return migration, and accordingly left to perish as the cold season advances; and this is likewise the case with our Shining Cuckoo. As an illustration of this, I may mention that a young bird of this latter species, which had been picked up dead in a garden, was brought to me at the end of February (long after the old birds had quitted the country), and that I found it excessively fat, and the stomach crammed with caterpillars-strong presumptive evidence that the bird had not suffered from the neglect of its foster-parents, but had succumbed to the exigencies of its late birth.

In the early dawn and during the cool hours of the morning, the Long-tailed Cuckoo resorts to the low underwood and brushes; but although its cry may be frequently heard, it is not easy to find the bird, inasmuch as the sound, though produced within a few yards of the listener, has the effect on the ear of one coming from a remote distance. This species, in fact, appears, like some others of the samc family, to be endowed with a sort of natural ventriloquism, and its apparcntly far-off cry is often very deceptive.

While searching for his food the Koheperoa moves about with much activity; but as soon as the sun is up he betakes himself to the top branches of a kahikatea or other lofty tree, where he remains closely concealed till sunset. He continues to utter, at intervals of ten or fifteen minutes,

* Dr. Finseh has identified a young male in the spotted dress in a colleetion of birds from the island of Eua. 
his prolonged shrill note (quite distinct from all other sounds of the forest, and very pleasant to hear) till about noon, when he remains perfectly silent for two hours or more. As soon, however, as the heat of the day is over, he resumes his cry, and shortly afterwards leaves his retreat to hunt for food again.

It is not unusual to hear a pair of these birds answering eaeh other for hours together from the tops of neighbouring trees. Indeed, I have observed that it is habitually stationary, for it may often be heard uttering its long, plaintive scream for a whole day in the same tree, but always quite out of view. During the quiet nights of December its piereing cry may be heard at intervals till break of day, varied only in the earlier watehes by the solemn hooting of the Morepork.

This speeies is more predatory in its habits than is usual with the members of this group. Lizards and large insects form its principal diet; but it also plunders the nests of other birds, devouring alike the eggs and young. From the stomach of one which I shot in December 1856, I took the body of a young bird (apparently a Piopio), partly fledged and only slightly mutilated, showing the enormous capacity of the Cuckoo's throat. This interesting object, preserved in spirit, is now in the collection of the Colonial Museum at Wellington. The large nocturnal beetle (Prionoplus reticularis), the rarious speeies of Deinacridae and Phasmida, the kekereru or fetid bug, the large bush Cicada, and different kinds of spiders and caterpillars, all contribute to the support of this bird; for I have found their remains in abundance in the stomachs of specimens I have disseeted.

As already stated, it is accustomed to rob the nests of other birds; and whether from this or some other eause, it is an objeet of eonstant perseeution to the Tui or Parson bird. The instant one of these birds shows itself, the Tui commences its pursuit, chasing it from tree to tree, and fairly driving it out of the woods. I have actually seen three or four of these perseeutors at one time following the unfortunate Cuckoo, with loud cries of intimidation, and, finally, compelling it to take refuge in the long grass on the banks of a stream.

During its sojourn with us it is generally met with singly or in pairs, but Captain Mair gives the following interesting particulars of a summer flight:- "Passing down the Hurukareao river, in the Urewera country, during the intensely hot weather of February 1872, I was astouished at the number of Koheperoa that coursed about overhead. During the three days that we were making the passage, I saw some hundreds of them, swarming about in the air like large dragon-flies, as many as twenty or thirty of them being sometimes associated together. The loud clamour of their notes became at length quite oppressive. There was mueh dead timber on the banks of the river, and it appeared to me that the birds were feasting on the large brown cicada. This is the only occasion on which I have observed this bird consorting as it were in parties."

Very little is at present known of the breeding-habits of this species. As I have mentioned above, it is parasitical ; but to what extent is not yet fully determined. The theory put forward in my former edition was, that it performs itself the duty of incubation, and then abandons its young to the Grey Warbler, which instinctively aecepts the charge and caters untiringly for its support. In the first place it is difficult to conceive how a bird of the size and form of the Long-tailed Cuckoo could deposit its eggs in the domed nest of the last-named species; and even supposing that it did, it would seem almost a physical impossibility for so small a creature to hatch it; and, again, even were this feasible, it is difficult to imagine how the fiail tenement of a suspension nest could support the daily increasing weight of the young Cuckoo*. Over and above all this, there was the significant

* Mr. Justice Gillies thus describes a nest of the Grey Warbler which he found depending from a manuka bush closo to the roadside, and about five feet from the ground, at the Bay of Islands (it was on the 7 th October, and the nest contained four eggs) :"It is of the shape of a soda-water bottle, eight inehes in length by about four in diameter at its widest part. The side aperture way down from the twig on whieh it hung, and measured one and a half inehes across by about one ineh 
fact that I had once shot an adult female in which the underparts were quite denuded of feathers, as if the bird had been long incubating. Strange as such an hypothesis may appear, we are not altogether without a parallel instance in bird-history; for in the case of the Chrysococcyx smaragdineus of Western Africa, it is alleged that this Cuckoo hatches its single egg and then, utterly unmindful of its parental obligations, casts the care of its offspring on a charitable public ; and that almost every passing bird, attracted by the piping cry of the deserted bantling, drops a caterpillar or other sweet morsel into its imploring throat! My artist, Mr. Keulemans, assures me that he often witnessed this himself during his residence on Prince's Island. As entirely opposed to this theory, however, there is one undoubted case of an egg of this Cuckoo being hatched out by a Wood-Robin (Miro albifrons) in whose nest it had been deposited. The young Cuckoo was removed by the finder and soon afterwards died *. The question arises, If it had been allowed to leave the nest, would the Robin have reared it, or would she have delegated this task to the Grey Warbler?

An egg forwarded to me some years ago by the Rev. R. Taylor, of Wanganui, as belonging to this species, is almost spherical in shape, with a slightly rough or granulate surface; it is of a pale buff or yellowish-brown colour, and measures 1.25 inch in length by 1.15 in breadth. A specimen in the Canterbury Museum, taken by Mr. Smith from a Warbler's nest at Oamaru, in November 1885, corresponds exactly with mine (which is now in the Colonial Museum at Wellington) except that it is slightly narrower.

perpendicular. The upper portion of the nest somewhat overhangs the aperture, forming a sort of hood. The nest is composed of twigs, grass, cow-hair, and greenish spider-ncsts, with a white coral-like moss scattered over the ontsido. The eggs are ten sixteenths of an inch in length by seven sixtcenths of an inch greatest diameter, ovoid, of a faint pinkish colour, with small brown spots, more numerous at tho larger end of the egg." The learned author continues:- " How the Long-tailed Cuckoo (Euclyncmis taitensis) can, as stated by Dr. Buller ("Birds of New Zcaland,' p. 75), deposit its eggs in such a nest I can scarcely understand. On the 22nd instant (October) onc of my children discovered, under a large Cupressus macrocarpa in my garden, a specimen of tho Eudynamis taitensis, recently killed, apparently by a Hawk. It would have been impossible for the Eudynamis to have entered the opening in the nest of the Gerygone." (Trans. N.-Z. Inst. vol. vii. p. 524.)

On referring to the page of my first edition as cited above, it will be scen that, so far from making the supposed statcment, I then expressed, as I now repeat, a very decided opinion to the contrary.

* Mr. W. W. Smith sends me the following particulars of this case :-

“Oct. 29th. Found Wood-Robin's nest with two eggs. Oct. 31. Visited Robin's nest; four eggs. Nov. 3. Agreeably surprised to find egg of Eudynamis taitensis placed among the rost ; for this is the first time I have seon its egg in the nest of this species. It was almost round in shnpe, with a decper shade of colour than the specimen in the Cantcrbury Mruseum. Nov. 7. Found Robin sitting, and did not disturb her. Nov. 10. Made bird fly off, in order to cxamine the eggs, which I found to be all right. She was very tame, and came close to my faco whilst I was looking at the eggs. Nov. 15. $\Lambda$ gain found bird on the nest, and left her undisturbed. Nor. 24. Visited nest again, and found all the cggs hatched; young Cuckoo of enormous size comparcd to, its mates; must have been hatched out later than the others, as one of the young Robins was dead. I took the former in my hand, and found it to be a very helpless creature, with the skin almost entircly naked and the eyes closed. Nov. 28. Found young Cuckoo thriving well, being kept constantly supplied with food by tho Robin, whose own surviving offspring, three in number, appear likewise to be doing well. Dec. 2. Young Cuckoo growing rapidly. It will soon be too large for the nest, and already has to lio on the top of the young lRobins. Dec. 6. Cuckoo still in nest, and now covercd with thick blackish downy feathers. It seems very robust; and I obscrved it raise its body orcr the edge of the nest in order to void its excrement. Dec. 8. Young Cuckoo has grown so much that it quitc fills the cavity of the nest. The joung Robins appear instinctively to remain at the bottom for self-preservation; for if the Cuckoo conld displace them, he could occupy the whole of the cavity of the nest. Dec. 9. Removed two of tho young Robins, in order to make room for the increasing size of the Cuckoo. Dec. 10. Young Cuckoo and remaining Robin doing well, the latter being nearly ready to fly. Dec. 11. Placed the nest, with both occupants, inside a box with wire-netting in front-the mesh being large enough to admit the head of the parent-and left it there. Dec. 15. Found young birds quite actiro, having been fed by the old ones through the netting. Iiberated the Robin and brought the Cuckoo home. It is now in fine plumage, spotted with white or gresish white on a brown ground. Dec. 17. Cuckoo doing well and eats freely. Moves about the box in a clumsy way, and utters a peevish chirp, usually after being fed. Legs well developed, but apparently weak; eyes very bright. Dec. 22. Young Cuckoo died last night, much to my regret, as I was anxious to make it live through the winter." 


\title{
CHRYSOCOCCYX LUCIDUS.
}

\section{(SHINING CUCKOO.)}

Shining Cuckoo, Lath. Gen. Syn. ii. p. 528, pl. xxiii. (1782).

Cuculus lucidus, Gm. Syst. Nat. i. p. 421 (1788, ex Lath.).

Variable Warbler, Lath. Gen. Syn. Suppl. ii. p. 250 (1801).

Sylvia versicolora, Lath. Ind. Orn. Suppl. ii. p. Ivi (1801).

Chalcites lucidus, Less. Traité d'Orn. p. 153 (1831).

Cuculus nitens, Forst. Descr. Anim. p. 151 (1844).

Cuculus versicolor, Gray, Gen. of B. ii. p. 463 (1847).

Chrysococcyx lucidus, Gould, B. of Austr. iv. pl. 89 (1848).

Cuculus chalcites, Illiger, MS. in Mus. Berol., undè

Chrysococcyx chalcites, Licht. Nomencl. Av. p. 78 (1854).

Lamprococcyx lucidus, Cab. \& Heine, Mus. Hein. Th. iv. p. 14 (1862).

Chrysococcyx plagosus, Hutton (nec Lath.), Trans. N.-Z. Inst. (1872), vol. v. p. 223 *.

\section{Native names.}

\author{
Warauroa, Pipiauroa, and Pipiwarauroa.
}

$A d$. suprà metallicè viridis, æneo et cupreo nitens, supraeaudalibus lateralibus latè albo semifasciatis : fronte, supercilio distincto et facie laterali albo maculatis, viridi transfasciatis : loris mentoque albidis haud viridi notatis : tectricibus alarum dorso concoloribus : remigibus brunneis, ad basin pogonii interni albidis, primariis extùs ænco nitentibus, secundariis magis conspicuè lavatis et pennis dorsalibus omninò dorso concoloribus : caudâ brunncâ, æneo-viridi nitentc, fasciâ anteapicali nigricantc, rectricibus tribus cxterioribus ad apicem pogonii interni albo maculatis, pennâ extimâ albo conspicuè fasciatâ, penultimâ in medio vix rufescente tinctâ: pectore et subalaribus albicautibus transversim æneo-viridi fasciatis : abdomine puriùs albo, hypochondriis subcaudalibusque conspicuè æneo-viridi transfasciatis: rostro nigro: pedibus brunnescenti-nigris, plantis pedum flavicantibus : iride nigrâ.

Juv. obscurior et sordidior, minùs metallicus : tectricibus alarum brunneo marginatis : caudâ nusquam rufescente : gutture et pectore superiore fulvescenti-albis, fuscescenti-brunneo variis, vix viridi lavatis : corpore reliquo subtùs fulvescenti-albo, hypochondriis et corporis latcribus fasciis interruptis metallicè viridibus notatis : subcaudalibus maculis viridibus triquctris transnotatis.

Adult male. Upper parts bright golden green, changing to coppery purple in certain lights; frontal feathers tipped more or less with white; superciliary streak formed of irregular whitish spots; throat, sides of head, and fore part of neck white, with narrow broken bars of coppery green; breast and underparts generally white, with transverse bands of changing golden grcen, coppery brown in certain aspects; on the sides, flanks, and under tail-coverts these bands arc very regular and conspicuous, each feather being erossed by

* "Captain Hutton says that the Chatham-Island Bronze Cuekoo is not the same as the New-Zealand one, but is C.plagosus of Australia, in which opinion I do not agree, after having eompared a speeimen from the Chatham Islands lent me by the NewZealand Institute. The underparts show a little broader gold-green erossbands, and the seeond tail-feathers, instead of two welldefined rusty bands, have only indieations of them; but there is no other differenee, and I see no reason to separate the Chatham Island bird from the New-Zealand C. lucidus." (Finseh, Trans. N.-Z. Inst. vol. vii. p. 227.) 

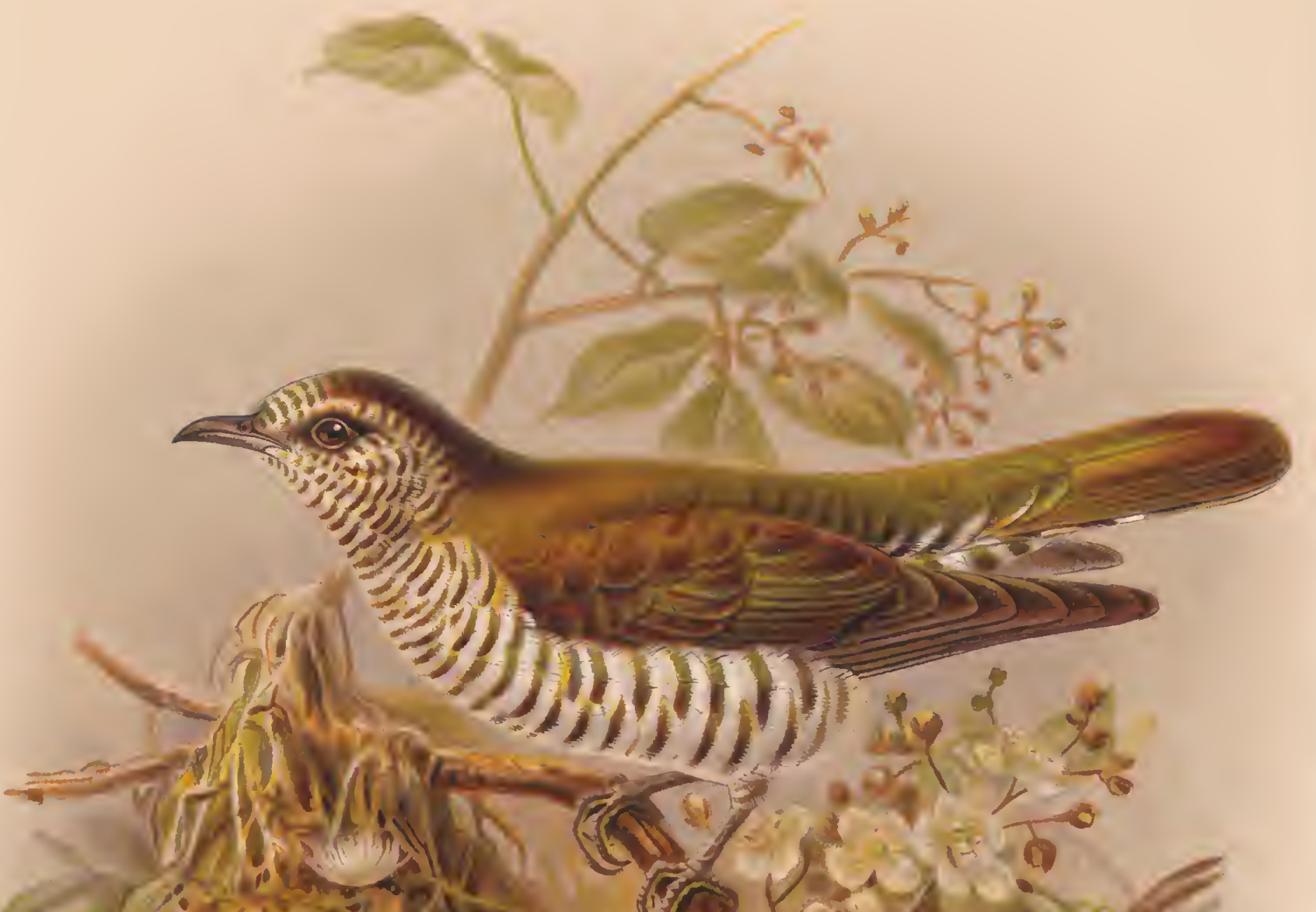

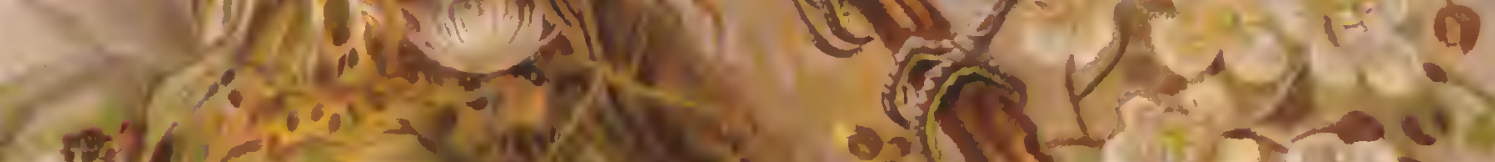

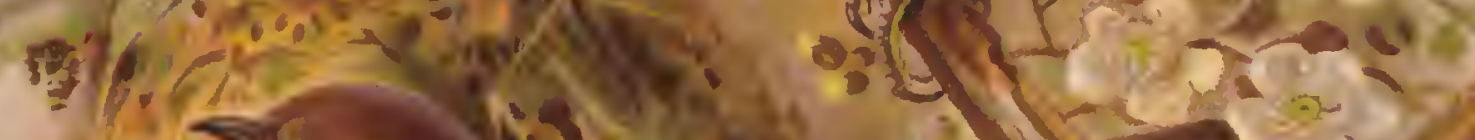

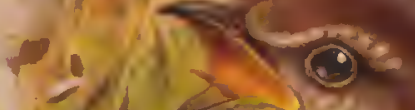

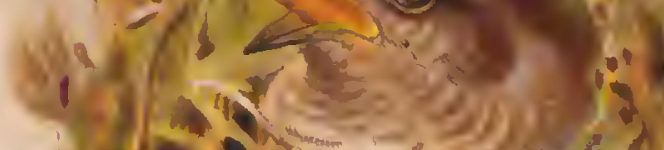

(2)

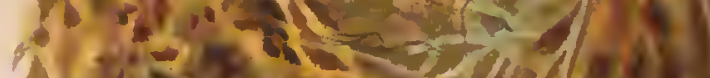

If

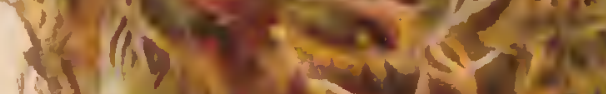

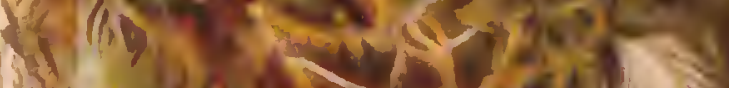

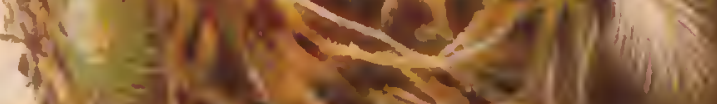

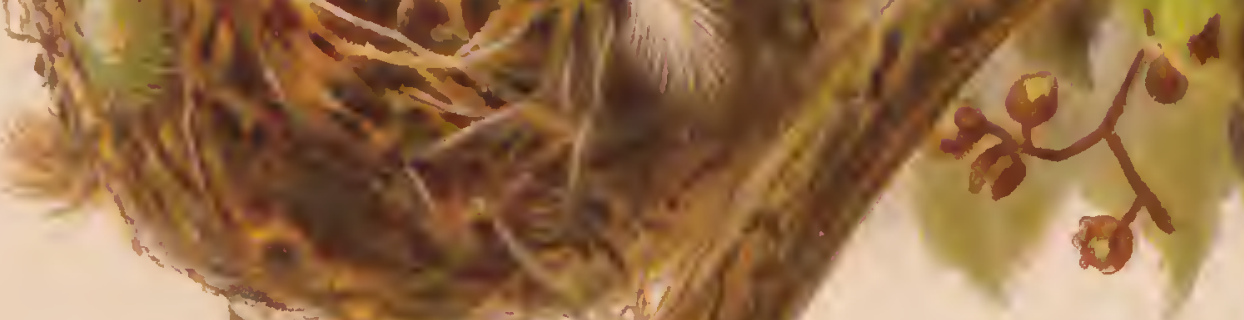

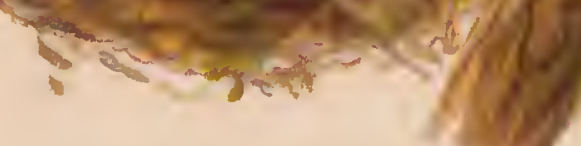

THE SHINING CUCKOO

CHRYSOCOCCYX LUCIDUS

(WITH YOUNG CUCKOO IN WARBIER'S NEST. 

two broad, equidistant bars; the lower part of the abdomen pure white; quills dark brown, glossed with eoppery brown, ehanging to briglit golden green on the seeondaries; with the exeeption of the three outer primaries, all the quills are yellowish white in the basal portion of the inner webs, forming a broad oblique bar on the under faee of the wing; under wing-eoverts and axillary plumes indistinetly barred with eoppery brown; tail, when elosed, bronzy green, with a broad subterminal band of purplish brown; upper taileoverts bright golden green, the lateral ones largely marked with white on their outer webs. On spreading the tail the outermost feather on each side is found to be blackish brown, with tive broad white bars on the inner web, the fifth one being terminal, and with five irregular spots of white on the basal portion of the outer web; the next feather blackish brown, slightly glossed with green, marked on the inner web with two obseure spots of rufous, darker brown towards the tip, and terminated by a round spot of white; the sueeeding one similar, but without the rufous markings, and with the terminal spot on the inner web mueh smaller; and the median feathers eoppery brown, glossed with green, and erossed by a darker subterminal bar. Irides and bill blaek; tarsi and toes brownish blaek; soles of feet yellowish. Total length 7 inehes; extent of wings $11 \cdot 75$; wing, from flexure, 4 ; tail $2 \cdot 75$; bill, along the ridge $\cdot 5$, along the edge of lower mandible $\cdot 75$; tarsus $\cdot 5$; longer fore toe and elaw $\cdot 8$, longer hind toe and elaw $\cdot 65$.

Young. Metallie tints of the upper parts duller; upper wing-eoverts edged with brown; tail-feathers as in the adult, but with the rufous markings obsolete; throat and fore part of neek yellowish white, elouded and mottled with dusky brown, faintly glossed with green; underparts generally yellowish white, marked on the sides and flanks with fragmentary or interrupted bands of dull shining green; the under tail-coverts erossed by broad triangular spots of the same.

THERE is nothing more delightful, on a sultry summer's day, than to recline in some cool shade and inhale the sweet fragrance of the native woods. All is still and quiet save the hum of bees in the air and the loud drumming of the tarakihi as it clings to the bark overhead. 'Then there falls upon the ear the well-known cry of the Koheperoa-not the vociferous scream of the early morning, but a low sleepy cry-issuing from some lufty tree-top where the bird is resting during the heat of the day. From a neighbouring tree comes the full rich note of the Tui, uttered at short intervals like the slow tolling of a silver bell; then the low whistle of a Kaka calling to its mate to come and seek repose while the sun is at the meridian; then all is still again, and nothing is heard but the soft murmur of insects in the air and the languid cry of a solitary Fantail as it flits around with full-spread wings and tail, dancing from side to sidc, or the sweet trill of the Ngirungiru, full of pleasant associations. But while we are still listening, a new sound arrests the attention-a peculiar whistling cry, different from that of any other bird. This announces the arrival in our country of the Shining Cuckoo, an inhabitant of Australia, and probably New Guinea*, which appears in New Zealand (also in Norfolk Island) only as a summer migrant. Its cry is always welcomed by the colonists as the harbinger of spring; and during its short stay with us its sweet but plaintive notes may be heard in every grove throughout the long summer days. It makes its appearance, year after year, with surprising punctuality, arriving first in the extreme north, and about a fortnight later spreading all over the country. A correspondent informs me that for three successive years, at Whangarei (north of Auckland), he first heard its familiar note on the 21st September, and that on one occasion he noticed it as early as the $3 \mathrm{rd}$ of that month. Another correspondent, in the same locality, informs me, as the result of twelve years' careful observation, that this migrant invariably appears between the 17th and 21st of September. For a period of ten years I kept a registcr of its periodical arrival at Wellington, and noted its regular occurrence between the 5th and 10th of October. Mr. Potts writes to me from Canterbury that it generally arrives there on or about the 8th of October, although in one year (1855) it visited that part of the country as early as the 27 th September. It usually departs about the first or second week in January : but in the far north it sometimes lingers 
till the end of that month. As is always the case with migratory birds, there are occasionally stragglers arriving before the appointed time or lagging behind the departing flights. For example, I have a record" of their occurrence in Auckland as early as August 17th, and I have met with a solitary bird in the south as late as April.

This is undoubtedly the most tropical-looking of our birds. The glancing of the sunlight on its burnished plumage is very effective, especially, too, when the bird is seen resting on the bare stems of the quasi-tropical Cordyline, or feeding on the green-and-gold cicada, which is so abundant there *.

* In New-Zealand scenery there is much to remind one of a tropical country. The scattered clumps of " cabbage-trees" in the open and the nikau-palms in the deep wooded gullies havo quite a tropical aspect, and the wild luxuriance of the evergreen bush brings vividly to mind the rank prodigality of a Brazilian forest. To show that this is not a mere play of funej, I will give here a leaf from my orm diary coutaining an account of a day at Rio de Janeiro:-

"We landed from the S.S. 'Tongariro' at 9 A.M. on tho 1st $\Lambda$ pril, and eame on board again before midnight, having spent a very pleasant day on shore. On landing, we walked through the market-place, which was interesting, then up the.principal street, through which no wheeled vehicles arc permitted to pass. Tho passage is narrow and the balconies are overhanging, giving it the appearance of a street in Constantinople. Nany of the shops are most attractive in their multifarious exhibitsfeather-plumes, rare butterflies, and brilliant boetles beiug not the least interesting objects. At the street eorner we took a tramear, and, after one or two changes, proceeded to tho railway station, passing on our way some fine public and private buildings, notably a marblo palace, the property of a rich coffec-planter. Many of the gardeus are very beautiful, being brilliant with tropical fiowers of evcry hue. After a short delay at the station, we entered the railway carriage aud started up the Coreo Vardo line. From the commencement to the finish at the peak the trip was one of unmitigated enjoyment. Tho day was clcar as erystal, with the sun hot and bright; and the seenery was enchanting. The railway line, which asconds spirally at a gradient of 1 in 3 , is something quite unique. Looking down into the doep gullies, I was often reminded of our beautiful New-Zcaland bush in the tangled richness of the vegetation. There was the same character of forest-growth, the same crowding together of the tree-tops, the same wealth of lianas, vines, and cpiphytes, but all on a more luxuriant scale. In place of our Astelia cunninghamii, with its narrow flag leaves, the trees were laden with large clumps of some tropical species with leaves six inches in width; in place of our tiny-flowered orchids there were magnificent tropical species with gorgeous blossoms. There was along the wayside a dense undergrowth in every shade of green, but the leaves were larger and the foliage richer than in tho New-Zealand woods, whilst in the places exposed to the sun beautiful flowers of brilliant hues added the charm of high colour to this sylvan picture. The ground below the forest trees was covered with vigorous young plants of many kinds; but the eye sought in vain for that everpresent charm of the New-Zealand bush, the carpot of spreading ferns and mosses. Here and there could be secu a tuft of maiden-hair or a elump of Pteris struggling to assert itself, but nothing to remind the observer of the glorious beds of Lomaria, the fields of Asplenium bulliferum, and the other beautiful forms so familiar to the wauderer in our native woods. As our train moved slowly up the side of tho mountain, the oye seemed nerer tired of gazing on this view of tropical growth, rendered the more conspicuous by clumps of banana-trees and groups of beautiful palms, lifting their tops proudly above the forest vegetation, whilst hugo masses of crimson and purple flowers lightened up the rolling landscape of living green.

"Then all along the line brilliant butterflies of overy size and colour fluttered in the warm sunlight; glorious morphos, with a spread of six inches and of the richest metallic blue, hovered, havw-like, among tho trees; large black-and-grey 'swallow-tails' winged their way like Swifts among the lower vegetation; erimson Danaidx and smaller forms of different kinds-scarlot, golden-yellow, green, or spotted-rested on the leaves or hovered over the flowers, almost within reach of our delighted party, some being actually caught by the hand from the carriage windows. Then here and there a tiny humming-bird, sparkling like a ruby under the rays of the midday sun, might be seen suspended bofore an open flower or spinning like a moth through the air in search of its absent mate. Such were the sights of tropical lovcliness through which wo passed on our way to the summit of the Coreo Vardo. The view from this point, which is just 2200 feot above tho sea-level, baffles description. The far-reaching panorama of sea and land, the wondrous archipelago in front and the glorious amphitheatre of mountains behind-on the one hand the boundless Atlantic, on the other the towering peak of Techuka, 3300 fect high, rising out of deep valleys filled with tropical forests; then, eontracting the scope of vision to the left, the city of Rio in all its quaint oriental beauty lying before you far down in the plains, its suburbs of villas and gardens spreading away for miles and far as the eye ean reach, whilst to the right, nestling as it were in an illimitable expanse of ornamental shrubbery, are the Rotanical Gardens, with their double row of Imperial palms in perfect symmetry, their feathery tops rcarod nearly a hundred fect abore the ground, presenting a picture of unparallelled beauty; then, still further contracting the scopo of vision, the sides of the Corco Vardo and the deep ravine below, clothed and filled with a perfect tangle of tropical vegetation, wildly exuberant in its growth, presenting every hue of green, and enlironed with spreading floral masses of purple and white. The view which burst upou us whon wo took our stand on the topmost peak of the Coreo Vardo was, in short, one which no human artist could depict aud no words describe: a riow to be gazed on once and then remembered all through life!" 
During its sojourn with us it subsists almost exclusively on caterpillars, and the black leech which attacks our fruit-trees. It is therefore entitled to a place among the really useful species.

In disposition it is very gentle. On one occasion I was watching this bird from the window of my hotel, foraging in the garden below for caterpillars, while a brood of young Sparrows were doing the same. Whilst the Cuckoo rested for a moment on a slanting stick, the Cock Sparrow dropped down till it almost touched him, as if to inspect his shining coat. The object of these attentions never left his percl, but simply swerved his body and spread his outer wing, without uttering a sound. I noticed that the young Sparrows were far more active in catching caterpillars than the Cuckoo, although both birds adopted the same plan of search, darting right into the shrub-tops and bringing out their victims to batter and kill them before swallowing.

Its general attitude is that depicted in the Plate, with its tail half-spread and its wings drooping, my artist having utilized a pencil-sketch which I made of a captive bird as it rested quietly on the paper-basket in my study.

Its cry is a remarkable one, as the bird appears to be endowed with a peculiar kind of ventriloquism. It consists of eight or ten long silvery notes quickly repeated. The first of these appears to come from a considerable distance; each successive one brings the voice nearer, till it issues from the spot where the performer is actually perched, perhaps only a few yards off. It generally winds up with a confused strain of joyous notes, accompanied by a stretching and quivering of the wings, expressive, it would seem, of the highest ecstasy. The cry of the young birds is easily distinguished, being very weak and plaintive *.

I had a young bird brought to me as late as the 15th February. It appeared to be in vigorous health, with the membrane at the angles of the mouth still visible; and on being approached by any one would open its mouth in an imploring sort of way, but without making any sound.

Like the Long-tailed Cuckoo already described, this species is parasitic in its breeding-habits, and entrusts to a stranger both the hatching and the rearing of its young.

The little Grey Warbler (Gerygone flaviventris) is the customary victim; but exceptional cases have been recorded where the duty was entrusted to the South-Island Tomtit (Myiomoira macrocephala); and Captain Mair assures me that he once saw the young of this species attended and fed by a Korimako (Anthornis melanura). Dr. Bennett, writing of the same bird in Australia, states $\uparrow$ that the egg of the Shining Cuckoo has been found in the nest of Acanthiza chrysorhina, and that he has seen a nest of this bird with five eggs, that of the Cuckoo being deposited in the centre of the group, so as to ensure its receiving the warmth imparted by the sitting bird, and thus less likely to be addled. He also narrates the following circumstance:- "A White-shafted Flycatcher (Rhipidura albiscapa) was shot at Ryde, near Sydney, in the act of feeding a solitary young bird in its nest, which, when examined, was found to be the chick of the Bronze Cuckoo of the colonists. . . . . It was ludicrous to observe this large and apparently well-fed bird filling up with its corpulent body the entire nest, receiving daily the sustenance intended for several young Flycatchers."

Mr. G. M. Thomson records in the 'Journal of Science' (vol. ii. p. 5i6) that an egg of this Cuckoo was found on November 5th in a House-Sparrow's nest which had been built in a large bramble-bush and which contained besides three legitimate eggs. He describes it as being " 10 lines long, of very thin texture, and much paler than usual, being of a pale greenish white feebly marked with pale brown spots and markings" \$.

* Captain Mrair writes to me:- "Speaking from ten years" observation of this bird in tho Tauranga distriet, I may state that it never sings after the middle of February and seldom after the beginning of that month. As late as the end of Mareh or beginning of April, during several successive years, I have met with these birds in the Mangorewa forest between Tauranga and Rotorua, but never heard them utter a note at this season. I have seen numbers of them perehed in silenee on the branehes of the poporo (Solanum nigrum), always in full feather, but absolutely sougless. This I logard as a very eurious fact."

t Gatherings of a Naturalist in Australasia, p. 207.

¥ Mr. Thompson states, further, that in Otago, Gerygone Aaviventris, Myiomoira macrocephala, and Zosterops carulescens. 
As it is usual to find the Cuckoo's egg associated with those of the Grey Warbler, we may reasonably infer that the visitor simply deposits its egg for incubation without displacing the existing ones. But the young Cuckoo is generally found to be the sole tenant of the nest; and the following circumstance, related to me by the Rev. R. Taylor, sufficiently proves that the intruder ejects the rightful occupants and takes entire possession. He discovered the nest of a Grey Warbler in his garden-shrubbery containing several eggs, and among them a larger one, which he correctly assigned to the Shining Cuckoo. In due time all the eggs were hatched; but after the lapse of a day or two the young Cuckoo was the sole tenant of the nest, and the dead bodies of the others were found lying on the ground below. At length the usurper left the nest, and for many days after both of the foster-parents were incessantly on the wing, from morning till night, catering for the inordinate appetite of their charge, whose constant piping cry served only to stimulate their activity.

Since the above was written, I have had all opportunity of examining a young Cuckoo in possession, and it exhibits a droll phase of bird-life, the intruder occupying the entire cavity of the nest, with its head protrnding from the opening.

I have received from Mr. W. W. Smith, of Oamaru, some interesting notes from his diary*, showing how inevitably the young Warblers, in the struggle for existence, must succumb to the more vigorous intruder.

The egg of the Shining Cuckoo is of a broad ovato-elliptical form, generally of a greenish-white or very pale olive colour, often clouded or stained with brownish grey, and measuring $\$ S$ of an inch in length by .5 in breadth. One taken by myself, many years ago, from the nest of a Grey Warbler, in the manuka scrub, on what is now the site of a flourishing city, was of a pale creamy colour; and another, which was laid by a captive bird in my possession, is pure white. A specimen in the Otago Museum is broadly elliptical in form, measures $\cdot 7$ of an inch in length by $\cdot 5$ in breadth, and is of a uniform dull olivaceous grey inclining to brown. Of two specimens in my son's collection one is rather more elliptical in form and of a uniform olivaceous brown, somewhat paler at the smaller end ; the other (which came from the Chatham Islands) is pale olivaceous grey, perceptibly darker at the larger end, and very minutely granulated with brown over the entire surface.

are the usual foster-parents. Mr. Gould records that, in Australia, the task of incubation is often delegated to the Yellow-tailed Acanthiza, and adds, "I have sereral times takeu the egg of the Cuckoo from the nest of this bird, and also the young, in which latter case the parasitical bird was the sole oceupant." Mr. Potts reports (Journ. of Science, ii. p. 477) that at Ohiuitahi he found an egg of this species in the nest of Zosterops ccemulescens, together with three eggs of the dupe. He enumerates sixteen instances, between Oct. 28 and Jan. 6, of its being found in the nest of Gerygone flaviventris. Gencrally there were from one to three eggs of the dupe in the nest; in two cases (Dec. 18 and Jan. 6) the Cuckoo egg only; and in thrce other cases (Dec. 17, Dec. 23, and Jan. 1) the young Cuckoo only. He states further that he has in his possession an egg of this bird taken from the nest of Gerygone allofrontata at the Chatham Islands.

* "Oct. Fth. Found a nest of Gerygone flaviventris, with four small eggs and one much larger. The latter I take to be the egg of the Shining Cuckoo (Chrysococcyx lucidus). Left the nest, intending to return in a few days. 11th. Visited place again. The Grey Warbler flew out when I approached. Five eggs still all right. 21st. Still unhatched. 24th. Two young ones hatched; one egg lying on the ground outside the ncst, containing chick quite cold and dead. 25th. Three young ones in nest; large egg unhatched. 26th. Large egg hatched-a chick of the Shining Cuckoo ; very elumsy in nest, lying on top of the threc young Warblers. 30th. Found one dcad ehick lying on the ground; two young Warblcrs still alive; young Cuckoo growing rapidly, being now nearly large enough to fill the nest itself; beak and logs fairly well developed. Nov. 2nd. One of tho young Warblers lying dead in nest, the other alive. Young Cuckoo has now its eyes open; sigus of feathers on the neek and wings, but underparts of the body pcrfeetly bare. 5th. Visited nest again. Yonng Cuckoo thrust out its head to receivo food when I approached. Lifted the surviving young Warbler out of the nest, and found it very feeble. 6th. Young Cnekoo lying with its head at opening of nest, having taken full possession. Its lifeless companion was lying underneath, haring apparently died from starvation. 8th. Found young Cuckoo almost ready to leave its cradle. Brought both nest and bird home with me. 10th. Thriving well, being fed on small worms, grubs, flies, spiders, and very small pieces of lean meat. 15th. Has now come out of nest; eats largely three times a day, but does not eare for meat; inereasing rapidly in size. 20th. Ncarly feathered. Placed it in a eage, but it looks sickly. 21st. Young Cuckoo died. Proved, on skinning, to be a male bird." 


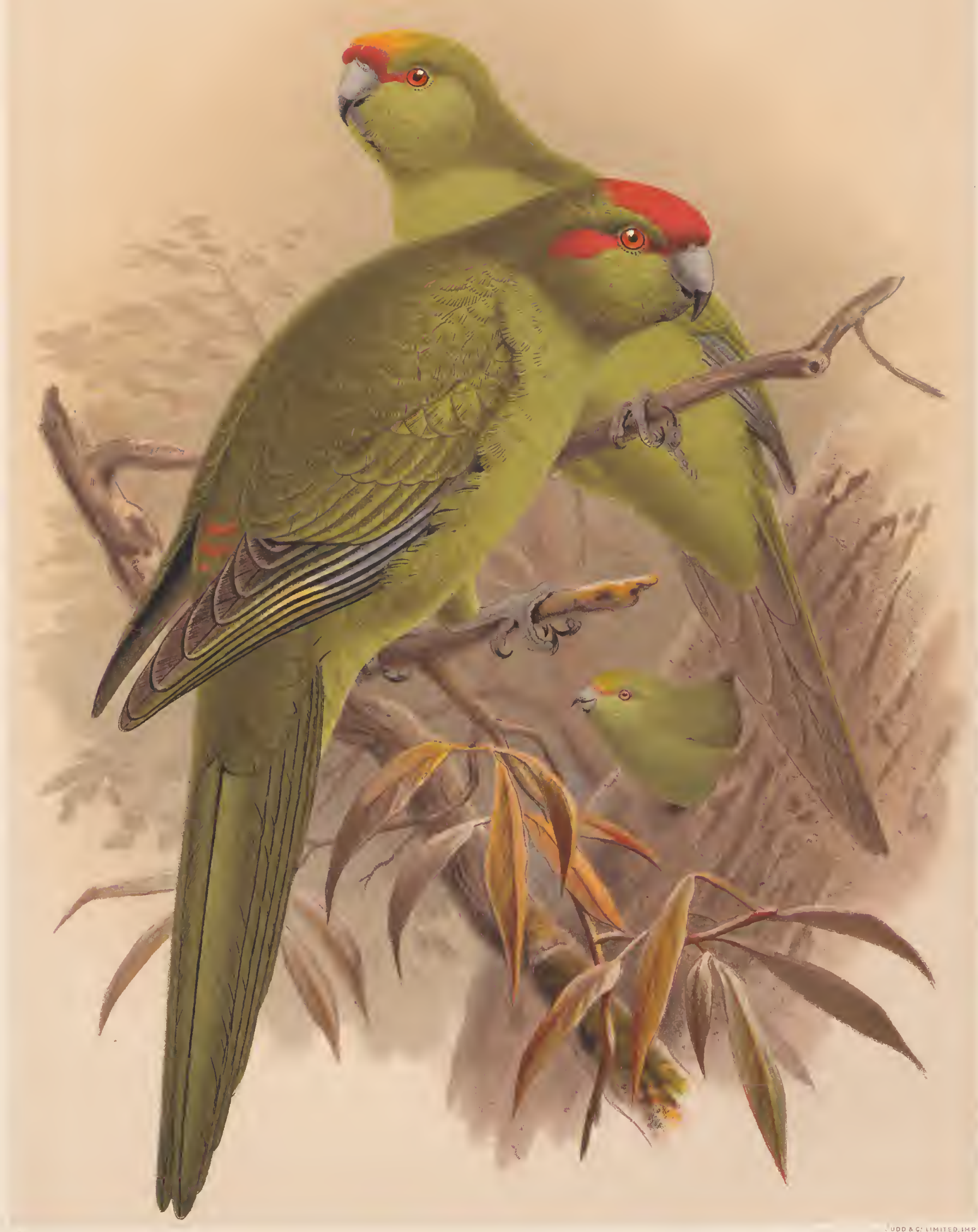

YELLOW-FRONTED. RED-FRONTED. AND ORANGE-FRONTED. PARRAKEETS PLATYCERCUS AURICEPS, P. NOVE ZEALANDIA. AND P. ALPINUS 



\section{PLATYCERCUS NOVÆ ZEALANDIÆ.}

(RED-FRONTED PARRAKEET.)

Pacific Parrot, Lath. Gen. Syn. i. p. 252 (1781).

Psittacus novee zeelandice, Sparrm. Mus. Carls. pl. 28 (1787).

Psittacus pacificus, Gm. Syst. Nat. i. p. 329 (1788).

Platycercus pacificus, Vigors, Zool. Journ. i. p. 526 (1825).

Pezoporus nove zeelandice, Voigt, ed. Cuv. Thierreich, p. 750 (1831).

Lathamus sparmanii, Less. Traité d'Orn. i. p. 206 (1831).

Platycercus erythrotis, Wagl. Monogr. Psitt. p. 526 (1835).

Cyanoramphus erythrotis, Bonap. Rev. et Mag. de Zool. vi. p. 153 (1854).

Cyanoramphus nova zelandice, Bonap. Rev. et Mag. de Zool. vi. p. 153 (1854).

Cyanoramphus aucklandicus, Bonap. Naumannia, 1856, Suppl. p. $35 \%$.

Cyanoramphus novee guinece, Bonap. Naum. 1856, Suppl. p. 352.

Platycercus aucklandicus, Gray, Cat. Brit. Mus. Psitt. p. 13 (1859).

Platycercus cookii, Gray, Cat. Brit. Mus. Psitt. p. 13 (1859).

Platycercus novce guinece, Gray, Cat. Brit. Mus. Psitt. p. 13 (1859).

? Cyanorhamphus saisseti, Verr. et Des Murs, Rev. et Mag. de Zool. xii. p. 387 (1860).

Platycercus rayneri, Gray, Ibis, 1862, p. 228.

Coriphilus nova zeelandia, Schlegel, Dierent. p. 77 (1864).

Euphema nove zeelandia, Schl. Mus. Pays-Bas, Psittaci, p. 105 (1864).

Platycercus forsteri, Finsch, Papag. ii. p. 287 (1868).

\section{Native names.}

Kakariki, Kakawariki, Powhaitere, Porere, and Torete.

$\delta$ prasinus, uropygio paullò lætiorc: genis et corpore subtùs flavicanti-viridibus : pileo antico, maculâ antcoeulari, alterî supraauriculari et plumis paucis ad latcra uropygii positis puniccis: oecipite ad lasin plumarum celatè citrino : tectricibus alarum dorso eoneoloribus : remigibus brunncis, alâ spuriâ lætissimè ultramarinâ : primariis extùs ad basin ultramarino, versus apicem angustè flavido marginatis : caudâ suprà læetè prasinâ, subtùs magis flavicantc : subalaribus cyanescenti-viridibus : maxillâ cyancscenti-albâ, versus apiccm nigricante, mandibulâ omninò nigricante : pedibus pallidè brunucis : iride rubrâ.

Adult male. General plumage bright grass-grecn, lighter, or rather yellowish-green, on the underparts. Forchcad, crown, and streak aeross the cye tcrminating on the ear-covcrts dcep crimson, with a spot of the same, morc or less distinct, on cach side of the rump; on the nape a broad basal mark of yellowish white, obscrvable only when the plumage is disturbed or raised. The wing-feathers are dusky black, lighter on the under surface, and crossed by an obscure ycllowish band; the outer primaries and thcir coverts, as well as the bastard quills, bright blue on thcir outer webs. Irides cherry-red; upper mandible bluish white, with a black tip; lower mandible bluish black; feet pale brown. Extreme length 12 inches; wing, from flcxure, 5.5 ; tail 6 ; culmen $\cdot 8$; tarsus $\cdot 8$; longer forc toe and claw $1 \cdot 15$; longer hind toc and claw 1 .

Adult female. Of similar plumagc to the malc, although the frontal crimson cap is not so conspicuous. It is, however, somewhat smaller. Extreme length 10.25 inehes; extent of wings 14; wing, from flexurc, 5 ; tail 5 ; tarsus $\cdot 75$; longer fore toe and claw 1. 
Young. The plumage of the young bird does not differ appreeiably from that of the adult.

Varieties. Like many other members of the large natural family to which it belongs, this specics exhibits a strong tendency to variability of eolour; and the slight differenees which some of the ornitlologists of Europe have recognized as sufficient specific charaeters are elcarly of no valuc whatever. A specimen brought to me by a native, in the Kaipara district, maxy years ago, had the whole of the plumage of a brilliant scarlet-red. Another, obtained in the woods in the ncighbourhood of Wellington, had the green plumage thiekly studded all over with spots of red; this handsome bird was eaged, and at the first moult the whole of the spots disappeared. An cxample of this species in the British Museum lias the abdomen and under tail-coverts bright yellow mixed with green; the thigh-spots very large and bright; the rump stained, and the tail obseurely banded on the upper surface, with dull yellow.

A Southland paper thus deseribes a speeimen whiel was shot in the Seaward Bush:- "One of the most beautifully plumaged native birds we have ever secn was shown us yesterday by Mr. James Morton, a taxidermist, to wlom it had been handed to be stuffed. It is a variety of Platycercus nove zealandice, and proved to be a male. Instead of the usual green hue, the feathers of the onc in question are tipped and edged with green on a beautiful lemon-ycllow ground-the small feathers of the wing showing a stecl-blue tint at the edges, or mixed bronze and yellow. The large pinion-feathers are yellow and green, merging in to bronze at the tips-the tail-fcathers bcing similarly eoloured. The bcak is surmonnted by a creseentshaped patch of blood-red, and there are two others on the baek."

I have in my possession a feather of rich uniform yellow with a white shaft, from the tail of a tame bird of this speeics, formerly in the possession of the Wellington Working Men's Club, in which all the rest of the plumage was of the normal colour. I am indebted to Mr. W. W. Smith, of Oamaru, for a curious specimen ( $q$ ) in which the back, rump, upper surface of wings, and nearly the whole of the abdomen are marked with irregular patehcs of pale lemon-yellow.

There are three very beautiful varieties in thc Otago Museum :-

No. 1 has the entire plumage of a uniform vivid canary-yellow, except that the vertex, car-coverts, and uropygial spots are erimson as in the ordinary bird; there are a few dashes of ultramarinc blue on the tertials aud some "invisible green" markings on the quills and tail-feathcrs, the shafts of whieh are white, as though the normal colours had here endeavoured to assert themselves; the bill, fcet, and claws are white. The crimson markings, espeeially on the sides of the uropygium, are bright and eonspicuous, and the bird altogether is as lovcly an object as the most ardent ornithologist could desire as the type of a new speeics; but, alas, it is nothing but a "freak of nature" whose exaet eounterpart may never oecur again. This specimen was obtained at Seaward Bush in Oetober 1874, and was presented to the Museum by Mr. J. M. Broderiek.

No. 2 is a beautiful instanee of cyanism. The entire plumage of the eheeks, throat, and underparts is a delieate marine-blue, or isabelline, the feathers on the lower parts and sides of the body narrowly edged with dusky; supplying the place of erimson on the vertex and ear-eoverts is a palc yellowish or greyish brown; the rest of the upper surface is a deeper isabelline, varied with a still darker shade of blue, and with the feathers more distinctly margined with dusky; thcre are no uropygial spots; the quills are marked witl ultramarine as in ordinary spccimens; the tail-feathers have greenish refleetions, with a wash of blue down the outer vane of the lateral ones, the under surfaee of wings and tail being dusky brown. Bill and feet of the normal colours. This is the Parrakeet mentioned by Prof. Hutton as the "blue variety from Southland."

No. 3 is a very different looking bird, from Invercargill. The entire plumage is dirty yellow, with a varying wash of green, whieh is deepest on the underparts and least apparent on the quills and tail-feathers; the vertex and ear-eoverts are erimson, the former having a flush of canary-yellow along its posterior edge ; the shafts of the quills and tail-feathers are whitc, and on the primaries and tertials there is just the faintest indication of the normal colour in a delieate shade of greenish blue; the upper wing-coverts are washed on their edges with green; the erimson uropygial spots are present, and the bill and feet are the same as in ordinary specimens.

Note. The synonymy of the genus Platycercus, as may be seen above, has been involved in mueh confusion. Wc are indebted to Dr. Otto Finsch, of Brcmen, for a complete elueidation of the subject, in his able Monograph of the Psittacidx (Die Papageien, ii. p. 275, 1868). Examples of $P$. nova zealandia vary 
mueh in size and in the depth of their eolouring. The shade of the prevailing green, the brillianey of the erimson vertex, and the extent of red eolouring on the car-eoverts and of blue on the wings are alike variable.

Dr. Tinseh is of opinion that $P$. (Cyanorhamphus) saisetti (Verr.) is inseparable from this speeies. On eomparing a specimen sent by Mr. Edgar Layard from New Caledonia to the Otago Muscum, I find that this bird differs from $P$. nove zealandice only in having the sides of the faee, throat, breast, and underparts generally greenish yellow, deepening into grass-green on the sides of the body and on the flanks. If, however, this is a eonstant eliaraeter I aeeept it as specifie. There is a wash of blue on the outer vanes of the tail-feathers, but this may be an aceidental peeuliarity. The erimson of the vertex likewise has a wash of yellow in it, to which the same remark will apply, for I lave met witl New-Zealand examples tinged in the same manner. The erimson uropygial spots in Layard's specimen have an admixture of yellow; and the bill is blue and blaek, without any of the whiteness eharaeteristie of our bird.

I am of opinion that $P$. forsteri, admitted with some hesitation by Dr. Finseh, and founded on a single example in the British Museum, is nothing but $P$. nove zealandia, with the red uropygial spots aecidentally absent; and I have aeeordingly ineluded it in the synoptieal history of this species as given above.

There is an example in the Otago Museum with an abnormally developed bill, as slown in the aecompanying woodeut. It likewise has a wash of yellow on the seeondary quills.

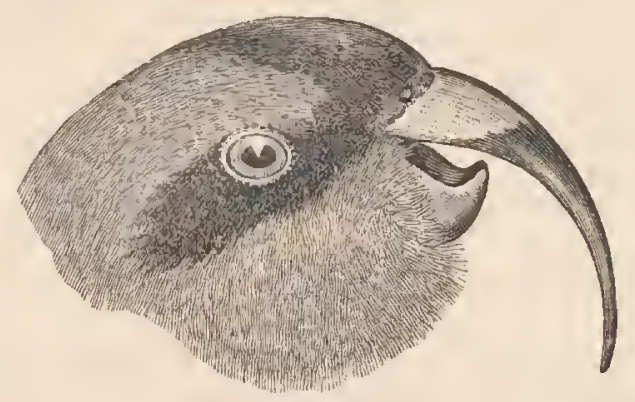

THE Red-fronted Parrakeet is very generally dispersed over the whole country, but is more plentiful in the southern portion of the North Island than in the far north, where the yellow-fronted species predominates. It frequents every part of the bush, but appears to prefer the outskirts, where the vegetation is low and shrubby, as also the wooded margins of creeks and rivers. It is often met with amongst the dense koromiko (Veronica) which covers the low river-flats, or among the bushes of Leptospermum and other scrub. It seldom ventures beyond the shelter of the woods, unless it be to visit the farmer's fields for its tithe of grain, or to reach some distant feeding-place, when it rises rather high in the air and flies rapidly, but in a somewhat zigzag course. When on the wing it utters a hurried chattering note; and when alarmed, or calling to its fellows, it emits a cry resembling the words " twenty-eight," with a slight emphasis on the last syllable. It often resorts to the tops of the highest trees, but may always be enticed downwards by imitating this note. It is gregarious, forming parties of from three to twelve or more in number, except in the breeding-season, when it is generally met with in pairs *.

Its food consists chiefly of berries and seeds; but I suspect that it also devours small insects and their larvæ; for I have observed flocks of a dozen or more on the ground, engaged apparently in a search of that kind, and it is a well-established fact that several of the Australian members of this group subsist partly on insect food. When the corn-fields are ready for the harvest, flocks of this gaily-coloured Parrakeet resort to them to feed on the ripe grain; and it is very pretty to see them, on any alarm being given, rise in the air together and settle on a fence, or on the limb of a dead tree, to wait till the danger has passed, keeping up all the time a low, pleasant chatter.

Sir William Fox, after his return from a trip through the Canterbury district in 1871, informed

* "At nesting-time the old birds often indulge in a low murmuring note to each olher." (Journ. of Science, ii. p. 480.) 
me that the farmers had suffered a visitation, tens of thousands of these birds having descended on their ripening crops of corn and proved almost as destructive as an army of locusts. It is difficult to account for these occasional irruptions in such numbers, in the case of a bird not otherwise plentiful. The sudden failure, or scarcity, of the ordinary food-supply in certain wooded districts is the most rational way of accounting for such unexpected visitations; but, apart from this cause, there are doubtless others directing and regulating the migratory impulse, although at present we are unable to define them. The same sort of thing is occurring, more or less, in every part of the world and in every department of the animal kingdom. Beyond laying down general principles, it is impossible to explain some of the phenomena. For example, who has been able to account satisfactorily for the sudden irruption of Pallas's Sand-Grouse (Syrrhaptes paradoxus) into Europe in 1563? These birds, which had scarcely ever been heard of before, came from beyond the Caspian Sea, traversing some 4000 geographical miles, spreading themselves over Europe in countless flocks like a Tartar invasion, without any apparent cause, and disappeared again just as suddenly and unaccountably as they had come. The same question may be asked of the remarkable iuflux of the Waxwing into England in the winter of 1849-50, an event quite unparallelled in the ornithological history of the country. To come nearer home, what naturalist was able to account, more than theoretically, for the plague of caterpillars which (up to the time of the introduction of the muchabused House-Sparrow) periodically, but at long intervals, visited our country districts, coming in countless millions, sweeping all before them, and utterly wrecking the hopes of the farmers?

This species bears confinement remarkably well, and is very docile and familiar even when taken as an adult bird. It is also very intelligent, and possesses the faculty of mimicry in a high degree.

It is quite the cottagers' friend in New Zealand. Riding or driving through the suburbs of the provincial towns-the Porirua and Karori districts for example, near Wellington-you will notice in many of the farmers' houses and roadside cottages small wooden cages of primitive construction (often merely a candle-box or whisky-case, faced with wire netting or thin wooden bars) fixed up to the front of the building or under the simple verandah. On closer inspection each of these cages will be found to contain a tame Parrakeet-the pet of the rustic home and "Pretty Poll" of the family; and I have often been quite interested at finding how attached these simple people become to their little captive.

One of these birds has been in the possession of a lady at Christchurch (Canterbury) for more than eight years. Although full-grown when first caged, it has learnt to articulate several words with great clearness. It is very tame, and displays a considerable amount of intelligence-leaves its cage every day for exercise, and returns to it immediately on the appearance of a stranger. It knows its fair owner's voice, will respond to her call, and will "shake hands" with each foot alternately in the most sedate manner. Another, in our own possession, survived confinement for more than eleven years, and appeared then in perfect health and strength, when it fell a victim to the household puss. 'This bird could articulate sentences of three or four words with great precision; and the loss of so intimate a family-friend was " sincerely lamented" by all our circle.

At the Foxton railway-station there used to be (and may be still) a tame Parrakeet that had learnt to say "Be quick!" and was accustomed to repeat these words with energy and clear articulation as the passengers by train crowded round the ticket-window.

In certain particular woods where, for some unaccountable reason, all other birds are scarce, this Parrakeet may always be found. One such tract lies between Cambridge and Ohinemutu, where the coach-road passes through some twelve miles of the most picturesque bush imaginable. Destitute as it generally is of bird-life, the scenery is enchanting. At intervals of a few miles there are deep wooded gorges, the eye often resting on tree-tops some three hundred feet below the spectator. 'The bush itself 
is of the usual mixed kind, with every gradation of shade in green and brown; but the dominant feature, as almost everywhere else in New Zealand, is the beautiful tree-fern, which I think I have never seen in grcater beauty or abundance. In some places you come upon whole groves of Cyathea smithii, with its grand expanse of graceful fronds, then groups of Dicksonia antarctica nestling among the denser vegetation on both sides of the road. And bcfore the cye has had time to take in the full beauty of the scene, the aspect changes and straggling clumps of Cyathea cunninghomii present themselves to view, with their soft and feathery fronds, some exhibiting an open coronet of slender stalks and others with their crowns depressed; then, at a fresh turn in the road, far away in the depths of the gorge, and shaded by the overhanging foliage, may be seen superb umbrclla-tops of mamaku (Cyathea medullaris), resting on giant stems often sixty or scventy feet in height. In the more open glades of the forest the stately Cyathea dealbata lifts its graceful head, those in exposed positions displaying the silvery whitc of their under surface with every breath of wind. On nearer inspection other forms may be distinguished, there being apparently no limit to their beauty and variety. Each fcrn is a study in itself, and the natural grouping is such as no landscape gardener with all his artificial skill could ever produce. Somc have their stems encircled with vines, ferns, and crecpers, from base to summit; others have their trunks hung thickly round with the withercd fronds of a former growth. Some have slender, naked stems, while others have massive pyramidal trunks. Some stand out clearly and sharply defined against the darker background, while others are almost lost in the luxuriance of their epiphytic growth. I do not mention the ever-present groundferns, in their infinite variety, because no Ner-Zealand bush could well exist without them; but I ought to notice here the most beautiful object on the road. A little more than halfway through, from the Cambridge side, our coach stopped at a point near which the crape-fern, or "Prince of Wales' feather," is known to exist. We alighted and cntered the forest. At a distance of only a chain from the highroad we came upon one of the lovcliest sylvan sights I have ever witnessed. This was a dense bed of Todea superba growing close together, each plant with beantiful deep green, vclvety fronds, arranged like the fcathers on a shuttlecock, each with a spread of three fcet or more, and covering altogether about an acre of ground. This luxuriant bed of an elsewhere rare fern, of the richest green and of crape-like texture, closely covering the ground and protected from the sun by a thick forcst canopy, presentcd a picture of surpassing beauty never to be forgotten.

A hole in a decaying or dead tree affords this species a natural breeding-place, the cggs being laid on the pulverized rotten wood at the bottom; for, as a rule, thcre is no further attempt at forming a nest *. I ought to mention, however, that in the Canterbury Museum there is a loose nest, formed of moss, and lined with fern-hair and green Parrakeet feathers, which was taken from the hollow of a tree and is assigned ( $\mathrm{I}$ believe correctly) to this species. The months of November and December constitute the breeding-season. The eggs vary in number from three to seven; and a native stated that he once found a nest containing as many as eleven; but five is the usual numbcr. Captain Mair informs me that a pair of these birds bred in the hollow trunk of a hinau-tree for several successive years, although robbed of their young every season, and that he has frequently observcd the cock bird feeding the hen, during incubation, by regurgitating berries from his crop.

Although exhibiting a preference for hollow trees, they sometimes nest in the holes or crevices of rocks. On the Upper Wanganui the natives pointed out to me a small round cavity in the perpendicular cliff forming the bank of the river, and assured me that this was the entrance to a small chamber where a pair of Parrakects had rcared their young in security for many years. The eggs are very broadly oval, mcasuring 1.05 by .85 inch; they are pure white and are very fincly granulate on the surface, sometinies with minute limy excrescences near the larger end.

* Prof. Scott states that during a visit to Campbell Island he found this species of Parrakect there "in great numbers round the shore," and that, in the absence of woods, it makes its nest under the grass-tussocks. 


\section{PLATYCERCUS AURICEPS.}

\section{(YELLOW-FRONTED PARRAKEET.)}

Platycercus auriceps, Kuhl, Consp. Psittac. p. 46 (1820).

Pacific Parrot, var. C, Lath. Gen. Syn. i. p. 252 (1781).

Psittacus pacificus, var. $\delta$, Gm. Syst. Nat. i. p. 329 (1788).

Platycercus auriceps, Vigors, Zool. Journ. i. p. 531 (1825).

Platycercus novee zelandice, Bourjot St.-Hilaire, Perroq. t. 37 (1837).

Euphema auriceps, Licht. Nomencl. Av. p. 72 (1854).

Cyanoramphus auriceps, Bonap. Rev. et Mag. de Zool. vi. p. 153 (1854).

Cyanoramplıus malherbi, Souancé, Rev. et Mag. de Zool. ix. p. 98 (1857).

Platycercus malherbii, Gray, Cat. Brit. Mus. Psitt. p. 14 (1859).

Coriphilus auriceps, Schlegel, Dierent. p. 77 (1864).

\section{Native names.}

The same as those applied to the preceding species.

Ad. $P$. nove zealandice similis, sed valdè minor, et vertiee aureo, fronte punieeâ facilè distinguendus.

Adult male. General plumage beautiful grass-green, paler or more suffused with yellow on the underparts. A band of dark erimson eonneets the eyes, passing aeross the forehead, immediately above the nostrils; upper part of foreliead and erown golden yellow; on the nape a basal spot of yellowisl white, apparent only on moving the featlers; on eaeh side of the rump a eonspieuous spot of erimson ; quills dusky blaek, crossed on their under surface with a band of pale yellow ; the outer web of the bastard quills and first four primaries, with their eoverts, indigo-blue, narrowly nargined with yellow. Irides pale eherry-red; upper mandible bluish white at the base, blaek towards the tip; under mandible bluish black; feet pale brown. Extreme length 10.5 inehes; wing, from flexure, 4.5 ; tail 5 ; eulmen $\cdot 6$; tarsus $\cdot 6$; longer fore toe and elaw 1 ; longer hind toe and elaw $\cdot 9$.

Varieties. Like the preeeding bird, this speeies also exhibits abnormally eoloured varieties. A young bird, brought to me from the nest, and not fully fledged, had the plumage of the body pale yellow, shaded with green on the upper parts, and the quills and tail-feathers marked with red. Another had numerous light ereseentie marks on the wing-eoverts. In the summer of $1863 \mathrm{I}$ obtained a very beautiful variety at Manawatu. I found it in the hands of a labouring settler, who had purehased it from the natives for something less than a shilling. Finding him unwilling to part with it, I tempted him with a guinea, and seeured the prize. It was a bird of the first year, and presented the following appearanee :-Froutal band erimson; vertex golden yellow; spaee around the eyes and a band eneireling the neek green; head, shoulders, and lower part of baek red, the intermediate spaec variegated with red and green; quills dusky, obseurely banded with yellow, and margined on the outer web with blue; wing-eoverts greenish yellow, barred and margined with red; tail-feathers green, obseurely barred with yellow in their apieal portion; underparts green, variegated with erimson and yellow, an interrupted band of the former eolour crossing the breast. Like the spotted variety of $P$. nove zealandice already mentioned, within a short time it eommeneed to moult, and was fast assuming the common green livery of the speeies, when it was aeeidentally killed. This speeimen, which still exhibits traees of its original eolours, belougs now to the type colleetion in the Colonial Museum. 
A pretty male bird obtained by Reisehek near Dusky Sound, at an elevation of 2000 feet, has the entire plumage tinged with saffron-brown, whiel is darkest on the breast, shoulders, and upper wing-eorerts; the yellow on the vertex is mixed with orpiment-orange; the blue on the bastard quills and primaries is unusually brilliant; the seapulars have a wash of yellow; and the uropygial spots are very indistinet.

I have seen several examples exhibiting marks of red on the vertex and erown; and in the Canterbury Museum there is a speeimen which has the frontal band dull red instead of crimson, the erown, upper surface of wings, and the abdomen more or less marked with yellowish brown, the primaries tipped and the secondaries largely margined with paler brown.

Mr. Henry Travers obtained one on Mangare Island (at the Chathams) "with a faint tinge of yellow on the head."

A speeimen obtained by Dr. Lemon at Takaka, in the South Island, and presented to the Colonial Muscum, is one of the loveliest objects in the mounted eolleetion. The whole of the plumage is of a vivid eanary-yellow, whieh is brightest on the vertex, and is bordered by a narrow baud of erimson aeross the forehead. The uropygial spots are large and of flaming erimson. The only indications of the normal eolour are on the quills and tail-feathers. The quills are pale eanary-ycllow, inelining to white; the middle primaries in one wing are clouded with dark grey, and in the other wing there is a splash of green aeross the secondaries; in both wings the bastard quills are edged with blne; the two middle tail-feathcrs are stained with green, and the two sueeeding on either side are green in their eentral portion; one of the outer laterals also is marked with green. Bill pure white; legs and feet flesh-white.

This bird, as Dr. Lemon informs me, was shot in May 1882, in Eve's Valley, Waimea, by Mr. Fabian, telegraph lineman, who had the good sense to preserve it. By the eourtesy of Sir James Hector, it was. brought to England, and exhibited in the New-Zealand Court at the Colonial and Indian Exhibition, 1886.

Obs. This speeies is very readily distinguished from all the other members of the group of Platycerci by its beautiful golden vertex. Individuals vary both in size and in the brillianey of their plumage.

Some speeimens exhibit the yellow vertex stained morc or less with erimson. The type of Platycercus malherbi, in the British Museum, reeeived from the Auekland Islands, and eharaeterized by Souancé as "eneore plus petit que l'auriceps," is nothing but a very small example of this speeies. There is an equally small one in the same eolleetion from the Bay of Islands, New Zealand.

Professor Hutton states that two speeimens brought by Mr. Henry Travers from the Chatham Islands are slightly larger than the New-Zealand bird.

The Yellow-fronted Parrakeet, althongh generally dispersed over the country in all suitable localities, is more plentiful than the red-fronted species in the northern parts of the North Island, and less so as we approach Cook's Strait. In the South Island, however, the two species appear to be more equally distributed.

In habits this bird elosely resembles the preceding one; but it is less gregarious, being seen generally in pairs. It loves to frequent the tutu bushes (Coriaria ruscifolia), to regale itself on the juicy berries of this bushy shrub; and on these occasions it is easily snared by the natives, who use for that purpose a flax noose at the end of a slcnder rod. When feeding on the tutu-berry, the whole of its interior becomes stained of a dark purple. When the wild dock has run to seed, this pretty little Parrakeet repairs to the open fields and feasts on the ripe seeds of that noxious weed; at other seasons the berries of Coprosma lucida, Fuchsia excorticata, and other forest-shrubs afford it plentiful and agreeable nutriment.

Far up the course of the Northern Wairoa, just below Mangakahia, the banks of the river for some miles are cleared of the original forest, the land having been in years gone by oceupied by Maori plantations. A new growth has eovered the long-abandoned "wairengas," and, just along the margin of the stream, the soil, enriehed by deposits of fine silt throngh the oceasional overflowing of the muddy waters, supports a belt of tupakihi, intermixed with other shrubs and eompletely overgrown with elimbing convolvulus. In no part of New Zealand have I found the Yellow-fronted 
Parrakeet so numerous as in this tangled retreat, cspecially at the season when the tutu-berries have ripened and are hanging in drupes from every branch. I have seen a native lad enter this thicket - which is open below and matted overhead-and, armed only with a flax noose at the end of a slender rod, catch numbers of them with perfect ease, by slipping the loop over the head of the unsuspicious bird.

My son met with it in the stunted woods in the Owhaoko-Kaimanawa district, when the whole country was under snow.

At irregular periods, after intervals of from seven to ten years, this Parrakeet (in company with the preceding species) visits the settled and cultivated districts in astonishing numbers, swarming into the gardens and fields, devouring every kind of soft fruit, nibbling off the tender shoots on the orchard trees, and eating up the pulse and grain in all directions. Sir William Fox gave me a graphic account of one of these sudden irruptions in the South Island in the summer of 1870-71, when great injury was done to the crops. The last of these visitations occurred in the early part of 1886 , and the one before that at the close of 1877 . On each of these occasions much public interest was excited by the occurrence, and many theories (such as the devastation of the country by bushfires) wcre put forward to account for this recurrent "plague of Parrakeets." Whilst the newspapers werc busy with these more or less colourable theories, the birds vanished as suddenly as they had come.

There is a widespread popular belief that the movements of certain species of birds indicate approaching climatic clianges, or form a sort of index to the seasons; and it would not be difficult to find and multiply apparent proofs of such a connection. But the theory, as generally accepted, is true only to a certain extent. Everyone is probably aware that birds, of all animals (except perhaps frogs), are the best natural barometers. For example, to every native colonist the vociferous cry of the Sparrow-Ilawk betokens change; the altitudes at which these birds habitually fly make them susceptible to the slightest change of temperature, and to all observers of outdoor nature they announce the fact with no incertain sound. Even our little Wood-Robin, which keeps near the ground and never leaves the seclusion of its forest home, is so ready to detect any atmospheric disturbance and to predict by its peculiar note a change of weather, that it is commonly called the "rain-bird" in many parts of the country. The presence on a calm day of the snow-white Gannet, sailing majestically over our harbours and, ever and anon, plunging headlong into the placid waters, or of a flock of playful Sea-Gulls coming inland to rest themselves in our fields and pasturcs, is a sure indication that a storm is brewing at sea, although there may be no actual appearance of it at the time. But, of course, it does not follow from such instances as these that any species of bird can foresee an impending changc of season, or, by any ratiocinative process, prepare for it by migration. So far as I understand the facts, the case is simply this:-The failure, more or less complete, of their natural food (which in itself is often a safe indication of seasonal derangement) neccssitates the migration of all birds dependent on such foodsupply to other parts of the country in search of the ordinary means of subsistence. And as the migration always precedes the other evidences of climatic change, the popular notion that birds are instinctively prophetic in the matter of seasons is easily accounted for. The sudden irruption of Parrakeets in the South Island, referred to above, to such an extent as to be an actual "pest" is, it seems to mc, but an illustration of this natural law of cause and effect. This pretty little Parrakeet is strictly an arboreal bird. It is an inhabitant of the woods, and, besides being well distributed, its plumage is so admirably suited to its natural surroundings by the law of assimilative colouring that, although it exists in tens or hundreds of thousands, it is rarely seen, and except to the lovers of nature and bush-craft its very existence is almost unknown to the colonists. But when, from some unknown cause, there is a failure of its everyday food-supply, the fact is proclaimed by the sudden and unexpected appearance of countless numbers of these birds in our cultivated fields, gardens, and 
hedgerows, all fugitives under a common calamity anıl becoming a nuisance by the very intensity of their hunger.

The same thing happens, although in a less pronounced manner, with the Tui and Korimako, both of which species occasionally appear in our midst, all miserably lean and in a state of absolute starvation.

What occasions this widespread failure of the natural food is generally a mystery; but that such failure is the chief factor in the migratory impulse there can be little doubt. The case of the Passenger Pigeon in the United States is strongly in point. The movements of this bird are irregular in the extreme-completely disappearing from entire districts for years together, and then returning in prodigious numbers (in flocks of hundreds of thousands), the migration being regulated entirely by the scarcity or abundance of the natural food.

In captivity it is very gentle and tractable, but it is far inferior to the larger red-fronted bird in its talking-capacity. One or two instances of its being taught to articulate words of two syllables have come to my knowledge; but, as a rule, the attempt to instruct it ends in failure.

Like its congener it nests in hollow trees, and lays from five to eight eggs, resembling those of Platycercus novee zealandice, but smaller. Specimens in my son's collection measure $\cdot 9$ of an inch in length by .75 in breadth; others are more broadly ovoid, measuring .85 by .70 , and are stained yellowish white, probably the result of incubation. Major Mair informs me that he watched a pair of these birds breeding in the cavity of a dcad tree for three successive seasons. The first year's brood numbered five, the second eight, and the third seven.

As will be seen by the synonymy at the head of this article, there has been a considerable amount of confusion in the nomenclature of this and the preceding species, notwithstanding their strongly marked characters. I trust that the reference lists and full descriptions now given will, for the future, make it impossible to confound these forms with other members of the genus. As a brief review, however, of the types in the National Collection may help to elucidate the synonymy of the group, I will reproduce here the notes on the subject which I published in the 'Transactions of the New-Zealand Institute' (vol. xi. pp. 368, 369).

British-Museum Collection.-My examination of the types gives the following results :-Platycercus aucklandicus not distinguishable from $P$. nove zealandie, but smaller than ordinary examples; bcak decidedly smaller, being of same size as in $P$. auriceps, but lighter at basc ; car-spots iudistinct; frontal spot lcss cxtensive, but of samc colour as in $P$. nove zealundice. $P$. malherbii $=P$. auriceps, but smaller than average specimens of the latter. $P$. pacificus similar to $P$. novce zealandic, but much larger, with a morc robust bill. P. erythrotis, from Macquaric Islands, $=P$. pacificus, but with lighter plumage. $P$. forsteri $=P$. nove zealandice, with the thigh-spots accidentally absent. There is anotlier" specimen marked "Platycercus forsteri," to which I shall refer again presently, in very different plumagc. $\quad P$.cookii $=P$. pacificus. $P$. unicolor, a much larger and very distinct species. P. rayneri, from Norfolk Island, is like $P$. pacificus, but larger and with a more powerful bill; the frontal spot is more extensive but lightcr in colour; ear-spots small and obscurc as comparcd with $P$. novce zealandice. I think we may pretty safely conclude that $P$. rayneri is in reality $P$. pacificus, although the British-Museum specimen is both larger and lightcr-coloured than ordinary spccimens of the latter. Platycercus ulietanus, from the Society Islands, is very clistinct in appearance from all thosc cnumerated above. The so-called $P$. forsteri, before referred to, labelled as from the main island Otaheiti, appears to hold an intermediate position betwcen $P$. ulietanus and $P$. pacificus. It has the gencral plumage of $P$. pacificus but of much duller tints, mixed with brown on the upper parts and clouded with a colder green on the underparts. It wants the crimson vertex; but there is a frontal patch of brownish black corresponding to the colour of P. ulietanus, which changes to crimson in front of the eycs; behind which, also, there is a small obscurc spot of dull crimson. It has the conccalcd nuchal patch of yellowish whitc whiclı is found in $P$. pacificus; while, on the other hand, it has the bright crimson rump which is characteristic of $P$. ulietanus. The tail has a dingy, washed-out appearance, and the colours of the plumage generally arc very undecided. The bill and feet are cxactly as in P.ulietanus, of which spccies this bird may be an accidental variety, or possibly a hybrid. There is likewise in this collection a specimen of our P. nove zealandia, cxhibiting much bright yellow mixed with the green on the abdomen and under tail-coverts. It likewise has the thigh-spots very largc and bright; the rump stained, and the tail obscurely banded on the upper surface witl dull ycllow. 


\title{
PLATYCERCUS ALPINUS.
}

\author{
(ORANGE-FRONTED PARRAKEET.)
}

Platycercus alpinus, Buller, Ibis, 1869, p. 39 ; Birds of New Zealand, 1st ed. Intr. p. xvi (1873).

Ad. $P$. auricipiti similis, sed minor, et fronte aurantiacâ, vertice pallidè flavo distinguendus.

Adult. Plumage bears a general resemblance to that of Platycercus auriceps; but the frontal band is orange and the vertex pale yellow; and there is an absence of the yellow element in the gcneral plumagc, which is of a cold pure green, much paler on the underparts ; the rump-spots, moreover, are smaller and less conspicuous, being orpiment-orange instcad of crimson. Extreme length 9 inches; wing, from flexure, 4:2; tail 4.5 ; culmen 5 ; tarsus $\cdot 5$; longer fore toe and claw $\cdot 85$; longer hind toe and claw $\cdot 75$.

Note. In treating of the members of this section in my former edition, I had recourse to Dr. Otto Finsch's elaboratc Monograph on the Parrots ('Dic Papageien'), a work the carc and labour of which may be estimated from the fact that, of the 350 spccies described thercin, all but 18 wcre examined by the author personally. Accepting the decision of so able an authority, I agrced to sink my Platycercus alpinus as a species, and to consider it the young state of $P$. auriceps (vide Birds of $\mathrm{N}$. Z. 1st ed. pp. 61 \& 62). The validity of the spccies, however, was afterwards established beyond all doubt. More than twenty specimens wcre brought to this country bcfore the complction of my work; and I accordingly took the opportunity, when writing the Introduction, to rehabilitate the species (at page xvi) under the head of Platycercidx.

This species is probably the bird mentioned by Latham as the "Buff-crowned Parrot."

THIs form differs from its near ally (Platycercus auriceps) both in size and in the tints of its plumage ; so that we have, thus far, three species of Platycercus presenting a distinct gradation in size and colouring. In $P$. nove zealandice the frontal spot, ear-coverts, and rump-spots are deep crimson, while the general plumage is dark green. In the smaller species ( $P$. auriceps) the frontal band is crimson and the vertex golden, while the general plumage is a warm yellowish green. In $P$.alpinus, which is smaller, again, than the last-named species, the frontal band is orange, and the vertex pale yellow, while there is a further modification of the body-plumage as described above. On comparing the bills of the two species the difference is very manifest, that of $P$. alpinus being fully one third less than that of $P$.auriceps. A fourth species has yet to be mentioned, in which a size intermediate between $P$. auriceps and $P$. alpinus is combined with the well-defined plumage of Platycercus nover zealandice.

The present bird was originally described by me, under the above name, from specimens obtained in the forests of the Southern Alps, at an elevation of from 2000 to 2500 feet. In its native haunts it may be found frequenting the alpine scrub, in pairs or in small parties, and is very tame and fearless. It is by no means uncommon in the wooded hills surrounding Nelson.

Mr. Reischek met with this little Parrakeet in the scrub on the summit of Mount Alexander (above Lake Brunner); and he met with the species again on the Hen, where he shot two, and on the Little Barrier, where he observed another pair on the highest peak and killed the male. It does not exist on the opposite mainland, nor indeed, so far as I am aware, in any part of the North Island.

At Nelson I saw many caged birds of this species, and one in particular was remarkable for the clear manner in which it articulated the words "pretty Dick," repeating them all day long in the most untiring way. 


\section{PLATYCERCUS ROWLEYI.}

\section{(ROWLEY'S PARRAKEET.)}

Platycercus rowleyi, Buller, Trans. N.-Z. Instit. vol. vii. p. 220 (1874).

Ad. P. nove-zealandice similis, sed conspicuè minor.

Adult male. Similar in plumage to $P$. nove zealandie, but considerably smaller. Total length 10 inches; wing, from flexure, 4.75 ; tail 5 ; bill, along the ridge $\cdot 55$; tarsus $\cdot 65$; longer fore toe and claw 1 ; longer hind toe and claw 9 .

Female. Slightly smaller than the male, but differing in no other respect.

Young. A specimen from Dusky Sound has the frontal spot of crimson mixed with grcen, and a line of undevcloped feathers in silvery shields along the base of the upper mandible; the aural bar of crimson very small and indistinet; the abdomen palc yellowish green; the bill greyish white, tinged with blue on the sides of the upper and base of the under mandible. The culmen measured along the curve only 45 of an inch.

Obs. There is an appreciable difference in size between this bird and the type of Bonaparte's P. aucklandicus.

When I was in England superintending the publication of the first edition of this work, the late Mr. Dawson Rowley of Brighton sent me for examination the skin of a red-fronted Parrakeet received from the South Island, and remarkable on account of its small size. On comparing the specimen with the type of Bonaparte's Platycercus aucklandicus in the British Museum, I came to the conclusion that although Mr. Rowley's specimen was somewhat less in size, both were referable to $P$. novee zealandice, being only exceptionally small examples of that species. On my return, however, to the colony, my attention was directed to a very large series of Parrakeet skins collected by the late Mr. F. R. Fuller in the provincial district of Canterbury; and, after making due allowance for the great individual variation which some members of this group exhibit, I found it impossible to resist the conclusion that there does exist another species, having similar plumage to P. novae zealandice, but so much smaller in size as to be even less than ordinary examples of the Yellow-fronted Parrakeet (P. auriceps). Mr. Fuller, who had skinned some hundreds of Parrakeets for the Canterbury Museum, assured me that the bones of this smaller red-fronted bird could be readily distinguished from those of $P$. novce zealandioe, being weaker and more slender, and more like the bones of $P$. alpinus. He likewise informed me that all his specimens of this small form had come from Canterbury North; and it seemed to me a significant fact that although $P$. novee zealandice is a very common species in the North Island, none of the very small examples have been recorded there.

We have thus a regular gradation in the following sequence: Platycercus novce zealandice (redfronted), $P$. auriceps (yellow-fronted), $P$. rowleyi (red-fronted), and $P$. alpinus (orange-fronted).

In selecting a specific name to distinguish this diminutive form, I thought I might appropriately dedicate it to Mr. Dawson Rowley, who first called my attention to its existence, and whose interest in New-Zealand ornithology found expression in a charming little museum of rarities, numbering among its treasures the unique specimen of the Moa's egg from the Kaikoura sepulchre *.

Reischek met with this small form on the Hen, but on none of the other islands in the Hauraki Gulf, although $P$. novce zealandice was abundant everywhere.

* There is an excellent figure of this species in Rowley's ' Ornithological Miscellany,' vol. ii. facing p. 115. 


\title{
PLATYCERCUS UNICOLOR.
}

\author{
(ANTIPODES-ISLAND PARRAKEET.)
}

Platycercus unicolor, Vigors, Proc. Zool. Soc. 1831, p. 24.

Platycercus viridis unicolor, Bourj. St.-Hilaire, Perr. t. 34 (fig. fide Leon), 1837.

Cyanoramphus unicolor, Bonap. Rev. et Mag. Zool. 1854, p. 153; id. Naumannia, 1856.

Platycercus anicolor, Gray, Gen. of B. ii. no. 19 (1845); id. List of Psitt. 1859, p. 14; id. Ibis, 1862, p. 229.

Platycercus unicolor, Finsch, Die Papag. 1868, p. 289.

Platycercus unicolor, Buller, 'Trans. N.-Z. Instit. vol. vi. p. 121 (1873).

Platycercus fairchildii, Hector (in litt. 1886).

$\delta$ ad. omninò prasinus, vertice capitisque lateribus lætioribus : dorso et corpore subtùs flavido lavatis : alâ spuriâ ct primariis extcrioribus cxtùs cyanescentibus : caudâ sordidè viridi, subtùs flavicanti-brunneâ : rostro nigro, versus basin albido: pedibus brunnescentibus : iride flavicanti-rubrâ.

o mari simillima, sed valdè minor et pallidior : maxillâ cinerascenti-albo, versus apicem nigricante, mandibulâ omninò cinerascenti-albâ.

Adult male. General plumage grass-grecn, brighter on the crown, sides of the lead, facc, and ear-covcrts; back, rump, and all the under surface strongly tinged with ycllow; primaries bright green on their outer vanes; the margins of the outermost primaries, as well as their coverts, and the whole of the bastard quills, indigobluc; tail-feathers dull grecn, olivaccous or ycllowish brown on their under surface. Bill black, greyish white towards the base of lower mandible; legs and fect dull brown. Total length 13.25 inches; wing, from flexure, 6 ; tail 6.25 ; culmen 1.25 ; tarsus $\cdot 9$; longcr fore toe and claw $1 \cdot 4$; longer hind toe and claw 1.25 .

Female. Of smaller sizc and paler plumage than the male. Bill grcyish white, the upper mandible brownish black in its apical portion, and with a clouded bluish spot in front of each vostril. Wing $5 \cdot 75$ inches; culmen 1 ; tarsus 8 .

Obs. My description of the male is taken from the type specimen in the British Museum; that of the female from the specimen referred to bclow.

Note. One of the specimens collected by Captain Fairchild (as stated bclow) was scnt to the Canterbury Museum; and of this Prof. Hutton has sent me the following note:- "It answers very well to your

b description of the bird in Trans. N.-Z. Inst. vol. vi. p. 122, cxcept tlat in the bill it is the basal half of the upper mandible that is grcyish white, and not the lower. The measurements are as follows, but taken from the skin aftcr it had been mounted:-Extrcme length 14.25 inches; wing, from flcxurc, 6.25 ; tail 6 ; culmen 1 ; tarsus $\cdot 9$; longer fore toe and claw $1 \cdot 18$; longer hind toe and claw $\cdot 95$. The foot seems smaller than in the British-Museum specimen; but I measurcd with a pair of compasses from point of claw, while you may have measured round the curvc."

Sir James Hector sends me the following account of two spccimens received at the Colonial Museum :"General plumage yellowish green, lighter on the underparts; forchcad and checks with minute feathers of intcnse verditer-green ; first threc quills and covcrts dull blue on outer wcb, rest dusky black; tail-fcathers green above, dusky below; under surface ash-colour and very downy; upper mandible pale blue, with black margin and top ; lower black; mandible not grooved. Legs and feet black ; irides yellowish red." 
On my first visit, in company with the late Mr. G. R. Gray, to the fine collection of Parrakeets in the galleries of the British Museum, a mounted speeimen standing on the same shelf with Platycercus novce zealandice and $P$. auriceps immediately arrested my attention. $\mathrm{My}$ eompanion informed me that this was the type of Platycercus unicolor (Vigors), and that it was supposed to have eome from New Zealand. On further inquiry I found that the bird had eome to the Museum from the Zoologieal Soeiety's Gardens, where it had lived for some time, that its origin was quite unknown, and that the speeimen was unique.

Mr. Gray had included the speeies in his "List of the Birds of New Zealand" (l. c.); but in the absenee of any positive evidenee as to the habitat I felt bound to omit it from my former edition.

The home of Platycercus unicolor has at last been diseoverel. Captain Fairehild, of the Government steamboat 'Hinemoa,' on a visit to Antipodes Island in Mareh 1886, found the bird eomparatively eommon there and brought several speeimens baek with him to New Zealand. One of these was forwarded to me by Sir J. Heetor; and this has enabled me to add the deseription of the female to that of the hitherto unique speeimen of the male bird in the British-Museum eolleetion.

Although this type speeimen (whieh has been in the Museum for upwards of fifty years) had no aseertained habitat it was always supposed to have eome from New Zealand, and Mr. G. R. Gray ineluded it in his list of our avifauna, published in 'The Ibis' (1862).

Captain Fairehild, who is an exeellent observer, reports that on Antipodes Island he found it inhabiting a plateau 1320 feet above the sea. It was very tame and easily eaught. He never saw it take wing, whieh he attributes as mueh to the boisterous winds that sweep over this exposed island as to its naturally feeble powers of flight. It habitually walks and elimbs among the tussoekgrass, reminding one of the habits of the Australian Ground-Parrakeet (Pezoporus formosus).

Besides eolleeting several good speeimens, Captain Fairchild brought with him to Wellington a live one. Sir James Hector sends me the following aceount of this interesting bird, for whieh he had proposed the name of Platycercus fairchildii:- "It is a ground Parrakeet, $i$. e. a Parrakeet that resembles a Kakapo. It is twiee the bulk of P. novce zealandice, flies feebly, does not care to pereh, elimbs with its beak and feet, and walks in the same waddle-and-intoed fashion as the Kakapo."

So far as external eharaeters go there is absolutely nothing by which to separate this bird from Platycercus. An investigation of its skeleton (of whieh the Colonial Museum has fortunately seeured a speeimen) may perhaps bring to light some new eharaeter showing its relation to a different group. But my own view at present is that the apparent inability to use its wings for purposes of flight is just another of those remarkable eases where the museles have in some degree atrophied through long-eontinued disuse. Even in the ease of Pezoporus from Australia, neither Mr. Sharpe nor I ean find anything, apart from the different style of eoloration, by which to distinguish the genus.

Sir George Grey tells me that forty years ago the natives assured him of the existenee of a strange Parrot on Cuvier Island, and deseribed the sexes as differing from eaeh other. Exeepting only Mair Island, Cuvier is the most seaward point in the Hauraki Gulf. It is a mountainous island of a few thousand aeres, rising abruptly from the oeean and elothed to the very summit with dense vegetation. It is diffieult of approach, but there are several praetieable landing-plaees in fine weather. Tamihana Te Rauparaha and other natives of the present generation deelared to Sir George that they had in their youth visited the island and aetually seen these Parrots. He suggested to me that they might be descendants of some stragglers from the South-Sea Islands; but if sueh birds do really exist there, it seems far more likely that they are the last survivors of a speeies that has beeome extinet on the mainland, for, as before remarked, expiring forms linger longest on sea-girt islands remote from the eoast, where the struggle for existenee is less severe. 


\section{NESTOR MERIDIONALIS.}

(KAKA PARROT.)

Southern Brown Parrot, Lath. Gen. Syn. i. p. 264 (1781).

Psittacus meridionalis, Gm. Syst. Nat. i. p. 333 (1788).

Psittacus nestor, Lath. Ind. Orn. i. p. 110 (1790).

Psittacus anstralis, Shaw, Mus. Lever. p. 87 (1792).

Nestor novee zealandice, Less. Tr. d'Orn. p. 191 (1831).

Centrourus australis, Sw. Classif. of B. ii. p. 303 (1837).

Nestor meridionalis, Gray, in Dieff. Trav. ii., App. p. 193 (1843).

Psittacus hypopolius, Forst. Descr. Anim. p. 72 (1844).

Nestor australis, Gray, Gen. of B. ii. p. 426 (1845).

Nestor hypopolius, Bonap. Rev. et Mag. de Zool. 1854, p. 155.

Nestor occidentalis, Buller, Ibis, 1869, p. 40 ; Hutton, Cat. of N. Z. Birds, p. 20 (1871); Buller, Birds of New Zealand, 1st ed. p. 50 (1873).

\section{Native names.}

Kaka ; varieties distinguished as Kaka-kura, Kaka-kereru, Kaka-pipiwarauroa, Kaka-reko, and Kaka-korako.

Ad. pileo albicanti-cinerco, plumis nuchæ brunneo. marginatis : torque collari aurantiaeo et eoccineo mixtâ : facie laterali fusco-brunneâ, regione auriculari aurantiacâ ct genis anticis sordidè eoeeineo notatis: dorso superiore olivascenti-brunneo, interdum olivaeco-viridi nitente, plumis omnibus nigro marginatis : uropygio et supracaudalibus sordidè coccineis, plumis lætiore coccineo fasciatis et nigro terminatis : tectricibus alarum pallidè brunneis, nigro marginatis : rcmigibus pallidè brunneis, pogonio interno dilutè coccineo transfasciatis : caudâ pallidè brunncâ, snprà vix distinctè olivaceo vel rubro tinctâ, sed subtùs hôc colore lavatâ ct ad basin coccineo irregulariter fasciatâ: pectore toto cincreo-fusco, plumis nigro terminatis: abdomine toto cum hypochondriis et subcaudalibus pallidè brunneis, plumis omnibus coecineo et ad apicem nigro transfasciatis : subalaribus et axillaribus coccincis, plus minusve aurantiaco tinctis, et minimis brunneo transfasciatis : rostro cyanescenti-cinereo, mandibulâ versus basin fulvcscenti-brunneâ: pedibus cyanescenti-cinereis, plantis pedum flavieanti-brunneis : iride saturatè brunneâ.

$J u v$. torque nuchali indistinctiore: alâ subtùs fusco transfasciatâ.

Adult. General plumage olivaecous brown, each feather margined with darker brown, flushed on the lower parts of the body with dark red, the plumage of the upper parts somctimes with a metallic grcen tinge; crown and sides of the head grey, margined with dusky brown; ear-coverts orpiment-orauge, margincd with brown; feathers projeeting over the lower mandible dark vinous red, with black hair-like filaments; on the nape the feathers are dingy red, margincd with ycllow and black, and forming a broad collar with blending edges; feathers of the lower part of the back, rump, sides, abdomen, upper and lower tail-coverts, in thcir outer portion, dark blood-red, of varying shades, and more or less tinged with yellow in different examples; on the underparts these feathers are narrowly margined with black, on the upper they are banded alternately with black and a lighter shade of red; quills light olivaceous brown, toothed on the inner web with pale yellowish red, and the secondaries washed, on their inner surface, with pale red; lining of the wings, as well as the axillaries, brilliantly eoloured with searlet and yellow, varying in shade in almost every specimen, and differing in their markings according to age. In the fully mature bird all these soft feathers, excepting 


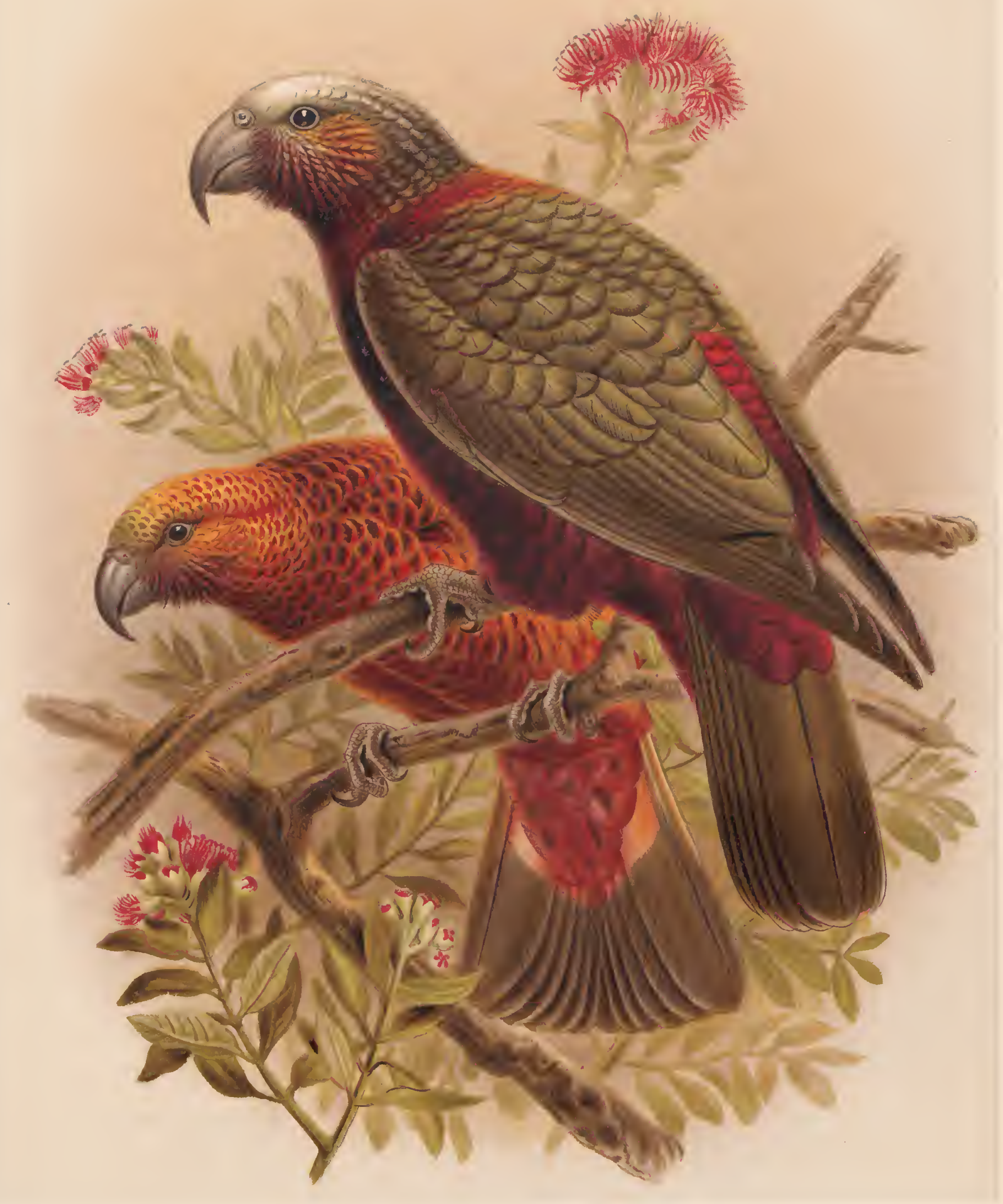

KAKA PARROT AND VARIETY "KAKA-KURA".

NESTOR MERIDIONALIS. 

the longer ones underlying the primaries, are of a bright searlet, variegated more or less with yellow, especially towards the outer edge of the wing, where the ground-colour changes to olivaccons; in some specimens the yellow tint predominates, while in rare instances the whole of this plumage is of a uniform bright eanary-yellow, the axillaries alone being tinged with scarlet, and the toothed markings on the quills almost white, or only tinged with orange. The long axillary plumes are always bright scarlet, barred with olivaceous brown, and sometimes tipped with yellow; tail-featliers light olivaccous brown on their upper surface, with a broad transverse band of dark brown near the tips, obscure vinous red on the under surface, with toothed markings of brighter red on their inner webs, and with the subterminal band very distinet. Irides dark brown; eyelid dull yellow; bill dark bluish grey, the lower mandible sometimes yellowish brown towards the base; legs bluish grey; soles of feet yellowish brown. Total length 18.5 inehes; extent of wings 32 ; wing, from flexure, 11 ; tail 7 ; bill, along the ridge $2 \cdot 25$, along the edge of lower mandible 1 ; tarsus $1 \cdot 25$; longer fore toe and elaw 2.5 ; longer hind toe and elaw $2 \cdot 25$.

Young. In the younger birds the scarlet lining on the under surface of the wings is marked by numerous transverse bars of dusky brown; and towards the carpal edges the feathers are olivaceous brown, barred and margined with orpiment-orange; the long soft feathers underlying the seeondaries are dusky grey, with faint bars of scarlet. In some examples the nuehal eollar is very indistinet, being simply indieated by a tinge of yellow, while in others it is fully as conspicuous as in the adult.

Nestling. The newly hatehed nestling is covered with soft white down, thinly distributed, and very short on the underparts; abdomen entirely bare; bill whitish grey, the upper mandible armed near the tip witl a white horny point; cere pale flesh-colour; rictal membrane greatly developed and of a pale yellow eolour; legs dull einereous. The bill and fcet scem disproportionately large, giving the nestling a very ungainly appearance. The fledgling (Feb. 5) has the membrane at the angle of the mouth and the rim encireling the eyes yellow.

Obs. In this species of Nestor the cere is very prominent, and towards the head generally has an abraded appearance, as if the feathers had been rubbed off. The two mandibles are conneeted at the base by a tough elastic membrane, eapable of much expansion, the mandibles being more than an ineh apart when fully extended. The tongue, whieh, like the beak, is bluish grey, is hard and smooth on the under surface, having the appearanee of a human finger-nail much produced, along the terminal edge of whieh there is a fine brush-like development. The upper surfaee of the tongue is soft, rounded on the edges, with a broad central groovc. In adult birds the denuded shaft of the tail-feathers is produeed to a fine point a quarter of an ineh or more beyond the web. Freshly killed birds have a peeuliar woody odour, which is sometimes very strong. During the season that the rata is in bloom the long featlicrs of the eheeks and the light parts of the lower mandible, as wcll as the bare membrane at its base, are stained a rieh orange-eolour by contact with the juiee of these flowers, whieh evidently contain strong colouring-matter.

Apart from the strongly marked varieties to be presently noticed, individual speeimens exhibit a considerable amount of variation in the details of their colouring. The nuchal eollar varies not only in extent, but in colour, from pale orpiment-orange to a dark wine-red margined with yellow; and there is mueh differenee in the eolour of the ear-coverts and of the filamentous feathers overlapping the under mandible. Examples also vary in size, a small one in my possession measuring only 16.5 inehes in length; wing, from flexure, 10 ; tail 6.

Varieties. The members of the genus Nestor show a great tendency to individual variation, cxamples even of Nestor productus (which is confined in its range to a single rocky island) presenting such differenees of plumage as almost to induce a belief in the existence of more than one species. But this variability of character is developed to the highest degree in Nestor meridionalis. Although it may be necessary, or convenient, to recognize a larger and a smaller race, the former eonfined to the South Island, and the latter having a wider dispersion, I have eome to the eonelusion that the following are merely aberrant varieties of the typieal form, and, although sometimes recurrent in different loealities, are not entitled to recognition as distinet speeies.

Var. a. Nestor superbus, Buller, Essay on New-Zealand Ornithology, p. 11.

This is one of the most beautiful of the many varieties to be noticed. Owing to the discovery, at the same time 
and in the same loeality, of several examples, all in the same brilliant plumage, I felt no hesitation in eharaeterizing the speeies as new, under the above designation. Several eonneeting forms, however, have sinee been found, and I now feel bound to sink $N$. superbus as a speeies. The following deseription of this supposed speeies appeared in my 'Essay' (l.c.) :- "Crown, hind neek, breast, seapulars, and upper wing-eoverts eanary-yellow of different shades, and tinged with searlet; upper surfaee of wings whitish yellow, the primaries inclining to pale ash; upper surfaee of tail, when closed, pale ashy yeilow, the sides being briglit canary-yellow with a searlet tinge; sides, abdomen, lower tail-eoverts, axillaries, lining of wings, lower part of baek, and upper tail-eoverts bright searlet, varied on the underparts, and minutely edged on the upper tail-coverts with eanary-yellow; eheeks, throat, earcoverts, and a broad nuehal collar paler searlet, largely mixed on the ear-eoverts and eollar with bright yellow. The under wing-coverts are beantifully marked with alternate bands of searlet and jellow; the primaries, on their under surfaee, are ashy, marked on their inner vane with triangular spots of searlet and yellow; under surfaee of tail-feathers pale searlet for two thirds of their extent, and banded on their inner vane with brighter, asliy beyond, and yellowish towards the tip. Bill and legs dark bluish grey."

There are two speeimens (said to be $\delta$ and $q$ ) in the Canterbury Museum. They differ slightly in the details of their eolouring. In one the nuehal collar of searlet and yellow is mueh broader and brighter than in the other, while the erown of the head is paler, being of a dull yellowish white. The lower part of the baek is equally brilliant in botll; and the peeuliar ashy white, whieh is eharaeteristie of albinism, is very strongly apparent in the primaries and tail-feathers, although tinged on the latter with yellow. One has the bill eonsiderably larger and stronger than the other, while in both the tail-feathers have denuded tips, or, more properly, the shaft is produced half an inel beyond the webs.

An example in my colleetion, obtained on Banks Peninsula (Canterbury), eorresponds exaetly with the supposed male above deseribed.

There is another speeimen (obtained in the Tararua ranges) in the possession of Wi Parata at Waikanae. It is well mounted in a glass ease, and cxhibited with other novelties in his elegant Whare-puni. The general plumage is white, with a wash of canary-yellow, shading into erimson on the eheeks and feathers overlapping the lower mandible; a narrow nuehal collar of erimson and golden yellow intermixed; the feathers of the breast and the small wing-eoverts tipped with bright ycllow; the whole of the abdomen, flanks, and under tail-eoverts bright crimson, and the under surface of tail-feathers flushed with the same. Bill white; legs and feet grey.

Var. ß. Nestor esslingii, Souaneé, Rev. et Mag. de Zool. 1856, p. 223.

M. de Souneé, the original deseriber of the supposed speeies, says :- "Le Nestor dont nóus allons donner la deseription est, sans eontredit, l'oiseau le plus remarquable de la colleetion Masséna. Intermédiaire entre le $N$. hypopolius et le $N$. productus, ee magnifique Perroquet réunit, dans son plumage, des détails earaetéristiques de ees deux espèces. Coloration générale semblable ì eclle du N. hypopolius."

Mr. Gould, in the Supplement to his 'Handbook to the Birds of Australia,' says of it:- "A single speeimen only of this magnifieent Parrot has eome under my notiee; and this example is perhaps the only one that has yet been sent to Europe. It formerly formed part of the eolleetion of the Prinee D'Essling, of Paris, but now graees the National Museum of Great Britain. It is in a most perfeet state of preservation, and is, without exeeption, one of the finest speeies, not only of its genus, but of the great family of Parrots. The native country of this speeies is supposed to be Ncw Zealand; but I, as well as M. de Souaneé, have failed to learn any thing definite on this point. - In sizc it even execeds the great Kaka (Nestor hypopolius), whieh it resembles in the form of its beak, while in its general colouring it closely assimilates to Nestor productus."

Dr. Finseh, on the other hand, states, in his Monograph, that Nestor esslingii, De Souaneé (of which the type is in the British Museum), is in size and general eolour the same as Nestor meridionalis, but has the breast ashgrey, with brown terminal margins and a broad yellowish-white transverse band straight aeross the belly. He adds that he was not able to make sueh an examination of it as he wished, owing to its being in an hermetieally elosed glass ease, but quotes Souance to the effeet that the red marks on the inner vane of the quills and tail-feathers are preeisely as in Nestor meridionalis; whercas Mr. Gould distinetly says that while the tail-feathers in N. meridionalis and $N$. productus are strongly toothed on the under surfaee with red, "in Nestor esslingii no sueh marks oeeur, the toothing on the inner webs of the primaries is not so elear and well-defined, and the light-eoloured interspaces are more freekled witl brown."

Referring to these several aecounts, I expressed the following opinion, in the "Transaetions of the NewZealand Institute' (vol. iii. 1870, p. 51) :-“Assuming Dr. Finsch's deseription to be strictly correet-that it most 
nearly resembles Nestor meridionalis, from which it is only distinguishable by the broad yellowish-white band across the undcrparts of the body-and considering the extreme tendency in that spccies to variability of colour, I should be inclined to regard the British-Museum bird as an accidental varicty of the common Kaka. Among the numerous abnormally coloured examples which I have seen, from time to time, varying from an almost pure albino to a rich variegated scarlct, I remember one which, although like the common bird in its gcneral plumage, had a broad longitudinal band of yellowish white on the abdomen. The specific identity of this specimen with Nestor meridionalis was unmistalsablc."

It only remains for me to add that the examination which $I$ have since made of the type specimen in the British Museum has entirely verified this conclusion. It may be mentioncd that this bird furnished Mr. Gould. with a subject for a bcautiful picture in the Supplement to his 'Birds of Australia.'

My son saw one at Owhaoko with a white tail, the rest of the plumage being dingy brown. He cndeavoured in vain to shoot it.

Var. $\gamma$. Nestor montanus, Haast.

This is a larger race than the common Kaka, and is gcnerally much brighter in colour. It appears to be confined to the South Island, whence all the examples that have come under my notice have becn obtained. No doubt some vaturalists will be disposed to regard this larger race as a distinct bird; and for a considerable time my own. inclinations wcrc in that dircction; but, looking to the extreme tendency to variation in this specics, and to the difficulty of drawing a clear line between the larger and smaller raccs, in consequence of the occasional intermediate or connecting forms, I feel that I am taking a safe course, eoncurrently with Dr. Finsch, in refusing, for the present at least, to separate these birds *.

* While adhering to the view expressed abovo, I think it only right to quote the following opinions as to its claims to take rank as a distinet speeies:-

Sir Julius von Haast in forwarding me a specimen wrote :-

"I send you another skin of our Alpine Parrot. Even judging from its habits alone, it is quite distinet from the eommon Kaka. It is never found in the Fagus forest, whilst the other nevor goes above it into the sub-alpine vegetation. Near the glaeier sourees of the Waimakariri, whero I was iu the latter part of Mareh, I saw them frequently in the alpine meadows4000 to 5000 feet high-feeding on the largo red berries of Coprosma pumila and nivalis, two dwarf plants lying elose to the ground. We found these berries in the gullets of those we opened. They evidently had their nests with young ones among tho crags of the vearly perpendieular roeky walls (about 6000 feet abovo the sea), and I repeatedly observed them flying baekwards and forwards, as if feeding their young. After the first day's shooting they got exeedingly shy, and eould uot be approaehed within gun-shot."

Sir James Heetor informs me that it was to this bird (and not to the so-ealled Nestor occidentalis as previously quoted) that he intended the following note to refer:-

"I never met with it in the forests of the low lands. It is more aetive in its habits and more hawk-like in its flight than the common Nestor. It often sweeps suddenly to the ground; and its ery differs from that of the eommon Kaka in being more shrill and wild."

Mrr. Fuller (taxidermist to the Canterbury Museum) also stated, as the result of very eareful observation, that "tho mauner" of flight is quite different from that of the eommou Kaka, for they sour after the manner of the Kea (Nestor notcbilis)."

Mr. Reisehek, to whom I am indebted for some fine speeimeus, of all ages, obtained at Dusky Sound, is strongly of opinion that this is a distinet species. Ile says (Trans. N.-Z. Inst. vol. xvii. p. 194) :-

"This bird ropresents Nestor meridionalis in the sounds, but it is not very plentiful. I have found them alone or in pairs or with their young, from two to four. They breed in hollow trees. Tho nest eonsists of a deepening lined with wood-dust and feathers out of the paront birds. They lay their eggs from the beginning of March till April. Maie and female hateh and rear the young birds togethor; in August the young are full-grown. This bird is not so gregarions as its ally meridionalis, also different in plumage and construetion of the skeleton [?] and habits. The ery and whistle is shriller; the male is fiery red under tho wings, the female golden yellow and a little smaller. These birds are very bold. On the 13th April, 1884, I found in a hollow tree a female with one egg and three young birds, whieh she pluekily defended by biting and seratehing. At the ery of the fomale tho male eame swooping several times past my head. This speeies is the finest of the throe existing speeies of Nestor."

Among the speeimens reeeived from Mr. Reisehek is a nestling eovered with grey down; but it differs in no respeet from that of the eommon Kaka, exeept perhaps that the downy eovering is a shade darker. An egg whieh he submitted to me differs, however, slightly from that of Nestor meridionalis; it is ereamy white, the surfaee eovered with extremely fine punetæ, making it almost granulate, of a regular oroid form, and measuring 1.5 ineh in length by 1.25 in breadth. 
There are some beautiful examples of this larger form in the Canterbury Muscum. One of these has the crown silvery grey; the sides of the head and ncck washed with sea-green; the ear-coverts glossy golden yellow; the feathers overlapping the lower mandible, and the whole of the throat and fore neck, rich vinous red with paler centres; the nuchal collar very broad, and composed of various shades of scarlet and ycllow bcautifully blended; the breast and sides varicd with crimson and ycllowish olive, blcnding on each feather, and across the former an indistinct pectoral band of yellowish grey; the rump, flanks, abdomen, upper and lower tail-coverts as in ordinary specimcns, but brighter in colour. In another example thc small wing-coverts are pale orange-red, terminally margined with llack; while in a third the abdomen has a conspicuous, irregular patch of canary-yellow. An unusually finc specimen forwarded to me by Sir Julius von Haast for examination had the forehead of a rufous-orange eolour; but this proved to be entirely the result of flower-stains, as I had no difficulty in demonstrating. This bird measured 20 inches in length, wing from flexure 12, tail $7 \cdot 5$, culmen $2 \cdot 75$, tarsus $1 \cdot 5$. The plumage of the upper parts was faded and snow-beaten, the cnds of the primaries and tail-fcathers being mueh worn and jagged. Crown and sides of the head grey tinged with dull mctallic green; ear-coverts bright golden yellow with darker edges; breast and sides olivaecous brown, with a reddish lue; fcathers composing the nuchal collar dull red, with golden tips; those covering the shoulders marked in the centre with a large irregular spot of red, and stained with golden yellow ; rump and upper tail-eoverts dull arterial red, each fcather with a narrow terminal margin of black; under surfaee as in ordinary specimens, but more largely suffused with yellow.

In another example of the southern bird (in my own collection, which contains a good series) the crown and hind part of the head are light grey edged with darker grey; the feathers composing the nuchal collar are rich orange-red, narrowly barred with ycllow and black; ear-coverts bright orpiment-orange, changing into deep vinous red on the cheeks; the feathcrs overlapping the lower mandible cdged with black; the fore neck, breast, shoulders, and upper wing-coverts olivaceous brown margined with darker brown, and having, more or less, a grecn metallic lustre; sides, abdomen, rump, and upper tail-coverts dark red, banded with bright arterial red and dusky brown ; under tail-coverts dull red, tipped with brighter red, olivaceous brown at the basc; quills olivaceous brown, lighter on the outer web, largely toothed on the inner one with pale orange-red; lining of wings and axillary plumes bright scarlet tipped with yellow, and banded, more or less distinctly, witl brown; tail-feathers olivaccous brown, darkcr in their apical portion, washed on their under surfacc with dull vinous red, and toothed with pale scarlet. Bill uniform bluish grey; tarsi and toes dark bluish grey.

In another specimen the general colours are altogether duller; but there is more of the metallic lustre on the wings; the arterial-red bands on the rump and abdomen are wanting, the plumage of these parts being dark red edged with dusky brown or black; the lining of the wings is less brilliant; the toothed markings are paler on the quills, and far less distinct on the tail-feathers.

A beautiful specimen in Mr. Reischek's collection ( $\delta$ ) has the light feathers of the erown tipped witl yellow, the feathers of the nape deeply margined with oil-grcen, the nuchal collar broad and very richly coloured, the whole of the chin, fore neck, and breast flushed with crimson; abdomen, sides of the body, and under tail-coverts flaming crimson with transversc bands of a lighter colour; small wing-coverts metallic green, flushed in their apical portion with crimson and terminally margined with a narrow band of black; rump and upper tail-coverts same as abdomen and crissum, but darker.

Var. $\delta$.

The following brilliantly coloured variety of $N$. meridionalis was obtained more than twenty years ago in the Wanganui district, and is now in the author's colleetion, in the Colonial Muscum, at Wcllington. General plumage bright scarlet-red, deepest on the lower part of back, sides, and abdomen, and variegated with orpiment-ycllow on the nape, sides of the neck, and breast. Crown grcenish yellow, with a metallic gloss, each feather centred with brown; feathers overlapping the under mandible, and a broad patch on the throat, dark reddish brown, as in ordinary examples. The feathers of the breast are stained in the centre with dull ashy brown, and, as wcll as those of the upper parts, are narrowly bordered with black. Primaries dark olivaccous brown, largely marked in their basal portion with yellowish white; secondaries and their coverts pale scarlet, variegatcd with yellow, olivaceous brown in their apical portion; all the quills on their under surface pale orange in their basal portion, but without the toothed markings; lining of wings vivid scarlet, varied witl yellow. Tail-feathers pale scarlet with a bruad tcrminal band of olivaccous brown; under tail-coverts darker scarlet. On the bright mpper surface of the tailfeathers therc are obsolete bars, and on the under surface there is a broad olivaceous margin ; but the "toothed" eharacter peculiar to the species is entirely wanting. Bill bluish grey ; feet dark grey, paler on the soles; claws black. 
A specimen in the possession of Mr. W. Luxford, at Wellington, has the prevailing eolour a bright scarlct; but on the back and wings each feather has a narrow terminal band of blackish brown; head and throat rusty brown; breast darker rust-colour, caeh feather broadly margined with yellow. Primaries canary-yellow on tlie outer web for one third of their length, then brown; upper wing-coverts brown margined with scarlet. About two thirds of the tail pale scarlet; there are then a few interrupted bands of brown, and the terminal portion is of that colour. This bird was shot in the hills near the town of Wellington in the early days of the colony, and before the requirements of the scttlers had led to the destruction of the surrounding woods.

Under this section may be placed a gorgeous cxample obtained in the Hawke's Bay district, and sent by Mr. J. Baker to the recent Colonial and Indiau Exhibition at South Kensington. It is somewhat similar to my Wanganui bird, but is more brilliant. Feathers of the vertex and crown orpiment-orange centred and narrowly margined with brown; throat, cheeks, and many of the upper wing-coverts much as in ordinary specimens, being olivaceous brown, the normally coloured fcathers irregularly marked and margined with pale scarlet; shoulders and interscapulars olive-brown washed with crimson, banded with golden yellow, and narrowly margined with brown; on the head and neck the brown centres almost disappear, whilst the feathers composing the nuchal collar are entirely scarlet, witl broad golden-yellow margins; the whole of the rump, abdomen, and lower sides of the body, with the upper and under tail-corerts, fiery scarlet, very narrowly and sparsely tipped with dusky black; the breast is a mixturc of dark brown, scarlet, and orpiment-orange, tbc latter predominating; primaries and tertials dark olivaccous brown, the outer vanes palc canary-yellow towards the base; secondaries pale scarlct for two thirds of their length, then olivaceous brown; tail-fcathers with a similar extent of pale scarlet, then blackish brown with olivaceous tips; but the colouring gets paler on the lateral feathers, fading to canary-yellow on the outermost vanc and presenting only a tinge of scarlct on the succeding one. Bill and feet as in ordinary examples.

The tail-feathers in the Canterbury Museum found near Cass river (mentioned in Trans. N.-Z. Instit. vol. iv. p. 148) are exactly similar to tbose here described.

Var. $\epsilon$.

The following is the description of a very light-coloured variety obtained by the natives near the burning mountain of Tongariro, and prescnted to me by Mr. R. W. Woon, R.M. :-

General plumage pale canary-yellow; the crown tinged with grey; ear-coverts bright orange-ycllow ; feathers of the throat, hind part of the neck, and some of the upper wing-coverts margined with the same; feathers on the lower part of the cheek, and those ovcrlapping the lower mandible, yellowish red, with paler shafts; sides, abdomen, rump, upper and lower tail-coverts vivid scarlct, the feathers of the underparts narrowly margined with yellow; lining of wings bright yellow tinged with scarlet; axillary plumes, and the soft feathers underlying the secondaries, bright scarlet, tipped with yellow; quills pale canary-yellow on their upper surface, ashy on their under surface, with broad toothed markings of pale red, obsolete on the outcr remiges, and diminishing on the secondaries ; tailfeathers aslıy yellow, with brighter margins, tinged with orange in the centre and along the tips, changing on their under surface to orange-yellow, in their basal portion witl narrow toothed markings of scarlet. Bill white horncolour. Irides dark brown. Tarsi and toes pale brown or flesh-coloured; claws white horn-colour.

The late Rev. R. Taylor, who resided more than twenty years on the Wanganui river, and who published many interesting notes on the natural history of the country, informed me that he had seen several examples of this beautiful variety from the same locality as the onc noticed above. The natives assured him that they always pair together, ncsting in the erevices of the rocks.

Var. $\zeta$.

I am indebted to Sir Julius von Haast for a specimen showing a very decided tendency to albinism, although still exhibiting the bright scarlet facings which adorn the others. In this bird the crown is greyish white, with palc ycllow margins; the nape dull crimson, with yellowish tips, forming a broad nuchal collar; car-coverts bright orpiment-orange stained with red; feathers overlapping the lower mandiblc, and those covering the throat, palc vinous red; fore neck and upper part of breast smoky grey, washed with red, and each feather tipped with dull ycllow; back and upper surface of wings smoky yellow tinged with gambogc; lining of wings and axillary plumes bright scarlet-red; quills dark yellowish grey, obscurely tootled, and washed at the base with pale scarlet; sides, flanks, and abdomen scarlet-red, tipped more or less with dusky and ycllow; tail-feathers yellowish brown, with paler edges, washed on the under surface with scarlet, marked with dusky freckles, but not toothed; upper and 
lower tail-coverts bright gamboge, crossed near the tip by a band of bright red. Bill very narrow and fine; ycllowish grey in colour, bluish at the tip. Tarsi and toes dark grcy; claws bluish horn-colour.

Under this head may be placed the creamy-whitc Kaka with scarlet rump and abdomen, and a narrow nuchal collar of canary-ycllow, which was shot in the Makcreru ranges near Waipawa, and sent by Mr. J. Baker to the Colonial and Indian Exhibition of 1886.

Var. $\eta$

A spccimen obtained by Mr. Henry Travers in the Provincial district of Marlborough is remarkably small, as compared with ordinary examples from the same locality, and is differently coloured.

Crown of the head hoary grey; fringed behind the eyes and on the occiput with pale sea-grecn; car-coverts golden ycllow tinged with red; mantle, scapulars, and wing-coverts dull olivaccous green, margined with black; nuchal collar dull vinous red, with lighter tips; neck above dark olivaceous brown; checks, throat, front and sides of the neck dark brown, strongly tinged with red; breast, sides, abdomen, and uuder tail-coverts of different shades of arterial red shaded with brown; lower part of the back, rump, upper tail-coverts, and thighs dark arterial red banded with lighter red, and tipped with black; lining of wings and axillary plumes bcautiful scarlct, transversely barred with dusky black. Quills and tail-feathers olivaccous brown, with palcr edges, toothed on their inner wcbs with pale orangc-red.

Var. $\theta$. "Kaka-kereru" of the natives.

The following description is taken from a specimen in my collection, which was obtained in the vicinity of Wellington, in 1856 :-

Upper parts gencrally tinged with oil-grecn, and each fcathcr narrowly margined with black; crown light grcy, with darker shades, varied with decp sea-grecn over the cycs and on the hinder part of the head; nape seagrcen, mixed with brown and ycllow; nuchal collar, which is nearly two inches broad, dark crimson, each feather faintly margincd with yellow and black. Upper wing-coverts and upper portion of the tail-feathers tinged with olivaceous. The ear-coverts are orpiment-orange varying in shade; whilc the cheeks and throat arc dark vinous red, each feather having a bright centre; feathcrs of the ncck and breast dark brown, with a marginal tinge of crimson; rump, upper and lower tail-coverts, thighs, and abdomen deep crimson, with lighter crescentic bands and narrow tcrminal margius of black. This bird was shot with a flock of twelve others (all bagged), and was the ouly one presenting this character of plumagc.

In another example, obtaincd at Otaki in Septcmber 1862, all the tints of the plumage are very rich, and the red of the underparts extends to the brcast, each fcather having two bright crescentic bands of arterial red aud a tcrminal margin of dusky black ; the ear-coverts arc gallstone-ycllow, and the nuchal collar, which is much extended, is of the same colour intermixed with red; the secondaries and lesscr wing-coverts are pale metallic grcen, narrowly edged with black; and the whole of the dark upper plumage is tinged with the same colour.

Var. $\bullet$.

In June, 1870, I reeeived from Manawatu a very beautiful specimen of the variety known among the natives as "Kaka-pipiwarauroa." The whole of the plumage was most handsomely variegated, cach feather having a brownish-black centre, and the margins broadly edged with orange-red and yellow. These bright markings wcre most conspicuous on the napc and upper surface of the wings. 'The sides of the face and the ear-coverts werc of a bright golden yellow, changing to red on the long featlers ovcrlapping the lower mandible; the sides, thighs, and lower part of the abdomen arterial red, with lighter bands; the lining of the wiugs brilliant scarlet, banded with yellow and black. The natives had this beautiful bird in their possession for many months; and the delighted settler who wrotc apprising me of it described it as "a bird with all the colours of the rainbow." I ultimately induced the owner to part with it, giving him iu return a block of the much-prized grecnstonc, weighing more than 20 lb. I designed this rara avis for the Zoological Socicty of London, and shipped it aecordingly with every carc; but it appeared to suffer from the cxtremc cold, and, unfortunately, perished beforc it was out of sight of the NcwZcaland coast.

Var. $\kappa$.

In the Otago Muscum thcre is a remarkable specimen, obtained in the south, in August 1874, and presented by Mr. J. Coulan. This bird (which is a malc) has the plumage of the upper parts smoky yellowish brown, and, except on the crown, cach feather has a dusky margin; the feathers of the crown, wings, and tail pale yellowish 
brown, the latter flushed with scarlet, and the outer ones edged with yellow ; underparts gencrally of a darker hue, shaded with brown and flushed with crimson; the sides of the face, nuchal collar, rump, upper and lower tailcoverts, abdomen, flanks, and inner lining of wings all very highly coloured, the crimson fcathers forming the collar being prettily rayed with orpiment-orange; bill and elaws white horn-colour.

Var. $\lambda$.

A fine bird received from Catlin river (likewise prescrved in the Otago Muscum) has the hind part of the crown and the whole of the nape and hind ncck ricl canary-yellow of varying shades, the normal nuchal collar only appearing at the outer cdge of this gorgcous hood. The car-coverts are briglit orpiment-orange; and the filamentous fcathers overlapping the mandibles are crimson with light shafts; so also are the chin-feathers, under which there is a band of rich canary-yellow suffused with crimson, spreading over the throat and connecting the two sides of the head. On the breast and underparts of the body there are numerous canary-yellow feathers intcrspcrsed irregularly with the ordinary plumagc. The upper surface is in the plumagc of the "Kaka-kereru" (var. $\theta$ ), being highly flushed or burmished with metallic green.

Var. $\mu$. Nestor occidentalis, Buller, Birds of N.Z. 1st ed. p. 50.

To the above numcrous varictics I fecl bound now to add the form which, with some hesitation, I kept distinct under the above name in my former cdition. As stated in the text, my reason for then rejecting the supposition of its boing a mcre abcrrant varicty of the common species was the account of its habits and peculiar cry furnished by Sir James Hector, who found it "frequenting the precipitous wooded cliff's in the neighbourhood of George Sound and thence along the coast to Milford Sound." As however, during the last fifteen years, no furthcr cxamples have becn obtained, and no additional evidence to support its rccognition as a species, it will be safer to treat this as another instance of congenital variation. For its more exact definition I will quote here my original description when proposing to differentiate tle speeics :-

"Upper surface dark olivaccous brown, tinged with ycllow on the wing-coverts, cach feather margined with dusky black; feathers of the nape dull red, margined with yellow and black, and forming a narrow nuchal collar; rump, tail-coverts, and abdomen dark arterial red, the fcathers of the latter banded with a brighter tint; ear-coverts palc orpiment-orange; feathers projecting over the lower mandible tinged with red; throat, neck, and breast dark olivaccous brown; lining of wings and axillary plumes bright scarlet, obscurely barred with black, and tipped with golden ycllow; quills and tail-feathers russet-brown, the former toothed with yellow on the inner web; bill and fect dark olivaceous grey. Length 16.5 inches; wing, from flexurc, 10.5 ; tail 6 ; tarsus 1 ; longer fore toe and claw $2 \cdot 25$; longer hind toe and elaw $2 \cdot 1$; bill, following curvature $2 \cdot 25$, along edge of lower mandible $1 \cdot 5$.

"Apart from the differenec of plumage this specics is appreciably smaller than the common one, while the bill is more slender and has the upper mandible produced to a finer point. The two specimens obtained by Dr. Hcetor on the west coast of the Sonth Island differ very slightly in the details of their colouring, and there is scarcely any perecptiblc difference in their sizc."

Note. To illustrate the brilliancy and beauty of some of thesc accidental forms, I have given a portrait of the brighter of the two specimens sent by Mr. Baker to the Colonial and Indian Exhibition, both of which are now in my collection.

General Remarks. To M. Blanchard and Pclzcln belong the credit of having first determincd the true affinitics of the genus Nestor. It bears a close relation to the Australian Lories; and the Ncw-Guinca form known as Pecquct's Parrot (Dasyptilus pecqueti) appcars to exhibit the transitional or connecting link betwcen thesc two well-marked groups.

In habits and structure the members of the genus Nestor are true flower-suckers, the tongue being furnished at its extremity with a fine brush-like development for that special purpose. The common Kaka of New Zealand is the type of the genus.

Modem systematists, as a rule, have placed it in tlie subfamily Trichoglossince; but I accept Prof. Garrod's view that its proper station is among the typical Parrots *. Its decidedly aberrant characters, howevcr, cannot be denied; and I have thought it the safost course to place the genus in a separate family minder the name of Nestoridæ. 
SPRightiY in its actions, eminently social, and more noisy than any other inhabitant of the woods, the Kaka holds a prominent place among our native birds. Being semi-nocturnal in its habits, it generally remains quiet and concealed during the heat of the day. If, however, the sportsman should happen to find a stray one, and to wound instead of killing it, its cries of distress will immediately rouse the whole fraternity from their slumbers, and all the Kakas within hearing will eome to the rescue, and make the forest echo with their diseordant screams. Unless, however, disturbed by some exciting eause of this sort, they remain in close cover till the approach of the cooler hours: then they eome forth with noisy clamour, and may be seen, far above the tree-tops, winging their way to some favourite feeding-plaee; or they may be observed climbing up the rough vine-clad boles of the trees, freely using their powerful mandibles, and assuming every variety of attitude, or diligently tearing open the dead roots of the close epiphytic vegetation in their eager seareh for insects and their larvæ. In the spring. and summer, when the woods are full of wild blossom and berry, these birds have a prodigality of food, and may be seen alternately filling their erops with a variety of juicy berries, or sucking nectar from the crimson flowers of the rata (Metrosideros robusta-a flowering branch of which is depicted in the Plate) by means of their brush-fringed tongues.

With the earliest streaks of dawn, and while the underwoods are still wrapped in darkness, the wild cry of this bird breaks upon the ear with a strange effect. It is the sound that wakes the weary traveller encamped in the bush; and the announeement of his ever active Maori attendant, "Kua tangi te Kaka," is an intimation that it is time to be astir. But although habitually reeluse during the day, it is not always so. During gloomy weather it is often very aetive; and, sometimes, even in the bright sunshine a score of them may be seen together, flying and eircling about, high above the trees, uttering their loud screams and apparently bent on convivial amusement. When the shades of evening bring a deeper gloom into the depths of the forest, and all sounds are hushed, save the low hoot of the waking Morepork, or the occasional cheep-cheep of the startled Robin, the Kaka beeomes more animated. It may then be heard calling to its fellows in a harsh rasping note, something like the syllables "t-chrut, t-chrut," or indulging in a elear musical whistle with a short refrain.

It is strietly arboreal in its habits, and subsists to a large extent on insects and their larwæ, so that it is probably one of our most useful species. Where they exist in large numbers, they must aet very beneficially on the timber-forests; for in the domain of nature important results are often produced by apparently trivial ageneies. Like all the honey-eaters, while supplying their orn wants, they do good service with their brush-tongues, by fertilizing the blossoms of various trees, and thus assisting in their propagation; while, on the other hand, the diligent search they prosecute for inseets and grubs, and the countless numbers daily consumed by each individual, must materially affect the economy of the native woods.

I am aware that in some parts of the country there is a prejudice against the Kaka on account of its alleged injury to forest trees by barking them; but this animus is quite undeserved *. On the

* Against this unmerited eharge the Kaka is well defended by Mr. Potts, who writes:- " Although so often accused of injuring trecs by stripping down the bark, from eareful observation we do not believe a flourishing tree is crer dumaged by its beak. It is the apparently vigorous, but really unsound trec that is attacked, already doomed by the presence of couutless nultitudes of insects, of many varieties, of which it is at once the food and refuge, either in their perfect or larval state. In the perserering and laborious pursult of this favourite food, the Kaka, doubtless, lends lis nssistance in hastening the fall of decaying trees; the loosened strips of bark dissevered admit to the exposed wood rain and moisture eollected from dews and mists, to be dried by evaporation by the heat of the sun, by the desiccating winds, only to become saturated again. Under this alternation the insidious fungi take root, docay rapidly scts in, the close-grained timber gives place to a soft spongy texture, branches drop off, and gradually the once noble-looking tree succumbs to its fate: but its gradual decay and fall, the work of years, has proved beneficial to the surrounding plants ; the dropping of the branches admits light and air to the aspiring saplings, assists in checking the undue spread of lichens and epiphytes; and when the old stem falls, tottering down from its very rotten. ness, its place is supplied by vigorous successors." 
contrary, the bird does good service in this respect, for its vigilant eye is the first to detect the insidious attacks of the small longicorn beetles and other borers, and it is to search out and devour these enemies to forest conservation that it takes the trouble to break the bark at all. I have seen a vigorous limb cut to a depth of two inches or more by the Kaka's beak, for that purpose only, the cutting or rasping being effected by means of the under mandible, the hook of the upper giving the necessary leverage. Such a wound in a healthy tree rapidly heals over and thus the limb is saved through the intervention of the bird at the right moment.

This is one of our highly charactcristic forms and is met with, more or less, in every part of the country. Far away in the depths of thc forest-where the trees are clad with rich mosses, cryptogams, and lycopods to their very tops-where, as if to hide the mouldering decay of nature, huge masses of green vines and creeping plants cover the aged trunks and bind the busli together-where the sunlight, struggling through the leafy tops, discloses here and there a feathery tassel of Asplenium flaccidum hanging from the branches or a clump of the scarlet-flowered mistletoe--there the Kaka is at home and may be studied to advantage. So long as he does not know he is watched, he may be seen twisting and turning among the sprays, hopping Cockatoo-fashion along a branch, then climbing higher with graceful agility; resting for a moment to whistle for his mate and, when she has joined him, expressing his pleasure in a sharp chuckling note, like the striking together of two quartz pcbbles; then, as if suspecting some treachery below, he suddenly takes wing with loud cries of $k a-k a$ and glides smoothly through the leafy maze, closely followed by his spouse. On a near view the brilliant plumage under the wings is very conspicuous when the bird is flying; but when the bird is climbing or hopping, in the manner habitual to it, the wings are kept closed. Then on the outșkirts of the forest you meet with him again-more generally in the early morning-hunting diligently for his insect food or regaling himself on ripe berries of various kinds in the thick underwood; and towards evening three or more of them may be seen in company, flying high above the forest level; then alighting on the withered, naked top of some lofty kahikatea or kauri tree-always pcrching on the highest points—resting a few moments, and taking wing again till they are fairly out of sight. In the early watches of the night, too, especially during the breeding-season, and just before the break of dawn, its peculiar cry betrays its wakeful restlessness.

In the dark Fagus-forests, both north and south, it shares the domain with the stcalthy Woodhen, descending often to the ground to hunt for grubs and insects among the moss-covered roots and decaying wood. In the low-lying woods, whore the climbing kiekie (Freycinetia banksii) attaches its rooted stems to the larger trunks and, spreading upwards its tufted coils, wraps the whole tree in a flowing mantle of brilliant green, there too at flowering-time the Kaka will be found, feasting on the sugary bracteæ and fleshy-white spadices of this remarkable plant. He fills his crop with this delicious food, and then betakes himself to some leafy shade to avoid the heat of the noonday sull. In more open places, on the outskirts of the bush, where huge clumps of Astelic fasten themselves to the dead or withering branches, the Kaka may somctimes be seen eagerly tcaring opcn the matted roots of this parasite, in quest of the worms and beetles which find an abode there, attracted by the moisture.

In the South Island, during certain scasons, it frequents the open land, alternately perching on the rough blocks of trachyte and feeding among the grass and other stunted vegetation. I remember on one occasion, some years ago, counting upwards of twenty at a time on the Port hills which divide Lyttelton from Christchurch.

On its feeding-habits Captain Mair writes to me:- "In Junc 1875 I was at Tuhua in the upper Wanganui. I found the Kakas therc so fat that they could not fly. I actually cauglit fifteen of them on the ground, as they werc unable to take wing."

Mr. Buchanan informs me that he has secn the Kaka stripping off the bark from a green tree 
(Panax colensoi), and sucking up with its tongue the gummy matter underneath, in the same manner that it extracts the honey from the flowers of the Phormium tenax; and Mr. Potts has observed it luxuriating on the viscid nectar which fills the blossoms of this tree in spring time, till sated at last it cleanses its beak against a neighbouring bough, and then, with grateful clatter, glides off to join its fellows.

It is said also to feed on the sweet honey-like substance which exudes copiously from the bark of the Fagus when it is attacked by the fatal grub.

When migrating from one part of the country to another, the Kakas travel in parties of three or more, and generally at a considerable height, their flight being slow and measured and their course a direct one. They occasionally alight, as if for the purpose of resting, and in a few minutes resume their laboured flight again. On these occasions the bleached and bare limbs of a dry tree are always selected, when one of the requisite elevation is within reach, as affording most fully that which they appear to delight in, an unobstructed prospect.

A curious circumstance in the natural history of the Kaka was mentioned by me, on the authority of an eye-witness, in a communication to the Wellington Philosophical Society*. At a certain season of the year, when this bird is excessively fat, large numbers of them are found washed ashore in Golden Bay, or on the Spit which runs out from it. They are generally dead, but if not, are so exhausted as to be unable to take wing. The apparent explanation is that the Kakas in their migration across Cook Strait, which is widest at this part, are unable to maintain the long flight, owing to their fat and heavy condition, and fall into the sea. The set of the current being towards Cape Farewell, the bodies of the perishing birds are swept in that direction and finally cast ashore.

It is surprising how seldom one meets with dying birds in their natural or wild state. Like Macgilliwray's wounded Gull, seeking some quiet retreat in order to "pass the time of its anguish in forgetfulness of the outer world," birds in general, and indeed all wild animals, have the faculty of hiding themselves away when the time of their dissolution approaches. During the many months I have spent in the New-Zealand woods I never but once picked up a bird that had died from natural causes, and this was a little Riroriro at the base of a kauri tree, as mentioned on page 45 . On one occasion, however, at Omahu; about the end of July, a native brought in a Kaka which he had caught by the hand at the roadside. It seemed sickly, drooping its wings and uttering its "ketekete" when touched. My friend, Renata Kawepo, put it on a parrot-perch as a mokai, but it died that night.

On the ground it generally moves by a succession of hops, after the manner of the Corvidx, and not with the awkward waddling gait peculiar to most Parrots. In the trees, where it is more at home, it is perpetually on the move, often walking deliberately along a branch, and then climbing to another by a dexterous use of both beak and feet, or silently winging its way to a station in a neighbouring tree. Its alarm-cry resembles that of the Sulphur-crested Cockatoo of Australia. During the pairing-season the two sexes are always together, and when on the wing keep side by side, both calling as they go. In the neighbourhood of their nests they have a low call-note, like $k i-i-t o, k i-i-t o$, and a very soft whistling cry.

Possessing excellent powers of mimicry, and useful to the natives as a decoy-bird, the Kaka is much sought after, and almost every native village has its "mokai." Like most Parrots, it is a longlived bird; and one which had been in the possession of the Upper Wanganui tribes for nearly twenty years presented the curious feature of its overgrown mandibles completely crossing each other. This was no doubt attributable to the fact of its having been constantly fed with soft food, thereby depriving the bill of the wear and tear incident to a state of nature. It is not so easy, however, to

* Trans. N.-Z. Instit. 1878, vol. xi. p. 369. 
account for this abnormal growth in a wild specimen, obtained by Mr. Lambert at Akaroa, which presents the same feature, and in an exaggerated degree, both mandibles being quite deformed.

It would seem that in this species there is a natural tendency to a deformity of growth in this respect. This will be manifest from the dravings of two renarkable examples which I gave in the 'Transactions of the New-Zealand Institute' for 1876 (vol. ix. page 340).

One of these represents a specimen in the Canterbury Museum; and the other a case of natural deformity in the British Museum, which was brought under my notice by Dr. Günther.

The tame Kaka is very susceptible to kindness, and forms strong attachments. It soon learns to distinguish its keeper's voice, and will respond to his call. It often, however, proves a mischievous pet, especially if it gets access to the orchard, where I have known it, in a single day, nip off thousands of blossoms from a promising pear-tree. I have seen it treat a favourite vine in a similar manner and apparently from a sheer love of mischief.

If it be allowed the freedom of the house, it will destroy the furniture in the most wanton manner with its powerful beak and proclaim itself a nuisance in a variety of ways*.

When the korari-flower (Phormium tenax) is in season, the Kakas repair in flocks to the flaxfields to feast on the flower-honey; and on these occasions numbers of them are speared by the nativcs as an article of food. In the woods also at certain periods they are captured in abundance by means of an ingenious snare called a "tutu" worked by a decoy-bird.

I have seen it climbing among the crimson flower-stalks of the tree-honeysuckle (Knightia excelsa), gathering the honey most carefully with its long brush-fringed tongue. At another season it feeds on the pollen of the kowai (Sophora grandiflora), when the feathers of its head become stained with the yellow juice.

The tame village Kaka is not the useless pet that Parrots generally are. It may amuse the young people by its wonderful articulation of Maori words and phrases, and by its whistling powers, but it has far more substantial attractions for the owner. It is a source of profit and subsistence to him; and as it requires the experience of several scasons to give it a proficiency as a decoy-bird, it acquires a specific value according to its age and training. I have known a native refuse an offer of $£ 10$ for a well-trained "mokai," although an aged bird and in a very ragged condition of plumage.

* MIr. W. T. L. Travers writes :- " The habits of the Kaka are in many respcets remarkable. In its absolutcly wild state it is fearloss and inquisitive. I have often, whilst resting on the banks of a stream which falls into the lake [Guyon], and runs through forest frequented by these birds, seen several of them gravely take post upon some trees close to me, cyeing mo with the utmost apparent curiosity, and chattcring to themsclves as if discussing the character and intentions of the intruder. After the lapse of a few minutes they have darted away, nttering loud eries, as if proclaiming to the rest of the forest the presence of a stranger, who was eithcr to be avoided or not, as tho case might bo. During the winter season the wild birds often unhesitatingly enter the house for food, making themsclves thoroughly at home, and even roosting on the cross-beams in the kitchen on spccially iuclement nights. Two of these in particular soon learnt how to open the door of the dairy, which they were fond of getting iuto, in ordcr to regale themselyes on ercam and butter, both of which they appeared to likc excessively. I have had sevcral of thesc wild birds billing on the eaves of the house in the evening, waiting to be fed, and coming readily to receivo from the hand pieces of bread spread thickly with butter, and strewed with sugar. But they rarely eat any of the bread itself, dropping it as soon as they had cleared off tho butter aud sugar. If one bird happened to have finished his portion before the others, he unhesitatingly helped himsclf to a share of some neighbour's goods, which was always yielded without the slightest demur. They are fond of raw flesh, and I have seen them hovering in front of a shecp's pluck hung on a tree, precisely as a Humming-bird hovers in front of a flower, eating fragments which they tore off, giving the preference to the lungs, When anxious to get into the house, they take post on the window-sills and beat at the window with their beaks until admitted. They are very mischievous, however, invariably cutting off all the buttons from any article of clothing which may happen to be left within their reach. I regret to say, indeed, that in some instances their familiarity degencrated into such gross impudence, that my manager was obliged to kill them, in order to prevent their constant mischief." (Trans. N.-Z. Inst. 1871, vol. iv. pp. 209, 210.) 
These pets are never caged, but are secured to a perch by means of a "poria " made of bone, in the form shown in the accompanying woodcut, the bird's foot being squeezed through the ring, so as to make the latter encircle the tarsus, and a thong of plaited flax-fibre, of convenient length, being then attached to the outer process and tied to the perch".

As will be seen by the full descriptive notes given above, very beautiful varieties of the Kaka are net with. I have never seen a pure albino; but I am assured by the natives that they are occasionally found, and. Major Messenger of Taranaki has the skin of one which he has kindly promised to send me. I am informed that a bird very nearly approaching that condition was shot at Whauwhau (in the county of Marsden) in the summer of 1863. The value set

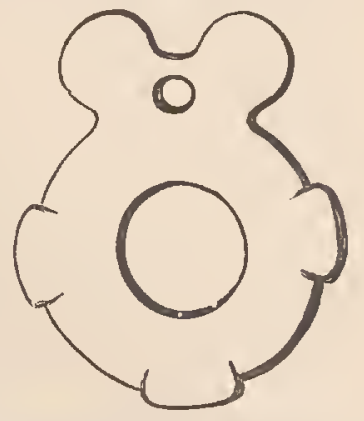
on these rare varieties by the natives may be inferred from the following circumstance:-A "kakakorako" was seen by a party of Rangitane in the Upper Manawatu, and followed through the woods as far as the Oroua river, every effort being made to take it alive. The Oroua people (of another tribe) then took up the chase, and followed the bird to the foot of the Ruahine range; and although carrying guns, to their credit they allowed it to escape rather than shoot it, in the remote hope that it might hereafter reappear in their district. Nor were they disappointed. Two seasons later the bird came back to the Oroua woods, and was taken alive by a native trapper. It was forwarded to Wellington by Mr. Alexander MacDonald, and, after passing through several hands, was ultimately sent to Europe. Finally it came into the possession of the late Mr. Dawson Rowley of Brighton, and formed the subject of the beautiful plate which faces page 26 of his 'Ornithological Miscellany, part i.

From some unaccountable cause the Kaka has always been a comparatively scarce bird in the forests north of Auckland, although there is no lack of its ordinary food supply. In some other districts it is less common than it formerly was; but it still exists, in very considerable numbers, in various parts of the country. In the months of December and January when the rata is in flower, thousands of these birds are trapped by the natives, in the manner already indicated, and which I will presently describe more fully. Partly owing to this cause and partly to the extension of settlement in some districts, where, in former years, they were excessively abundant, their cry is now seldom or never heard; but in the wooded parts of the interior they are as plentiful as ever. Certain wooded ranges are noted as Kaka-preserves, and are very jealously protected by the native tribes owning them, who annually resort to them for the purpose of trapping these birds as an article of food. Nor is this its only practical value. Some half-dozen of the pillows in my house are filled with the feathers of the Kaka; and they are so delightfully soft and elastic that it is a positive luxury to sleep on them. These feathers were obtained at Raukawa, in the Upper Monawatu, some twenty years ago, when Kakas were far more plentiful in that part of the country than they are now: With the march of settlement, roads have been made, townships have sprung up, and a railway-line is being laid down within a mile or two of Raukawa, thus altering the whole face of the country. At the time to which I refer this place could be only reached by a canoe journey of some eighty or ninety miles from Foxton, or by a rude bush-track-one of the Maori war-paths of former times. The Manawatu gorge, lying just above, has now become a highway of busy traffic; the telegraph-wire already connects it with the commercial centres, and so, indirectly, with every

* The Rev. W. Colcnso, F.R.S., remarks :- " The poor prisoners had not the eommon chanee allowed them of biting and tearing their perch, or any wood (and this from mero thoughtlessness and carelessness, or long-eontinued enstom, on the part of their Maori owners), for they were invariably kept fastoned by a bone ring or earved eirelet around ono leg, and thus tied securely, but loosely, with a strong, short eord to a slender, polished, eylindrieal hard-wood spear, up and down which, for the space of 2 or 3 feet, the poor bird ran and danced and flapped his wings, always without water, and frequently in tho hot burning sun, without any shade." 
part of the civilized world; steamboats are on the river, and the forest solitudes have exchanged the Kaka's scream for the whir of the saw-mill and the sound of the woodman's axe. This is, of course, the inevitable result of progress all over the country. What the condition of our avifauna will bc in another twenty years it is not very hard to predict, especially when we reflect that, in addition to this legitimate pressure from without, the Government is threatening to bring about the extinction of all the terrestrial native species by the wholesale introduction of stoats and fcrrets.

The Kaka is particularly abundant in the Urewera country, and during the short season the rata is in bloom the whole Maori population, old and young, are out Kalka-hunting. An expert bird-catcher will sometimes bag as many as 300 in the course of a day; and at Ruatahuna and Mangapohatu alone it is said that from 10,000 to 12,000 of these birds are killed during a good rata. season, which occurs about every threc years *.

There are several modes adopted for catching the Kaka, but the commonest and most successful is by mcans of a trained mokai or tame decoy, the wild birds being attracted to artificial perches, skilfully arranged around the concealed trapper, who has simply to pull a string and the screaming Kaka is secured by the lcg, as many às three or four being often taken at the same moment. At the close of each day the dead birds are buried, and when a sufficient number have been collected they are unearthed, stripped of their feathers, fried in their own fat, and potted in calabashes for winter use, or for presents to neighbouring tribes. The perches used for Kaka-trapping are often elaborately carved and illuminated with paua shell.

It may be mentioncd that the birds manifest extreme fastidiousness in the matter of these perchcs (or tutu-kaka as they are called), alighting very readily on some, and avoiding others in the most careful manner.

'Thcy commence breeding in the early part of November; and at Christmas the young birds are old enough to be taken from the nest, although, if unmolested, they probably do not leave it before the second week of January, or even later. The place usually selected for depositing their eggs is the deep hollow of a tree the heart of which is completely decayed. There is very little attempt at forming a nest, the eggs being placed on the dry pulverized wood which these cavities usually contain.

Mr. James Edwards of Kihi-kihi assures me that on more than one occasion, when taking wild honey from old Kaka holes, he has found the skeletons of the young birds underneath the honeycomb, showing that the bees had dispossessed the birds and appropriated the nest as a natural hive. I have heard similar accounts from Maoris in various parts of the country, and have no reason to doubt the fact.

The cggs are generally four in numbcr (sometimes, according to the natives, six), broadly ovoid, measuring 1.6 inch in length by 1.2 in breadth, with a slightly glossy surface, and pure white in colour till they become soiled and staincd in the process of incubation. Much care, and even some degree of fastidiousness, is displayed in the choice of a suitable tree; and once decided on, it is often resorted to by the same birds for many seasons in succession. On this account the natives set a high value on their "rua Kaka." The mere robbing of the nest, if accomplished with caution, does not cause the birds to abandon it; but the natives consider it of importance not to breathe into the cavity or to touch any part of it with their hands, for fear of "polluting" the nesting-place and causing its desertion. A nest which I discovered in the Otairi range, on my journey to Taupo, on the 23rd December, contained two young ones, apparently about ten diays old. In a large maire tree with a decayed heart, about three feet from the ground there was a long narrow opcning (measuring 2 feet in length by only 14 inches in width) leading into an inner chamber more than a foot in diameter. The walls of this chamber were smooth; and on the floor there was a deep layer of decayed wood,

* "Rarangi tahi" is the Maori proverb in allusion to this periodic recurrence of the Kaka season. 
mixed with fragments of dry rata-bark, evidently collected by the birds and brought into the cavity. The natives state that two females, attended by one male bird, sometimes breed in the same cavity, their nests being placed side by side. The fact that during the breeding-season three birds are frequently seen in company, appears to give some colour of truth to this statement.

Mr. Enys informs me that, on Sir Charles Clifford's station at Stonyhurst, he found two nests of the Kaka, one of them situated in the crevice of a rock in a low mountain-gully, and the other in a deep cavity under the roots of a tree. This was on the 24 th of December ; and both nests contained young birds.

An egg of this species received from Reischek is much soiled on the surface, being more or less of a dark brown colour, as if stained by contact with decayed wood or some other colouring-matter. It was taken (late in December) from a hollow pukatea tree in the central part of the Little Barrier, just below the high pinnacle of rocks so distinctly visible at sea. The nest contained four eggs, all of which, as my correspondent assures me, were stained in a similar manner.

An egg from Dusky Sound yields somewhat larger measurements than those given above, is creamy white in colour, and marked with extremely fine points, making the surface almost granulate; but these may be regarded as mere individual variations. It was taken on the 13th April, from a tree-hole, in whicl a soft nest had been formed by means of pulverized rotten wood and feathers, apparently plucked from the bird's own breast. Besides this egg there were three young birds in the nest, and the mother, who remained in possession, defended her offspring in a very plucky manner.

A nest of four eggs in my son's collection presents this difference, that all of them are slightly larger than ordinary examples, measuring 1.7 inch in length by 1.25 in breadth. They were evidently freshly laid when taken, the surface being beautifully white.

Besides Nestor meridionalis, there is another very distinct species ( $N$. notabilis) inhabiting New Zealand, a full account of which will follow next in order. But, in addition to these, there recently existed on Phillip Island a closely allied form (Nestor productus) which is now extinct, although many specimens of it are preserved in public and private museums in this country. Another (N. norfolcensis), formerly inhabiting Norfolk Island, although recognized by Dr. Finsch as a distinct species*, was probably only a local variety of this highly variable form. These are the only known representatives of the genus Nestort.

* N. producto similis; at pileo et eervieo viridibus; dorso ae teetrieibus alarum olivaeeo-viridibus, horum maculis apiealibus nigris triangulis; genis flavis; peetore abdomineque superiore ochraceis, unieoloribus ; rostro insigniter longo, introrsum eurvato.

t The following "Note on tho Tongue of the Psittaeine genus Nestor" was communieated to the Zoological Socicty by the late Prof. Garrod, F.R.S.:- “On the death of a specimen of Nestor hypopolius in the Society's Gardens, a short time ago, Mr. Sclater kindly directed $\mathrm{my}$ attention to the peculiarity of its tonguo, and referred me to Dr. Finseh's work on the Parrots, whero Nestor is placed among tho Trichoglossine, though tho author states that he is not possessed of any very precise information on the subjeet.

"Mr. Gould, in his 'Birds of Australia' (vol. v. pl. vi.), partly deseribes the tongue of this bird, and shows that it is not that of a Lory; but he has omitted to notice its chief peeuliarity.

"Dr. Buller, in the recently published 1st part of his 'Birds of New Zealand' [1st edit.], has also described the tongue quite correctly, though not much in detail_but nevertheless places Nestor close to the Lories, mentioning that this affinity was first shown by MIM. Blanehard and Pelzelu. As, however, the tongue of Nestor does not in reality resemble that of the Trichoglossi at all, it may be of interest to deseribe it more fnlly.

"As far as I have had opportunity of observing, in all Parrots the fleshy tongue ends anteriorly by a dilated portion, supported on a narrower neek. This tip is mueh like the end of a human finger, as mentioned by most observers: and its funetion is similar also; for it is employed by the bird as a third prehensile organ in connexion with the upper and lower beak, any solid substanee being held by the tongue and upper beak, while the mandible is freed to give another bite. Continuing the 
simile of the finger, the tip is directed forwards with the nail-like portion downwards, the part corresponding to the free edge of the nail appearing along the lower margin of the anterior rounded surface. This unguis, or nail-like porlion, appears to me further to resemble a nail in that its anterior edge is not quite regular and is free, while the posterior margin is continuous with the neighbouring epithelium, which is almost enough to show that it grows forwards, and is worn down, as is a nail, by constant contact with foreign substances. In the typical Parrots this unguis of the tongue is broader than long, horny in texture, semicylindroid, with its latcral margins extending up the sides of the organ and cncroaching on the borders of the superior surface for a short distance; not imbedded at the sides as is a nail. Its anterior border is nearly straight.

"In the Trichoglossi this horny plate is also present, and is similarly constructed; but on the superior surface of the tongue, between the lateral edges of the unguis, in the part which in others is covered by a smooth longitudinally plicated epithelium, there is an arrangement of retroverted papillw forming a spinous covering; and their mechanism is such that when tho tongue is protruded beyond the mouth to grasp any object, the papillæ stand upright or are even directed somewhat forward.

"In Nestor there are no papillæ of this description, but the tongue is here, as Dr. Buller says, 'soft, rounded on the edges, with a broad central groovc, and it is as smooth as in other Parrots. 'Thereforc the Kaka Parrot cannot in this point be said to approach the 'Triehoglossi (badly so called).

"The peculiarity of the tongue of Nestor consists in the fact that the anterior edge of the unguis, always free (though for a very short distance) and jagged, as mentioned above, in the other birds of the cluss, is here prolonged forwards, beyond the tip of the tongue, for about $\frac{1}{10}$ inch as a delicate fringe of hairs, with a crescentic contour. This fringe seems to rcsult from the breaking up into fibres of the forward-growing plate, which is always marked by longitudinal striations, clearest antcriorly, the result of nncqual density and translucency of tho tissue composing it, though on making a cross section I was not able to find any of the longitudinal papillary ridges whieh are present in the human nail and which the striation led me to cxpect. The unguis is also longer than broad, and vory narrow considering the sizc of the bird, as is also the whole tongue, thongh the length is greater than in others of the class. In the living bird the mouth is moist, as in the Lories, and not, as in the Cockatoos and others, dry and scaly.

"From these considerations, and a comparison of the tongues of Stringops, Nestor, and Trickoglossus, it is erident that the structure of this organ would lead to the placing of Nestor among the typical Parrots, thongh an aberrant one, and not with the Trichoglossina ; and other points in its anatomy farour this conclusion." (P.Z.S. 1872, pp. 787-789.)

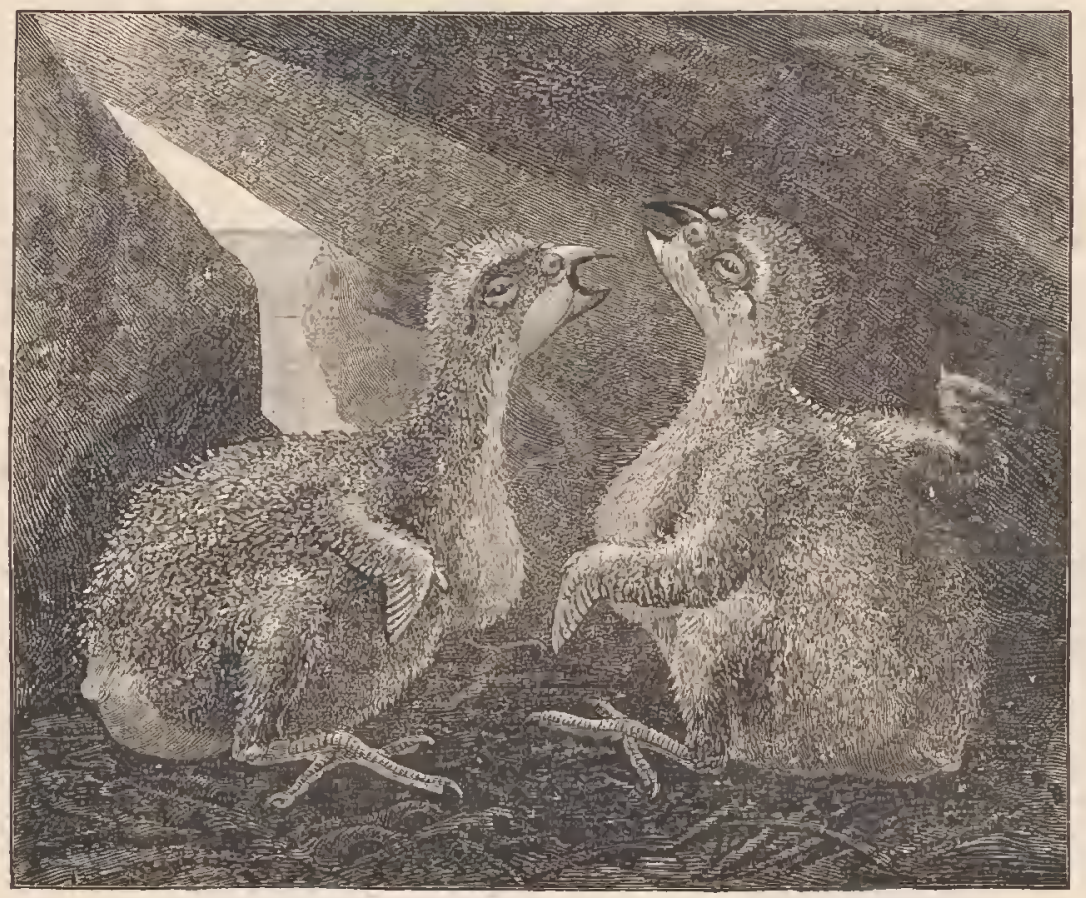

Nestlings of Nestor notabilis. (Seo page 174.) 


\section{NESTOR NOTABILIS.}

\section{(KEA PARROT.)}

Nestor notabilis, Gould, P. Z. S. 1856, p. 94.

\section{Native names.}

Kea and Keha; "Mountain-Parrot" of the colonists.

đิ superne omninò olivacco-viridis : plumarum omnium scapis et marginibus nigricantibus : pilco panllò dilutiore, vix canesceutc: facie latcrali magis brunncsccntc: dorso postico, uropygio et supracaudalibus sordidè crucntatis versus apicem angustè flavicantibus et nigricante marginatis, his imis olivaceo-flavicantibus: scapularibus et tcctricibus alarum dorso concoloribus, his majoribus extùs vix cyanescente lavatis, remigibus nigricantibus, alâ spuriâ et primariis vcrsus basin cyanesccntibus, secundarïs olivaceo-viridibus dorso concoloribus : remigibus subtùs pogonio interno versus basin citrino transfasciatis : caudâ olivacco-viridi, suprà sordidè cyanesccnte lavatâ et fasciî̀ nigrâ anteapicali transnotatâ, rectricibus subtùs flavicante tinctis, et pogonio interno citrino vix aurantiaco dentatis: corporc toto subtùs olivaceo-viridi, plumis nigricante marginatis, abdomine dilutè aurantiaco lavato: subalaribus et plumis axillaribus læè̀ scarlatinis, minimis flavicantibus, angustè nigricante tcrminatis: rostro cinerascenti-brunnco, mandibulâ ad basin læatè flavicante : pedibus flavicanti-olivaceis.

q mari simillima, sed sordidior et plumis nigricante latiùs marginatis.

Adult male. Gcneral plumage dull olivc-green, brighter on the upper parts, with a rich gloss; each feather broadly tipped and narrowly margined with dusky black, with shaft-lincs of the same colour, except on the head, where therc is merely a darkcr shaft-linc; ear-coverts and cheeks olivaceous brown, with darkcr margins; feathers on the sides strongly tinged with orange-red; primaries dusky brown, the outcr webs light metallic blue in their basal portion, largely toothed on the inncr web with bright lemoll-ycllow; secondaries greenish blue, changing to olive on their outer wcbs, dusky brown on thcir inner, and toothed with orange-ycllow ; lining of the wings and axillary plumes vivid scarlet, with narrow dusky tips; inner coverts towards the flcxure washed with lemon-yellow; rump and upper tail-coverts bright arterial-red mixed with olive, and prettily vandyked at the tips with dusky black, this colour being richcst on the middle tail-coverts and changing on the lateral ones to bright olive sladed with red and tipped with brown; tailfeathers olive-grecn on their npper surface, with a finc metallic gloss, paler at the tips, inclining to blue on the outer feathers, the whole crossed near the extremity by a broad band of blackish brown; the under surface palc olive-grecn, with the subterminal band less distinct, and broadly toothed on their inner webs with bright lemon-ycllow; under tail-covcrts dull olivc-green, tipped with brown. Iridcs black; bill greyish brown; lower mandible rich wax-yellow in its basal portion; cyelid and cere dull yellow; feet yellowish olivc, with paler soles. Total length $19 \cdot 5$ inches; wing, from flexurc, 12.5 ; tail 7.5 ; bill, along the ridge $1 \cdot 75$, along the edge of lower mandible 1 ; tarsus 1.5 ; longer fore toe and claw $2 \cdot 25$; longer hind toe and claw 2.

Female. Similar to the male, but having the tints of the plumage generally duller, and the dusky margins of the fcathers broader.

Obs. The bill is very variable, measuring in one of my specimens $2 \cdot 25$ inches along the ridge, and $1 \cdot 5$ along the edge of lower mandible. In somc cxamples the lowcr mandible, instead of bcing ycllow at the basc, is dark brown, like the upper onc, with only a faint line of lighter brown down the centre. This is probably characteristic of the young bird. 


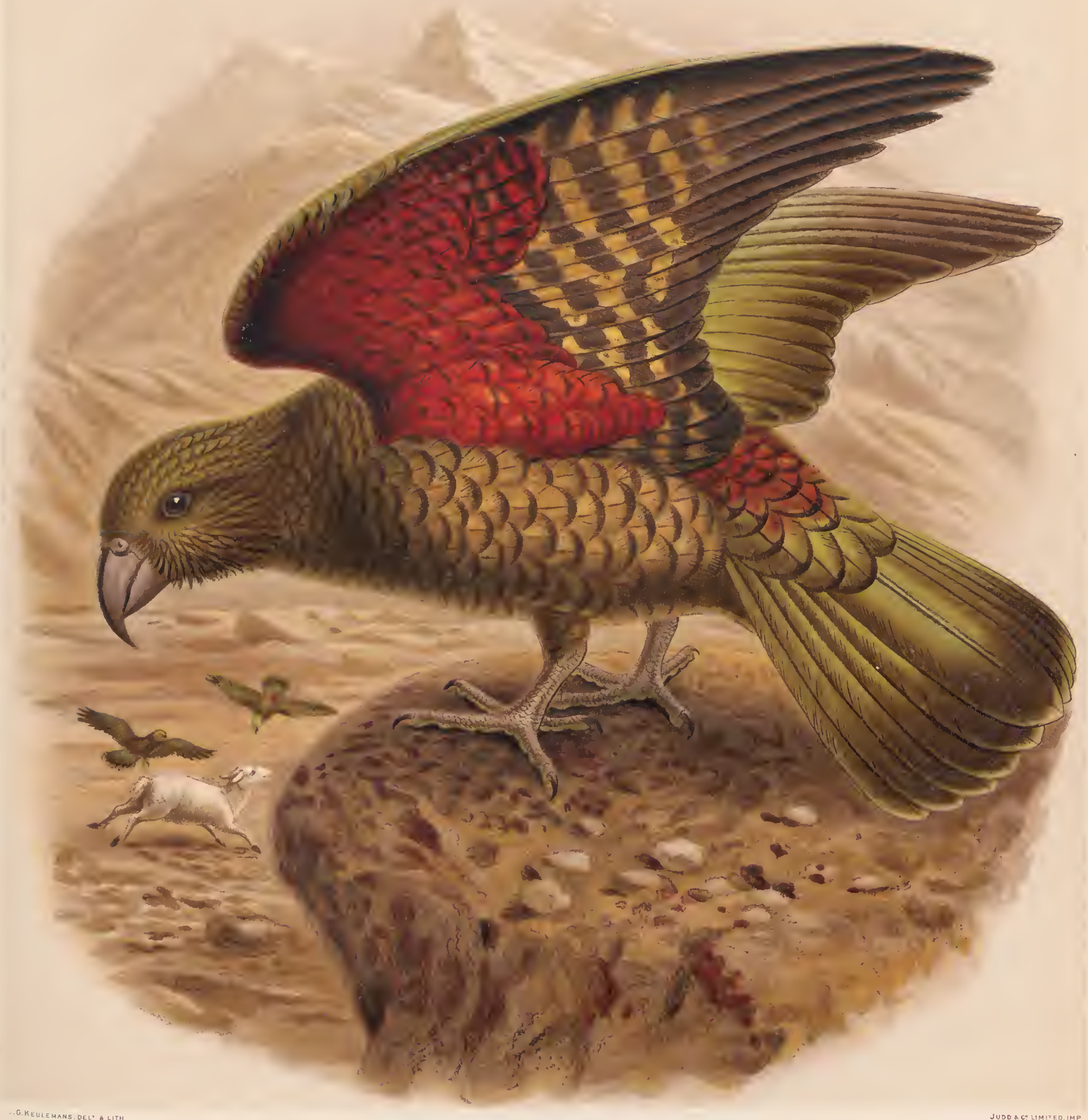

K E A PAR R O T

NESTOR NOTABTLIS. 

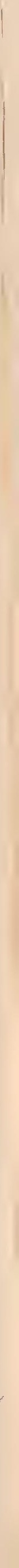
I examined a very brightly coloured specimen in the Otago Museum, the marlkings being unusually distinct. On the upper parts ench feather has a narrow subtcrminal crescent of dull yellow, bordering the blaek and imparting a very pretty effect. The nuchal eollar is heavily margined witl brownish black, giving it the appearance of a collaret of looped lace-work. The feathers covering the rump and the short upper tail-coverts are dull crimson shading into green, then bordered by bright crimson and terminally margined, in a deeply notched manner, with black; on the tail-coverts there are generally two bands of bright crimson, and the larger coverts are uniform olive-grcen with black margins. These margins are very conspicuous on the back and mantle; but the blue on the outer webs of the primarics is less vivid than in many other specimens I have seen. Bill dark grcy, without any tinge of yellow; the sides of the lower mandible paler grey. (Presented by Mr. Spence, Aug. 1877.)

Varieties. As with the other members of the genus Nestor, individuals vary much in the brilliancy of their tints. In July 1883, Mr. J. H. Berryman sent me the following description of a specimen procured by a friend of his in the interior of Otago :- "Bright canary-yellow, with a fer red feathers interspersed throughout the plumage; vivid red on the rump and upper tail-coverts, as well as under the wings. Such a gorgeous bird has never been seen in the district before."

Remarks. Apart from the difference in plumage, this spccies differs from Nestor meridionalis in having more pointed wings; it likewisc has a longer, slighter, smoother, and less curved bill, witlout any notch. The subjoined woodcuts will best illustrate the divergence of character in this respect.

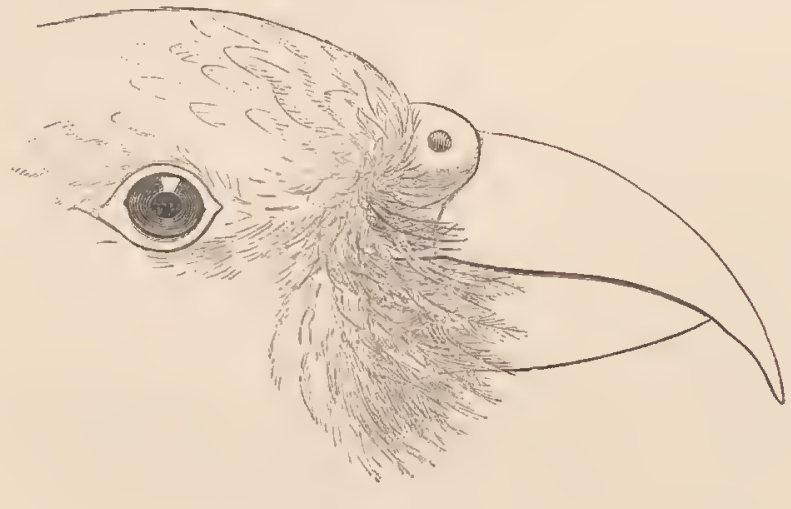

Nestor notabilis.

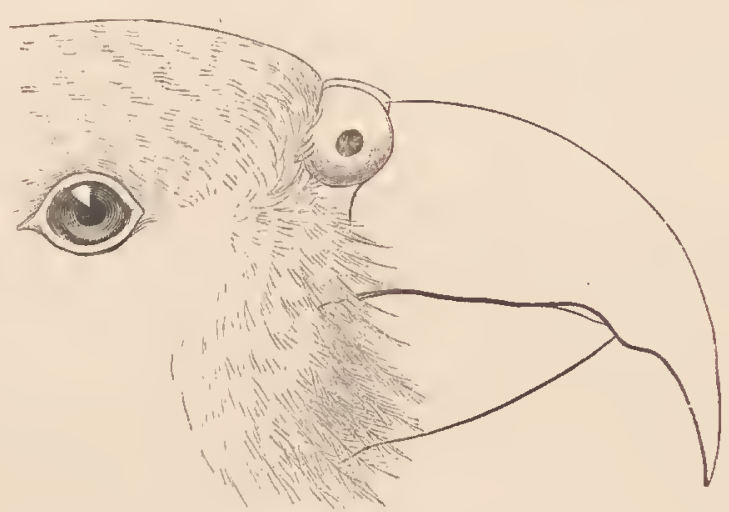

Nestor mevidionalis.

The first recorded examples of this interesting bird were obtained in 1856 by $\mathrm{Mr}$. Walter Mantell, one of the early explorers of New Zealand, to whom we are indebted for many valuable discoveries in natural history, and who is now one of the patrons of science in his adopted country. Two specimens, from the Murihiku district, in the South Island, were forwarded by that gentleman to Mr. Gould, who thereupon characterized the species in the Proceedings of the Zoological Society, and figured it in the Supplement to his 'Birds of Australia.' Nothing more was heard of the Kea till the year 1859, when Dr. Haast received a fine example which had been caught on Mr. Tripp's station, near Mount Cook, and forwarded it, preserved in spirit, to Professor Owen. In the winter of the following year I first made the acquaintance of the species on a station near the Rangitata Gorge, where a live one, which bad been snared by a shepherd and partially tamed, was frequenting the premises. Of late years, however, owing to the spread of colonization and to the development of a new character in the bird itself, to be presently mentioned, we have become better acquainted with this remarkable Parrot*.

It is essentially a mountain species, inhabiting the rugged slopes of the Southern Alps, and

* Cf. remarks on the skeletons of Nestor notabilis and Stringops habroptilus, with illustrative plates, by L. v. Lorenz, SB. Ak. Wiss. Wien, Bd. Ixxxiv. Abth. 1, pp. 624-633, pls. i.-iii. 
descending to the plains only during severe winters when its customary haunts are covered with snow and its means of subsistence have consequently failed *.

That distinguished explorer and geologist, the late Professor von Hochstetter, in describing the physical features of New Zealand, gives the following graphic account of the grand scenery in the South Island:- " High, precipitous, craggy mountain ranges, intersected by narrow longitudinal valleys, run parallel to each other from Foveaux Strait to Cook's Strait. They are connected by transverse ridges and intersected by the deep transverse valleys of the various rivers. In the centre of this range are seen, towering up in majestic grandeur, the peaks of Mount Cook, Tasman, and the adjacent mountain giants, glistening with perpetual snow and ice, to a height of 13,000 feet above the level of the sea, almost as high as Mont Blanc. Splendid glacier streams, lovely mountain lakes, magnificent cataracts, mountain passes, and gloomy ravines with roaring mountain streams rushing through them-such are the charms of a wild and uninhabited Alpine region but seldom trodden by human foot!" But this furnishes only a passing glimpse of our noble southern Alps, with their lofty peaks, capped with perpetual snow, flanked with glaciers of almost measureless depth, and presenting some of the finest mountain scenery in the world. In the deep valleys which divide these upheaved zones of stratified rocks of different ages luxuriant forests flourish, and on the high mountain-slopes there is the characteristic low vegetation, becoming more and more stunted as it approaches the line of perpetual snow. Such are the haunts of the Kea! I have seen it soaring or flying-often in parties of three or more-from one peak to another, high above the wooded valley; but it is more generally to be met with on the open mountain side, flying from rock to rock, or hopping along the ground amongst the stunted alpine regetation, in quest of its natural food.

Sir James Hector found it everywhere in the snow-mountains of Otago during his topographical survey of that region in 1861-62. As a rule these birds were so tame there that he had no difficulty in knocking them over with a stone, or other missile, when he wanted to replenish his larder.

For many years the Kea ranked amongst our rarest species, and it is not very long ago that a specimen fetched $£ 25$ in the London market. But all this is changed, and, although still of very rare occurrence in the northern parts of the South Island, and quite unknown in the North Island, it has become, as will presently appear, an absolute pest in the middle and southern districts.

At the heads of all the principal rivers in the provincial district of Canterbury it is comparatively common; and especially near the sources of the Rangitata river.

The late Sir Julius von Haast sent me, from time to time, some beautiful specimens obtained in these localities, in the course of his geological and other scientific work. He informed me that in disposition it is most inquisitive, prying into and examining everything that comes in its way. On one occasion he left a large bundle of valuable alpine plants, which he had collected with much labour, lying exposed on the summit of a lofty mountain-crag. During his temporary absence a Kea

* "The rigour of a hard winter, when the whole face of the alpine country is changed so as to be scarccly reeognizable under a doep canopy of snow, is not without its influcnee on the habits of this hardy bird. It is then driven from its stronghold in the roeky gully, and compelled to seek its food at a far less clevation, as its food-supply has passed away gradually at the approach of wintor, or lies burjed beyond its reach. The honey-bearing flowers have faded and fallen long before; the season that suceeded, witb its larish yield of berries, and drupes that gaily decked the elose-growing Coprosmas, the trailing Paimelias, or the sharp-lcared Leucopogos, has succumbed to the stern rule of winter. Nor has this change of season affected the flora of the Alps alone; the insect world, in a thousand forms, which enlivened every mountain-gully with the chirp and busy hum of life, now lies entraneed in its mummy state, as inanimato as the torpid lizard that takes its winter sleep, sheltered boneath some well-pressed stone. Under the effects of such a change, that cuts off the supply of food, the Ken gradually descends the gullies, where a certain amount of shelter has encouraged the growth of the kowhai that jields its supply of hard, bitter seeds, the beautiful Pittosporums with their small hard seeds packed in clusters, and the black-berricd Aristotelia; these and numerous other shrubs or trees, such as the pitch-pine and totara, furnish the means of life to the Parrot. It is during the continuance of this season that we have had tho best opportunities of becoming somewhat familiar with it."-Out in the Open. 
came down, and, with a supreme disregard for botanical science, tumbled the collection of specimens over into the ravine below, and quite beyond recovery. Mr. Potts also records an instance of this bird's extreme inquisitiveness. On one occasion a shepherd's hut was shut up, and left for a day or two, the man being required elsewhere. On his return he was surprised to hear something moving about within the hut; and on entering, he found that the noise proceeded from a Kea, which had gained. access by the chimney. On a closer survey, the worthy shepherd discovered that his visitor had been exercising its powerful mandibles to some effect on his slender stock of goods and chattels. Blankets; bedding, and clothes were grievously rent and torn, pannikins and plates scattered about; and everything that could be broken was apparently broken very carefully, even the window-frame having been attacked with great diligence.

When hunting for food in its wild mountain home, it may be seen perched for a few moments on a jutting rock, then descending to the ground to hunt for grubs and insects, or to gather the ripening seeds from certain alpine plants, it disappears for a time and then mounts to the summit of another rock, just as I have seen the Common Raven doing in the higher parts of the Bernese
Alps.

On the level ground their mode of locomotion is similar to that of the Kaka, consisting of a hopping rather than a walking movement. Like that bird also, they are semi-nocturnal, exhibiting
much activity after dusk and in the early dawn.

The cry of the Kea, as generally heard in the early morning, has been aptly compared to the mewing of a cat; but it likewise utters a whistle, a chuckle, and a suppressed scream, scarcely distinguishable from the notes of its noisy congener.

But the most interesting feature in the history of this bird is the extraordinary manner in which, under the changed conditions of the country, it has developed a carnivorous habit-manifesting it, in the first instance, by a fondness for fresh sheep-skins and other station offal, and then, as its education progressed, attacking the living sheep for the purpose of tearing out and devouring the kidney-fat, and inflicting injuries that generally prove fatal *. This habit, confined at first to only a few of the more enterprising birds, soon became general, and it is a common thing now for whole parties of them to combine in this novel hunt after live mutton! So destructive, indeed, have they become on some of the sheep-runs that the aid of Parliament has been invoked to abate the nuisance by offering a subsidy to Kea-hunters $\uparrow$.

* The first announeement of this strange development of character in the Kea was made in the 'Otago Daily Times' newspaper, in the following terms:-_"For the last thrce years the sheep belonging to a settler, Mr. Henry Campbell, in tho Wanaka district (Otago), appcared afflicted with what was thought to be a new kind of diseaso; neighbours and shepherds were equally unable to aecount for it, having never seen auything of the kind before. The first appearance of this supposed disease is a patch of raw flesh on the lnin of the shecp, about the size of a man's hand; from this, matter eontinually runs down the side, taking the wool completely off the part it touches; and in many cases death is the result. At last a shepherd noticed one of the Mountain-Parrots sticking to a sheep, and picking at a sore, and the animal seemed unable to get rid of its tormentor. The runholder gave direetions to keep watch ou the Parrots when mustering on the high ground; the result has been that, during the present seasou, when mustering high up on the ranges near the snow-line, they saw several of tho birds surrounding a sheep, which was freshly bleeding from a small wound on the loin; on other sheep were uoticed places where the Kea had begun to attack them, small pieces of wool haring been picked out. .... The birds come in floeks, single out a sheep at random, and each, alighting ou its back in turn, tears out the wool and makes the sheop bleed, till the auimal runs away from the rest of tho sheep. The birds theu pursue it, continue attacking it, and force it to run about till it becomes stupid and exhausted. If, in that state, it throws itself down, and lics as much as possible on its back to keep the birds from picking the part attacked, they then pick a fresh holc in its side; and the sheep, when so set upon, in some instances dies... . Whore the birds so attaek the shecp, the elevation of the country is from 4000 to 5000 feet above the sca-level; and they only do so there iu winter-time. On a station owned by Mr. Campbell, about thirty miles distant from the other, and at the same altitude, in the samo district, and where the birds are plentiful, they do not attaek the sheep in that way."

t The following statement appeared in one of the leading newspapers of the eolony:- In one instanee a foal was attacked in this manuer, and would havo died had it not been rescued; in another, 200 out of 500 ehoice sheep worc destroyed by these 
On the surgical operation performed on the living sheep by the Kea, an interesting paper was read before the Pathological Society of London, in November 1879, by the distinguished surgeon, Mr. John Wood, F.R.S. He exhibited the colon of a sheep in which the operation known as colotomy had been pcrformed by this Parrot, of which likewise he produced a skin, both specimens having been sent to him for that purpose by Dr. De Latour of Otago. Mr. Wood was informed by his correspondent that when the sheep are assembled, wounds resulting from the Kea's "vivisection" are often found on them, and not unfrequently the victims present an artificial anus-a fistulous opening into the intestine-in the right loin.

"The specimen exhibited was from a sheep that had been so attacked. It consisted of the lumbar vertebræ and the colon, showing the artificial an us between the iliac crest and the last rib on the right side-just in the place, that is, where modern surgeons perform the operation known to them as Amussat's; below the wound the intestine was contracted, while it was enlarged and hypertrophied above. The sheep was much wasted. 'The modus operandi was described as follows :-The birds, which are very bold and nearly as large as Rooks, single out the strongest sheep in the flock; one bird, settling on the sacrum, tears off the wool with its beak, and eats into the flesh till the sheep falls from exhaustion and loss of blood. Sometimes the wound penetrates to the colon, when, if the animal recovers, this artificial anus is formed; it may be on the left, but is more frequently on the right side *. It has been suggested that the bird aims at the colon in search of its regetable contents; but the Kea's carnivorous appetite has been too frequently noticed to necessitate any such hypothesis. 'This strange phase of development through which the Kea has gone since the European colonization of New Zealand, and the consequent introduction of sheep to islands in which indigenous mammals are almost unknown, by which it has come to prefer an animal to a vegetable diet, was first described in 1871 by Mr. T. H. Potts ("Nature,' vol. iv. p. 489); but it was reserved for Dr. De Latour to discover the interesting result which Mr. Wood has just introduced to English naturalists."Zoologist, Feb. 1880.

Before the full development of the raptorial habit described above, the penchant for raw flesh exhibited by this Parrot in its wild state was very remarkable. Those that frequented the sheepstations soon manifested a distaste for all other food and lived almost exclusively on flesh. They took possession of sheep's heads that were thrown out from the slaughter-shed, and picked them perfectly clean, leaving nothing but the bones. An eye-witness thus described this operation:"Perching itself on the sheep's head, or other offal, the bird proceeds to tear off the skin and flesh, derouring it piecemeal, after the manner of a Hawk, or at other times holding the object down with one foot, and with the othel grasping the portion it was eating, after the ordinary fashion of Parrots."

At this period of its history the plan usually adopted on the stations for alluring this bird was to expose a fresh sheep-skin on the roof of a hut; and whilst engaged in tearing up the bait it was easily approached and shot.

birds, whieh are the more difficult to shoot from their noeturnal habits. Two or three runs in wild distriets hare been abandoned in eonsequenee of the ravages of these harpies. This is a remarkable instance of change of habits, under altered conditions, for, of course, it is only within a fow years that sheep have been introduced into the part of the eountry the Kea inhabits, and there was formerly no indigenous animal for it to prey on. In the summer the Kea lives on honey and berries. It is in the winter, when these fail, that it descends from the mountains and harries the flocks." Another newspaper, by way of comfort, adds:- "The Keas have found rivals in Seagulls, which are now to be scen in the Lake Country, Otago, driving away the Kieas from the earcases of sheep these birds are devouring."

* Cf. an interesting article on Nestor notabilis, "Zoologist,' 1881, pp. 290-301; also the figure facing p. 184 of 'Out in the Open.' This illustration represents a secne from the alpine country when under snow ; a well conditioned merino is attaeked by a Kea, and the animal in its terror, rushing hither and thither, has broken away from a small mob of sheep and is undergoing the first experience of torture from the beak of the Parrot. 
In connection with the flesh-eating propensity of Nestor notabilis, I may mention a very remarkable case that occurrẹd within my own experience, in which a whole fraternity of caged Parrots took to " cannibalism," if I may so term the killing and devouring of one another, without necessity, and in defiance of their natural habits and instincts. I had the following Parrots associated together in one compartment of my aviary at Wanganui, viz. two King Lories (Aprosmictus scapulatus), a pair of Rosellas (Platycercus eximius), a pair of Blue Mountain-Parrots (Platycercus pennantii), and a Grass-Parrot (Platycercus semitorquatus), all of them species indigenous to Australia. For nearly two years they lived together on terms of perfect amity and friendship, feeding from the same seedtroughs, often playing and coying with each other, and forming a constant source of attraction by their noisy clamour and the glittering of their rich plumage in the sunlight. One species alone (the last-named) was moody and shy, generally retiring to the highest perch under the domed roof, and disputing its possession with the rest. At length one of the pretty Rosellas met with an accident, which, in part, disabled it in the wing. The attention that it received from its partner was quite touching to witness. The maimed bird being unable to reach its perch, and therefore compelled to roost at night on the lower framework of the ariary, its mate forsook its sheltered perch under the dome and took up its position beside it; and during the day it was constantly chattering to it in a low confidential sort of manner. But this mishap led to a series of disasters that proved fatal, in the end, to the whole company. The Grass-Parrot, still retaining his sulky demeanour, began to persecute the disabled Rosella, and ultimately killed and partly devoured it. There was abundance of grain and other food in the troughs; but the Blue Mountain-Parrots followed suit, and whetted their appetites on the defunct Rosella. Attributing this contretemps to the rveakly condition of the victin, I simply renoved the mutilated body, and left the murderer in the aviary. On the following morning, howrever, I found, to my dismay, that he had killed and partly eaten one of the beantiful Blue Mountain-Parrots, and was murderously pursuing the'surviving Rosella. I at once removed the author of all this mischief, and hoped to see harmony restored in the family; but the spirit of evil had been fairly roused, and I next found that the surviving "Blue Mountain" lad killed the male King Lory and was devouring his body. Then I witnessed another touch of nature; for the mate of the last-named bird fretted and moped, refused her food, and died of a broken heart. Finally, the bereaved Rosella, as if to seek revenge for the murcler of his sickly mate, made open war on the surviving female Blue Mountain-Parrot, and succeeded in killing her. I found this valiant little Parrakeet standing on the body of its vanquished eneiny, and whistling in the most excited manner. And thus, within the linits of a single week, a group of Parrots that had lived together so long on the most satisfactory terms had, during a contagious passion for killing and devouring, come to utter grief, and only a solitary male Rosella remained! This bird shortly afterwards gained its liberty; and thus terminated my first and last experiment with Australian Parrots. But it must be remem. bered that this was an abnormal development of character under domestication, or at any rate under the artificial restraints of confinement. The difference in the case of the Kea is that, in its wild and natural state, it readily feeds on raw meat, and seems to prefer that to its proper vegetable diet.

When the Ken first began to frequent the outstations and sheep-yards, it was very unsuspicious and tame. Mr. Potts, Jun., snared a number of them by means of a simple flax noose at the end of a long rod. He describes them as exhibiting great boldness and confidence, clambering about the roof of his hut, and allowing a very close approach, for they had not yet learnt to regard man as their natural enemy. When caught (he tells us) they remained quite still, without any of the noisy fluttering which usually accompanies the capture of birds, even when managed with adroitness. One of the birds caught by him was placed on the floor under an inverted American bucket, the places for the handle not permitting the rim of the bucket to touch the ground. The Kea, taking advantage 
of this, wedged its beak into the space, and using its head as a lever, it moved the bucket, raising it sufficiently to effect its escape *.

The 'New Zealand Herald' of Sept. 12, 1880, contained the following announcement, which shows how rapidly the Kea nuisance had spread through the southern part of the country :-

"Mr. D. A. Cameron, one of the oldest runholders in Lake Country, Otago, is throwing up his run at the Nokomai through the Keas, which, if not more numerous, are, according to report, becoming greater adepts at the destruction of sheep. Formerly the birds used to annoy and worry, but now they kill outright. There is not a run which includes mountainous country, but is more or less plagued with the infliction, and on one spur alone on one mountain range in the Wakatipu, a runholder lost no less than 1000 sheep during last year."

From the KcKenzie country Mr. W. W. Smith reports in 1883 :- “The estimated number of sheep annually destroyed by these birds is fifteen thousand. Formerly they attacked only the weak and dying sheep, canght in the snow-drift; but now the strongest and weakest suffer alike, both in summer and winter."

The war which is now being waged against this Parrot must, in the end, bring about its extermination. On some of the sheep-runs a bonus of three shillings a head is paid to the men for all they kill. Mr. Rolleston informed me that on his own little run at the Ashburton he had paid in one season for as many as 800 ; and I noticed, as far back as April 1884, a newspaper report that at the previous meeting of the Lake County Council no less than 2000 Keas' beaks were paid for.

In March 1884, Mr. R. Bouchier, the Sheep Inspector at Queenstown, reported that on a station on Lake Wanaka a mob of hogget-sheep were attacked by Keas, and in one night no less than 200 of them killed. Most of the birds, however, were afterwards destroyed by the shepherds, whose zeal in this work was stimulated by the bonus. The Inspector reported further that at the subsequent shearing hardly a sheep was marked, while the death-rate had been reduced by nearly one half. In the meantime the beaks of 1574 birds had been delivered at his office, for payment of the reward.

It is the fashion for cabinet ornithologists to declaim against the destruction of this "interesting form." But there is a good deal to be said on the other side. In some parts of the country the Ken nuisance has reached such a pitch that the runlolders have been fairly driven off their country. In places where a few years ago only occasional birds were seen they now appear in hundreds, attracted of course by the sheep $\dagger$. They are most numerous in winter, when, as already explained, they are driven down from their natural home in the mountains by the severity of the climate; and so bold do they become in their depredations, that, as I have been assured by credible eye-witnesses, they will actually attack a mob of sheep whilst being driven to the yards!

As a rule they confine their attentions to the latter animal; but there is at least one well-

* At a mecting of the Wellington Philosophical Society, a paper was read by Mr. Alexander MicKay, who related a number of personal observations on the Kea, which went to prove that this bird possesses a high degree of intelligence. The author expressed his own conviction, as the result of carcful observation, that the Keas had the power of communicating ideas among themscles. He rolated an anecdote within his own experience in support of this view. He statcd that on "one occasion a numher of Keas, aftor a consultation, delegated one bird twice in succession to untie the knot in a string which fastened one of their number to a piek-handle. This statement," the report continues, "evolied some diseussion. Mr. W. M. Maskell expressed great astonishment that even an intelligent bird like tho Kea should know how to untie a knot at first sight; but Dr. Hector, Mr. W. T. L. Travers, and other gentlemen who were present related instances of still more surprising sagacity on the part of native birds."

$\uparrow$ There oceurs the following singular confusion of two well-known Now-Zealand species (the Kakapo and the Koa) in Mr. A. R. Wallace's 'Anstralasia,' at page 561 :-- "Another remarkuble bird is the Owl-Parrot (Stringops habroptilus) of a greenish colour, and with a circle of feathers round the eyes, as in the 0 wl. It is noctumal in its habits, lives in holes in the ground under the tree-roots or rocks, and it climbs ahout the bushes after berries, or digs for forn-roots. It has fully developed wings, but hardly ever flies, and has lately exhibited a singular taste for flesh, picking holes in the backs of shecp and lambs" (!). 
authenticated case of their coming in force and attacking a valuable mare, which they seriously injured in the loins.

On the habits of this species Mr. John Gcorge Shrimpton, of Southbrook, Canterbury, has sent mc the following very intercsting notes:-

"While residing at the Wanaka Lake, I reccived a letter from my brother Walter (of Matapiro) to the effect that you would like a specimen of the Kea or Mountain-Parrot, and any notes of their habits which I might be able to afford you. My time there was so short after reccipt of his letter that, although many Keas were killed, I only succeeded in getting one fair skin, which I forwarded to you by mail a few days ago, and trust it has reached you safely. By this mail I forward a watercolour skctch of some young ones drawn from nature by Mr. Huddleston. In the rocky cavern, high up on the mountain, whence these werc obtained, were scveral broods of young ones of various ages and sizes.

"I believe the Kea does not come farther north than the Rakaia River, Canterbury, and is strictly confined to the central range and its spurs as a rule, but may occasionally and will probably be more seen on those hills adjacent to the main range which attain an elevation of five thousand feet and upwards. 'Thcre is no doubt that, in spite of the war waged against them, they are increasing very rapidly, probably owing to the plentiful supply of food in the shape of mutton which they can get, and to which they help thcmsclves most liberally. Fifteen years ago, when I first knew the Lake country, it was a rare thing to see these birds on the hills even in their chosen home among the snow ; but now you meet them in flocks of fifty even, and so bold have they become that they will attack sheep under the shepherd's immediate carc. Not that they werc ever very wild; on the contrary, I think they are the tamest birds in New Zealand; and it is their insatiable curiosity that has probably led them to find out the taste of mutton. At first, they contented themselves with tearing up tcits, blankets, and sheep-skins, the nsual impedimenta of a musterer's camp. They have now so improved upon that, that nothing less than the primest mutton will suit their fastidious tastes. Though so tame that you can often knock them down with a stick, and apparently so inoffensive, a single Kea will swoop down on the strongest fat wether or hogget, fix himself firmly on its back, generally facing the shcep's tail, and commence digging his daily mcal. Sometimcs the sheep runs till exhausted, sometimes contents itself by trying to dislodge its adversary by a serics of contortions only, but the Kea troubles himself very little about either; he hangs on till the sheep gives in. He then digs away, carefully avoiding the backbone, till he reaches the kidney fat. This is his choicest relish. His cries soon attract othcrs, and between them the poor sheep is soon fitted for a muscunı. Sometimes a sheep gets away from a timid or pcrhaps less expericnced workman; but he carries with him an indelible scar. On some stations about 5 per cent. of the wholc flock are mustercd in at shearing-time more or less marked in this manner, and the death-rate is almost incrediblc. I have no hesitation in saying that, on the runs bordering the Wanaka and Hawea Lakes, the loss from Keas alone is nothing short of from fiftecn to twenty thousand sheep annually, and these the primest of the flocks. Although Keas are scen openly enough in the daytime, there is no doubt thcy work their mischief mostly at night, a bright moonlight one being preferred. A severe wintcr, with sheep snowed in, is thcir great opportunity; and this they avail themselves of to the uttermost. Although, likc other Parrots, they are given to anything in the shape of fun or mischief (and, on one occasion they killed a young Kaka, tethered), I have never known them to seriously attack any animal other than a sheep. But as a moiety of them have advanced so far in the course of the last eight or ten years, it is impossible to say to what lengths they may aspirc in the future.

"I cannot state for certainty that there are no Keas north of the limits I have herc assigned as their habitat: I can only say that I have travelled over a considerable portion of that country without 
either seeing or hearing of them. But as to their habits and destructiveness in the neighbourhood of the great lakes south, I can speak from a long and painful experience."

I have reproduced, on a smaller scale, in the woodcut given on page 165 , the spirited drawing received from Mr. Shrimpton, exhibiting a pair of ungainly nestlings in their alpine nursery.

There is a fine living specimen of the Kea in the "Parrot-house" at the Zoological Society's Gardens, which appears to thrive in spite of the unnatural semi-tropical heat to which it is subjected *.

This bird was received from Dr. De Latour, who sent the following interesting account of it to 'The Field' prior to its departure from the colony:-

"A shepherd in bringing down a mob of sheep was annoyed by one of these Keas attacking the sheep while he was driving them down the mountains; being angry, he threw a stone at it and knocked it over. He succeeded in capturing it alive; he did not kill it, and in return the Kea made great havoc with his clothes. However, after cutting its wings and tying its legs together, he brought it down to his camp. There the shepherd broke lis own leg, and came under my care, and the Kea came down shortly after. He was in an ordinary cage made of wood and small iron wire. He was only a day and a half coming down eighty-four miles, but in that time the cage was all but destroyed, the wires bent, some broken in two, as though cut with pliers, and the woodwork was reduced to tinder, and it was just a piece of luck that he did not escape. I had a strong cage of galvanized iron and stout wire built for him, and he has now been with me for two years. The cage is a big one, about 3 feet high, 2 feet across, and 18 inches deep, so that he has lots of room to move about in. He is rather expensive to keep, as he generally gets a mutton chop every day; he does not like cooked meat, and will only take it if very hungry; he will not touch beef if he can get mutton, but is not averse to pork. Some say the Keas only want the fat, but this bird takes lean and fat impartially; indeed I find the fat parts often left on the bone, but never any of the flesh. I have tried him with canary and hemp seed, but he does not seem to care for it, only scattering it about as though for mischief, and they are very mischievous. I am told that when they get into an empty hut-and there are many of these huts used only on occasions when the shepherds are out mustering and away from home for some days-if any blankets, tin pots, sacks, \&c. are left, the Keas tear the blankets and sacks to pieces, and bend the tin pots until they are useless.

"My Kea does not care much for vegetable food; give him a lettuce or cabbage and he only tears it up and throws it away; he is, however, fond of the seeds of the sowthistle. I see that your say in your article that a specimen was received by the Zoological Society in 1872, which only survived a few days. It has struck me that my bird having been in captivity for two years, and being now tame, and we will suppose reconciled to his lot, would be in a favourable condition to bear the

* The advent of this Parrot was thus chronicled in the London press :-

"There is now in the ' Zoo' a very remarkablo bird, the Nestor notabilis, or Mountain Koa, of New Zealand. It is a parrot of strong frame and powerful bill and claws, which were used like those of all Parrots for obtaining a vegetable dict, until the colonists introduced sheep and pigs. As soon as this was done the Kea scems to have abandoned regetable food, and to have taken entirely to flesh-eating. He attacks sick or dyiug or disabled sheep, and with his powerful cutting beak opens a passage through the back, and eats the intestines. Even healthy animals are sometimes assailed by the Nestor notabilis, and thore are shecp-runs in New Zcaland where considerable losses have been iucurred through these strangely degeucrated birds. The specimen in the Zoological Gardens gave as much troublo to capture as an Eagle, tearing the elothes of the shepherd who knocked it down while pouncing on a lamb, and laccratiug his hands. The Foa scorns cooked meat, biscuits, fruit, or sceds, and likes raw mutton better than any food. He will tear the skin and flesh from a sheep's hoad after the furious fashion of a Vulture, leaving nothing but the bare skull. He at one time holds the morsels in his lifted elaw, after tho style of Parrots, and at another grips them under his fect while rending with his boak like a Hawk. This is a very curious example of change of habit, for there is every reason to believe that before sheep and pigs were introduced into New Zealand the Kea was as frugivorous in its meals as most, if not all, other Parrots. He will now eat pork and beef, as well as mutton, aud has become, in fact, utterly and hopelessly carnivorous. It is to be feared, after this example, that temptation is often fatal to birds and beasts as well as man. IIad it uot been for Captain Cook and the English shecp flocks, the Nestor notalilis would have lived and died innocent of crime; but now its bloodstained earease is suspended outside many a sheepfold near Otago." 
voyage. I shall be very pleased to present him to the Society-that indeed has been my intention always-but I imagined that they would have specimens.

"My purpose in writing has been mainly to acquaint you with the habits of the bird in captivity, and somewhat of what I have learnt of its habits in the wild state; and also to ask you for hints as to sending the bird home should the Zoological Society care to have him.

"I have just now another specimen of a sheep attacked by these birds; it is of even greater pathological interest than the other one which I sent home, for in this case the opening is into the rumen or large stomach; the sheep survived for a long time. There are also several other living sheep that have been injured waiting for favourable opportunities to be sent down. I want one with an opening into the rumen, so as to be able to watch the process of digestion. I think it would be very interesting."

Although, as already shown, very easily captured, it is difficult to detain the bird against its will. My brother, during his residence in the back Mackenzie country, obtained, at various times, no less than eight live specimens for me; but in every instance they managed to escape, either by eating their way out of the wooden cage, or in some other, unaccountable manner, before reaching their destination *. If taken young, however, they are readily tamed and become very tractable pets. Dr. Finsch, during his travels in New Zealand, was accompanied by one which was daily allowed to leave its cage, and could be handled with impunity. I never heard whether Dr. Finsch sent it to Europe, as he then proposed doing, or whether it remained to share the vicissitudes of his consular life in the South Pacific Islands.

On being removed from its cage and fondled with the hand it crouched down and ruffled up its feathers after the manner of an Owl. I noticed that whilst in the cage it had a habit of dancing up and down in true Nestor-fashion. It seemed very prying and inquisitive, trying the quality of anything within its reach by means of its well-curved beak.

A live one in the possession of Mr. J. Baker, at Waipawa, became perfectly tame and was allowed the freedom of the establishment.

The inference I ventured in my former edition, that, judging from its general economy, the Kea nests in the crevices and crannies of the rocks in its wild alpine haunts, has since been verified, many nests of this Parrot having from time to time been met with, and always in such situations $\dagger$.

An egg in my son's collection, being one of two found in a Kea's nest "under a high cliff at Forest Creek," is of similar form and appearance to that of Nestor meridionalis, but is appreciably larger, measuring 1.75 inch in length by 1.3 in breadth; it is pure white, with a slightly glossy surface.

* " $\Lambda$ Kca has been scen by his gratified captor to cat his way out of a wooden eage almost as quiekly as it had been coaxed to entcr it. Two which had been tamed by a neighbouring friend wcre permitted to wander at large. They regularly returned to his house for their meals and then rambled away again, scrambling and clambering anongst the trecs and outbuildings. Any kind of food appeared to suit their accommodating appetite, but a piece of raw meat was eridently the bonne bouche." - Out in the Open.

$\uparrow$ 'The following account is given ('Zoologist,' 1883, p. 276) of an egg obtained by Mr. H. Campbell :-“" The specimen, with three others, was taken from a nesting-place, in an almost inaecessible fastness of rocks, high up the mountains near Lake Wanaka. An egg was broken in getting out; two of those remaining have also come to grief. Placed among a series of eggs of the Kaka $(N$. meridionalis) it can be pieked out at once; it is larger, rougher, the surface being granulated, dotted orer irregularly with small pits, a very few slight chalky incrustations towards the smaller end. The shell is very stont and thiek, exceeding in that respect any examples that I have secn of the eggs of the Kaka. It is broadly ovoid, measuring one inch seven lines in length; in width it is one inch thrce lines." 


\section{STRINGOPS HABROPTILUS.}

(OWL PARROT.)

Strigops habroptilus, Gray, P. Z. S. 1847, p. 62.

Strigopsis habroptilus, Bonap. Consp. Gen. Av. i. p. 8 (1850).

Stringops habroptilus, Van der Hoeven, Handb. Zool. ii. p. 466 (1856).

Stringopsis habroptilus, Schl. Mus. Pays-Bas, Psittaci, p. 107 (1864).

Stringops habroptilus, Finsch, Papag. i. p. 246 (1867).

\section{Varieties.}

Strigops greyii, Gray, Ibis, 1862, p. 230.

Stringops greyi, Finsch, Papag. i. p. 253 (1867).

\section{Native names.}

Kakapo, Tarapo, and Tarepo; "Ground-Parrot" of the colonists.

$A d$. viridis : plumis pilei dorsique medialiter pallidè flavidis, irregulariter nigrieanti-brunnco transtaselatıs et transvermieulatis: uropygii plumis lætiùs viridescentibus : loris plumisque rietum obtectentibus pallidè fulveseentibrunneis, medialiter albicantibus: regione aurieulari brunneâ, rachidibus plumarum fulvescentibus : facie laterali brunneâ, plumis medialiter latè flavicantibus : remigibus nigricanti-brumneis, primariis extùs et intùs flavieante maculatis, sccundariis irregularitcr flavido fasciatim variis et extùs olivaseenti-viricli lavatis : caudâ olivaseenti-brunneâ, ubique nigrieante fasciolatâ: subtùs magis flavicans, viridi lavatus, alıdomiue puriùs flavieante: peetoris plumis paullò nig̣ricante variis, hypoehondriis magis conspieuè fasciatis : subalaribus olivaseenti-flavis, obseurè brunnco faseiatis: subalaribus flavieantibus, minoribus nigro variis : rostro flavicanti-albido, ad basin saturatiore: pedibus flavicanti-brunncis, unguibus saturatioribus.

Adult. General colour of the upper surface dark sap-green, brighter on the wings and lower part of baek, and largely varied with dark brown and yellow; on thcir under surface the feathers of these parts arc light verditer-green towards the tip, with a fine metallic lustre; on the crown and nape the centre of eaeh feather is blackish brown, with a narrow shaft-line of dirty yellow and a broad terminal band of dull green; on the back, rump, and upper surface of the wings, each feather is silvery brown at the base, pale lemon-yellow beyond, changing to sap-green on the sides and towards the tip, and crossed by numerous broken bars and vermieulations of dark brown; on the anterior portion of the back these bars are regular and distinet, but on the other parts they are interrupted by a broad shaft-line of lemon-yellow. Thesc details of eolouring, however, ean only be obscrved when the plumage is disturbed, the general effect on the surface being as already described. The featliers at the base of the upper mandible, lores, sides of faee, and feathers projeeting over the lower mandible dull yellowish browu, with darker filaments; ear-coverts darker brown, mixed with yellow; fore neck, breast, and sides of the body yellowish sap-green, varied with palc yellow and brown, the distribution of colouring on each individual feather being the same as on the upper parts, but with more yellow down the shaft; lower part of abdomen, thighs, and under tail-coverts light greenish yellow, the longer coverts obscurely barred with light brown; lining of wings pale lemon-yellow, blotehed and streaked with dark brown; primaries dark brown, largely toothed on thcir outer webs with dull lemonyellow, and on their inner with paler; secondaries and their coverts dull greenish yellow, rayed and freckled with dark brown on the outer webs; dusky brown on the inncr webs, with broken transverse markings of lemon-yellow; tail-feathers ycllowish brown, with arrow-shaped markings along the shaft, and largely 


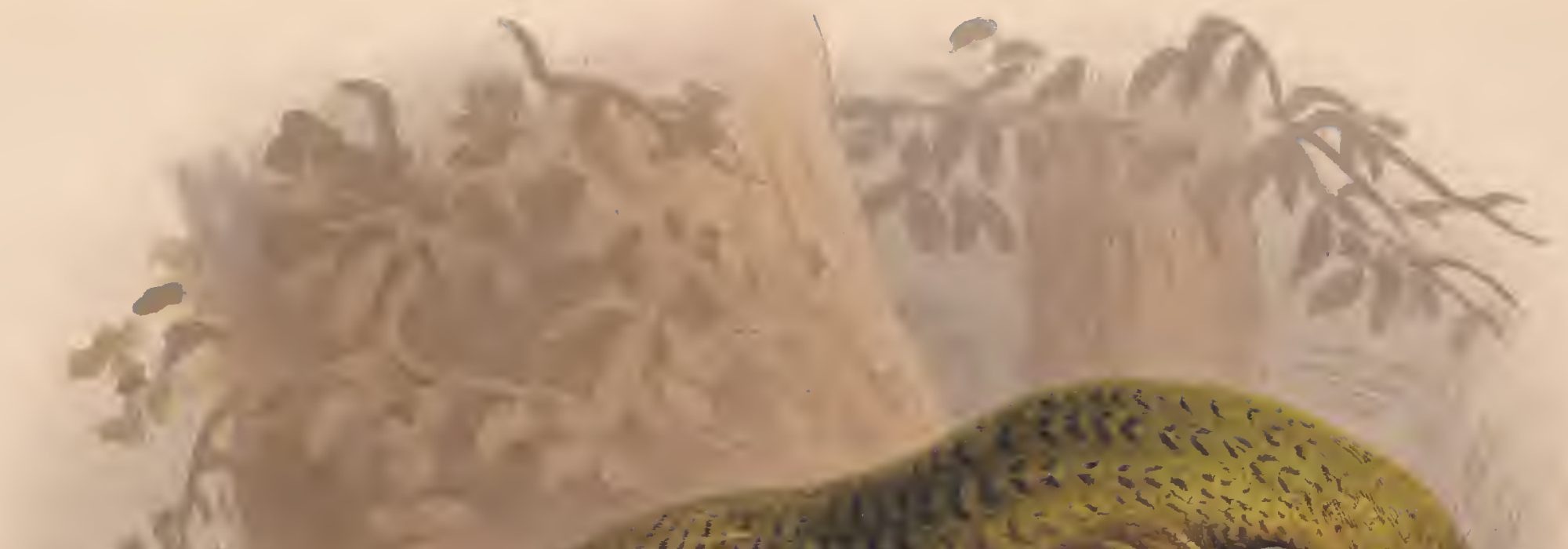

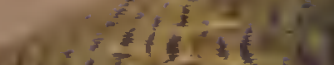
Ling.

som rivin

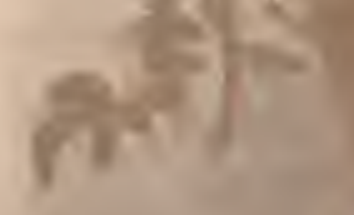

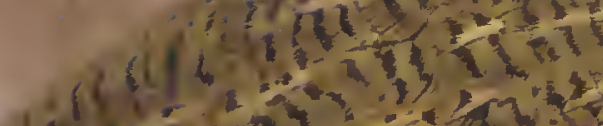

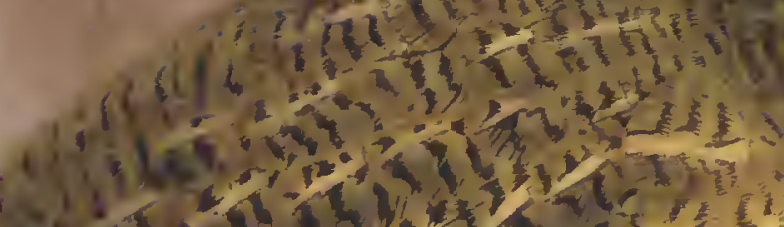

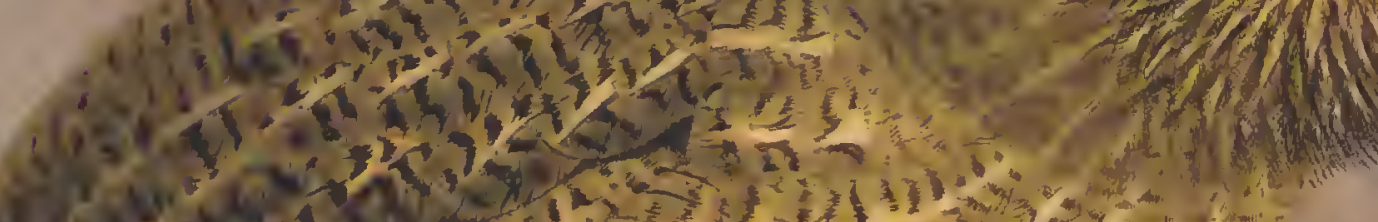
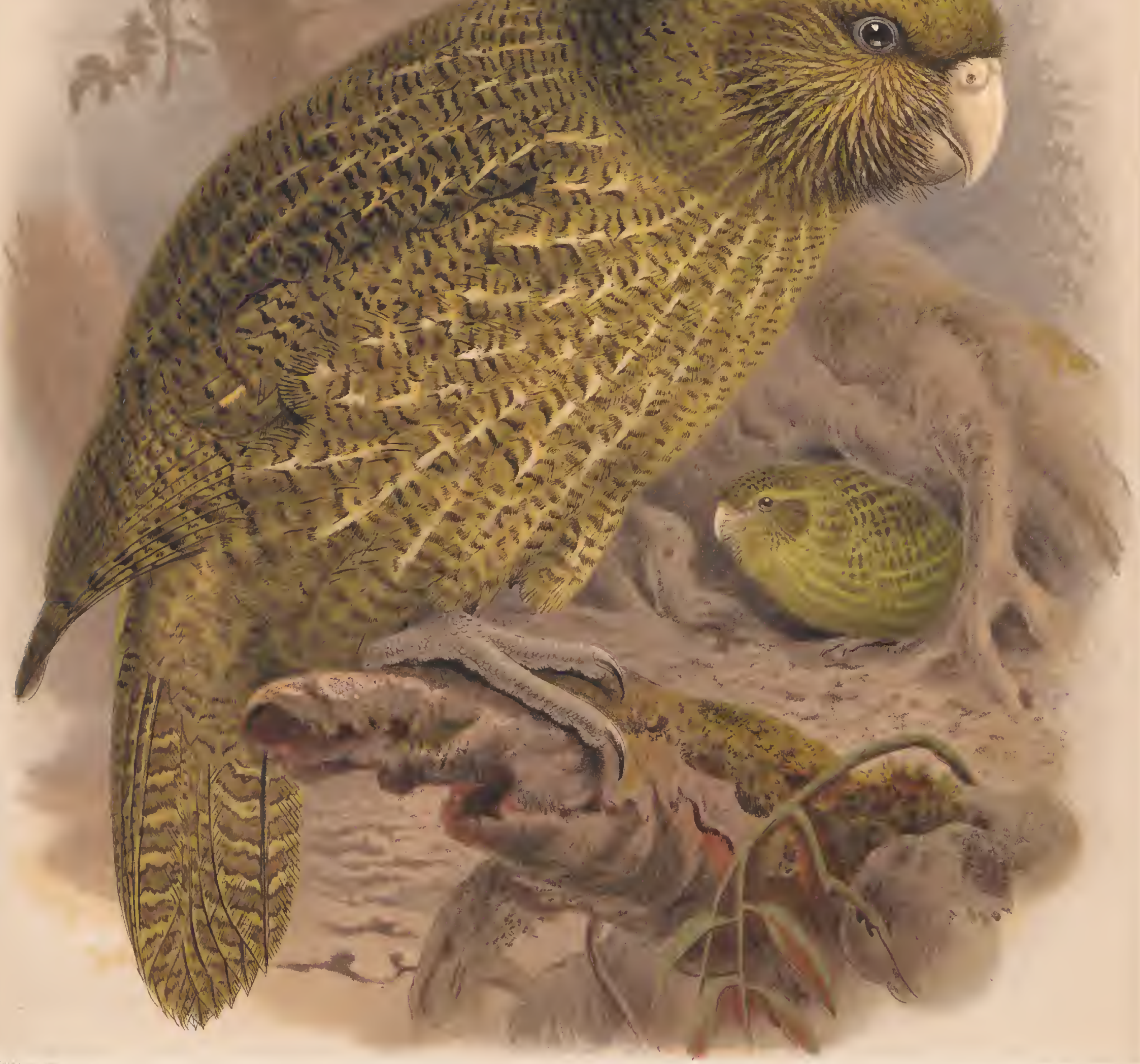

THE KAKAPO OR OWL PARROT

STRINGOPS HABROPTILUS 

freckled and mottled with blackish brown. Irides black; bill ycllowish white, darker at the base and along the fluting of the lower mandible; tarsi and toes ycllowish brown; claws darker. Extreme length 26 inches; wing, from flexurc, 12; tail 10; bill, along the ridge (from base of cerc) 2 , along the edge of lowcr mandible 1 ; tarsus 1.75 ; longer fore toe and claw 3 ; longer hind toe and claw 2.5 .

Obs. The sexcs are alikc in plumage. Individuals vary a good deal both in the brilliancy of their tints and in the details of their colouring. The ground-colonr of the upper parts varies from a dull sap-grccn to a bright grass-grcen, and in some cxamples the whole of the plumage of the undcrparts is strongly suffused with lemon-yellow. The barred character of the individual feather is more defined in some spccimens, while in others the light markings on the quills and tail-feathers arc softened to a pale yellow. Individual birds also differ perceptibly in size, owing probably to conditions of age and sex.

Captain Preecc, R.M., has in his possession the skin of a Kakapo obtained at Hikurangi, in the North Island. Its plumage is in no respect different from that of the southern bird. Length 25 inches; wing, from flcxure, 11 ; tail 8 ; tarsus 2 ; longer forc toc and claw $2 \cdot 5$.

Varieties. Of this species there is a beautifully marked variety in Mr. James Brogden's collection of NewZcaland birds, at Portheawl. The whole of the plumage is largcly suffused with ycllow, cspccially on the underparts, where each feather has a broad irregular central spot of pale ycllow, edged witl dusky brown; towards the tips the feathers are grcenish ycllow. The upper parts are bright grcen, prettily rayed with black, and varied more or less obscurely with ycllow, the feathers of the nape and sides of the neck having spear-head points of bright ycllow ncar the tips. The tail is conspicuonsly marked at regular intervals with vandyked bars of clear lcmon-ycllow, getting darker towards the tips; these yellow markings arc edged with black, and the intcrspaces arc yellowish brown, more or less frecklcd and marbled with black. The primaries and sccondaries are similarly marked on thcir outcr webs, but the yellow js not quite so clear.

A spccimen in my collection has the cheeks of a bright reddish brown, this colour fading away on the cdges. Therc is a somewhat similar example iu the Otago Museum, with the crown, sides of the facc, chin, aud upper part of the throat diugy reddish brown. I suspect that this coloration results from some vegetable stain, inasmuch as in this specimen I obscrve that the ridge and sides of the upper mandible and the fluted grooves in the lower are similarly stained.

In Mr. Silver's finc collection of New-Zealand Birds at Letcomb Manor there is an abnormally small spccimen, the mcasurements being:-Total length 20 inches; wing, from flexure, 10.5 ; tail 7.5 ; bill, along the ridge $1 \cdot 5$, along the cdge of lower mandible $\cdot 75$. The plumage as in the ordinary bird, cxcept that, on the lcft chcek, therc is a patch of ycllow about an inch in cxtent, completely covering the ear-covcrts and extcuding dowuwards.

I have examined the typc specimen of Mr. G. R. Gray's Striyops greyii in the British Museum and have come to the conclusion that it is simply an accidental variety, although a very singular onc, of the true S. habroptilus. The specimcn is in very bad condition, the quills bcing much worn and abraded, and the tail worn down to a mere stump; indeed the whole of the plumage is dingy and soiled, apparently the result of long confinement. The featliers of the upper parts, instead of being sap-grecn at the ends, arc of a dull greenish blue, changing in certain lights to a purplish blue. There is, moreover, somewhat lcss of the terminal colour; and as the barred markings on the basal portiou of the feathers arc fulvous white instead of yellow, the back has a more variegated appearance. The entirc plumage of the undcrparts is a pale yellowish fulvous, mottled, cxcept on the abdomen, with brown. The checks and feathers ovcrlapping the lower mandiblc are the same as in ordinary examples, but without any yellow tingc. On the sides and flanks the fcathers are slightly tinged with bluc, but of a duller tint than on the upper parts; thighs deeply stained with yellow. The newest of the tail-feathers ( $i . e$. the stumpy portion that remains) is rayed in the same manner as in ordinary examples, but without the yellow element, showing a decided tendency to albinism. In the wing-feathcrs, in which also the ycllow colour is abscnt, the bars appcar at first sight more regular and distinct; but on closcr examination it will be found that in both wings the broad inner secondaries and the scapulars have becu torn out (doubtless due to the bird's captivity), and the barred effect is thereforc more conspicuous. Although, among the numerous cxamples that have come under my noticc, I have never scen one in any degree approaching this condition, yet I have detected in some a tendency in the fcathers of the back to assume a bluish margin, and in all specimens these feathers have a bright metallic lustre on their under surfacc. There is no means of detcrmining the exact length of the 
wing, as the long primarics, on both sides, have been broken off; but the specimen does not appear to differ in size from ordinary small examples of S. habroptilus. But what tends more than any thing else to convince me that the so-called S. greyii is merely an abnormal or accirlental variety of the spccics under review is the fact that some of the small coverts on both wiugs, and the feathers of the crown, have assumed the normal sap-green colour, thus betraying a strong tendency to reversion. Iu the absence of any other examples in a similar condition of plumage, this fact appears to me of itself fatal to the recognition of the specics. At the same time, I should add that the differcnce in colour was so manifest and striking, that Mr. G. R. Gray was perfectly justified in charactcrizing it provisionally as a distinct species, although (as appears from his Catalogue of Psittacidx, 1859) he was himself of opiniou that it might ultimatcly prove a mere variety. Even Dr. Finsch, who is scrupulously careful in all his identifications, states (in his valuable Monograph of Parrots) that, after a careful examination of the type specimen, he felt bound to admit S. greyii as a good species. It only remains for me to say that I regret that my convictions compel me to sink a name designed by the describer as a compliment to Sir George Grey, who has always taken so zealous a part in the furtherance of ornithological scicnce.

In Reischek's eollection there is a specimen with a single canary-yellow feather among tlie scapulars; and another has a bluish glint on the feathers of the upper parts, somewhat like that describcd above.

I examined a remarkable varicty from Dusky Bay, this example having been obtained (as I was assured) at a considcrablc elevation. This bird had the crown of the head uniform dark green, the cheeks dull greenish brown, the markings on the upper surfacc generally very obscurc, and the plumage of the underparts dull grecnish yellow, with faint marbled markings of a paler colour, prescnting a very soft appearance, whilst the flanks were prettily marked with numerous narrow bars of brown; the bill was pale yellow, the sides of the under mandible iuclining to brown.

Mr. J. D. Enys seuds me the following note:-"Mr. G. Müller, the Chief Surveyor of Westland, has a Kakapo with the cntire plnmage yellow. It came from Jackson's Bay. Have you heard of it?"

Mr. Reischek, who spent six months in the West Coast Sounds, brought back with him some very beautiful specimens, differing from the conmon Kakapo in having the entire upper surface rayed with narrow transverse, more or less wavy, bars of brownish black, and the markings on the wing-feathers vcry regular and distinct, being of a pale lemon-yellow. Of this bird he writes:- "The Alpiue Kakapo-so called by me, as I have never found this beantiful bird anywhere except on high mountains-is considcrably larger and much brighter than the ordinary Kakapo. The young ones are much duller in plumage than their parents. These alpine birds are rare, but I was fortunate in securing about a dozen of them. Amongst them was a specimen of a beautiful varicd plumage : on the top of the head very light green; back, wingcoverts, and tail yellowish grecn with crimson spots; round the bill crimson; throat, breast, and abdomen yellow with crimson spots ; bill light yellow; legs silver-grey; eyes dark brown."

Sevcral of these fine specimens are now in my collection, and although I fully apprceiatc the difference in the plumage of the upper surface, yct, with my knowledge of the extreme variability of this form, I am unable, howerer willing, to recognize a ncw species. As to individual size, that counts for very little, for I have in my collection even larger specimens in the ordinary plumage. Again, one of the alpine birds received from Mr. Reischek, in which the colours are particularly brilliant, has little thrcad-like tufts of down adhering to the tips of the secondaries; it is obviously a very young bird, and does not conform to Mr. Reischel's description as quoted above.

On the accompanying Plate my artist has represented this Alpine form, in the distant figure, just emerging from its burrow.

Young. The young Kakapo assumes the adult plumage from the nest, although the colours are duller than in the mature bird and with a less admixture of yellow; the ear-coverts are darker and the facial disk less eonspicuous. The bill, instcad of being horn-coloured, is of a delicate bluish-grey colour.

Nestling. In the Otago Muscum thcre is a Kakapo chick apparently just extruded from the shell. It is extremely small for such a bird, and is covcred with thick fluffy down of a creamy-whitc colour; bill and feet white. It was obtained at Dusky Bay, in April 187\%, by Mr. Doclierty, who presented it to the Museum. I have scen more advanced nestlings covcred with greyish down. (See woodcut on page 191.)

General remarks. In the peculiar form which constitutes the unique member of the genus Stringops the bill is 
broad and powertul; the upper mandible has a peeuliar rasp-like eharaeter within, while the lower mandible is deeply fluted on its outer surface, with a worn, notehed process near the extremity. The plumage is soft but compaet; the wings apparently well developed, but useless for purposes of flight, with the quills mueh curved or bent; the tail long and slightly deeurved, the feathers composing it aeuminate and sometimes with the tips abraded; the projeeting feathers on the cheeks loose, with disunited filaments and shafts muelı produced; the legs strong and wcll formed; the tarsi covered with clevated rounded seales; the toes similarly proteeted in their basal portion, seutellate towards the end; the claws strong, well-arehed, sharp on their inner edge, and with fine points.

'THIS is one of the very remarkable forms peculiar to New Zealand, and has been appropriately termed an Owl Parrot. Dr. Sclater refers to it as "one of the most wonderful, perhaps, of all living birds." As its name Stringops indicates, its face bears a superficial likeness to that of an Owl. In all the essential characteristics of structure it is a true Parrot; but in the possession of a facial disk (in which respect it differs from all other known Parrots), in the soft texture of its plumage, and especially in its decidedly nocturnal habits, it betrays a striking resemblance to the Owl tribe. Its toes, as in all other members of the order, are zygodactyle; but, as pointed out by Mr. Wood in an interesting article communicated to the 'Student' (1870, p. 492), the foot of an Owl, when the bird is perched, considerably resembles that of a Parrot, as the outer toe is then placed backwards with the hind one, so that the bird's feet may be said to be temporarily zygodactyle, whereas those of the Parrot are permanently so.

Although it may, perhaps, be morphologically incorrect to say that this form supplies a quasiconnecting link between the Owls and the Purrots, there can be no doubt that the Kakapo, in some of its external characters as well as in its mode of life (as Mr. A. R. Wallace has well expressed it), "imitates the Owl" in a rery remarkable manner.

Although exclusively a vegetable-eater, its habit of hiding during the day in holes of trees and dark burrows exhibits a further point of resemblance to the nocturnal birds of prey. As these latter are in reality night Hawks, so is this bird, what the native name indeed implies, a night Parrot; and the analogy thus presented harmonizes with the idea expressed above.

The feathers surrounding the eyes and filling the lores differ from those on the other parts of the body not only in being of a lighter colour, but also in form and strueture, being narrow and penicillate, with the shaft considerably produced. Those overlapping the base of the lower mandible are more stiff and elongated.

All who have studied the bird in its natural state agree on this point, that the wings, although sufficiently large and strong, are perfectly useless for purposes of flight, and that the bird merely spreads them to break the force of its fall in descending from a higher point to a lower when suddenly surprised; in some instances (as one of the writers quoted below informs us) even this use of them is neglected, the bird falling to the ground like a stone.

We are naturally led to ask how it is that a bird possessing large and well-formed wings should be found utterly incapable of flight. On removing the skin from the body it is seen that the muscles by means of which the movements of these anterior limbs are regulated are fairly well developed, but are largely overlaid with fat. The bird is known to be a ground-feeder, with a voracious appetite, and to subsist chicfly on vegetable mosses, which, possessing but little nutriment, require to be eaten in large quantities; and the late Sir J. von Haast informed me that he liad sometimes seen them with their crops so distended and heavy that the birds were scarcely able to move.

These mosses cover the ground and the roots or trunks of prostrate trees, requiring to be sought for on foot; and the bird's habit of feeding at night, in a country where there are no indigenous predatory quadrupeds, would render flight a superfluous exertion, and a faculty of no special advan- 
tage in the struggle for existence. Thus it may be reasonably inferred that disuse, under the usual operation of the laws of nature, has, in process of time, produced the modification of structure which distinguishes this form from all other known Parrots and thereby occasioned this disability of wing.

The sternum, which in all other birds of its class has so prominent a keel, is so completely altered that it presents almost a flat surface, although the symmetry of the skeleton does not appear to have suffered in any other respect.

Prof. W. K. Parker says:- "Like all those who glory in 'high degree,' the Parrots have a poor relation or two to abate their pride. The Owl-billed Parrot (Stringops halroptilus) of New Zealand is as lowly as ' the younger son of a younger brother.' If birds were to be classified by the sternum only, then the Stringops should be put near the Apteryx and the Tinamou attached to the train of the Peacock."

The late Prof. Garrod has pointed out that the Parrots, as an order, are peculiar for the variation that occurs in their carotids, which show four different arrangements, and that Stringops is one of those forms in which the two carotids run normally *.

Conformably also with the doctrine of natural selection, we have here another striking instance of the law of assimilative colouring, which obtains more or less in every department of the animal kingdom. Nature has compensated this bird for its helplessness when compelled to leave its hidingplace in the daytime, by endowing it with a mottled plumage so exactly harmonizing with that of the green mosses among which it feeds, that it is almost impossible to distinguish it.

Although the existence of a large ground-Parrot was known to the early colonists of New Zealand from the reports of the natives, who set a high value on the feathers for purposes of decoration, it was not till the year 1845 that a skin of this bird reached Europe; and this was purchased by the Trustees of the British Museum for the sum of $£ 24$.

* The same distinguished anatomist, in ono of his earlier papers on the museles of Birds, pointed out that the ambiens may be present normally, or it may be differentiated in the thigh, but fail to eross the knee, being lost in the faseia over it, or it may be absent; and he stated that in Stringops habroptilus it is present but does not eross the knee. In a subsequent papor "On the Anatomy of the Parrots" (P. Z. S. 1874, pp. 596-598) he says:- "I have twice had the opportunity of disseeting Stringops habroptitus. As a Parrot it is not so strikingly peeuliar as many seem to think. Its wings are useless, and the earina sterni is correspondingly redueed, it is true; but as points of elassifieational importance, I regard these as insignifieant. The points of speeial anatomical interest whieh it does possess, however, are partieularly instrnetive. The proximal ends of the ineomplete fureula are well developed, so mueh so that it might at first sight seem that the symphysial ends are only lost in eorrelation with the oxeessive reduetion of the powers of flight; though this is probably not the ease, beeause the allied similarly modified genera Euphema \&e. do not keep to the ground. Further, in the Soeiety's speeimen above mentioned, though the ambiens musele did not eross the knee, yet its fleshy belly was well differentiated on both sides, its thin tendon being lost over the eapsule of the joint. In the College of Surgeons' specimen, however, this musele was entirely absent in the only knee whieh was in a fit state for disseetion, the other being mueh shot. It is only in the genus Edicnemus that I have elsewhere found a similar partial loss of the ambions. The partial development of this musele in this particular instanee shows that the tendeney to lose it is not of great antiquity ; and it is to be noted that there is no other Parrot with normal earotids in whieh any trace of an ambiens is to be found. These considerations suggest, what may perhaps be the ease, as is suggested by the peeuliarities of their geographieal distribution, that Agapornis may be the representativo among the normal-earotid Parrots of the Platyeereine branch from the Arinæ, whilst the Stringopinæ proper (ineluding Geopsittacus, Melopsittccus, and Euphema) are more diroet continuations of the main stem, Stringops itself being the nearest living representative of the common ancestor of the whole suborder." And in a postseript (dated Dee. 8, 1874) he adds:- "On the 25th of last month, from the death of ono of the speeimens of Stringops Tabroptilus, reeently purehased by the Soeicty, I havo had an opportunity of disseeting a third individual of the speeies. In it tho ambiens musele is eompleto, of fair size, at the same time that it erosses the knee as in Psittacus. This makes me feel more convineed that the arrangement indieated by me is the eorrect one, and that the main stem has given rise to three instead of two branches--the Stringopini being the nearest representatives of the aneestral form, somo of its members (Geopsittacus, Melopsittacus, Euphema, and Cyanorhamphus) having quite reeently lost, whilst Stringops itself is just now on the point of losing the ambiens musele. It is, howerer, quite possible, if external resemblanees and greographieal distribution are left out of eonsideration, that Stringops must stand as the sole representative of the Stringopinx, thus conforming with generally reeeived ideas." 
According to native tradition, the Kakapo was formerly abundant all over the North * and South Islands; but at the present day its range is confined to circumscribed limits, which are becoming narrower every year. In the North Island it is rarely heard of; but it still exists in the Kai-Manawa ranges, and, as I have been assured by the chief Herekiekie, it is still occasionally met with in various parts of the Taupo district + .

Until within the last few years the Kakapo abounded in the Urewera country, and the natives were accustomed to hunt them at night with dogs and torches. The Maori proverb, "Ka puru a putaihinu," relates to the former abundance of this bird. The natives say that the Kakapo is gregarious, and that when, in the olden time, numbers of them congregated at night their noise could be heard to a considerable distance. Hence the application of the above proverb, which is used to denote the rumbling of distant thunder $\$$.

The first published account of this singular bird is that given by Dr. Lyall, R.N., in a paper read before the Zoological Society of London, on the 24th of February, 1852, and which I have transcribed from the "Proceedings' of that year:-" Although the Kakapo is said to be still found occasionally on some parts of the high mountains in the interior of the North Island of New Zealand, the only place where we met with it during our circumnavigation and exploration of the coasts of the islands in H.M.S. 'Acheron,' was at the S.W. end of the Middle Island. There, in the deep sounds which intersect that part of the island, it is still found in considerable numbers, inhabiting the dry spurs of hills or flats near the banks of rivers where the trees are high and the forest comparatively free from fern or underwood. The first place where it was obtained was on a hill nearly 4000 feet above the level of the sea. It was also found living in communities, on flats near the mouths of rivers close to the sea. In these places its tracks were to be seen, resembling footpaths made by man, and leading us at first to imagine that there must be natives in the neighbourhood. These tracks are about a foot wide, regularly pressed down to the edges, which are two or three inches deep amongst the moss, and cross each other usually at right angles.

"The Kakapo lives in holes under the roots of trees, and is also occasionally found under shelving rocks. The roots of many New-Zealand trees growing partly above ground, holes are common under them; but where the Kakapo is found, many of the holes appeared to have been enlarged, although no earth was ever found thrown out near them. There were frequently two openings to these holes; and occasionally, though rarely, the trees over them were hollow for some distance up. The only occasion on which the Kakapo was seen to fly was when it got up one of these hollow trees and was driven to an exit higher up. The flight was very short, the wings being scarcely moved; and the bird alighted on a tree at a lower level than the place from whence it had come, but soon got higher up by climbing, using its tail to assist it. Except when driven from its holes, the Kakapo is never seen during the day; and it was only by the assistance of dogs that we were enabled to find it. Before dogs became common, and when the bird was plentiful in inhabited parts of the islands, the natives were in the habit of catching it at night, using torches to confuse it. It offers a formidable resistance to a dog, and sometimes inflicts severe wounds with its powerful

* Te Heuheu's father, Ngatoroairangi, a renowned Maori naturalist of former times, was a suceessful Kakapo-hunter. He was (so the natives relate) accustomed to lie in ambush near the beaten tracks of these birds, and capture them, in the early dawn, on their way to their hiding-places. This good old chief is said to have attempted the introduction of the Snapper into the Taupo Lake. Ho planted the island of Mokoia, in the Rotorua Lake, with totara, and left bohind him other evidenees that he was a "seicntific man" far in advanco of his time.

$\uparrow$ Through the kindness of Mr. White, R.M., I obtained a native-prepared skin of the Kakapo from Taupo, for comparison with examples from the South Island. It was a very small specimen, measuring only 21 inches in length and 8.5 in the wing ; but I was able to satisfy myself of the real identity of the specios in both islands.

$\ddagger C f$. Note on Stringops Tuabroptilus and its skeleton by E. Deslongchamps, Ann. Mus. H. N. Caen, i. pp. 49-53; also skeleton as figured by A. B. Meyer, Abbild. Vögelsk. 
claws and beak. At a very reeent period it was common all over the west coast of the Middle Island; but there is now a race of wild dogs said to have overrun all the northern part of this shore, and to have almost extirpated the Kakapos wherever they liave reached. Their range is said to be at present confined by a river or some such physical obstruction; and it is to be feared that, if thcy once suceed in gaining the stronghold of the Kakapo (the S.W. end of the island), the bird may soon become extinct. During the latter half of February and the first half of March, whilst we were amongst the haunts of thesc birds, we found young ones in many of the holes-frequently only one, never more than two, in the same hole. In one casc where there were two young ones, I found also an addled egg. There was usually, but not always, an old bird in the same hole with the young ones. They build no nest, but simply scrape a slight hollow amongst the dry dust formcd of decayed wood. The young were of different ages, some being nearly fully fledged, and others eovered only with down. The egg is white and about the size of a Pigeon's.

"The cry of the Kakapo is a hoarse croak, varied occasionally by a discordant shriek when irritated or hungry. The Maoris say that during winter they assemble together in large numbers in caves, and that at the times of meeting, and again before dispersing to their summer haunts, the noise they make is perfectly deafening. A good many young ones were brought on board the ship alive. Most of them died $a$. fow days afterwards, probably from want of sufficient care ; some died after being kept a month or two; and the legs of others became deformed after they had been a few wecks in captivity. The causc of the deformity was supposed to be the want of proper food, and too close eonfinement. They werc fed chiefly on soaked bread, oatmeal and water, and boiled potatoes. When let loose in a garden they would eat lettuces, cabbages, and grass, and would taste almost every green leaf that they came across. One which I brought within six hundred miles of England (when it was accidentally killed), whilst at Sydncy ate eagcrly of the lcaves of a Banksia and scveral species of Eucalyptus, as well as grass, appearing to prefer them all to its usual diet of bread and water. It was also very fond of nuts and almonds, and during the lattcr part of the homeward voyage lived almost entirely on Brazilian ground-nuts. On several occasions the bird took sullen fits, during which it would eat nothing for two or threc days at a time, screaming and defending itself with its beak when any one attempted to touch it. It was at all times of an uncertain temper, sometimes biting severely when such a thing was least expected. It appeared to bc always in the best humour when first taken out of its box in the morning, hooking on eagerly with its upper mandible to the finger held down to lift it out. As soon as it was placed on the deck it would attack the first object which attracted its attention-sometimes the leg of my trousers, sometimes a slipper or a boot. Of the latter it was particularly fond: it would ncstle down upon it, flapping its wings and showing every symptom of pleasure. It would then get up, rub against it with its sides, and roll upon it on its back, striking out with its feet whilst in this position. One of these birds, sent on shore by Capt. Stokes to the care of Major Murray, of the 65th Regiment, at Wellington, was allowed to run about his garden, where it was fond of the society of the children, following them like a dog wherever they went.

"Nearly all the adult Kakapos which I skinned were exceedingly fat, having on the breast a thick layer of oily fat or blubber which it was very difficult to separate from the skin. Their stomachs contained a pale green, sometimes almost white, homogeneous mass, without any trace of fibre in it. There can be little doubt but that their food consists partly of roots (their beaks are usually more or less corered with indurated mud), and partly of the leaves and tender shoots of various plants. At one place where the birds were numerous we observed that the young shoots of a leguminous shrub growing by the banks of a river were all nipped off; and this was said by our pilot, who had frequented these places for many years in a whaling-vessel, to be the work of the Kakapo. 'Their flesh is white and is generally esteemed good eating." 
Sir George Grey, two years later, sent the following interesting account of the Kakapo to Mr. Gould, who gave it a place in the Appendix to his 'Birds of Australia ':-

"During the day it remains hid in holes under the roots of trees or rocks, or, very rarely, perched on the boughs of trees with a very dense thick foliage. At these times it appears stupid from its profound sleep, and if disturbed or taken from its hole immediately runs and tries to hide itself again, delighting, if practicable, to cover itself in a heap of soft dry grass; about sunset it becomes lively, animated, and playful, issies forth from its retreat, and feeds on grass, weeds, vegetables, fruit, seeds, and roots. When eating grass it rather grazes than feeds, nibbling the grass in the manner of a rabbit or wombat. It sometimes climbs trees, bnt generally remains npon the ground, and only nses its short wings for the purpose of aiding its progress when running, balancing itself when on a tree or in making a short descent, half-jump, half-fight, from a higher to a lower bough. When feeding, if pleased with its food, it makes a continued grunting noise. It is a greedy bird and choice in its food, showing an evident relish for any thing of which it is fond. It cries repeatedly during the night, with a noise not very unlike that of the Kaka (Nestor meridionalis), but not so loud.

"The Kakapo is a very clever and intelligent bird-in fact, singularly so; contracts a strong affection for those who are kind to it; shows its attachment by climbing about and rubbing itself against its friend, and is eminently a social and playful bird: indeed, were it not for its dirty habits, it would make a far better pet than any other bird with which I an acquainted; for its manner of showing its attachment by playfulness and fondling is more like that of a dog than a bird.

"It builds in holes under trees and rocks, and lays two or three white eggs, about the size of a pullet's, in the month of February; and the young birds are found in March. At present (1854) the bird is known to exist only in the Middle Island of New Zealand, on the west coast, between Chalky Harbour and Jackson's Bay, and in the Northern Island about the sources of the Wanganui and in part of the Taupo countries. It was, within the recollection of the old people, abundant in every part of New Zealand; and they say it has been externinated by the cats introduced by the Europeans, which are now found wild and in great numbers in every part of the country. They say also that the large rat introduced from Europe has done its part in the work of destruction.

"'The natives assert that, when the breeding-season is over, the Kakapo lives in societies of five or six in the same hole; and they say it is a provident bird, and lays up in the fine season a store of fern-root for the bad weather. I have had five or six of the birds in captivity, but never succeeded in keeping them alive for more than eighteen months or two years. The last I had I sent home as a present to the Zoological Society ; but it died off Cape Horn."

Mr. G. S. Sale (now Professor of Classics in the New-Zealand University) succeeded, in 1S70, in bringing, for the first time, to England a live specimen of the Kakapo. This bird was deposited for a short period in the gardens of the Zoological Society, and excited much interest *. An excellent portrait of it appeared in the 'Field' newspaper of October 15, 1870, accompanied by a short article on the subject, in which the readers of that journal were informed that " unfortunately for the gratification of the curiosity of visitors, the Kakapo in the gardens obstinately persists in indulging in its nocturnal habits. During the day it remains concealed; and it is only at night, when the visitors have departed, that the singular movements and habits of this animal can be studied with advantage." This notice called forth a letter $\uparrow$ from Mr. Sale, the owner of the bird, in which further interesting particulars of its history are recorded. After explaining that the bird had been in his possession for several months before he deposited it in the gardens, and that he had carefully observed its habits, Mr. Sale continues:- "Sir G. Grey exactly hit the chief characteristics of the Kakapo when he

* The Couneil of the Society offered a sum of $£ 50$ for this bird, but were unable to eome to terms with the owner.

† 'Field' newspaper, Norcmber 12, 1870. 
spoke of its affectionate and playful disposition. During the whole time that the bird has been in my possession it has never shown the slightest sign of ill-temper, but has invariably been goodhumoured and eager to receive any attention. Its playfulness is remarkable. It will run from a corner of the room, seize my hand with claws and beak, and tumble over and over with it exactly like a kitten, and then rush back to be invited to a fresh attack. Its play becomes sometimes a little severe; but the slightest check makes it more gentle. It las also, apparently, a strong sense of humour. I have sometimes amused myself by placing a dog or cat close to its cage; and it has danced backwards and forwards with outstretched wings, evidently with the intention of shamming anger, and has testified its glee at the success of the manœurre by the most absurd and grotesque attitudes. One trick especially it has, which it almost invariably uses when pleased: and that is to march about with its head twisted round, and its beak in the air-wishing, I supposc, to see how things look the wrong way up; or, perhaps, it wishes to fancy itself in New Zealand again. The highest compliment it can pay you is to nestle down on your hand, ruffle out its feathers, and lower its wings, flapping them alternately, and shaking its head from side to side; when it does this it is in a superlative state of enjoyment. I do not think it is quite correct to say that it has dirty habits ; certainly it is not worse in this respect than an ordinary Parrot.

"I am surprised to find that during the time it was in the Zoological Gardens it very rarely showed itself in the daytime. My experience has been the reverse of this. It has generally been lively emough during the greater part of the day, though not quite so violent and noisy as at night. I had this bird at Saltburn, in Yorkshire, during the summer; and any of your readers who were at that place in the month of August, will remember seeing this bird at the bazaar held in aid of the district church, on which occasion its playfulness never flagged during the whole day. This may partly have been due to excitement at seeing so many strange faces; but it also, no doubt, felt the excellence of the cause (recollect, Sir G. Grey testifies to its cleverness and intelligence), and exerted itself accordingly to help the Church-building Fund."

In another account of the habits of the particular bird in his possession, Mr. Sale remarks:"I observe that it rarely makes any noise by day; but about dusk it usually begins to screech, its object being apparently to attract attention; for if let loose from its cage and allowed to have its usual play, it ceases to make any noise. It also makes a grunting noise when eating, especially if pleased; and I have myself attracted it to me by imitating the same sound. It also screeches sometimes when handled, not apparcntly from anger, but more from timidity." In a note he adds:"The sound of the bird is not a shrill scream, but a muffled screech, more like a mingled grunt and screech."

Sir James Hector found the Kakapo very numerous on the west coast of the Otago Province during his exploration of that country in 1861-62; and his collection of birds in the Otago Museum contains many beautiful specimens of it. He succeeded in bringing some live ones to Dunedin; but although they had become perfectly tame, they did not long survive their confinement. IIaving had good opportunities of studying this bird in its native haunts, the following additional particulars from his pen will be read witl interest:-

"The name of Owl Parrot is very appropriate, from the aspect of its head and face, as the bill is short and aimost buried among feathers and long bristly hairs like the whiskers of a cat. These whiskers, no doubt, are nsed in the same manner, as delicate feelers for distinguishing objects in the dark, as the Kakapo is strictly nocturnal in its habits--never stirring from the holcs and burrows in which it rests during the day until nightfall. They then emerge from the woods to the sides of the rivers; and, as they feed, their harsh screams can be heard at intervals until they return at daybreak to the depths of the forest. Notwithstanding the shortness of their legs and large size of thcir feet, they run at a good pace, with a waddling duck-like gait; and though they climb with great facility, 
and rapidly take to trees when disturbed or pursued, they never make any attempt to fly. They are found on the mountains at all elevations; but their favourite haunts are either on the flats by the sides of the rivers, or at 3000 to 4000 feet elevation, where the forest is very scrubby and dense and merges into open ground, and where the spurs that lead to the precipitous and rocky ridges are covered with coarse grass. In their nocturnal rambles on the mountain-tops-which the Kakapos seem at some seasons to indulge in-they appear to keep in line along the spurs and ridges, as they beat down broad tracks which it would be quite excusable to mistake for the well-frequented patlis leading to some encampment in the woods. They seem strictly herbivorous, their food being principally grass and the slender juicy twigs of shrubs, such as the New-Zealand broom (Carmiehellia), which they cherv up into a ball without detaching it from the plant-satisfying themselves with the juice which they extract. Their haunts are therefore easily recognized by the little woolly balls of chewed fibre which dangle from the branches of the shrubs, or strew the ground where they have been feasting on the succulent grasses. It is stated by the Maoris that in winter they assemble in large numbers, as if for business; for after confabulating together for some time with great uproar, they march off in bands in different directions. However, they are not gregarious at all seasons of the year, but are generally found in families of two or three together. They breed in February, having two eggs at a time, which they lay in the holes they scrape for dormitories under the roots of decayed trees and fallen rocks.

"The Kakapo can only be successfully hunted with dogs. The best time for hunting these birds is in the early morning, as soon as it is sufficiently light to permit of the sportsman passing rapidly through the bush, as at that time the scent is still fresh of the birds that were abroad during the night. The Maori dogs enjoy the sport very keenly, and follow it largely on their own account-so much so that, when the Maoris encamp in a locality where these nocturnal birds abound, the dogrs grow fat and sleek, and the birds are soon exterminated. The Kakapo is esteemed a great delicacy by the natives; but its flesh has a strong and slightly stringent flavour."

Probably no New-Zealand explorer enjoyed more favourable opportunities for investigating the natural history of the Kakapo than the late Sir Julius von Haast, whose observations on the subject were embodied in a paper, full of scientific interest, read before the Canterbury Philosophical Society on the 4 th June, 1863.

A German version of this paper was contributed by the author to the 'Verhandlungen' of the Zoological and Botanical Association of Vienna, of October 10, 1863. A translation appeared in 'The Ibis' of the following year (pp. 340-346); and, curiously enough, a retranslation was published in the 'Journal für Ornithologie' for 1864 (pp.458-464). But the paper as originally written has never been published; and as the author favoured me at the time with a private copy of it, $I$ have much pleasure in finding room for the following copious extracts :-

"So little is known of this solitary inhabitant of our primeval forests, that the following short narrative of observations which I was fortunate enough to make during my recent west-coast journey may interest you. Although I was travelling almost continuously for several years in the interior of these islands, it was only during my last journey that I was enabled to study its natural history. I was well acquainted with its call, and had often observed its tracks in the sands of the river-beds and in the fresl fallen snow, but I had not actually seen it. The principal reason for this was, that formerly I had no dog with me; and consequently it would only be by the greatest accident that this bird, not at all rare in those untrodden regions, could be obtained.

"The true habitat of the Kakapo is the mossy open Fagus-forest, near mountain-streams, with occasional grassy plots; but it also lives both on the hill-sides, amongst enormous blocks of rock, mostly overgrown with roots of trees and a deep covering of moss, and on wooded flats along the banks of the larger rivers, liable to be inundated by heavy rainfalls or by the sudden melting of the 
snow . . . . It is a striking fact that, with the exception only of the valley of the river Makarora, forming Lake Wanaka, I never found the Kakapo on the eastern side of the Alps, although extensive Fagus-forests exist there also. It appears to have crossed the main chain at the low wooded pass which leads from the source of the Haast to that of the Makarora, and reached the mouth of this river at Lake Wanaka, where probably the absence of forest put a stop to its further advance. It is very abundant in the valley of the last-mentioned river, and is found even in the Makarora bush, notwithstanding that numerous sawyers are at work there. When camped on the borders of that forest, we continually heard its call near our tents; but none of the sawyers had any idea of the existence of such a large bird in their neighbourhood, although the irregular shrill call had sometimes attracted their attention. It also occurs in the valley of the Wilkin, but is less numerous there, which may be accounted for by the existence of wild dogs in this locality. We may therefore safely assume that from the junction of this river with the Makarora the Kakapo ascended toward the sources of the former. In the valley of the Hunter, only divided by a mountain-range of great altitude but with some low saddles, no sign of it was to be observed, although large Fagus-forests would appear to offer a propitious abode. . . . . . This bird has hitherto been pronounced to be of true nocturnal habits; but I think, from observations I was able to make, that this opinion ought to be somewhat modified. It is true that generally an hour after sunset, the dense foliage of the forest giving additional darkness to the country, its call began to be heard all around us. It then commenced to rove about, and, attracted by the glare of our camp-fire, frequently came close to our tent, when the heedless bird was immediately caught by our dog. But as we met with it on two occasions in the daytime, occupied in feeding, and as I observed that it knew and understood perfectly well the danger which approached, we may safely assume that it has, at least in this respect, some relation to diurnal birds. In order to show why I come to this conclusion, I will particularize the two occurrences I have mentioned, especially as they appear to bear directly upon some other important points in the structure of this bird. When returning from the west coast, we observed, in the afternoon (the sky being clouded), a Kakapo sitting on the prostrate trunk of a tree in the open forest. When about ten yards from it, the bird observed us, and disappeared instantly in its hole, from which, with the aid of the dog, we afterwards took it. It is clear that in this case the bird was not overtaken by the coming day, when far away from its abode, but that it left its retreat voluntarily during daylight. The second instance I shall mention is more striking, and shows that the Kakapo feeds also during the day. It was towards evening, but still broad daylight, when we passed along the hill-side near a deep rocky gorge, and saw a large Kakapo sitting on a low fuchsia tree, about ten feet from the ground, feeding on the berries. When close to it, the bird saw us, and instantly dropped down, as if shot, and disappeared amongst the huge fragments of rocks strewed along the hill-side. But the most remarkable circumstance was, that the frightened bird did not open its wings to break its fall, but dropped as if it did not possess any wings at all ..... In order to see whether they would fly, or eren flutter, when pursued by an enemy, I placed on the ground a full-grown specimen, which had been caught by the dog without being hurt. It was on a large shingle-bed; so that the bird had ample room for running or rising on the wing, if for this purpose it wanted space. I was not a little astonished to observe that it only started running towards the nearest point of the forest, where a dark shadow was apparent-and quicker than I had expected, considering the position of its toes and its clumsy figure, resembling closely a Gallinaceous bird in its movements. As I was standing sideways to it, I thought that it kept its wings closed upon its body, so little were they opened; but my companion, who was equally anxious to see how our prisoner would try to escape, and who stood a little behind it, observed that it opened its wings slightly, but without flapping them in any degree, using them apparently more for keeping its balance than for accelerating its movements. This would almost lead to the conclusion that the Kakapo does not travel far, especially as I have already shown 
that its whole structure is ill adapted for running. But having myself frequently follorved the tracks, and found them to extend a great distance over the sandy reaches along the river, such a conclusion as that suggested above would be erroneous. It must be exceedingly fond of water, because in many localities its tracks were observed for half a mile over shingle and sand to the banks of the river; and I am unable to explain the curious fact, unless the object be to mix river-water with the enormous mass of pulpy vegetable matter which is to be found in its crop. With the exception of two specimens, the crops of which wcre filled with the large berries of a small-leaved Coriaria, by which their flesh was flavoured, all the birds examined by me had their crops widely distendcd by a mass of finely comminuted vegetable mosses, weighing many ounces . . . . . I I carefully examined the subterranean abode of this bird. From the account given by the natives, I thought that it would be found living in well-excavated holes, rescmbling in their construction those of the fox or badger, that the entrance would be so small as to enable only the inhabitant to enter, and thus to exclude larger animals from persecuting it. 'This, however, is not the case, because, with one exception, all the specimens obtained were either in fissures amongst rocks, or in cavities formed by huge blocks, tumbled onc over another, and overgrown with moss, or in holes formed by the roots of decaycd trees. The cavities in the rocks were generally sufficiently large to allow of my dog (a good-sized retriever) freely entering them. The openings to the other holes being smaller, it was sometimes necessary to cut arvay a few roots at the entrance. Inside, the cavity was invariably of very large size, because we could plainly hear the dog advancing several yards before commencing his scuffle with the occupant; and on returning, with the bird in his mouth, he always emerged head foremost, thus proving that the chamber was large enough to enable him to turn himself round. Before he liad become accustomed to the work, the dog was often punished severely by the bird's powerful beak and claws; but he ultimately became quite an expert, always seizing his prey by the head and crushing the skull. He appeared to take a delight in scarching for these birds, and was never tired of providing for us in this manner ..... The holes or abodes of the Kakapo wcre not only on the mountain-sides, but also on the flats near the river-banks, which are liable to be overflowed. There can bc no doubt that, when a sudden inundation takes place, the bird can save itself upon a busl or neighbouring tree. I do not think, however, that it can climb the boles of standing trees, because it nerer resorted to them during the night or when persecuted by the dog-except in one single case, when the bird ascended a leaning tree close to our camp, and remained till the dog had given up the attempt to obtain it. But, notwithstanding that almost all the abodes that came under examination were natural cavities, I met with one hole which seemed to have bcen regularly mined. On the northern bank of the river Haast, just below the junction of the river Clarke, a large flat occurs, formed by deposits of sand, over which a thin layer of vegetable mould is spread, and on which a luxuriant vegetation has sprung up. The river, in washing against these deposits, has in some places formed nearly perpendicular banks, abont six to eight feet high. At one spot, about two feet below the surface, several rounded holes were observed; and the dog tried in vain to enter them. After carefully scenting the ground, he began to scratch the surface with his paws, and soon succeeded in widening the entrance sufficiently to admit his body; and he immediately afterwards emerged with the bird in his mouth. There is no doubt, in my own mind, that this holc, at least, had been excavated; and the burrowingfaculty of the bird may be considered so far established. On a flat, in the valley of the Makarora, the dog brought one from the interior of a hollow drift-tree, which was lying amongst sedges and grasses in an old river-channel. There was never more than one individual in the hole, although very often within twenty or thirty yards of it another specimen would be scented out by the dog, the two being generally of opposite scxes. At night-time, in visiting our camp-fire, they generally came in pairs, the two being successively caught by my dog, a single or sometimes a repeated angry growl from the bird informing us that he had hold of it. These circumstances lead me to conclude that 
during the day each inhabits separately its hole, and that only after dark do they meet for feeding and for soeial intereourse."

In his Nelson report *, the same naturalist informs us that "in former years the Maruia Plains were a eelebrated hunting-ground of the Maoris for this bird. They generally went there on fine moonlight nights, when the berries of the tutu (Coriaria sarmentosa), a favourite food of the Stringops, were ripe, and ran them down partly with dogs, or even killed them with long sticks upon the tutu bushes. Another mode of eapture was, when they had found their holes, to introduee a long stick, to which they had fastened several strong flax snares. Feeling the bird with the end of it, they twisted the stiek until some part of the bird was eaught in the snares, and thus drew it,out. The ery of the Kakapo, heard during the night, very much resembles the gobble of a 'Turkey."

The following notes were contributed to 'The Ibis' $(1875, \mathrm{pp} .390,391)$ by the Baron A. von Hügel:-

"One thing I can boast of already is having been in the midst of the Kakapos: but I did not aceomplish this without some trouble; for the Stringops, unfortunately, is driven yearly further and further up country by the settlers, and now it is only met with in the most lonely mountain-districts. But I hardly think that any trouble and labour would be too great to see the bird as I saw it, at home, and, what is even better, procure a fine series of specimens. My trip was undertaken from Invercargill, and eonsisted of forty miles by rail, twenty-four in a coach, and some fifty more on horseback, with finally a ten-mile row up and across Lake Te-Anau. This brought me into the midst of the Parrots. The whole ground in the bush, whieh is covered with thiek moss, is honeycombed with their burrows-which emit a strong scent, a sort of greasy essence of Parrot-bouquet. 'I'he entranee to each-as in fact is the whole ground-is strewn with their exerement, so as almost to make one believe that a flock of sheep had been grazing there. I had an old Scoteh shepherd and his dog with me, and they both proved very useful. The latter caught the birds very eleverly by the baek, and invariably brought them already lilled to us with their feathers in perfect order; but some we lost through his killing them in the bush instead of on the open traet of bracken where we were posted, and then feeding on them quietly before we could make out his whereabouts. The note of the Stringops is very peculiar, quite unlike that of a bird. I think it is when feeding that they indulge in a series of the most perfect porcine squeals and grunts. It is really as like a young pig as any thing can be. Then their other note, whieh I think answers more to a call or warning, is a very loud aspirated scream, with a sort of guttural sound mixed in with it, almost impossible to describe. Then, when pursued and eaught by the dog, it emits a low harsh sort of croak; but some were perfectly silent to the last ..... The food I found to consist of the bracken (Pteris aquilina), both frond-tips and roots, but ehiefly the former. I examined six; and all were crammed with it; but what surprised me much was to find parts of two moderate-sized lizards in the gizzard of an old male. I think this is quite a new faet in the Stringops life-history" $\dagger$.

Mr. Reisehek says (Trans. N.-Z. Inst. vol. xvii. pp. 195-197):-“In April 1884 I found under the root of a red birch, in a burrow, two young Kakapos, covered with white down. During the same month I found several other young birds of this speeies. So late in the season as the 12th May, Mr. Doeherty found a Kakapo's nest containing a female sitting upon an egg, with a chick just

* Loc. cit. p. 7 .

In this communication the Baron mentioned that although he was unable then to give a complete life-history of the Kakapo, his observations did not altogether agree with those recorded by me on the authority of Sir J. von Haast, who was the first to study the bird in its native haunts. As, however, he did not either then or subsequently point out in what respects the account appeared to him faulty, I have, since my arrival in England, written to Baron von Hiigcl asking him for the desired information, and he has kindly sent me the following:- "The notes I promised, about the habits of the Kakapo, to "The Ibis' (which fact until you reminded me of it I had completely forgotten) were never sent. I do not remember now the point in which I thought Haast in error." 
hatehed. He kindly pointed out the nest, which I measured. The burrow had an entrance from both sides and two compartments. Both entrances led to the first compartment, the second and deeper ehamber being connected with the first by a small burrow of abont a foot. The nest was in the outer eompartment, and was guarded by very strong roeks, rendering it difficult to open it. The distanee from the entrances to the nest was two feet and three feet respeetively. The first ehamber was twenty-four inehes by eighteen inches, and twelve inehes high; the inner compartment was fourteen inehes by twelve inches, and only six inches high. The nest was formed by a deepening, lined with wood-dust, ground by the bird as fine as sawdust, and feathers, which the female had evidently plucked from her own breast whieh was quite bare. From my observations I am of opinion that the male bird takes no part in the hatching or the rearing of the chicks, as in all cases the fernale was the sole attendant from first to last. I did not see a male near a breeding burrow nor did $\mathrm{I}$, in any single instance, find two grown-up birds in one burrow, though I have seen them in pairs on their noeturnal rambles. Whenever two males meet they fight, the death of the weaker sometimes resulting. The female is muel the smaller (probably about three-fourths the weight) and duller in plumage. 'These bush Kakapos are very eommon in various parts of the Sounds distriet. . . . I was partieularly anxious to observe the manner in which the Kakapos make their tracks; I therefore hid myself on several oecasions in proximity to one of the tracks, and in such a position that I could see every bird as it passed along. It was very amusing to wateh these creatures-generally one at a time-coming along the track feeding, and giving a passing peek at any root or twig that might be in the way. Thus the tracks are always kept clean; in faet they very mueh resemble the native tracks, with the exception that they are rather narrower, being from eight to fourteen inehes wide. The Kakapos generally seleet the tops of spurs for the formation of their traeks. I was curious to know low the birds would manage when their tracks should be covered with snow. Opportunities were afforded of satisfying my curiosity. I found that they travelled on the surface of the frozen snow, and that their tracks were soon plainly visible, though not more than an ineh below the level of the surrounding snow. In many places the scrub, whieh consists of silver pine, akeake, and other alpine vegetation, is so dense that the snow eannot penetrate it. The Kakapos take advantage of this to make their habitations under the snow-covered scrub, where it is both dry and warm.

"The Kakapos leave their burrows after sunset and return before daylight. If they cannot reach their own home during the darkness, they will shelter in any burrow whieh may be unoccupied, as they travel long distanees. They consume large quantities of food, which consists of grass, grass-seed, and other alpine vegetation. In July they are in splendid condition, those found having as mueh as two inches of fat upon them. I was much surprised and interested to find in the intestines of the old birds parasites from six inches to two feet long. These parasites are flat, abont a quarter of an inch wide, milky white, and jointed very closely. I have found three of these parasites knotted together and many single ones tied in three or four knots.

"In the spring, when the sun begins to shed its warmth, the Kakapos emerge from their burrows, and select some favourable spots in the sunshine, where they eroueh down and remain the whole day. In September I selected a suitable day for observing this peeuliarity. The snow had disappeared from all the sunny places. I found three birds in different places, sitting upon low silver-pine scrub. They took no notice of my approach until I had them safely in my hand, when they endeavoured to release themselves by biting and scratehing."

On two oceasions I have myself kept a live Kakapo, for the purpose of studying its habits. My first bird was somewhat vicious and would not allow itself to be handled. It had a great penehant for raw potato, of which it could stow away a surprising quantity. It was an adult bird when caught and did not long survive the eomplete change in its eondition of life. My other Kakapo was brought to me as a young bird, being readily distinguishable as such by its dark cheeks, with little or no 
admixture of yellow, and its delicate pale grey bill. This proved a far more satisfactory pet, and soon became attached to the surroundings of its new home. On our first interview, it gave me a severe bite in the hand, fairly cutting out a piece of flesh; but at the end of a day or two, on being taken from its cage, it would spring upon my arm, mount to the shoulder, and nibble my beard in a playful way. It would partake freely of almost any kind of food, eating as readily of fat mutton as of a green apple or potato; but it seemed most at home when nibbling grass and other succulent herbage. It uttered at times a low grunt, and when excited a peculiar growling sound. It was sometimes allowed the freedom of the garden; and on these occasions I have been much struck with its wonderful assimilation of colouring to the surrounding vegetation, it being quite impossible at a little distance to distinguish it, the singular distribution of green and brown markings in the plumage being very deceptive.

To illustrate the extreme vitality of this Parrot, I may mention that on one occasion the Kakapo's cage was left for a whole day in an outhouse where some painting operations had been carried on. The fumes of red lead and probably the absorption of the poison by the water which the bird had been drinking produced their natural effect; and at nightfall the Kakapo was found at the bottom of his cage, lying on his side quite helpless and to all appearance in articulo mortis. Restoration to fresh air, aided by a small quantity of spirit poured into his crop, brought the bird out of this state of asphyxia; and, although he continued very weak and tottery for twenty-four hours, he ultimately regained his full vigour and spright tliness.

On its general conduct I find the following entry in my note-book:-It is decidedly nocturnal in its habits, making for any dark corner or shaded recess immediately on being liberated from its cage. It walks in a measured deliberate way, and when hurried expedites its movements by flapping its wings. Sometimes it utters a scream not unlike that of the Kaka when excited or alarmed. It partakes freely of every kind of vegetable food: it nibbles grass, rolling up and detaching a blade at a time in a very deliberate manmer; it devours with avidity lettuce, ripe tomatoes, apples, and raw potatoes; it sucks up the contents of ripe grapes with great relish; and it is at all times ready to make a substantial meal off fat mutton or soaked bread; so that, in point of fact, the bird is omnivorous.

It loves to move about among the herbage in our shrubbery, exploring with its bill and nibbling off the leaves, but never attempting to climb. In the evening it becomes more active in its movements, perambulating its cage when confined, and showing every inclination to be abroad. One night it succeeded in effecting its escape by twisting some of the wire bars, and after foraging about to its heart's content it voluntarily returned before daylight to its prison-house, squeezing its body through the aperture it had made.

Its distinguishing characteristic, however, is its playfulness. When not permitted to climb one's arm and "make-believe" at biting, it thrusts its head into the little tin drinking-vessel, visor-like, and struts about its cage, with every appearance of delight.

On examining my captive Kakapo at night, by the aid of a candle, I was much struck with the resemblance of its general contour to that of the Laughing Owl. It had the same habit of standing almost bolt upright, with the feathers of the head raised and the brows arched, as if in an attitude of contemplation. I mention this as among the many superficial characters justifying the appellation of Owl Parrot.

Mr. Kirk, the well-known botanist, informs me that this bird, as observed by him in captivity, evinces a great partiality for the male flowers of Pinus pinaster.

A specimen, sent to England by Mr. Murdoch, the Inspector of the Bank of New Zealand, lived for a considerable time in the Zoological Society's Gardens, but in the same retired way as its predecessor, closely concealing itself in its box by day, exhibiting itself to the public only under coercion of the keeper, and then manifesting the utmost impatience to regain its dark retreat. 
A life-sized drawing of this species was given in Gray and Mitchell's 'Genera of Birds ' (1842), admirably coloured, but placed in an attitude quite foreign to the habits of the bird. Mr. Gould gave a portrait of it in the Supplement to his 'Birds of Australia,' executed in his usmal masterly style; and other figures, of less note, have appeared at various times. The coloured drawing of this bird in the 'Student' for 1870, as well as the woodcut in the 'Field,' although in other respects excellent pictures, possess a fault in common-namely, in having the tail broad and fan-like, instead of being compressed, narrow, and inclined inwards. This, as I have been informed, was owing to the damaged condition of the tail in the particular bird from which both of these figures were taken.

The egg of the Kakapo, of which there is a figure (from the pencil of Mr. Wolf) in the 'Proceedings' of the Zoological Society for 1852, is broadly ovoido-conical in form, and of pure whiteness till discoloured in the process of incubation. A specimen in the Canterbury Mnseum, much stained and slightly damaged, measures 2 inches in length by $1 \cdot 4$ in its grentest breadth: the surface of the shell is smooth, but without any gloss or polish; and on close inspection it is found to be finely granulate. Another in the Otago Museum is of almost exactly similar size, measuring 2 inches in length by 1.45 in breadth: this specimen is somewhat discoloured, probably by contact with the bird's feet; the shell is minutely granulate, liaving a slightly rough surface to a sensitive touch. Another in my son's collection is appreciably smaller, measuring 1.85 inch in length by 1.35 in breadth, and, originally of a greenish-white colour, is stained and discolomred, though somewhat unequally, to a pale yellowish brown.

A specimen from Preservation Inlet is rather larger than the last mentioned one, measuring 2 inches in length by 1.4 in breadth. It is yellowish white and somewhat soiled, the surface being without any gloss, and slightly granulate, or marked with extremely fine points.

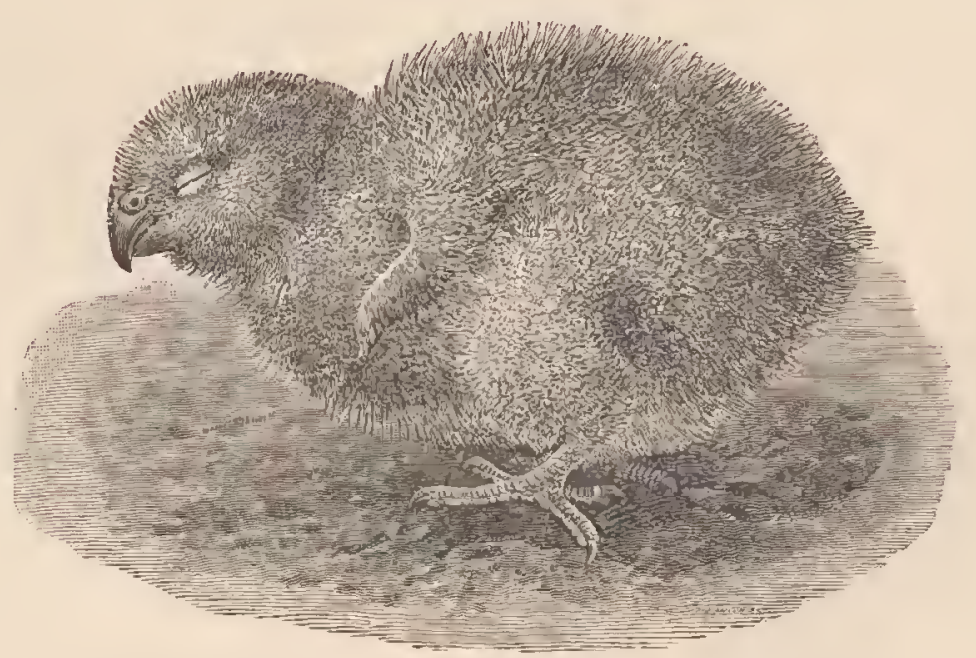

Kakapo chick, just hatched: natural size. (Sce page 178.) 


\title{
SPILOGLAUX NOVÆ ZEALANDIÆ.
}

\author{
(NEW-ZEALAND OWL, OR MOREPORK.)
}

New-Zealand Owl, Lath. Gen. Syn. i. p. 149 (1781).

Strix novce seelandice, Gm. Syst. Nat. i. p. 296 (1788, ex Lath.).

Strix fulva, Lath. Ind. Orn. i. p. 65 (1790).

Noctua zelandica, Quoy \& Gaim. Voy. de l'Astrol. Zool. i. p. 168, t. 2. fig. 1 (1830).

Athene novce seelandice, Gray, Voy. Ereb. \& Terror, p. 2 (1844).

Athene nove zealandice, Gray, Cat. Brit. Mus. Accipitr. p. 52 (1844).

Noctua venatica, Peale, U. S. Expl. Exp. p. 75 (1848).

Spiloglaux novoe seelandice, Kaup, Isis, 1848, p. 768.

Ieraglaux nover zealandice, Kaup, Tr. Zool. Soc. iv. p. 218 (1852).

\section{Native names.}

Ruru, Koukou, and Peho; "Morepork" of the colonists.

Ad. suprà chocolatinus, scapularibus maculis fulvis plus minusve celatis notatis: loris, genis anticis ct supercilio distincto fulrescentibus : rcgione auriculari chocolatinâ : tectricibus alarum mcdianis et majoribus extùs fulvo vel albo maculatis : remigibus brunncis, extùs albo maculatis, et saturatè brunneo transfasciatis : eaudâ suprà brunnê̂, subtùs pallidiore, fasciis distinctis saturatè brunneis transnotatâ : collo laterali et corpore subtùs toto lætè fulvis, medialitcr latè brunneo striatis : abdomine imo, hypochondriis ct subcaudalibus pulchrè albo marmoratis: cruribus et tarsorum plumis lætè fcrrugincis : rostro nigro, culminc albicante: pcdibus flavis, digitis setis nigricantibus indutis : iridc aurco-flavâ.

Adult male. Crown of the head and all the upper parts dark umber-brown, obscurely spottcd on the scapulars and wing-coverts with fulvous white; lores and region of the bill white, with black produced filaments; forchead, forc neck, and upper part of the breast light fulvous, mixcd with brown; underparts gencrally fulvous, with triangular spots of dark brown disposed in rows and blending; under tail-corcrts fulvous barred with whitc; quills and tail-feathers dark brown obscurcly banded, the former touched on the outer wcbs with fulvous white; feathers covering the tarsi fulvous. Irides golden yellow; toes yellow, with dark hairs; bill black, white on the ridge. Length 12.5 inches; extcnt of wings 25 ; wing, from flexure, 8 ; tail $5 \cdot 75$; bill, along the ridge 1 , along the cdge of lower mandible $\cdot 75$; tarsus $1 \cdot 5$; middle toc and claw $1 \cdot 25$.

Female. The fomale is slightly smaller, and the markings of the plumage are less distinct than in the male.

Nestling. A nestling obtaincd at Westland (and apparently a fortnight old) is covered with thick, fluffy down, of a sooty-brown colour, with loose white filaments; inclined to tawny on the underparts, and whiter on the sides of the head and ncck; bill dark brown, with a whitish ridge; legs and fect ycllow. Thcy assume the full plumage before quitting the nest.

Fledgling. In my collcctiun there are two specimens of different ages :-

No. 1 has the forehead, chin, and sides of the face destitute of feathers; the crown of the hcad and all the upper surface sooty brown, or almost black, without any light markings; the plumage extremely soft and fluffy, with the downy whitc filaments still adhcring to it, and more abundantly on the head, neck, and rump; underparts sooty brown, mixed with fulvous; on the thighs thick fluffy plumage of a dull tawny 


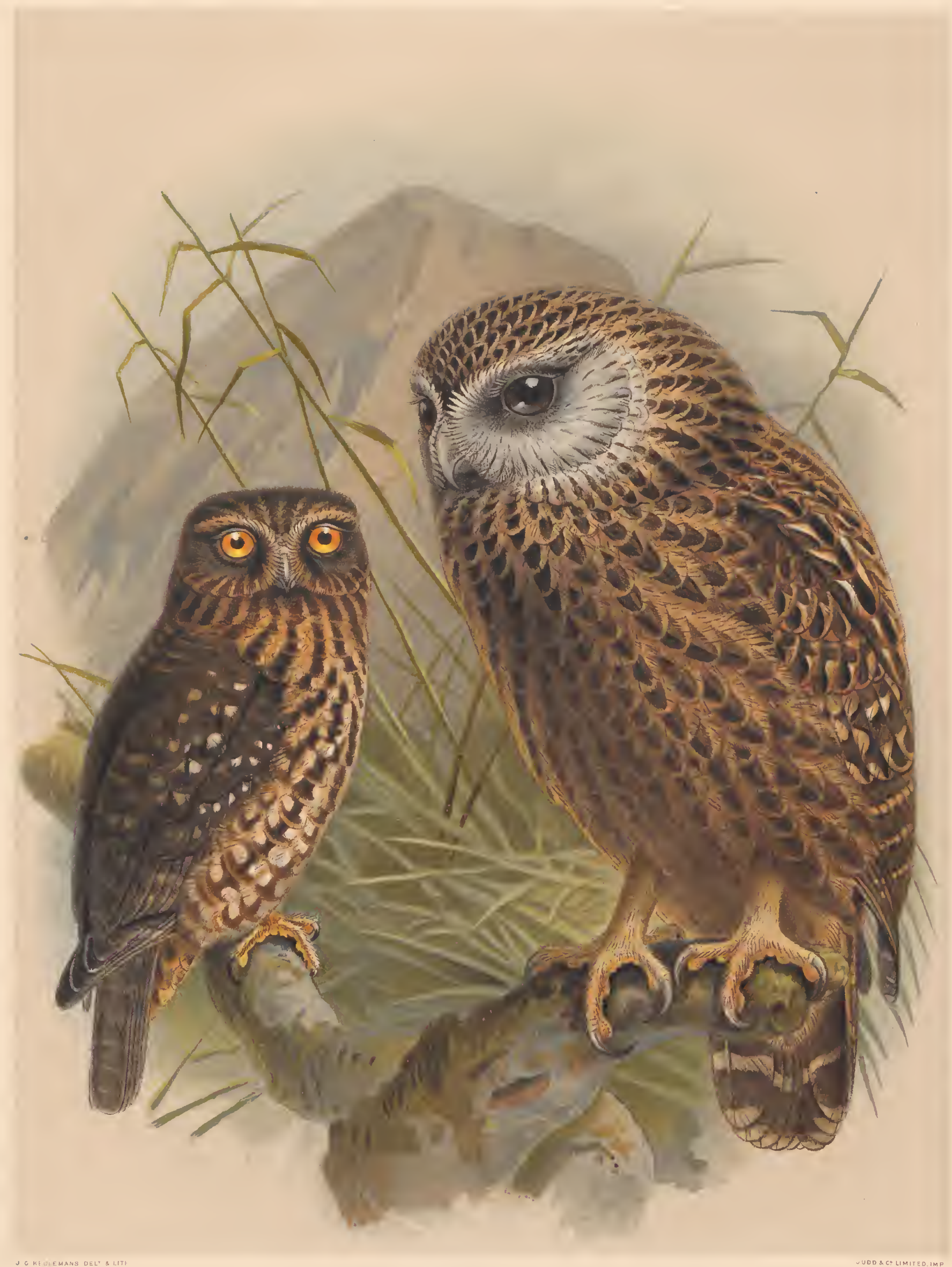




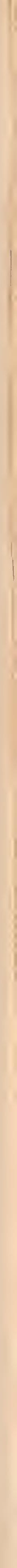


colour; the tarsi thiekly eovered to the toes with white down, having the appearance of stockings; quills and their corerts just developing, the rounded white spots on the latter being rery eonspicuous; bill grcenish black; toes yellow; claws dark brown.

No. 2, whieh is apparently ten days or perhaps a fortnight older, is in a condition to leave the nest : plumage as in the adult, but duller, and mixed with dark-eoloured down on the breast; head well-feathcred, but with less white abont the chin and facial disk; feathers very fluffy and with downy filaments still adhering on some parts of the body; white spots on wings more regular than in the adult, forming two parallel diagonal series, following the order of the corcrts; bill dark brown.

Varieties. Examples from different localities present slight but uniform differences of plnmage. Specimens from the Nelson district are, on eomparison with tlose from the nortlı side of Cook's Strait, invariably found to be more largcly marked with white around the eyes and on the feathers surrounding the bill. As we proeeed further south the variation is still more apparent, the whole plumage partaking of a ligliter charaeter. There is also considerable variation in size; and a specimen received by me from Mr. W. T. L. Travers is not only unusually small in all its proportions, but has the wholc of the plumage decply stained with ferruginous. A beautiful albino was shot at Te Whanwhau (Whangarei) in the winter of 1871.

In Mr. J. C. Firth's fine collection of New-Zealand birds, at Mount Eden, Auekland, there is a beautiful specimen (obtained at Coromandel) in partial albino plumage. The whole of the body is marked with white, presenting a mottled appearancc, and partieularly so on the underparts, where the white is softly blended with the normal tawny eolour, producing a very pretty effect; eaeh wing has two white primaries, but the tail-feathers are as in ordinary examples.

Every New-Zealand colonist is familiar with this little Owl, under the name of "Morcpork" *. It is strictly a nocturnal speeies, retiring by day to the dark recesses of the forest, or hiding in the ereviees of the rocks, and coming abroad soon after dusk to hunt for rats, miee, and the various linds of moths and bectles that fly at night. It is common in all parts of the eountry, although not so numerous now as it formerly was; and the familiar ery from whieh it derives its popular name may often be heard in the more retired parts of our principal towns, as well as in the farmcr's country home or in the rustie Maori "kainga": I have even known several instanees of its voluntarily taking up its abode in a settler's house or, more frequently, in the barn, and remaining there a considerable time.

When discovered in its hiding-placc during the day, it is found sitting upright, with the head drawn in, the eyes half elosed, and the feathers of the body raised, making the bird appear much largcr than it really is. It will then allow a pcrson to approach witlin a few yards of it, and, if disturbcd, will fly off noiselessly for a short distance and attempt to secrete itself. It will often

* "This bird gave riso to rather an amusing incident in the Hutt Falley during the time of the fighting with Mamaku and Rangihaeata, and when, in anticipation of a morning attack, a strong piquet was turned out regularly about an hour before daylight. On ouc occasion the men had been standing silently under arms for some time, and shivering in the eold morning air, when they were startled by a solemn request for 'more porks.' The officer in command of the piquet, who had only very reecntly arrived in the country, ordered no talking in the ranks, which was immediatcly replicd to by another dcmand, distinctly cnunciated, for 'more pork.' So malapropos a remark produced a titter along the ranks, whieh roused the irate offieer to the neecssity of haring his eommands obcyed, and he accordingly threatened to put the noxt person under arrest who dared make any allusion to the unelean beast. As if in defiance of the threat, and in contempt of the constituted authorities, 'more pork' was distinctly demanded in two places at once, and was succeeded by an irresistible giggle from one end of the line to the other. There was no putting up with such a breach of discipline as this, and the officer, in a fury of indignation, went along tho line in search of the mutinous offender, when suddenly a small chorus of 'more pork' was heard on all sides, and it was explaincd who the real culprits were.

"At the attack in the Bay of Islands by Heke and Kawiti, the native parties, in moving to their positions about the blockhouses and town before daybreak, commnnicated their whereabouts to one another by imitating the ery of this bird, whieh the sentries had been so aeeustomed to hear of a morning that it did not attract their notice." (Captain Power's "Skctches in New Zealand,' 1849.) 
remain many days, or even weeks, in the same piece of bush. In the volcanic hills or extinct craters that surround the city of Auckland there are numcrous small caves, formed by large cracks or fissures in the ancient lava-streams, the entrance to them being generally indicated by a clump of stunted trees growing up among loose blocks of scoria. These gloomy recesses are a favourite resort of the Morepork in the daytime.

On the approach of night its whole nature is changed: the half-closed orbits open to their full extent, the pupils expand till the yellow irides arc reduced to a narrow external margin, and the lustrous orbs glow with animation, while all the morements of the bird are full of life and activity. It then sallies forth from its hiding-place and explores in all localities, preferring, however, the outskirts of the forest, where nocturnal insects abound, and the bush-clcarings in the nciglibourhood of farms, or the ruins of Maori villages, these places being generally infested with rats and mice, on which it chiefly subsists. Like other birds of prey, it afterwards regurgitates the hair and other indigestible parts of these animals in hard pellets. That the Morepork also preys on small birds there can be no reasonable doubt, although it has been frequently called in qucstion. Captain Mair has seen one, at sunset, seated on the branch of a tutu bush (Coriaria ruscifolia) with a live Korimako in its claws, and in the act of killing it; and a native once told me that he had seen one of these Owls killing and devouring a Parrakeet. Mr. Drew, of Wanganui, informs me that the stomach of one which he skinned contained the entire body of a House-Sparrow. Captain Robinson, of Manawatu, further attests the fact; for on one occasion, when walking in his garden after sunset, he saw a Morepork emcrge from a blue-gum and spring upon a Kingfisher, firmly grappling it in its claws. The bird uttered a cry of pain or terror; and on my informant advancing towards the spot, the Owl released its rictim and flew off, but immediatcly aftcrwards made a second attack, securing the Kingfisher firmly in its grasp, and only relaxing its hold at the moment of being scized.

Mr. J. 'T. Stewart informs me that, in his own garden at Foxton, he has witncssed two instances of the Owl attacking and vanquishing the Kingfisher, this happening on both occasions towards evening.

I have becn informed by Sir George Grey that, of nearly a hundred Diamond-Sparrows which he liberated on the island of Kawau, very few survived the ravages of this little Owl, and that some other importations suffered in like manner. Sir Edward Stafford, who had for many years interested himself in the introduction and acclimatization of useful birds, has also given evidence against the Morepork on this charge; for he has assured me that on one occasion, having turned out a large number of insectivorous birds in his grounds at Wellington, an unusual number of Owls sought harbour there, and preyed on the littlc immigrants till scarcely a single one remained. For a considerable time, however, it was doubted whether the Morepork was destructive to acclimatized birds; and a lengthy controversy on the subject appeared in the Auckland ncwspapcrs. The careful observations of Mr. Brighton, the Curator of the local Acclimatization Society, at length placed the matter beyond all discussion. Frequently he had to forego his night's rest in order to watch the aviaries, and during a period of only a few months he shot no less than fourteen of these birds. Some of these were surprised in the act of attacking the aviarics, and all of them in the immediate vicinity. He repeatedly found the dead and lacerated bodies of Sky-Larks and Chaffinches lying on the wooden ledge just inside the eave of the wire-roofing; and the abundance of Morepork-feathers found entangled in the nctting afforded a clue to the perpetrator of these murderous attacks. From the appearance of the feathers, and the mutilated condition of the dead birds, it was evident that the Morepork had tried hard, but unsuccessfully, to pull them through the wire netting in the roof. The following account, by the Curator, renders this pcrfectly intclligible:-

"The aviary is constructed in the usual manner, on the modcl of a bird-cage, of wire netting over a wooden framework, with a sloping roof, also of wire netting. Attached to the framework 
comprising the wall-plates, on either side, there are wooden ledges, resembling shelves, on which the Larks rest at night, while the Chaffinches roost upon twigs planted within the aviary, and reaching within a few inches of the wire netting of which the roof is composed. During moonlight nights the Moreporks have been seen to fly upon the roof of the aviary, and after making, as it were, a reconnaissance of the defences, to pounce repeatedly against the wire, causing a loud vibration, and startling the feathered inmates. These, in their fright, fly towards the light, dashing themselves against the wire netting, until the Morepork, by hopping about on the roof, succeeds in fastening upon one of them, and, of course, making short work of him."

In addition to the above evidence, sufficient of itself before any common jury to convict the culprit, I may mention that on one oecasion in Christchurch I saw a Morepork, towards the cool of the evening, enter the verandal of the house in which I was staying and boldly attack a Canary whose cage was suspended there, vainly endeavouring to clutch it as it fluttered against the wires. I heard of another instance in which the depredator actually succeeded in tearing off a limb of the occupant in its efforts to pull it through the bars.

There has, in consequence, been a crusade against the Morepork in many parts of the country. But whether this wholesale destruction of an indigenous species, on account of these predatory habits, is wise, or even prudent, may be seriously questioned. The Morepork, as we have already shown, not only preys on rats and miee, but is also a good insectivorous bird, with a voracious appetite. Its habit of feeding largely on the nocturnal lepidoptera is of itself an inestimable benefit to the agriculturist, as it tends to check the spread of the caterpillar, whose ravages are becoming more severely felt every year. It is a dangerous thing to disturb the balance of nature by violent means; and, in a new country especially, we must be careful that in removing one evil we are not opening the door to an immeasurable greater one. For my own part, I eonsider the killing of a single Owl a positive injury to the farming industries of the country, and scarcely compensated for by the introduction of a score of soft-billed insectivores in its place.

I have sometimes found this species, at night, among the rocks along the sea-margin, from which it may be inferred that crabs and other small crustacea contribute to its support. In the stomachs of some I have found remains of the large wood-beetle (Prionoplus reticularis); and those of others I have found crammed with moths of all sizcs, or with nocturnal coleoptera. I examined some castings of the Morepork in the Canterbury Museum. They are hard pcllets, of an oval form, and of the size of a Sparrow's egg, eomposed chiefly of the hard elytra and heads of various coleopterous insects, among which I noticed particularly the shining covering of the mata (Feronia antarctica), a handsome ground-beetle which is found on the Canterbury plains, but docs not occur in the North Island.

I have noticed that individual birds arc very local in their disposition, often fixing on a particular roost or hiding-place by day, to which they will regularly resort for weeks or perbaps months together, the ground immediately below the perch bccoming at length quite foul with their accumulated droppings.

Judge Munro informs me that some years ago on opening a bird of this species he found in its stomach a specimen of the weta-punga, or tree-cricket (Deinacrida heteracantha), with a body as large as a magnum-bonum plum; and the stomach of another which I obtained in the Rimutaka Ranges, in the month of March, was filled with broken remains of the small weta (D. thoracica).

The flight of the bird is light, rapid, and so noiseless that, I verily believe, it could surprise and capture a mouse at the very entrance to its burrow. On examining the feathers of the wing, it will be found that they are furnished with a soft or downy margin, and are specially adapted for this manncr of flight. From an examination of the orifice of the ear we are led to infer that the power of hearing in this Owl is very acute. It is therefore the more surprising that, on two occasions atter dark, I have succeeded in seizing this species with the hand, when perched on the eaves of a verandah, 
over which its tail projected. It is comparatively easy to capture it on the wing by a dexterous use of a strong insect-net. When canght, it manifests its anger by a repeated clicking of the mandibles, while it dexterously uses its beak and talons in its appeals for libcration. The ordinary call of this Owl at night consists of two notes uttered with vigour, and having a fanciful resemblance to the words "more pork," from which it derives its popular name. These notes are repeated at rcgular intervals of from eight to ten seconds, as I have ascertained by timing the pcrformance with my watch. Sometimes the bird breaks off at the end of half an hour, probably to go in quest of food; at othcr times he keeps up this hooting for a couple of hours or more continuously, espccially on

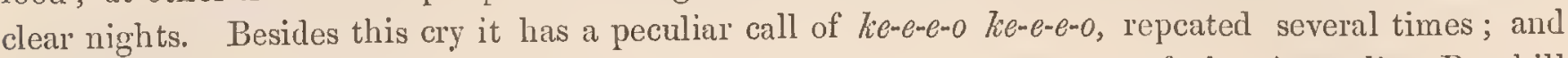
when disturbed or excited a scream, which is not unlike the alarm-cry of the Australian Rosehill Parrakeet (Platycercus eximius), but londer and more shrill. At dusk also, before leaving its retreat, it utter's a low croaking note, quickly repeated, which is responded to by the other Owls within hearing. This notc rescmbles the syllables kou-kou, uttered from the chest; and among the northern tribes the bird is nsually called by a name rescinbling that cry. It is, however, more generally known as the "Ruru," and in some districts as the "Peho" *.

At night two rival inales may be heard answcring each other from neighbouring woods, or, as Longfellow expresses it,

$$
\begin{aligned}
& \text { "Talking in their nativo language, } \\
& \text { Talking, seolding at each other." }
\end{aligned}
$$

Although habitually nocturnal I have occasionally secn it abroad in the daytime, but only during very clull weather. On the occasion of my last visit to Auckland, about 5 o'clock one afternoon, I observed a Morepork, in broad daylight, sail across the public highway, in the very midst of the busy traffic, and take refuge in some trecs in the old Collcge grounds, in a spot where (although it no longer forms part of the school enclosurc) thirty years before I had played cricket and football with the friends of my youth. A few evcnings later I heard another screaming among the chimneytops in Shortland Crescent, in the very heart of the city-facts showing conclusively, I think, that this species has not been much affcetcd by the spread of civilization in its native country.

Althongh naturally very fierce, I have known at least onc instancc of its becoming quite tame in confinement and taking food from the hand of its keeper.

It nidificates, as a rule, in hollow trees; but in the Mackenzie country, where there is little or no timber, nests have been found under the shelter of loose boulders. 'The young leave the nest about the bcginning of January, and may be heard during every niglit of that month uttering a pcculiar, sibilant, snoring sound, sometimes sufficicntly sharp to resemble the stridulous song of the native cricket. But the breeding is occasionally delayed to a much later period of the ycar; for I have heard young Owls in the woods at Palmerston North on the 6th March, and on onc occasion, at the North Shore (Anckland), I both heard and saw a young bird so late as the 11th of April. On the other hand, there are sometimes very early broods; for the downy nestling, of which a figurc is given on the opposite pagc (and which is now in my collection), was taken from the cavity of a tree near Dunedin in the month of November.

Mr. J. D. Enys writes to me that he met with a nest of the Morepork at the Ohunga river, containing three eggs; and I have a similar report from Mr. W. Fraser, who found a nest in a hollow puriri (Vitex litoralis), containing three young birls. The Owls continued to breed there for three successive seasons. Captain Mair found a nest of this species in the hollow of a dry hinau tree

\footnotetext{
* Aecording to Maori legend, this bird was one of the first winged inhabitants of New Zealand :- " He kopara te manu nana i noho tuatahi te puhi o te rakau; he ruru to te po; no muxi nga manu nunui i noho ai ki te motu, te kaka me te kereru, me nga manu katoa."
} 
(Elceocarpus dentata), containing two very young birds, which were "covered with soft white down, plumbeous beneath." In a clump of wood on the banks of the Wairoa river I found a nest, also containing tro fully fledged young ones. I sent my native lad, Hemi Tapapa, up the tree to capture them; and while he was so engaged the parent birds came forth from their hiding-place, and darted at his face with a low growling note, making him yell with fear*. The Maoris share in the almost universal feeling of superstition regarding the Owl. Hemi's conscience was troubled; and as the shades of night were closing in upon us with the call of "more pork!" in every direction, he handed me the captives and hurried away from the scene of his exploit, evidently sharing, in some degree, the horrors of that luckless wight, immortalized by Mr. Stevenson in his 'Birds of Norfolk,' who, having killed the church Owl as it flitted past him, ran shrieking home and confessed his awful crime"I've been and shot a Cherubim!"

There are two eggs of this species in my son's collection. One of these is almost spherical, the other is slightly ovoid, measuring 1.5 inch in length by 1.2 in breadth; they are perfectly white, with a very slight gloss on the surface.

* "Once the writer had an unusual adventure with one of these birds. It was early evening in the summer-time. The Owl was sitting on a gate. Anxious to watch and study its motions we sat down elose by it; soon it left its perch, making a sudden swoop at the intruder. This manourre it continued to repoat time after time, most perseveringly, and with great gravity and deliberation. Only onee was a blow felt; after each attack the bird resumed its perch on the gate. After a while the writer rose and walked up a dark ferny gully at some distance, when the $O$ wl followed and again attacked him. This is the only instance we have met with in whieh this species has shown any symptoms of boldly resenting an intrusion on its privacy." -Out in the Open.

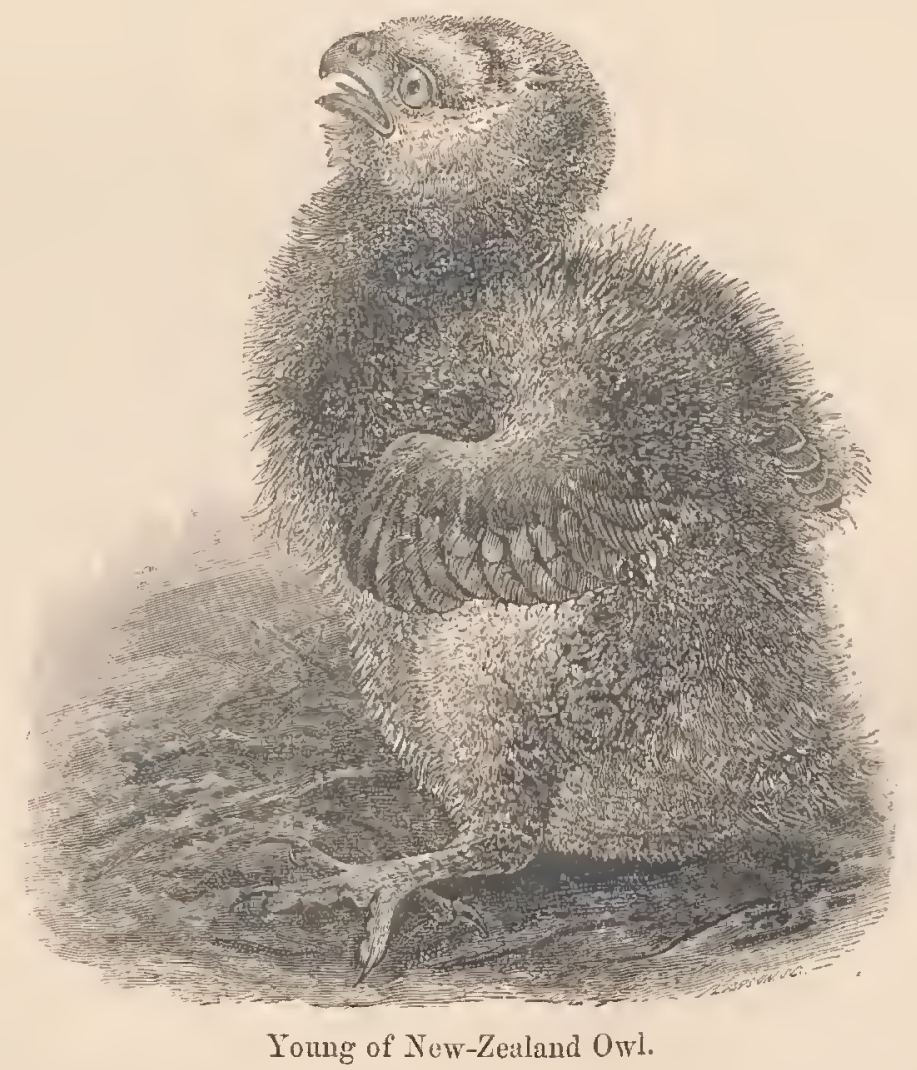




\section{SCELOGLAUX ALBIFACIES*.}

(LAUGHING-OWL.)

Athene albifacies, Gray, Voy. Ereb. \& Terror, p. 2 (1844).

Sceloglaux albifacies, Kaup, Isis, 1848, p. 768.

Ieraglaux albifacies, Kaup, Tr. Zool. Soc. iv. p. 219 (1852).

Athene ejulans, Potts, Trans. New-Zeal. Inst. vol. iii. p. 63 (1870).

\section{Native names.}

Whekau, Ruru-whekau, and Kakaha; “ Laughing-Jackass" of the colonists.

$A d$. suprà lætè fulveseens, plumis omnibus medialiter latè nigro striatis: uropygio lætiùs fulvo: seapularibus et dorso postico brunnescentioribus, latè albido marmoratis : teetricibus alarum magis ferrugineo tinetis, fulvo marmoratis : remigibus brunneis, extùs ferrugineo lavatis et fulvo maculatis : caudâ brunneâ, fasciis fulvis eonspieuè transnotatâ : fronte, superciliis, gulâ cum collo laterali grisco-albidis, angustè nigro striatis : regione oculari et auriculari brunncscentibus : corporc rcliquo subtùs lætè aurantiaco-fulvo, plumis medialitcr brunneo striatis : tarso plumulis albidis induto: rostro nigro, versus apicem cornco : pedibus corncobrunneis, setis fulvescentibus ornatis, unguibus nigricantibus : iride rnfescenti-brunneâ.

Adult. Forehead, throat, ear-eoverts, and sides of the head greyish white, with black shafts and hair-like filaments; sides of the ncck white, eaeh feather laving a narrow eentral streak of black; upper parts dark brown, the feathers of the erown and nape broadly margined with yellowish brown towards the tip; those of the lowcr part of the baek streaked, spotted, and barred with fulvous and white; lower part of the fore neck and the whole of the brenst dark brown, cach feather narrowly margined with bright fulvous or ycllowish brown; on the abdomen, sides of thc body, and under tail-eoverts the latter colour predominates, the centre of each feather being dark brown; the soft ventral featlers and the short plumage covering the thighs and tarsi light fulvous, without any dark markings ; primaries dark brown, marked on the outer wcb with equidistant angular spots of white, and on the inner web with obsolete bands; secondaries dark brown, with broad transverse bands of white, and clouded in the ecntre ; seapulars dark brown, handsomely varicgated with ocellated spots of whitc. The feathers forming the mantlc are all differently marked, some having two broad approximate lateral bars of white, othcrs a double series of spots on each web, while others again have a narrow lateral bar of white on one side of the shaft, and broad angular spots on the other; a few of them are transversely barred and margined with a narrow terminal creseent; upper wing-coverts dark brown, with numerous oval spots of fulvous white more or less distinct; tail-fenthers dark brown, with fivc cquidistant transvcrse bands and a terminal margin of fulvous white. Irides dark reddish brown; tocs flcshy brown, and covered with eoarse ycllow hairs; bill black, horn-colour towards the tip; claws blaek. Extreme length 19 inehes; wing, from flexure, 11 ; tail 6.5 ; bill, along the eurvature to anterior edge of eere, $2 \cdot 75$; cere $\cdot 25$; middle toe and claw $1 \cdot 6$; hind toe and elaw $\cdot 75$.

Obs. The above description is taken from one of the specimens in the Colonial Muscum. In the BritishMuseum example, figured in my former edition, thcre is less of the spottcd character on the upper surface, and the plumage is stained with ferruginous. The aeeompanying drawing is from a fine speeimen, in my own eolleetion, obtained near Timaru in 1874.

* Inadvertently named Sceloglaux nove zealandice on the accompanying Plate. 
Nestling. When freshly hatched the young bird is sparsely covered with coarse yellowish-white down, the abdomen being barc.

Varieties. Examples differ from eaeh otleer in the minutc details of thcir colouring. The two specimens in the Canterbury Muscum have less white about the face; the soft feathers forming the faeial disk are tawny whitc, witl black shaft-lines and liair-like filaments; and along the exterior edge of the disk there is a narrow crescent of purc white, cach feather marked witl a narrow brownish streak down the eentre. In onc of these examples the lengthened spots or fusiform markings on the upper surface arc less distinct, while in the other they are wholly wanting; but in the latter the fulvous-white bars on the primarics are very conspicuous, and add much to the beauty of the plumage. In this specimen the featlicrs of the upper surface arc blaekish brown, with a broad tawny margin, those forming the mantle, scapulars, and uppcr wing-coverts having, on each wcb, a broad oblique oar of fulvous white. A specimen morc lately received at the Canterbury Museum, and forwarded to Europe, and another in my own colleetion arc sufficiently white about the faee to justify the speeific name bestowed by Mr. G. R. Gray. In ordinary cxamples, lowever, this is quite a subordinate featurc. One of those figured in Mr. Darson Rowley's 'Ornithologieal Miscellany' lias an cutirely white faee; the other cxhibits a strong wash of rufous. The North-Island bird (in the Colonial Museum) is several shades darker than those from the South Island, the whole of the plumage being deeply stained with ferruginous. The feathers at the base of the upper mandible, and those immediately above the eyes, are white, with blaek shaft-lines; but the faeial disk is washed with fulvous. There is an entirc absenec of the white markings on the upper surfacc; underparts rieh tawny fulvous, with a dark brown stripe down the centre of each feather; tail dark brown, crossed by five broad V-shaped bands of tawny fulvous.

A specimen obtained from the Albury Rocks is inclined to albinism, there being a number of white feathers on the head, shoulders, and mantle, giving the bird a very pretty appearanee.

'THIs bird was originally described by Mr. G. R. Gray, in the 'Voyage of the Erebus and 'Terror,' under the name of Athene albifacies; and Dr. Kaup afterwards made it the type of his genus Sceloglaux, of which it still remains the solc representative. Mr. Gould, in treating of this singular form, has already pointed out that its promincnt bill, swollen nostrils, and small head are characters as much Accipitrine as Strigine, and that its short and feeble wings indicate that its powers of flight are limited, while its lengthened tarsi and shortened toes would appear to have been given to afford it a compensating increase of progression over the ground; and it does, at first sight, appear strange that a bird specially formed by nature for preying on small quadrupeds should exist in a country which docs not possess any. It must be remembered, however, that when the Laughing-Owl was more plentiful than it now is, New Zealand was inhabited or, rather, overrun by a species of frugivorous rat, which is now almost, if not quite, extinct. The kiore maori, which has been exterminated and replaced by the introduced Norway rat (Mus decumanus), formerly abounded to such an extent in the wooded parts of the country that it constituted the principal animal food of the Maori tribes of that period. It was a ground-feeder, subsisting almost entircly on the fallen mast of the tarwa, hinau, towai, and other forest-trces; and it would therefore fall an easy prey to the Sceloglaux. The fact that the extiriction of the native rat las been followed by the almost total disappearance of this singular bird appears to warrant the conclusion that the one constituted the principal support of the other *. Be that as it may, the Laughing. Orw, as it has been termed, in allusion to its cry, is at the

* On this point Mr. Smith writes to the 'Journal of Science,' vol. ii. pp. 86, 87 :-

"The suggestion of Dr. Buller that the kiore maori (natiro rat), before its cxtermination, may have constitnted the principal food of this $\mathrm{Owl}$, is an important onc; and my researches among the rocks at Albury, and experiments with the living birds in captirity, are greatly in support of this. In sovcral of tho crevices where I captured them, I found an ancicnt conglomerate of exuvia ranging from thrce to twelre inches thick. From the under surface, and through tho mass to nearly tho upper surface, this conglomerate is thickly studded with $O_{w l}$ 's castings, composed entircly of light brown hair (which is unquestionably that of the kiorc maori) and small bones. The castings more recently deposited among the rocks are composed of elytra and legs of bcetles." 
present day one of our rarest species. There are three specimens in the British Museum, and one in the fine eollection of raptorial birds formed by Mr. J. H. Gurney, and presented by him to the Norwich Museum. The Colonial Museum at Wellington and the Canterbury Museum * entain two specimens each; and there is a fifth in the loeal Mnseum at Dunedin. There are three fine specimens in the late Mr. Dawson Rowley's private museum at Brighton, and a still finer series in my own collection. All these examples, but one, were obtained in the South Island-the exceptional one having come from Wairarapa, in the provineial distriet of Wellington.

My first acquaintance with this Owl in the live state was made in the Acelimatization Society's Gardens at Christchurch. Unfortunately this Owl, which had lived in the Gardens for upwards of two years, was stone-blind, and its large eyes had a dead, glassy appearance; but I saw quite enough to satisfy me that, in its natural state, it is strictly a ground-feeder. Its appearanee was very full and rounded, the feathers of the head and neck being puffed out to a considerable extent. Although it had the freedom of a commodious shed, I observed that it remained eonstantly on the ground, standing high on its feet, the strong, feathered tarsi being vrey conspicuous. It manifested much impatienee or, rather, restlessness, striding with rapidity along the ground, or sometimes moving by a succession of hops, and generally in a rotatory manner, whieh may have been due to its blindness. The keeper informed me that this bird was a very poor eater, refusing fresh meat, and taking nothing but newly killed birds and live mice. A young mouse, quite paralyzed with fear, was crouching near the ground awaiting its fate, but the Owl took no heed of it; and in another part of its shed there was lying the half-devoured body of a hen Pheasant. I remarked of this bird that the feathered tarsi were mueh broader and stronger than they appear to be in the dried specimens. It walks quickly and with long strides, the body being held very erect; and when its speed is inereased, the wings are raised with a quivering motion. During the whole time of its confinement, the keeper had never heard it utter a sound, except once, when it startled him with its lond mocking cry.

It should be mentioned that this bird, which was obtained near the souree of the Cass River, in the eounty of Westland, was mueh darker in plumage than the speeimens in the Canterbury Museum, and more nearly resembled the North-Island example mentioned above. As the colours underwent no ehange during its long eonfinement, it is sufficiently clear that the dark plumage is not a eondition of immaturity.

The late Sir J. von Haast believed latterly that the large Owl eaptured by his dog amongst the rocky precipices in a creek near the Lindis Pass, and noticed by me, on his authority, under the provisional

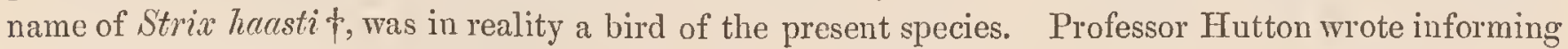
me that this was the Owl referred to in the following passage, in his account of the Birds of the Little Barrier Island \$:- “ Another bird also lives on the island, apparently in the cliffs, and comes out

* Of the examples in the Canterbury Museum, one was procured from the Kakahu Bush, near Arowhenua; and the other, killed at the Levels Station, near Timaru, was presented to tho Museum by Mr. Donald MeTean. Mr. Potts writes :- "In May 1857, while living in a tent on the Upper $\Delta$ shburton, we were constantly disturbed at night by thcir doleful jells amongst the rocky momntain-gullies. When disturbed on the ground, it bursts forth its wcird-liko cry immcdiately after taking wing. Its robust form, thickly clothed with soft feathers, is admirably adapted for cncountcring the severities of climate to which it must be frequently cxposed whilst scouring its wild hunting-grounds. Far less arboreal than its smaller congener, it roams orcr the blcakest tracts of country in many districts where bush of any cxtent is rarely to be met with, finding shelter among the numerous crevices in the rocks of rugged mountain-gullics. Being strictly nocturnal in its habits in pursuit of its prey, it must brarc the icy hlast of the alpino snowstorm at the lowcst temperature. The sererity of the elimate in thesc elevatcd regions would scarcely be credited by those who hare only knowi the mildness of thic coast-line. As may be inferred, the real home of this hardy raptorial bird is amongst the fastnesses of the Southern Alps, from whence it makes easual cxcursions by the numerous rirer-beds to the lower-lying grounds, these eccasional visits extending as far as the plains. Although well known from its cry, not many specimens hare been obtained."

† Essay on New-Zcaland Ornithology, 1867.

$\ddagger$ Transactions of the New-Zcaland Institute, rol. i. p. 162 (1868). 
only in the evenings. Its cry is a peculiar kind of laugh in a descending scale, and is very ridiculons to hear. I saw it twice by the light of the fire." But he afterwards found reason to modify this opinion (Ibis, 1874, p. 35). My own belief is that there has been some misconception on this point, and that the "series of dismal shrieks, frequently repeated, waking the tired sleeper with almost a shudder," as described by one writer on the subject, are not due to this Owl, but probably to a nocturnal species of Petrel (Procellaria affinis); for during the very long periods that captive birds were kept by Mr. Smith and myself, although habitually noisy, they were never guilty of this "convulsive shout of insanity." That they do, however, when on the wing produce a sound not unlike laughter, is beyond question; and when several of them are hunting together they seem to laugh in unison. This is specially noticeable on very dark nights.

Mr. Enys informs me that it has been seen at the Bealey Police Station (in the Southern Alps), and that it sometimes utters a note "something like that of the Morepork, but just as if he had his mouth full."

Mr. W. W. Smith, formerly residing on the Albury estate near Timaru, and now settled at the Ashburton, has sent me from time to time very interesting notes on this rare Owl. He has not only been exceptionally fortunate in getting specimens, but he has likewise been successful in his endeavours to make them breed in captivity. The following extracts from one of his earliest communications on the subject (already published by me in the Trans. N.-Z. Instit. vol. xvi. pp. 308-311) will show what a good observer $\mathrm{Mr}$. Smith is, and how keen his love of natural history. I have received many letters from him since, all replete with interesting facts, chiefly relating to this species; and I am also indebted to him for several fine specimens of the bird, together with the eggs and a newly-hatched chick :-

"February 8,1882 . In compliance with your request I have much pleasure in writing a short account of my experience in trying to breed the Laughing-Owl. The drawing of the bird made a great impression on me when I saw it for the first time in your 'Birds of New 'Zealand,' and since then I had been searching for over five years, trying to procure a specimen ; but I was never successful until April of last year, when I succeeded in finding a very handsome one. In June I found another pair; and again in September I found two more. They have been a great source of pleasure and instruction to me. I found the birds in fissures of the limestone rocks at this place (Albury), but they are certainly very difficult to find. I first discovered that they were about the rocks by finding several fresh pellets, and being anxious to secure a specimen, I procured long wires and felt in the crevices, but with no good results. I, however, discovered a plan which proved successful. I collected a quantity of dry tussock grass and burned it in the crevices, filling them with smoke. After trying a few crannies, I found the hiding-place of one, and, after starting the grass, I soon heard him sniffing. I withdrew the burning grass, and when the smoke had partly cleared away, he walked quietly out, and I secured him. I obtained four birds by this means. I explained in a former letter how very tame they became in a short while after being captured. I also mentioned their call, which varies considerably during the year. When I captured the second pair (male and female) their call for a long time, in waking up in the evening, was, as formerly stated, precisely the same as two men 'cooeying' to each other from a distance. The voice of the male is much harsher and stronger than that of the female, and he is also a much larger and stronger bird. During the period of hatching he is very attentive in supplying his mate with food, as no sooner had the food been put into the large apartment of their house, than he would regularly carry every morsel into the dark recess ; when feeding her she would utter a low peevish twitter and rise off her eggs. I may here correct a mistake which $\mathrm{I}$ made in writing to you on a former occasion. I stated that ' the male sits by day, the female by night.' I only saw the male twice on the eggs, and it was at this time I wrote the letter; but I certainly was mistalsen, as the female performs most of the duty of hatching. I also 
ascertained the difference of the sexes by separating them at night until the second egg was laid. The females are much shier and more timid than the males, as they hide themselves on hearing the least noise. After sitting nine days on her first egg, the female forsook them, and all efforts to induce her to sit again were unavailing. She laid two more eggs a month afterwards, and had sat seven days, when, I regret to say, I had to leave home for medieal treatment at Timaru. When I returned, eight days afterwards, she was still sitting and eontinued to sit until the 17 th November, when she left the eggs without bringing out the young. The eggs must have been allowed to get cold when eight or nine days sat-on, as when I tried to blow them I found they contained embryo ehieks. I am glad, however, that I sueeeeded in getting the eggs; another season I may succeed in getting young birds. I supplied them with many different articles of food, sueh as beetles, lizards, mice, rats, rabbits, and mutton, of all of which they partook freely; but they have the greatest preferenee for young or half-grown rats. They are a little slow and clumsy in eapturing living prey, but their want of proper exercise and freedom may account for this; it may be otherwise in their wild state. After what I have pointed out, there ean be no doubt that the Sceloglaux inhabits the dry warm crevices of rocks. All the birds I captured I found in such places, generally five or six yards from the entrance, perfectly dry, and where no wet could possibly enter. One thing surprised me muchthe very narrowness of the entranee to their cranny. In some instances the birds must have forced themselves in. I notieed, however, that the erevices widened as they extended into the rock. The bottoms are covered with soft sand crumbled down from the sides, and affording comfortable resting plaees.

"Regarding the nidification of this bird, I am no longer surprised that so little is known, and likewise of its natural habits, eonsidering that it eonceals itself in sueh inaeeessible plaees, and where few would think of searehing for it. As a rule they could lay their eggs and hatch their young unseen and unmolested.

"The breeding-season may be said to extend over September and October. I found the bird mentioned in my last letter sitting on an egg on the 25 th September; but it must have been laid about the beginning of the month, as it eontained the chick I sent you. I discovered the bird by reaching a long stick with a lighted taper into the crevice. My captives laid on the 23rd, 27th, and 29th September, and again on the 20 th and 22 nd Oetober*. The birds were very restless and noisy for a fortnight before nesting. They began to moult in December, and are not yet (Feb. 8) in full plumage. When casting their feathers they have a very eurious appearanee, as they become almost naked. At this stage two of my birds were stung to dcath, a month ago, by a swarm of bees passing through the fine wire netting and taking up their quarters on the roof of their dark recess. I was very sorry to lose them, as I cannot now send you a living pair. I have one very fine male I will send you in April. I am going to Lyttelton at that time, and I will forward it by the first steamer bound for Wellington. I will likewise send you another Owl's egg, but hardly sueh a fine specimen as either of the two I sent before. I intend to search the rocks carefully for more birds, and, if I sueeeed in finding more, I will not fail to send you a pair. You may, however, rely on getting a second speeimen from me. I should mention that I have eolleeted a quantity of pellets at different times, eomposed of the hair of rats and mice and the elytra of beetles. Three large speeies of the latter swarm among the débris beneath the main rock, and certainly eonstitute part of the bird's food."

From Mr. Smith's further notes I have extracted the following aeeount, merely modifying it for convenience of narrative :-

* "There is an error in the account given by Mr. Potts in his artiele 'On Oology' published iu 'Nature' in regard to this species. Ile describes an egg in the possossion of Master C. Richardson as having becn 'laid early in January.' As I procured the speeimen I may state that it was laid on the 4th of Octobcr. The writcr of the abore-mentioned article was eridently nisinformed.-W.W. S." 
"I first heard the Laughing-Owl on a very dark, damp night; and I frequently afterwards found its castings before I.was able to discover the bird. After repeated searches I was at length fortunate enough to capture a very handsome one. He had secreted himself in a deep fissure in the rocks, from which I dislodged him by burning some tussock grass at the entrance-in fact I smoked him out. I think I was never so pleased at capturing any bird. I brought it home and put it in a comfortable cage, where its demeanour was very quiet. It was in beautiful plumage, with the facial disk grey, shading off to white on the outer edges. I remarked that the eyes were conspicuously large, and the iris bright hazel. From the blunted condition of its claws it was evidently a fully matured bird, and to all appearances a male. During the first night of his incarceration he remained perfectly quiet, and refused to take any food. On the following night he moved restlessly about his cage, and once in the evening uttered a loud hailing call, as if wishing to communicate with an absent mate. By this time hunger had overcome his scruples, and before morning he had devoured two live mice which I placed in his cage, besides several pieces of mutton. After a few days' confinement he appeared to become more reconciled to the restraint, ceased to run about when approached with food, and indulged in a loud calling note when waking up in the evening. On one occasion I placed four live mice in the cage, and cautiously watched the result. After intently looking at the mice for a time, the Owl seized one of them, and, after bruising its head, tore it from the body, and swallowed it, and then devoured the other parts, tearing them to pieces before swallowing. After a pause of a few minutes he repeated the same operation on another mouse; but, although quick in despatching its prey, it is not so active as the nimble little Morepork. The latter species, instead of tearing a mouse to pieces, will reduce its head to a soft state and then swallow the animal whole. I tried my captive with some large lizards, which he immediately began to consume. I then offered him some beetles. After a long pause he commenced to eat them, with a quick snap of the bill. It was interesting to observe the rapidity witl which he caught and swallowed them in succession, the elytra flying from the bird's mandibles like sparks from a blacksmith's forge. Eleven days afterwards I picked up in the cage a hard pellet composed of mouse-hair and the wings and legs of beetles: the rejectum of this savoury feast. On a subsequent occasion I gave the Owl three live mice: he treated two of them in the manner described above, and swallowed the other whole. I tried my bird with a live rat, but he failed to kill it after many attempts. I then despatched the rat and cut it up into small pieces, which the Owl readily devoured. At the end of a fortnight he had become quite tame, would watch all my movements very attentively, and with every appearance of confidence.

"On the 19th April I was lucky enough to capture two more birds. These were together, in one fissure of the rock, and were undoubtedly male and female. I had considerable trouble in dislodging them from their hiding-place. When I caught the female bird (the smaller of the two) she uttered a peevish twitter, and bit my hands severely. I placed them in a roomy cage, with a good supply of beetles and lizards. On the following morning $I$ found that they had consumed all the food, and that they had already settled down to their new quarters in a spirit of contentment. I then gave them some pieces of mutton, two live mice, and a lizard, all of which they disposed of during the night.

"I placed all three Owls together, and although for a few days they appeared to agree very well, they afterwards commenced fighting; so I removed my first captive to a separate house, and left the pair together. The latter seemed perfectly happy in each other's company, and on walking up every evening, both of them joined in the peculiar hailing-call already mentioned.

"On the 26th July I made a fresll excursion among the rocks, in the evening, in the hope of seeing this Owl in its native haunts, but without success. Later in the night I heard the laughing call from several birds simultaneously. They evidently fly a considerable distance from the rocks, as 
I heard them several miles down the river. A few days later I heard one 'laugh' while passing on the wing elose over my Owl-house, possibly attraeted thither by the call-note of my eaptives. They appear to fly very high, and to laugh every few minutes, particularly on dark and drizzly nights.

"On the evening of August 23rd, when I went as usual to attend to my eaptives, I notieed that one of them did not come out to be fed, and on looking into their dark recess I found the female sitting on an egg. On the next evening when I dropped the food into the eage the larger bird was alone; and pieking up a pieee of the meat, he walked into the dark recess with it, uttering all the while a low, hoarse, eroaking sound. I gently looked in and saw that as he approaehed the sitting female she rose from the nest with a very peevish twitter, and taking the meat from his bill dropped it at her side. This operation was repeated over and over again, till all the pieces of meat were strewed around the nest. On the 27 th I found a seeond egg in the nest, scareely equal in dimensions to the first one laid, and more oblong in form *. I particularly observed that cluring the breedingtime both birds were habitually silent, scareely ever uttering a sound of any kind, except when the male was feeding his mate in the manner deseribed. This touch of nature was very pleasant to witness, and the gentleness and caution he displayed at this time were remarkable. At the slightest noise the female would utter her peevish scream, and would sometimes rise from the eggs. When all was quiet again, she would settle down, and the male bird would then retire to the outer house, and would remain there, apparently keeping wateh over his mate."

On the 22nd September Mr. Smith found a nest eontaining one egg in a deep natural fissure near Rocky Peninsula. The parent bird was in the nest, and he left it in the hope of getting a ehiek, as the $\mathrm{Owl}$ was incubating. He continued, at frequent intervals, to visit the nest till the 17 th of the following month, when, for some unaeeountable reason, the bird had abandoned it.

A fine male bird received from him lived for a considerable time in my aviary, and afforded me much interest. During the spring months it was aeeustomed to make a peeuliar barking noise all through the night, just like the yelping of a young dog. At times the ery changed, resembling that of a Turkey ealling in the peeuliar key that denotes it is about to roost. It was a melancholy ery, and is perhaps aptly described as that of a "disconsolate Owl seeking a mate." But it ceased altogether at the end of Deember.

Subsequently two more examples (male and female) were reeeived from Mr. Smith, and were placed in the aviary with the previous occupant, who manifested his pleasure, but not in a very demonstrative way, at seeing old faces onee more.

They seemed in perfect health, and partook readily of all the food offered to them. I eontemplated, with some degree of eertainty, being able to forward them to the Zoologieal Society of London, but my hopes were destroyed. Through an unfortunate accident to the temporary cage in which these birds were being removed to my new residence on Wellington Terrace, they both escaped one

* The following further observations on this case are from Mr. Smith's diary :-

"Sept. 28. Bird sitting closely on the eggs. To-night I found the female in the outer house, and the male in the recess, standing over the eggs. I retired for an hour, and on my roturn I found, to my surprise, that the male was sitting on the nest. 29th. To-night I found in the nest a third egg, which I removed. Again the male bird relieved the female in the task of sitting. 30th. The female resumed her duty on the nest, and the male bird carried every pieco of meat into the dark recess, his mate responding with a weak eall, and, taking the meat from him, dropped it again on the stones closo to the nest, but did not leare the eggs. Oct. 7. To-night both birds were in the outhouso, and on looking into the recess I found the two eggs forsaken and perfectly cold. I attribute this to the intonse inelemency of the weather on the previous night. Oet. S. I confined the female to the dark recess in the hope of inducing her to sit, but to no purpose. Oct. 9. Eggs still cold, and I accordingly removed them. Oct. 20. On feeding the birds to-night $I$ observed the male acting precisely as he did a month ago, and on opening the lid of the recess I found that the femalo had laid another egg. Oet. 21. Female sitting elosely, and male carried every morsel of food to her. Oct. 22. Examined nest, and to my delight found a second egg. Oet. 23 . Owl still sitting on eggs, but becoming excecdingly timid. Oct. 28. Nest abandoned, and on remoring the ehilled cggs, found that they eontained welldeveloped embryos." 
stormy night, and were never seen again. Active search was made in the vicinity, day and night, for several weeks, but without any satisfactory result. Many persons declared having heard them, from time to time, on the neighbouring hills, and guided by these reports the fugitives were traced through Sir James Prendergast's grounds to the Episcopalian Cemetery, where the scent was hopelessly lost, although the old sexton solemnly averred he had heard "most all kinds o' noises among them graves"!

Owing to my absence from home when the last-mentioned pair arrived, I never had an opportunity of studying them; but my son has furnished me with the following interesting note :-

"The three birds agreed very well together from the first; but after the first few days I noticed that our old bird was scarcely considerate enough to the lady, 'wolfing' all the meat and leaving her to take her chance. So I separated them, placing the new couple in the adjoining compartment, with only wire netting between. It was interesting to see them come out of their boxes torvards dusk, which appears to be their favourite feeding-time, and take up their station on their respective rocks. On a piece of meat being thrown to one of them, it will stoop down and gaze very reflectively at it for a minute or more, and then niarch off to its perch to devour it. I have noticed that they frequently make a whistling noise, and sometimes a note very much like a Turkey chuckling. Another sound they produce is exactly like the mewing of a cat. Solemn as they are, they seem to be inquisitive birds. If you make a whispering noise, all three of them will turn round and gaze steadfastly at you, remaining as motionless as a statue, until the whispering has ceased, when they immediately relax. During the day they remain concealed in the boxes, but they appear to keep up a constant low chatter with each other. Altogether they are very amusing birds in an aviary."

There are two specimens of the egg in niy son's collection. One of these is almost spherical, measuring 1.70 inch in length by 1.55 in breadth; the other is broadly oval, measuring 1.9 by 1.5 . They are perfectly white, and the spherical one has' some minute granular papillæ on its surface. I have examined several other specimens, and the former seems to be the more typical one.

The two forms of Strigidce described above are the only ones inhabiting New Zealand of which we have, as yet, any positive knowledge *. But the natives are acquainted with another species, which they describe as being very diminutive in size, and strictly arboreal in its habits. This is, no doubt, the bird indicated by Mr. Ellman as Strix parvissima † ('Zoologist,' 1861). Mr. J. D. Enys informed me that he once captured an Owl "standing only five inches high," and that it was perfectly tame and gentle. Mr. Potts records, on hearsay evidence, several instances of the occurrence in the provincial district of Canterbury of an $\mathrm{Owl}_{\text {" }}$ about the size of a Kingfisher"; and the accounts which lie has received appear to confirm one another in all material points, the gentleness of this $\mathrm{Owl}$ when captured being in singular contrast to the habitual fierceness of Spiloglaux novee zealandice.

In the British Museum Catalogue (Birds, vol. ii. p. 43) Mr. Sharpe refers Strix parvissima, Ellman, to Scops novce zealandice, Bonaparte; but I can find no evidence that the unique specimen of the latter in the Leiden Musenm ever came from New Zealand, the only authority for this being a label in Temminck's handwriting, "Nouvelle Zélande," but without locality.

* Dr. Finsch says:- “Mr. Sharpe includes Strix delicatula, Gould, in the avifauna of New Zealand ('Erebns and Terror,' 2nd edition, p. 23) on aecount of my statement (Journ. für Ornith. 1867, p. 318). But I long ago stated (Journ. für Ornith. 1870, p. 245 ) that $I$ had made a mistake on this point."

$\dagger$ "A mongst the desiderata of our public eollections, a rers small Owl (Athene parvissima) has for some time held a place. Many doubt its existenee, few have scen it, fowcr still have formed any note or observation concerning it. From the information that has been gleaned about this rare bird, it would appear that one of its habitats used to be tho woods about the Rangitata river. One was eaptured with the hand on the bank of a creek, at no great distance from Mount Peel forest." - Out in the Open. 


\title{
CIRCUS GOULDI.
}

\author{
(GOULD'S HARRIER.)
}

Circus assimilis, Gray, Voy. Ereb. and Terror, Birds, p. 2 (1844, nec J. \& S.).

Circus gouldi, Bonap. Consp. Gen. Av. i. p. 34 (1850).

Falco harpe, Haast, Layard, Taylor (nec Forst.), 1859-1861.

Falco aurioculus, Ellman, Zoologist, 1861, p. 7464.

Circus approximans, Gray, Hand-l. of B. i. p. 36 (1869).

\section{Native names.}

Kahu and Manutahae ; in some districts Kahu-maiepa and Kahu-komokomo ; also Kahu-korako and Kahu-pango*, to distinguish the very old and the young birds.

$A d$. suprà brunneus, sub certâ lucc cuprco nitcns, dorsi plumis plus minusve fulvo lavatis ct terminatis : pilei plumis medialiter et longitudinaliter nigris, ferrugineo marginatis : nuchâ cum eollo postieo ct laterali clariùs fulvescentioribus: regione oculari nigrâ: facie latcrali brunneâ, plumis medialiter nigris : radio faeiali saturatè brunneo, ferruginco tincto et fulvesccnti mixto: dorso postico brunneo, plumis latè fulvo terminatis : uropygio imo ct supracaudalibus albis, his fasciâ fulvâ anteapicali transnotatis : tectricibus alarum dorso concoloribus, minimis fulvo et albo lavatis : alâ spuriâ cincreo lavatî : remigibus brunneis, ad apicem saturatioribus, extùs argentco-cinereo lavatis, saturatè brunnco transfasciatis : caudû cincreâ, rectricibus exterioribus ferrugincis, plus minusve albicantibus, pennis centralibus distinctc̀, cxterioribus irrcgrulariter brunnco transfasciatis, omnibus ad apicem albis : candâ subtùs albicante, fasciis brunneis interruptis notatâ : subtùs lactescenti-albus, paullò fulvcscens : gulâ brunnê̂, plumis medialitcr nigris : pectore toto distinctè brunneo longitudinaliter striato: cruribus parllò ferrugineo tinctis, suprà angustè ferrugineo striatis: subalaribus albis, maculis ferrugineis et brunneis notatis : cerâ et pedibus flavis : rostro et ungulis nigris : iride lætè flavâ.

q mari paullò major et fcrè pallidior : scapularibus rufescenti-albo terminatis.

Juv. ehocolatinus, cupreo nitens, pileo vix nigricantiore: nuchâ albicanti-fulvo notatâ : subtùs fcrrugineo tinetus : caudâ subtùs albicante, suprà chocolatinâ, ferrugineo marmoratâ : remigibus subtùs ad basin lactescentibus, plus minusve brunneo marmoratis : cerâ ct pedibus flavis : iride saturatè brunneâ.

Adult male. Upper parts dark brown, the feathers of the head and neck broadly margined with reddish fulvous, the wing-coverts and scapulars terminally edged with palc rufous brown; quills black, with the outer web silvery grey, obseurely banded; tail, when closed, light silvery brown, with interrupted transverse bars and a subtcrminal band of dark brown; the latcral tail-feathers washed with rufous; the bars morc conspicuous when the tail is spread; upper tail-coverts pure white, barred near the tip with rufous brown; supcradjacent feathers tipped with rufous. Underparts gencrally pale fulvous, with a broad dash of rufous brown down the centre of each feather, thcse markings being thickest on the breast and sides; tibial plumes paler fulvous, with the central streak much reduced; the axillary plumes, which are remarkably long, pale rufous, barred

* Mrr. Gurney has sent me the following note:- "The circumstanco which you mention (pago 11 of 1st edition) of Circus gouldi being called by the natives 'kahu-pango' strikes me as very curious, as C. macroselis bears the name of 'papango' in Madagascar, and C. maillarli in Réunion (vide Ibis, 1863, p. 338 and note). The fact of the Réunion Harrier being called 'papango' was also mentioned to me by a resident there." 


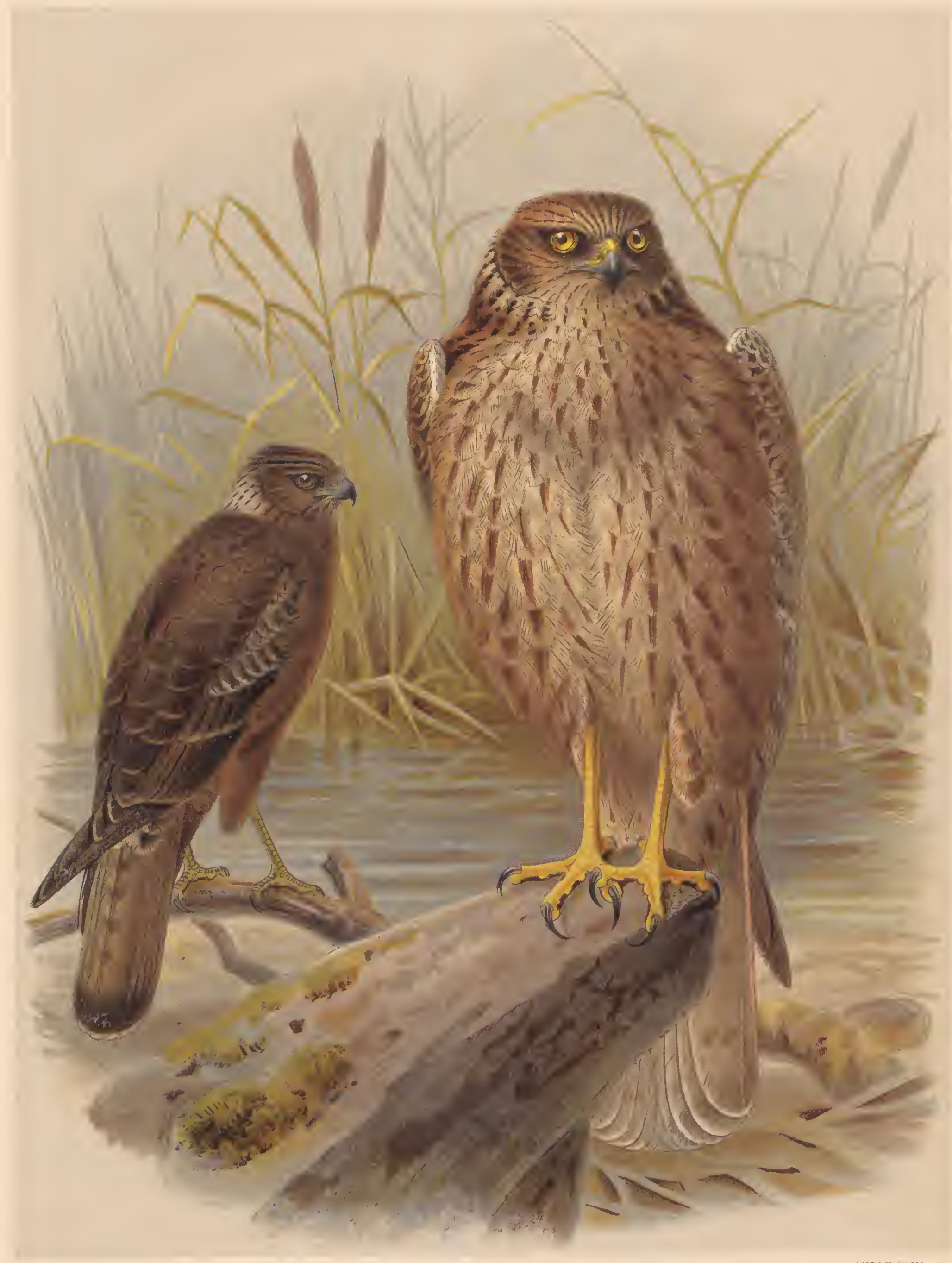

NEW-ZEALAND HARRIER (ADULT \& YOUNG) 

with darker rufous; under surface of wings and tail light fawn-eolour varicd with grey. A narrow white fringe, varied with brown, encireles the throat, terminating behind the ear-coverts ; bill bluish black; eere dull greenish yellow, brighter on the ridgc; legs and fcet bright lemon-yellow; claws black; irides bright yellow. Length 22.5 inches; extent of wings 52.5 ; wing, from flcxure, 17 ; tail 10 ; tarsus 4 ; middle toe and claw 2.5 ; hind toe and elaw $1 \cdot 75$; bill, along the ridge 1.5 , along the cdge of lower mandible 1.5 .

Adult female. Slightly larger than the male, but differing very little in plumage. The tints generally are lighter, the edges of the scapular's are rufous white instead of brown; and the wings are varied witl rufous and white, especially towards the flexure. Length 23 inches; extent of wings $\mathbf{5 4 .}$

Young. In the young bird the whole of the plumage is chocolate-brown, darker on the upper parts, and edged with paler brown; lind part of the neck varied with white, and tinged with rufous; upper tail-eoverts rufous brown, with paler tips and fulvous at the base, sometimes white barred with rufous brown. Cere and legs yellow ; irides dark brown.

Nestling. Covered with very thick or woolly down of a buffy white or pale ycllowish cream-colour, darker on the upper surface. Bill and legs yellow. The feathers appear first on the shoulders, wings, and tail ; thesc are blackisl brown, the tail-feathers with rufous tips.

Fledgling. Has the plumage of the underparts much suffused with brown, the primary wing-coverts and the scapulars with a filamentons fringe of rufous; a similar fringe on the sccondaries but paler; tail-feathers and their upper coverts largely and somewhat irregularly marked at the tips with rufous; fcathers of the nape edged with darker rufous.

A well-feathered fledgling in my colleetion, with rectrices more than four inches long, has still some fulvous-white down adhering to the crop, flanks, and upper edges of wings. Claws well developed and very sharp.

Progress towards maturity. Upper parts dark brown with a purple gloss; the tail with five rather obscure bars of black, about lialf an ineh apart, and darkest towards the tip; upper tail-coverts delicate fawn-colour, with the centrc of each feather brown, shaded off on the sides. The wing-coverts have a coppery liue, and the longer ones, together with the scapulars, are narrowly tipped with rufous white. Underparts bright chocolate-brown, tinged with rufous, especially on the neck and abdomen; tibial plumes rufous brown. Cere and legs ycllow; beak and claws black; irides bright yellowish brown.

Obs. It must be noted that individuals differ, more or less, in the details of their colouring during their progress towards maturity*. With extreme age, the fulvous of the lower parts changes to white, and the brown markings become much narrower, being almost obsolete on the tibial plumes. The silvery grey on the quills and tail-feathers increascs, while the rufous colouring diminishes, and the lining of the wings becomes pure white, with narrow shaft-lines of dark brown. There is a beautiful albino specimen in the Nclson Museum.

THE present species is spread orer a wide geographical area; for uot only is it found in all parts of our own country, but it also occurs in Australia and Tasmania, and extends eastward to the Fiji Islands. Mr. J. H. Gurney has already drawn attention (Ibis, 1870, p. 536) to the fact that our Harrier is exactly the same species as that figured by Mr. Gould in the 'Birds of Australia' under' the name of Circus assimitis. The true Circus assimitis of Jardine and Selby (Ill. Orn. ii. pl. 51) has proved, however, to be only the young of Circus jardimii, also figured in the 'Birds of Australia' (pl. 2T); and therefore the New-Zealand Harrier bears the name of Circus gouldi, Bonap. (l.c.) $\uparrow$.

* My eldest son, writing to me from Horowhenua on the 6th of MIay, 1881, says :- "I shot a beautiful Harricr jesterday, winging it when very vearly out of range. The plumage is handsomely mottled, and on the upper surface of tho wings there is a stecl-blue lustre; the breast jellowish white; lower part of body and tibials nearly pure white. Instead of the unpleasant odonr peculiar to these carrion-feeders, it has a "woody' smell like that of the Kaka."

$\dagger$ Dr. Finseh writes:- " $A$ comparison of specimens in the Leiden Museum from Australia, New Zealand, Fiji, and New Caledonia has fully conrineed me of their identity. The specimen from New Caledonia (C. walfi, Gurney) does not show a 
It is a very common bird in New Zealand, being met with on the fern-eovered hills, in the plains, among the marshes of the low country, and even along the open seabeach, where it feeds on carrion. It is seldom, however, found in the dense bush, although I once surprised one there in the aet of picking a large Wood-Pigeon *.

Like all the other members of the genus, it hunts on the wing, performing wide circles at a low elevation from the ground, and sailing over meadows, fern-land, or marshes in quest of lizards, miee, and other small game. Its flight is slow but vigorous and well sustained. The small size and speeific gravity of its body, as compared with the great development of wings and tail and corresponding museles, enable it to eontinue thcse wanderings for a whole day without any apparent fatigue. When sailing, as it often does, at a high elevation, the wings are inelined upwards so as to form a broad obtuse angle (with the tail half spread), and there is no pereeptible motion in them, except when the bird alters its course. A pair may often bc secn sailing thus in company, mounting higher with each gyration, and emitting a peevish whistle as they cross each other's eourse. On these oecasions I have sometimes scen the birds close in upon and attaek cach other, the upper one making the first swoop, and the lower one instantly turning on its baek, with upstretehed talons, to receivc him, and, after thus parrying the attack, wheeling upwards and becoming in turn the assailant. Whether it be the angry meeting of rival nuales, or the amorous gambols of raptorial lovers, $I$ have ncver been able to determine; but this aerial eneounter, whether in earnest or in play, has a very pretty effeet. A correspondent informs me that he onec observed five of these birds cngaged together in this manner, at the commeneement of the breeding-season, and that it was one of the pretticst sights of the kind he had ever witnessed.

It is worthy of remark that the birds of the first year are apparently ineapable of the peeuliar sailing flight whieh I have deseribed, their loeomotion being effecter entircly by slowly rcpeated flappings of the wings. This circumstanee, taken in conjunction with the dark colour of the young bird (appearing perfectly black at a little distance), has lcd to the eommon belief that there are two distinet species.

When gorged with food, the Harrier takes up its station on a rising knoll, a projeeting stump, or the naked limb of a detaehed tree standing in the open, when it assumcs an ereet posture, with the head drawn elosely in and the wings folded (as represented in thc accompanying Plate), and remains perfectly motionless for a considerable time. When thus reposing, it is possible to get within gun-range of a "Kahu-korako," or vcry old bird; but at other times it is extremely difficult to obtain a shot. Hawks are known to be long-lived; and they appear to gain more experienee of the world as they grow older. The dark-plumaged Harrier falls an easy prey to the gunner: it may be winged as it sails above him at an easy elevation, or it may be approaehed quickly and surprised when it descends to the ground to eapture and devour a mouse or lizard. But the wary old "White Hawk" carries with him thc experienee of many dangers, and is not so easily

single character by which it can be specifieally distinguished. As the true C. assimilis, Jard. \& Sclby, is undoubtedly the same as C. jarclinii, Gould (which, thorefore, must bear the former appellation), the New Zealand Harrior must stand as approaimans, Pealc." But Mr. J. H. Gurney, who is a recognized authority in regard to the Accipitres, has arriced at a different conclusion; and even were the matter entircly frec from doubt, I should hesitate before disturbing a name so generally understood and accepted as that of Circus gouldi.

* I am indebted to Mr. J. A. Wilson for the following interesting information :-In March 1884 thero was a violent eruption from tho crater of White Island in the Bay of Plcnty. For some weeks there was a eontinuous discharge of volcanic débris from the pit of the erater, with tho usual accompaniments; and the heat thus evolved had the cffect of driving out the rats which abound there in prodigious numbers (a small black rat, supposed by some to be the true liore maori). This exodus, strange to say, was the signal for the appearance on the island of the Harrier, which eame over in large numbers from the mainland, as many as seventy haring been counted on the wing together in one spot alone. 
taken. I have followed one for the greater part of a day before $I$ have succeeded in shooting it. These old birds, notwithstanding the extreme abundance of the species, are comparatively rare, and they are called Kahu-korako by the natives, in allusion to their hoary plumage. Birds in ordinary adult plumage are also somewhat shy; but on horseback I have often approached near enough to detect the colour of the cere and legs.

Besides devouring carrion of all kinds, the Harrier subsists on rats, mice, lizards, feeble or wounder birds, and even grubs and spiders. One, which I had confined in an outhouse, subsisted for several days entirely on spiders, for which he made a systematic search among the cobwebs that covered the walls. At the close of each day I found him with a matted circlet of spiders' webs surrounding the base of his bill. On my offering him the body of a Wood-Robin (Miro australis) he struck his talons into it, and, holding it firmly down, plucked off the feathers with his beak with remarkable rapidity, and then, tearing it to pieces, devoured it-the whole proceeding occupying only a few minutes. Captain Mair, who kept several of these birds in confinement for a considerable time, fed them frequently with freshwater fish, which they devoured with great avidity; and he assures me that he has observed them, in the wild state, capturing mullets in a shallow fish-pond.

The Harrier secures his prey by grappling it in his talons, sometimes bearing it off with him, but more generally remaining on the spot to devour it. On newly ploughed land he may occasionally be seen regaling himself on grubs and earthworms. It may be noticed that on these occasions, instead of walking, he moves by a succession of hops, the toes being turned inwards, in order, as it would appear, to protect the fine points of his grappling-instruments.

When the winter rains have inundated the low-lying flats and filled the lagoons, these places become the favourite resort of Wild Duck, Teal, Pukeko, and numerous other waterfowl ; but this Hawk also puts in his appearance with the new comers, and is a perpetual terror to them. I have frequently seen one attack a full-grown Pukeko (Porphyrio melanotus), attempting to grapple it in its talons-its long tarsi and legs being stretched downwards to their full extent, accompanied by much noiseless fluttering of the wings. The Pukeko, anticipating the attack, springs upwards with open mouth and outstretched neck, and generally succeeds in warding off its assailant till it reaches cover and hides in the sedge. Audubon, in his 'Birds of America,' states that he has seen the Circus cyanous attack the Marsh-Hen (Rallus crepitans) in the same manner. Young birds, and those wounded by the sportsmen, suffer most. On one occasion I fired at and disabled a large Pukeko, which at once took refuge in some rushes on the edge of the lagoon; but before I could get round to the spot, one of these Hawks had killed, plucked, and partly devoured it.

Once I saw a Harrier boldly attack a party of seven Pukekos. The birds crowded together, as if for mutual protection, on a dry clump in the midst of the swamp, and eventually succeeded in warding off their assailant.

But although, under press of extreme hunger, it will thus attack live birds, it is in reality a very cowardly representative of its tribe; for $I$ have seen one chased by a pair of Australian Magpies (Gymnorhina tibicen) whose nest was in danger and driven ingloriously off the field, the pursuers assaulting it in a most determined manner and from opposite directions. An observant friend assured me that on one occasion he witnessed an attack made by four or five of these Magpies, acting in concert, and that the Harrier was not only vanquished but actually killed by them.

In the spring months it may be seen skimming low along the edges of the lagoons in pursuit of young Ducks, ever and anon swooping down among a swimming brood, but not always with success, the young birds instinctively diving under water on the approach of their natural enemy.

I have known the Harrier, when urged by excessive hunger, visit the poultry-yard and snatch up a chicken in its talons; and I have occasionally seen it attack both the wild and the domestic 
duck; and Mr. Gould, in writing of this species in Australia, declares that it is addicted to the stealing of eggs. On the other hand, I have seen it assailed by the Common Sea-Gull (Larus dominicanus) on approaching the nest of this bird, and put to an ignominious flight.

It is worth recording that the Harrier will sometimes pursue on the wing. Riding along the road near the Whenuakura river, on one occasion, I observed a Kahu pursuing a small bird (apparently a Ground-Lark) high in the air. 'The pursuit was continued for a considerable time, the Hawk making frequent swoops and the small bird eluding its grasp by suddenly altering its course and thus gaining on its pursuer. When nearly out of sight the Hawk was joined by another, both in pursuit of the same bird, from which circumstance I concluded that the raptor was foraging for hungry ones at home. This might account for the eagerness of the pursuit, and for a mode of chase which I had never observed before during a very long acquaintance with this species.

Mr. Hamilton, of Petane, states that he has on two occasions surprised the Harrier in the act of devouring an eel in the bed of a shallow creek.

When travelling through the Waikato district in July 1883, I observed one of these birds hawking in the rain. Although a heary shower was falling the Harrier continued to hover without any apparent inconvenience, only occasionally shaking the raindrops off its tail.

It is said to be very destructive on the sheep-runs during the lambing-season; and I have been assured by eye-witnesses that three or four of them will sometimes detach a lamb from the flock, and then, assailing it from different points, tear out the animal's eyes and ultinately kill it. I am of opinion, howerer, that these attacks are confined to the weakly or sickly lambs of the flock, and occur only in times of great famine. Be that as it may, the practice of poisoning Hawks in the lambingseason has now become very general; and I have known upwards of a hundred of them destroyed in this manner, during that season, in a single locality. It is accomplished by rubbing a small quantity of strychnine into the body of a dead lamb or piece of offal, and leaving it exposed on the run. The poison takes immediate effect, and often eight or ten birds are thus destroyed in the course of an hour. As stated in my former edition, on one station alone in Canterbury upwards of a thousand Hawks per annum were destroyed in this manner during the preceding two or three years, and, as an almost necessary corollary of this, rats became excessively abundant on this particular sheep-run. I have always been of opinion that the wholesale killing of Hawks in a country like this is a questionable policy, from a utilitarian point of view, as it tends to alter the balance of nature, and to interfere with the general conditions of animal life, already too much disturbed by the operations of Acclimatization Societies. The rapacious birds have an important part to perform in the economy of nature; and species like the present, which are partly insectivorous, are too valuable to the practical agriculturist to be destroyed with impunity, although they may occasionally attack a sickly lamb in the flock, or swoop on an inviting young turkey. The damage to a flock where these Hawks abound is, no doubt, greatly overrated. It is true, however, that this species does sometimes hunt in packs, for I have counted as many as twenty of them at one time hovering over a small mob of sheep detached from the main flock; and three of them have been seen to attack a full-grown turkey, and, acting in concert, to overpower and kill their quarry.

The natives take this species by means of flax snares, arranged in such a manner that the bird, in attempting to grapple the bait, gets its legs entangled in a running noose, which its efforts to escape only serve to tighten. I have frequently taken it alive by means of a steel trap, with muffled edges, baited with a dead rat or clicken. When shot at, and wounded in the wing, it attempts to escape by a succession of leaps along the ground, and, on being overtaken, defends itself vigorously with beak and claws, its beautiful golden eyes sparkling with passion. In captivity it is at first fierce, throwing itself backwards when approached, and striking forwards with its long talons; but it soon becomes reconciled to the situation, and permits itself to be stroked with the hand. The late Captain 
Buck, 14th Regiment, informed me that, while stationed at Napier, one that he had winged became so tame that, on recovering health and liberty, it was accustomed to return every evening to his garden and ronst in the arbour.

The peculiar whistling note already alluded to is only heard when two or more of these birds are in company. The young has a cry resembling the hoarse note of our Stilt-Plover. Professor Hutton informs me that the cry of this Hawk is very similar to that of the Govinda Kite of India, which he has frequently heard in that country.

I have observed that in very old birds of this species the feathers of the upper parts present a faded and ragged appearance, from which it may be inferred that the moulting-power becomes impaired as age advances. A specimen that came under my examination, in the flesh, presented the following singular condition, for which I was quite unable to account, although probably the result of disease. A space on the breast and the whole surface of the sides were entirely denuded of feathers, these parts being covered by a thick growth of white down; on the back also there was simply a narrow strip of feathers down the line of the spine. The head of this bird was greatly infested with parasitic ticks.

There is a very beautiful albino variety in the Nelson Museum, presented by Mr. Goodall, of Riwaka, where the bird was obtained. The whole of the plumage is of a very delicate white ashcolour, the underparts having a rosy-purple tinge. 'The primaries are ashy grey; and both these and the tail-feathers present, on the under surface, obsolete bands, as though they had beeu washed out. The shafts of all the feathers on the upper parts are dark grey, presenting the appearance of finely pencilled lines. The bill, as also a superciliary line of hairs and those covering the lores, black; cere, tarsi, and toes yellow. The taxidermist to whom this handsome specimen was entrusted, with a full appreciation of its value, charged the modest sum of eight guineas for stuffing it, and had to be compelled to give it up by process of law.

During a visit to the lake district, in the autumn of 1877, I saw another, apparently very like the last-mentioned bird, hovering over the fern ridges that close in the intensely blue waters of Tikitapu. As he swooped down upon a rat or lizard in the fern lis underparts appeared to be perfectly white, and the upper surface of the body and wings ashy. Major Mair informs me that, in 1885, he observed a similar one at Lake Rotoiti.

This species prefers a swamp for its breeding-place, and generally builds its nest on the ground, though sometimes in a tussock. It often repairs to the same place for several successive seasons, the old nest forming a foundation for the new one, which is usually constructed of the dry blades of Arundo conspicua and the flower-stalks of the Spaniard-grass rudely placed together and overlaid with dry grass*. The breeding-months are October and November; but as late as Christmas Day (1863) I saw, in Matene Te Whiwhi's house at Otaki, a very young one that had been taken from a nest (containing two) about three weeks previously. It was about the size of a half-grown

* Mr. C. H. Robson, of Cape Campbell, has sent me the following interestiug note:- "In the spring of 1873, I obsorved a very large female Hawk of a brighter colour than usual, with very distinct markings, and prosonting quite a yellow appearance as compared with the ordinary Hawk. She rose, the first time I saw her, out of a pieco of swampy ground near the beach, and, on a subsequent occasion, finding her in the same place, I hunted abont and found her nest in a tussock, with two white oggs in it. Bcing anxious to secure the young birds, I did not handle the oggs, but visited the nost every week, each timc coming quito close to the bird. In duc time one of the oggss hatched out a little yellow-white chick, but a few days later, to my great regret, it was taken, I presume, by a rat. On flying off the nost the Harks was joined by the male bird, not ncarly so large as herself, and always too high in the air for me to observe his plumage."

"In Novernber 1884 in one of the largo swamps in the Hind district, on the Canterbury Plains, a nest of this Harrier, built on a large tuft of coarse growing rushes (Juncus) was knocked ovcr by a 'mob' of cattle. The nest boing set up again and tho eggs put back the Hawk returned and resumed incubation. The ncst contained fivo eggs ; another nest in the Horoatu district also contained fire eggs."-Zoologist, 1885, p. 421. 
gosling, and was covered with thick cottony down of a dirty white colour inclining to buff, with feathers beginning to show themselves on the back, wings, and tail; cere and legs yellow. It opened its mouth for food on being approached, and when provoked would strike forward or upward with its well-armed feet. It made one aware of its presence by its rather fetid odour, as well as its occasional cry, which was like a half-suppressed whistle.

When there are two young birds in a nest there is often a remarkable disparity in their size. They are always very savage when molested, throwing themselves on their back and striking vigorously with their talons at the hand of the intruder.

A nest found by a Wanganui settler contained, in addition to two full-grown young birds, the remains of 11 Pheasants, 5 rats, 3 Quail, and a Weka.

The eggs are from two to four in number, but generally three, ovoido-conical in form, with a smooth or fincly granulate surface, perfectly white, till stained by the bird's feet during incubation, and measuring 1.9 inch in length by 1.5 ; my largest example measures 2 by 1.6 . At first sight they appear to be disproportionately small for the size of the bird; but they are not so in reality, for the body of this Hawk, when stripped of the feathers, is almost ridiculously small. After being blown, if held np against the light, the interior of the shell presents a surface of a beautiful clear green.

Before passing on to the next group, I may mention that in a case of mounted Raptores which I had the pleasure of presenting, some years ago, to the Colonial Museum there is a fine specimen of the White-bellied Sea-Eagle (Ichthyaêtus leucogaster), which I received from the late Mr. Gould as having been obtained in New Zealand. This species has been observed along the whole southern coast of Australia, from Moreton Bay on the east to Swan River on the west, including Tasmania and all the small islands in Bass Strait; and as it is a powerful flier there is no physical reason why it should not occur sometimes as a straggler on the New-Zealand coast. Mr. Gould had satisfied himself that this specimen was obtained there, although unable to ascertain the precise locality. In corroboration of its presumed occurrence, I may mention that an officer of the 14th Regiment, who was a good sportsman and a tolerable naturalist, assured me that he had actually seen and fired upon a "Sea-Eagle" on the rocks near the entrance to the Wellington harbour.

Two other species of Accipitres, the Falco subniger (a rare bird inhabiting South Australia) and the Milvus isurus, or Australian Kite, have had New Zealand assigned as their habitat, on the authority of Mr. J. H. Gurney, who, in a letter to 'The Ibis' $(1870$, p. 536), offers the following explanation:- "My authority for quoting New Zealand as a habitat for the former (Falco subniger) was the veteran ornithologist, M. Jules P. Verreaux, who informed me that a New-Zealand specimen had passed through his hands. With regard to the latter (Milvus isurus), the Norwich Museum possesses a specimen, which I obtained from Mr. A. D. Bartlett, who assured me, at the time, that he had received it from New Zealand, and had satisfied himself that it had been killed in that country. Probably both these species, if not indigenous to New Zealand, may occasionally occur there as accidental visitors from the Australian continent." In support of Mr. Gurney's surmise, I may state that the account sent to me, many years ago, by Sir Julius von Haast, of a Hawk observed by him in the Southern Alps, although unfortunately not secured, seems to accord with that given by Captain Sturt of the Australian Falco subniger. 


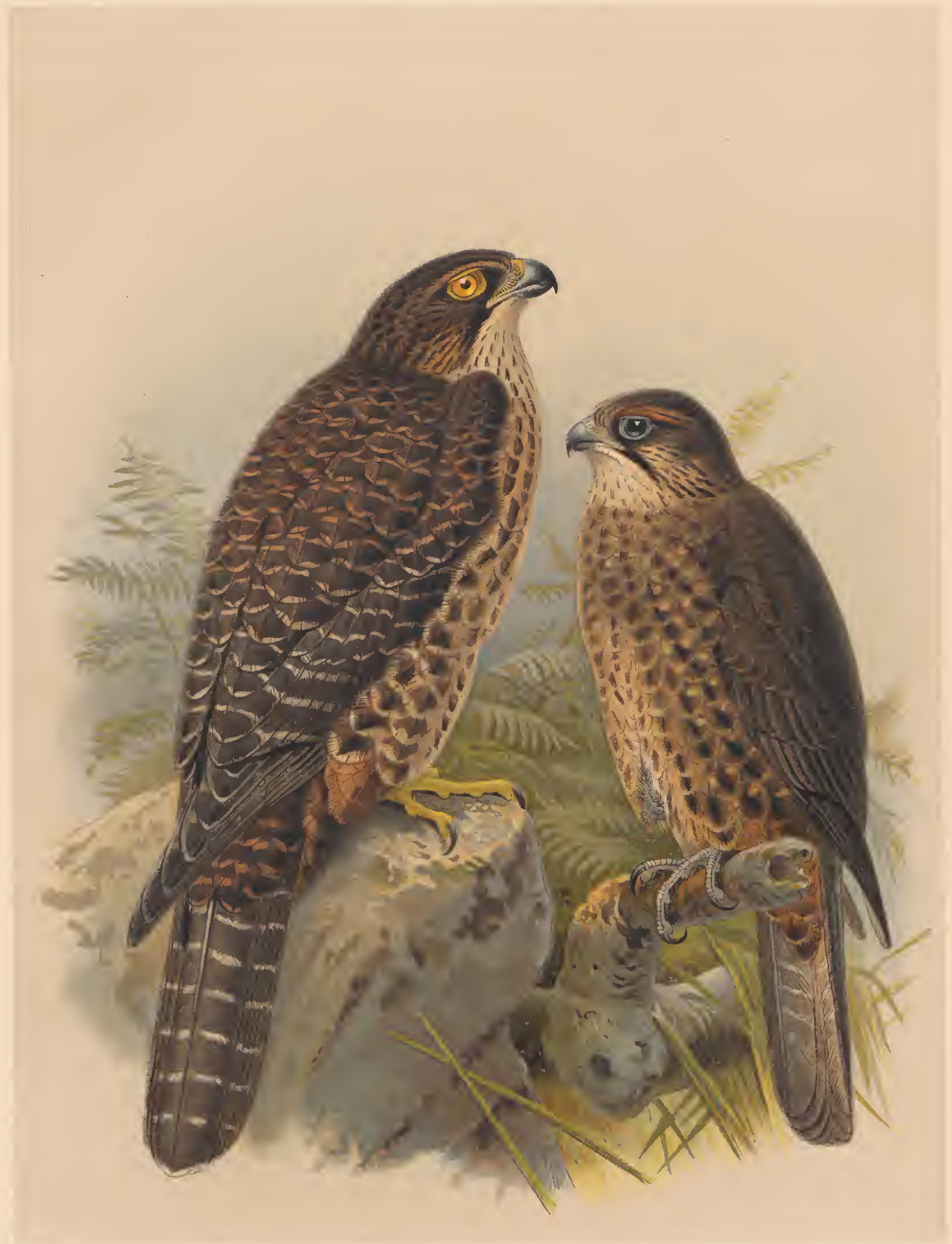

QUAIL HAWK. (ADULT AND YOUNG)

HIERACIDEA NOVE-ZEALANDIE.

(ONE-HALE NATURAL SIZE) 



\section{HARPA NOVA ZEALANDI无。}

\section{(QUAIL-HAWK.)}

New-Zealand Falcon, Lath. Gen. Syn. i. p. 57 (1781).

Falco novce seelandice, Gm. Syst. Nat. i. p. 268 (1788, ex Lath.).

Falco australis, Hombr. et Jacq. Ann. Sci. Nat. 1841, p. 312.

Hypotriorchis nova zealandia, Gray, Gen. of B. i. p. 20 (1844).

Falco harpe, Forst. Descr. Anim. p. 68 (1844).

Hieracidea nover zealandice, Kaup, Isis, 1847, p. 80.

Harpe nover-zealandice, Bonap. Comptes Rendus, xli. p. 652 (1855).

Ieracidea novce zealandice, Gray, Hand-l. of B. i. p. 22 (1869).

Hieracidea novae zealandice, Buller, Birds of New Zealand (1st ed.), p. 1 (1873).

Harpa novee zealandio, Sharpe, Cat. Brit. Mus. Birds, vol. i. p. 372 (1874).

\section{Native names.}

Karearea, Kaiaia, Kaeaea, Kakarapiti, Karewarewa, and Tawaka.

ơ suprà nigricanti-brunneus, pilco unieolore saturatiore: dorso fasciis irregularibus fulveseentibus transnotato: rcmigibus nigricanti-brunneis, pogonio interno albo transfasciato: seeundariis cxtùs faseiis angustis albidis notatis : caudâ nigricanti-brunneâ, albido angustè et interruptè transfaseiatâ : faeie laterali nigricante, supercilio indistincto et genis imis rufesccutibus : gutture fulvescenti-albo, seapis plumarum nigro indieatis : eorporc reliquo subtùs lætiùs fulvesecnte, peetoris plumis saturatè brunneo medialiter striatis et fulvo plus miuusve distinctè occllatis : hypochondriis imis cum cruribus et subcaudalibus lætissimè eastaneis : subalaribus fulvescentibus, castaneo tinetis, his ct axillaribus fulveseeuti-albo occllatis : rostro cyanescenti-nigro, ad basin mandibulæ corneo : eerâ pallidè flavâ : pedibus flavis : iride sordidè flavâ.

q mari similis, sed paullò major.

đo juv. suprà fuliginoso-brunneus, pileo magis cinerasecnte: eaudâ minùs distiuctè transfasciatâ: gutture fulveseenti-albo, angustè brunneo striato : subtùs fuliginoso-brunneus, pectore paullò nigricante et hypochondrijs cruribusque vix castaneo tinetis : pectore medio albido obscurè maculato : abdomine imo crissoquc fulvescentibus : hypoehondriis distinetè fulvo oeellatis : eerâ et plagâ oeulari cyanescenti-albis : pedibus plumbeis : ungulis nigricantibus.

Pull. lanugine plumbeâ indutus.

Adult male. Crown of the head and nape glossy blaek; upper surface generally brownish black, barred on the seapulars and tail-eoverts with rufous, and narrowly on the wing-coverts with rufous grey; a line over each eye, and sides of the neel, varied with rufous; facial strcak and ear-coverts blaek; throat fulvous white, with narrow blaek shaft-lines, broadening out towards the breast; fore part of the neck and breast fulrous varied with rufous, and having the eentre of each feather brown; sides of the body dark brown varied with rufous, and with large roundcd spots of fulvous white; abdomen and vent rieh fulvous; under tail-coverts and tibial plumes rufous brown, with narrow black shaft-lines; quills and secondaries obseurely marked on their outer wcbs with grcy ; tail with eight narrow iutcrrupted bars of greyish white, and slightly tipped with rufous; under surface of quills and tail-feathers dusky, the former largely toothed and the latter 
barred with white. Bill bluish black ; base of lower mandible horn-colour; eere pale yellow ; legs brighter yellow; claws black; irides brownish yellow, beeoming purer yellow with advaneing maturity. Extreme lcngth 19 inches; cxtent of wings 31 ; wing, from flexure, $11 \cdot 25$; tail 8.25 ; culmen $1 \cdot 2$; tarsus 2.5 ; middle toe and elaw $2 \cdot 75$; hind toc and claw $1 \cdot 75$.

Adult female. The plumagc is similar to that of the male, exeepting, perhaps, that the spotted markings on the sidcs are more distinet; but there is a slight difference in the size. Extreme length 19.5; wing, from flexure, 11.5 ; tail 8.5 ; tarsus 2.75 .

Young. Crown of the head and upper parts generally brownish blaek, glossed with grey in certain lights; line over eaeh eye reddish fulvous; throat fulvous whitc, with a eentral line of brown on each feather; sides of the neek, breast, lining of wings, and underparts gencrally dark brown varied with fulvous; sides marked with rounded spots of fulvous white, very obscure in some specimens; tibial plumes reddish brown; lower part of abdomen, vent, and inner side of thighls fulvous; under surfacc of quills and tail-feathers dusky, with numerous transverse bars of white. Cere and barc space around the eyes bluish whitc; irides black; legs dark grey, with black claws.

Nestling. Covered with plumbeous-grey down.

Obs. The above measurements wcre taken from a pair of birds of this speeies formerly in the Christchurch Aeelimatization Gardens, and now preserved in the Canterbury Muscum, the sex in both cases having been earefully aseertained by dissection. The figure of the adult female is from a fine specimen obtained in the Sonth Island, and now in my collcetion. Examples vary in the details of their colouring. In some the light spots on the sides are far more conspicuous and the tibial plumes are of a brighter rufous than in others. As a rule, the white bars on the tail-feathers, although interrupted in the middle, are conterminous on each side of the shaft. In a specimen, however, obtained by Mr. Travers in the South Island the bars are altcrnate on each web, as was also the ease with another, shown to me at Ohinitahi ; but this eharacter is quite exceptional.

THE synonymy given above will serve as a tolerably complete guide to the scientific and literary history of the present species; but much confusion has arisen at various periods with regard to the nomenclature employed, and a few words in further explanation of the subject appear to be necessary.

In Mr. G. R. Gray's 'List of the Birds of New Zealand,' published as an Appendix to Dieffenbach's 'Travels' (1843), that naturalist recognizes only two species of Accipitres, which he calls respectively Falco harpe, Forst., and Falco brunneus, Gould, thereby intending, of course, to indicate the existence of two distinct species of true Falcons in New Zealand; but in this list there is no mention whatever of the Harrier (Circus gouldi), a common and well-known bird in our country. In adding the native names an unfortunate mistake occurred; for Falco harpe was stated to be the bird known to the inhabitants as "Kahu" and "Kahu-papango," whereas these are in reality the native appellations for the Harrier, which, as already stated, had been omitted from the list. This will, no doubt, account for the mention of Gould's Harrier, in the earlier writings of Layard, Haast, and Taylor, under the erroneous title of Falco harpe. Mr. Gray himself afterwards, in his 'Birds of New Zealand' (Voy. Ereb. and Terror), partially rectified this error by introducing the Circus in its proper place; but the misapplication of the native names was continued. In that work Mr. Gray substituted the prior title of Falco novee zealandia, Gmel., for F. harpe, Forst., with F. australis (Homb. et Jacq.) correctly added as a synonym; he likewise reduced Gould's F. brunneus to the rank of a synonym; but in a subsequent list (Ibis, 1862, p. 214) he recognized it again as a distinct species, and equivalent to $F$. ferox of Peale (U. S. Explor. Exped. 1848), referring both forms to Kaup's genus Hieracidea. Unfortunately Mr. Gould's description of $H$. brunnea was founded on an 
immature bird, in a condition of plumage exactly corresponding with the young of $I$. novae zealandio. This circumstance, together with the great difference in size between the male and female, led me, among others, to the eonclusion that the two birds were referable to one and the same species*. Dr. Otto Finsch (Journal fuir Ornithologie, 1867, p. 317) expressed his belief that II. brumnea was the female of $H$. nova zealandice - a decision based (as he has since informed me) on Forster's account of the bird; but in a subsequent paper (op. cit. 1870), rcferring to my observations on the subject, he adopts the view of its being the young of that species, quoting, at the same time, Dr. Haast's opinion to the contrary. In Captain Hutton's 'Catalogue' $\uparrow$ only one species is admitted, the author remarking that it is very variable in size, and that " a large male can be distinguished from a small female by its more slender legs, which are 0.6 of an inch in eircumference in the male, and 0.88 of an inch in the female." On the other hand, several excellent local observers have always held that they could distinguish a larger and a smaller species, the former differing in some of its habits from the common Bush-Hawk, and frequenting the open eountry in preference to the woods. Mr. Gurney also called attention to the subject in a letter to 'The Ibis' $(1870$, p. 535), in which he gave the dimensions of various examples that had come under his notice. Of these, the small speeimen of II. Zrunnea, in the Norwich Museum, marked o (measuring 14.5 inches in total length, wing 9.25), is, no doubt, as Mr. Gurney suggests, incorreetly labelled; for I have never met with so small an example of that sex; and it must be confessed that eonclusions based on a mere examination of skins, in the absence of a positive determination of the sex, are very unsatisfactory.

It will be seen, on reference to the measurements I shall give in trenting of the smaller species, that the sexes differ very much in size, the female, as is always the case with members of this family, being the larger bird. The fact that a male of the present species (of which the sex was carefully aseertained by Dr. Haast) was actually larger than the female of $H$. brunnea appeared to me sufficient of itself to warrant a specific separation. Having, howvever, brought with me to England good examples of both forms for illustration in my former edition, I compared them with the fine series of specimens in the British Museum (about twenty in number) and with Forster's original drawings, and came to the eonclusion that there were in reality two distinct species, closely rcsembling each other in plumage in both the young and adult states, but differing appreciably in size. In this examination I was kindly assisted by Mr. J. H. Gurney, an ornithologist who, as is well known, has made Birds of Prey his special study; and as he entirely coneurred in the eonelusion arrived at, I felt that I could publish it with some degree of confidence.

Mr. Sharpe afterwards pointed out (Ibis, 1873, p. 327) that the name of Falco brunneus of Gould had been preoccupied by Bechstein, who thus called the common Kestrel of Europe, and that consequently our small bird, if allowed to be distinet from $I I$. novee zealandiox, must bear another title. He eonsiders that this should be Hieracidea australis (Homb. \& Jacq.); but it seems to me that this is only a synonym of the older species and that the right name to fall baek upon for the former is Falco ferox of Peale. In his official catalogue of the Accipitres in the British Museum, under the generic name of Harpa, he not only gives $H$. australis the preccdence, but eommits (as I venture to think) the further error of making it a "subspecies," or constant variety, of $H$. novce zealandice. The two birds are either specifically distinct or they belong to one and the same species.

Professor Hutton contributed to 'The Ibis' for October 1879 a table of measurements for the purpose of showing that there existed only one species; but in my reply to that paper (Ibis, 1881, p. 453) I pointed out that his argument was quite inconelusive, inasmuch as " his $q$ speeimen $B$ gives a wing-measurement only $\cdot 25$ of an inch longer than that assigned by me to the female of the smaller species."

* Vide Trans. N.-Z. Instit. rol. i. p. 106 (1868).

† 'Catalogue of the Birds of New Zealand,' by F. W. Hutton, Geol. Survey of N. Z. (1871). 
Since that time the question has received much attention at the hands of local ornithologists; and although there may be still some difference of opinion as to the propriety of keeping the birds distinct, nearly all the subsequent evidence is in support of my contention.

Apart from the manifest difference in size already mentioned, the Quail-Hawk may be distinguished from the smaller species by the colour of the irides, which become yellow in the fully adult bird, whereas in Harpa ferox they are dark brown.

This larger form is seldom if ever met with in the North Island, where the other is comparatively plentiful. The only specimen ever obtained by me there was shot in the Kaipara district, more than five-and-twenty years ago, and this is preserved in my old type-collection in the Colonial Museum. It is met with in suitable localities all over the South Island.

Its food consists of birds, rats, mice, lizards, and the larger kinds of insects. It often takes its prey on the wing, swooping down on its terrified quarry with the rapidity of an arrow. It never feeds on carrion or offal.

I have been informed by a credible eyc-witness that on one occasion a Quail-Hawk swooped down upon a man who was carrying a dead Pigeon, and, striking the bird forcibly out of his hands, retired to its station in a puriri tree to wait the course of events. It unfortunately fell a victim to its intrepidity, as it was instantly shot.

The late Sir J. von Haast, who always believed in the existence of two species, stated that their habits differ in the manner of taking their prey; and his collector, the late Mr. Fuller, assured me that he had invariably found the large birds paired together in the plains, and the small ones in the bush.

Mr. Reischek, who has been collecting for eight years in every part of the country, declares that all the examples obtained by him in the North Island were undoubtedly referable to the smaller form. He has collected both species in the South Island, where he invariably found the Quail-Harvk on the plains and lower ranges of hills, and the Bush-Hawk near the summits of the wooded ranges. Even on the Hen Island (in the Hauraki Gulf) he found the latter species frequenting only the tops of the hills. Having studied the birds in their native haunts and shot and compared scores of specimens in every condition of plumage, he unhesitatingly affirms that the two forms are specifically distinct.

Mr. Smith, whose full notes on the subject were communicated by me to the Wellington Philosophical Society*, writes that having procured upwards of thirty specimcns and worked out the subject for himself he is "decidedly in favour of the existence of two species." He states that he had nestlings of both, and that those of $H$. ferox never attained to the size of H. novce zealandice, although he kept them four months longer. In disposition, too, they differed, being fiercer and more untamable than the larger form.

Mr. Potts, who also recognizes two species, makes the following pertinent remarks :-

"If the cabinet ornithologist will not permit the fauna to possess two species, Falco ferox= F. brunnea must be the young state of Falco novce zealandice. In this case we must try to believe that the greatest boldness and audacity in attacking, the greatest activity and swiftness of wing in pursuing, is exhibited by the Quail-Hawk before it has reached the adult state; neither may we have regard to the difference of size which specimens of either sex very often present.

"In November 1868 two sets of young Falcons were found on Lake Coleridge by Mr. Oakden's shepherd; they were taken from the nesting-place and presented by Mr. Oakden to the Canterbury Acclimatization Society. He stated to the writer that the birds from one nest were readily distinguishable from those of the other nest even from the first. In size there was a marked difference,

* Trans. N.-Z. Instit. vol. xvi. pp. 318-322. 
perhaps of about one-third, this contrast of size being maintained up to the time when some of the birds were shipped for export to England. The writer has seen numbers of both species, and has a series of many specimens that have been collected in the course of some years. In life, besides the marked difference in size and in robustness of frame, the Sparrow-Hawk ( $F$. ferox) looks flatter about the head and carries the wings more prominently forward, this carringe giving the bird a less rounded appearance than is observable in the larger species. The smaller Falcon is more savage and resolute, and swifter in flight than its congener *.

“The Quail-Hawk exhibits great perseverance in pursuit of its prey, and almost unequalled audacity. I have known it pursue and strike down a large Spanish hen in a stockyard, not relinquishing its hold till killed with the blow of a stick. I have also known it pursue its prey into the inner room of a small cnttage. When Quail-shooting, year's ago, I have been on different occasions attended by this dauntless fowler, and have shot an individual in the act of pouncing on the flying Quail. I have seen a female of this species bear off a Tui trussed in her talons, and carry it some distance without a rest, the male bird apparently keeping watch and ward, soaring within easy distance. I remember also seeing a Quail escape the rapid pursuit of one of these Hawks by dropping like a stone, at the very instant that I expected to see it trussed up in the talons of its pursuer, so close was the chase before the Quail adopted its last resource for escape."

On the breeding-habits of this species, the same observer has communicated the following particulars:- "At present it is in the 'back country' only that we can hope to find its breeding-place, which is usually in a ledge of rock commanding a prospect over some extent of country. Such an outlook gives an advantage of no little value, of which the Falcon is not slow to avail itself, should such a bird as a Tui or Pigeon appear in sight. Several of the breeding-places which we have had opportunities of examining have presented, in a remarkable degree, very similar conditions as regards situation. Amongst bold rocks, on the mountain-side, somewhat sheltered by a projecting or overhanging mass, appears to be its favourite site for rearing its young. The eggs very closely resemble those of Falco peregrinus of Europe in colour, size, and shape, are usually three in number, and are deposited on any decayed vegetable matter that wind or rain may have collected on the rocky ledge; for the efforts of this bird in the way of nest-building are of the feeblest description." He gives nctober, November, and December as the breeding-months; and states that above the upper gorge of the Ashburton or Haketere River he discovered a nesting-place on the bare soil, sheltered by a large isolated rock. It contained two young Hawks covered with grey down; and the old birds were very bold in defence of their offspring.

From my brother, in Canterbury, I received a very handsome pair of eggs belonging to this species. Although taken from the same nest, they differ somewhat from each other, both in size and in the details of their colouring. One of them measures 2 inches in its longer axis, by $1 \cdot 4$ in diameter; is elliptical in form; mottled and blotched with dark brown on a lighter ground, and encircled at the larger end with a broad zone of very rich brown, varied with blotches of a paler or

\footnotetext{
* "We once had the gratifieation of witnessing a most interesting trial of powers between a Sparrow-Hawk and the Brown Parrot (Nestor meridionalis). It was near the shore of that most romantic sheet of water Lake Mapourika. Standing just within the trees that fringe its margin, we heard the alarm-ery of the Kaka, and swiftly there eame in sight, crossing a eorner of the open spaee above the plaeid waters, two birds in aetive eontest, the Parrot labouring heavily, wheeling and elumsily gliding aside, as its fieree pursuer drove at it with its talons. Then the rapid shifting of colours-now one saw the olive-brown of the Kaka's baek, then the blood-red markings of its soft under-plumage, almost hidden the mext instaut with tho dark brown, blaekish pinions of the Faleon. Borno downwards with the momentum of a lost stroke, the Hawk oceupied sume time in regaining ' the air,' whilst the terror-strieken Kaka hastened at its topmost speed towards the friendly eover of the wood. Onee more its persevering enemy darted towards it with almost ineredible swiftness, but the perseeuted bird scemed to tumble amongst the trees that ensured its safety, quite regardless of appearanees, so that it reaehed an asylum." - Out in the Open.
} 
reddish tint. The other is more broadly elliptical, measuring in its axis 1.9 ; diameter 1.45 . It wants the well-defined dark zone of the former, the whole surface being more or less mottled and blotched with reddish brown on a paler ground.

The fine series of eggs of this species in the Canterbury Museum exhibit considerable individual variation. Two specimens, taken from the same nest, are more ovoido-conical than ordinary examples, having an appreciably smaller end. One of these is of a rich reddish brown towards the larger end, with darker blotches, and towards the other end pale brown, profusely sprinkled and mottled with dark reddish brown. The other is somewhat similar, but more blotched with dark brown in its median circumference, and with the ground-tint towards the smaller end reduced to a whitish cream-colour. In two other examples (also from one nest) the whole surface is reddish brown, stained, mottled, and blotched with darker brown; but one of them has the brown of a richer tint, and the mottled character more distinct.

Among the more recent additions to this collection there is a singular specimen of the egg of this species. It is very ovoido-elliptical in form, measuring 2.25 inches by $1 \cdot 4$, of a warm sepiabrown, prettily freckled and spotted, more thickly so in the middle, and confluent in a large patch at the larger end, with reddish brown varied with darker brown.

A very handsome specimen in my son's collection (obtained at Oamaru) is broadly ovoido-conical, measuring 1.9 inch in length by 1.3 in breadth; it is of a rich cream-colour, thickly spotted, speckled, and freckled over the entire surface with dull reddish and chocolate-brown, these markings becoming entirely confluent at the larger end, which is entirely reddish brown smudged and daubed all over with chocolate-brown.

On the subject of the systematic position of this form, Dr. Finsch published the following remarks in the 'Journal für Ornithologie' for March 1872, which I have translated from the German :- "Falco nove zealandice must be ranged among the Tree-Falcons, and follows next in order to Falco femoralis, having, like the latter, a long tail, which is only half covered by the wings. . . . . Third primary longest; second shorter and somewhat longer than fourth; first and fifth equal. Tarsi covered in front with ten hexagonal scutes in double rows. Middle toe very long, being with the claw nearly as long as the leg; lateral toes equal, the points of their claws scarcely reaching to the base of the middle-toe claw. A subgeneric distinction appears justifiable."

Mr. Sharpe, who contributed to 'The Ibis' $(1873$, p. 327) some critical notes on the subject, says :- "The New-Zealand Hieracidece are rather abnormal members of the Falconine series; for it is rare to find a bird which, when young, is uniform above, and becomes barred when it is old; nor do they here closely coincide with their Australian congeners, excepting as regards their uniformly cloudy.breasts when young." He afterwards (Cat. Birds Brit. Mus. vol. i.) adopted Bonaparte's genus for our bird, merely altering the termination, for classical accuracy, and making it Harpa.

In a communication to the Wellington Philosophical Society, in September 1878 *, I took exception to the proposed generic separation of our bird from that inhabiting Australia; but I have lately gone into the question with Mr. Sharpe himself and have come to the conclusion that the distinction he makes is a reasonable one. I have accordingly adopted Harpa in lieu of Hieracidea, although my Plate of the species, which had already been worked off, bears the latter name, being that by which the bird has been hitherto known in the Colony.

Mr. Gurney in his 'Diurnal Birds of Prey' (p. 95) says, in reference to the smaller species:"Mr. Sharpe applies to this Falcon the specific name of 'australis' proposed by MM. Hombron and

* Trans. N.-Z. Inst. vol, xi. pp. 366,367 . 
Jacquinot in the 'Annales des Sciences Naturelles,' 2nd series, vol. xvi. p. 47 ; but, according to the letterpress of the 'Voyage au Pôle Sud,' Zool. vol. iii. p. 47, this name was given to the species inhabiting the Auckland Islands as well as New Zealand, which is $H$. nove zealandice. I therefore agree with Dr. Buller in considering 'Falco australis' a synonym of the larger specics." He also questions Mr. Sharpe's right to sink the specific name of brumnea, for he argnes that "its having been proposed for a species of the genus Tinnunculus docs not render its employment illcgitimate when it is applied to a bird belonging to another and distinct genus." As will be seen, however, I have followed Mr. Sharpe in this respect, so as to avoid all possiblc confusion of names in the future.

Mr. Gurney, after a careful study of the series of specimens in the Norwich Museum, wrote to me saying, "I am sure you are right about the distinctness of the two New-Zealand Hieracidece"; but Profcssor Hutton, who still adheres to the contrary opinion, says in one of his last letters:- "I examine and measure carefully every specimen of $\mathbb{H}$. novce zealandice that comes in. So far as my present measurements go they indicate one species only."

Before passing on, however, to my account of Harpa ferox, I will give here the results of a comparison of two carefully selected birds which I cxhibited at a mecting of the Philosophical Institutc of Canterbury, as recorded in the 'Transactions of the New-Zealand Institute':-

"Among Ilawks generally-and the genus Hieracidea is no execption to the rule-the female is both larger and more handsomely marked than the male. Sueh heing the ease, let us for our present argument eompare an adult female of Hieracidea nove zealandice with an adult female of $H$. ferox. This will afford us the fairest mode of determining their relative size, and the best means of aseertaining any differenees in the plumage of the two species.

"For this purpose I shall lay before the meeting two speeimens seleeted from the type eolleetion in the Canterbury Museum. The larger of these birds was obtained at Castle Hill, and the other on the Bealey-well known localities within this provinee-and both individuals proved on disseetion to be females. The following is a eomparative statement of their measurements :-

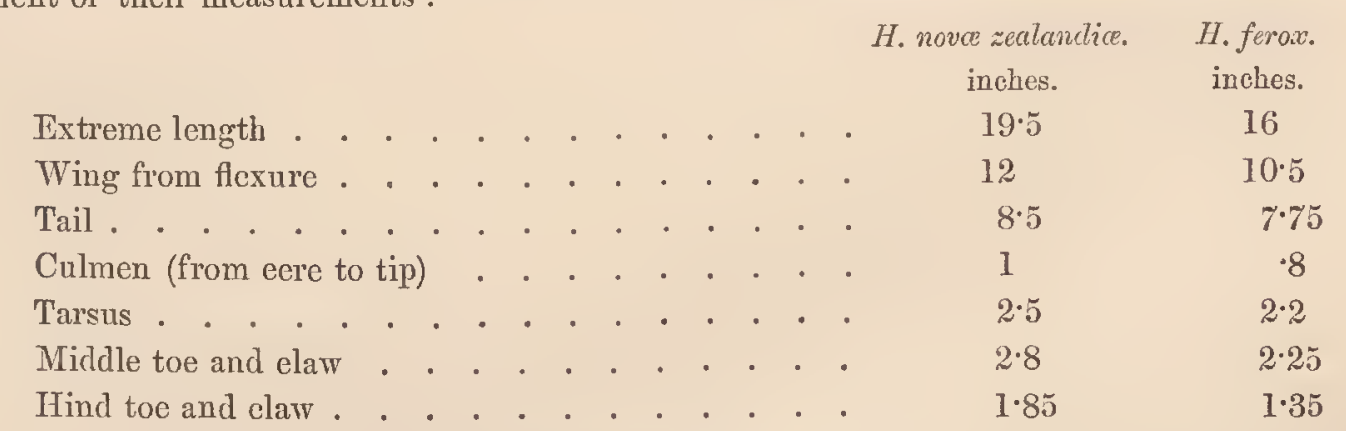

"It will be seen from this that Hieracidea nova zealandice is a considerably larger bird than $H$. ferox. It has a proportionately powerful bill, while its legs and feet are deeidedly more robust. In the eolours and markings of the plumage there is a general similarity between them; but oll a elose eomparison of the two examples exhibited it will be seen that $H$. nove zealandia has the bars on the upper surface far more distinet and numerous besides being of a brighter rufous, the tail-eoverts are more eonspicuously marked, the bars on the tail are bronder and whiter, and there is a larger amount of white on the tliroat, breast, and abdomen. In the present example of $H$. ferox the breast is much darker than in the other lird, the middle portion of each feather being oceupied by a broad laneeolate mark of blaekish brown, and there is less of the buff aud rufous stains whieh impart so warm an effect to the breast of $H$. nove zealandia. There are other minute points of differenee, but these may be mere individual peeuliarities. Fnough has, however, been pointed out to show that the two speeies may be readily distinguished from each other; and this is the only point at issue.

"Of course the whole value of this evidenee depends ou the aeeuraey of the 'sexing' in eael ease. I think this, however, is plaeed beyond all doubt, for the larger bird was determined by Mr. J. D. Enys, who obtained it, while tlıe smaller one was reeeived at the Museum in the flesh, and was disseeted by the taxidermist for the express purpose of aseertaining the sex. Mr. Fuller assures me that he was most eareful in his examination, and that the speeimen exhibited is to an absolute eertainty a female." 


\section{HARPA FEROX.}

\section{(BUSH-HAWK.)}

Falco brunneus *, Gould, P. Z. S. 1837, p. 139.

Falco ferox, Peale, U. S. Expl. Exp. p. 67 (1848).

Hieracidea brunnea, Griay, Ibis, 1862, p. 215.

Harpe Urunneus, Gray, Hand-l. of B. i. p. 22 (1869).

Hieracidea brunnea, Buller, Birds of New Zealand, 1st ed. p. 6 (1873).

Harpa australis, Sharpe, Cat. Birds Brit. Mus. vol. i. p. 373 (1874).

\section{Native names.}

The same as those applied to the preceding species; but sometimes distinguished as Karewa rewa-tara. "Sparrow-Hawk" of the colonists.

ô similis $I$. nova zealandice, sed valdè minor : suprà magis einereus : eaudæ fasciis angustioribus et obscurioribus : subtùs pallidior, distinetiùs striatus et maculatus.

i maris staturam eonspieuè superans.

$J u v$. a specie præcedente haud distinguendus, sed subtùs obseurior.

Adult male. Upper parts generally greyish black, darkest on the head and nape; shoulders, seapulars, and small wing-covcrts narrowly barred with grcyish white, the baek and uppcr tail-eoverts with small eresentic bands of rufous; throat ycllowish white; ciliary bristles, ear-coverts, and the faeial streak black; a line over each eye, and the sides of the neek, reddish brown, varied with fulvous and blaek; breast and sides fulvous, varied with reddislı brown, and largely marked with black. On the breast each fcather has a central dash of black; and on the sides these markings assume a triangular form, giving a spotted charaeter to the surfaee of the plumage. The wing-feathers are marked, on their outer web, by narrow transverse bands of greyish white; and the tail-feathers, whieh are black with a purplish refleetion, have a series of seven narrow white bars disunitcd at the shaft, and are tipped with rufous brown; axillars dark rufous brown, with a series of round white spots on each web; abdomen and vent pale fulvous; tibial plumes rufous, with black shaft-lines. Bill blaek, whitc at the base of lower mandible; irides very dark brown; eere, lores, and eyelids bright lemon-yellow, slightly tinged on the cere with green; legs and feet paler yellow and more tinged with green; claws blaek. Extreme length 16 inches; extent of wings 26.5 ; wing, from flexure, 9 ; tail $6 \cdot 5$; tarsus $2 \cdot 25$; middle toe and claw $2 \cdot 3$; hind toe and elaw $1 \cdot 3$; bill, along the ridge $\cdot 85$, along the edge of lower mandiblc 1 .

Adult female. Differs from the malc in its somewhat larger size and in the darker and richer colouring of its plumage; but in other respeets the sexes are alike. Extreme length 16.75 inches; wing, from flexure, 10 ; tail $7 \cdot 7$; tarsus $2 \cdot 4$.

Young. The young of this speeies bears a general rescmblance in its plumage to that of the preceding bird; but on a close comparison it will be observed that the brown of the underparts is darker, while the spotted markings on the sides are rather more conspicuous. The tibials, moreover, are of a brighter rufous, and are crossed with numerous arrow-shaped marks of brown.

Nestling. Covered with bluish-grey down; bill black; tarsi and toes leaden grey.

* Preoccujied by Bechstein, as mentioned on page 215. 
Var. Individuals cxhibit the usual variation in the details of their markings. A young example from the Bay of Islands, which I had the opportunity of examining, was peculiar in being largcly markcd with pale fawncolour on the throat, breast, and abdomen, the lower part of the body bcing cntircly of that colour.

A beautiful adult male specimen, from the Seventy-mile Bush, which came into my possession alive, differed slightly in its dimensions from that described above. Total lcngth $15 \cdot 5$ inches; extent of wings 27.25 ; wing, from flexure, 9.5 ; tail 6.5 . Another, from Wainuiomata, measured 16 inches in length; 28.5 in extent; tail 7.

Obs. This spccies closely resembles Harpa nova zealandie, but is decidedly smaller, and has more slcnder legs and claws; otherwise it would perhaps be impossible to distinguish the two birds.

Although not so common as it formerly was, the Bush-Hawk is more frequently met with than its congener. The high wooded lands of the interior appear to constitute its favourite haunts; and on the southern mountain-ranges of the North Island, as well as in the subalpine woods of the Canterbury provincial district, I have found it comparatively abundant. The skin of a Hawk from Macquarie Island, sent to me by Mr. Bourne of the Otago Museum, proved on examination to be identical with this species.

It is a spirited little hunter, and subsists by the chase, its food consisting principally of mice and small birds. During the breeding-season it is more than usually bold and fearless, assailing with fury all intruders upon its nest or young. Some remarkable instances of its courage are mentioned by the late Sir J. von Haast in his interesting 'Journal of Explorations in the Nelson Province' *.

"One day," says this traveller, "walking along near the margin of the forest in Camp Valley, my hat was suddenly knocked off my head, and at the same time I heard a shrill cry. On looking up, I found it was one of these courageous little Sparrow.Hawks that had attacked me, and which, after sitting for a moment or two on a branch, again pounced on me; and, although I had a long compass-stick in my hand, with which I tried to knock it down, it repeated its attack several times. ... We met with another instance of the courage of these birds in the Matakitaki Plains. A White Crane, of large size, standing in the water, was attacked by three of them at once; and they made frequent and well-concerted charges upon him from different quarters. It was admirable to behold the Kotuku (White Crane) with his head laid back, darting his pointed beak at his foes with the swiftness of an arrow, while they, with the utmost agility, avoided the spear of their strong adversary, whom at last they were fain to leave unmolested. Another day, in the same neighbourhood, a Cormorant (Graculus varius) passing near a tree on which two of these Sparrow-Hawks were sitting, was pounced upon by them and put to hasty flight with a shrill cry of terror, followed closely by his small but fierce foes; and all three were soon out of sight."

The ordinary flight of this Hawk is direct and rapid; but it may sometimes be seen soaring high in the air, with the wings almost motionless and the tail spread into a broad fan. On the wing it often utters a prolonged petulant scream. This is the signal for a general outcry among the small birds within hearing; and the Tui and Korimako will often rise in large flights and follow him into the air. But the little Hawk, heeding not their menaces, pursues his course, and the excitement among the feathered fraternity gradually subsides till all is quiet again. The appearance of an Owl in the daytime produces a similar commotion among the small birds of the forest; and I have often been guided to the hiding-place of the unfortunate "Morepork" by the clamour of the persecuting mob.

Besides the prolonged shrill note which is generally uttered on the wing, this species has also a low peevish cry, exactly like the squealing of a young pig, which is peculiar, I believe, to the breeding-season.

* Report of a Topographical and Geological Exploration of the Western Districts of the Nelson Province, New Zealand, undertaken by the Provincial Government. Nelson : 1861. 
It is well known, as already stated, that birds are good natural barometcrs. The height to which they rise in the air renders them susceptible to the slightest change in the temperature of the atmosphere; and they are thus warned of approaching changes in the weather. Thus the continuous screaming of the Bush-Hawk is understood by the natives to be a sure indication of change; and they have a common saying "Ka tangi te Karearca \&c." (If the Karearca screams in fine weather, 'twill soon rain; if in rainy weather, 'tis about to clear). Wilson, the American ornithologist, in treating of the Fish-Hawk (Pandion haliaëtus), states that when these birds are seen sailing high in air, with loud vociferations, "it is universally believed to prognosticate a change of weather, often a thunderstorm in a few hours. . . . . On the faith of the certainty of these signs, the experienced coaster wisely prepares for the expected storm, and is rarely mistaken." I have met with some remarkable instances of this unerring instinct in the species under consideration, and this, at times, when the glass gave no indication of a coming change.

The Bush-Hawk is generally met with on the outskirts of the woods or among the dead timber of native "wairengas," these localities being favourable for mice, on which it largely subsists. I once observed a young male of this species playing in the air with mice, after the manner of a cat; and the sight was as pretty as it was novel. When I first observed the bird, he was perched on the naked limb of a tree, apparently engaged in examining his quarry. Then mounting in the air with a mouse in each of his talons, and expanding his wings and tail to their full extent, he dropped first one mouse and then the other, and instantly darted after them, catching them in his talons before they reached the ground, then mounting high in the air again to rcnew the feat. Ultimately losing one of the mice, he discontinued his play, and, returning to the tree, killed and devoured the remaining one.

Formerly this spirited little Hawk was very common in the Hutt Valley and in the wooded suburbs of Wellington; now it is rarely, if ever, seen there. The last instance I know of was in April 1883, when a Sparrow-Hawk, after sailing inquisitively over the city and hovering for a time above the Colonial Museum-uttering all the time its shrill cry, as if in defiance of taxidermists and naturalists in general-eventually settled in the blue-gums in my garden, where it remained for half an hour ; and then, after another rapid survey of the town, disappeared over the lills in the direction of Makara. A few years nore, and the clarion cry of this fierce little hunter will be a thing of the past! Its appearance on this occasion was quite unusual, for my gardener, who is an old Wellington settler, declared he had not seen or heard the bird for more than ten years before.

I may mention that this species, unlike the gencrality of Hawks (so far as I am arvare), may be attracted by an imitation of its cry. Riding along alone one fine autumn evening through the country at the northern end of Lake Taupo, on my way to Ohinemutu, I saw what appeared to be a Bush-Hawk come out of the woods at some distance and descend into an old or deserted Maori garden. By way of experiment I imitated the clamorous cry of this bird when on the wing; and in a few minutes the Hawk (a fine young male) came sailing up to me and performed several circuits in the air immediatcly overhead, and then took up his station on the dry limb of a tree close by the road, where he rcmained till I was out of sight.

The natives state that this little Hawk usually builds its nest in a bunch of puwharawhara, often at a great elevation from the ground, forming it rudely of loose materials; that it lays generally two, but sometimes thrce eggs; and that the young birds remain on the tree for several days after quitting the nest. The puwharawhara (Astelia cunninghamii) is a parasitical plant, with short, thickly set flag-leaves, radiating upwards from a clump of roots by which it adheres firmly to the parent tree. These plants, which often attain a circumference of many feet, are very common on the forks and naked branches of aged or withered trees on the outskirts of the forest, a single tree sometimes supporting twenty or more of them. A better situation for a Hawk's nest than the centre of one of these plants could hardly be selected, combining as it does the requisites of warmth, security, 
and shelter; and the Bush-Hawk seems to be instinctively aware of this. Some years ago I was informed that a pair of these birds had bred for several successive seasons in a nest placed as described, and situated in the high fork of a dead kahikatea tree near the Horowhenua Lake. Having waited for the breeding-season, I offered the natives a half-sovereign each for the eggs; but, although excellent climbers, they failed in all their attempts to reach the nest. They afterwards observed the Hawks carrying mice, lizards, and small birds to their young; and the latter, on quitting the nest, were shot and destroyed. When I last visited the spot the old kahikatea was still standing, and the bunclı of withered Astelia, which had cradled several. successive broods, was still clinging to the tree; but the persecuted Hawks had quitted their exposed eyrie for some more secure retreat.

In the summer, however, of 1867 , during a visit to Taupo, I was fortunate enough to find the nest of this species. We had fixed our bivouac for the night on the banks of the Waitangi Creek, only a ferr miles from the base of the grand snow-capped Ruapehu. Our native companion soon detected the old Hawks carrying prey to their young, and on the following morning he discovered the nest*. It was situated on the ground, under cover of a block of trachyte, which cropped out of the side of the hill. There liad been no attempt to form a proper nest; but the ground was covered with the feathers of birds (almost entirely those of the Ground-Lark) on which the young Hawks had been fed. The latter were three in number, of different sizes, the largest being apparently three weeks old, and the smallest scarcely a fortnight. They were extremely savage, striking vigorously with their sharp talons and uttering a peculiar scream. While we were engaged in securing them in a basket the old birds were flying to and fro, occasionally dashing up to within a few feet of us, and then off again at a sharp angle, alighting at intervals, for a few moments only, on the rugged points of rock above us, but never uttering a sound. They were in perfect plumage; and when they occasionally poised their bodies overhead, with outspread wings and tail, they presented a very beautiful appearance. During our journey of forty miles through the bush, the gun supplied the young Hawks with a sufficiency of food; but they were very voracious, two large Pigeons per diem being scarcely enough to appease their joint appetites. Fifty miles more by canoe, and about forty on horseback, brought the captives to their destination, when they were placed in a compartment of the aviary. They continued to be very vicious, punishing each other severely with their claws. The youngest one was an object of constant persecution, and ultimately succumbed to a broken back. A small tame Sea-Gull that had unwittingly wandered into the aviary, through an open doorway, was instantly pounced on, although the young Hawks, in their unfledged condition, could only move by hopping along the ground. In about three weeks these birds (which proved to be male and female) had fully assumed the dark plumage; and for about two months after they were very clamorous, especially during wet or gloomy weather. By degrees they became less noisy, till at length they were perfectly silent and moody, never uttering a sound for weeks together, with the exception of a peculiar squeal when they were fighting. A more quarrelsome couple never existed. The female, being the larger and stronger bird, generally came off best, leaving the male severely punished about the head. At the end of six months the climax was reached by her actually killing and devouring her mate. I found the aviary strewn with feathers, and the skeleton of the poor victim picked clean! The surviving bird underwent a partial moult in the month of September following, and the plumage began to assume a spotted character. The legs also became slightly tinged with yellow. By the beginning of March in the following year she had acquired the full adult plumage, except that the throat and spots on the sides were not so light as in more mature examples. The legs had changed to a pale greenish yellow, and the irides from lustrous black to a dark brown colour-the cere retaining its pale blue tint, but with indications of a change to yellow. After two months' absence I

* Captain Mair, writing to me in February 1880, says :- "The Sparrow-Hawks still build at the cliff on the Waitangi Stream where we obtained our young birds in $1867 . "$ 
again saw the bird, and noticed that the lores were becoming tinged with yellow, while the colour of the legs had deepened. Unfortunately, at this stage she was found dead on the floor of the aviary; and on dissection I found in the cavity of the back an amazing number of parasitical worms, many of them measuring from six to eight inches in length. A wild specimen, which I afterwards examined, was similarly afflicted.

The result of my observations is, that the Bush-Hawk attains the mature livery during the second year, the plumage being liable to some slight variations as the bird gets older. The irides had undergone very little perceptible change at the time of the bird's death, but the eyes were large and somewhat sparkling.

This bird, a stranger to liberty from the very nest, had become quite attached to its aviary. It never attempted to escape when the door was accidentally left open; and on one occasion when it did get out it remained perched on the dome of its house, and voluntarily re-entered it. It partook readily of all kinds of meat, cooked or raw, although preferring the latter. Beef, pork, or mutton were alike acceptable; but a preference was always shown for birds. On a live bird being offered to it, the Hawk would eye its quarry intently for a short time and then make a suclden swoop upon it, seizing with the talons of one or both feet, according to the size and strength of the object. It would then proceed cautiously to destroy life by crushing the head of its victim in its powerful beak, only relaxing its hold when life was quite extinct. While thus employed, its eyes were full of animation, and its whole body quivered with excitement.

A pair of these birds bred for two successive seasons on a rocky crag at Niho-o-te-kiore. They guarded their nest with great vigilance, fiercely attacking all intruders; and on both occasions brought up their brood in safety.

The description of the male is taken from a fine specimen shot in the Karori Hills, near Wellington, in 1859, and of which I sent, at the time, a clescriptive notice to the Linnean Society. Its much smaller size led me to suppose that it was distinct from Harpa novce zealandice; and it was not then known that Mr. Gould's $I$. brunnea was founded on an immature example. That such was really the case is sufficiently proved by the account given in the foregoing pages, and previously recorded in the Transactions of the New-Zealand Institute (1868, vol. i. p. 106).

The eggs resemble those of $H$. novce zealandice, but are somewhat smaller and lighter in colour. There are three examples in the Canterbury Museum, differing in the details of their colouring; but they may be defined as yellowish brown, stained and mottled with reddish brown, and having a rather soiled appearance. In one of them the blotched character is more apparent at the smaller end; in another it is equally dispersed, while in the third the dark brown markings present a smudgy character over the whole surface. They measure 1.9 inch in length by 1.45 in breadth.

In the same fine collection there is a beautiful specimen of the Bush-Hawk's egg from the Chatham Islands. It is of a rich or warm reddish brown, freckled and slightly smudged with darker brown, presenting a close resemblance to the Merlin's egg, broadly ovoido-conical in form, and measuring 1.95 inch by 1.5 inch. There is another egg of the same species, from Paringa River (South Westland), differing very perceptibly in being of a dull cream-colour, freckled and stained all over with brown. It is of the same size as the Chatham-Islands specimen, but is slightly more oval in form.

A specimen brought by Mr. Reischek from Martin's Bay, in the South Island, measures 1.8 inch in length by 1.5 in breadth, being of a regular ovoid form; the whole surface is pale reddish brown, blackish brown, and cream-colour mixed together in an irregular way, being decidedly darker at the larger end, and the light markings at the smaller end having the appearance of abrasions or scratches on the surface. The nest from which it was taken was placed in the leafy crown of a high forest tree. 


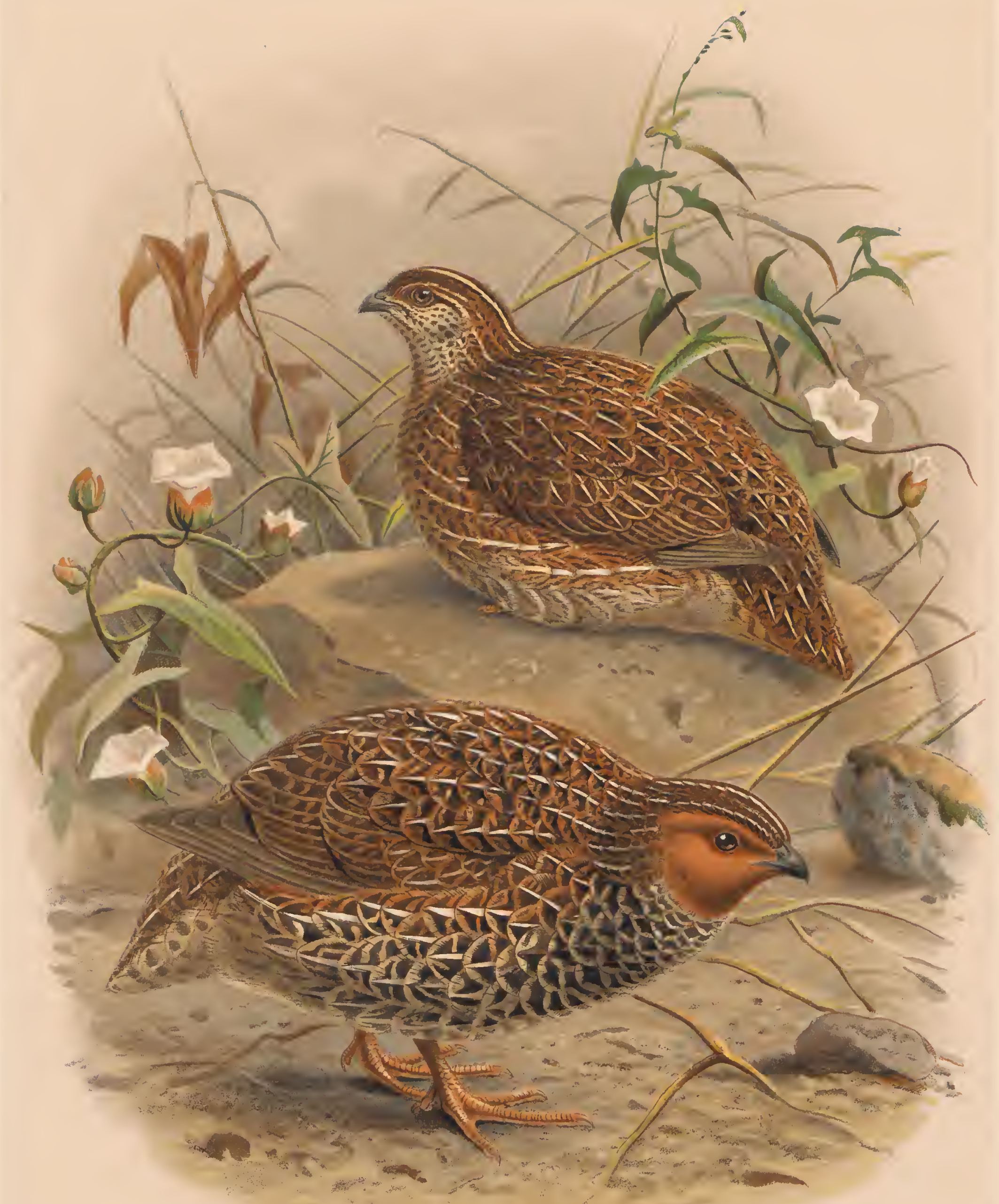





\title{
COTURNIX NOVE ZEALANDIE.
}

\author{
(NEW-ZEALAND QUAIL.)
}

Coturnix novae zealandice, Quoy et Gaim. Voy. de l'Astr. (Zool.) i. p. 242, pl. 24. fig. 1 (1830).

Native names.-Koreke and Kokoreke.

đ ad. suprà rufescenti-brunneus: dorsi plumis medialiter fulvo striatis, utrinque nigro marginatis, plumis quibusdam nigro irregulariter maculatis aut vermiculatis : pileo saturatiùs brunneo, supercilio et lineâ verticali fulvescentibus : collo postico et latcrali fulveseente : facie laterali et gutture toto eastaneis, genis et regione auriculari paullò nigrieante variis : tectrieibns alarum minimis ct medianis dorso concoloribus, his magis fulvescentioribus : remigibus nigricantibus, secundariis angustè fulvo vermiculatis : reetricibus nigris, fulvo transfasciatis, scapis etiam rufcscenti-fulvis: subtùs albicans, peetore superiore et abdomine imo fulvescentibus : pectoris plumis nigro marmoratis, fasciâ latâ nigrâ transfasciatis, abdominis plumis fasciis sagittiformibus nigris notatis : hypochondriis rufescenti-fulvis nigro transversim irregulariter fasciatis, et conspieuè medialiter albo striatis : erisso et subcaudalibus nigro notatis et fasciatis : subalaribus albidis, augustè brunneo marginatis, margine alari brunneo vario: rostro nigro, versùs apieem dilutiore: pedibus pallidè carneis : ,iride pallidè brunneâ.

q ad. mari similis, sed paullò major, ubique dilutior : facie eastaneâ et pectore nigro absentibus : facie laterali guttureque fulvescenti-albis, illâ brunnco maculatâ: corporc reliquo subtùs rufescente, abdomine medio albicante, plumis omnibus nigro marginatis, peetoris plumis ct hypochondriis medialiter albo lineatis.

ऊ juv. similis fcminæ adultæ, sed facie laterali et gutture pallidè rufeseentibus : eorporis subtùs plumis latiùs nigro marginatis.

q juv. similis feminæ adultæ, sed eorporis subtùs plumis magis distinctè nigro marginatis.

Adult male. Crown of the head and nape dark brown edged with paler, a series of feathers down the centre and on the sides marked in the middle with yellowish white; shoulders, mantle, and all the upper surface rufous brown, beautifully varied with black, and marked with numerous lanccolate stripes of white. On closer examination it will be found that this cffeet is produeed by each feather having a broad lanceolatc mark of white down the shaft, bordered on cach side with black, dark brown on the webs, fancifully rayed, or banded transversely, aud largely tipped with rufous brown. Lores, line over the eycs, sides of head, and throat rufous, with a lunar mark from the ear-coverts on each side, and an anterior edging or border of black; lower part of the neck mottled or obscurely spotted with black and whitc, the former preponderating; examined separately, however, each feather is black crossed by irregular bauds and largely tipped with white; sides and long plumage overlapping the thighs rufous brown, each feather margined and marked down the centre with white, and handsomcly streaked and barred on the wcbs with brownish black; abdomen fulvous white, the under tail-coverts barred with black; primaries and outcr secondaries dark brown, the latter rayed on their outer webs with zigzag lines of paler brown; inner secondaries and all the wing-coverts, as well as the tail-feathers, greyish brown, varicd with pale rufous, cach feather with a narrow shaft-line of white. Irides light hazel; bill black, paler at the tip; tarsi and tocs pale flcsh-brown. Total length $8 \cdot 5$ inches; extent of wings 14; wing, from flexure, $4 \cdot 25$; tail $1 \cdot 5$; bill, along the ridge $\cdot 5$, along the edgc of lower mandible $\cdot 6$; tarsus 1 ; middle toe and elaw 1:25.

Adult female. In the female there is no rufous colour on the face or throat; the upper surface is light ferruginous brown mixed with fulvous, and handsomely varied with black; the lanceolate stripes are yellowish 
white, changing to fulvous on the longer seeondaries and on the lower part of the back; the throat, fore neck, sides, and flanks ferruginous brown, and the breast fulvous white, all more or less varied with black; on the neck and breast each feather is marked near the tip with a broad crescent, and on the webs with irregular spots of brownish black; the feathers covering the sides, and the long feathers overlapping the thighs, have a broad stripe of white down the shaft and are streaked and marbled on both webs with black; the abdomen is white, the sidcs fulvous, and the under tail-coverts dark fulvous varicd with blaek. The female is, moreover, slightly larger than the male in all its proportions.

Young male. In the young male the prevailing colour of the upper surface more nearly approaches that of the adult female. The rufous colouring on the eheeks and throat is very pale, and the lunate marks are less distinct than in the adult. The plumage of the underparts is largely washed with fulvous, and the dark crescents are broader and more eonspieuous.

Young female. The only pereeptible differenee in the markings of the young female is that the dark creseents on the under surface are better defined and less blotehed than in the adult bird. In my old collection (now in the Colonial Muscum) there are two young females from the same nest, in one of which the prevailing tint of the plumage resembles that of the adult female, while in the other it approaehes very near to that of the adult male.

Very young state. Crown of the head light fulvous varied with dark brown; ear-spots black; back and upper surfaee of wings yellowish brown, with dull black markings, each feather with a lanceolate stripe of fulvous white down the centre; throat and fore neck buffy white; breast and undcrparts pale buff, each fcather marlied near the tip with two eonverging elongate spots of a dull black colour. Bill, tarsi, and toes pale brown.

Obs. A beautiful male specimen obtained many ycars ago at Whangarei, in the North Island, and presented to me by Major Mair, differs from all my South-Island examples in liaving the whole of the plumage darker, the breast being almost cntircly brownish black, relieved only by a few touches of fulvous whitc; the rufous colour on the faee and throat is brighter, the laneeolate markings on the upper surfaee are very distinet, and the abdomen is fulvous.

THis handsome species-the only indigenous representative in New Zealand of the order Gallinæwas "on the verge of extinction" when I published my former edition. It is probably now extinct, for no specimen has been heard of for at least twelve years. In the early days of the colony it was excessively abundant in all the open country, and especially on the grass-covered downs of the South Island. The first settlers, who carried with them from the old country their traditional love of sport, enjoyed some excellent Quail-shooting for several years; and it is matter of local history that Sir D. Monro and Major Richmond, in 1848, shot as many as forty-three brace in the course of a single day within a few miles of what is now the city of Nelson: while a Canterbury writer has recorded that " in the early days, on the plains near Selwyn, a bag of twenty brace of Quail was not looked upon as extraordinary sport for a day's shooting." But, partly owing to the introduction of dogs, cats, and rats, and partly to the prevalence of the so-called "bush-fires" or burning of the runs (a necessary incident of sheep-farming in a new country), the Quail rapidly disappeared, and if not so already, it will ere long be numbered among the many extinct forms of animal life in New Zealand. Its place, however, has been more than adequately supplied by several introduced species, all of which appear to thrive well and multiply in their new home. Among these we may enumerate the following as being now permanently established in the country, viz. the common English Pheasant (Phasianus colchicus), the Chinese Pheasant ( $P$. torquatus), the Partridge (Perdix cinerea), the Californian Quail (Ortyx californicus), and the Australian Quail (Coturnix pectoralis)*. The last-mentioned bird closely

* To these may now bo added the Swamp-Quail (Synoïcus australis), which has rapidly spread itself over the North Island, being plentiful oven in the Taupo country. Three specimens of this bird (obtained at Tauranga) were sent to me by the Hon. Dr. Pollen, the then Premier, and I afterwards handed them over to the Colonial Musoum with the following note:- "Two of 
resembles the subject of this notice both in appearance and habits; and it will be curious to observe whether it will succeed in resisting for any length of time those physical conditions which have proved so fatal to the indigenous species.

According to the Maoris, even in the North Island it was formerly very abundant, certain grassy plains, like the Murimotu, in the Taupo district, being noted for them. Even at the present day, in the investigation of title in the Native Lands Court, the older generation of Maoris, when giving their evidence, often refer to the Quail preserves of former times in support of the tribal title*.

Sir Edward Stafford related to me the following circumstance in illustration of the suddenness with which the Quail disappeared from localities where it had once been plentiful:-On one occasion about the year 1848, accompanied by two other sportsmen, he went out to his own estate, about thirty miles from Nelson, for a day's Quail-shooting; and in the course of a few hours the party bagged $29 \frac{1}{2}$ brace. In the hope of preserving the game, he prohibited any shooting over this ground during the following year; but in the ensuing season, when he naturally looked for some good sport, there was not a single Quail to be found!

Sir Frederick Weld (the present Governor of the Straits Settlements), about the same period, tried a similar experiment on his property at Stonyhurst, but with no better success. Finding the Quails very abundant in a particular locality, and being anxious to preserve them, he protected a suitable cover of about 2000 acres, never allowing the sheep upon it, nor permitting fires to overrun it. When this protection was first extended, there were almost incredible numbers of Quails on the land; but in less than a year they had all disappeared. In 1851 Dr. Shortland found it very numerous on the open downs of Waikouaiti ; and as late as 1861, as we learn from Haast's 'Journal of Fxploration in the Nelson Province,' it was "still very abundant on the grassy plains of the interior, rising close to the feet of the traveller at almost every step."

A specimen was shot by Major Mair at Whangarei in 1860; Sir James Hector reports the taking of a pair at Mangawhai in 1866; Captain Mair saw one at Maketu in 1867; and the Hon. J. C. Richmond met with some in the Taranaki district in the months of November and December 1869. These are, I believe, the last recorded instances of its occurrence in the North Island. In the more retired portions of the South Island it was occasionally to be found down to 1875; but it had before that entirely disappeared from the settled country on the eastern side of the Alps.

In the autumn of 1860 I met with a bevy of nine on a dry grassy ridge in the midst of some shallow swamps about two miles from Kaiapoi (in the provincial district of Canterbury); and having with me a good pointer, I fortunately succeeded in bagging the whole of them. They afforded capital shooting, rising quickly and, after a low rapid flight of fifty yards or more in a direct line, dropping suddenly into the grass again. The stomachs of those I opened contained green blades of grass and a few bruised seeds, as well as some small fragments of quartz. The bevy consisted of an adult male and female, with seven birds of the first year; and as we may infer from the circumstances under which they were found that they comprised a single family, we have some evidence that this species is not less prolific than the other members of the extensive tribe to which it belongs.

Mr. Potts, writing of the bird before it had become rare, says:- "They often give utterance to a low purring sound that one might suppose to proceed from an insect rather than from a bird. The

these are in the normal plumage of the $\delta$ and $q$; tho other is a remarkable instance of melanism. The cntire plumage is a brownish slate-colour, palcr on the underparts; on the crown and napo there are obsolcte shaft-lines, and the whole of the upper surface is obscurely varied and mottled with blackish brown, washed with chestnut-brown on the wings. It is slightly smallor than the other specimens and proved on dissection to be a male." (Trans. N.-Z. Inst. vol. xiv. p. 534.)

* Extract from Apcrahama Te Kumc's evidence in tho Tokoroa casc, at Cambridge, Jne 1880:- "Wahineiti died at Tauranga. He said to Ngatikca, "Don't take me to Maungatautari but to Tokoroa, that the rushes of my land may grow over me, and that my body may drink the derws of Tokoroa.' This occasioned the name of Horohau : hence, too, the proverb 'Nga wi o Tokoroa.' These plains were famous for the abundance of Quail." 
call is indulged in most frequently during moist or wet weather; it sounds something like 'twit, twit, twit, twee-twit,' repeated several times in quick succession. In very stormy gusty weather these birds appear dull and silent, secreting themselves among thick tıssocks. When flushed, they do not rise perpendicularly, but still very straight for a few feet from the ground. In confinement they are fond of picking about amongst sand, and thrive well on soaked bread, grain of various kinds, and the larvæ of insects. The male is not an attentive mate at feeding-time; and where several are kept in the same enclosure, constant little bickerings take place without actual hostilities being indulged in. The eggs require twenty-one days' incubation; and the chicks are most active directly they emerge from the shell. They grow very rapidly; and at about four months old the young cannot very readily be distinguished from adult birds, either by contrast of size or plumage."

It may be interesting to mention, as showing the value attaching to extinct or rapidly expiring forms, that a skin of this bird (and that, too, a female) sent from the Canterbury Museum to Italy fetched as much as $£ 75$. My owl collection contains an adult male and female (from the North and Soutl Islands respectively), a young male of the first year, and another in the "very young state" described above. The last-named bird was one of a clutch of four, and I am indebted for this, among other rare specimens, to my lamented friend Sir Julius von Haast, the announcement of whose death in New Zealand reached me whilst these pages were passing through the press.

There is a specimen of the egg of this species (probably the only one in Europe) in Professor Newton's fine collection at Cambridge; and there are five examples in the Canterbury Museum which exhibit a slight variation in form and a considerable difference in colour. Two of them (presumably from the same nest) are of a regular oval form and of equal size, measuring $1 \cdot 3$ inch in length by 1 in breadth; these are of a pale yellowish-brown or buff colour, thickly marked with umber, the dark colour often preponderating and having the appearance of daubs or smudges on the outer surface of the shell. Two others (also exactly alike) are of a slightly larger size and of a thicker or broader form; these are of a dull cream-colour, sprinkled and minutely dotted all over with blackish brown. In one of them the spots are confluent at the larger end, forming a greyish-brown patch nearly half an inch in diameter; and in both the more conspicuous spots have a light or faded centre. The fifth egg is smaller and more rounded than any of the rest; it is of a yellowish-white colour, covered all over, but more thickly at the ends, with small smudgy spots of umber; and it has likewise a more glossy appearance than the others. On comparing the eggs of this species with those of Coturnix pectoralis, of Australia, there is a manifest difference, those of the latter bird being, as a rule, creamy white, with very obscure surface-spots.

After the above article had been sent to press, I received from the Colony the welcome intelligence that the last refuge of this well-nigh extinct species had lately been discovered. During the recent expedition of the Government steamboat 'Stella' to the Kermadec Islands, for the purpose of annexing them to New Zealand, Captain Fairchild, on his return voyage, landed on the Three Kings, a group of small islands situated about 32 miles W.N.W. of Cape Maria Van Diemen, the largest of them being only $1 \frac{3}{4}$ miles long by $\frac{3}{4}$ of a mile in width, and rising about 900 feet above the sea-level. There is no "bush" on this island, but the surface is covered with stunted Leptospermum, fern, flax, and sedges, with here and there a grassy flat. Notwithstanding the scantiness of the vegetation, no less than five plants were discovered entirely new to the New-Zealand flora, and these have since been described and named by Mr. Cheeseman, F.L.S., not the least interesting one being Pittosporum fairchildi. But, from an ornithologist's point of view, the most important discovery made was the existence there of several bevies of New-Zealand Quail, which were comparatively tame and fearless; and the explorers being fortunately without frearms they were left unharmed.

It is to be earnestly hoped that prompt steps will be taken by the Government to save and perpetuate this last remnant of an expiring race! 


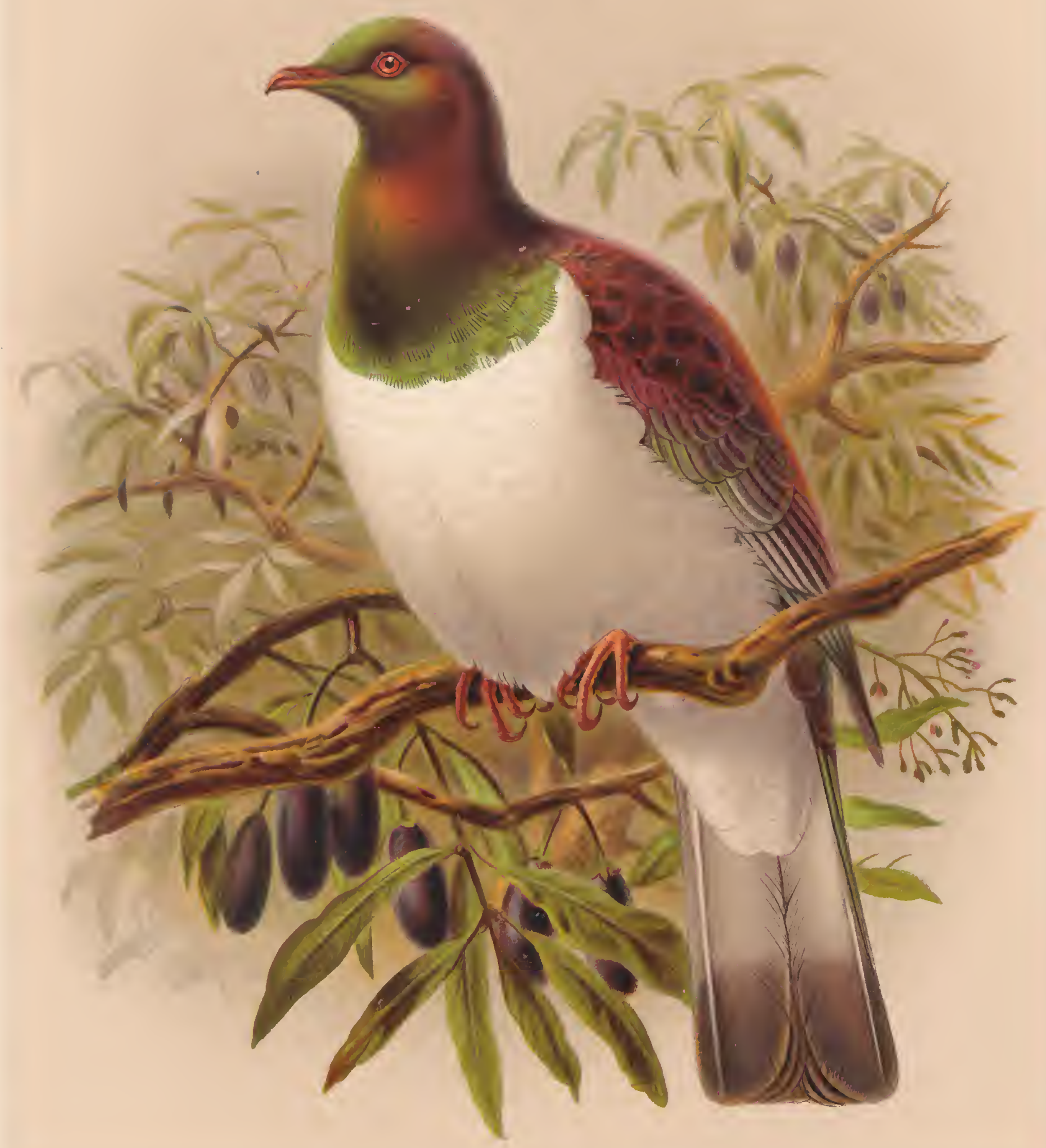

NEW-ZEALAND PIGEON.

CARPOPHAGA NOVE ZEALANDIF

(ONE-HAIF NATURAL SIZE.) 



\title{
CARPOPHAGA NOVE ZEALANDIE.
}

\author{
(NEW-ZEALAND PIGEON.)
}

\author{
New-Zealand Pigeon, Lath. Gen. Syn. ii. pt. 2, p. 640 (1783). \\ Columba nove seelandice, Gm. Syst. Nat. i. p. 773 (1788). \\ Columba zealandica, Lath. Ind. Orn. ii. p. 603 (1790). \\ Columba spadicea, Less. Voy. Coq. i. p. 710 (1826). \\ Columba spadicea leucophcea, Hombr. \& Jacq. Ann. Sci. Nat. xvi. p. 319 (1841). \\ Carpophaga novce seelandioe, Gray, in Dieff. Trav. ii., App. p. 194 (1843). \\ Columba argetraa, Forst. Descr. Anim. p. 80 (1844). \\ Hemiphaga novee-zealandice, Bonap. C. R. xxxix. p. 1077 (1854).
}

Native names.-Kuku, Kukupa, and Kereru.

$A d$. dorso æneo-ferrugineo : pileo antico lætè mctallicè viridi, posticè cum nnchâ et colli lateribus magis æneo nitentibus, his cyancscente tinctis: dorso postico et uropygio nitidè viridibus eyanesccnte lavatis, supracaudalibus olivasccnti-viridibus æneo lavatis : tcctricibus alarum minoribus et majoribus dorso proximis æneo-ferrugineis dorso concoloribus, majoribus et medianis exterioribus nitidè viridibus : remigibus nigris suprà cyancscenti-viridi nitentibus, secundariis æneo lavatis : caudâ nigrâ suprà saturatè viridi lavatâ, subtùs nigricante, pennis omnibus versùs apicem cinerasecntibus : facie laterali cum gutturc toto et pectore supcriore lætissimè metallicè viridibus : corpore reliquo subtùs purè albo: subcaudalibus cinerascentibus : subalaribus cincreis : rostro coccineo, versus apiccm flavicante: pedibus coccineis : iride coccineâ, annulo ophthalmico pallidè rubro.

Adult male. Head, neck, and fore part of breast shining gold-green, changing according to the angle of view; nape, shoulders, and upper surface of wings, as far as the carpal joint, coppery purplc, with bright metallic reflections where this colour blends with the grcen of the surroundiug parts; baek and rump greyish grcen, with dull metallic reflections; quills and their coverts bronzy grcen, with the iuner wcbs dusky, the secondaries tinged with coppery purple; an obscure band of grey (more conspicuous in the young bird) crossing the outer webs of the primaries, being widest on the fifth and sixth quills; tail-feathcrs black, with blue reflections on their edges, and terminally margined with brown; under surfaee of tail-feathers silvery grey towards the base, espceially on the outer ones, blackish in their apical portion, with lighter tips; their upper coverts dull shining green; underparts from the breast downwards purc white, the lower tail-coverts tinged with yellow; lining of wings delicate ash-grey. The line of demarcation betwecn the lustrous grecn and the white is well defined, crossing the breast with an easy curve and terminating immediately above the inscrtion of the wings, so that when the bird is at rest a narrow margin of white appears over the bend of each wing. Irides and fcet carmine-red; soles ycllow and covcred with small flattened papillæ; claws black; bill carmine-red in its basal half, changing to ycllow towards the tip ; eyelids pale red, with a retieulate margin, imparting to the brilliantly coloured cyes a very soft expression. Total length 21 inches; extent of wing 32 ; wing, from flexnre, $10 \cdot 75$; tail 8.5 ; bill, along the ridge $\cdot 75$, along the edge of lower mandible $I \cdot 4$; middle toe and claw $2 \cdot 25$; the lateral toes equal, being $\cdot 75$ shorter ; hind toe $1 \cdot 4$.

Female. Hardly distinguishable from the male, but with the metallic tints of the plumagc somewhat duller.

Young. The bronzy plumage of the neck and breast has much less iridescence than in the adult, but the hind neck and smaller wing-coverts are of a rich metallic purple shot with blue and changing in different lights ; 
the throat is greyish, each feather with a terminal margin of fulvous; the white of the underparts is washed with eream which deepens to fulvous, or sometimes pale rufous, on the flanks and under tail-eoverts; the inner lining of the wings is uniform dark grey, and along the carpal flexure there are a few touches of fulvous. The size is appreciably less than that of the fully-grown bird; the bill and irides are of a less deeided or lighter colour; the feet instead of being earmine are of a bright coral-red, and the soles pale brown instead of yellow.

Fledgling. A speeimen in my eollection has the chin and upper part of throat greyish brown, the feathers minutely tipped with whitish grey; the white plumage of the underparts washed with cream-yellow; the under tail-coverts stained with pale rufous; nape and hind neck shaded with eoppery and vinous brown; lining of wings elear ash-grey.

Nestling. A very young chick, which I examined as a dried speeimen, was eovered sparingly with yellowishwhite down, looking very mueh like flax tow, and perfectly bare on the abdomen.

Obs. Before arriving at full maturity the plumage is subject to slight variations. It is not unusual to find the under tail-eoverts pale rufous and the white plumage of the underparts elouded or marked witl grey.

Varieties. There is a lovely albino in the Colonial Museum, from the Wairarapa, the entire plumage being of a pure milk-white, the small wing-coverts alone prescnting a slight tinge of yellowish brown; bill and feet carmine-red. Partial albinos, or light-coloured varieties, are occasionally met with. A speeimen presented to me by the late Mr. Edward Hardcastle, R.M., has the head, ncck, fore part of the breast, and all the upper parts pale yellowish brown, more or less glossed with purple; the wing-eoverts and scapulars stained towards the tips with coppery brown; the quills and tail-fcathers uniform pale yellowish brown, tinged with vinous, the tips of the lattcr paler. In another speeimen, shot at Maungakaramea, near Whangarei, and for which I was indebted to the late Mr. Henry Mair, tle neek, shoulders, back, upper tail-coverts, seapulars, and wing-coverts present scattered feathers of pure white, imparting to the plumage of the upper parts a spotted appearance. Botlı of these specimens are now in the Colonial Museum. A third example, in the possession of Mr. William Luxford, of Wellington, has the head, neek, sloulders, and upper wing-eoverts eoppery brown, and the rest of the upper parts pale grey; the primary quills tinged with brown at the tips; the underparts of the body white. Another in the Colonial Museum has the head, neck, breast, and upper parts gencrally pale vinous brown, without any gloss, and becoming darker on the inner webs of the quills and tail-feathers; the shoulders and smaller wing-coverts dark velvet-brown, fading off on the outer featliers, this dark pateh upon the lighter plumage forming a very conspieuous feature; bill and feet almost white. Another in my own collection, presented by Mr. W. Marshall, who obtained it in the Upper Rangitikei district, is very similar, but there is a larger admixture of brown in the general plumage, and the relvetbrown extends over the entire mantle but is relieved by a light feather here and there; the quills on their inner webs and all the tail-feathers except the middle one are rufous brown with pale tips. In eaeh wing two of the quills are entirely dark.

There is a very eurious examplc in the Auekland Museum (marked $q$ ) and obtained from the Waikato in June 1884:- The head, neck, breast, upper surfaee of wings and tail pale vinous brown, relieved by touches of creamy white; the lind neek shaded with darker brown with a very faint gloss; shoulders, mantle, and smaller wing-eoverts bright coppery brown, shaded with ashy brown, the eentral part of each feather being of that colour; this darker colour prevails on the seapulars, which are entirely dark brown with paler tips, delicately glossed with purple, and witl whitish shaft-lines; primaries and tail-feathers dark vinous brown on their inner vanes, and paler brown shading off into ereamy white on their outer; the larger wing-coverts pale vinous brown with whitish margins. Underparts pure white. Irides, bill, and feet as in the normal bird. The distinguishing feature is the bright coppery brown mantle, which is very conspieuous. The outcr tail-feathers are much abraded and worn.

Mr. Cheeseman showed me a very finely coloured specimen shot by himself in the neighbourhood of Auekland. In this bird all the colours were highly iridescent, even the tail-feathers having a fine edging of metallic blue *.

* Mr. T. W. Kirk gives the follorving description of another remarkable varicty shot by Mr. Greville in the Serenty-mile 
Differing again from all the foregoing is a partial albino obtained at Ngunguru and sent to me by Capt. Mair. In this bird the shonlders, baek, rump, and upper tail-eoverts have a riel appearanee, the white predominating. Some of the wing-feathers and their eoverts are wholly white, with bronzed edges and elouded with grey, while others again present the normal eoloration. The distribution of eolours, however, is quite irregular, the white largely predominating in the right wing.

In the Natural History Museum of the Jardin des Plantes there is a eurious variety, from the eolleetion of MM. Hombron aud Jaequinot, marked "Akaroa, $q . "$ In plaee of the bronzy green the general plumage is dark einnamon-brown, shaded with vinous brown on the smaller wing-eoverts; underparts white with a slight wash of cinnamon whieh is darker on the under tail-eoverts. The wing-feathers are uniform eimnamon-brown; so are the tail-feathers, but these are darker in their eentral portion and have whitish tips. Bill and feet yellow. This is, I believe, the type of Carpophaga spadicea leucophae of those naturalists. This was suggested by me in my former edition (p. 158), but I had not at that time examined andidentified the bird, as I have sinee done.

Remarks. The head is small, the neek of moderate length, and the body full, with a prominent and rounded breast; the primaries graduate upwards to the third and fourth, whieh are generally of equal length; the fifth is slightly shorter, and the rest are rapidly diminished; the seeondaries are broad and rounded; the tail-feathers large and eveu, forming together an ample fan when the tail is expanded. The plumage is thiek and eompaet, and eaeh feather is furnished with a dense undergrowth of downy plumules of extreme fineness, whieh branch laterally from both sides of the shaft. This peeuliarity is most fully developed in the long plumage of the baek, where only the tips of the feathers assume the surface eharaeter. By this wise provision of nature, the bird is perfeetly elothed in a thiek undereovering of soft down, and mueh warmth imparted to the body. The tarsus is eompletely eoneealed. On moving the lowest feathers, however, two broad seutella are exposed; on the middle toe there are 11 seutella, on the outer toe 10 , on the inner toe 7 , and on the hind toe 4.

On some speeimens, partieularly young birds, a fine white powder, like pulverized elialk, is observable on the feathers of the head and hiud neek. I notieed this in a very pronouneed degree, and extending to the baek, in a bird whieh I. shot on the Pirongia Range in the month of November-so mueh so as to leave a distinet ehalk-mark on any dark objeet brought into eontaet with it. It is evidently an emanation from the skin, and doubtless serves some useful purpose in the natural economy of the bird.

OF the large and well-defined group of fruit-eating Pigeons found dispersed over the sea-girt lands of the sonthern hemisphere, the single species inhabiting New Zealand is undoubtedly one of the finest both for size and brilliancy of plumage.

In its native country it is less esteemed for its beauty than for its value as an article of food; and to both Maoris and colonists, in every part of New Zealand, pigeon-shooting, at certain seasons of the year, affords agreeable recreation, while to many it is a source of profitable employment. Owing to the loud beating of its wings in its laboured flight it is readily found, even in the thickest part of the bush, and being naturally a stupid bird it is very easily shot; so that in a favourable locality it is not an unusual thing for a sportsman single-handed to bag fifty or more in the course of a morning. In some districts the slaughter has been so great during a productive season that the Pigeons have never afterwards recovered their numbers; but in most of our woods, notwithstanding this persistent persecution, they reappear in each successive year in undiminished plenty. 'The

Bush and presented by him to the Colonial Museum :- "Head, neek, and fore part of breast, whieh in ordinary speeimens are shining gold-green, are here thiekly strewn with white feathers. On the fore neek the eoppery purple band is replaced by a largo patch of pure white feathers. The nape, shoulder, and upper surface of wings are also thiekly strewn with white feathers; back and uropygium have likewise very white patehes, but getting fewer towards the latter portion. The bright green of tho breast is suecceded by a band of pale grey, which fudes as it approaehes the abdomen. Quills and tail-feathers normal eolour. In no instanee is a parti-eoloured feather to be found, the white feathers being pure; even the shafts are destitute of eolour. Eyes pink, with carmine-red as is usual; feet paler than eustomary; the soles flesh-colour rather than yellow; bill normal colour." (Trans. N.-Z. Inst. vol, xriii. p. 129.) 
"season" is indicated by the ripening of certain berries on which this species subsists; and the abundance of the birds is regulated to a great extent by that of the food-supply, whieh is more or less variable. A sporting gentleman pointed out to me a taraire grove at Ramarama, near Auckland, where in 1869 he found the Pigeons so numerous that he shot eighty-five in the course of two mornings; but in the following year, owing to the partial failure of the taraire berry, there was hardly one to be seen there.

It is to be met with on the Little Barrier, and more plentifully on the Hen and Chiekens, just before the large-leaved parapara (Pisonia umbellifera) has ripened its fruit. This bird seems to be fond of the green berries; and it is aceordingly very diffieult to obtain ripe seed of this valuable tree.

It is said to have made its first appearance at the Chatham Islands about the year 1855 . Be that as it may, it is now comparatively plentiful on all the islands of the group, and has been found breeding on Mangare.

In the spring and early summer it is generally very lean and unfit for the table; but as autumn advanees and its favourite berries ripen, it rapidly improves in condition, till it becomes extremely fat. It is esteemed most by epieures when feeding on the mast of the miro, which imparts a peculiar richness to the flesh. In January the berries of the kohutuhutu, poroporo, kaiwiria, puriri, mangiao, and tupakihi constitute its ordinary bill of fare. From February to April their place is supplied by those of the tawa, matai, kahikatea, mapdu, titoki, and maire. It is worth remarking that in localities where it happens to be feeding exclusively on the pulpy fruit of the kahikatea, it is not only in very poor eondition, but acquires a disagreeable flavour from the turpentine contained in the seeds. Towards the close of this period also, the ti-palm, which comes into full bearing only at intervals of three or four years, oceasionally supplies this bird with an abundant feast. These tropical-looking palms often form extensive groves in the open country or in swampy situations; and when the Pigeons resort to them they are speared and snared in great numbers by the Maoris, an expert hand sometimes taking as many as sixty in a single day. In May and June it feeds chiefly on the miro and pate, when it reaches its prime and is much sought after. From July to September it lives almost entirely on taraire in the north, and on hinau, koeka, ramarama, and other smaller berries in the south. During the months of Oetober, November, and December it is compelled to subsist in a great measure upon the green leaves of the kowhai (Sophora tetraptera), whauhi, and of several ereeping plants. It also feeds on the tender shoots of the puwha, a kind of sow-thistle; and the flesh then partakes of the bitterness of that plant. When the bird is feeding wholly on the dark berries of the whao the colour of its flesh is said to become affeeted by that of the food.

The Pigeon-season, however, is to some extent eontingent on locality ; for example, in the spring of $1863 \mathrm{I}$ found these birds in the Upper Manawatu living on kowhai-leaves, and so lean in body as to be scareely worth powder and shot, while in the low timbered flats under the ranges, where they were feeding on the ripe berries of the karaka (Corynocarpus lcevigata), they were in exeellent condition.

At the Rev. Mr. Chapman's old mission station at Te Ngae (Rotorua), formed in 1835, and now much out of repair and overgrown, there are several hundred acres of sweet-briars, run wild and presenting quite an impenetrable thicket. During the autumn months, when the red berries of the briars are fully ripe, large numbers of the Wood-Pigeon resort to these grounds to feed on this fruit, and at this season become exceedingly fat.

Captain Mair, who kept a winged bird in his possession for about eight months, informs me that it fed readily on boiled potato, riee, wheat, and berries of every kind, and that it ultimately died of sheer fatness. It eontinued shy and untamable to the last, and on being handled would strike fiercely with its wings. The late Dr. Allison, of Wanganui, however, succeeded in rearing a young one which became perfectly tame and associated with his domestic Pigeons. I may also mention 
here, as a somewhat curious fact, that at the Chatham Islands, in 1855, I observed one of these birds flying and consorting with a flock of common dove-cot Pigeons which had taken to the woods and become partially wild.

There is probably no New-Zealand bird that could be domesticated to greater advantage than this Pigeon. Some years ago a tame, healthy, and remarkably handsome one was exhibited at the Wellington Pigeon and Poultry Show, and carried off the palm against every competitor in that department. Another, which lived for many months in the Acclimatization Gardens at Christchurch, was shipped home to the Zoological Society, but did not long survive the change of climate.

The New-Zealand Pigeon is strictly arboreal, and appears, as a rule, to prefer the densest foliage. When not engaged in filling its capacious crop with fruit or berries, it generally reposes on a thick limb, with the tail drooping and half-spread, the wings closely folded, and the head drawn in; but on the slightest alarm it stretches up its lustrous neck, and gently sways its head to and fro, uttering a scarcely audible $c 00$, slowly repeated. It rises with an awkward flapping, and flies direct, with a rapid opening and closing of its wings, producing the sound so familiar to the gunner's ear. In the bush it generally flies low, but when settling it habitually makes a graceful upward sweep in its course.

Whell seen from the front its ample white breast is a very conspicuous object in the bush, and the woodcut at the end of this article (from one of my own sketches) will recall its showy appearance to those who are familiar with the bird in its native haunts.

I have remarked a peculiar soaring habit which this bird indulges in during the breeding-season. Mounting high in the air, in a direct upward course, it suddenly opens its wings and tail to their full extent, and glides slowly downwards in an oblique direction, and without any apparent movement of those members. I very frequently observed this peculiar soaring flight during my ascent of the Upper Wairoa river, north of Auckland, where the solitudes of the endless pine-forests afford this species a secure and quiet breeding-place.

On the wing the whiteness of the underparts is very conspicuous, owing to the manner in which the body is swayed from side to side.

This species retires to the high wooded lands of the interior to breed; and its nest is therefore seldom met with. It is a very rude, flat structure, composed of twigs loosely placed together, and containing generally only one, but sometimes two eggs. These are perfectly oval in form, measuring 1.9 inch in length by 1.4 in breadth; the surface is smooth without being glossy, and of the purest white. Mr. J. D. Enys informs me that on the 8 th of January, 1862, he found a nest containing: one egg perfectly fresh, on the 31st of the same month another containing a young Pigeon fully fledged, and on the 3rd of February, two more nests, in both of which there was a solitary halfgrown bird.

A nest in the Canterbury Museum (received from Milford Sound) consists merely of a layer of dry twigs, so loosely put together that the eggss are visible from beneath.

There is another nest, from Little River (April 1873), which forms a very pretty object. It is placed on the lateral fork of a branch of totara, supported underneath by an epiphytic growth of native mistletoe (Loranthus micranthus), which, although dried, still retains its leaves. The nest (which contains a single egg) is very slight, and admits the light through its foundations, being formed of slender dry twigs of Leptospermum laid across each other and forming a shallow depression, with the ends of the twigs projecting all round. Slight as the structure is, however, there is some appearance of finish about it.

In the Rev. Mr. Spencer's fine old garden at Tarawera, where well-grown specimens of English oak, elm, and wahnut mingle in rich profusion with almost every kind of native tree and shrub, a pair of these birds some time ago took up their abode and bred for two successive years, at a spot 
not fifty feet from the reverend pastor's study windows. And they would doubtless have continued to breed in this quiet retreat had not one of the Maori school-boys, anxious to try his forwling-piece and wholly unmindful of the consequences, shot both birds during the brecding-season, leaving a pair of callow young to perish miserably in their nest.

Some colonists arc of opinion that this fine Pigeon is less plentiful than it was formerly; but I do not think there is much fear of its becoming extinct so long as the native forests remain.

Its relative abundance may be inferred from the fact that in July and August 1882, Rawiri Kahia and his people snared no less than eight thousand of them in a single strip of miro bush, about two miles in extent by half a mile in width, at Opawa, near Lake Taupo. The birds thus snared are preserved in their own fat and potted as "huahua kcreru." Food of this kind is estcemed a great delicacy and elaborately carved lumetes are sometimes used for serving it at the tribal feasts.

Notwithstanding its uncertain seasonal movements, there is perhaps no bird so characteristic of the native woods, for, at one time or another, it is met with everywhere. But there are certain tracks of forest which the Pigeon specially affects, the preference being of coursc due to the predominance of particular fruit-bearing trees. One of these favourite districts is the extensive forest track known as the "Forty-mile Bush," lying between the townships of Masterton and Woodville, and extending thence eastward towards Napier under the name of the "Seventy-mile Bush." A good macadamized road passes through this bush-land, a great portion of which is perfectly level; and perlaps in no part of New Zealand can the transcendent beauty of the native woods be seen to greater advantage. Coming from the Wairarapa side, you first of all pass through some magnificent clumps of rimu, many hundreds of acres in extent, with just a sufficient admixture of kahikatea and rata to set off the peculiar softness of the former, with its "fountain of foliage" and its uniform tint of yellowish green, the young trees gracefully drooping their tasselled branchlets of still paler green. Then, fringing the road on the upper or hill-side, for miles together are glorions beds of Lomaria procera, their fronds from three to five fect long, on gracefully pendent stalks, and so closely set that a wholc regiment of soldiers might lie in ambush therc; then a sudden turn in the road brings you into dense bush again, with its ever-varying shades of green and yellow and brown, blended together in one picturesque and harmonious whole. The tree-fern with its sprcading crown is always present-the shapely form of Cyathea dealbata with its large umbrella top, the taller Cyathea medullaris rcaring its head some forty feet or more, and Dicksonia antarctica on its massive stem hung round with a brown garment of withcred fronds-the lofty dark green rewarewa and brighter kohekohe mingle with the titoki and miro, and the tawa with its light green foliage stands out in bold relief against a dark background of kahikatca trees standing close together. Then you come upon an old Maori clearing abutting on the road, presenting a tangle of new-grown shrubs and saplings, close and compact, and all of the freshest green; and from the very midst of this there rises, like a silent monitor with its bleached arms pointing heavenward, a former monarch of the forest, long since dead and withered and now decaying slowly under the crunbling hand of time, but bearing on its lower forks hugc bunches of green Astelia, and quite hidden at its base by a luxuriant growth of underwood. In the more recent openings in the bush the trunks of the trees may be seen laden with tons of climbing plants and epiplyytic vegetation of various kinds-the kiekie with its hydra-headed branches of waving tufts, the alialiura and the waxy Metrosideros-and the ground below them covered with ferns and mosses and cryptogams in amazing variety. And so, on and on, through endless changes of timber-growths and woodland scenery, as the coach rattles along the road, disclosing new beauties at every turn-now through a river-bottom filled with close-growing kahikatea, then over a ridge covered with Fagus, dark and sombre; now past a wide opcning caused years since by the ravages of fire or flood and overgrown with the red-stemmed mako, the native myrtle, and a hundred other less conspicuous shrubs, bound and matted together by masses of tataramoa or covered 
with a spreading network of pohuehue; then entering again a stretch of what is known as "mixed bush," where all kinds of New-Zealand trees and shrubs and ferns are crowded together in harmonious confusion, presenting a study to which no pen, however gifted, could do adequate justice. As you gaze upon this sylvan picture you are forced to admit that there is nothing in the world more beautiful!

As we approach the river-banks, the low bushes are covered with a thick mantle of convolvulus, closcly studded or spangled with the pure white flowers, like innumerable luminous stars on a cloth of vivid green; and the tree night-shade (Solcmum nigrum) grows in wild luxuriance, its pale blue bells having a pretty effect against the sombre foliage.

But the principal charm of these woods is the rapid change in their aspect as one season succeeds another. In the autumn months, when the berries of various trees have ripened, they are swarming with Pigeons, cspecially in the more fruitful seasons which occur at intervals of two or three years. In the winter they are desertcd, and you may travel for a wholc day without secing or hearing a bird of any kind, except those that commonly frequent the road. But this lifcless season is of short duration, and is followed by the gladness of the early spring-timc. The whole bush is then decked out with the beautiful star-like Clematis, hanging in garlands round the trees, festooned in clumps among the lower vegetation along the open roadside, and displaying its petals of snowy white in great profusion. The pukapuka, which is abundant everywhere, supports on its poisonous stems a crown of creamy blossoms in clusters so thick as quite to conceal the leafy top; the kowhai, having shed its leaves, is transformed into a glory of golden yellow, each branchlet bending under a cluster of horn-shaped flowers of uniform pale yellow with a green peduncle.

Visit these woods again at the commencement of summer and the whole scene has changed. The hanging festoons of Clematis have disappeared and in their place may be seen bunches of green silky tasscls, containing the seed-vessels of this plant and possessing a characteristic beauty of their own; and underneath the golden kowhai trecs the ground is carpeted with fallen petals. But the crowns of Cordyline arc now bearing, in rich plenty, their drooping branchlets of fragrant flowers; the tawhero, of which the lowcr forest is largely composed, is covered with bottle-brush flowers of delicate waxy white; the miro is one mass of whitish inflorescence, intermixcd with the pale green foliage of that trce; whilst clinging to the underwood and hanging from almost every branch the kohia creeper exhibits its minute pearly bells in rank profusion. Then every here and thcre may be seen, placed high up in some sturdy fork, a bunch of Loranthus ablaze with its crimson flowers and forming a picturesque object amidst its green surroundings. The rata, or Christmas-flower, as it is called, is just making its appearance; here and there a vigorous young tree in advance of the rest has swathed itself in colour, but for the most part the only indication at prescnt is a crimson blush on some of the branches. Before the ides of Decembcr have passed these noble rata trecs will bc enveloped in a mantle of ficry red. But the whole woodland alrcady seems abloom and the air is laden with a faint but pleasant perfume. As a consequence of this, and the abundance of insect life which it betokens, the bush is again alive with Tuis and other birds.

We rest for awhile in a lovely wooded valley which is illumincd by the bright afternoon sun and exhibits some wonderful effects of light and shade. 'The road lies before us, straight as an arrow, through a wooded vista nearly two miles in length; fringing it, where we stand, is a grove of the beautiful silver-lcaved Pittosporum, with shapely tops as if specially trained for some ornamental garden; bcyond this a clump of its broad-leaved cousin (Pittosporum undulatum) closely comminglcd with the ramarama and niany other stately shrubs, whilst in the shaded hollow bclow us are some splendid spccimens of the native fuchsia, attaining to the size of veritable trccs, some having trunks two feet in diameter and branches laden with moss; then behind comes the low forest all abloom as describcd, and beyond that, far and away, the rolling "forest primeval " of rimu and rata and kali- 
katea. To add to the enchantment of the spot, there is a whole choir of singing Tuis, who, having regaled themselves among the flowers, are now piping and sobbing in chorus; a wandering flock of Zosterops, quite concealed from view, are warbling a low, pathetic lay; a solitary Warauroa from a lofty tree-top emits his plaintive call, with none to answer; and heedless of all the rest a tiny Riroriro, hiding in a bramble-bush, trills its silvery note with untiring energy. Then, as we move forward, a Parrakeet, startled by our approach, rises from the low underwond with laboured and zigzag flight and settling on a branch near the roadside adds its lively chatter to the other sounds of this sylvan valley. As the sun goes down and the shades of evening advance all these voices are silenced; but the Tui continues still to flit across our path, and the Flycatcher to display its pretty fan as it hawks for invisible flies. Then comes the scream of the Kaka as it wings its distant way high above the tree-tops; after which, with scarcely a moment of twilight between, the woods are plunged in gloom, the Owl comes out from its hiding-place, and the glow-worms shine on the damp roadside.

Such is the New-Zealand bush, replete, as it is, with a flora entirely its own-charmingly green in summer and winter alike-the pride and glory of the land and the natural home of the birds whose life-history I hare endearoured to portray in the foregoing pages.

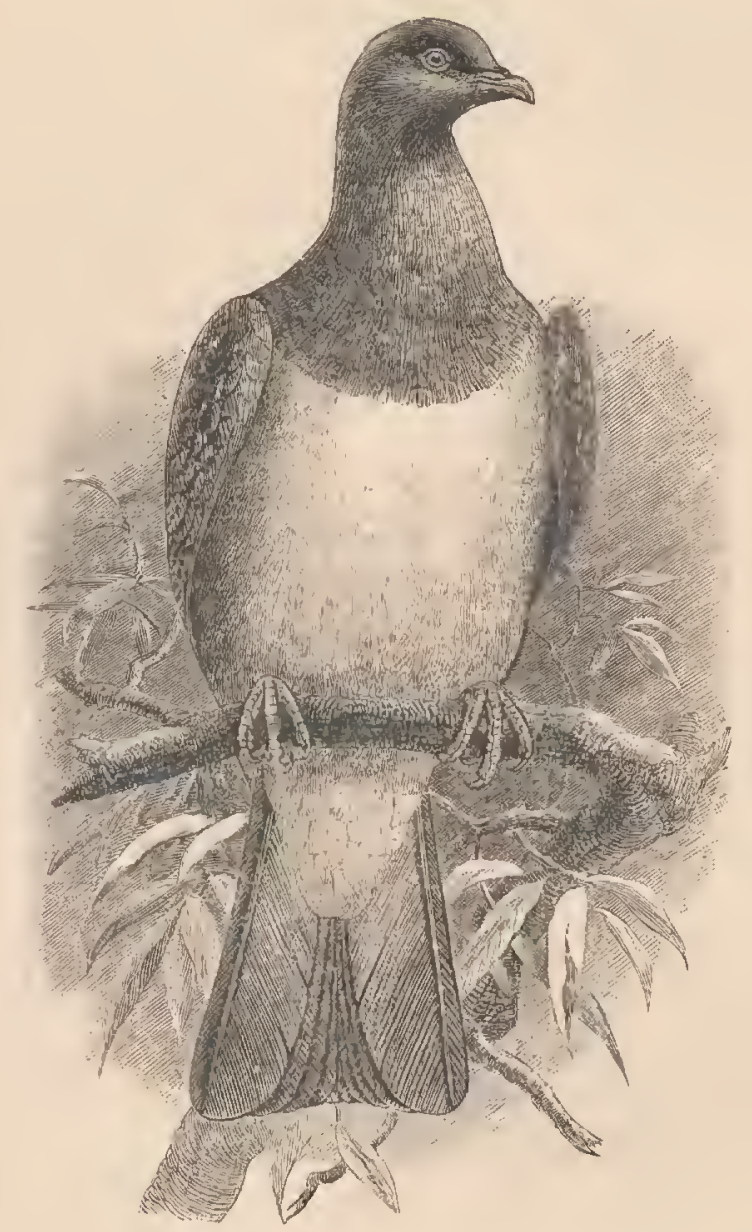




\title{
SUPPLEMENTARY NOTES
}

\author{
TO THE
}

\section{'BIRDS OF NEW ZEALA N D.'}

\author{
VOL. I.
}

TIIE following additional notes on some of the Families treated of in the present volume may be of interest to the general reader.

Fam. CORVIDEE.-The only representative of this family in New Zealand belongs to the somewhat aberrant genus Glaucopis. At page 4, in my account of G. wilsoni, I have stated my reasons for placing this form at the head of the New-Zealand Avifauna; and at p. $30 \mathrm{I}$ have given the result of Dr. Gadow's careful examination of a skeleton which I had submitted to him.

Fam. TURNAGRID正.-At pp. 26-30 I have given what may be considered the final record of the North-Island Piopio, a species now on the verge of extinction. Its South-Island representative (Turnagra crassirostris) is still to be met with in certain wooded districts, but in rapidly diminishing numbers, and, with other interesting forms that still linger, its doom is sealed.

As recently as December 1887 last one of my New-Zealand correspondents, writing to me from the west coast, says :- "Since I came here I have formed the acquaintance of several old gold-diggers, from whom I have gathered much information on the haunts and habits of many of the species. All of them agree that certain birds are disappearing fast, viz. the Crow, the Saddle-back, the Thrush, the Robin, the Kakapo, the Woodhen, and the Kiwi. Fifteen years ago all these birds existed here in abundance. Every digger keeps a gun and a dog, besides, as a rule, having one or more cats in their huts. All the birds I have mentioned, either from their tameness, their incapacity for flight, or their habit of feeding on the ground, would fall an easy prey to dogs and cats, both of which animals often stray away from the diggers' camp and become wild. Man also contributes to the work of wholesale destruction. Last Sunday I dined on stewed Kiwi at the hut of a lonely gold-digger, who, besides the three cooked for dinner, had four other fat Kiwis hanging on the wall, to serve through the week. My host informed me that he varied his bill of fare with Wekas and Kakapos. These men lead lonely 
lives in the bush, and only emerge once in a week or fortnight to get stores from some central point whither the trader brings them on a pack-horse. The well-trained dog of the gold-digger is perhaps the most destructive agent as regards the Kalsapo and Kiwi. The felling and clearing of forests and the consequent diminution in the supply of honcy-producing flowcrs will account to some extent for the present scarcity of the Bell-bird and the Tui. But, as you have already pointed out, the chief factor in this work of extermination is no doubt the introduced rat, which now exists in immense numbers over the whole extent of the west coast, from the gold-diggers' townships to the remote bushcovered ranges. Added to all thcse potent causes, I have no doubt that, owing to the changed conditions under which they exist, and the more scanty supply of food, disease in various forms contributes to the general sum of destruction."

Fam. STURNIDE.-The Saddlc-back (Creadion carunculatus), which was extremely common in all suitable localities fifteen to twenty years ago, has now disappeared from the North Island, and is becoming scarce in the South, although both this and the allied species (C. cinereus) are still plentiful on certain small islands in the Hauraki Gulf. Profcssor Hutton was the first to discover the nest of this bird on the Little Barrier Island, where he found it lodged in the hollow stem of a tree-fern.

The accompanying figure appeared in the 'Transactions of the New-Zealand Institute' (vol. v. pl. 17), together with the following descriptive notes by Mr. Potts:-

"For its nesting-plaecs a hollow or decayed tree is usually sclected; sometimes the top of a tree-fern is preferred. The first nest wo knew of was found by an old friend in a hole about four feet from the ground in a hugo white pine (Poclocarpus dacrydioides), elose to the bank of the Ahaura river; it contained three cggs hard-set. We found a nest in a dead tree-fern not far from Lake Mapourika, Westland. This was of slight eonstruction, built principally of fern-roots, deftly woven into rather a deepshaped nest with thin walls; for as the structuro just filled the hollow top of the tree-fern thick walls were unneccssary. Another nest (the one figurcd), found in a small-sizod dceayed trec in tho Okarito bush, was in a hole not more than three feet from the ground. It was roughly eonstructed, principally of fibres and midribs of deeayed leares of the kiekie (Wreycinetive banksii), with a few tufts of moss, leaves of rimu, lined with moss and dowu of tree-ferns; it measurcd across from outsidu to outside of wall 12 inches 6 lines, the cavity 3 inehes in diameter with a depth of 2 inehes."

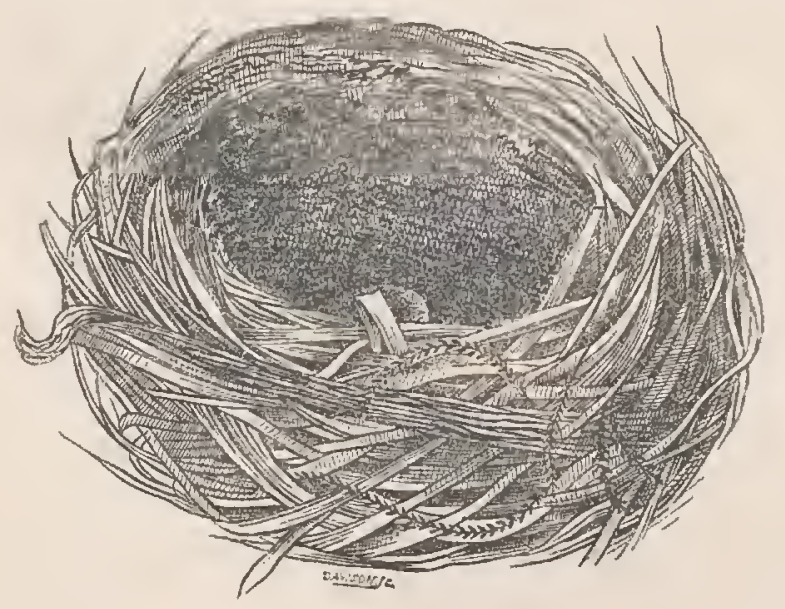

Fam. SYLVIID无.-When I was engaged on my former edition, Mr. T. H. Petts sent me a large series of pen-and-ink sketches of nests which he had collected at various times, all executed by himself and exhibiting the characteristics of each in a very happy manner. These were afterwards published in illustration of that gentleman's "Notes on the breeding-habits of New-Zealand Birds," 
which appeared from time to time in the 'Transactions of the New-Zealand Institute.' But as some of the original sketches are still in my possession, I have much pleasure in reproducing them here, on a somewhat reduced scale. One of the most interesting of these is a representation of the nest of the South-Island Robin (Miro australis), which differs from the typical form in its more slender walls and thinner foundation. Mr. Potts, who has collected a large number of these nests, says :"Its nest is wider and larger altogether than that of Myiomoira macrocephala, but not so closely interwoven; moss, sprays, leaves, fine fibres, and grass enter into its construction. Diameter of nest from 5 to 6 inches, of the cavity 3 inches, with a depth of 1 inch 3 lines. A favourite situation appears to be behind such protuberances as are to be found on the huge gnarled trunks of Griselinia litoralis, very often not more than 3 feet from the ground."

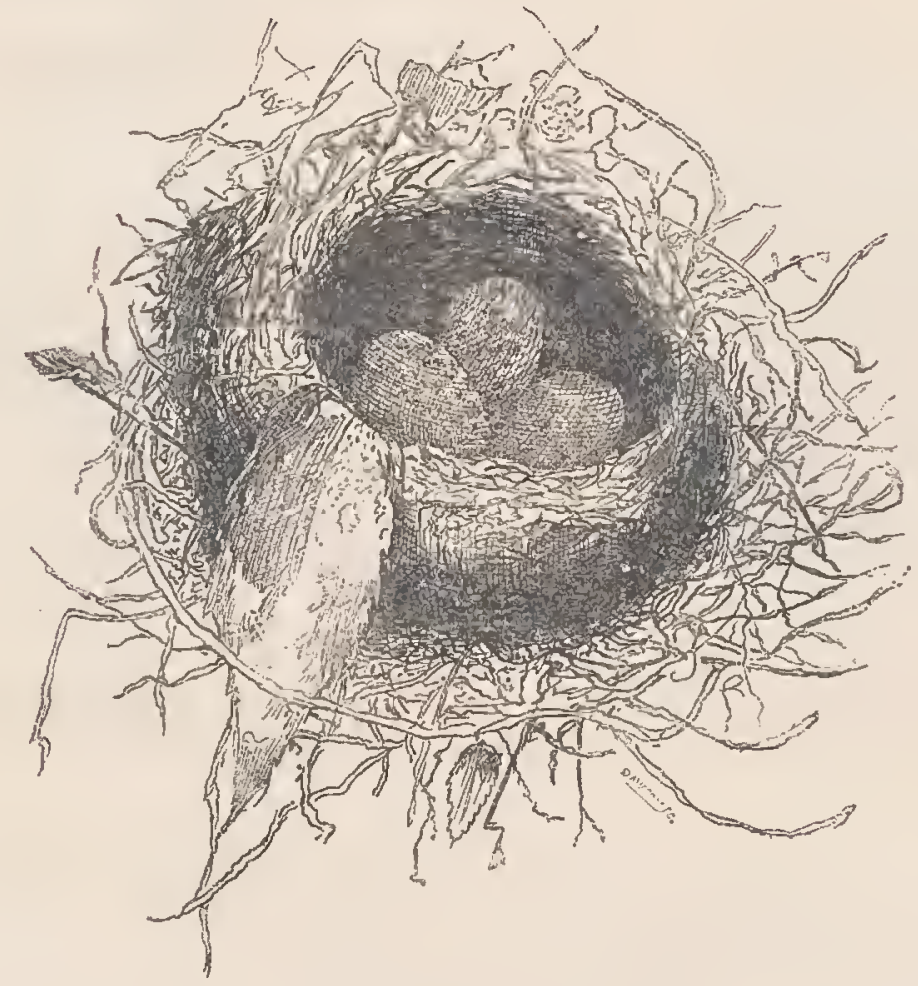

The South Tomtit (Myiomoira macrocephala) is somewhat eccentric in its mode of nidification. Among the sketches mentioned above there are representations of four of the nests of this species from one locality, near Ohinitahi, and as they exhibit very different types of architecture I have given woodcuts of all of them.

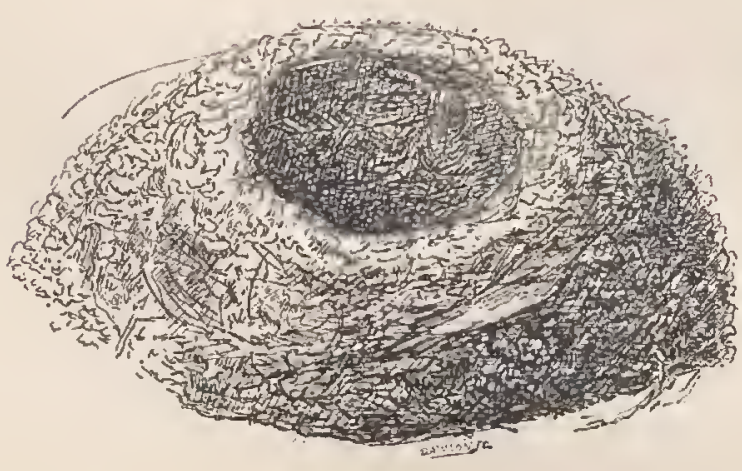

Fig. 1.

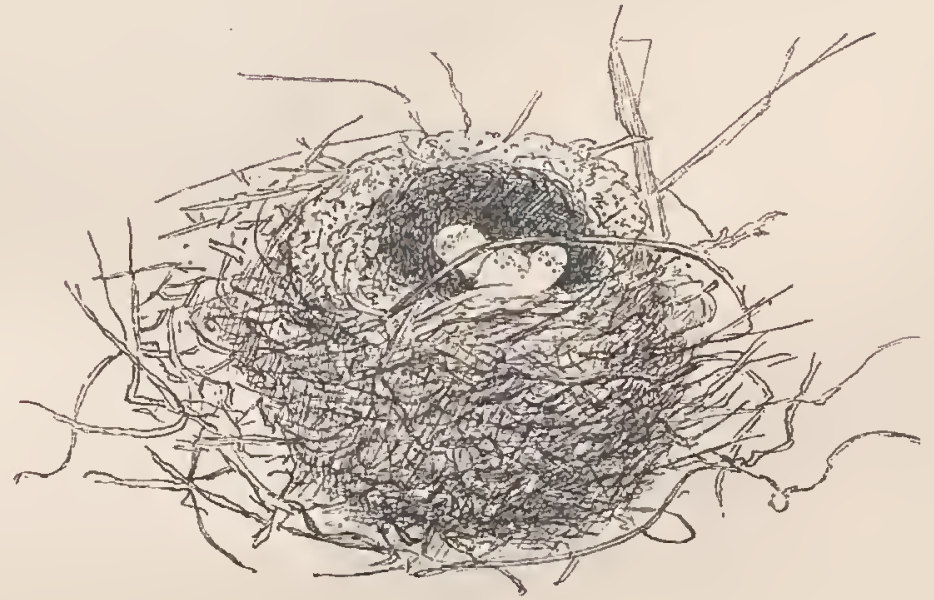

Fig. 2. 
No. 1 was built of dry sprigs of climbing-plants intermixed with grass-bents and strengthened by means of split shreds of ti-palm leaf, the cavity being lined, as usual, with soft moss. This structure, which appeared to be more loosely put together than usual, was discovered in the head of a ti-palm and contained, in addition to two unfledged young birds, three bad eggs. No. 2 was composed almost entirely of dry moss with a few slender strips of bark fixed to the outer surface, in order to give it stability, and in the lining of the cup could be seen a few green Parrakeet feathers. This nest was placed in a mossy recess on a rocky ledge in thick bush, and when found contained four eggs.

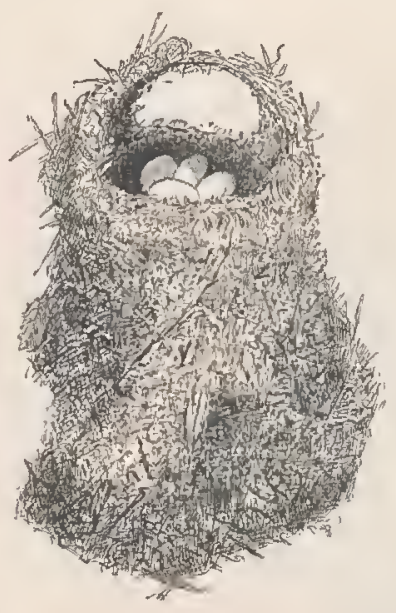

Fig. 3.

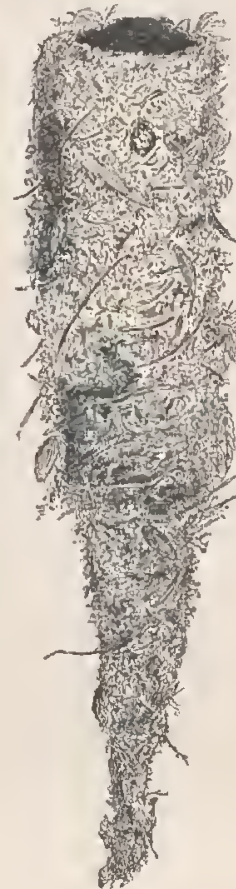

Fig. 4.

Figures 3 and 4 represent very unusual forms - one of them having an exact resemblance to a mossbasket, with a profusion of tree-fern down in the centre and cavity; the other being of a long tapering form and measuring fully fifteen inches in length from the rim of the cup to the lower extremity of the nest.

I have given, at page 48 , some pocket-book sketches showing a considerable amount of variation in the nests of Gerygone flaviventris. The following are further illustrations of the kind, the one exhibiting a side view being ornamented with Accena-burrs.
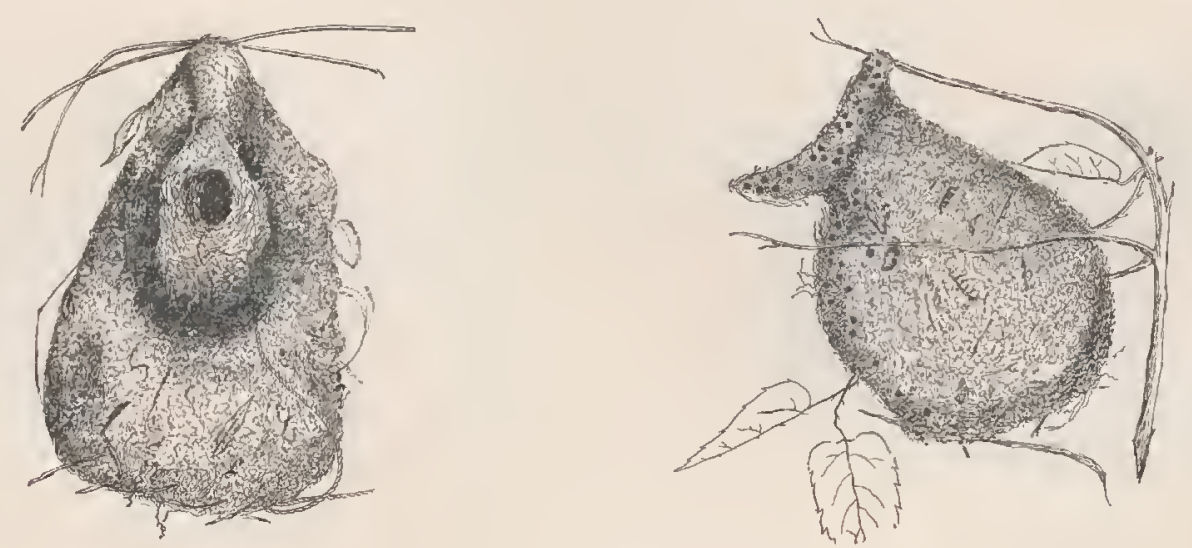
At p. $50 \mathrm{I}$ have stated my reasons for giving Gerygone sylvestris (erroneonsly referred to in the first paragraph of that article as G. flaviventris) a place among the birds of New Zealand, although, so far as is known, no specimen of it exists. Mr. Potts, who described the species under that name, seems very positive that the bird which he killed in the dense bush between Okarito and Lake Mapourika was quite distinct from our common species; and Mr. Reischek's report of a small bird on the west coast whose notes he could hear, although he could not see it, may perhaps be confirmatory of its existence.

Fam. TIMELIID卌-I have given, at page 58, my reasons for insisting on the association of Clitonyx albicapilla and C. ochrocephala in one and the same genus. The subjoined woodcuts of the nests show very plainly that the architecture of both species is the same.

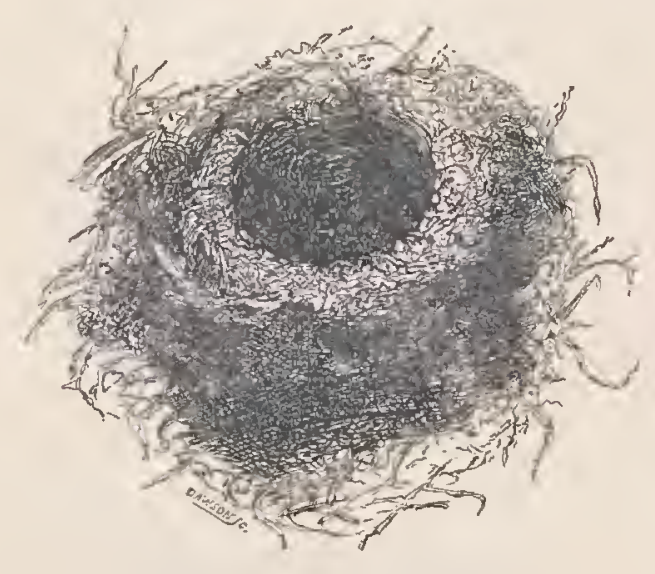

Clitonyix albicapilla.

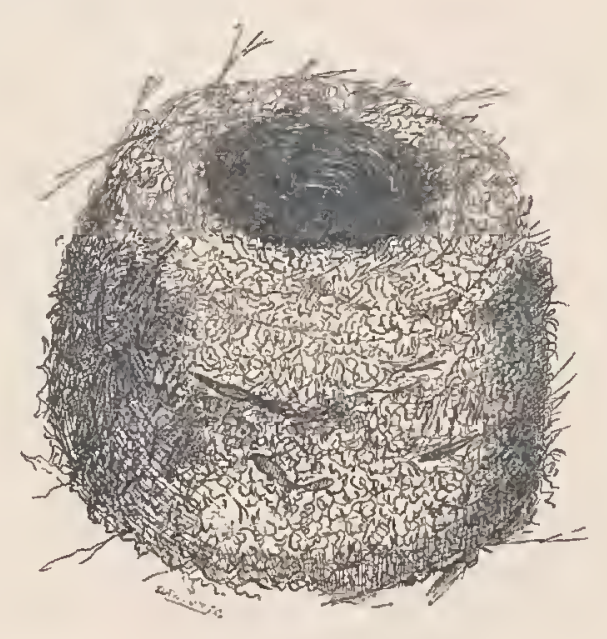

Clitony ochrocephala.

As already stated at p. 60, the Grass-bird (Sphenoeacus punctatus) attaches its slender nest to thin reed-stems standing in close proximity to each other, but it is sometimes placed on the ground under shelter of a tussock or tuft of rushes. One of the latter kind (formed entirely of dried grassleaves) is here depicted.

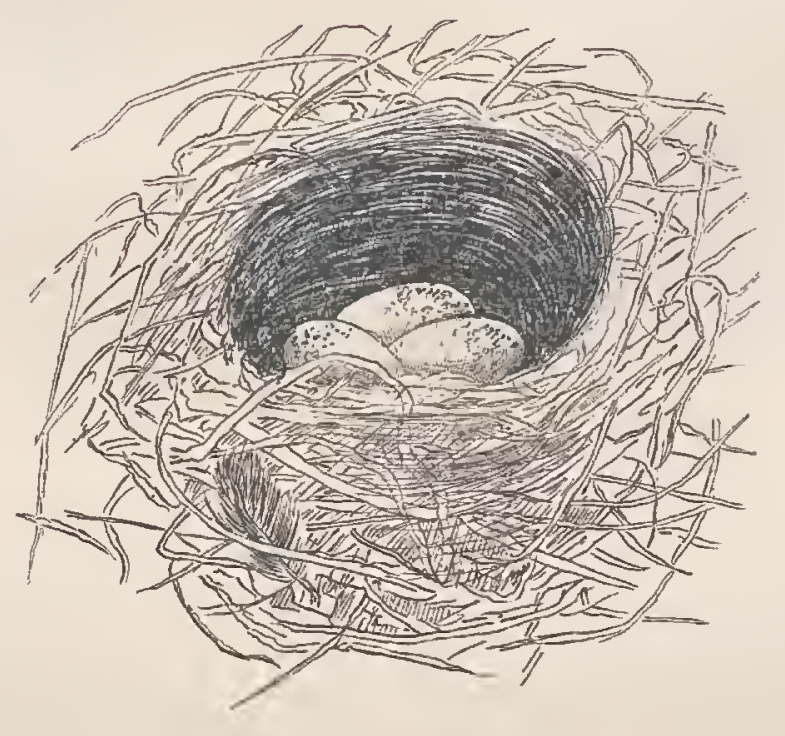


Fam. MELIPHAGIDE.-Mr. T. Hunt, who has lived on Pitt Island for more than thirty years, in a letter to the press dated the 5th of September last, states that the Zosterops (to which he applies the name of Fish-eye) appeared there and on Chatham Island about three weeks after the great Australian fire known in local history as Black Thursday *.

As fully explained at pp. 83, 84, the nests of this species exhibit a considerable amount of individual variation, but the typical character is always the same, and this is well illustrated in the subjoined drawing of one of these pensile cups fixed in a sprig of fern.

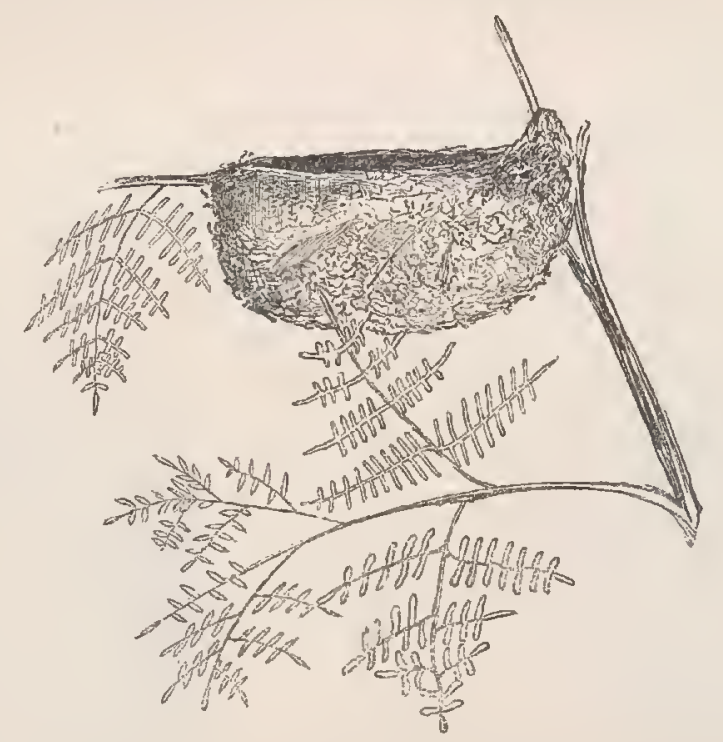

As will be seen from the accompanying sketches, the Tui and the Korimako construct their nests on the same principle; but the fondness for gaily coloured feathers (as specially mentioned at p. 9i) is confined to the latter bird.
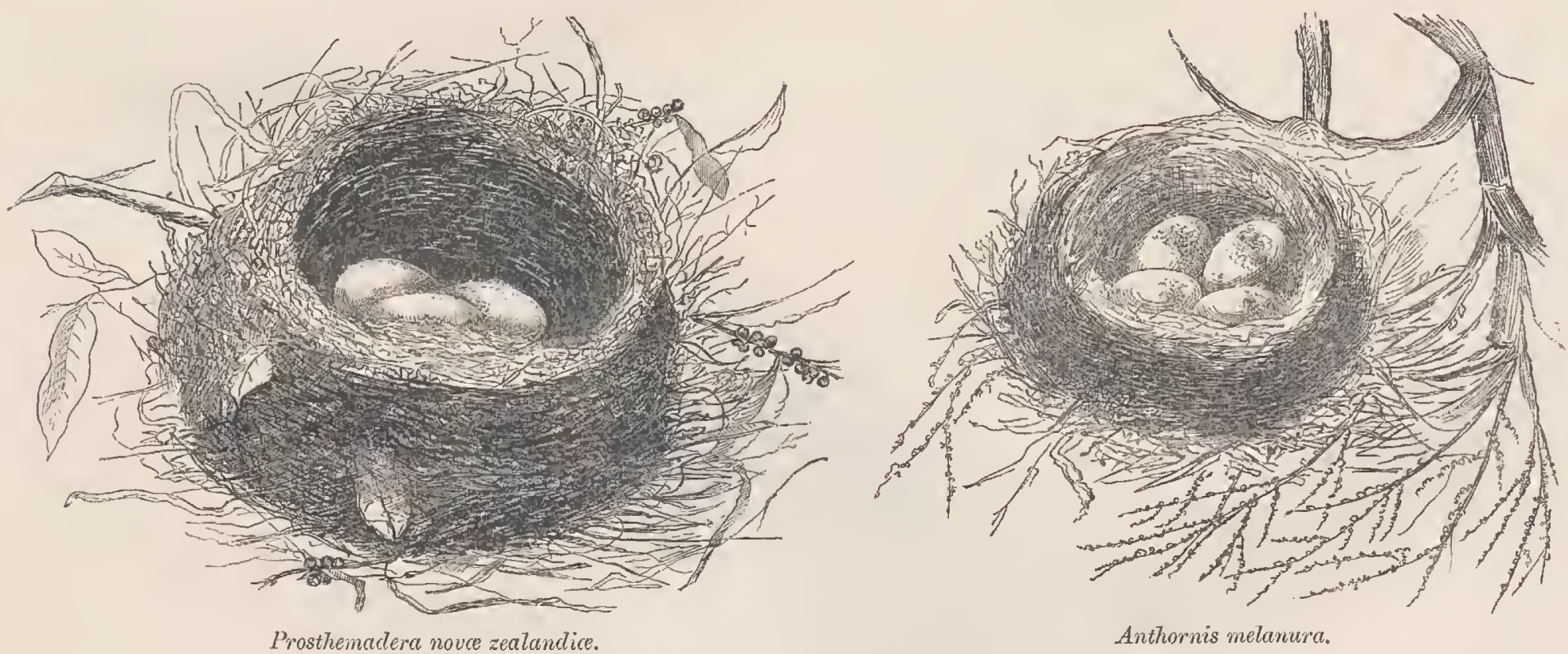

The Stitch-bird (Pogonornis cincta), which less than fifteen years ago was comparatively plentiful

* He mentions the further eireumstanee that the Honse-Sparrow, the Linnet, and the Blackbird have all come orer to the Chatham Islands from New Zealand (a distance of 300 miles) and are now so numerous as to threaten to become a nuisanee to the agriculturist. 
in the southern portions of the North Island, is now quite extinct on the mainland, being met with only on a small wooded island in the Hauraki Gulf. As stated at p. 105, a nest of this species is prescrved in the Colonial Museum; and I have much plcasure in reproducing here a sketcle of this specimen which appearcd in the 'Transactions of the New-Zealand Institute' (vol. iii. pl. 12).

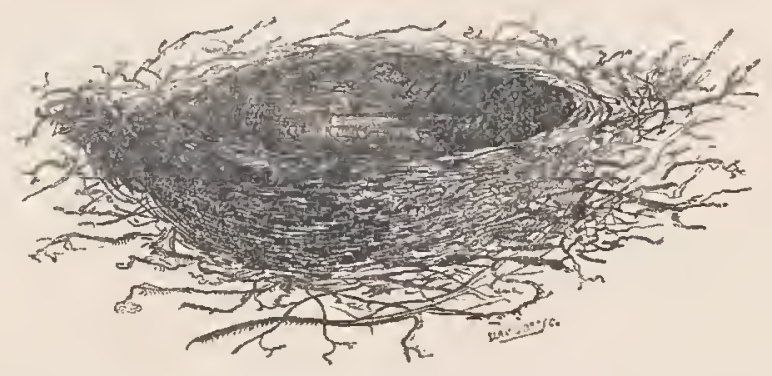

Fam. XENICID正.-The recent discorery of the true relations of the New-Zealand gencra Xenicus and Acanthidositta is extrcmely interesting from a biological point of view; and my own belicf is that as we become better acquainted witl the anatomy or internal organs of our many cndemic forms other equally important alterations will require to be madc in our present classification of the gcnera. In my account of Xenicus longipes I have given all the information I have been able to collect respecting it. I have shown, I think, conclusively that Xenicus stokesii is a myth, the creation of this ncw species having been due to an erroneous figure. In company with the late Mr. G. R. Gray, I examined the original drawing at the British Museum, in which I found the bill dcpicted as straight, and a mere indication given of the white superciliary streak. Mr. Gray told me that his artist was responsible for the alterations in the published figure, and that his own description of the spccics was inadvertently taken from the lattcr.

The nest of Xenicus gilviventris mentioned at page 112 is now in my collection, and on account of its extreme rarity I have had it photographed and carefully drawn for reproduction here; but, being to a larger scale than the other woodcuts, I have placed it at thc end of these 'Notes on page 250 .

At page 115 I harc described some peculiar conclitions under which the nest of Acanthidositta chloris has been found at different times. By way of adding another curious instance, Mr. W. W. Smith has sent me the following note:- "I latcly procured an egg of A. chloris under peculiar circuinstances. Onc of the men in the garden, when moving somc broken pipes formerly belonging to the hot-water apparatus in the vinery, noticed a nest in one of them. Thinking it to be the nest of a mouse, he tore it out, when the tiny egg dropped upon the ground, but escaped injury. I am sending you the specimen, together with the materials composing the nest."

Fam. PLATYCERCIDÆE.-As will be secn at page 149, an interesting addition has been made to our Avifanna by the rediscovery on Antipodes Island of Platycercus unicolor, a species hitherto without any known habitat. The unique specimen upon which $\mathrm{Mr}$. Vigors founded the species was more than half a century ago living in the Zoological Society's Menagerie at Regent's Park. On the 11th January, 1831, the abovc-named naturalist exhibited the bird at a Meeting of the Society and made some remarks upon it, stating that, although its native place bad not becn ascertained, "from the more graduated form of the tail and the plumbeons colour of the bill it was conjectured to have belonged to some of the Australian islands, the Parrakeets of which are distinguished by these 
characters from the allied groups of the same genus, Platycercus, of the Australian continent." 'The lively and active gait of this bird, as distinguished from the slow and climbing motions of the Parrots, was particularly noticed*. On the death of this rarity it was skilfully mounted and placed in the bird-gallery at the British Museum, where it has remained to the present day. Its bill is conspicuously larger than in the specimens recently brought by Captain Fairchild from Antipodes Island, but this was doubtless due to its having been kept for a long time in confinement. In other respects it corresponds exactly with the specimen forwarded to me by Sir James Hector, and which I have had the pleasure of presenting to the Cambridge Museum. The discovery of the home of Platycercus unicolor, after so long a lapse of time, is just one of those events in Ornithology that serve to stimulate and reward the labours of our naturalists abroad.

The subjoined figures of the heads (natural size) of Platycercus novce zealandice (fig. 1) and P. unicolor (fig. 2) will show, at a glance, how much these species differ from each other in size; whilst the uniform green plumage of the latter readily distinguishes it from all other members of the group. Fig. 2 is taken from the British Museum specimen, in which the bill is rather larger than in mine, owing perhaps to the long captivity of the bird, and the consequent tendency to abnormal growth.

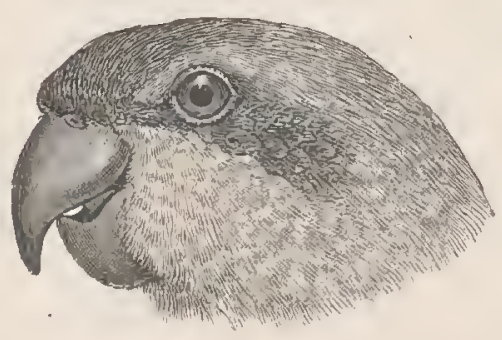

Fig. 1.

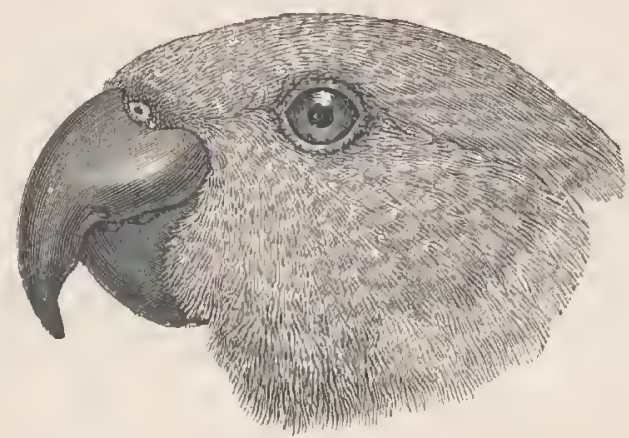

Fig. 2.

I stated at page 149, on the authority of Sir George Grey, that the northern Maoris have a tradition of some very remarkable kind of Parrot as inhabiting Cuvier Island, a high wooded islet near the entrance to the Hauraki Gulf. It may be of interest to mention that this locality has very recently been thoroughly explored by Mr. Adams, a collector employed by the Auckland Museum, and that, although he met with the common New-Zealand Parrakeet and several other familiar species, he found no strange birds there.

Fam. NESTORID\&E.-It will be seen that I have given a full account of the Kea, or Sheepkilling Parrot, with a history of its development into a carnivorous bird. The extraordinary habit which it has so speedily acquired of attacking live sheep, for the purpose of feasting on the kidney-fat, has been the subject of much discussion among naturalists $\uparrow$. By its addiction to this vicious habit

* Proc. Zool. Sor. 1830-32, pp. 23, 24.

† At the Colonial and Indian Exhibition, 1886, a painting in oils of considerable merit was exhibited by ILr. George Sheriff, of Wanganui, showing a pair of Keas at work on a sheep; but the artist has made the mistake of substituting a dead animal for a live one, thus falsifying the record in its most essential feature. As mentioned at p. 170, a pen-and-ink skotch by Mr. Potts in 'Out in the Open ' represents the incident correctly in this respect, but the figure of the animal opcrated upon is devoid of all expression, just as if the sheep submitted to the viviscotion as a matter of eourse or treated the whole thing as a joke. A largo drawing in my possession, from the talented pencil of $\mathrm{Mr}$. J. Wolf, gives an admirable idea of the subjeet. The sccne selected is the gorge of the Rangitata, under moonlight, showing the far-off snow-capped peaks of the Southern Alps, flanked by enormous 
the bird is doomed, and at the present rate of destruction a few years at most will witness its extermination. For this reason, if for no other, it was incumbent on me as its historian to give the fullest possible account of its natural history.

Mr. Walter Chamberlain, of Harborne Hall, Birmingham, in an interesting paper read before the Largo Field-Naturalists' Society last year, makes the following observations on this remarkable Parrot:-

"Between 1865 and 1870 the shepherds who were pushing their flocks in the south further and further up the slopes of the central range began to complain that the Kéas visited their huts and ate the hanging meat, more particularly the kidneys and fat. Here, then, we have the first evidence of the pernicious and, to them, fatal taste for kidneys which has since so rapidly dereloped. They found the meat hanging with the kidneys in situ. They took a special liking to the latter and sought for them high and low, all tho more zealously no donbt that the shepherds took eounter precautions to prescrve tho delicacies for thomselves. It is most likely that they soon began to find and tear open with their strong bills the sheep that died among the hills, and were thrs guided by degrees to tho actual seat of the kidner's in the living animals and the readiest way of approaehing them. At any rate, about the year 1875, the first sheep-still in the far south-were found wounded just over the loins. There was much puzzling over these wounds, and not unnaturally they were at first ascribed to wild dogs, that is dogs run wild; but at last all doubts were set at rest by a shepherd actuilly catching a bird on the back of a live sheep haeking at its loius in order to reach the kidneys. Gradually sinco then the habit has travelled northwards, until only in I885 the first shcep was attaeked in the Rakaia district, not very far south of the extreme northern range, as at present kuown, of the species. Iu the meantime the southern birds that had already learnt the triek, commenced to follow the floeks lower down during the winter, and to carry on their devastations more systematically. . . . . . Now, this sudden accuisition of an altogether strange habit by birds in a state of uature is, I think, absolutely unique, and it is certaiuly a case of great interest to naturalists everywhere as well as to New Zealand run-holders. I cannot call to mind any instance that I have heard or read of which at all runs parallel with it. New habits when they are aequired by species in a natural state have always hitherto, so far as I know, been very slowly developed, aud the habit itself, as a rule, is little more than a modification of some previous one performed by instinct, as for instance the painfully a equired experience which teaches wild creatures to aroid a new form of danger, or the easily made experiments which teach them that some erop nowly grown by man near their haunts is suitablo for food as it stands.

"Consider for a moment tho sequence of events and the extraordinary change of habit involved to the parrot. Between 1865 and 1870 the Kéa first comes in contant with the shepherd, and commencos to steal his moat with a marked preference for the kidneys. This is natural enough, and any other parrot with a tendeney to animal food might do the same, but here the matter would ordinarily rest. The shepherds would protect their meat, and the parrots would return to their usual food. Not so with the Kéas. Between fire and ten years later they havo found out not only that kidneys are somewhere inside living sheep, but whereabouts inside and the nearest point on the back from which to reach them. A few years more and they have learnt further, not only that sheep are incapable of defeuce and unable to hurt their aggressors, but that they are singularly stupid animals, and may be redueed to a still further state of impotence by the simple expedient of worrying, and, moreover, they have workerl out a plan of thus worrying the shcep by combining together and attacking the nnfortunate aninals one after another in succession.

"In the first part of these notes I have stated that I see no reason to rate the intelligence of the Psittacidce geuerally abore the average of other families of birds, but ecrtainly if we were to meet with a few more instances among the former of habits acquired by a process which bears sueh a striking resemblanee to inductive reasoning, or at least to the putting of two and two together, we shonld not be able to deny them possession of intelligence which, were they a more powerful family, might be dangerons to mau himsolf. ... . . . I have stated elsewhere on the authority of Dr. Karl Russ, and as a matter of common observation, parrots are not flesh-eaters, and in eonfinement even the Nestor can be kept in health without it, whilst a moderate amount only is apt to cause disease. Yet the Kéa seems able suddenly to abandon to a largo extent its uatural food and to gorge itself incessantly on raw meat, like a Hawk. Altogether the matter is one well worthy the attention of ornithologists, and it is to be regretted that the too probable extermination of the speeies may prevent the preseut or succeding generations of naturalists

glaciors; and the middle distance is veiled in mist, partly obscuring the stunted Fagus-forest which clothes the lower ranges. In the foreground, below the gorge, a sheep attacked by a Kea is writhing its body in agouy and kicking up the loose suow from the ground in its frantic efforts to rid itself of this cruel tormentor, which clings tenaciously to its brok. Two other Keas on the wing are coming to assist in this work of torture. A small mob of sheep are huddled together under a projecting cliff, trying to obtain a little warmth, whilst one sheep, more inquisitive than the rest, has advanced a hundred yards or more towards tho suffering victim, aud is looking on, in silent wonderment, showing that these animals have hardly yet learnt to regard this Parrot as their natural enemy. 
witnessing the ultimate development of the habit, which one would expect to result in the production of a purely carnivorous parrot, with modifications of feet and digestive organs in accordance.

"In conclusion, I may remark that the Këa has not yet taken to flesh-eating throughout its range-possibly only from want of opportunity. Further north it still kecps well up in the mountains, and seems content with the diet that satisfied its predecessors; but as the habit commenced in the south and travelled northwards, so fresh cases keep occurring one beyond another, and it seems certain that the necessary information is passed onwards and northwards."

Fam. STRINGOPIDE.-At page 180 I have mentioned some structural peculiarities in the osseous frame of Stringops habroptilus. I have since had the pleasure of presenting a skeleton of this bird to the British Museum, and it is now exhibitcd in one of the wall-cases in the main hall of the Natural History section. The subjoined woodcuts (after Meyer) will show how widely it differs from the skeleton of Nestor.
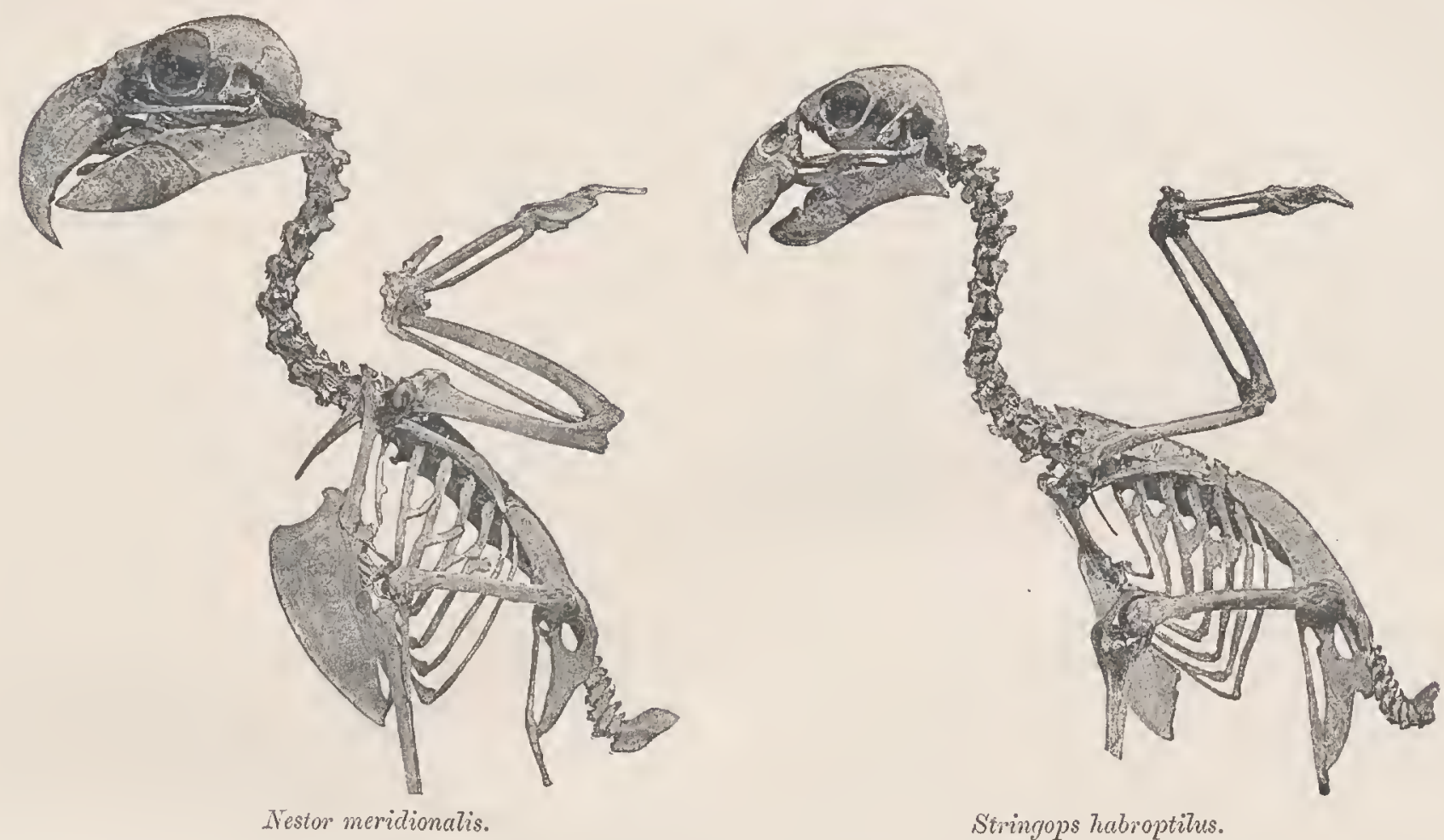

Stringops Tabroptitus.

Fain. STRIGIDEA.-It has long been supposed that an Owl of much smaller size than the well-known Morepork exists in New Zealand, but I hare never myself met with any positive evidence respecting it. Mr. Ellman, as far back as 1861, describing it as " not larger than a Starling," gave it the name of Strix parvissima, and Mr. Sharpe, in the British Museum Catalogue (Birds, vol. ii: p. 43), refers the species, without any apparent hesitation, to Scops novec zealandice, Bonaparte, of which he gives a full description.

I have stated at p. 205 that the only authority for regarding the unique specimen in the Leyden Museum as a New-Zealand bird is a label in 'Temminck's handwriting. Deeming this, in itself, insufficient evidence, I sent Mr. Keulcmans over to Leyden to make a drawing of the bird in watercolour. He brought back a beautiful picture, of life-size, showing the mottled markings of its plumage in marrellous detail. But I saw, at a glance, that this Scops equalling in sizc small cxamples of Spitoglaux nove zealandice, and with strikingly promineut "horns," could never have bcen the bird intended by those who have described an Owl "about the size of a Kingfishcr." The occipital tufts, characteristic of the genus Scops, are so strongly developed in this species that they could not have 
escaped the notice of the most casual observer, and yet we have no mention of them in any of the hearsay accounts that have been recorded from time to time. In addition to the instances mentioned in the body of this work, the following are taken from 'Out in the Open,' p. 127 :-

"Another speeimen was proeured by a gentleman in one of the forests far above the Rangitata gorge; on being observed on a braneh of a tree, it was knoeked down and caught during its fall. There was fur on its beak, as though it had not long before devoured a mouse. This bird also was set at liberty.

"It has bcen taken at the Waimate, where it remained for a day in the roof of a hut. Mr. M. Studholme had it in his hands, but permitted it to eseape.

6: The late Mr. Phillips, of Roekwood, one moonlight night captured a speeimen by taking it quietly off a bough of an appletrec. Mr. Phillips, like Mr. Studholme with his bird, earried it between his hands and allowed it liberty. Ho deseribed it as being about the size of our Kingfisher. Note that each observer of this pretty Owl was impressed with its gentleness and its fearless eonfidenee. Both had enjoyed long colonial experience, were aeeustomed to birds, men of position and well-known beyond their own distriets. Athene parvissime must not be given up, even to satisfy the most erudite of ornithologists."

Professor Newton, to whom I submitted the drawing, writes to me:- "I certainly admit that your caution has been justified, for it is almost impossible to suppose that the wonderful Strix parvissima (!) could have been a bird of the same species." And Mr. J. H. Gurney, whose opinion on such a point is of the utmost value, sends me the following report:-

"I have earefully eompared Mr. Keulemans's drawing of the type speeimen of Scops nove zealandice with the series of Seops Owls preserved in the Norwich Museum, and after doing this, and also referring to the late Professor Sehlegel's deseriptions of the speeimen in his 'Mruséum des Pays-Bas,' Oti, p. 27, and 'Revue,' Noetuw, p. 13, and to Mr. Sharpe's deseription in a footnote at p. 44, vol. ii. of his 'Catalogue of Birds in the British Mrusenm,' I coneur in the belief there expressed by Mr. Sharpe, that Scops novce zerlandice is a distinet speeics; but if it be so, two questions will still remain undeeidod-1st, whether the loeality of New Zealand assigned to tho Leyden specimen by Temminek's label is eorrect; and 2nd, if so, whether the speeies is, or is not, identieal with the New-Zealand bird for whieh Irr. Ellman proposed the name of 'Strix parvissima.'

"The type speeimen of Scops novce zealendice, judging from the materials before me, appears to approaeh most nearly to Scops morotensis, Sharpe, a uative of the islands of Morty and Ternate, deseribed and figured in Mr. Sharpe's Catalogue of Birds, vol. ii. p. 75 , pl. 7. fig. 1; but it would seem to differ from that species in having a somewhat eonspienous nuehal eollar, in the under wing-eoverts being 'almost entirely ochraeeous,' and (to quote Sehlegel's words) 'par le manque de taehes elaires aux plumes seapulaires.'

"I return Mr. Kculemans's beautiful portrait of the Leyden speeimen by parcel-post and thank you mueh for tho opportunity of examining it."

In my account of the Langhing-Owl (Sceloglaux albifacies) I have mentioned a tendency to variation in the plumage. I have since examined very carefully Mr. G. R. Gray's type (brought to England by Mr. Percy Earl in 1845), and it seems to be a case of partial albinism, for the face is so white as fully to justify the specific name bestowed by him. It has the forehead, cheeks, lower sides of the head, and the whole of the throat conspicuously white; the feathers composing the facial disk and the rictal plumes with black shafts, and those on the lower parts of the face with a central streak of brown widening towards the base.

Fam. FACCONIDE.-Mr. J. H. Gurney writes to me (under date March 29, 1888):"The Australian Harrier found in the Celebes is not Circus approximans $=C$. gouldi, but $C$. assimilis $=$ jardinii, and neither of these species occurs in the Malay Archipelago"*. It will be seen that in my account of Circus gouldi I have limited the eastward range of this species to the Fiji Islands.

* Cf. also Gurney's 'Diurnal Birds of Prey,' p. 22, footnote.

As mentioned in the Introduetion to my former edition, Mr. Gurney haring sent to the Norwieh Museum for a speeimen of his Circus wolfi of New Caledonia (P.Z.S. 1865, p. 823) for my inspeetion, I felt no hesitation, after comparing it with adult examples of Circus gouldi, in aecepting it as a good species, notwithstanding the opinions to the eontrary of Professor Sehlegel and other eontinental ornithologists. It appears to me to be readily separable from our bird by its blackish crown and ear-corerts, 2 K 2 
I have given an exhaustive account of this fine Hawk because it is one of our most conspicuous birds, being met with in all localities; but, I am sorry to say, it is becoming perceptibly scarcer in many parts of the country, owing to its wholesale destruction by farmers. On one occasion I counted no less than ninety-six heads nailed up in imposing rows against the wall of an outhouse on a small sheep-station. This crusade arises from the popular belief that the Harrier attacks and kills young lambs. That it occasionally does so in the case of wcaklings is beyond doubt, but I am of opinion that the mischief done is very much exaggerated. In my history of the species I have endeavoured to vindicate its character as a useful bird.

Fam. CUCULID出.-Of this family we have in New Zealand one representative of each of the two well-known genera Eudynamis and Chrysococcyx. Like Cuckoos in general, both of these species arc parasitic in their habits of nidification, and, as a rule, both of them find their dupe in the Grey Warbler (Gerygone faviventris), the builder of a pensile, dome-shaped nest. Mr. Potts has called attention to the frequency with which torn nests of this species are met with, and suggests that this may be due to the endeavours of the Cuckoo to make these nests available for their purpose; yet this view is hardly compatible with the fact that whenever the Cuckoo's egg is found among those of the Warbler, the nest is always in pcrfcct condition. But how the intrusive egg is deposited by its owner is certainly a mystery, particularly in the case of such a bird as the Long-tailed Cuckoo *. Mr. Rainbow writes that, as the result of much observation, le is firmly convinced that the English Cuckoo, after laying its egg, takes it up in its foot and deposits it in the nest of its victim. The process, he argues, cannot be satisfactorily accounted for in any other way. In connection with this I nuay mention the circumstance that a friend of mine in New Zealand shot a Long-tailed Cuckoo which appearcd to be carrying some object in its bill. On picking up the bird, he found a broken egg, of a creamy-white colour and, so far as he could judge, of a size corresponding to its own.

Mr. Rainbow's view seems to find confirmation in the following statement, which appeared in 'The Ibis,' 1867, p. 374 :- "'The long-presumed opinion of the Cuckoo first laying her egg on the ground and then carrying it off for deposition in the nest of some other bird, has of late been singularly confirmed by actual observation. In the German periodical 'Der Zoologische Garten' for 1866 (pp. 374, 375) appears a note by Herr A. Müller, stating that the author watched a Cuculus canorus through a telescope, saw her lay an egg on the grass, take it in her bill, and deposit it in the nest of a Motacilla alha!"

The feeding of the unwieldy young of the Long-tailed Cuckoo by the diminutive foster-parent and the appropriation of the Warbler's nest by the young of the Shining Cuckoo are such droll phases of bird-life that I have introduced both incidents into the Plates illustrating those species.

One of my best correspondents says:- "It is not a difficult task to find the Warbler's nest when the Long-tailed Cuckoo is about to lay her egg or immediately afterwards. It is laid very early in

and likewise by the much darker colour of its wing-coverts. In the otherwise exeellent drawing, from the pencil of Mr. Wolf,

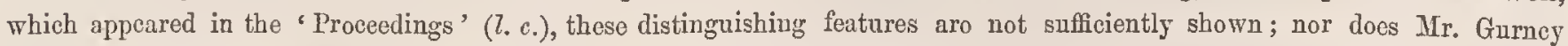
give the necessary prominence to them in his descriptive account, his object having been (as he has since informed me) to point out the distinguishing characters of the specios as compared with $C$. maillardi (Verreaux), rather than with $C \cdot$ goulili.

* Tho late Mr. Henry Mair met with this species, with which he was quite familiar in New Zealand, during a visit to Danger Island. It also occurs at Samoa, but, according to the Rev. S. Whitmce, it is less abundant there than in many of the Polynesian Islands. 
the morning, and after the female has deposited it her mate may be seen flying rapidly after her, dashing through the trees and sometimes in the open, the female uttering a distressed, peevish cry. On such occasions I have sometimes seen them fly long distances outside the bush." Referring to the foster-parents' nest he says:- "I may inform you of a curious position in which the Gerygone occasionally builds its nest. Of course you have seen the grand old white-pines whose trunks are thickly 'bearded with moss.' Selecting a spot where this moss is four or five inches thick, it constructs its nest among it, leaving the entrance just flush with the outer fringes. I was shown one by an old gold-digger, who assured me that during the last 25 years he has on frequent occasions found the nest of the Warbler in such situations."

It is singular that in the same way that the Tui persecutes this Cuckon in New Zealand, it is the victim in Samoa of another Honey-eater, a much smaller bird*. It is difficult to account for this unless it be due to the Hawk-like markings of its plumage.

Fam. TETRAONIDE.-The rapid and total disappearance of such a bird as the New-Zealand Quail is very remarkable, when we consider that the members of the restricted group to which it belongs have an almost universal diffusion, and continue to exist, under somewhat similar conditions, in other countries in undiminished plenty $\uparrow$. The causes to which we are accustomed to attribute the extirpation of the Quail (the introduction of sheep and the prevalence of bush-fires) ought to operate with equal effect on such a bird as the Woodhen (Ocydromus australis), which, being utterly incapable of flight, is placed at a greater disadvantage even than the Quail ; yet this species, instead of being exterminated, continues to thrive and multiply, and is even more numerous than formerly in the settled districts of the South Island. Some have endeavoured to account for the disappearance of the Quail on the theory of migration; but situated as New Zealand is in the great waste of the Pacific Ocean, such a theory seems to me quite untenable. It is true that, as stated at page 228 , the bird has recently been found, apparently in considerable numbers, on the Three Kings; but I take it that this is a mere outlying refuge of the species, and that the birds to be found on these small islands are the only survivors of a race now extinct on the mainland, and not to be met with in any other part of the world.

The extreme fecundity of the Quail tribe ought, one would have thought, to have saved this species from such rapid extinction. Mr. J. R. Hill, of Christchurch, kept some California Quails (Lophortyx californicus) in his aviary, and was perfectly amazed with their productiveness. One of the hens laid in a single season no less than 80 eggs, forming several new nests during that pcriod. At length she discontinued laying, and collecting 23 of the eggs into one nest commenced to incubate. She brought out all but one, and reared the 22 young ones to maturity.

* The bird is chiefly known to the Samoans as an example of arrant cowardice, owing to the fact that when seen it is almost always ehased by a number of Iaos (Ptilotis caruncelata), from which it tries to escape in the most precipitate manner. I scarcely ever hear the name of the Aleva mentioned by a natire without some such remark as this:- "Tho big bird that is ehased by the littie Iro!"

† A correspondent who has earefully noted the disappearanco of the Quail writes to mo:- "It seems to me to be of importance that the lifc-history of this bird should bo correctly recorded; for the story of its rapid extinction will possess much interest for futuro naturalists. It cannot be said, as in other eases, that this species was exterminated by the introduction of other birds into its natural habitat, because it had almost disappeared before any acclimatized birds had reached the grasscovered downs whero formerly it was so abundant. The tussock-fires have been the prime cause of the annihilation of this useful bird by destroying the seeds and insects on which it subsisted. So far as I have been able to diseover, the last speeimen seen alive was on the Raincliffo Station, in the year 1878." 
Fam. COLUMBID画,-The New-Zealand representative of this group is perhaps the finest of the whole. It is scarcely inferior in size to Carpophaga galeata of the Marquesas Islands, fully as large as $C$. goliath of the Isle of Pines, larger than C. concinna of the Moluccas, and far more beautiful in plumage than all three of them. The Nicobar Pigeon (Calonas nicobarica), from the Louisiade Archipelago, is certainly more brilliant, but it is much inferior to our bird in size. The largest Wood-Pigeon in Australia, the Wongawonga (Leucosarcia picata), is not to be compared with the New-Zealand bird.

The genus Carpophaga is confined to the Philippines, New Guinea, Australia, and New Zealand; the nearest ally of our bird being probably Carpophaga forsteri of the Celebes, on the western limit of the Austro-Malayan subregion.

In my account of the species I have mentioned (at p. 234) the immense numbers that are annually killed without any appreciable effect on their abundance, in suitable localities, on the recurrence of each season. In further illustration of this I may add that in a small area of bush between Nukumaru and Weraroa, places of historic interest in connection with the Maori war, four young settlers shot upwards of 400 in the course of two days !

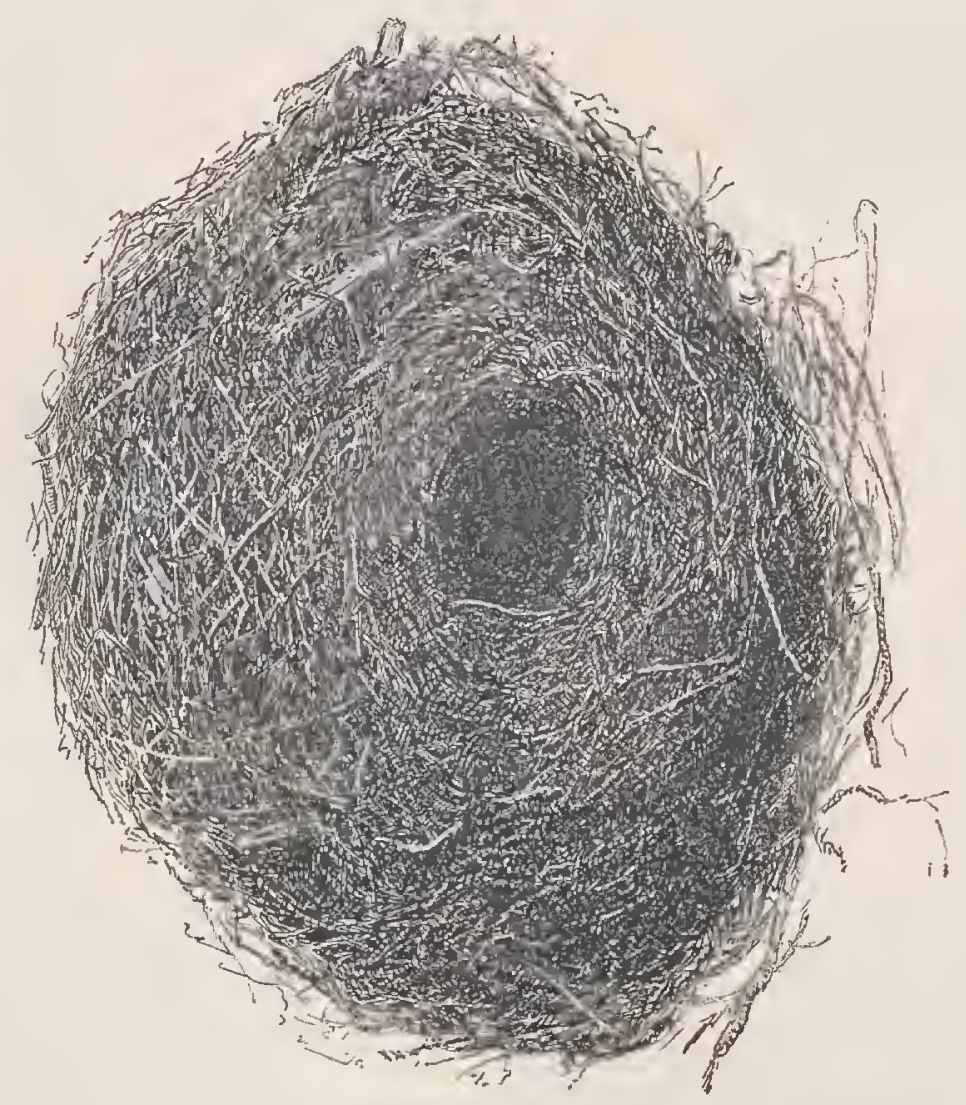

Nest of Xenicus gilviventris (four-fifths natural size). See page 243. 


\section{THE BIRDS OF NEW ZEALAND.}

\section{EXTRACTS FROM REVIEWS OF FIRST EDITION.}

"Birns, as most people know, or ought to know, form the most important part of the vertebrate fauna of New Zealand; and their importance is maintained not only when they are compared with their compatriots of other classes, but when regarded in reference to members of thcir own class in the world at large .......

"The birds of New Zealand, therefore, merit especial attention, and we are happy to say they receive it at the hands of the authors whose works are above cited. Taking the field in or about the year 1865, Mr. Buller, till then umknown to fame beyond the limits of his natire colony, brought out an 'Essay on the Ornithology of New Zealand,' which at once attracted notice in this old world of ours. Some of his views were challenged by Dr. Finsch, then of Leyden, who had paid attention to this extraordinary arifama; and a controversy ensued. This, to the credit of the controversialists, was carried on in a spirit rery different from that in which many another war in natural-history circles has been waged; and the happy result is that on most points the combatants have arrived at the same conclusion, thereby giving assuranco to the general public of its being the right one. The essay we have mentioned may be regarded as the preliminary canter which a race-horse takes before he puts forth. his full strength; and Mr. Buller's book, or that part of it which is as yet published, shows what he can do now that the colonial autloritios have allowed him to come to England for the express purpose of completing his design.

"Captain Hutton is known as an observer who, during sereral long voyages, had proved that some rational occupation could be found at sea even by a landsman; for, instead of deroting his energics to the ordinary time-killing amnsements of shipboard, he watched the flight of the rarions oceanic birds which presented themselves, and speculated on the mode in which it was performed and the fores it brought into operation-to some purpose, as the Duke of Argyll and Dr. Pettigrew hare testified, The pamphlet whose title we give is in some respects a not less significant, if a less ambitious, work than Mr. Buller's; and though to the last must belong the crown of glory, we by no means wish to overlook the useful part which Captain Hutton's publication will play. If here we do not noticc it fnrther, it is because its ralue will be most appreciated in the colony itself, while Mr. Buller's beautiful book appeals to a larger pnblie. . . . . . . .

"Of the Kakas (Nestor) Mr. Buller admits three specics-Nestor meridionalis, N. occidentalis, and N. notabilis-the two first of which, we think, are barely scparable. This very remarkable genus of l'arrots includes some two or three other species, one of which, the $N$. productus of Phillip Island, is beliered to have gone the way of so many animals that only iuhabit small islands; and the same fate in all likelihood arraits its congeners. Most animals suffer from not being able to accommodate themselfes to change of circumstances; bnt the rery adaptability of the Mountain-Kaka, or Kea, will tend to its early destruction: for, thongh belonging to the group of Parrots distinguished by their brusll-like tongue, and deriving a considerable portion of their subsistence in a manner worthy of the Golden Age, from the nectar of flowers, this wretched Kea $(N$. notabitis), since the introduction of sheep to New Zealand, has incurred tho imputation of a fondness for mutton-cutlets $a$ la Abyssinie; and the charge, whether true or false, is likely to bring about its doom, since the shepherd is apt to practise what in good old times was called 'border justice,' and the speeies will probably suffer extinction before its guilt is fully proved or extenuating circumstances admitted. The Common Kaka (N. mericlionalis), on the other hand, is ably defended by Mr. Buller as one of the most uscful birds in the country; yet this also is rapidly diminishing. 'In some districts', he says, 'where in former years they were excessively abundant, their cry is now seldom or never heard;' and though he adds that 'in the wooded parts of the interior thoy are as plentiful as erer,' it roquires no prophetic eye to see that, with the extension of settlement, the Kaka mnst succumb.......

"Here we must pause. Mr. Buller's book is in cvery way worthy of its subject; and we trust that we hare shown that the subject is worthy of close attcution-whether we regard the various forms of New-Zealand birds from the point of view of their intrinsic interest, or from that of so mans being now on the rerge of extinction. It is easy to be wise after the erent, and ornithologists at home do not in these days look back affectionately towards their predecessors who hare let so many species pass away without tracing the process of extermination."-Nature (Jnly 18, 1872). 


\section{EXTRACTS FROM REVIEWS.}

"New Zealand is especially fortunate in the possession of many admirable Naturalists, including geologists, botauists, and zoologists. One of the latter (born and bred in the colony), a gentleman who has made many zoological contributions to the 'Transactions of the New-Zealand Institute,' and whose acquirements, more especially as an ornithologist, have been recognized by his having had conferred upon him the Degrec of Doctor of Science, as well as the Fellowship of tho Linnean, Geological, Royal Gcographical, and Zoological Societics, is at present in London passing through the press a magnificent work on the Birds of New Zealand, one that caunot fail to bring prominently into notice tho present aspects of scientific culture in that colony."Constitutional (Nov. 18, 1872).

"It is not often that thorough practical knowledge, both in the field and at home, is possessed by the author of a work like the present; but Dr. Buller has studied his subject in both aspects, and the value of his book is clearly enhanced thereby. Moreover he has set about his task in a way that shows us that he thoroughly appreciates the difficultics surrounding it. His personal acquaintance with the birds themselres has been followed up by a critical and impartial invostigation of the writings of previous authors; and, lastly, an independent examination of many of the typical specimens in England has placed him in a position to speak with great precision upon intrieate points of synonymy. The consequences to many of the indigonous birds of New Zealand, arising out of its colonization by Europeans, secm likely to be so disastrous, that it is high time that anthentic histories of them should be put on record before they finally disappear. Dr. Buller's work, therefore, supplies what might have proved a serious omission in ornithological literature. It is not too late to write a full life-history of those New-Zealand birds whose numbers are rapidly diminishing; but a few years hence it is more than probable such a task eould not be accomplished. Though the present active eauscs may be novel, the rapid destruction of the indigenous fauna of Now 'Zcaland dates back to far beyond historie times; for though Maori tradition may give an approximately recent time when the Moa still surrived, numbers of other similar forms have succumbed whose remains are now found in a semi-fossilized state, and of these we have not anothor vestige of record. They, like the Dodo and the Solitaire, seem to have fallen rictims to some cneny suddenly introduced into their domain, against which they were powerless to make successful resistanee. The remains of these extinct birds have furnished the materials for Prof. Owen's series of exhaustive memoirs on Dinomis and its allies. Dr. Bnller's will form a fit companion work, and thus provide us with a very complete record of tho birds of New Zealand both past and presont."-Fihe Ibis.

"The first work professing to give a completo account of the ornithology of New Zealand must nocds be an important ono. This ornithic fauna presents so many points of general biological interest, that only those of tho islands east of Africa can be compared with it. . . . . It was high time that a eompleto aceount of this fauna should be given by a competent naturalist. Some of the most interestiug forms have already become almost, if not quite, extinet; others are fast expiring, or obliged to aceommodate themselves to the changed conditions of the country. . . . . . Wo do not say that the majority of the native species will not survive, though in diminished numbers of individuals; but it is quito probable that some of these survivors will be preserved by accommodating themsclres to the new state of things, modifying in a more or less perceptible manner their nidification, food, or some other part of their mode of life; and if sueh changes should oeeur, the student of a future generation will find in Dr. Buller's work the means of comparing the birds of his time with thoso of tho past. . . . . . The author has shown unremitting care in addueing all the information that can possibly throw light ou his subject; he has spared no pains in illustrating it in the most porfect manner; and tho result is that a most valuable work is placed before the student of ornithology, whieh will offer to every lover of natural history real and permancut eujoyment, and which, by its attractire form, will allure many a joung man in that colony from the pursuit of other brauches into the camp of ornithology."-Ameals and Magazine of Natural History.

"A mind may be so imbued with the views of Darwin as to be blind to the evidence of his cyesight, deaf to the logic of facts; but there is no proof that Dr. Buller is cither: he is evidently friendly to Darwin's celebrated hypothesis, but sees, hears, and thinks for himself. . . . . . Happily for Scienee, the author for twelve years has held an official position iu New Zealand which has enabled him to visit every part of the eountry, while his frequent intereourse with the natives has greatly assisted him in acquiring the information required for making such a work complete. . . . . . It eontains a vast amount of the soundest natural-history teaching, and seems to eombine in an eminent degree the new with the true. . . . The illustrations in the first number, the only one yct published, are excellently drawn by M. Keulemans, who always aims at the representation of living birds rather than the conventional attitudes of birdstuffer's specimens. They are well coloured by hand, and thus the work is rendered as ornamental as useful. We cordially reeommend the 'History of the Birds of New Zealaud' to the readers of the 'Zoologist,' and we sincerely wish it crery success."-Zoologist.

"The aceounts which naturalists from time to time have giveu to the world of the birds iuhabiting New Zealand have been hitherto but fragmentary and incomplete; and although forty years have elapsed since the first of such publications made its appearauce, the available sources of information on this subject are still so few in number, that they may be enumernted almost in a breath. The Iate Mr. George Gray might deservedly be regarded as the pioneer of New-Zealand ornithologists; for, although 


\section{EXTRACTS FROM REVIEWS.}

never an actual explorer of the country himself, his official position gave him unusual faeilities for studying its avifauna by means of the numerous collections which from time to time passed through his hands, and not a few of these antipodean species were originally described by him. .....

"When Mr. Gould, in 1868, published his ' Handbook to the Birds of Australia,' he gavo, by way of appendix to his second volume, an account of various New-Zealand species which were scarcely known to Knglish readors, save in name; and in point of date this would soem to have been the latest publication on the subject in this country until a few months since, when Part I. of Mr. Buller's splendid work made its appearance. But, although so little, comparatively, has of lato becn puhlished here, naturalists in New Zealand have been activcly cngaged for somo years past in working out the natural history of thcir adopted country; aud the transactions of two of their scientific socicties contain many excellent contributions on ornithology from such ablo naturalists as Dr. Hanst, Dr. Hector, Mr. Potts, and the author of the work now bofore us. Nor have our friends in Germany been behindhand in their zeal to become acquainted with an avifauna perhaps the most remarkable in the world. . . . . .

"We recogniso in Mr. Buller's publication, however, the first attempt which has been made to give anything like a complete history of the birds of New Zcaland; and it would not bo easy to overrate the importance which attaches to such an undertakiug. ......

"Those who had an opportunity of sceing the Huia, which lived for some time in tho Parrot-house in the Zoological Gardens, could scarcely hare noticed it without wishing to learn something of its haunts and habits; and to them Mr. Buller's account of it will prove most ontertaining. In the following extract we seem to get a peep of the country which it inhabits, as we search for and find this rery curious bird. . . . . . Such skctches as these go far to enliven a comprehensive work on birds, which, in othor respects, is strictly scientific. As regards the illustrations Mr. Buller has been most fortunato; for, under his direction, his artist, Mr. Keulemans, has produced some of the most life-like and beantiful pictures of birds which we have seen. We understand the work is to he completed in five Parts, two of which have already appeared, and a third is in active preparation. It will assuredly become the toxt-book for all students of New-Zealand orvithology."-The Field.

"Dr. Buller has just produced Pari IV. of his great work on the ornithology of New Zealand; and we may uow fairly say that the high anticipations we had formed as to the author's capabilities have been fully realized. In the book before us we find the two great requircments of science combined-namely, a thorough appreciation of the necessary details which are expected of a scieutific work in the present day, and the ability to write in appropriate and entertaining language the life-histories of the hirds of which the author has to treat. So rarely aro these two qualitics found combined in a scientific writcr, that the greatest credit is due to the learned author for the admirahle manncr in which he has performed his task.

"The ornithology of New Zealaud is especially interesting, from the fact that the indigenous species are being gradually. extinguished; and we read with regret that cven within the memory of the author certain birds, which were formerly common, have almost ceased to oxist.

"The work contains claborate scientific diagnoses of the various birds, and a classification of the different names by which they have been known to different writers.

"The coloured plates are really exquisite cxamples of the lithographer's skill. In every respect the work is a most valuable addition to tho scientific student's library, as well as to that of the more general reader, and seems to contain the fullest information on every point connected with this interesting study."-Land and Water.

"Although several more or less complete treatises on and lists of the Birds of New Zealand have becn published, they wcre rather of a tentative and prelimiuary character; and the work before us is the first which gives a full account of this ornithic fauna, which, in zoological interest, is not excelled by that of any other country. . . . . Therc can be no doubt that Dr. Buller, well known in Europo hy his preliminary ornithological publications, is eminently qualified to fulfil this task. His long residence in the colony and his official positjou have given him rare opportunities of making observations and collecting materials; and by a lengthened visit to England he has derived the great advantages of stndying typical examples and of availing himself of that typographic and artistic skill in which this country excels. To judge by the first part issucd, Dr. Buller has stcceeded in producing a work of rcal excellence. The text is clear, instructive, and not overloaded witl unnecessary detail; while the illustrations are beautiful and life-like."-The Academy.

"New Zealand may he congratulated on having outstripped the other colonies in the race for scientific honours. Even Canada, with all the resources at her command, has produced uothing at all comparable with the 'Transactions of the New-Zealand Institute.' Now wo have before us something of a far more ambitious kind-namely, a complete life-history of the birds of New Zealaud, adapted to the presont advanced state of ornithological science, and mest beautifully illustrated with coloured plates. . . . The descriptive part of the text is very carefully worked out, both in English and Latin; and the history of each species is given in the most complete and exhaustive manner. The plates are extremely beautiful, and are rendored more attractive by the 


\section{EXTRACTS FROM REVIEWS.}

introduction of botanical accessorics, representing the indigenous flora of the eountry. The volume, when complcte, will not only be a valuable contribution to seicntifie literaturc, but will be an elegant drawing-room companion; for, to adopt the language of a leading seientifie journal respecting it, "the plates arc as beautiful in execution as the text is exeellent in quality." Home News.

"The lamentable way in which the indigenous birds are expiring in that country before the progress of civilization and other natural causes, has rendered it a necessity that a work should be prepared that will rescue from oblivion the feathered denizens of those places which in a short lapse of time 'shall know them no more.' This it has fallen to Dr. Buller's lot to aceomplish ; and it were small praise indeed to say that his task is executed in an admirable mamner. Few ornithologieal works that have been written come up to the standard of the subjeet of this notice; and none havo yet surpassed it, nor will it bo possible to do so. Certainly the author brings to his aid unusual advantages; but even these might fail in the hands of a less eonseientious person than Dr. Buller has shown himself to bo. . . . . . In the Part now before us the history is given of thirteen birds, ten of which aro figured; and this brings us down to the end of Accipitres, Psittaci, and Picaric. . . . . . . No one since the time of the late Professor Macgillivray has so successfully combined the two branches of cabinet and field ornithology as Dr. Buller; and his experiences, and those of his numerous coadjutors, are told in a pleasing and instructive manner, whieh cannot fail to interest and amuse his readers. Indeed it is seldom that we have seen a book whieh so thoroughly calls for unqualificd praise as the present...... We have only, in conclusion, to perform the pleasing duty of offering our congratulations to the inhabitants of New Zealand on their possession of so distinguished a naturalist as Dr. Buller, and to the author on the eomplete suceess with which his arduous task promiscs to be crowned."--European Jlail.

"This admirable work, which places New Zealand in the front rank of countries, from an ornithologieal point of view, does ercdit to all concerned in it. Nothing seems to have been spared to make it as good as possible: and this faet is the more gratifying as in a few ycars many of the native species will probably havo become extinct, and the opportunity of observing their habits, which are in most cases very fully described, will be lost for ever. The sclection of tho species for illustration is judicious, and the Plates are good."-Zoological Record.

"Before entering upon my own researches and a dissertation on the speeies, I will briefly refer to the Ornithologieal litorature that has been published during the last two sears; and on this oeeasion I seize with pleasure the opportunity of drawing attention to an undertaking whieh I desire to reeommend most warmly to all friends of and experts in Ornithology. It is the beautiful work cntitled 'A History of the Birds of New Zealand,' upon the publication of which my friend Dr. Buller is at present engaged, having eome from New Zealand to London for that special purpose. 'This work, as is proved by the First Part, whieh I have now before me, very worthily links itsclf in with Sharpo and Dresser's 'Birds of Europe,' Sharpe's 'Kingfishers,' and Marshall's 'Capitonidæ.' As with the last-mentioned works, the execution of the Plates has becn ontrusted to the clever peneil of Keulemans, whoso masterly work has long since gained universal aeknowledgment, and docs not stand in neerl of any further recommendation. Thus we shall before long bo in the enjoyment of an exhaustive deseription of the Birds of New Zealand, equally perfect in text and illustration, and every person whose meaus will permit of it ought, without delay, to obtain possession of this beautiful book, the morc so as its publication in Parts greatly faeilitates the acquisition."-Dr. Finsch in 'Journal für Ornithologie,' 1872.

"That New Zealand contains more than an avcrage number of persons interested in the advancement of science is crident, not only from the large number of members bclonging to the various scientific Soeieties in the Colony, but also from the liberal way in which the Legislature rotes money for seientifie purposes: and to all of those who wish to sce an intclligent interest taken in the subject of Natural History by our rising generation, Dr. Buller's beautiful work on the Birds of New Zealand cannot fail to bo most welcome. . . . . A book of this nature can be looked at either from a scientific or from a popular point of riew-the nomcnolature, descriptions, \&c. forming the strictly scientifie part, and the life-history of tho birds the popular part; eaeh being, in its own way, of equal importance. It is very rare indced to find the qualifieations necessary for tho pursuit of both branches of Ornithology eombined in one individual; and although we do not eonsider Dr. Buller's book irreproachable from either aspeet, still we know of no other work on Ornithology, the product of a single author, in which both branehes are so successfully combined, as in tho book beforc us. . . . . . Dr. Buller's style is exceedingly good, clear, and to the point. Without wasting words, he brings out in a few graphic touches the salient points of whatever he may be deseribing, and it is easy to see that he is a real lover of nature and delights in a camp-out in the bush. . . . . The descriptions of the speeies arc exccllent. Indeed, we think that these are the best portions of the book; and it is evident that a great deal of labour has been expended over them. In very fow books on Natural History do we get snch detailed descriptions of the adult, the young, and the varieties of the speeies, and the methodical manner in which thcy have becn drawn up adds greatly to thcir value."-Review by Prof. Inutton in New-Zealand Magazine' (January 1876). 


\section{EXTRACTS FROM REVIEWS.}

\section{EXTRACTS FROM REVIEWS OF NEW EDITION.}

"There ean be no question as to the eompleteness with which the author treats his familiar subject, nor as to the execllenee of the illustrations prepared by the pencil of Mr. Koulemans."-The Ibis.

"The Plates are absolutely perfeet. .... The birds are reprodueed in eolours on as large a seale as praetieable, and with a truth to nature which reflects great credit on the skill of the artist, Mr. Keulemans. So far as the letterpress goes, it ought to satisfy all wauts. Sir Walter Buller gives a very complete synonymy of eaeh speeies from the earliest systematie writers down to the present day. There are also full deseriptions of both sexes and of erery eondition of plumage, with explanatory notes whore necossary on the nomenelature and elassifieation, and a eomplete life-history of eaeh bird from Sir Walter Bniller's personal observations, made in the field and forest, and reeorded with scrupulous fidelity over a period of 20 years. The technical part (Latin and English deseriptive matter) is in smaller type than the popular history, whieh any one may read with understanding and pleasure."-The Times.

"When, in 1873, Dr. (now Sir Walter) Buller, brought out his first edition of the Birds of New Zealand, it took people in this eountry by surprise; for it seemed an extraordiuary thing that a mall who had lived the best part of his life at the Antipodes--far removed from the great seientifie eentres of thought, from the libraries and museums of Europo, and from all those olpportunities of fellowship whieh are considered so neeessary to sciontifie workers-should bo able to produee a high-class book, strietly scientific and quite abreast of the time. It needs scarecly to be pointed out that any author, whatever his position, who essayed to produee sueh a work, without possessing the nceessary qualifications-an intimate knowledge of his subjent and a well-trained seientifie mind-would have been promptly eut to pieees by the reviewers, who are rightly regarded as the guardians of seience, in its more teehnical sense. So far from injurious eomment, every seience-roview of acknowledged standing in London gave the book unqualified praise. Copious extraets from all these reviews were given at the end of the work, and are worth perusal. The author was eleeted F.R.S., the highest distinction open to a seientifie man in this eountry, and Her Majesty conferred upon him an imperial distinetion ' in reeognition of the great value of his work to seinnee.' But apart from the technical knowledge exhibited in this book, rogarded from the seientist's point of vicw, the author was execptionally fortunate in being able to portray the life-histories of the various spoeies in happy language, and thus to make what otherwise might have been a dry seientifie dissertation, pleusant and attractive to the ensual reader. The Daity Telegrapth, in its leading eolumns, referring to this, deseribed the author as ' the Audubon of New Zealand,' whilst another reviewer said of the life-histories that they were 'quite as seductive as novel-reading' ...... But undoubtedly the best proof that the book was appreeiated by the gencral publie was afforded by the rapid manner in which the edition of 500 was subscribed for, aud the price to which it afterwards rose..... It will hardly be a matter of surprise, therefore, that Sir Walter Buller has taken the opportunity, after a lapse of thirteeu years, of his risit to England to bring out a new and mueh enlarged edition. Of this, six parts have now been issued, containing 24 beautiful illustrations in colours. The next part will eontain a General Introduction to tho wholo subjeet, ombellished with numcrous woodeuts and lithographs, and this will eompleto Vol. I. It is believed that the seeond volume, finishing the work, will bo out before the end of tho ycar. It is on a much larger scale than the former edition; and the letterpress is so amplified and added to that the book is praetically a new one. Apart from the value of the work as a contribution to the scientifie literature of the day, it will form a very beautiful drawing-room exhibit; and all who take an interest in New Zealand, with its eurious forms of bird life and its quasi-tropieal regetation, ought certainly to possess themselves of a copy of this book before it is too late, beeause the number of copies available for Europe and Ameriea is strietly limited to 250, three-fifths of which have already been subseribed for."-Anglo New-Zealander.

"The speeimen Part is illustrated by the most perfect eoloured figure of a beautiful bird that I erer saw in any work."Prof. Owen's letter in 'Australian Times.'

"That the author possessed the true iustincts of a naturalist in his early days is shown by the execllont aeeouuts of the habits of the birds, whieh proves that he must have spent a great deal of time in studying the different speeies in the field. There is, in faet, no more interesting portion of Sir Walter Buller's book than his own personal observation of habits; and in future days, when the arifauna of New Zealand shall have been changed, as it will assuredly be, by the introduetion of foreign speeies to supply the plaee of the indigenous birds so fast disappearing, our author's work will possess uudying attraetion, as being the embodimeut of the observations of men who saw these interesting New Zealand birds in a state of nature, and mueh that they saw will read in ages to eome like an ornithologieal romance. . . . . . This melaneholy knowledge that so many of the indigonous birds of New Zenlaud are undergoing a proeess of extermination londs an inereased value to Sir Walter Buller's book; but even this might not be fortheoming in the work of a less erudite author. Loug study among the muscums of Europe, and aequaintance with the litorature of the subject on which he writes, have rendered Sir Walter Buller absolutely the first 


\section{EXTRACTS FROM REVIEWS.}

authority in the world on the New-Zealand avifauna, both as regards its scientific rclations and the life history of the speeies which inhabit that wonderful country. In this sceond edition of his great work the wholo subject is treated with a fulness and. accuracy certainly not cxcelled by any modern production; and it will erer remain not only a eredit to the author but to the Colony which gave him birth. All that energy of purpose and a thorough knowledge of his subject could do to render his book perfect has been dono by the author, who has been lavish to a dcgree in his efforts to render the illustrations the best on record, and no book of its size has probably had so much money spont upon the plates and woodcuts."- $(R$. B. Sharpe) "The Colonies and Indict.'

"I write to congratulate you on the admirable way in which you are carrying out the work. I must say that I cnvy you the opportunity which you are so well turning to account. There is no other Ornis in the world which so much needs an historian, and no other historian can orer again enjoy your opportunities of the past. Any naturalist who attempts to follow you must write largcly on hearsay, and, as I always tcll my friends, your book can nover bo superseded. The lctterpress is all that a naturalist could desire, and in the Platcs (though these are not unnaturally of unequal merit) Mr. Keulemans has, I think, exceeded by many degrecs anything whieh he bas yet done; and I spcak from considerable experience of his Plates, since I dabble mysclf in Ornithologieal drawing in oils, and refer constantly to his work and that of other delineators of bird-life." - Letter from a British Ornithologist to the Author.

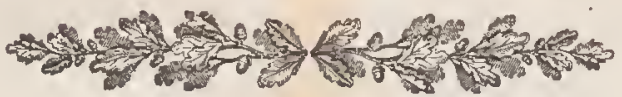





